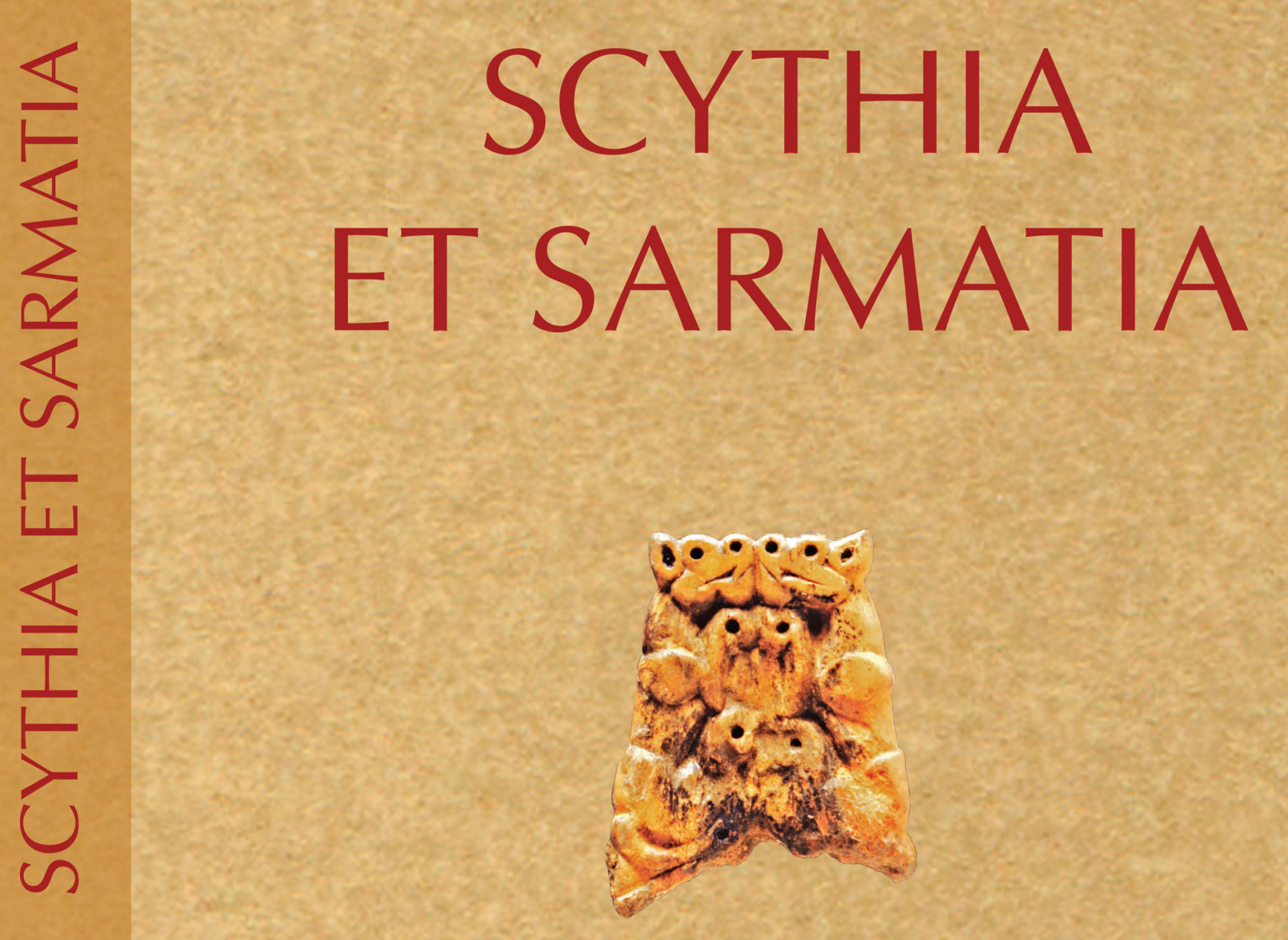




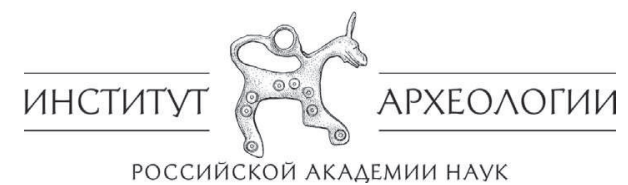

\section{SCYTHIA ET SARMATIA}

Сборник статей 
Ответственный редактор:

А. А. Малышев - кандидат исторических наук

Рецензенты:

A. Н. Ворошилов - кандидат исторических наук, Институт археологии РАН; B. E. Маслов - кандидат исторических наук, Институт археологии РАН

SCYTHIA et SARMATIA : Сборник статей / Отв. ред. А. А.Малышев. - Москва

C42 МАКС Пресс, 2019, 400 с. : ил.

ISBN 978-5-317-06274-3

http://10.25681/IARAS.2019.978-5-317-06274-3

13-14 ноября 2017 г. Институтом археологии РАН совместно с Государственным историческим музеем была успешно проведена Международная научная конференция «Новое в исследованиях раннего железного века Евразии: проблемы, открытия, методики». Конференция была приурочена к семидесятилетию Отдела скифо-сарматской археологии, созданного усилиями Бориса Николаевича Гракова в 1947 г. Это обстоятельство, а также столетие со дня рождения Константина Федоровича Смирнова, выдающегося советского археолога, специалиста в области савромато-сарматской и меотской археологии, широко обсуждались на заседаниях конференции. Сборник содержит материалы, которые были так или иначе освещены в устных и постерных докладах, представленных на конференции, при этом по замыслу редколлегии статьи не всегда дублируют темы докладов, поскольку соответствующие тезисы были специально опубликованы в сборнике материалов конференции (cм. http:// scythia-sarmatia.ru/publish/;https://drive.google.com/file/d/1rj7KhpCV5TAKw4Z9EvCSsWmMC Q0xXx3M/view).

В связи с этим данное издание имеет особое значение как своеобразный срез современного состояния исследований по проблемам археологии Раннего железного века Евразии.

Ключевые слова: ранний железный век, скифы, савроматы, сарматы, археологическая культура, Евразия, комплексные методы.

УДК 902/904

ББК 63.4 


\section{СОДЕРЖА Н ИЕ}

Гуляев В.И., Канторович А.Р., Коробов Д.С., Малашев В.Ю., Скорый С.А.

Международная научная конференция «Новое в исследованиях

раннего железного века Евразии: проблемы, открытия, методики»

(Москва, 13-14 ноября 2017 года). 5

\section{К 100-летию со дня рождения К.Ф. Смирнова}

Батченко В.С., Мальшеев А.А., Горланов С.С. Личный фонд К.Ф. Смирнова в архиве ИА РАН.

Лукьяшко С.И. Последние полевые сезоны К.Ф. Смирнова и проблема интерпретации памятников междуречья Дона и Северского Донца .

Чугунов К.В. Классификация стрел К.Ф. Смирнова и колчанные наборы раннескифского времени восточной зоны как хронологический индикатор .... 31

\section{Ранний железный век Евразии в Скифскую эпоху}

Гуляев В.И. На северо-восточных рубежах Скифии:

Средний Дон в V-IV вв. до н.э.

Иванов A.B. Элитный комплекс начала IV в. до н.э.

на западных границах меотской культуры

Иванов С.С. К выделению локальных вариантов сакской культуры

Притяньшанья

Кадиева А.А., Маслов В.Е., Биркина Н.А., Демиденко С.В.

Погребение конца VII - V в. до н.э. из могильника Заюково-3

Канторович A.P., Маслов В.Е. Бронзовый черпак

из могильника Новозаведенное-III на Ставрополье

Кисель B.A. «Сложный завиток» в скифском зверином стиле

и наборные пояса древних кочевников.

Кузнецова T.M. «Киты» скифской хронологии

и система датирования памятников

Лихачёва О.С. Случайные находки вооружения раннего железного века

из лесостепного Алтая

Марсадолов Л.С. Сакральная ориентировка «цепочек» курганов кочевников

Саяно-Алтая I тыс. до н.э. как этнокультурный признак.

Молодин В.И., Париингер Г. Погребальные комплексы с мерзлотой на Северо-Западе Монголии (пазырыкская культура) .....

Новожёнов B.A. Модель коммуникации ранних кочевников

Центральной Азии

Полин С.В., Дараган М.Н. Раскопки Александропольского кургана в 2004-2009 гг.

Попова E.A. Орнаментированные лепные курильницы с городища «Чайка»

в Северо-Западном Крыму. 
Разуваев Ю.Д. Бронзовые предметы скифского времени с верхнедонского городища у с. Верхнее Казачье

Советова О.С., Моор Н.Н. Два «мира» тагарского искусства:

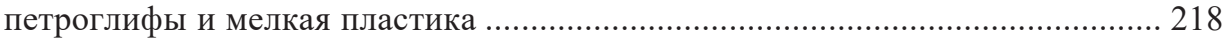

Эрлих В.P. Финал поздней бронзы в предгорьях Адыгеи........................................ 230

Ранний железный век Евразии:

Сарматская эпоха и Великое переселение народов

Аникеева O.B. Время появления и происхождение наборов бус

из раннесарматских погребений могильника Филипповка II 251

Бабиец А.И., Богачук Е.О. Монеты «неизвестного народа»

на полуострове Абрау

Березуичкий В.Д. Мужские погребения сарматов

Новочигольского курганного могильника.... 271

Калинина T.M. Арабский учёный ал-Хорезми (IX в.) о Скифии и Сарматии............. 280

Ковалевская В.Б. Возникновение раннеаланской культуры Кавказа

в свете теоретико-методических проблем 288

Сиротин С.В. Элементы конской сбруи из некрополя «Ивановские I курганы» на Южном Урале

Тишкин A.A. Фрагмент одежды из кургана № 4 памятника Бугры

(предгорно-степная зона Алтая, скифо-сарматское время).

Трейстер М.Ю. Парфянская резная кость из погребений кочевников азиатской Сарматии

Прюх М., Трейстер М.Ю. Погребение среднесарматского времени

в окрестностях Танаиса с китайской лаковой чашей «эр бэй»....

\section{Комплексный подход в исследованиях памятников эпохи раннего железа}

Воробьёва С.Л. Металлообработка эпохи раннего железа

по материалам исследований металлургического комплекса горы Курмантау

в Гафурийском районе Республики Башкортостан.

Гильмитдинова A.X. Краниофенетическая характеристика ранних кочевников

Южного Урала второй половины VI - II в. до н.э.

(предварительное сообщение)

Добровольская М.В., Чагаров О.С., Хартанович В.И. Данные

об изотопном составе костной ткани в изучении структуры обществ

кочевников раннего железного века

Лошенков М.И. Археоботанические коллекции

племён днепро-двинской культуры

Медникова М.Б. Погребения скифской элиты в могильнике Новозаведенное II по данным антропологии ....

Сыроватко А.С., Добровольская М.В. Изотопы стронция

в кремациях могильников Средней Оки середины I - начала II тыс. н.э.:

опыт изучения территориальной дифференциации населения. 


\section{МЕЖДУНАРОДНАЯ НАУЧНАЯ КОНФЕРЕНЦИЯ «НОВОЕ В ИССЛЕДОВАНИЯХ РАННЕГО ЖЕЛЕЗНОГО ВЕКА ЕВРАЗИИ: ПРОБЛЕМЫ, ОТКРЫТИЯ, МЕТОДИКИ» (Москва, 13-14 ноября 2017 года) \\ Гуляев В.И., Канторович А.Р., Коробов Д.С., Малашев В.Ю., Скорый С.А.}

http://10.25681/IARAS.2019.978-5-317-06274-3/5-16

Спектр научных тематик, изучаемых сотрудниками Отдела скифо-сарматской археологии ИА РАН на протяжении семи десятилетий, был необычайно широк и связан, главным образом, с ранним железным веком Евразии. Актуальность проведения научного форума сомнений не вызывает: в последние годы ощутимо ослабло взаимодействие между крупнейшими научными центрами России и ближнего зарубежья (Белоруссии, Украины, Казахстана и т.д.), в исследовательской среде отчётливо наметилась смена поколений. В этих условиях возросла потребность обмена опытом построения исследовательского процесса (новых методик), а также введения в научный оборот новых материалов. В целом в конференции приняло участие 140 учёных, среди которых 22 зарубежных участника. Они представляли ведущие учреждения Российской Федерации, ближнего (Абхазия, Белоруссия, Казахстан, Украина) и дальнего зарубежья (Германия и Китай). На заседаниях было заслушано 64 устных доклада, в холле конференц-зала были размещены постеры (35) заочных участников научного форума.

Ключевые слова: Ранний железный век, научный форум, междисциплинарные и комплексные исследования, история науки, скифы, сарматы, курган.

Инициатором организации и проведения конференции выступил Отдел скифо-сарматской археологии Института археологии РАН: 70 лет тому назад - 7 февраля 1947 г. на первом заседании Скифо-сарматской группы сектора Первобытной культуры ИИМК АН СССР прозвучал доклад К.Ф. Смирнова «О роксоланских погребениях». В 2017 году Константину Фёдоровичу, являвшемуся на протяжении ряда десятилетий лидером в изучении сарматских древностей, автору ставших классическими для этой тематики исследований, исполнилось бы сто лет со дня рождения.

Спектр научных тематик, изучаемых сотрудниками Отдела скифо-сарматской археологии на протяжении десятилетий, был необычайно широк и связан, главным образом, с Ранним железным веком Евразии. Актуальность проведения научного форума сомнений не вызывает: в последние годы ощутимо ослабло взаимодействие между крупнейшими научными центрами России и ближнего зарубежья (Белоруссии, Украины, Казахстана и т.д.), в исследовательской среде отчетливо наметилась смена поколений. В этих условиях возросла потребность обмена опытом построения исследовательского процесса (новых методик), а также введения в научный оборот новых материалов. 


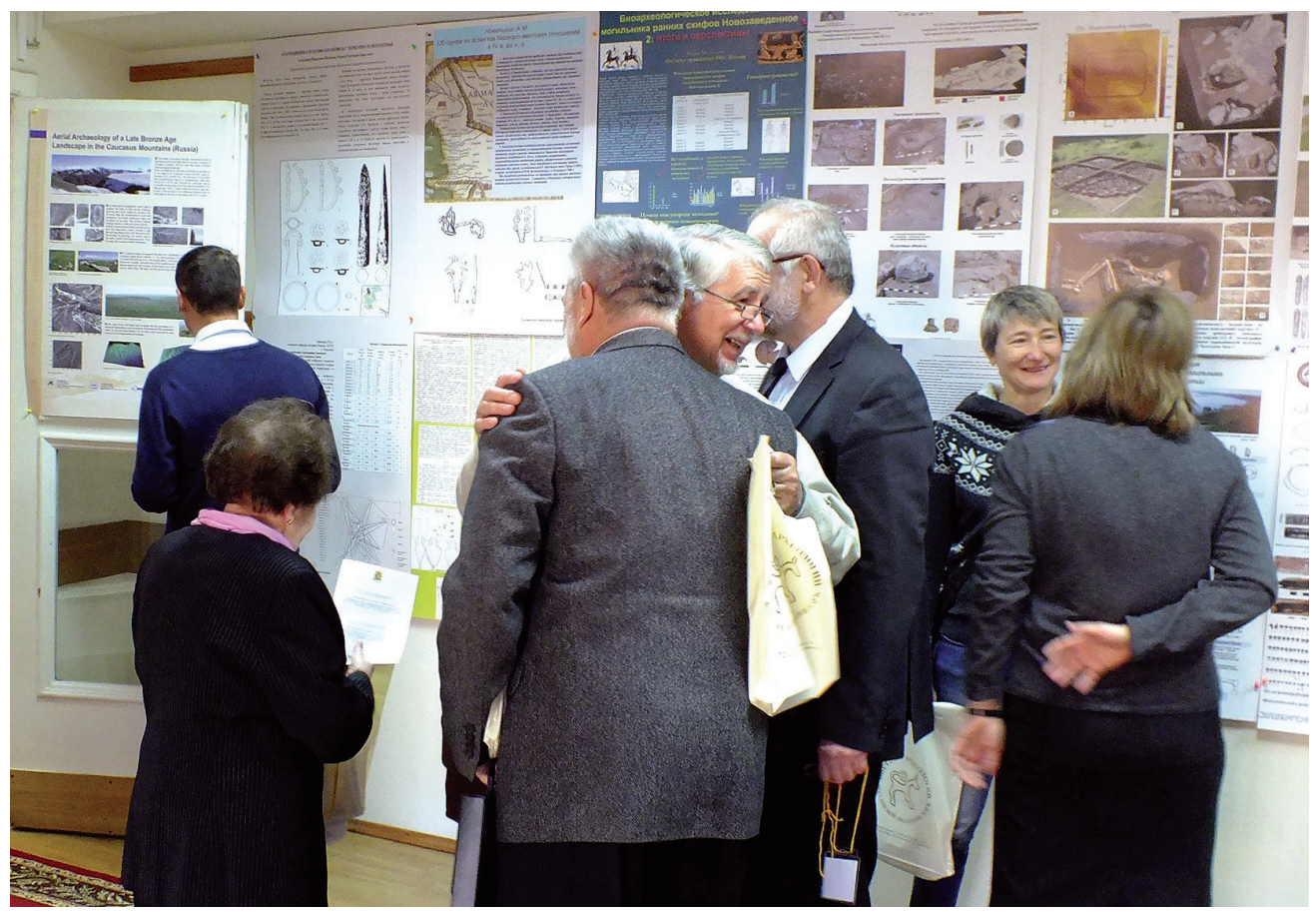

Перед пленарным заседанием в зале постерных докладов

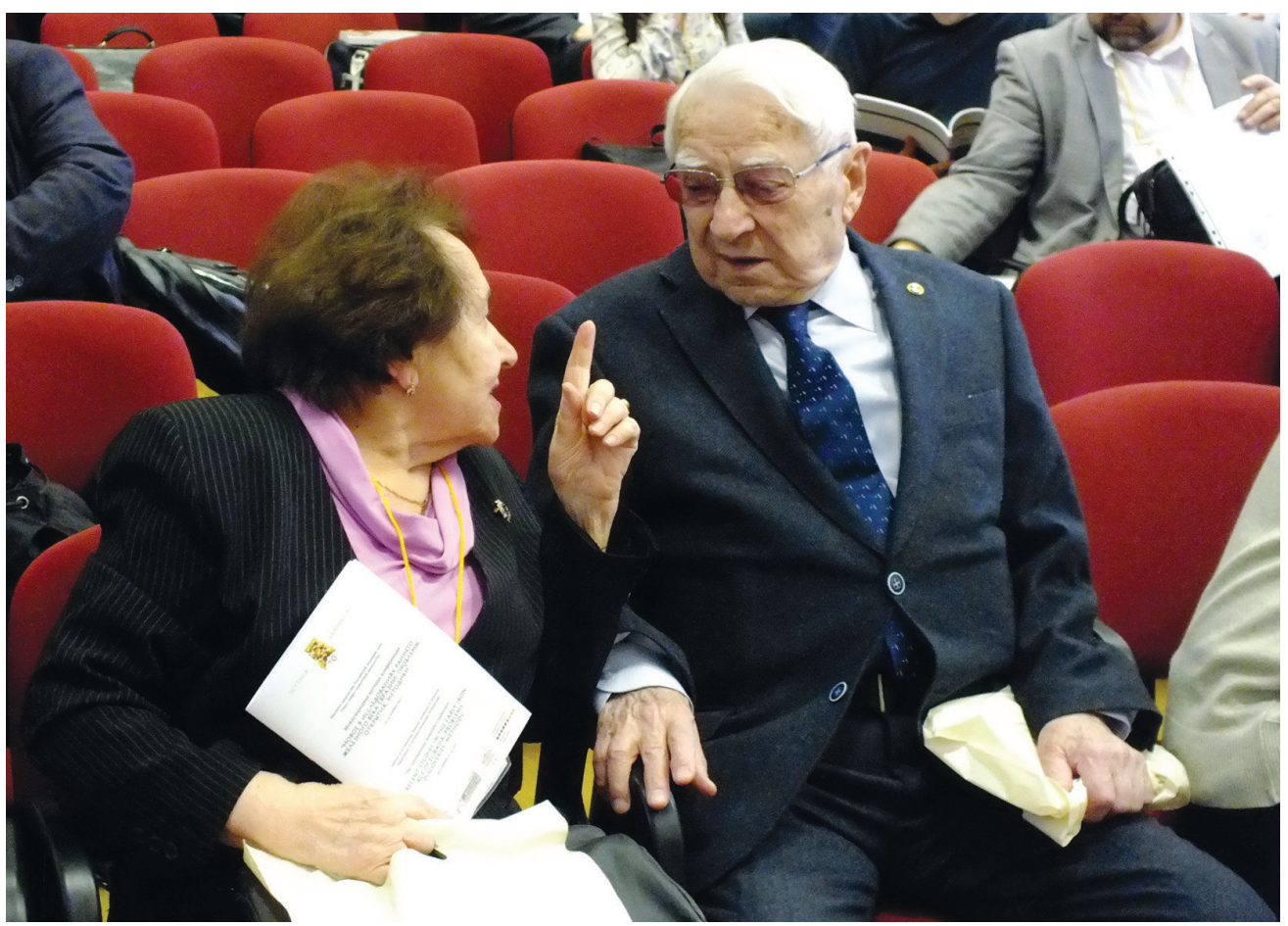

Перед пленарным заседанием: д.и.н. М.Г. Мошкова и чл.-корр. РАН Р.М. Мунчаев 


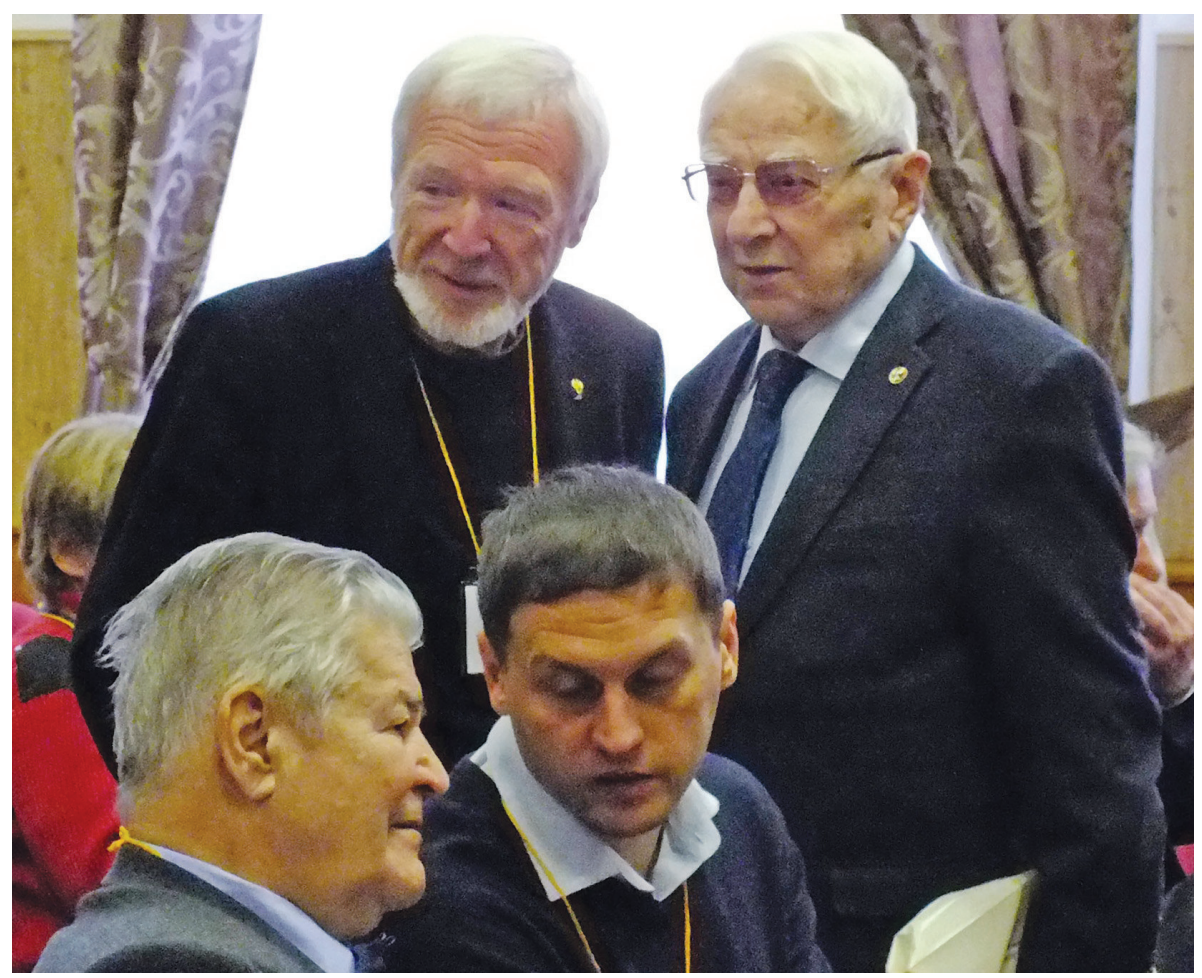

Перед пленарным заседанием: академик РАН В.И. Молодин, чл.-корр. РАН Р.М. Мунчаев, д.и.н. В.И. Гуляев, В.Н. Окатенко

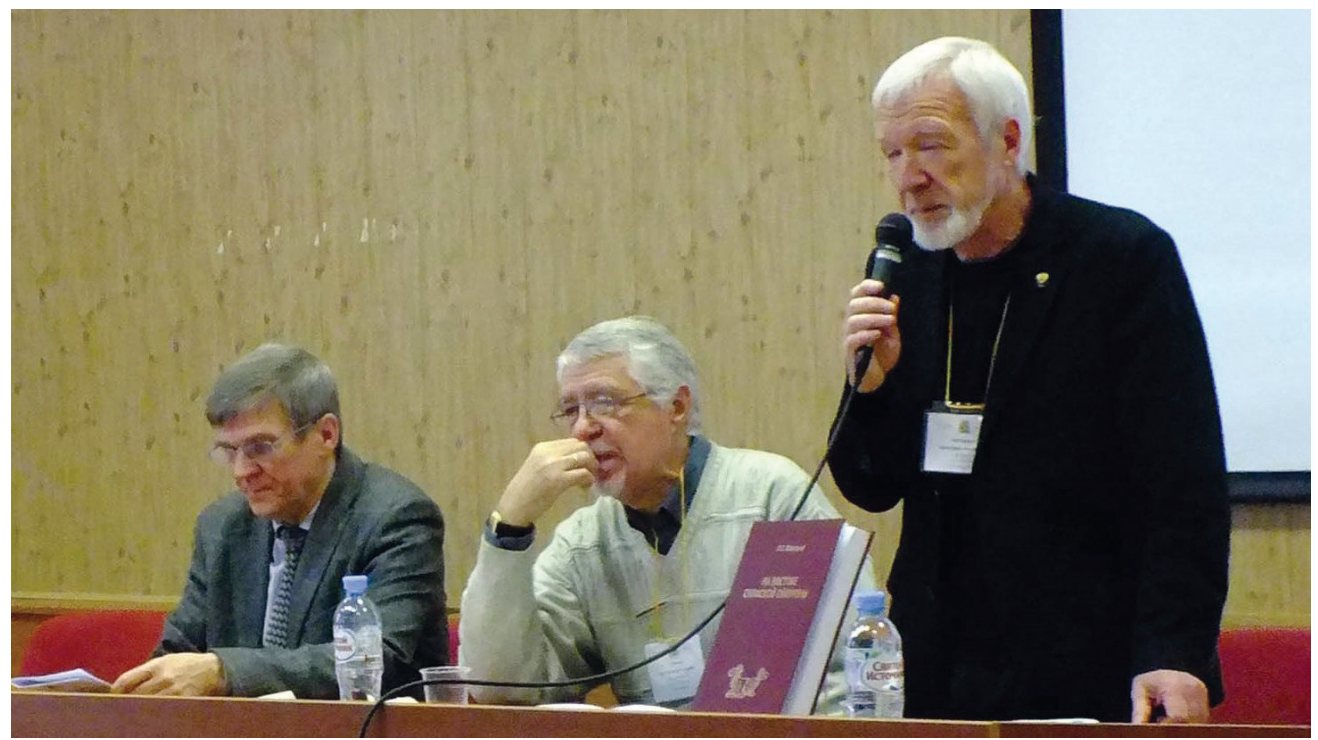

В Президиуме пленарного заседания: чл.-корр. РАН П.Г. Гайдуков, академик РАН В.И. Молодин (оба - Россия), д.и.н. С.А. Скорый (Украина).

В.И. Молодин озвучивает приветственное слово Директора Фонда прусского культурного наследия, профрессора Германа Парцингера 
Пленарное заседание первого дня работы конференции (в здании Института археологии РАН), открыл заместитель директора ИА РАН, член-корреспондент РАН П.Г. Гайдуков ${ }^{1}$. В его выступлении, а также в докладе заведующего отделом скифо-сарматской археологии к.и.н. А.А. Малышева был показан вклад отдела в изучение целого ряда направлений археологии России и зарубежья (Восточной Европы, Латинской Америки, Ближнего Востока). Поздравительные приветствия отделу и конференции прозвучали от научных учреждений ближнего и дальнего зарубежья (Фонда «Прусское наследие», исторического факультета Брянского государственного университета, Государственного музея Республики Абхазия) и ведущих научных учреждений России: Государственного Эрмитажа, Государственного исторического музея, ряда научных подразделений Волгоградского государственного университета, Государственного музея Востока, Института истории материальной культуры РАН, кафедры археологии исторического факультета Московского государственного университета им. М.В. Ломоносова, Института истории и международных отношений Южного федерального университета.

Торжественный момент подчеркнули и выступления, посвящённые руководителям отдела скифо-сарматской археологии в разные годы, исследователям кочевых культур Раннего железного века. Доклад А.Р. Канторовича осветил вклад основателя Отдела скифо-сарматской археологии Б.Н. Гракова в изучение Раннего железного века Евразии. Воспоминаниями о К.Ф. Смирнове как учёном, полевике и учителе поделился д.и.н. В.И. Гуляев.

На пленарном заседании была представлена изданная в 2017 году фундаментальная монография «На востоке скифской ойкумены». Знавший лично со студенческой скамьи автора исследования - безвременно ушедшего руководителя Отдела скифо-сарматской археологии (2002-2016) д.и.н. Л.Т. Яблонского член-корреспондент РАН Л.А. Беляев очертил жизненный и научный путь учёного серией ярких эпизодов.

Второй день работы конференции прошёл в Государственном Историческом музее под председательством ученика Б.Н. Гракова, лауреата Государственной премии РФ в области культуры А.И. Шкурко. Как и в первый день, пленарные доклады: И.В. Белоцерковской «Некоторые детали биографии А.П. Смирнова (по материалам Отдела письменных источников ГИМ)» и члена-корреспондента РАН Р.М. Мунчаева «О Владиславе Всеволодовиче Кропоткине как исследователе, руководителе и друге», - позволили вспомнить о выдающихся учёных и организаторах науки, руководителях Отдела скифо-сарматской археологии в 1950-1980-е годы.

В целом в конференции приняло участие 140 учёных, среди которых 22 зарубежных участника. Они представляли ведущие учреждения Российской Федерации, ближнего (Абхазия, Белоруссия, Казахстан, Украина) и дальнего

${ }^{1}$ Cм.: http://scythia-sarmatia.ru/конференция-scythia-et-sarmatia. Дата обращения: 20.11.2019. 


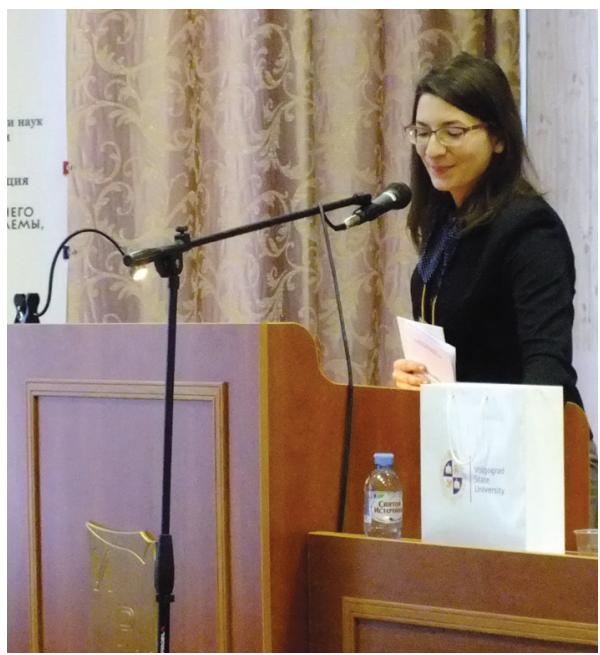

Пленарное заседание.

Приветственное слово от Германского дома науки и инноваций А.К. Савостиной

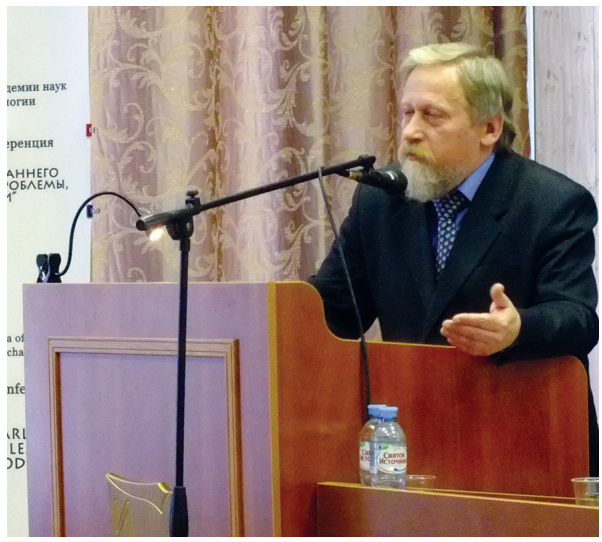

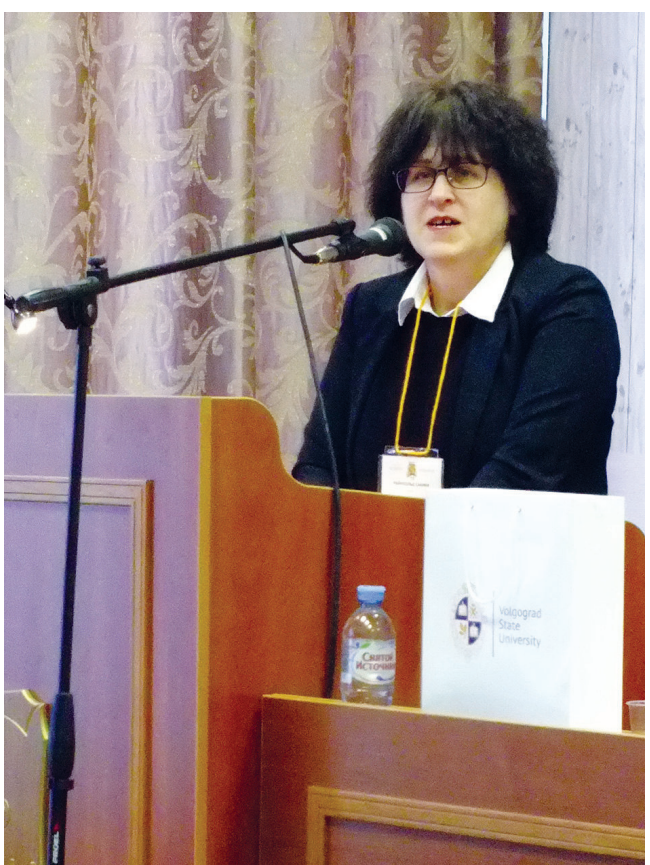

Пленарное заседание.

Приветственное слово от Берлинского отделения Немецкого археологического института доктора Сабины Рейнгольд

Пленарное заседание.

Приветственное слово от Государственного Эрмитажа д.и.н. А.Ю. Алексеева

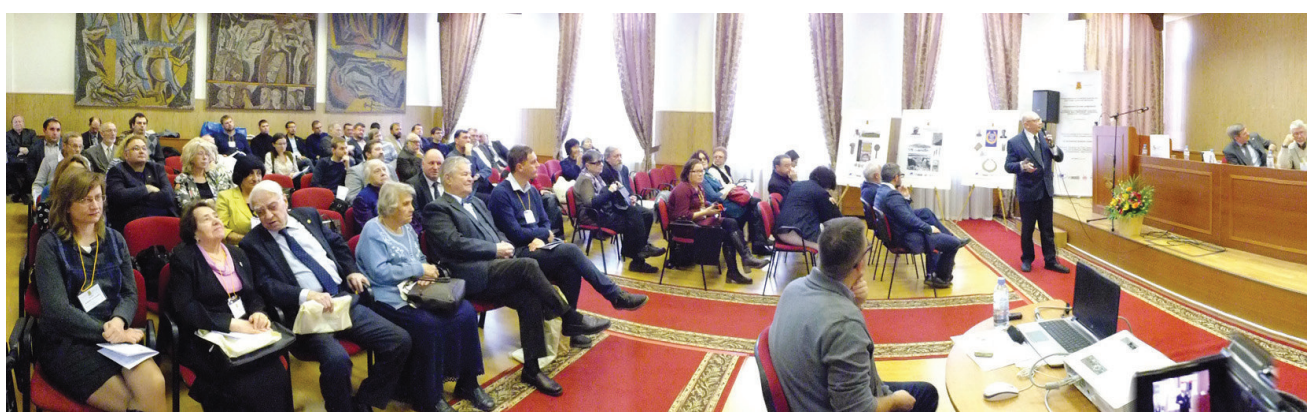

Пленарное заседание. Доклад зам. Председателя Оргкомитета конференции к.и.н. А.А. Малышева «История отдела скифо-сарматской археологии ИА РАН в материалах конференции "Новое в исследованиях раннего железного века Евразии: проблемы, открытия, методики”» 
зарубежья (Германия и Китай). На заседаниях было заслушано 64 устных доклада, в холле конференц-зала были размещены постеры (35) заочных участников научного форума ${ }^{1}$.

Наиболее насыщенной оказалась двухдневная работа секции «Ранний железный век Евразии в скифскую эпоху» (председатели секции - д.и.н. В.И. Гуляев, д.и.н. А.А. Скорый, д.и.н. А.Р. Канторович), на которой было заслушано 40 докладов.

Хронологически тематика докладов была, в основном, ограничена предскифской и скифской эпохами, т.е. IX - началом III вв. до н.э., тогда как в пространственном отношении охват был весьма широк - доклады были связаны со «скифо-сибирским миром» от Дуная до Байкала и с сопредельными территориями.

Ряд докладов был посвящён общим вопросам, относящимся к функционированию скифо-сибирской культурно-исторической общности, либо с определёнными аспектами её изучения.

Так, Н.Ю. Смирнов посвятил своё сообщение семиотическому статусу (в погребальном контексте) таких важнейших для кочевника скифской эпохи предметов, как лук и конская плеть.

В.А. Кисель в своём докладе специально обратился к одному из важнейших конструктивных мотивов скифо-сибирского декоративного стиля в азиатской части «скифо-сибирского мира» и на сопредельных территориях - к мотиву «сложный завиток», трактуемый рядом исследователей как результат стилизации изображения птичьей головы. Автор, напротив, привёл аргументы в пользу того, что фигура «сложного завитка» появилась в древнекочевническом мире в силу чисто функциональных причин, в качестве замысловатого поясного крючка, а уже затем последовала орнитоморфизация данной детали.

К.В. Чугунов в своём докладе подверг ревизии абсолютную хронологию наконечников стрел скифской эпохи, разработанную К.Ф. Смирновым, аргументируя необходимость удревнения этих наконечников почти на три четверти столетия; при этом относительная хронология, основанная на классификации К.Ф. Смирнова, представляется автору вполне актуальной.

Т.М. Кузнецова посвятила свой доклад сравнительной характеристике аристократических скифских захоронений из «Репяховатой Могилы», «Червоной Могилы» и Келермессского курганного могильника. Исследовательница, отрицая устоявшуюся датировку этих памятников VII в. до н.э., пришла к выводу о том, что данные памятники были оставлены близкими группами скифов, быстро продвинувшимися ко второй четверти VI в. до н.э. с территории Северного Кавказа в западном направлении.

А.Ю. Алексеев в докладе, посвящённом наконечникам стрел скифского типа, обнаруженным на поле Марафонской битвы, пришёл к выводу об их при-

${ }^{1}$ Cм.: http://scythia-sarmatia.ru/publish. Дата обращения: 20.11.2019. 
черноморском характере и датировал второй половиной VI - первой четвертью $\mathrm{V}$ в. до н.э., в то же время оставив открытым вопрос об источниках появления этих стрел в битве при Марафоне, во всяком случае исключив их персидскую или сакскую атрибуцию.

Ряд докладов был посвящён результатам новых исследований скифской культуры на территории Северного Причерноморья, Приазовья, Крыма и Предкавказья - т.е. собственно в зоне скифской археологической культуры.

В частности, доклад В.С. Синики представляет результаты исследований скифского кургана восьмой группы «Водовод»у с. Глиное на левобережье Нижнего Днестра, датируемого рубежом IV-III - первой третью III вв. до н.э. В данном кургане впервые для Северо-Западного Причерноморья было зафиксировано сочетание двух принципиально различных видов погребальных сооружений - ям и катакомб. Это, по мнению автора, демонстрирует трансформацию скифского погребального обряда в последней четверти IV - первой трети III вв. до н.э. в данном регионе.

В докладе С.А. Скорого, А.П. Орлика и Р.В. Зимовца представлены результаты раскопок кургана у с. Богдановка Кировоградской обл., относящегося к эпохе скифской «архаики».

Доклад В.Н. Окатенко, С.А. Скорого и Р.В. Зимовца был посвящён результатам раскопок кургана эпохи скифской «архаики» в рамках Люботинского могильника в Харьковской области.

В докладе В.И. Гуляева рассмотрен сложнейший вопрос этнической атрибуции населения Среднего Подонья в скифскую эпоху. Автор приходит к выводу об изначальной принадлежности соответствующих курганных могильников и городищ-убежищ V-IV вв. до н.э. группе кочевых или полукочевых скифских племён, периодически откочёвывавших в данные районы, и, соответственно, эти регионы следует считать северной периферией Большой Скифии.

Не менее сложной проблеме, связанной с той же территорией Среднего Подонья, посвящён доклад С.А. Володина, проанализировавшего по материалам раскопок могильников Мастюгино и Терновое-Колбино данные о подкурганных святилищах скифской эпохи, созданных для проведения поминальных ритуалов с применением огня.

Доклад Ю.Д. Разуваева был посвящён исследованиям, проведённым в 2015 и 2016 гг. на городище скифской эпохи у с. Верхнее Казачье на Среднем Дону, культурные слои которого дифференцируются автором по трём культурнохронологическим блокам.

Доклад В.В. Кропотова и С.Г. Колтухова посвящён интереснейшему с точки зрения скифской погребальной архитектуры кургану «Волчий Грот-1» в предгорном Крыму, - памятнику, раскопанному в 2017 г. в рамках работ в зоне федеральной трассы «Таврида».

Доклад А.Р. Канторовича и В.Е. Маслова посвящён обзору трёх сезонов исследований скифского могильника Новозаведенное-III (последняя треть V - 
IV в. до н.э.) в Георгиевском районе Ставропольского края. Авторы отмечают, что погребальный обряд и материальная культура данного могильника демонстрируют очевидную преемственность по отношению к памятникам скифской культуры архаического горизонта в данном регионе, а также обращают внимание на широкий круг культурных контактов создателей данного могильника с античными центрами и варварской (меотской) периферией Боспорского царства на Кубани, Колхидским царством и сарматами.

В докладе В.П. Копылова и А.Н. Коваленко на основании новых материалов, полученных при изучении системы обороны Елизаветовского городища, подтверждается ранее высказанное авторами предположение о военных конфликтах, имевших место в дельте Дона в третьей четверти IV - первой трети III в. до н.э., - в частности, о военных акциях в 40-х гг. IV в. до н.э. против жителей Елизаветовского городища ещё в его бытность ключевым скифским поселением, а также о последующем разгроме в 70-х гг. III в. до н.э. боспорской колонии, основанной на месте скифского городища.

Несколько докладов были посвящены замечательной пазырыкской культуре, в том числе новейшим исследованиям в этой области.

Так, в докладе В.И. Молодина и Г. Парцингера были представлены результаты исследований памятников пазырыкской культуры на Северо-Западе Монголии.

Д.В. Черемисин посвятил свой доклад анализу определённых наскальных изображений с территории Российского и Монгольского Алтая, вполне обоснованно отнесённых им к кругу звериного стиля пазырыкской культуры; автор наглядно продемонстрировал аудитории атрибуцию данных петроглифов на основе высококачественных фотографий.

А.А. Тишкин в своём докладе представил основные итоги раскопок кургана № 4 элитарного курганного могильника Бугры в северо-западных предгорьях Алтая.

Серия докладов была посвящена сугубо кавказской тематике (меотской, кобанской и колхидской культурам) на хронологическом срезе предскифской и скифской эпох.

Так, В.Р. Эрлих представил материалы трёх памятников финала бронзового века в предгорной и горной части Адыгеи, недавно открытых Кавказской археологической экспедицией Государственного музея Востока - могильника и поселения Шушук, погребения у хут. Гавердовского и поселения Деметра. Исследователь трактует эти памятники как особый субстрат предгорных протомеотских памятников Раннего железного века на Северо-Западном Кавказе, отличный от кобяковской и постдольменной культур.

А.В. Иванов в своём докладе дает подробную информацию о сложном диахронном элитном погребальном комплексе в Западном Левобережье Кубани, в рамках которого выделяется крупная меотская погребальная конструкция начала IV в. до н.э. 
А.И. Бабиец и Е.О. Богачук посвятили своё сообщение попытке реконструкции культурно-исторических процессов в зоне меотской культуры (в Анапской долине) на основе сравнительной топографии и хронологии археологических памятников данного микрорегиона.

А.А. Кадиева, Н.А. Биркина в своём докладе на основании исследований могильника Заюково-3 в Кабардино-Балкарии в 2015 г. предприняли реконструкцию женского погребального убора западной кобанской археологической культуры VIII-VII вв. до н.э. В другом докладе, посвящённом тому же памятнику, А.А. Кадиева и С.В. Демиденко представили новейшие результаты исследований данного могильника (сезон 2017 г.).

Анализу параллелей и реконструкции связей между кобанской культурой и гальштатской культурно-исторической общностью был посвящён доклад С. Райнхольд.

Доклад А.Ю. Скакова, А.И. Джопуа и З.Г. Хондзия посвящён весьма интересному элитному комплексу колхидской культуры в Абхазии.

Несколько докладов были связаны с позднескифской, сарматской и античной тематикой. В частности, позднескифской эпохе был посвящён доклад Е.А. Поповой, анализирующей лепные курильницы Крыма, происходящие с поселений или из близлежащих могильников.

Доклад Ю.П. Зайцева дает обзорную характеристику Крымской Скифии эпохи эллинизма - массива памятников последней четверти IV в. до н.э. - рубежа эр. Автор определяет три зоны их концентрации - западную, центральную и восточную - и выявляет динамику постепенного перемещения политических и культурных приоритетов от восточного «центра силы» к центральному в середине II в. до н.э.

Новым археологическим данным, характеризующим динамику греческой колонизации Таманского полуострова, посвятили свой доклад Д.В. Журавлёв и У. Шлотцауэр.

С.А. Яценко в своем докладе анализирует граффити, выявленные в 1998 г. на внешней облицовке у входа в храм Байте III на Устюрте. Автор приходит к выводу о параллелях между данными изображениями, связанными с поздним использованием храма на рубеже эр, и архаичными алано-осетинскими представлениями о поминках, попадании умершего героя в иной мир, его воскрешении и т.п.

Наконец, Н.А. Кренке и А.Л. Александровский представили в своём докладе итоги новейших исследований дьяковской культуры, в том числе результаты использования естественнонаучных методов (почвоведения и палеоботаники) в процессе реконструкции ландшафта и хозяйственной деятельности вокруг соответствующих городищ.

На секции «Ранний железный век Евразии: сарматская эпоха и Великое переселение народов» (председатель секции - к.и.н. В.Ю. Малашев) было заслушано 14 докладов. Следует отметить широкий территориальный (от Северного 


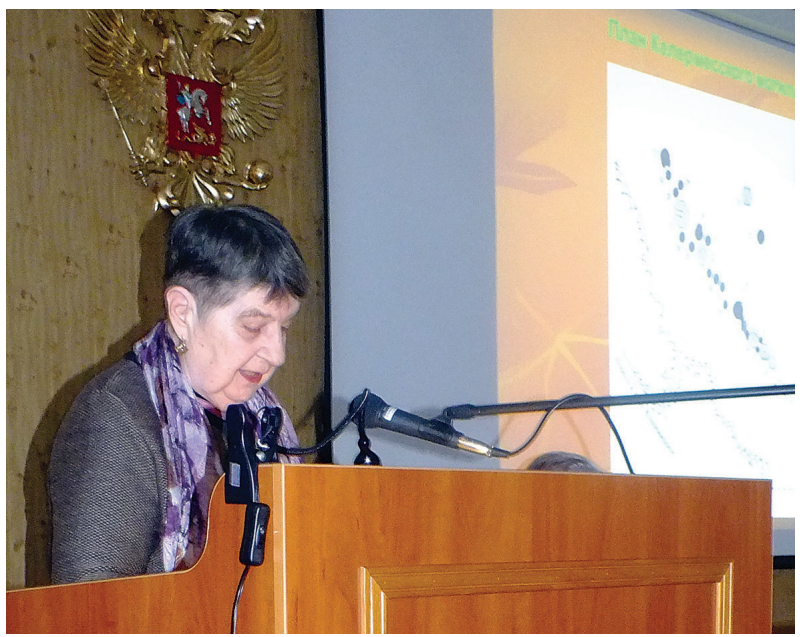

Заседание секции

«Ранний железный век Евразии в скифскую эпоху»

Заседание секции «Ранний железный век Евразии: сарматская эпоха и Великое переселение народов»
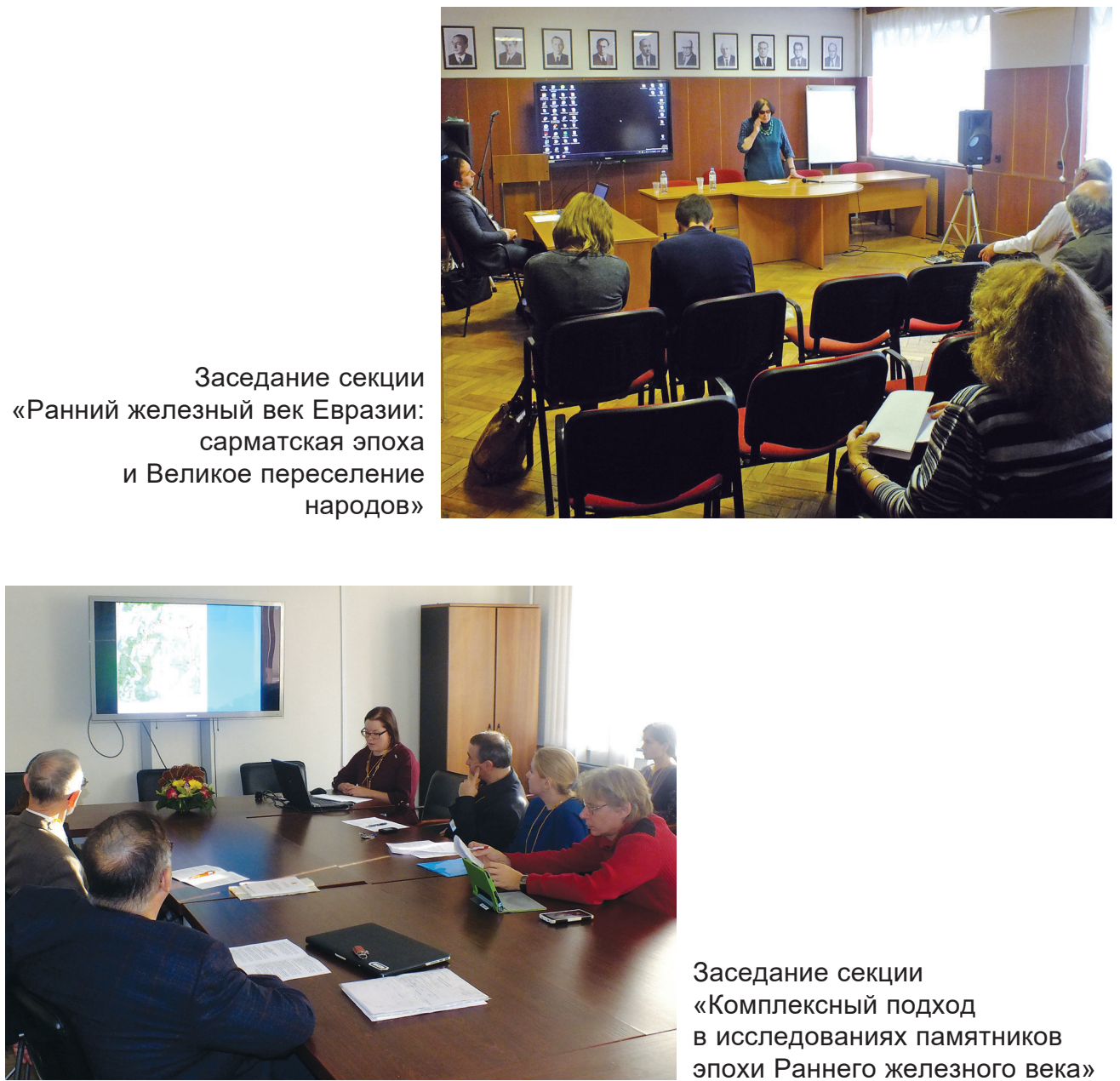

Заседание секции «Комплексный подход в исследованиях памятников эпохи Раннего железного века» 
Кавказа и степей юга России до Алтая) и хронологический (савроматское и сарматское время) охват тематики докладов. В докладе В.Б. Ковалевской «Теоретико-методический аспект изучения “модели происхождения" савроматосарматских культур на примере возникновения культуры северокавказских алан» на конкретном материале рассмотрен механизм взаимодействия оседлого (субстратного) и пришлого кочевого населения с последующей выработкой нового культурного комплекса и нового этнического образования. Большая часть докладов была посвящена анализу отдельных категорий инвентаря, в том числе импортным изделиям: В.Н. Мышкин «О типах подпружных застежек у кочевников Южного Приуралья в VI-IV вв. до н.э.», О.В. Аникеева «Наборы бус из погребений ранних кочевников южного Урала (конец VI - III в. до н.э.)», В.П. Глебов «О сарматских элементах в ритуальных кладах III-I вв. до н.э.», М.Ю. Трейстер «Парфянская резная кость из погребений кочевников Азиатской Сарматии первых веков н.э.», М. Прюх, М.Ю. Трейстер «Погребение среднесарматского времени могильника “Царский” в окрестностях Танаиса с китайской лаковой чашей “эр бэй”», А.В. Дедюлькин «Чернолаковый сосуд из погребения 14 Большого Ипатовского кургана и хронология прохоровских погребений». Некоторые аспекты погребального обряда были рассмотрены Е.В. Вдовченковым в докладе «Ровики на некрополях нижнедонских поселений в первые века нашей эры».

Е.М. Данченко в своем докладе «Саргатский феномен в контексте субкультурных взаимодействий» рассмотрел проблему наличия в составе саргатской общности различных этнических, языковых, социальных, религиозных групп.

В докладах М.А. Балабановой «Дифференциация антропологического типа сарматского населения Восточно-европейских степей» и Л.А. Краевой «Гончарные традиции ранних кочевников Западного Казахстана IV-I вв. до н.э.» отражено использование естественнонаучных методов при анализе археологического и антропологического материала.

Ряд докладов посвящён введению в научный оборот новых материалов из раскопок последнего полевого сезона: А.А. Бисембаев, А.И. Хаванский «Раскопки могильника Кайынбулак II в Актюбинской области Республики Казахстан в 2017 г.», О.А. Шинкарь «Кованый бронзовый котёл с надписью и сарматские погребения курганного могильника у хут. Базки с территории Волгоградской области. Раскопки 2017 г.», О.С. Лихачёва «Случайные находки вооружения VI-I вв. до н.э. из лесостепного Алтая».

На секции «Комплексный подход в исследованиях памятников эпохи Раннего железного века» (председатель - д.и.н. Д.С. Коробов) прозвучало восемь докладов. Н.Н. Белая представила доклад, подготовленный совместно с Е.В. Лукиной, посвящённый использованию естественнонаучных методов в изучении керамики скифского времени Среднего Дона. С.Л. Воробьёвой было сделано сообщение о результатах исследования металлургического комплекса эпохи раннего железа горы Курмантау в Республике Башкортостан. 
Большой интерес у аудитории вызвало выступление М.В. Добровольской и О.С. Чагарова, в котором давался анализ традиций питания и мобильности населения Среднего Дона скифского времени по данным изотопного анализа костных останков. Мультидисциплинарный подход к изучению технологических особенностей кузнечной продукции из памятников Степной Скифии и Сарматии был продемонстрирован В.И. Завьяловым.

Тема взаимодействия представителей гуманитарных и естественных наук была продолжена в докладе Д.С. Коробова, подготовленном совместно с В.Ю. Малашевым и Й. Фассбиндером. Работа коллектива археологов и геофизиков касалась комплексного изучения памятников ранних алан в Кисловодской котловине. М.И. Лошенков представил аудитории результаты археоботанического анализа материалов с памятников днепро-двинской культуры в Республике Беларусь.

Теоретические модели распространения инноваций и взаимодействия кочевого и оседлого населения на примере ранних кочевников на северных границах Китая и в Казахской степи рассматривались в докладе В.А. Новожёнова. Завершил работу секции совместный доклад А.С. Сыроватко и М.В. Добровольской, посвящённый комплексному изучению погребений-кремаций эпохи Великого переселения народов с территории Средней Оки. В последовавшей затем дискуссии отмечалась важность мультидисциплинарного подхода в современных археологических исследованиях и необходимость расширения потенциальной аудитории слушателей подобных сообщений.

Первый день заседаний завершился товарищеским ужином, а во второй участникам конференции была предоставлена возможность продолжить профессиональное общение в рамках экскурсионной программы по археологической экспозиции Государственного Исторического музея, подготовленной сотрудниками Отдела археологических памятников музея. Участники научной конференции отметили высокий научный и организационный уровень мероприятия, с материалами которого можно было ознакомиться в он-лайн режиме, и высказали пожелание подготовки и издания сборника материала конференции. 
К 100-ЛЕТИЮ СО ДНЯ РОЖДЕНИЯ К. Ф. СМИРНОВА 



\title{
ЛИЧНЫЙ ФОНД К.Ф. СМИРНОВА В АРХИВЕ ИА РАН
}

\author{
Малымев А.А., Батченко В.С., Горланов С.С. \\ http://10.25681/IARAS.2019.978-5-317-06274-3/19-24
}

Результаты многолетней творческой деятельности авторитетного учёного скифосарматолога Константина Фёдоровича Смирнова ныне доступны не только по опубликованным научным работам, но и в личном фонде исследователя в архиве Института археологии РАН. Фонд включает в себя одну опись, объединяющую 67 папок, сгруппированных тематически. В комплектации единиц хранения приоритет был отдан хронологическому признаку, так как деятельность учёных-археологов базируется на проведении экспедиций, результаты которых логично группировать по годам. Одновременно с этим информация объединена тематически (организация рабочих материалов и рукописей по тематикам) и на основе номинальных признаков (с учётом разновидностей документов). Коллекция фонда К.Ф. Смирнова располагает как материалами, уже вышедшими в печать, так и неопубликованными работами автора, и, возможно, благодаря чуткости будущих исследователей фонда труд Константина Фёдоровича ещё найдёт своё место среди специальных научных публикаций.

Ключевые слова: архив, фонд, фотодокументы, сарматская культура, экспедиция

Результаты многолетней творческой деятельности авторитетного учёного скифо-сарматолога Константина Фёдоровича Смирнова ныне доступны не только по опубликованным научным работам, но и в личном фонде исследователя в архиве Института археологии РАН. Фонд включает в себя одну опись, объединяющую 67 папок, сгруппированных тематически.

Систематизация документов проводилась с учётом нескольких признаков. В комплектации единиц хранения приоритет был отдан хронологическому признаку, так как деятельность учёных-археологов базируется на проведении экспедиций, результаты которых логично группировать по годам. Одновременно с этим информация объединена тематически (организация рабочих материалов и рукописей по тематикам) и на основе номинальных признаков (с учётом разновидностей документов).

Внутренняя организация единиц хранения фонда К.Ф. Смирнова предусматривает объединение в описи двух крупных блоков разновидностей документов: вначале даны материалы археологических экспедиций (папки 1-40), далее сгруппированы рукописи фондообразователя и рабочие материалы по изучению отдельных культур и территорий (папки 41-67).

Сведения об экспедиционной деятельности К.Ф. Смирнова в его личном фонде начинаются с 1948 года - с документов о работах Дагестанской экспедиции (в 1948-1949 гг. она также именовалась Сарматской Северо-Кавказской АЭ ${ }^{1}$ ), руководство которой в том же году он перенял у Евгения Игнатьевича Крупнова [Твердохлебов, 1948; Абакаров, Давудов, 1993. С. 9]. За Дагестанский период

\footnotetext{
${ }^{1}$ Археологическая экспедиция (далее - АЭ).
} 
научной работы Смирнова выделяются материалы по работам на Таркинском могильнике, поселении Агач-Кала, Карабудахкентских могильниках (№ 2, 3) и Манасских курганах.

Материалы четырёхлетнего периода работы над изучением памятников Дагестана включают в себя традиционное для Константина Фёдоровича видовое разнообразие экспедиционных источников: полевые дневники и описи находок, полевые и выбеленные на фотографической бумаге чертежи раскопов и планы погребений, собственноручные зарисовки находок с описаниями, размерами и имеющейся библиографией, фотографии погребений, рабочих моментов и находок, отчёты и результаты лабораторных анализов.

Судя по документам, в конце 1948 г. учёный заключил трудовое соглашение с Дагестанским краеведческим музеем (г. Махачкала) по составлению археологической карты Дагестана. Молодой кандидат исторических наук обязался за два года подготовить карточки археологических памятников Дагестана и собственно контурную карту «с нанесенными на ней условными знаками всех найденных археологических памятников» [Архив ИА РАН. Ф. 34. Оп. 1. Папка 9. Конверт 4. Л. 14]. В ходе этой работы Константин Фёдорович активно изучает археологические древности Дагестана как по опубликованным материалам, так и в фондах ГИМ, ИИМК, Дагестанской базы АН СССР, Краеведческого музея Дагестанской АССР и т.д. Любопытно, что в историографии исследований археологических памятников Дагестана данный факт до сих пор остаётся слабо освещённым. Начало масштабных археологических работ на территории Дагестана в послевоенное время историки относят к 1951 году, когда начинает собственные экспедиционные изыскания Институт истории, языка и литературы Дагестанского филиала АН СССР [Лысенко, 2015. С. 67]. Возможно, сохранившиеся документы о сотрудничестве К.Ф. Смирнова и Дагестанского краеведческого музея помогут внести коррективы в историю создания археологической карты Дагестана.

С 1952 года Константин Фёдорович приступил к работам Сталинградской археологической экспедиции, ведущей деятельность в зоне будущего затопления, связанного со строительством Волжской гидроэлектростанции (ГЭС). В рамках Сталинградской экспедиции тогда функционировало четыре отряда, Смирнов принял руководство I (первым) Нижне-Волжским отрядом. Начались систематические исследования курганных могильников у сел Политотдельское («Политотдельское», «Политотдельское-ІІ»), Иловатка (курганные группы «Иловатка», «Иловатка-аэродром»), Калиновка (Калиновский могильник) Сталинградской области; с 1954 г. появляются материалы раскопок курганов вблизи села Быково. С того же года Политотдельское и Иловатку местные власти начали переносить из зоны подтопления на новое место, что очевидно положительно сказалось на работе археологов. В фонде собрано большое количество полевых чертежей, иллюстраций находок (как рисунков, так и фотографий), полевых дневников и описей Нижне-Волжского отряда Сталинградской АЭ. 
Также за 1952 год отражены материалы по курганным группам в районе Запорожья - сёл Заможное, Большой Токмак и хутора Шевченко. В папках 11 и 13 собраны как рисунки и фотографии находок, так и планы погребений, выявленных в данных курганных группах. Сам учёный отнёс их к результатам деятельности Скифо-степной экспедиции 1952 г.

С 1956 года Константин Фёдорович приступает к раскопкам в Оренбуржье и работает там вплоть до 1974 г. Экспедиции Смирнова, во время так называемого Оренбургского этапа, носили разные наименования: Чкаловская, Оренбургская, Южно-Уральская (Оренбургский отряд). Вклад экспедиций в изучение археологического прошлого Оренбуржья под его руководством необычайно глубок. География памятников, исследованных экспедицией, обширна: «Пятимары - I, II, III» (1956, 1960), Ново-Белогорский, Увакский могильники (1957), курганный могильник Тара-Бутак (1957); курганные группы «Близнецы» (1957), Мечет-Сай (1957-1961); Новокумакский могильник (1958-1959, 1962, 1971-1972), курганы у хут. Барышников (1963), курганные группы «Герасимовка - I, III» (1964), «Шиханы» (1966-1967); Орские курганы (1971-1972), Кумакский могильник «Три мара» (1974) и др.

Экспедиционное наследие К.Ф. Смирнова оканчивается материалами Азово-Донецкой АЭ 1976-1977 гг., результаты которой, помимо традиционных чертежей, рисунков, дневников и описей, сохранили полевые фотографии рабочих моментов экспедиции с участием самого руководителя экспедиции, отчёты Константина Фёдоровича и организационную документацию.

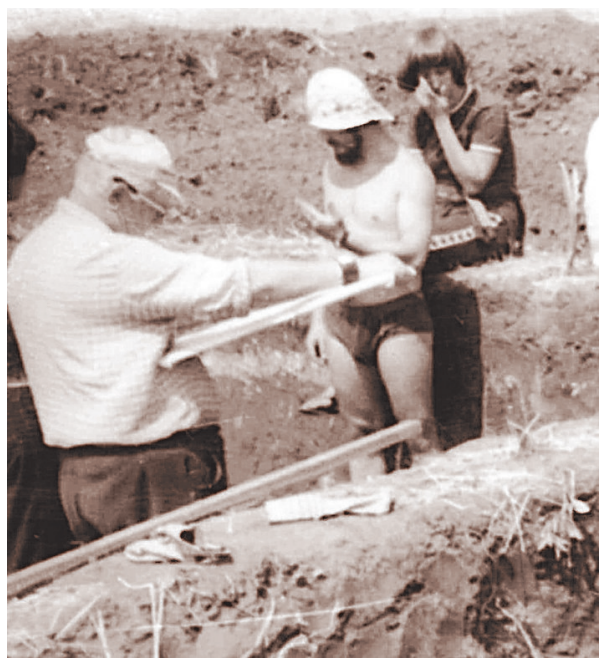

К.Ф. Смирнов в Азово-Донецкой археологической экспедиции (1977 год). Рабочий момент (Источник: Архив ИА РАН. Ф. 34. Оп. 1. Папка 40. Конверт 1. Л. 19)

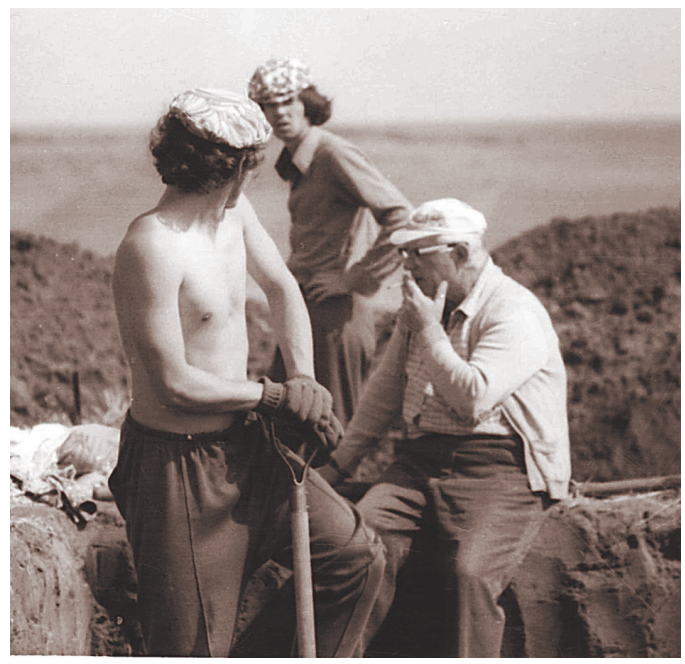

К.Ф. Смирнов в Азово-Донецкой археологической экспедиции (1977 год). Рабочий момент (Источник: Архив ИА РАН. Ф. 34. Оп. 1. Папка 40. Конверт 1. Л. 21) 
Большинство документов достаточно хорошо атрибутированы: надписи на чертежах, фотографиях, прорисовках и прочих документах свидетельствуют о добросовестности и глубокой научной педантичности фондообразователя, в значительной мере упрощая задачи будущих исследователей научного пути К.Ф. Смирнова.

Второй крупный блок документов фонда - это многочисленные материалырезультаты кропотливого научно-исследовательского труда Константина Федоровича. География рабочих материалов обширна: Южное Приуралье, Южный Урал и Зауралье, Поволжье, Подонье, Приднепровье, Запорожье, Центральный Кавказ и Закавказье, Прикубанье и Кубань, Приазовье и Крым. Все материалы сопровождаются описаниями погребений и находок, выписками и собственноручными иллюстрациями (планы раскопов, зарисовки вещей). Богат сохранившийся иллюстративный материал к публикациям К.Ф. Смирнова. Так, например, в материалах фонда отложились иллюстрации (и пленки негативов) к статье, подготовленной в соавторстве с известным египтологом Татьяной Николаевной Савельевой «Ближневосточные древности на Южном Урале» (Архив ИА РАН. Ф. 34. Оп. 1. Папка 57. Конверты 3, 4), опубликованной в 1972 году в «Вестнике древней истории» (Савельева, Смирнов, 1972).

Также для будущего исследователя фонда сохранились отзывы на кандидатскую диссертацию Константина Фёдоровича (1946) - докторов исторических наук Бориса Николаевича Гракова и Сергея Павловича Толстова. Уже тогда Борис Николаевич давал высокую оценку трудам своего ученика:

...Первоначальной задачей диссертанта было описать и осмыслить собрания государственного Исторического Музея, полученн.[ьле] в результате его экспедиций в Степное Поволюье и Приуралье за 1925-31 и 1933 г2. Поскольку эти коллекции были довольно обширны и сами по себе могли внести ряд новых деталей в построение, принятое в науке, при выборе темы я, как руководитель, считал это вполне достаточным для начинающего молодого учёного. Диссертант далеко превзошел мои ожидания.

Ознакомивиись со всею в настоящее время насчитываюшую до 200 работ литерат.[уры] вопроса, Смирнов иначе и очень плодотворно поставил трактовку темьл. Он исключил из своего рассмотрения памятники VI-II вв. до н.э., т.к. основные вопросы здесь решены гораздо определеннее и убедительнее, чем для позднего эллинизма и римского времени, целиком сосредоточивиись на памятниках более поздних... Все категории оружия, орудий, украшений и утвари описаны и систематизированы заново, для многих даны типологические ряды. Не только для Прикаспия, но и для других районов, занятых сарматскими племенами, этим дан отличный, определяющий и датировочный критерий. Особенно хороши главы о мечах, фибулах и бусах. Из описательных приемов автора заслуживает внимание помещение при каждом законченном отделе 
таблиц находок. Прием не новый, но почти нигде не проводимый с такой наглядностью в работах начинающих. Ново для изучаемых районов привлечение типов курганных групп для выводов о различных группах населения. Этого не делал ещзё никто из его предщественников... (Архив ИА РАН. Ф. 34. Оп. 1. Папка 67. Конверт 6. Л. 1-2).

Заметим, что личный фонд К.Ф. Смирнова представляет собой коллекцию материалов сугубо научного творчества, отражающих его профессиональную деятельность. Практически отсутствуют официальные документы биографического характера, как-то удостоверения, документы об учёбе, работе и общественной деятельности, наградные документы и т.п. Среди личных документов выделяются лишь некоторые, способные дополнить портрет учёного. Например, это письма, присланные в адрес Константина Фёдоровича от коллег и соратников (Архив ИА РАН. Ф. 34. Оп. 1. Папка 67). Всего их порядка четырех десятков. В них отражены как сугубо частные вопросы, так и научные - отклики на публикации, профессиональные консультации и обмен экспедиционными открытиями.

Яркой эмоциональностью, донёсшей до наших дней особенности экспедиционного быта, окружавшего Константина Федоровича, отличается письмо в Южно-Уральскую экспедицию от бывалого участника экспедиции, в силу причин вынужденного пропустить сезон, датированное 1967 годом. В цитируемом фрагменте письма сохранены орфография и пунктуация автора:

9 июня 1967 г

2. Новотроиик

Здравствуйте дорогие друзья!

Добрый день Сергей Александрович, Константин Федорович, Лев Николаевич, Юра, Алексей, Галя, Катя, Лида, «духи», «гардемарины». Незнакомыле новые и ещее кто есть в экспедиции. Поздравляю Вас с началом археологических работ, с оренбургским солнцем, большой лопатой и киркой. Желаю успехов на ниве археологической и конечно находок и открытий, о которых бы Рыбаков сказал - Южно-Уральская экспедиция - это гвоздь сезона, а валообразные сооружения величайшие сооружения огня в среде огнепоклонников всех народов в древности - и есть больиое научное открытие 1967 г. Одним словом Здравствуйте по товарищески! Думаю, что уже приступили к работам и лагерь стоит на старом месте и огуриьь в этом году поди не хуже прошлогодних, а чай по-Петровски с дымком степи с тонким ароматом субтропиков - мне и сейчас пить хочется. Только, что пишу, а так я вместе с вами у большого костра, что задает хлопот Сергею Александровичу.

И даже мысленно представляю как жарко. И как ещё не скоро перекур на раскопе. Жаль конечно, что меня нет там, чувствую, что без меня будет большое прямо таки в Савроматском мире, доселя неизвестное. Думаю, что Сергей Александрович кирки получил которые я передавал с режиссером театра и если да, то их теперь у Вас три. 
Надеюсь и думаю, что они к какой-то мере облегчат Вам земляную работу. От вас требуется только подправлять забоины напильником на фасках лопаточки кирок и к кониу сезона обстоятельно написать и указать недостатки и положительные стороны, и что бы требовалось сделать получьше в другом варианте кирок. Думаю, что Лев Николаевич напишет подобное о кирках. Быть им или не быть! < .. > (Архив ИА РАН. Ф. 34. Оп. 1. Папка 67. Конверт 5. Л. 46-47).

В числе прочих, вероятно, по досадному стечению обстоятельств одно из писем так и осталось непрочитанным. Пришло оно из Ленинграда от начинающего археолога Бориса Раева (датировано 7 октября 1976 г.) (Архив ИА РАН. Ф. 34. Оп. 1. Папка 67. Конверт 5. Л. 101-105). При комплектовании фонда письмо было вскрыто: в нем содержалось описание одного погребения из 5-го кургана Камышевахского могильника из раскопок автора, проведённых в 1974 году (с приложенным выбеленным чертежом и рисунком сосуда). Конверты и иллюстративные материалы (фотографии, рисунки), находившиеся при письмах, сохранены и приложены к соответствующим им отправлениям, корреспонденция систематизирована в хронологическом порядке - по авторской или почтовой датировке.

Коллекция фонда К.Ф. Смирнова располагает как материалами, уже вышедшими в печать, так и неопубликованными работами автора, и, возможно, благодаря чуткости будущих исследователей фонда труд Константина Федоровича ещё найдёт своё место среди специальных научных публикаций.

\section{ЛИТЕРАТУРА}

Абакаров А.И., Давудов О.М. Археологическая карта Дагестана. М.: Наука, 1993. C. 9 .

Архив ИА РАН. Ф. 34. Оп. 1. Папка 9, 57, 67.

Лысенко Ю.М. Становление и основные аспекты деятельности Дагестанской научно-исследовательской базы - Дагестанского филиала Академии наук СССР в $1946-$ 1959 гг. // Вестник Дагестанского научного центра РАН. 2015. № 56. С. 67.

Савельева Т.Н., Смирнов К.Ф. Ближневосточные древности на Южном Урале // ВДИ. 1972. № 3. С. 106-123.

Твердохлебов А.М. Об археологических работах в Дагестане в 1947-1948 гг. // Труды Первой научной сессии Дагестанской базы Академии наук СССР. Махачкала, 1948. 


\section{ПОСЛЕДНИЕ ПОЛЕВЫЕ СЕЗОНЫ К.Ф. СМИРНОВА И ПРОБЛЕМА ИНТЕРПРЕТАЦИИ ПАМЯТНИКОВ МЕЖДУРЕЧЬЯ ДОНА И СЕВЕРСКОГО ДОНЦА (Работа выполнена по программе ЮНЦ РАН 00-16-09 «Изучение межкультурных взаимодействий населения Нижнего Дона с древнейших времен до нового времени»)}

\section{Лукьяшко С.И.}

http://10.25681/IARAS.2019.978-5-317-06274-3/25-30

В рамках исследования проблемы распространения савроматской культуры на запад под впечатлением находок в Шолоховском кургане возникла идея создания Объединённой Азово-Донецкой археологической экспедиции под руководством К.Ф. Смирнова. В 1977 г. в экспедиции под Азовом был торжественно отмечен 60летний юбилей К.Ф. Смирнова, а полученные в ходе этих исследований материалы легли в основы последних статей учёного.

Ключевые слова: савромато-сарматский мир, материальная культура, курган, склеп

В конце 1960-х годов интерес Константина Фёдоровича был обращён к западной периферии, выделенной им савроматской археологической культуры, под которой он никогда не понимал известное по Геродоту конкретное историческое племя «савроматов», а видел большую группу племён, возможно, связанных союзническими отношениями. «Савроматы - древнейшее население восточной части Приазовья и земель, расположенных преимущественно к востоку от Дона - Танаиса. Об этом свидетельствуют как письменные источники, так и археологические данные. Утверждая автохтонное происхождение ряда племен, вошедших в савроматское объединение (ибо савроматы действительно составляли обширную группу племен, связанных между собой политическим союзом), я разделяю точку зрения М.И. Ростовцева о приазовском “автохтонизме” основного ядра савроматов» (Смирнов, 1984. С. 11). Современные критики савроматской концепции Константина Фёдоровича этого не замечают и соотносят культуру с этносом, а свои заблуждения приписывают К.Ф. Смирнову.

Изучая распространение савроматской культуры на запад, Константин Фёдорович в 1968 г. посетил Танаис, где в то время был и В.Е. Максименко. Сильно подозреваю, что это была их первая встреча, в результате которой возникла идея создания экспедиции на Дону. Идея реализовалась в форме «Цимлянской АЭ» в 1970 г. Началу работ экспедиции предшествовало скрупулёзное изучение Нижнедонского материала, в котором на тот момент в хронологическом диапазоне савроматской культуры выделялось доследованное И.И. Ляпушкиным погребение у хут. Карнауховского и случайная находка в разрушенном погребении Краснодворского жертвенника. Готовя экспедицию, Константин Фёдорович сделал доклад на секторе, в котором отметил следы влияния савроматской культуры на среднедонскую скифскую культуру. В каче- 
стве одного из аргументов была использована цитата Стефаном Византийским Псевдо-Скилака: «За скифами сирматы. Народ и река Танаис (составляют) границу Азии и Европы» (Псевдо-Скилак, 68). Попытка увидеть в этом известии продвижение савроматов-сирматов на правый берег Дона встретила решительное и эмоциональное сопротивление П.Д. Либерова, утверждавшего, что археологический материал не подтверждает савроматское присутствие на Среднем Дону, а античные источники вызывают у него, мягко сказать, недоверие. Константин Фёдорович не выдержал накала страстей, у него случился прямо на заседании сектора первый инфаркт. Этот эпизод показывает, насколько живо и бескомпромиссно велись дискуссии в отделе, и как милые доброжелательные люди в повседневном общении становились резкими и непримиримыми оппонентами, когда дело касалось науки.

Константин Фёдорович понимал шаткость своей позиции, и поэтому собственные работы на Дону и поиски новых памятников должны были состояться.

Подготовительная работа привела к появлению Цимлянской археологической экспедиции. Объектом исследования стали курганы, попадавшие в зону мелиоративного строительства у хут. Ясырева. Здесь среди курганов эпохи бронзы, всё же был обнаружен и курган конца IV в. до н.э. Комплекс был отнесён к савроматской археологической культуре (Мошкова, Максименко, 1973. С. 72, 73; Максименко, 1983. С. 42). В 1971 г. Константин Фёдорович приехал ненадолго в экспедицию, которая переместилась на Маныч, где исследовала курганы в зоне строительства Багаевско-Садковской оросительной системы.

В 1972 г. Константин Фёдорович болел и в экспедицию поехать не мог. Но интерес к теме не ослабевал.

В середине 1970-х годов Константин Фёдорович, живо интересуясь проблемой распространения савромато-сарматской культуры на Запад, на ДоноДнепровское междуречье, работал в музеях Украины и делился с нами впечатлениями. Напомню, что опубликованные сарматские комплексы на территории Украины в то время исчислялись единицами, работа же в фондах музея позволила Константину Фёдоровичу многократно увеличить это количество. В 1974 году на донском правобережье обнаруживается случайно бронзовый шлем типа «монтефортино» (Косяненко, Лукьяшко, Максименко, 1978. С. 266267). Сарматское присутствие на левобережье начинает обретать осязаемые черты.

В начале 1976 г. в Ростовский областной музей краеведения были сданы вещи из разрушенного кургана у пос. Шолоховского. Местные школьники нашли на поверхности кургана лисью нору, из которой были вынесены на поверхность бронзовые наконечники стрел и фрагменты золотой обкладки деревянного сосуда. Школьники решили раскопать нору, и вышли на могильную яму. Добытые находки они передали в музей. Срочно был организован рекогносцировочный выезд на место, который возглавил В.Е. Максименко. Материал, обнаруженный 
в придонной части могильной ямы, был представлен бронзовыми наконечниками стрел, предметами конской упряжи, железными наконечниками копий. Не было сомнений в хронологической позиции комплекса. Это, бесспорно, IV в. до н.э. Могильная яма большая квадратная, перекрытая бревенчатым накатом, представляла собой подкурганный склеп с многоразовыми подзахоронениями (Максименко, Смирнов, Горбенко, Лукьяшко, 1984. С. 124-140). Ничего подобного ранее на Дону не было известно. Познакомившись с материалом, Константин Фёдорович, несмотря на состояние здоровья, решил ехать в поле, и в результате была создана Объединённая Азово-Донецкая археологическая экспедиция под руководством К.Ф. Смирнова. В составе экспедиции было два отряда: Приморский отряд, которым руководил С.И. Лукьяшко, и СеверскоДонецкий отряд, во главе которого был В.Е. Максименко. В ходе доследования Шолоховского погребения, В.Е. Максименко обследовал окрестности, где на поверхности одного сильно распаханного кургана Сладковской курганной группы был обнаружен фрагмент красноглиняной синопской амфоры IV в. до н.э. Что и привело к исследованию группы. Здесь было обнаружено аналогичное Шолоховскому погребение с типологически и хронологически близким инвентарём.

Материалы были изданы, они хорошо известны среди специалистов (Смирнов, 1982. С. 120-130; Максименко, 1983. С. 29-33; Смирнов, 1984). Это была просторная дромосная могила, по сути, склеп с многоразовыми подзахоронениями. На завершающем этапе функционирования склепа в дромос была уложена принесённая в жертву лошадь, закупорившая вход в склеп. Важным для К.Ф. Смирнова было открытие в склепе погребения женщины, при которой находились предметы вооружения, меч и бронзовые наконечники стрел. В связи с этим Константин Фё дорович публикует статью «Погребение амазонки IV в. до н.э.» (Смирнов, 1982). Поскольку в это время женские погребения с оружием однозначно связывались с савроматами, то и вывод был ясен. Поиски аналогий шли по этому же пути.

Статья начинается со ссылки на Б.Н. Гракова и на утверждение гинекократии у савромато-сарматов. «На дне неограбленной юго-восточной части могилы на интенсивной посыпке меловым порошком или размельченным мелом лежала взрослая женщина (костяк 1) головой на юг, в свободной позе, со слегка расставленными руками и чуть согнутой в колене левой ногой, в обычной позе погребённых савроматов и сарматов» (Смирнов, 1982. С. 121). Далее указывается на развал лепного сосуда с оттисками пальцевых вдавлений, «характерных для савроматов Поволжья и Подонья» (Смирнов, 1982. С. 123).

Этническое определение погребению Константин Фёдорович дает, исходя из данных письменных источников, и лишь затем на основании погребального обряда и материальной культуры (Смирнов, 1982. С. 125). И, тем не менее, восточные савромато-сарматские черты видятся автору в орнаменте в виде оттисков пальцев на тулове большого лепного сосуда, в форме бронзового зеркала 
и бронзовых наконечников стрел, к тому же сделаны они были из уральского металла. При этом Константин Фёдорович не отрицает скифские элементы в культуре, как-то гривна, но они являются результатом тесных контактов давно живущих здесь сирматов со скифским миром.

Утверждение - «давно живущие здесь сирматы» - эмоциональное, дальнейшие исследования не смогли удревнить дату этих погребений глубже IV в. до н.э. Датировка В.Е. Максименко Шолоховского кургана V-IV вв. до н.э. встречала возражения уже у К.Ф. Смирнова. А курган кенотаф 25 из Сладковского могильника, датированный исключительно по сероглиняной амфоре, имел явно заниженную дату. Амфора не имеет близких аналогий, и датировка её пока ещё не нашла надежной опоры у антиковедов.

«С археологической точки зрения Сладковский курган более всего похож на те памятники IV в. до н.э. Поволжья и Южного Приуралья, которые, несомненно, принадлежат савроматам и ранним сарматам. Есть здесь и общие черты, известные на разных территориях Евразии, например дромосные могилы, которые встречаются и на Днепре, и на Среднем Дону и теперь довольно хорошо представлены в савромато-сарматском мире V-III вв. до н.э. в Южном Приуралье. Однако курганы с дромосами с коллективными захоронениями совсем не этнический признак, а скорее всего социальный» (Смирнов, 1982. С. 128). Почему это так, к сожалению, не ясно, ведь иных форм погребений на этой территории до сих пор не обнаружено.

В 1977 г. Константин Фёдорович нашёл в себе силы приехать в поле, хотя всю зиму он пролежал в больнице. Этот год был годом 60-летия Константина Фёдоровича, и в августовский вечер в лагере под Азовом мы торжественно отметили юбилей К.Ф. Смирнова. Это был последний экспедиционный вечер Константина Фёдоровича. Собрались все близкие друзья и ученики, участники Южноуральских экспедиций. Состояние здоровья не позволило Константину Фёдоровичу больше ездить в экспедицию. В этот же день в экспедиции Константин Фёдорович познакомился с только что открытым погребением 8 Новоалександровского 7 кургана. Он искренне радовался, и, поздравляя меня с открытием, приговаривал: «Вот они и иксаматы». Рассматривая обломки ещё не реставрированной амфоры, И.Б. Брашинский продатировал её концом VI в. до н.э., при этом допускал и более позднюю дату.

Работа над темой «Сарматы и завоевание Скифии» продолжалась. Константину Фёдоровичу не удалось закончить эту тему, но были сделаны основные наброски, из которых появилась монография, изданная в посмертном варианте (Смирнов, 1983). Многие идеи работы только были намечены и основательно не проработаны. Вносить коррективы в текст своего учителя издатель работы М.Г. Мошкова не могла. Но друзья и соратники брали на вооружение идеи этой посмертной работы и, опираясь на авторитет Константина Фёдоровича, превращали гипотезы в теории, а замечания в решения. Так родилась идея переселения части западных савроматов, носивших имя «сирматы», в Доно- 
Донецкое междуречье. А обнаруженные здесь подкурганные склепы были определены как могилы сирматов. Сама эта гипотеза даже не принадлежала Константину Фёдоровичу, это идея В.Е. Максименко, а Константин Фёдорович лишь заявлял, что он её разделяет. Археологической аргументации под гипотезой было явно недостаточно, и как бы она развивалась, если бы Константину Фёдоровичу дано было прожить дольше, нам не дано знать. Но появившись в печати, гипотеза была воспринята как безусловный факт, подтверждённый авторитетом К.Ф. Смирнова. Сирматы стали одним из элементов конструируемого этнического пространства в Юго-Восточной Европе.

При этом скифологи, занимающиеся среднедонской скифской культурой (Медведев А.П.), отказываются видеть в этих комплексах савромато-сирматов, мигрантов из районов Южного Приуралья, в то же время они отказываются видеть в счастливо открытой группе памятников и сходство с памятниками среднедонской скифской культуры. Вызревшая проблема настоятельно требует решения. И оно кроется в новых полевых исследованиях в регионе.

Моя позиция по отношению к этому материалу сформировалась в ходе наблюдений за развитием темы и изучением материалов и сводится к следующему:

1. Исследованиями С.А. Скорого убедительно доказано продвижение скифов с Днепровского Правобережья в Доно-Днепровскую лесостепь. С этим движением связано появление памятников на Харьковщине. И, собственно, среднедонская культура есть конечный восточный пункт этой миграции, с чем солидаризируется и А.П. Медведев.

2. Рассматривая этот массив памятников, мы не можем не обратить внимание на близость погребального обряда: подкурганные склепы с дромосами, деревянными перекрытиями.

3. Единство материальной культуры.

В рассматриваемой серии северско-донецкая группа является крайним южным флангом этого движения лесостепных скифских групп на восток.

Но при этом более широкий взгляд на проблему показывает, что традиция погребения в подкурганных склепах, перекрытых бревенчатым накатом, существует в ближайшем окружении именно на Северском Донце, Среднем Дону и на Харьковщине.

Критический анализ показывает, что в археологическом отношении счастливо обнаруженная культурная группа ближе среднедонской скифской культуре. На территории западных савроматов ничего подобного не было. И, следовательно, выделиться из этой области так называемые сирматы не могли.

Южноприуральские связи невозможно отрицать, они прослеживаются по зеркалу, колчанному крюку, некоторым типам наконечников стрел. Но здесь же находятся предметы из прямо противоположной культурной провинции: гривна, жаровня. Мы вынуждены констатировать, что выявленная культурная группа носит синкретичный характер и по материальной культуре, и по по- 
гребальной обрядности не может получить однозначную культурную атрибуцию. По мнению С.Ю. Гуцалова, близкий по обрядовым и хронологическим признакам Песочинский могильник под Харьковом отражает мощный выплеск населения из Южного Приуралья (Гуцалов, 2009. С. 69-79).

Лингвистический анализ термина «сирматы», «савроматы», «сарматы», проведённый С.Р. Тохтасьевым, показал, что корневая основа восходит к одной общей лексеме, а её огласовка отражает диалектные особенности языка (Тохтасьев, 2005. С. 291-306). Видеть за этими понятиями этносы нельзя, это субэтнические группы, что, собственно, и подтверждается наличием диалектов.

Анализ археологического материала не даёт решительного перевеса ни одной версии происхождения этой группы памятников на Дону. Как и 40 лет назад, мы вслед за М.Г. Мошковой можем сказать, что требуются новые полевые исследования, привлечение антропологического материала. Без получения новых материалов новое знание не появится. А до появления этого нового знания следует осторожно относиться к «сирматской» гипотезе К.Ф. Смирнова - В.Е. Максименко.

\section{ЛИТЕРАТУРА}

Гуиалов С.Ю. Могильник Песочин под Харьковом. Древности. Харьков, 2009. C. 69-79.

Косяненко В.М., Лукьяшко С.И., Максименко В.Е. Два шлема из фондов Ростовского областного музея краеведения // СА. 1978. № 2. С. 265-267.

Максименко В.Е. Савроматы и сарматы на Нижнем Дону. Ростов н/Д: Изд-во РГУ, 1983. $224 \mathrm{c}$.

Максименко В.Е., Смирнов К.Ф., Горбенко А.А., Лукьяико С.И. Курган у пос. Шолоховский // Смирнов К.Ф. Сарматы и утверждение их политического господства в Скифии. М.: Наука, 1984. 184 с.

Мошкова М.Г., Максименко В.Е. Сарматские погребения Ясыревских курганов Нижнего Дона // КСИА. 1973. Вып. 133. С. 72-79.

Смирнов К.Ф. Сарматы и утверждение их политического господства в Скифии. М.: Наука, 1984. 184 с.

Смирнов К.Ф. Амазонка IV века до н.э. на Дону // CA. 1982. № 3. С. 120-130.

Тохтасьев C.P. Sauromatae - Sarmatae - Syrmatae // Херсонесский сборник. Севастополь, 2005. Вып. 14. С. 291-306. 


\title{
КЛАССИФИКАЦИЯ СТРЕЛ К.Ф. СМИРНОВА И КОЛЧАННЫЕ НАБОРЫ РАННЕСКИФСКОГО ВРЕМЕНИ ВОСТОЧНОЙ ЗОНЫ КАК ХРОНОЛОГИЧЕСКИЙ ИНДИКАТОР
}

\author{
Чугунов К.В.
}

http://10.25681/IARAS.2019.978-5-317-06274-3/31-44

В статье рассматриваются вопросы формирования набора наконечников стрел кочевых племен скифского типа в восточной зоне Евразии. Основы классификации, предложенные К.Ф. Смирновым в начале 1960-х годов прошлого века, должны использоваться только с учётом хронологии опорных памятников. Предложены новые подходы к исследованию наконечников стрел, которые позволят уточнить хронологию начала эпохи ранних кочевников в азиатской зоне.

Ключевые слова: классификация, колчанный набор, хронология, индикатор, наконечник стрелы, типология, раннескифское время.

Базовые исследования наконечников стрел скифского времени были опубликованы ещё в 1960-х годах в работах К.Ф. Смирнова (1961) и А.И. Мелюковой (1964). В них заложены основы классификации предметов вооружения скифского времени, которые остаются актуальными и сегодня, несмотря на значительно возросшую базу источников. Относительная хронология и общее эволюционное развитие различных категорий предметов, благодаря тщательной разработке их типологических рядов, не претерпели существенных изменений. В то же время абсолютная хронология с тех пор была существенно уточнена, особенно ранних этапов эпохи ранних кочевников. В частности, К.Ф. Смирнов в датировках наконечников стрел Поволжья и Приуралья опирался на хронологию бронзовых стрел Скифии и Кавказа. Сдвиг датировки древнейших скифских памятников Предкавказья почти на три четверти столетия неизбежно должен приводить к удревнению многих комплексов и, самое главное, всех разработанных ранее типологических схем.

Прежде всего, это касается датировки Келермесского могильника - опорного раннескифского памятника, который к моменту составления первых классификаций оружия относили ко второй четверти VI в. до н.э. Сейчас нижняя дата келермесского пласта древностей определена в пределах середины - третьей четверти VII в. до н.э., верхняя не выходит за рубеж VII-VI вв. до н.э. (Галанина, 1997. С. 172-192). Соответственно, когда исследователи пользуются верными типологическими построениями без учёта того, что они основаны на устаревшей хронологии, это приводит к ошибочным датировкам комплексов. Особенно это касается восточных областей расселения ранних кочевников, в памятниках которых отсутствуют датированные импорты, и абсолютные даты зачастую устанавливаются методом привлечения аналогий из других регионов. 
В статье я коснусь самого раннего пласта памятников, относящегося к периоду формирования колчанного набора раннескифского времени в восточных областях Великого пояса степей. В исследовании использованы только металлические изделия, поскольку роговые или костяные наконечники гораздо менее эволюционировали в силу специфики материала. Кроме того, производство бронзовых наконечников стрел неразрывно связано с развитием металлургических традиций.

Подосновой типологических рядов наконечников стрел раннескифского времени К.Ф. Смирнов справедливо считал изделия предшествующей эпохи, которые он условно определил как «евразийские прототипы». Корпус источников за более чем полвека, прошедшие с момента составления его классификации, неизмеримо возрос. Сейчас мы имеем значительные серии металлических наконечников из памятников эпохи поздней бронзы, чрезвычайно редких в начале 1960-х годов. Они, с одной стороны, показывают справедливость основных рассуждений К.Ф. Смирнова, с другой - позволяют дать самую общую характеристику морфологических отличий втульчатых двухлопастных наконечников эпохи бронзы от соответствующих стрел раннескифского времени. Можно заметить, что наибольшая ширина лопастей у стрел эпохи бронзы, как правило, смещена в нижнюю часть наконечника, к втулке. Кроме того, в предскифский период распространены наконечники с очень узкими лопастями. Бронзовые стрелы из Синташты, обнаруженные в наборе с каменными, с одной стороны, показывают переход от одного материала к другому уже в конце III тыс. до н.э., с другой - демонстрируют древнейшие в этой зоне Евразии наконечники с черешковым насадом, чрезвычайно распространенные много позже.

К моменту составления классификации наконечников стрел Приуралья и Поволжья К.Ф. Смирнову было доступно очень ограниченное количество черешковых стрел и ромбических в сечении наконечников со скрытой втулкой. По сути, они не были включены в классификацию и сведены в две небольшие таблицы (Смирнов, 1961. Рис. 39, 40). Тем не менее, К.Ф. Смирнов отметил, что такие стрелы характерны для более восточных областей, и разработка этих типов наконечников должна производиться с учётом развития таких стрел там (Смирнов, 1961. С. 58-66).

Действительно, если мы посмотрим на наборы наконечников стрел из комплексов тасмолинской культуры Казахстана или могильников Приаралья, то многие формы не находят соответствий в таблицах К.Ф. Смирнова. Это касается не только черешковой группы наконечников, но и ряда втульчатых стрел. Зачастую типологический состав стрел в колчанах чрезвычайно разнообразен и включает как архаичные двухлопастные втульчатые стрелы, так и специфические трёхлопастные базисные наконечники (как, например, набор из кургана 84 Уйгарака). О.А. Вишневская в своей классификации наконечников стрел из курганов Уйгарака (1973. С. 88-96) посчитала возможным отнести к ранней группе VII - первой половины VI в. до н.э. колчанные наборы со стрелами отдела Б (трёхлопастные втульчатые). Однако, поскольку считается, что трёхлопастные 
втульчатые наконечники появляются позже двухлопастных стрел, то в памятниках Приаралья они являются хронологическим показателем, позволяющим отделить ранние комплексы от более поздних. Чтобы посмотреть, насколько это справедливо в отношении колчанных наборов азиатской части мира ранних кочевников, необходим самый общий взгляд на особенности стрелкового вооружения и на западе, и на востоке.

На основании опубликованных материалов было проведено обобщённое сопоставление стрелковых наборов по регионам на самом высшем таксономическом уровне (по принципу распространения наконечников с различным способом насада на древко) ${ }^{1}$. Подсчёты процентного соотношения втульчатых и черешковых стрел позволили выделить три группы регионов, различающихся по составу раннескифского колчанного набора (табл. 1). При этом, если средняя группа территориально близка, то в первую попадают регионы как западной зоны (раннескифская и ананьинская культуры), так и восточной (тагарская культура и немногочисленные находки в памятниках Горного Алтая, а также комплекс кургана Аржан в Туве). Третья группа включает регионы, большинство из которых объединяет южное расположение внутри Евразийского степного коридора. По-видимому, это не случайно, и решение вопроса такой закономерности лежит, с одной стороны, в установлении исходной территории происхождения черешковых наконечников стрел скифского времени, с другой - в последовательности и направленности культурных трансляций в древности.

Таблийа 1

Регионы, археологические культуры и памятники,

сгруппированные по процентному соотношению наконечников стрел втульчатой и черешковой группы

\begin{tabular}{|c|c|c|}
\hline $\begin{array}{c}\text { Абсолютное } \\
\text { преобладание } \\
\text { втульчатых наконечников }\end{array}$ & $\begin{array}{c}\text { Втульчатых наконечников } \\
\text { большинство, } \\
\text { черешковых }-20-30 \%\end{array}$ & $\begin{array}{c}\text { Черешковых } \\
\text { и втульчатых наконечников } \\
\text { примерно равное количество }\end{array}$ \\
\hline $\begin{array}{l}\text { 1. Аржан } \\
\text { 2. Тагарская культура } \\
\text { 3. Горный Алтай } \\
\text { 4. «Савроматы» } \\
\text { Поволжья и Приуралья } \\
\text { 5. Раннескифская } \\
\text { культура } \\
\text { 6. Ананьинская } \\
\text { культура }\end{array}$ & $\begin{array}{l}\text { 1. Северный Казахстан } \\
\text { 2. Гумарово } \\
\text { 3. Лесостепной Алтай } \\
\text { (случайные находки) }\end{array}$ & $\begin{array}{l}\text { 1. Алды-бельская культура } \\
\text { 2. Монголия (случайные находки) } \\
\text { 3. Лесостепной Алтай } \\
\text { (Каменская культура, } \\
\text { староалейская культура) } \\
\text { 4. Центральный Казахстан } \\
\text { 5. Семиречье } \\
\text { 6. Приаралье } \\
\text { 7. Памир }\end{array}$ \\
\hline
\end{tabular}

${ }^{1}$ Работа была выполнена в 2000 г., однако сохраняет свою актуальность, так как существенных изменений в соотношении процентного состава черешковых и втульчатых наконечников в отдельных регионах не произошло. Ссылки на публикации, на основании которых произведены подсчёты, приведены в опубликованной тогда работе (Чугунов, 2000а. С. 165-168). 
Северная граница распространения черешковых стрел в раннескифское время соответствует средней промежуточной территориальной группе нашей таблицы, где процент черешковых стрел в колчанах значителен, но преобладающими являются всё же втульчатые наконечники. Для установления исходной территории традиции черешковых наконечников в раннескифский период, необходимо вновь обратиться к материалам предшествующей эпохи.

Н.А. Аванесовой учтено всего 15 экземпляров черешковых наконечников из комплексов эпохи бронзы (1991. С. 45). Как следует из таблицы 39 её монографии, где показаны направления типологического развития стрел с привязкой к хронологической шкале, черешковая группа имеет большую временную лакуну в своём развитии. Зафиксированные в синташтинских комплексах, черешковые стрелы появляются вновь только в памятниках эпохи поздней бронзы. Можно предположить, что этот способ насада, несмотря на лёгкость его производства, не получил широкого распространения в андроновскую эпоху. Для андроновских племён, пришедших на смену синташтинцам, был характерен втульчатый способ насада. Следовательно, можно сделать вывод о том, что традиция, зародившаяся здесь ещё в конце третьего тысячелетия до н.э., не получила развития на этой территории.

Регион, где, начиная с XVI в. до н.э., широко распространены черешковые двухлопастные наконечники стрел - иньский Китай и его ближайшее окружение. В западном могильнике Аньяна найдено свыше четырёхсот бронзовых наконечников и только один из них (явно инокультурный) втульчатый (Варенов, 1989. С. 34-37). В эпоху Западного Чжоу наконечники стрел продолжают иньские традиции. Изредка встречаются трёхлопастные экземпляры, которые считаются инокультурными (Комиссаров, 1988. С. 76-78). Но в целом, на протяжении всей эпохи поздней бронзы, в Китае существовала устойчивая традиция изготовления черешковых наконечников стрел. То, что на этой территории, несмотря на абсолютное господство втульчатых копий, практиковался именно этот способ насада стрелы, может быть объяснено традицией изготовления древков стрел из бамбука и тростника. Этим же обусловлено и то, что черешки иньских и чжоуских стрел круглые в сечении. Наконечники с уплощённым черешком, распространенные в степных культурах, и тем более втульчатые, были предназначены для насаживания на деревянные древки. Таким образом, представляется правомерным предположить, что именно Китай эпохи Западного Чжоу являлся исходной территорией появления у кочевых племен, населявших южные регионы степной зоны, стрел с черешковым насадом.

Транслятором этих традиций в евразийскую степь могли выступать скотоводческие племена, обитавшие на северных границах китайских княжеств. Более того, учитывая концепцию тесного взаимодействия земледельцев Центральной равнины Китая и скотоводов горных областей к северу от неё (Rawson, 2017), не исключено, что комплекс вооружения лучника мог изначально сформироваться именно в варварской среде. Обмен инновациями с далёкими от Китая 
регионами Северной Евразии, вероятно, был взаимным. Материалы могильника Юйхуанмяо показывают присутствие в колчанах как черешковых, так и втульчатых наконечников. При этом черешковая группа включает как собственно китайские стрелы, так и наконечники, характерные для культур раннескифского времени Казахстана и Тувы. Втульчатая группа считается местной формой и уже в самых ранних комплексах включает трёхлопастные типы стрел. Именно они напоминают базисные наконечники, встреченные в памятниках Приаралья, что ставит под сомнение позднюю датировку последних. Заметим, что хронология могильника Юйхуанмяо, расположенного к северу от Пекина, основана на многочисленных китайских импортах, включающих бронзовые сосуды, но, в основном опирается на уникальную стратиграфию слоев лёсса, перекрывающих могилы. Благодаря ей устанавливается относительная последовательность формирования разных участков этого памятника (Шульга, 2015. С. 110-116).

Материалы кургана Аржан, датированного рубежом IX-VIII вв. до н.э. (Зайцева и др., 2007), позволяют определить время культурного импульса, с которым связано распространение традиции черешковых стрел на эту территорию. Всего в восьми комплексах памятника найдено 48 наконечников, из которых 17 бронзовых (Грязнов, 1980; Чугунов, 2000б. С. 216. Рис. 3). Большинство их происходят из непотревоженной могилы 4 и составляли один колчанный набор. Все стрелы относятся к втульчатой группе, из которых только одна стрела четырёхгранная со скрытой втулкой и шипом, остальные - двухлопастные. Вероятно, появление черешковой группы наконечников можно связать с алды-бельской культурой раннескифского времени, которая сформировалась на территории Тувы не ранее середины или конца VIII в. до н.э. Далекие западные параллели в комплексе кургана Аржан в предскифских древностях Северного Причерноморья давно известны. Долгое время памятник выглядел изолированно в кругу региональных культур раннескифского времени. Сейчас заполнение этой лакуны постепенно происходит. В непосредственной близости от Аржана продолжается исследование разрушенного кургана Аржан-5 с подобной наземной деревянной конструкцией (Рукавишникова, 2017), где найден втульчатый двухлопастной наконечник. В предгорьях Китайского Алтая сейчас открыт могильник Мохучахань (Синьцзян Моху, 2016). Радиоуглеродные даты образцов из могил, содержащих многочисленные параллели аржанским материалам и включающих псалии аржанского типа, не выходят за пределы IX в. до н.э. При этом, в ряде комплексов найдены как втульчатые, так и черешковые наконечники стрел. Это позволяет предполагать, что первоначальный импульс с юго-востока проходил традиционным путем по Ганьсуйскому коридору. Соответственно, Казахстан принял его раньше, чем Саяно-Алтай. Не случайно в колчанных наборах тасмолинской культуры и в Приаралье присутствуют типологически более ранние двухлопастные черешковые наконечники, практически отсутствующие в Туве. 
До начала XXI века древности раннескифского периода Саяно-Алтая в целом и Тувы в частности были изучены ещё очень слабо. В Туве А.Д. Грачом была выделена алды-бельская культура, в Горном Алтае из общего пласта памятников майэмирского круга выделена бийкенская культура. Первая классификация наконечников стрел из памятников раннескифского времени Тувы была сделана ещё в 2000 году и основывалась всего на восьми колчанных набоpax (Чугунов, 2000б). Однако тогда были достигнуты некоторые результаты.

Во-первых, согласно классическому принципу классификации К.Ф. Смирнова, разделения наконечников по способу насада на древко, в отдельную группу были выделены зажимные стрелы, не встречающиеся в европейских комплексах. Во-вторых, выяснилось, что основное хронологическое значение в классификации имеют именно отделы, количество которых было несколько расширено за счет выделения трёхгранно-трёхлопастных наконечников. Несколько ранее такое деление было предложено М.А. Очир-Горяевой при классификации стрел Нижнего Поволжья (1996. С. 41-54). Дальнейшее накопление материала показало правомерность такого подхода.

Новые возможности анализа этой категории вооружения появились после исследования Аржана-2, царского кургана алды-бельской культуры, датированного второй половиной VII в. до н.э. (Zaitseva at al. 2004). Там найдено 82 наконечника, из которых четырнадцать роговых, один деревянный, 27 железных и сорок бронзовых. При этом в указанное количество не входят более полусотни железных стрел из основного захоронения, восстановить которые не удалось, однако можно предполагать их тип - четырёхгранные втульчатые наконечники со скрытой втулкой. Стрелы в колчанах из отдельных закрытых комплексов очень разнообразны, что позволило провести типологию наконечников и сопоставить между собой их наборы, обнаруженные на памятнике (Чугунов, 2011). Кроме того, чрезвычайно важно, что для ряда сопроводительных могил зафиксирована стратиграфическая последовательность их сооружения, а в одном таком захоронении (могила 25) найдено два набора стрел ранний, связанный с первоначальным погребённым, и более поздний.

Корреляция совстречаемости различных типов стрел в разных комплексах памятника отчётливо разделила всю коллекцию на две группировки (табл. 2), которые можно объяснить относительной хронологией комплексов внутри памятника.

Подавляющее большинство наконечников стрел втульчатой группы из Аржана-2 составляют типы, относящиеся к отделу четырёхгранных (один двухлопастной наконечник, вероятно, является анахронизмом, относящимся возможно ещё к эпохе поздней бронзы. На это указывает и состав его металла - мышьяковая медь). В позднюю группировку при корреляции попали четырёхгранно-двухлопастные наконечники и ещё две стрелы - трёхлопастная и трёхгранно-трёхлопастная с выступающей втулкой и шипами на окончании лопастей (рис. 1). 
Таблица 2

Корреляция совстречаемости типов/вариантов наконечников стрел в комплексах кургана Аржан-2. Первая строка и колонка - номера типов стрел; вторая колонка - название типа в классификации (Чугунов, 2011)

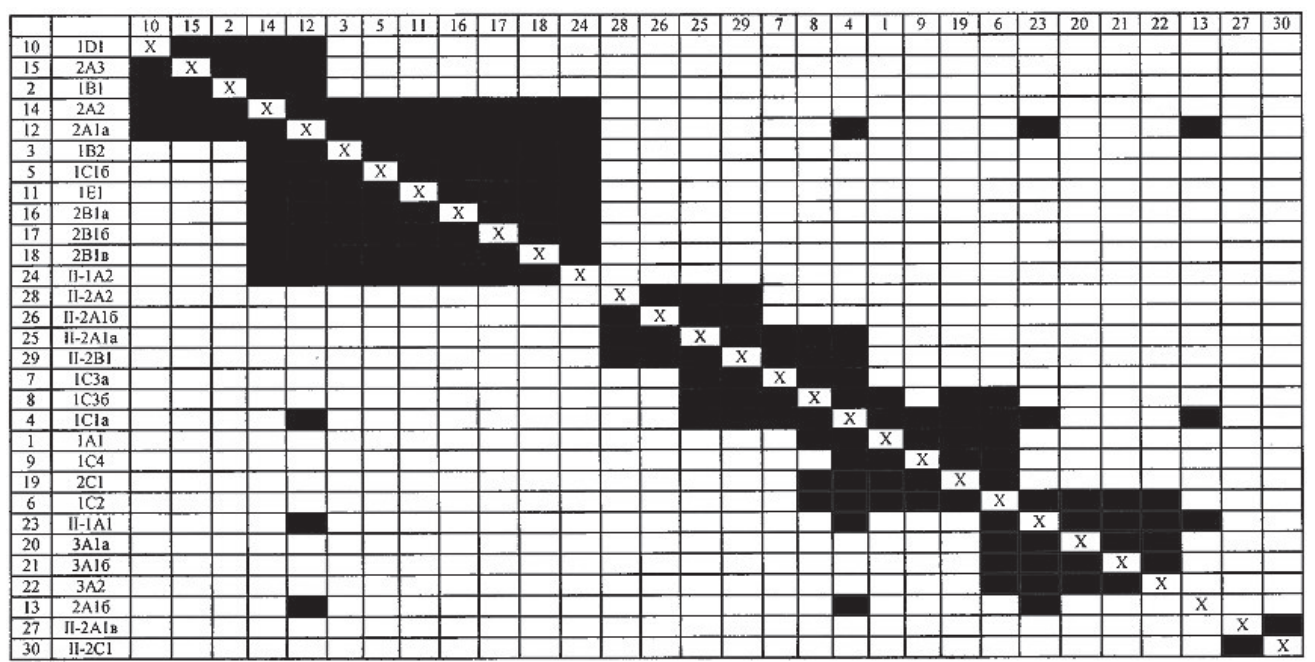

Группа втульчатых наконечников:

поздние типы
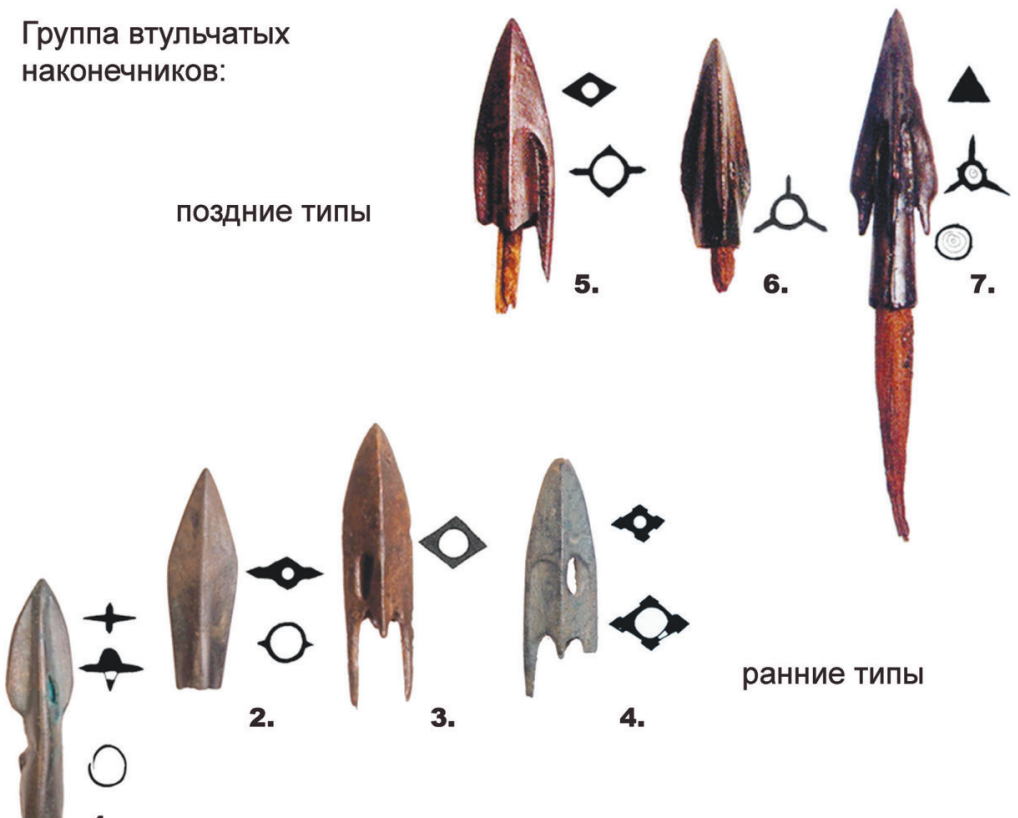

2.

3.

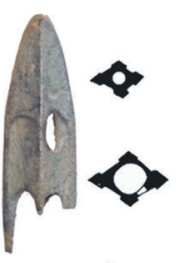

ранние типы

4.

1.

Рис. 1. Ранние и поздние типы наконечников стрел втульчатой группы из комплексов Аржана-2 
Стрелы черешковой группы распределились не столь однозначно. Трёхлопастные экземпляры присутствуют как в ранней, так и в поздней группировке. Однако трёхгранно-трёхлопастные наконечники попали при корреляции только в позднюю группировку (рис. 2).

В результате такого анализа среди сопроводительных комплексов Аржана-2 удалось выявить один (могила 26), не имеющий очевидной стратиграфической привязки к последовательным этапам функционирования памятника, который именно по набору стрел можно определить как относительно более поздний.

Как видим, в памятниках Тувы более «чувствительны» к хронологии оказались именно втульчатые стрелы, условное развитие которых можно представить, как абсолютное преобладание четырёхгранных типов на раннем этапе и появление трёхлопастных и трёхгранно-трёхлопастных форм на позднем. Базисные трёхлопастные типы - позднейшие в этом ряду - вероятно, могут датироваться уже VI в. до н.э. Такие наконечники, но чаще уже трёхгранных типов, встречаются в Туве и в памятниках уюкского типа.

На другом царском мемориале Чинге-Тэй I, который исследуется в настоящий момент, сейчас открыты семь комплексов, включающих 124 бронзовых наконечника, что позволяет проверить сделанные наблюдения с учётом нового материала.

В частности, очень показательно сравнение стрелковых наборов из Аржана-2 и Чинге-Тэя с двумя колчанами из комплексов могильника Сарыг-Булун. На этом алды-бельском памятнике, исследованном Вл.А. Семёновым (Семёнов, Килуновская, 1990), зафиксировано перекрывание одного кургана другим,

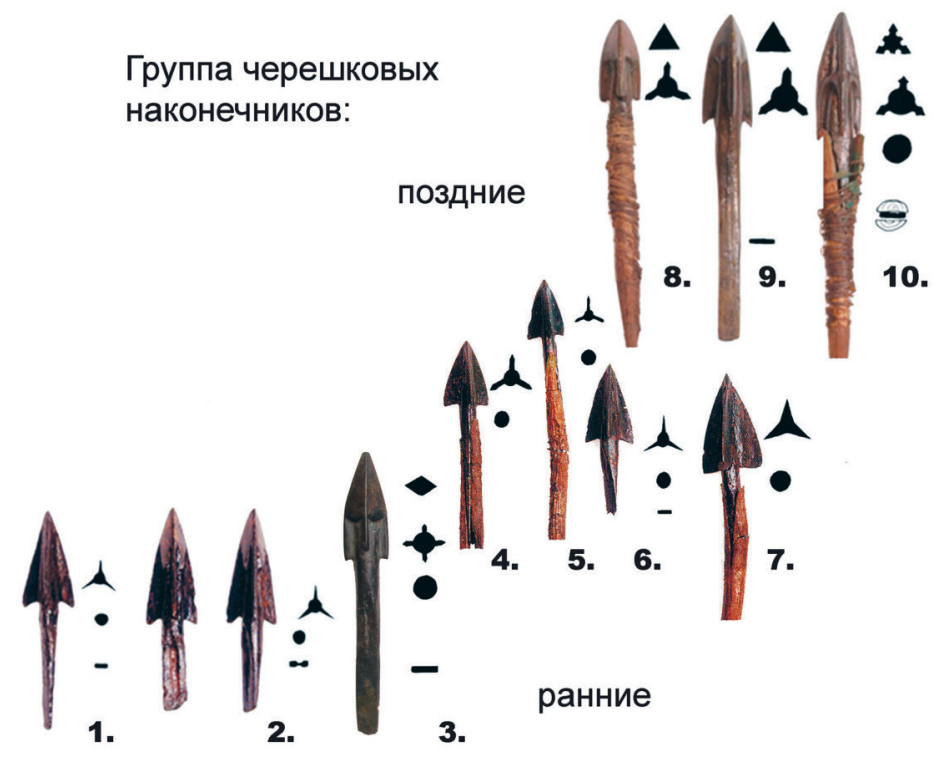

Рис. 2. Ранние и поздние типы наконечников стрел черешковой группы из комплексов Аржана-2 
причём кромлех более позднего кургана был устроен поверх более ранней могилы, содержащей мужское захоронение с колчаном. Второй колчан найден в относительно более позднем кургане. Несмотря на количественную разницу, распределение наконечников показало ту же группировку, что и при анализе стрел из Аржана-2 (табл. 3). Также очень показательно, что стрелы из комплексов Чинге-Тэя ближе к относительно более поздним наборам из Аржана-2 и Сарыг-Булуна, а ранний комплекс рядового кургана сближается с ранними наборами Аржана-2.

Как отмечено ранее, в основном хронологические определения «работают» на сопоставлении стрел разных отделов классификации, так как типы чрезвычайно разнообразны. Однако некоторые специфические индивидуальные типы стрел могут быть также сопоставлены. Они едва ли могут быть случайны и показывают близость по времени относительно поздних наборов из Аржана-2 и Чинге-Тэя, а также Чинге-Тэя и позднего комплекса СарыгБулуна (рис. 3).

Несколько слов необходимо сказать о тагарских наборах стрел, которых найдено немного, но они очень показательны. Как отмечено ранее, в ареале тагарской культуры абсолютно преобладает втульчатая группа стрел, что может показаться удивительным, учитывая соседство с Тувой. Мне уже неоднократно приходилось говорить о необходимости пересмотра хронологии начала формирования тагарской культуры в сторону значительного удревнения (Чугунов, 2013). Это необходимо не только на основании радиоуглеродных определений. На это указывают и представленные наблюдения за развитием стрелкового набора.
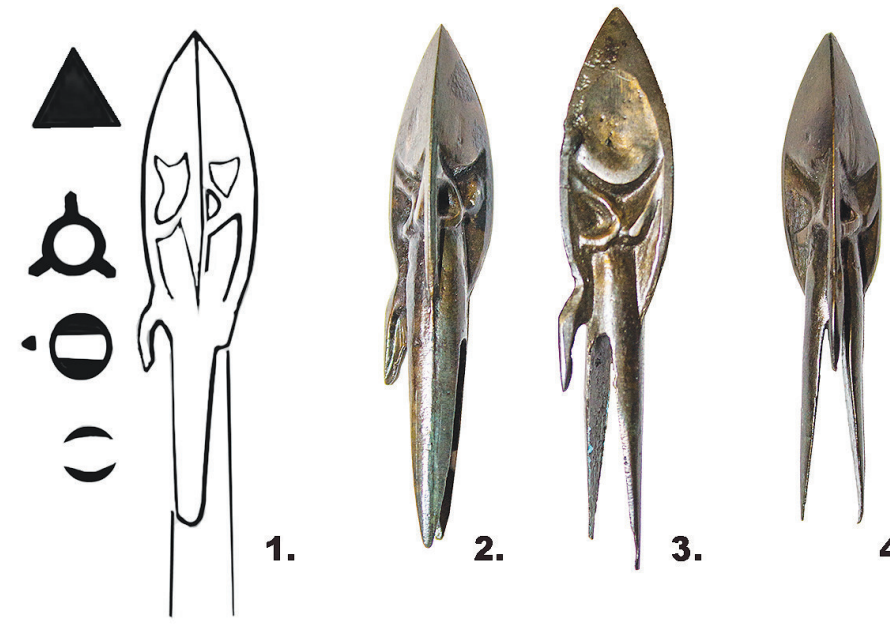

3.

4.
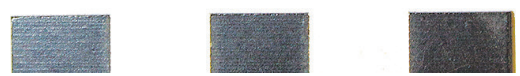

Рис. 3. Наконечники стрел зажимной группы с литым узором на головке: 1 - Сарыг-Булун, курган 2, могила 5; 2 -4 - Чинге-Тэй І, могила 3 (фото и рисунок автора) 


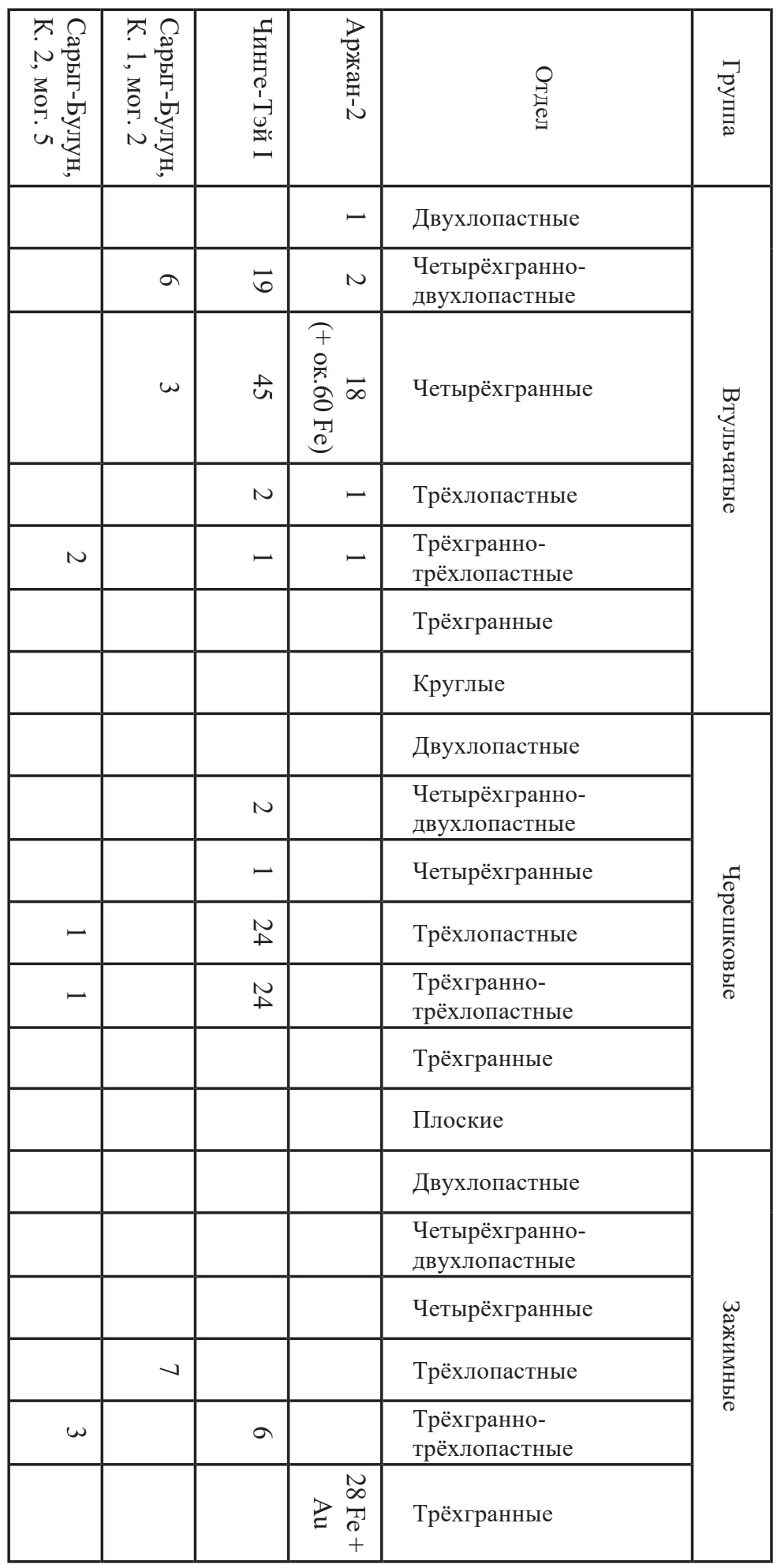




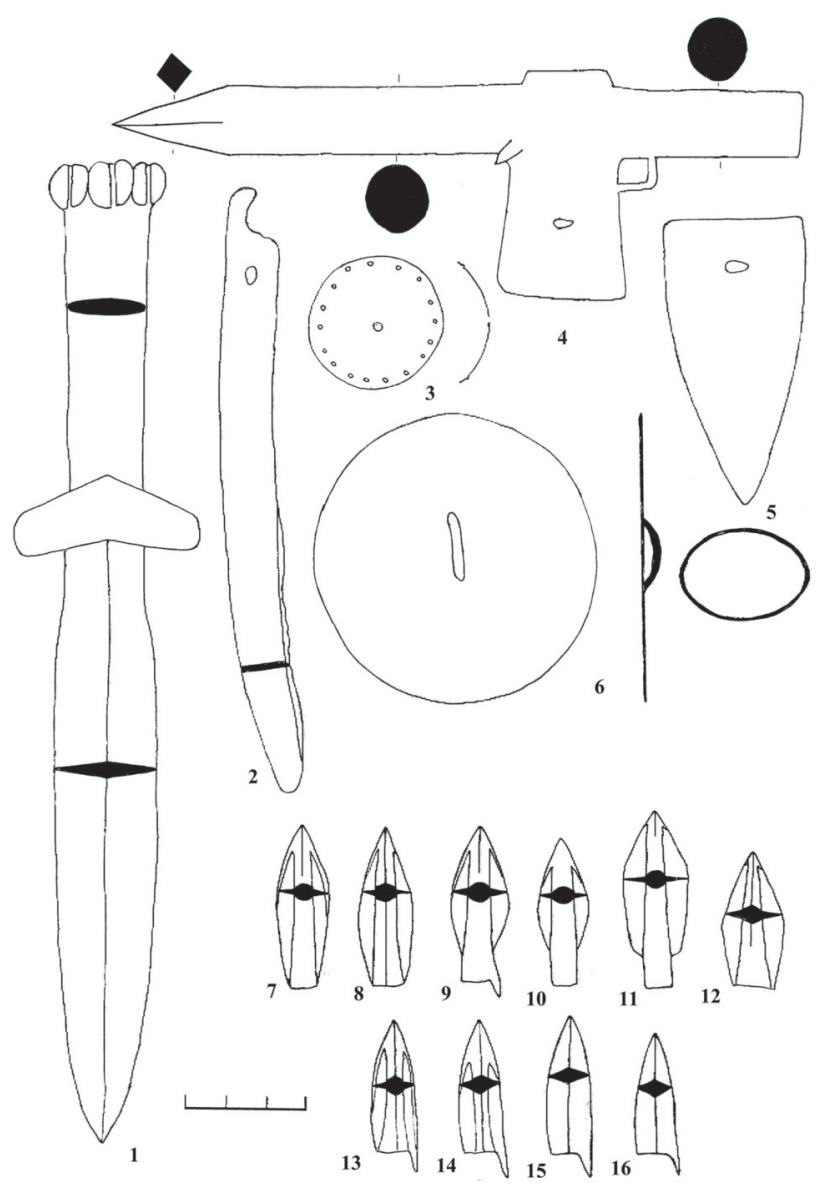

Рис. 4. Раннетагарский комплекс могилы 1 кургана 1 могильника Тигир-Тайджен IV (раскопки М.Л. Подольского 1999 г.)

Прекрасным примером является комплекс из могильника Тигир-Тайджен IV (раскопки М.Л. Подольского 1999 г.), где набор стрел, да и остальной инвентарь из раннетагарской могилы, почти точно соответствует комплексу Аржана (рис. 4). Но самые большие наборы стрел происходят из раскопок Я.А. Шера могильника Каменка (рис. 5). Интересно, что по составу они различаются между собой и здесь не исключена хронологическая причина этого различия. Сопоставление наконечников из Каменки со стрелами предскифского времени Причерноморья показывает их однотипность - это так называемые килевидные наконечники и стрелы с ромбическим очертанием пера, относящиеся к черногоровскому пласту древностей. Можно отметить ещё одну интересную особенность у раннетагарских экземпляров - деревянные шипы, привязанные к основанию втулки (рис. 5: Б 5). В качестве гипотезы можно предположить что-то подобное у новочеркасских наконечников, где иногда сохраняются остатки обмотки, ненужной при втульчатом способе насада на древко. 

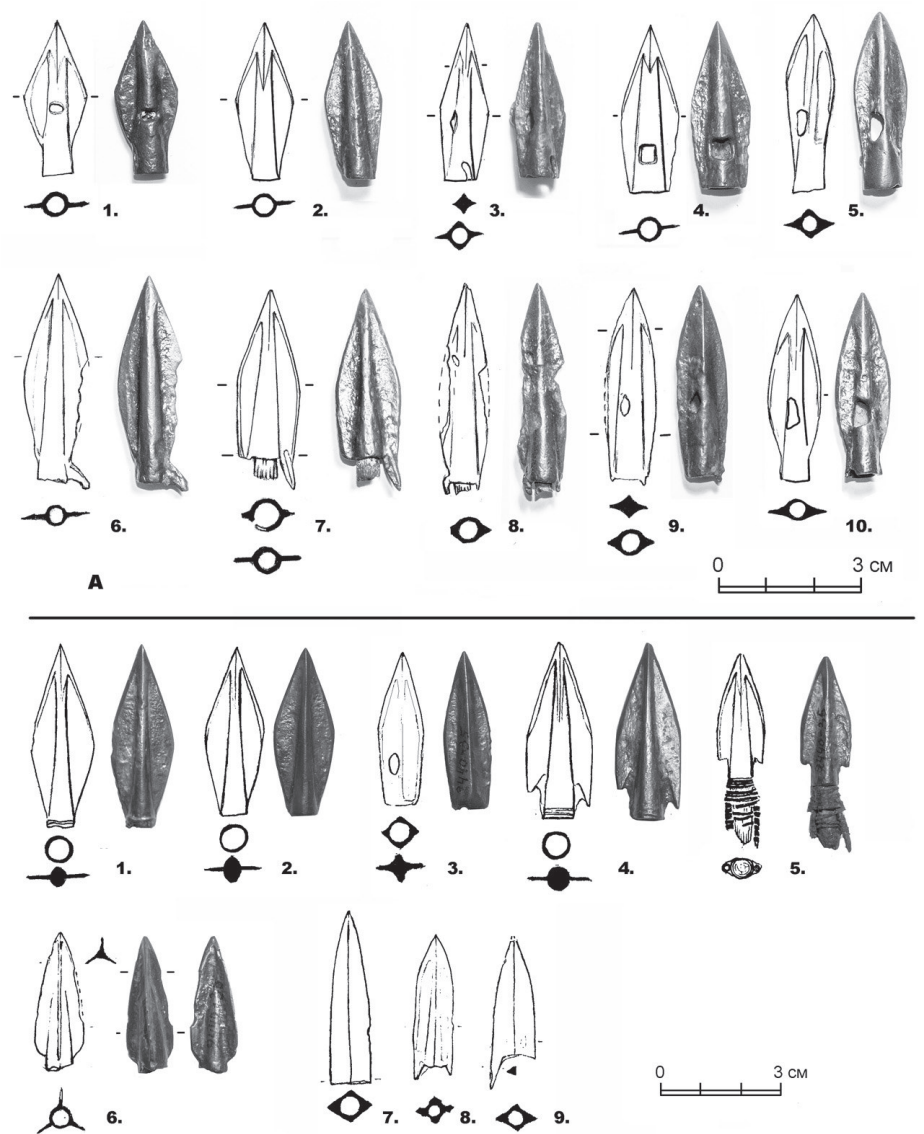

Б

Рис. 5. Некоторые бронзовые наконечники стрел из раннетагарского могильника Каменка I. A: курган 2, могила 3; Б: курган 4, могила 3 (раскопки Я.А. Шера; фото и рисунок автора)

В заключение можно предложить таблицу базовой модели классификации металлических наконечников стрел восточной зоны степной Евразии (табл. 4), основанной на классических принципах, предложенных более полувека назад К.Ф. Смирновым и дополненной одной новой группой и несколькими отделами. Использование единых классификационных подходов, безусловно, должно облегчить анализ и межрегиональное сопоставление такого важнейшего источника по хронологии эпохи ранних кочевников, как наконечники стрел. 


\begin{tabular}{|c|c|}
\hline Двухлопастные & \multirow{7}{*}{ 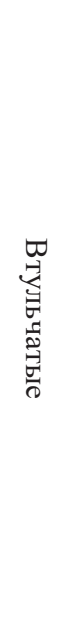 } \\
\hline Четырёхгранно-двухлопастные & \\
\hline Четырёхгранные & \\
\hline Трёхлопастные & \\
\hline Трёхгранно-трёхлопастные & \\
\hline Трёхгранные & \\
\hline Круглые & \\
\hline Двухлопастные & \multirow{7}{*}{ 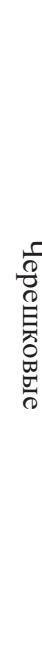 } \\
\hline Четырёхгранно-двухлопастные & \\
\hline Четырёхгранные & \\
\hline Трёхлопастные & \\
\hline Трёхгранно-трёхлопастные & \\
\hline Трёхгранные & \\
\hline Плоские & \\
\hline Двухлопастные & \multirow{6}{*}{ 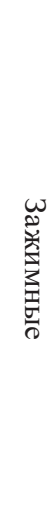 } \\
\hline Четырёхгранно-двухлопастные & \\
\hline Четырёхгранные & \\
\hline Трёхлопастные & \\
\hline Трёхгранно-трёхлопастные & \\
\hline Трёхгранные & \\
\hline
\end{tabular}




\section{ЛИТЕРАТУРА}

Аванесова Н.А. Культура пастушеских племен эпохи бронзы Азиатской части СССР (по металлическим изделиям). Ташкент: «Фан», 1991. 200 с.

Варенов А.В. Иньское оружие дистанционного боя // Известия СО АН СССР. Серия истории, филологии и философии. 1985. № 3. Вып. 1. С. 30-37.

Вишневская O.A. Культура сакских племен низовьев Сырдарьи в VII-V вв. до н.э. по материалам Уйгарака // Труды ХАЭЭ. [Т.] 8. М.: Наука, 1973. 160 с.

Галанина Л.К. Келермесские курганы. «Царские» погребения раннескифской эпохи // Степные народы Евразии. Т. 1. М., 1997. 269 с.

Грязнов М.П. Аржан. Царский курган раннескифского времени. Л.: Наука, 1980. 62 с.

Зайчева Г.И., Чугунов К.В., Алексеев А.Ю., Дергачев В.А., Васильев С.С., Семенцов А.А., Кук Г.Т., Скотт Е.М., Ван дер Плихт Х., Боковенко Н.А., Кулькова М.А., Бурова Н.Д., Лебедева Л.М., Юнгер Х., Соннинен Э. История и результаты радиоуглеродного датирования кургана Аржан // Радиоуглерод в археологических и палеоэкологических исследованиях. СПб.: ИИМК РАН, 2007. С. 251-262.

Комиссаров C.A. Комплекс вооружения древнего Китая. Эпоха поздней бронзы. Новосибирск: Наука, 1988. 120 с.

Мелюкова А.И. Вооружение скифов. САИ. Д 1-04. М.: Наука, 1964. 90 с.

Очир-Горяева М.А. Наконечники стрел кочевников Нижнего Поволжья // РА. 1996. № 1. C. 41-54.

Рукавишникова И.В. Звериный стиль Аржана-5 (комплексный подход в изучении предметов, декорированных в зверином стиле). КСИА. 2017. 247. С. 163-175.

Синьизян Моху чахань муди. Синьцзян вэйу’эр цзычжицю вэньу каогу яньцюйсо бяньчжу (Могильник Мохучахань в Синьцзяне / Сост. Институт археологии и культуры СУАР). Пекин: Кэсюэ чубаньшэ, 2016. (на кит. яз.). 400 с.

Смирнов К.Ф. Вооружение савроматов. М,. 1961 (МИА. [Вып.] 101). 160 с.

Семёнов Вл.А., Килуновская М.Е. Новые памятники раннего железного века в Туве // Информационный бюллетень МАИКЦА. Вып. 17. М., 1990. С. 36-47.

Чугунов К.В. 2000а. К вопросу о формировании колчанного набора в восточных регионах скифского мира // Сохранение и изучение культурного наследия Алтая. Выпуск ХІ. Под ред. Ю.Ф. Кирюшина и А.А. Тишкина. Барнаул: Изд-во Алт.ун-та. C. $165-168$.

Чугунов К.В. 2000б. Бронзовые наконечники стрел скифского времени Тувы // Мировоззрение. Археология. Ритуал. Культура. Сборник статей к 60-летию М.Л. Подольского. СПб. С. 213-238.

Чугунов К.В. Аржан-2: реконструкция этапов функционирования погребальнопоминального комплекса и некоторые вопросы его хронологии // РАЕ. 2011. № 1. СПб. С. 262-335.

Чугунов К.В. Актуальные проблемы хронологии памятников эпохи ранних кочевников Центральной Азии и Сибири // Вестник Томского государственного университета. История. 2013. № 3 (23). С. 97-102.

Шульга П.И. Могильник Юйхуанмяо в Северном Китае (VII-VI вв. до н.э.). Новосибирск: Изд-во ИАЭТ СО РАН, 2015. 304 с.

Rawson J. China and the steppe: reception and resistance // Antiquity, 91. 2017. P. 375-388.

Zaitseva G.I., Chugunov K.V., Dergachev V.A., Nagler A., Parzinger G., Scott M., Sementsov A.A., Vasiliev S., van Geel B., van der Plicht J, Sementsov A.A. and Lebedeva L.M. Chronological studies of the Arzhan-2 Scythian monument in Tuva // Radiocarbon. 2004. V. 46 (2). P. 277-284. 


\section{РАННИЙ ЖЕЛЕЗНЫЙ ВЕК ЕВРАЗИИ В СКИФСКУЮ ЭПОХУ}





\title{
НА СЕВЕРО-ВОСТОЧНЫХ РУБЕЖАХ СКИФИИ: СРЕДНИЙ ДОН В V-IV ВВ. ДО Н.Э.
}

\author{
Гуляев В.И.
}

http://10.25681/IARAS.2019.978-5-317-06274-3/47-60

Население степных и лесостепных областей Северного Причерноморья (несмотря на некоторые несущественные локальные различия в их культуре) входило в состав единого государства - Скифии, и северо-восточной окраиной этого военно-политического объединения была территория Среднего Дона. Этот вывод, основанный на бытовании единой на всей огромной территории Скифии - от Дона до Дуная и от широты КиеваПолтавы-Воронежа до берегов Чёрного и Азовского морей «культуры верхов», целиком укладывается в рамки той концепции, которую в своё время упорно отстаивали выдающиеся русские скифологи М.И. Ростовцев и А.И. Тереножкин.

Ключевые слова: военная аристократия, скифское государство, погребение, курган, локальный вариант

Проблемы скифской археологии и истории всегда находились в центре внимания отечественной науки. Однако с распадом СССР бо́льшая часть курганов и городищ, принадлежавших скифам, осталась в пределах суверенной Украины. В России же древности «европейских скифов» (т.е. живших между Дунаем и Доном, в Северном Причерноморье) и особенно памятники эпохи расцвета Скифии (V-IV вв. до н.э.) встречаются только на Среднем и Нижнем Дону, на территории Воронежской, Белгородской и Ростовской областей. Донские земли в тот период служили восточной окраиной скифских владений, но окраиной не захудалой и бедной, а стратегически важной и богатой. Именно здесь проходили тогда основные торговые пути древности. Именно здесь имели место крупные этнокультурные процессы I тыс. до н.э.: миграции племен с востока на запад (включая и приход самих скифских кочевых групп, пересёкших Дон не позднее начала VII в. до н.э. и захвативших Северное Причерноморье); торговые, культурные и политические контакты самых разных этносов - ираноязычных скифов, савроматов-сарматов, синдов, меотов, предков финно-угров и славян, фракийцев и эллинов.

Ниже речь пойдет только о регионе Среднего Дона. Географически он включает в себя современные Воронежскую и Белгородскую области целиком, а Волгоградскую и Ростовскую области Российской Федерации - лишь частично. По своим природно-климатическим условиям эта территория относится в основном к лесостепной, а на юге к степной зонам и представляет собой холмистую равнину, покрытую в ряде мест густыми широколиственными лесами и орошаемую многочисленными реками. Характерная черта Среднедонской Лесостепи - чередование открытых безлесных степных просторов с довольно значительными лесными массивами.

Регион обладает значительным числом археологических памятников раннего железного века в виде курганов и городищ. Археологическое изуче- 
ние Лесостепного Подонья началось в первом десятилетии XX в. (раскопки А.А. Спицына и Н.Е. Макаренко у с. Мастюгино, сотрудников ВУАК могильника Частые Курганы близ Воронежа) и интенсивно продолжалось в 1950-1990-е годы (Институт археологии АН СССР, Москва - П.Д. Либеров, А.И. Пузикова, В.И. Гуляев, Е.И. Савченко и др.; ВГУ - А.П. Медведев, ВГПУ А.Т. Синюк, В.Д. Березуцкий и др. - в Воронеже). К настоящему времени усилиями нескольких поколений исследователей в рассматриваемом регионе выявлено свыше 200 курганных погребений скифской эпохи и около 50 городищ (частично раскопанных - но их меньшинство).

Однако решение даже основных проблем, касающихся этнокультурной ситуации на Среднем Дону в скифскую эпоху, вызывает до сих пор значительные трудности.

Bo-nервыx, согласно имеющейся на сегодняшний день информации, носители скифской культуры появляются в Лесостепном Подонье сравнительно поздно - не ранее рубежа VI-V вв. до н.э. или даже начала V в. до н.э., причём культура эта имеет уже вполне сложившийся облик.

Bo-вторых, более всего местные древности (курганы и городища) рассматриваемой эпохи близки памятникам Левобережной Приднепровской Лесостепи, что, вероятно, косвенно свидетельствует о районе исхода данной скифской группы в сторону Дона (Танаиса).

$B$-третьих, пограничное положение среднедонских скифов далеко на северо-востоке Большой Скифии, на стыке с чуждыми этнокультурными массивами (финно-угры на севере, савроматы на востоке), не могло не сказаться со временем на некоторых чертах их культуры.

$B$-четвертых, местная скифская популяция просуществовала здесь сравнительно короткий срок: большинство древностей скифов датируется на Среднем Дону от середины V в. до н.э. до рубежа IV-III вв. до н.э., т.е. всего около 150 лет или чуть больше (всего лишь шесть поколений).

$B$-nятых, среди специалистов до сих пор ведутся острые дискуссии по поводу общего характера культуры и этноса жителей Лесостепного Подонья в V-IV вв. до н.э.: одни считают, что это часть Скифии, хотя и имеющая некоторую локальную специфику (вся отечественная историография до 1960-х годов, а позже - А.И. Пузикова, Е.И. Савченко, В.И. Гуляев, А.А. Шевченко, В.П. Копылов и др.); другие называют среднедонское население будинами и даже приписывают им финно-угорскую принадлежность (П.Д. Либеров); к этой позиции примыкают воронежские археологи А.П. Медведев и В.Д. Березуцкий, правда, считающие, что оседлые будины-автохтоны жили на городищах, а в курганах похоронены пришельцы - кочевые гелоны; наконец, третьи относят местные племена к савроматской культуре и этносу (К.Ф. Смирнов, В.Е. Максименко и др.); есть также мнение, что среднедонское население это меланхлены, упоминаемые Геродотом (И.В. Куклина). 


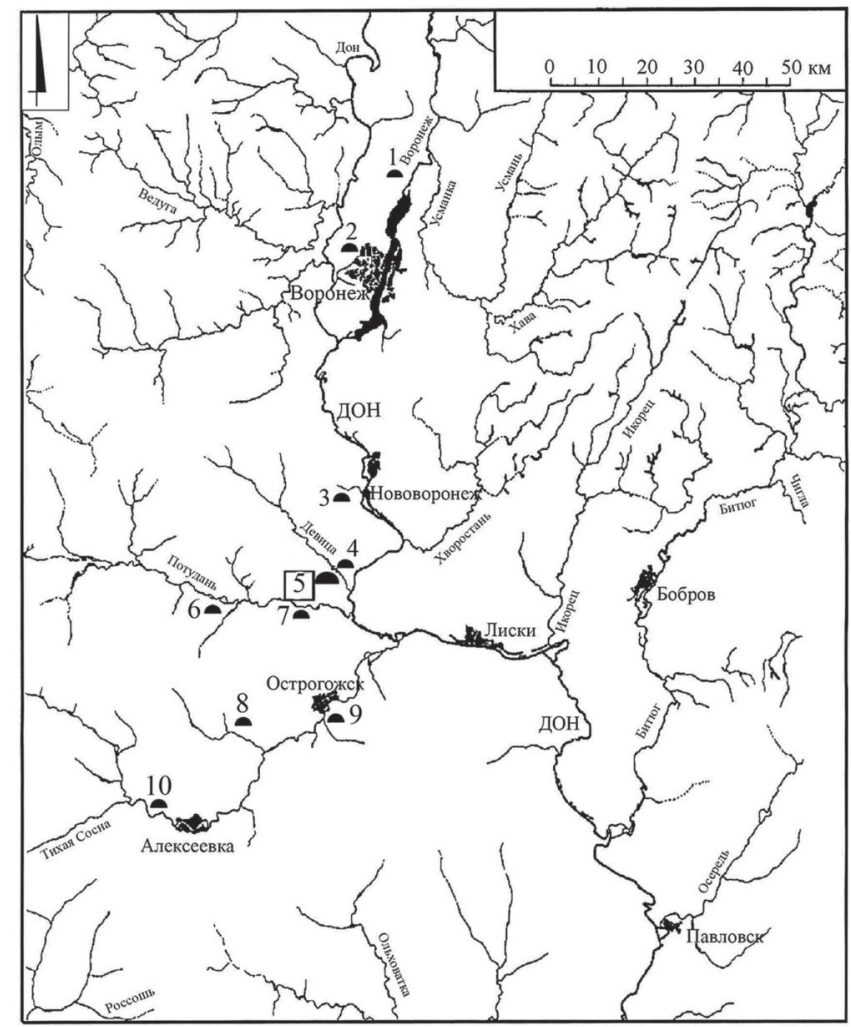

Рис. 1. Могильники скифского времени на Среднем Дону.

1 - Староживотинное; 2 - Частые курганы; 3 - Мастюгино; 4 - Дубовой;

5 - Девица V; 6 - Горки; 7 - Терновое - Колбино; 8 - Русская Тростянка; 9 - Ближнее Стояново; 10 - Дуровка

Донская археологическая экспедиция Института археологии РАН (ДАЭ) ведёт исследования памятников скифской эпохи на Среднем Дону с 1990 г. За этот период было изучено четыре городища и свыше 80 курганов V-IV вв. до н.э. в Воронежской и Белгородской областях. Причём, с самого начала этих работ удалось наладить постоянное и тесное сотрудничество с представителями естественных наук - антропологами, палеозоологами, палеоботаниками, палеогеографами и др., включая их участие в полевых проектах. В результате этих почти тридцатилетних комплексных исследований и полученного многочисленного и разнообразного материала, история населения среднедонского региона в скифское время в самых общих чертах и в сугубо предварительном плане теперь может быть воссоздана следующим образом. И главный вопрос, который нам предстоит решить, был ли Средний Дон частью Большой Скифии, или здесь, в лесостепи, жили финно-угорские будины и прочие нескифские племена. На наш взгляд, этнокультурная ситуация в Лесостепном Подонье в V-IV вв. до н.э. выглядит следующим образом. 
В начале V в. до н.э. какая-то довольно многочисленная группа кочевых или полукочевых скифских племён (место их исхода пока точно не известно, но оно почти наверняка находилось в пределах Европейской Скифии) установила свое господство в Лесостепном Подонье, подчинив (и частично уничтожив или вытеснив) местное население. Пришельцы возвели на вновь приобретённых землях свои родовые курганные могильники и соорудили укреплённые городища. Судя по имеющимся данным, в тёплое время года (весна - лето ранняя осень) эти кочевые или полукочевые скотоводы обитали в благодатных среднедонских краях, а на зиму уходили со стадами и семьями на юг, в более благоприятные для зимовки табунов и отар места. Городища-крепости на возвышенных местах служили убежищами на случай военной опасности в момент обитания всей орды в данном регионе, а в холодное время года их покидали даже стоявшие там небольшие воинские гарнизоны (пример - городище Россошки I на левом берегу реки Девица в Хохольском районе Воронежской области, исследованное комплексно и с промывкой культурного слоя). Для контроля за среднедонскими землями в зимний период особых усилий не требовалось. Но в нескольких стратегически важных пунктах такие гарнизоны, их семьи и обслуживающий персонал всё же, видимо, находились постоянно. Таково, например, городище Большое Сторожевое на высоком правом берегу Дона (площадь 7 га) или Волошинское I городище на реке Тихая Сосна. Там культурный слой имеет толщину 60-100 см и насыщен находками (бытовая керамика, кости животных, жилища с очагами, хозяйственные ямы и т.д.), а на большинстве других городищ мощность такого слоя не превышает 2030 см, что говорит о кратковременности пребывания там сравнительно небольших групп людей.

Учитывая удалённость Лесостепного Подонья от главных центров Скифии и его пограничное положение на стыке двух крупных этнокультурных областей (финно-угры на севере, воинственные савроматы-сарматы на востоке), можно предполагать, что политическое положение данной скифской группы было довольно неустойчивым и что ей пришлось почти два столетия вести упорную борьбу за свое выживание и за обеспечение безопасности своих владений. Следует напомнить, что по своим богатым природным ресурсам и выгодному географическому положению Лесостепное Подонье всегда привлекало к себе алчные взоры ближних и дальних соседей. И это предопределило необходимость формирования здесь боеспособного и хорошо вооружённого войска. Поэтому предметы вооружения и конской сбруи - наиболее частые находки в курганных захоронениях и, хотя и в меньшей степени, на городищах. По количеству железных «чешуйчатых» панцирей (примерно 20\% в изученных до сих пор мужских погребениях) Средний Дон занимает первое место в Скифии (включая и степные, и лесостепные области). Поражает и обилие предметов вооружения в среднедонских могилах. К началу XXI в. на территории рассматриваемого региона исследовано 10 курганных могильников скифского 
времени, в которых обнаружено свыше 200 захоронений эпохи РЖВ. В 175 погребальных комплексах (т.е. 75\% раскопанных могил) в том или ином составе представлены предметы вооружения и конской сбруи (Савченко, 2004. С. 154; Савченко, 2009. С. 224). Наступательное оружие включает в себя мечи, кинжалы, копья и дротики, лук и стрелы. К доспехам относятся железные «чешуйчатые» (из металлических пластин) панцири, шлемы, поножи и щиты. К 2017 г. в курганах Среднего Дона найдено 32 железных панциря (на 200 раскопанных погребений V-IV вв. до н.э.), которые распределяются по могильникам следующим образом: Частые Курганы - 12, Мастюгино - 4, Русская Тростянка - 3, Дуровка - 4, Колбино - 6, Горки - 1 и Девица V - 2 экземпляра.

К числу локальных особенностей среднедонского вооружения следует отнести явное преобладание железных втульчатых наконечников стрел над бронзовыми в колчанах местных воинов. Во всем остальном и защитное, и наступательное оружие людей, погребённых в среднедонских курганах, полностью
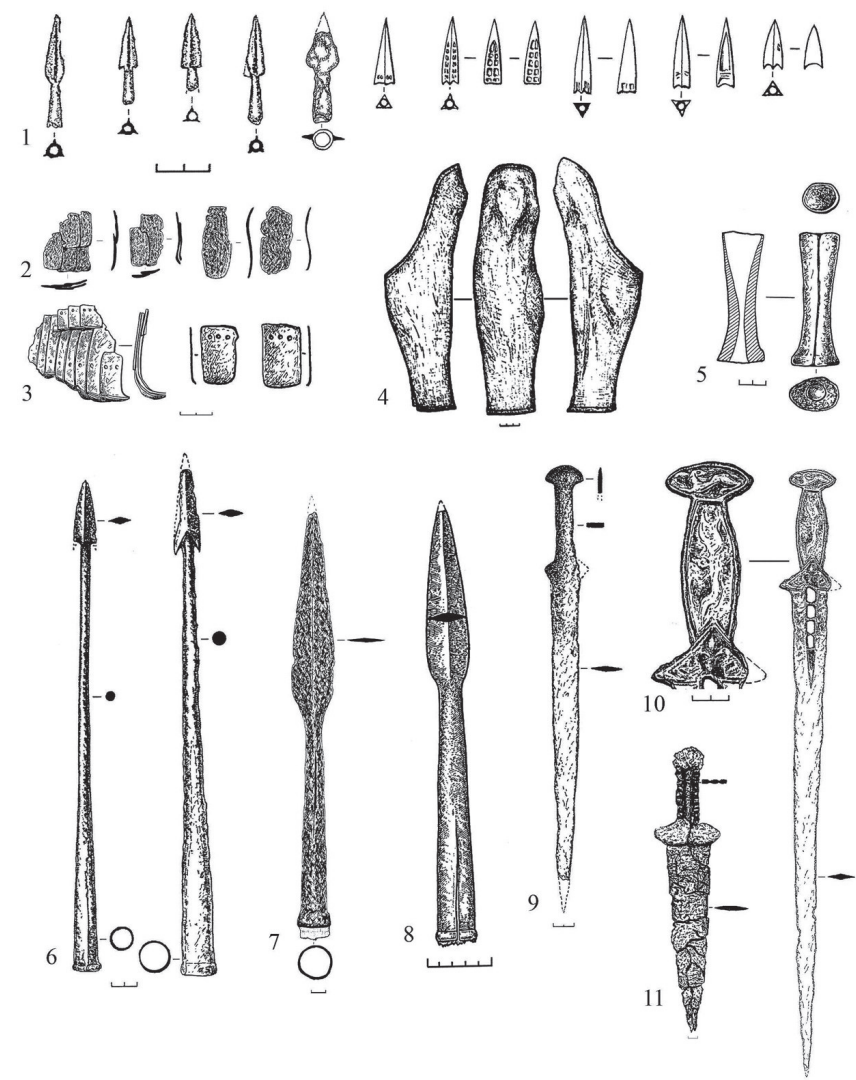

Рис. 2. Предметы защитного и наступательного вооружения (основные виды).

1 - бронзовые и железные наконечники стрел; 2-3 - пластины панциря; 4 - бронзовые поножи; 5 - железный вток дротика; 6 - наконечник дротика; 

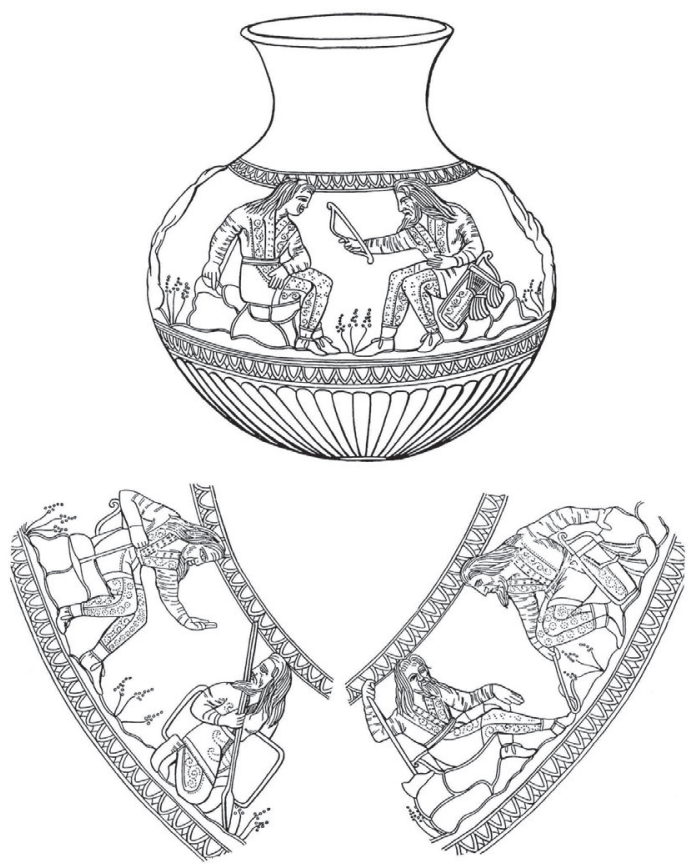

Рис. 3. Воронежский серебряный сосуд с изображением предметов вооружения

повторяет те образцы, которые господствовали в Степной Скифии в V-IV вв. до н.э. (Савченко, 2004. С. 151-277).

Исследования ДАЭ позволили установить общескифский характер погребального обряда племён Лесостепного Подонья. Ближе всего он к курганным комплексам Приднепровской Лесостепи и Скифии (исключая катакомбы) (Гуляев, 2009. С. 190-25; Савченко, 2001. С. 53-143).

Антрополог М.В. Добровольская, изучив останки более 120 индивидов разного пола и возраста из среднедонских курганов эпохи РЖВ, пришла к заключению, что полученные результаты позволяют характеризовать курганное население как степное, с демографическими особенностями, типичными для кочевого скотоводческого общества (Добровольская, 2009. С. 179; Она же, 2004. С. 81-89).

Изучение костей животных с поселений Лесостепного Подонья скифской эпохи палеозоологами показало, что в качестве мясной пищи у обитателей городищ на первом месте стоит лошадь (от 46 до 57\%), далее идут овца-коза и крупный рогатый скот. Доля свиней (если это не дикие особи) - ничтожна и составляет менее 1\%. Лошадь играла огромную роль и в погребальном ритуале: 95\% напутственной пищи в курганах - части конских туш (грудина), и это сближает материалы среднедонских могильников с погребальными памятниками степных районов Северного Причерноморья (Антипина, 2001. C. 171-187). 

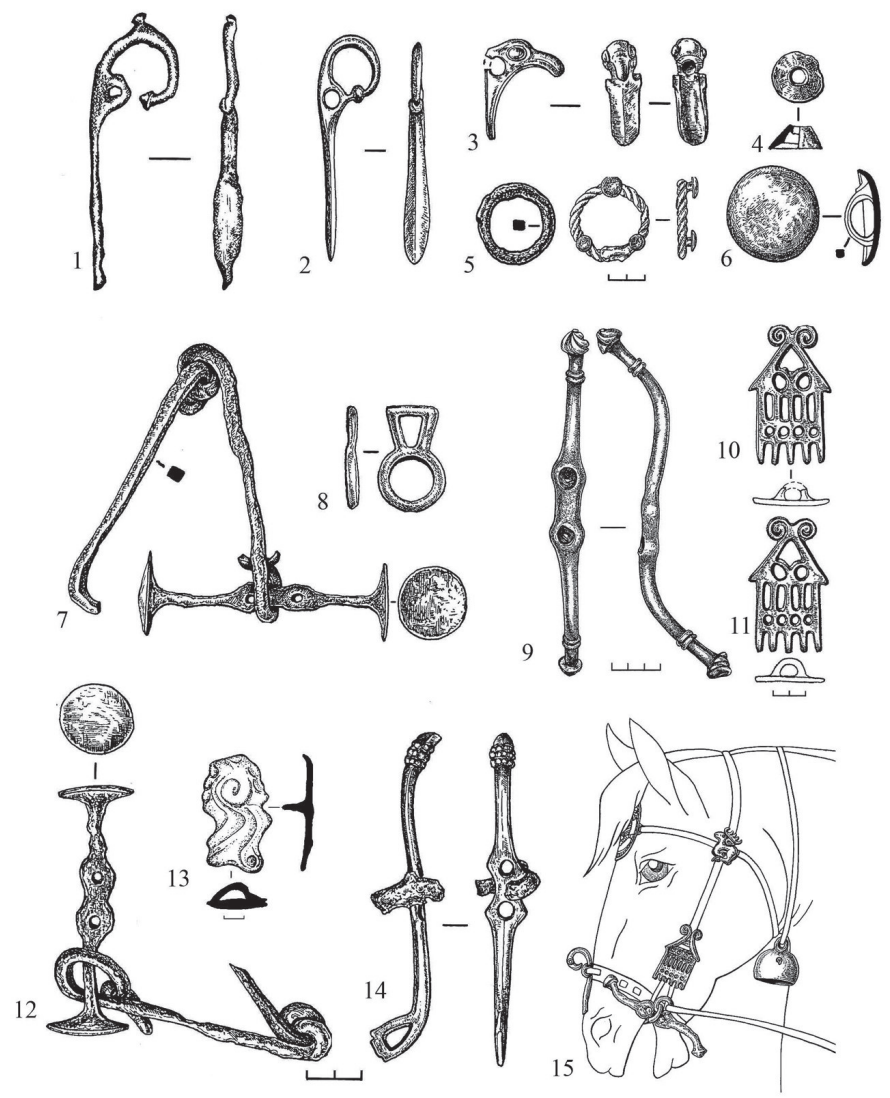

Рис. 4. Предметы конской упряжи (основные виды).

1-3 - налобники; 4 - ворворка; 5, 8 - пряжки; 6 - бляшка;

7, 9, 12, 14 - удила и псалии; 10-11, 13 - нащечники;

15 - реконструкция конской узды по П.Д. Либерову

Промывка культурного слоя исследуемых ДАЭ городищ (Россошки, Мостище, Архангельское) плюс анализ отпечатков зерновых на керамике (как с поселений, так и из курганных могил) показали, что населению Среднего Дона в V-IV вв. до н.э. был присущ в земледелии (оно играло, по сравнению со скотоводством, вспомогательную, вторичную роль в хозяйстве) хорошо известный общескифский комплекс возделываемых зерновых растений - просо (всегда преобладает), ячмень и пшеница-двузернянка. К тому же, на местных городищах (за редким исключением) наблюдается очень тонкий слой культурных отложений (20-30 см). Причиной столь явной бедности культурного слоя некоторых из исследованных городищ, - отмечает палеоботаник Е.Ю. Лебедева, - может быть кратковременный период их существования и функциональное назначение. Нельзя исключить, что эти городища не были поселениями в классическом виде, т.е. местом постоянного проживания значительных групп людей. Такие укреплённые пункты служили, вероятно, для 
укрытия населения близлежащих селищ только в период грозящей опасности, а постоянно там проживал (да и то, видимо, не круглый год) лишь небольшой гарнизон (Лебедева, Антипина, 2009. С. 208).

Объясняя причины слабой насыщенности костями животных слоев большинства исследованных на Среднем Дону городищ скифского времени, палеозоолог Е.Е. Антипина высказала предположение о подвижной скотоводческой модели хозяйства у местных племен (Антипина, 2001. С. 171-172).

Ещё более чётко указывает на близость среднедонских курганных комплексов V-IV вв. до н.э. со скифскими весь набор находимого в гробницах погребального инвентаря и особенно так называемых «престижных» вещей. Мне уже не раз приходилось высказываться на эту тему в печати (Гуляев, 2001, 2003, 2004, 2006, 2009, 2010 и др.). Здесь уместно будет привести и цитату из статьи известного специалиста по скифскому искусству А.П. Манцевич, посвящённой анализу коллекции находок из старых раскопок курганов у с. Мастюгино, хранящихся в Государственном Эрмитаже Санкт-Петербурга:

«Из всех курганов, исследованных в Мастюгинском могильнике, курган II (он же № 29/21 по классификации П.Д. Либерова. - В.Г.) дает наиболее яркую картину широких связей населения Среднего Дона с окружающими племенами. Инвентарь захороненных в нем лиц мало отличается от инвентаря могил богатой верхушки Скифии и Боспора... В Мастюгинских курганах немало исключительных по своему художественному и историческому значению образцов искусства и ремесла, как, например, греческие поножи, сходные с найденными в Куль-Обе и Ильинцах, или шлем, подобный Олонештскому, с мотивом сфинкса... Выделяются золотые украшения - серьги с изображением богини (это Кибела. - В.Г.) и двух львов (аналогии этим «серьгам»-подвескам есть в «царском» кургане Толстая Могила в степном Приднепровье. - B.Г.), ожерелья, перстни, а также серебряные («фракийские». - В.Г.) украшения уздечки... Все они ставят Мастюгинские курганы в один ряд с выдающимися памятниками скифской эпохи Северного Причерноморья - с «царскими» курганами скифов... IV в. до н.э.» (Манцевич, 1973. С. 41-42).

Но эти находки относятся к 1905-1908 гг. И с тех пор, кроме Мастюгино и Частых Курганов, раскопано ещё восемь курганных могильников Лесостепного Подонья, что во много раз расширило наши представления о погребальной практике местного населения скифского периода. Опираясь на эти новые археологические материалы, я предложил гипотезу о том, что территория Среднего Дона входила составной частью в состав Большой Скифии и там обитали скифы-иранцы (именно они и погребены в курганах). Независимо от их реальной численности, именно они были господствующей силой в данном регионе (Гуляев, 2004). При этом мною было предложено вернуться к старой (начала XX в.), но, как оказалось, вполне дееспособной концепции М.И. Ростовцева - о вхождении степных и лесостепных областей Северного Причерноморья в VII-IV вв. до н.э. в состав скифского государства, в котором 


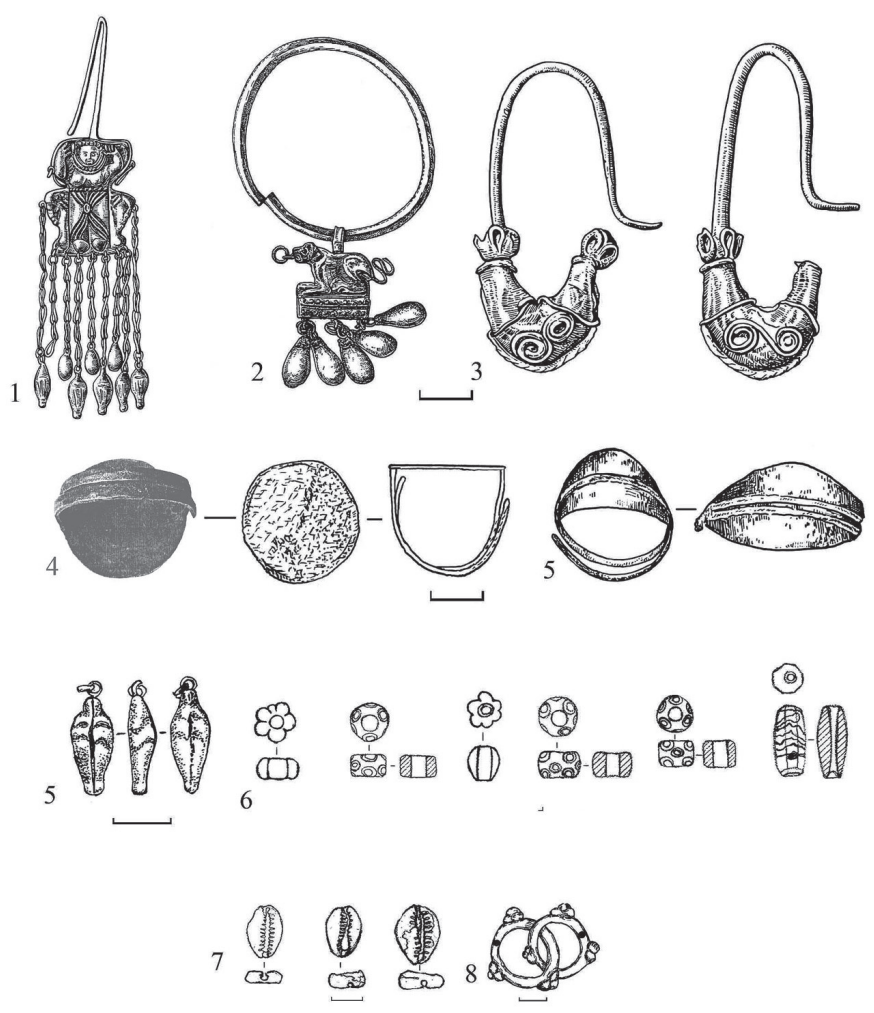

Рис. 5. Украшения (основные виды).

1-3 - серьги; 4-5 - перстни; 5 - золотая амфоровидная подвеска;

6 - бусы; 7 - раковины моллюска; 8 - бронзовая подвеска

ираноязычные скифы-кочевники держали под контролем (и в подчинении) все прочие народы и племена (Ростовцев М.И., 1918. С. 35-38). Одновременно, этот выдающийся русский учёный подчеркнул глубокое сходство элитных погребений (с их богатейшим инвентарем, в том числе и с «престижными», социально значимыми вещами) скифского времени в степной и лесостепной частях Европейской Скифии, включая Средний Дон (Ростовцев, 1918. С. 50-53). Эта «культура верхов» была, по словам учёного, единой на всей огромной территории Скифии - от Дона до Дуная и от широты Киева-Полтавы-Воронежа до берегов Чёрного и Азовского морей. «Наибольшее количество поразительных вещей из золота и серебра, - пишет М.И. Ростовцев, - дала недавно открытая Солоха и один из первых раскопанных курганов со скифским «царским» погребением, Куль-Оба около Пантикапея. В ближайшем соседстве с Солохой открыты однородные, одновременные и очень богатые курганные погребения в знаменитом Чертомлыке, в Александропольском кургане, в курганах Деевских и Серогозских... и в целом ряде других. Ту же картину в Прикубанье дает богатейший Карагодеуашх, в Придонье ряд курганов в урочище Частые Курганы около Воронежа и некоторые курганы около ст. Елизаветовской 

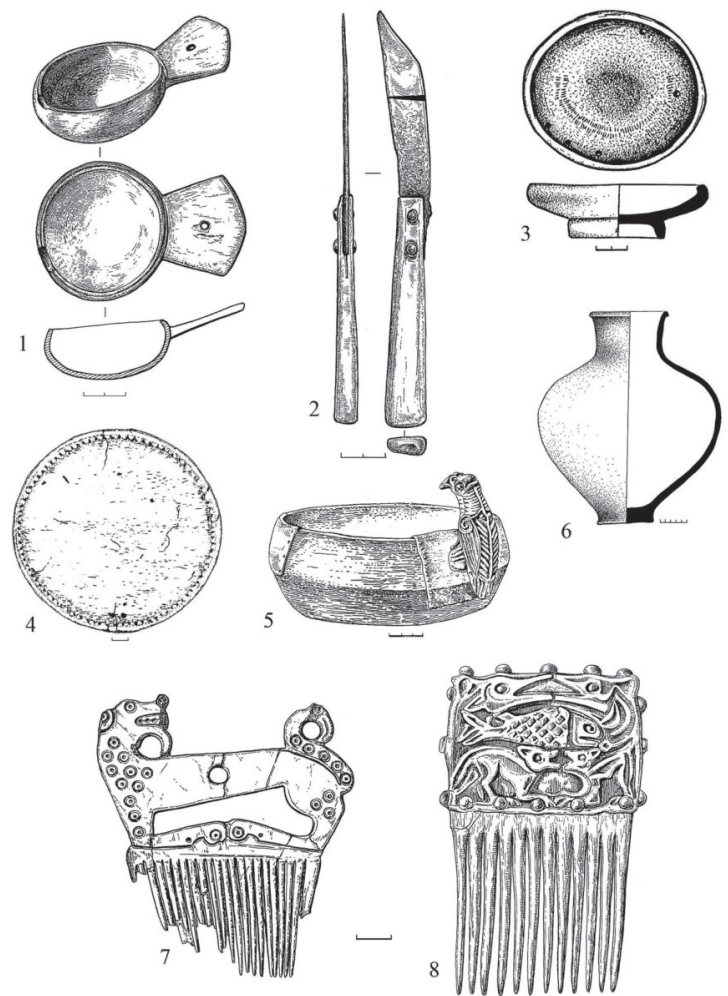

Рис. 6. Предметы быта.

1 - роговая чашечка; 2 - железный нож с костяной рукоятью;

3 - глиняная чернолаковая чашечка; 4 - бронзовое зеркало;

5 - деревянная чаша с золотыми обкладками;

6 - сероглиняный лепной сосуд; 7-8 - гребни

в устье Дона; в среднем Поднепровье знаменитый «Золотой» Рыжановский курган и ряд других; в Полтавщине - ряд курганов огромного некрополя городища, расположенного около деревень Будки, Волковцы и Аксютинцы. Все эти погребения отличаются, прежде всего, необычайным обилием золотых и серебряных вещей. Ножны мечей и гориты (налучия и колчаны, соединенные в одно целое) для луков и стрел обложены золотом или реже серебром, золотом украшены ручки мечей, древки и ремни нагаек, золотом обшиты головные уборы, одежда, пологи, покрывавшие погребённых... почти во всех погребениях находятся золотые, но чаще всего серебряные сосуды; золотом и серебром блещет конская сбруя... золотые шейные гривны, браслеты и кольца украшают мужчин и женщин...» (Ростовцев, 1918. С. 50, 53). Сам же Михаил Иванович убедительно показал, что круглодонные серебряные сосуды-кубки и серебряные с позолотой ритоны - несомненно, предметы культовые и часто непосредственно связанные у скифов с личностью царя (правителя) и царской властью в целом (Ростовцев, 1917. С. 6). 
Однако, ряд археологов (и, в частности, воронежские исследователи В.Д. Березуцкий и А.П. Медведев) полностью отрицают возможность использования «престижных» вещей и субкультуры военно-аристократической верхушки скифов для решения проблемы наличия единого большого скифского государства в Северном Причерноморье, объединяющего как степные, так и лесостепные области под эгидой «скифов-царских» (Медведев, 2002. С. 161; Березуцкий, 2002. С. 140). Они называют элитную культуру в различных местах Восточной Европы эпохи РЖВ «наднациональной», навеянной неизвестно откуда пришедшей общей модой и не имеющей прямого отношения к культуре основной массы населения - будь то скифы или иные племена и народности. Напротив, я, вслед за М.И. Ростовцевым (и, позднее, А.И. Тереножкиным), считаю, что, по крайней мере, в V-IV вв. до н.э. на всей указанной обширной территории восточноевропейской степи и лесостепи существовало могучее военно-политическое объединение - единая Скифия, в состав которой входили различные народы и племена, но контроль над ними находился в руках ираноязычных скифов-кочевников. Безусловно, в Подонье (Среднем и Нижнем) жили не только скифы, но и другие этнические группы, что вполне естественно, учитывая пограничное географическое положение данного региона в скифскую эпоху и соседство с такими крупными этнокультурными массивами, как финно-угры, савроматы-сарматы, меоты, синды и др. Однако если мы признаем факт существования единого государства - Скифии, то и присутствие самих скифов-иранцев (об их количестве здесь речи не идёт, но они, несомненно, были господствующей силой во всем Северном Причерноморье) также представляется вполне реальным. Что касается Нижнего Дона, то Геродот подтверждает, что владения «скифов-царских» доходили до нижнего течения Дона-Танаиса.

Теперь вернёмся к вопросу об элитарной культуре верхов Скифии и о том, можно ли использовать так называемые «престижные» предметы для решения некоторых общих проблем скифоведения. Ещё в начале ХХ в. М.И. Ростовцев высказал мнение, что в V-IV вв. до н.э. на всей территории Скифии, от Дуная до Дона, как в Степи, так и в Лесостепи, существовала единая элитарная культура военно-аристократических кругов. Но ведь именно эти военно-аристократические круги и определяли истинное лицо Скифии в тот период. Именно они управляли страной и получали в свое распоряжение основные материальные ресурсы. И если удается доказать близость «культуры верхов» на всём огромном пространстве от Дуная до Дона включительно, то это и есть главный аргумент в пользу наличия у скифов и подвластных им племён единого военнополитического объединения - государства, где все знатные лица, занимавшие те или иные должности (социальные посты), для успешного выполнения своих функций получали «сверху» (от центральной власти) или приобретали сами определённый набор «престижных» предметов ритуального, социальнополитического и военного назначения, практически одинаковый по всей об- 

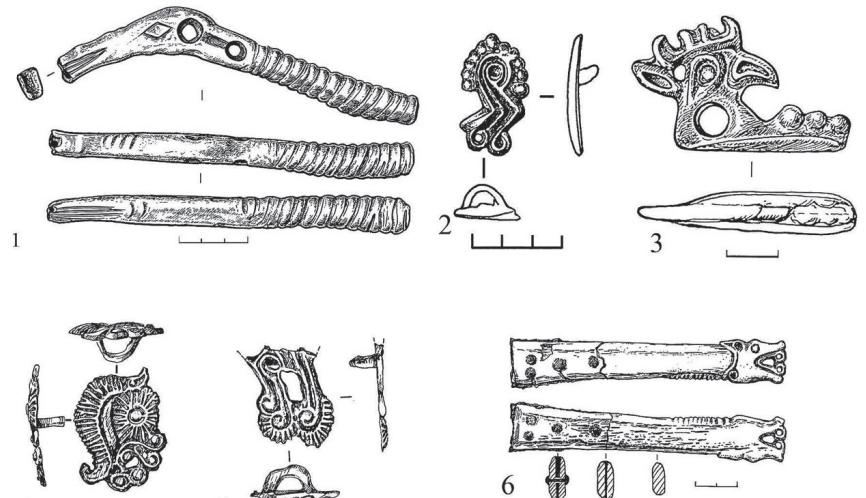

4
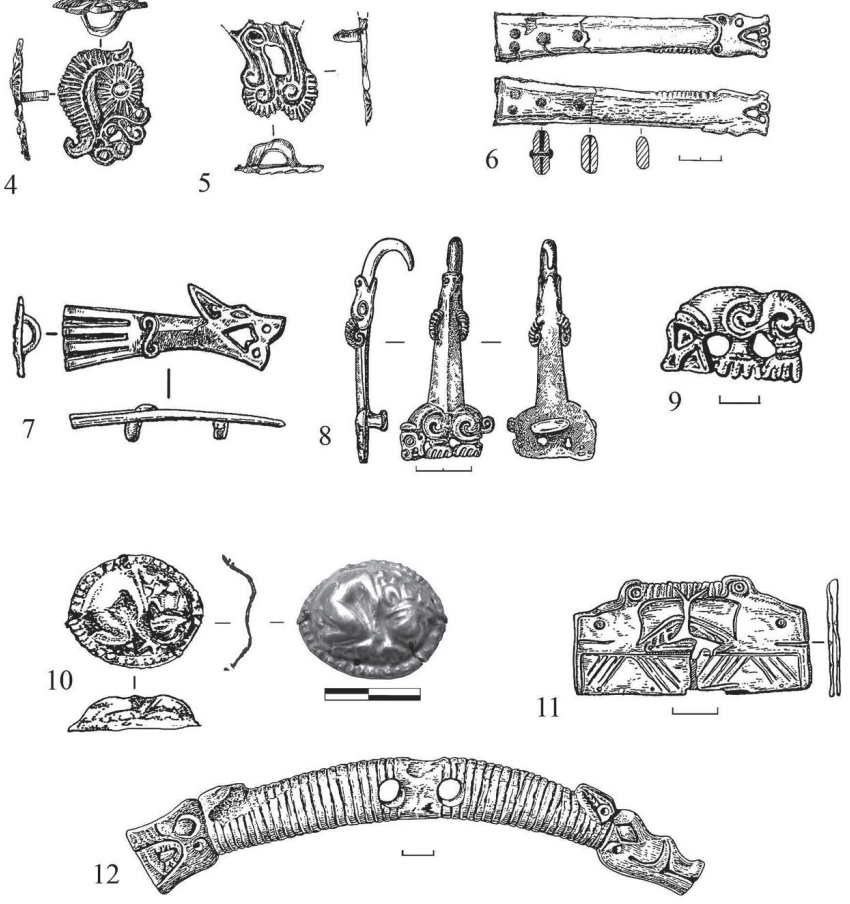

Рис. 7. Предметы, выполненные в зверином стиле (основные мотивы)

ширной Скифии. В число подобных вещей входили золотые и серебряные пластины - обкладки горитов с изображениями определённой тематической направленности, парадные мечи «чертомлыцкого» типа, шаровидные кубки и ритоны из драгоценных металлов, социально значимые деревянные чаши с золотыми обкладками, золотые гривны, золотые оплётки нагаек, золотые браслеты и перстни и др.

Таким образом, исходя из имеющихся на сегодняшний день археологических материалов, есть все основания считать, что население степных и лесостепных областей Северного Причерноморья (несмотря на некоторые несущественные локальные различия в их культуре) входило в состав единого государства - Скифии, и северо-восточной окраиной этого военно- 
политического объединения была территория Среднего Дона. И этот вывод целиком укладывается в рамки той концепции, которую в своё время упорно отстаивали выдающиеся русские скифологи М.И. Ростовцев и А.И. Тереножкин ${ }^{1}$.

\section{ЛИТЕРАТУРА}

Антипина E.E. Археозоологические материалы из раскопок памятников скифского времени на Среднем Дону // Археология Среднего Дона в скифскую эпоху. Труды Потуданской археологической экспедиции ИА РАН, 1993-2000 гг. М.: ИА РАН, 2001.

Березуикий В.Д. «Скифы на Среднем Дону» и некоторые вопросы интерпретации археологических источников // ВДИ. 2002. № 4.

Гуляев В.И. Общие проблемы археологии Среднего Дона скифского времени // Археология Среднего Дона в скифскую эпоху. Труды Потуданской археологической экспедиции ИА РАН, 1993-2000 гг. М.: ИА РАН, 2001.

Гуляев В.И. Донская археология, общескифские проблемы и научное наследие М.И. Ростовцева // Парфянский выстрел. М.: Росспэн, 2003.

Гуляев В.И. Ещё раз к вопросу об этнокультурной ситуации в Среднем Подонье в скифское время // Археология Среднего Дона в скифскую эпоху. Труды Донской (б. Потуданской) археологической экспедиции ИА РАН, 2001-2003 гг. М.: ИА РАН, 2004.

Гуляев В.И. «Престижные вещи» из среднедонских курганов скифского времени и проблема единой Скифии // Проблемы современной археологии. М.: ИА РАН, 2008.

Гуляев В.И. Парадные мечи V-IV вв. до н.э. из курганов Скифии // Археологические памятники Восточной Европы. Межвузовский сборник научных трудов. Вып. 13. Воронеж: ВГПУ, 2009.

${ }^{1}$ Большое сходство «культуры верхов» в Подонье и остальной Скифии было подробно рассмотрено в моих работах: «Общие проблемы археологии Среднего Дона скифского времени» // Археология Среднего Дона в скифскую эпоху. Труды Потуданской археологической экспедиции ИА РАН, 1993-2000 гг. М.: ИА РАН, 2001; Донская археология, общескифские проблемы и научное наследие М.И. Ростовцева // Парфянский выстрел. М.: Росспэн, 2003; Ещё раз к вопросу об этнокультурной ситуации в Среднем Подонье в скифское время // Археология Среднего Дона в скифскую эпоху. Труды Донской археологической экспедиции ИА РАН, 2001-2003 г. М.: ИА РАН, 2004; Парадные мечи V-IV вв. до н.э. из курганов Скифии // Археологические памятники Восточной Европы. Межвузовский сборник научных трудов. Вып. 13. Воронеж, 2009; «Престижные вещи» из среднедонских курганов скифского времени и проблема единой Скифии // Проблемы современной археологии. М.: ИА РАН, 2008; На восточных рубежах Скифии (древности донских скифов). М.: ИА РАН, 2010; Александрополь «царский» курган скифов: взгляд со стороны Среднего Дона // Вестник МГУ. 2017. Серия 8. История. № 4; Необычный курган скифского времени на Среднем Дону // Журнал истфака МГУ. 2017. Исторические исследования, № 8; Богиня Кибела - владычица зверей - в скифском искусстве // РА. 2018. № 1. 
Гуляев В.И. На восточных рубежах Скифии (древности донских скифов). М.: ИА РАН, 2010.

Гуляев В.И. Александрополь - «царский» курган скифов: взгляд со Среднего Дона // Вестник МГУ. 2017. Серия 8. История. № 4.

Гуляев В.И. Богиня Кибела - владычица зверей в скифском искусстве // РА. 2018. № 1 .

Добровольская М.В. К антропологии населения Среднего Дона в скифское время // Археология Среднего Дона в скифскую эпоху. Труды Донской (б. Потуданской) археологической экспедиции ИА РАН, 2001-2003 гг. М.: ИА РАН, 2004.

Добровольская М.В. Палеодемография среднедонского населения раннего железного века // Археология Среднего Дона в скифскую эпоху. Труды Донской археологической экспедиции ИА РАН, 2004-2008. М.: ИА РАН, 2009.

Лебедева Е.Ю., Антипина Е.Е. Городище Россошки I - «постоянный адрес или временная прописка?» // Археология Среднего Дона в скифскую эпоху. Труды Донской археологической экспедиции ИА РАН, 2004-2008. М.: ИА РАН, 2009.

Манцевич А.П. Мастюгинские курганы по материалам из собрания Государственного Эрмитажа // АСГЭ. 1973. № 15.

Медведев А.П. Античная традиция и археологические реалии скифского времени на Среднем и Верхнем Дону // ВДИ. 2002. № 3.

Ростовцев М.И. Представление о монархической власти в Скифии и на Боспоре // ИАК. 1917. Вып. 49.

Ростовцев М.И. Эллинство и иранство на юге России. Пг.: Огни, 1918.

Савченко Е.И. Могильник скифского времени «Терновое I - Колбино I» на Среднем Дону (погребальный обряд) // Археология Среднего Дона в скифскую эпоху. Труды Потуданской археологической экспедиции ИА РАН, 1993-2000 гг. М.: ИА РАН, 2001.

Савченко Е.И. Вооружение и предметы снаряжения населения скифского времени на Среднем Дону // Археология Среднего Дона в скифскую эпоху. Труды Донской (б. Потуданской) археологической экспедиции ИА РАН, 2001-2003. М.: ИА РАН, 2004.

Савченко Е.И. Снаряжение коня скифского времени на Среднем Дону как археологический источник // Археология Среднего Дона в скифскую эпоху. Труды Донской археологической экспедиции ИА РАН, 2004-2008. М.: ИА РАН, 2009. 


\title{
ЭЛИТНЫЙ КОМПЛЕКС НАЧАЛА IV В. ДО Н.Э. НА ЗАПАДНЫХ ГРАНИЦАХ МЕОТСКОЙ КУЛЬТУРЫ
}

\begin{abstract}
Иванов А.В.
http://10.25681/IARAS.2019.978-5-317-06274-3/61-70

В сезон 2015 г. был раскопан курган из состава курганной группы «Кеслерово-4», расположенной у села Кеслерово, Крымского района Краснодарского края. Обнаруженная под насыпью гробница относится к кругу элитных, статусных погребений. Этот вывод базируется на вполне очевидных позициях - расположение комплекса в кургане, его конструктивная сложность, жертвоприношение коней, а также состав инвентаря, содержавший такие маркеры престижа, как металлический панцирь, золотые предметы и чернолаковую посуду, весьма ценимую варварами. Комплекс стоит рассматривать исключительно в рамках меотской археологической культуры, в границах которой он территориально и находится.
\end{abstract}

Ключевые слова: меотская культура, миграция, гробница, погребальный комплекс, хронология, азиатский Боспор

В сезон 2015 г. был раскопан курган из состава курганной группы «Кеслерово-4», расположенной у села Кеслерово, Крымского района Краснодарского края (рис. 1). Территория, на которой находился курган, представляет собой узкую долину между предгорьями и рекой Адагум, за которой к северу, вплоть до реки Кубань, простираются плавни. Созданный природой своеобразный коридор с древности служил транзитной зоной для разного рода миграций, в том числе, в интересующую нас эпоху, здесь пролегали и торговые маршруты, соединяя греческие полисы Боспора с глубинными районами Кубани. Если же говорить о раннежелезном веке, то в этом микрорегионе довольно широко представлены памятники протомеотского времени, комплексы, соотносимые с древностями скифского круга, например, относительно недавно открытые Н.Ф. Шевченко погребения в кургане на хуторе Красный. Как бы подчеркивая значимость этого коридора в середине IV в. до н.э. в самом узком месте долины было основано Краснобатарейное городище - восточный форпост Боспора.

Исследованный курган был не высоким - чуть больше полуметра, имел простую стратиграфию и сооружён в одну насыпь ещё в эпоху бронзы. В пределах кургана исследовано 22 погребения и несколько объектов в хронологическом диапазоне от эпохи ранней бронзы до средневековья. Однако особое место на кургане занимало крупное впускное погребение, о котором и пойдет речь.

Итак, в самый центр кургана была впущена погребальная конструкция, состоящая из двух частей - гробницы и отделения для коней (рис. 2). Гробница помещалась в большой, в плане прямоугольной яме, размерами $-5,56 \times 3,74$ м, ориентированной длинной осью по линии восток - запад. Дно ямы было неровное. В нём отчётливо выделялись следы заглубления деревянных конструкций. Они отбивались на дне ямы широкими желобами-канавками с отпечатками 

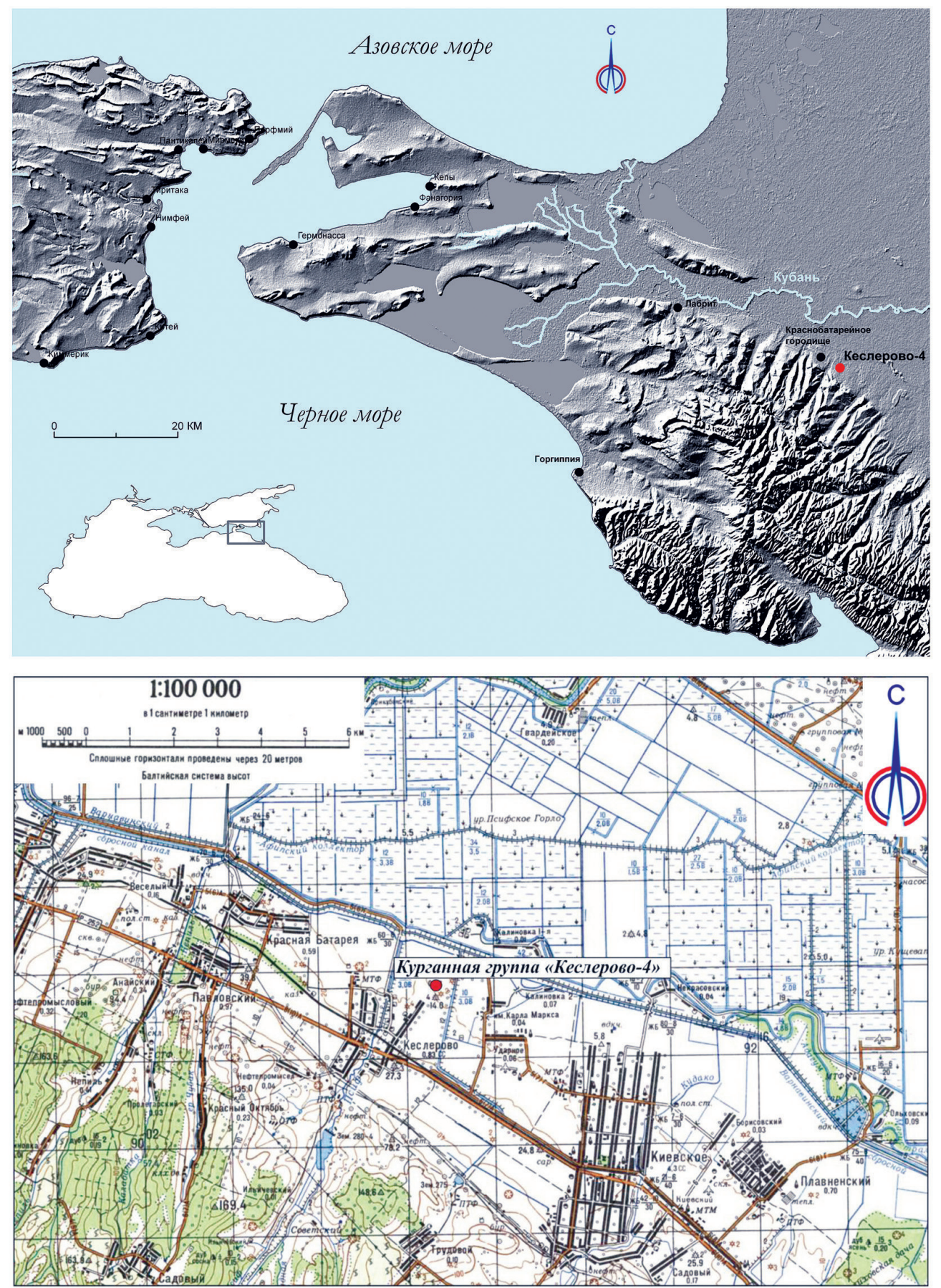

Рис. 1. Местоположение памятника 


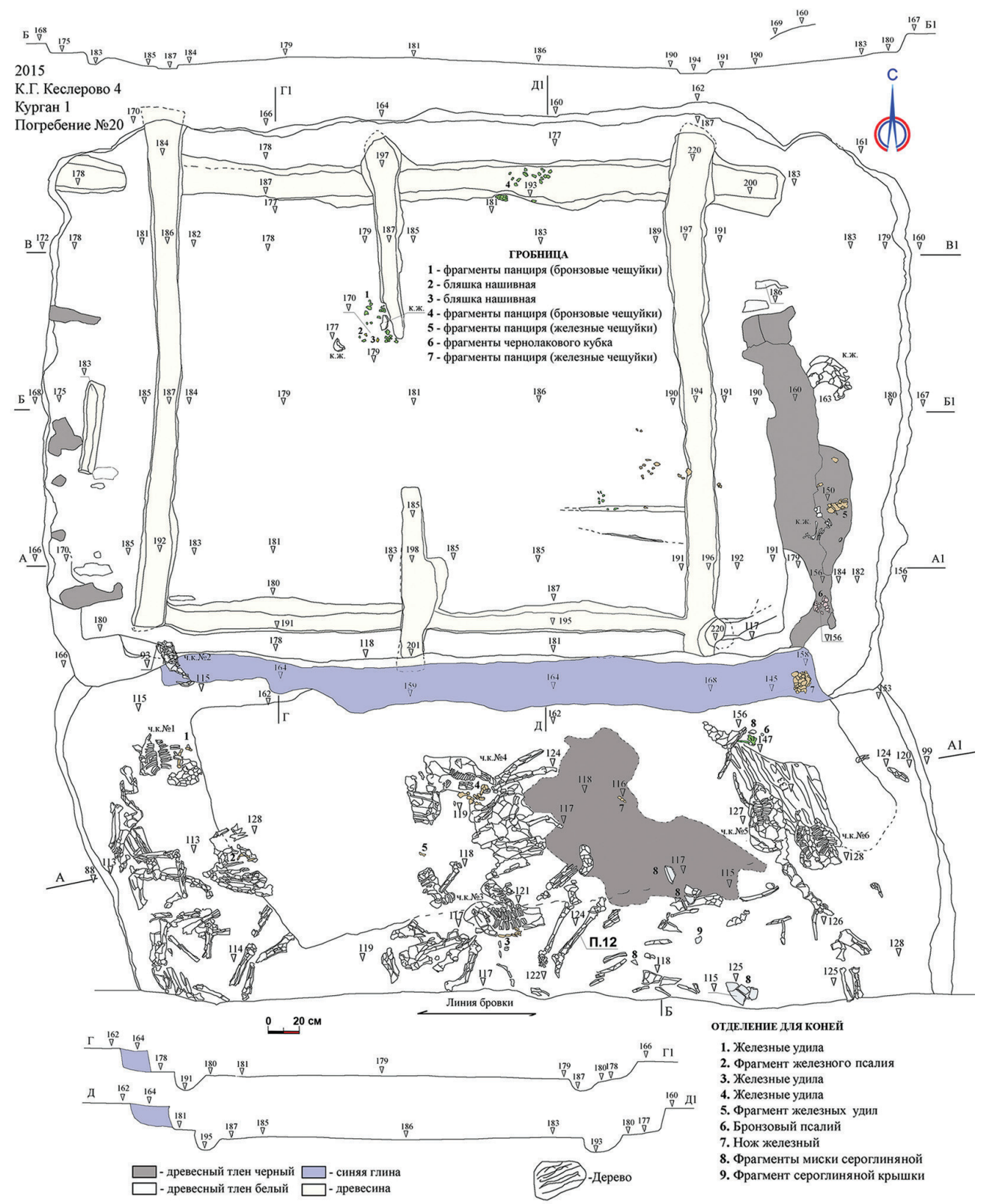

Рис. 2. Чертёж погребения 
коры дерева и светлой древесины. Ожидаемо, погребение ограблено в древности, причем с разборкой всех конструкций. Можно лишь предполагать, почему и что заставило грабителей поступить именно так. Вероятнее всего, искали тайники.

Так или иначе, по тому, что сохранилось, вполне возможно реконструировать конструкцию гробницы. Она выглядела следующим образом: в центре ямы был сооружён с небольшим заглублением в дно, видимо, для большей устойчивости, деревянный сруб размерами $3,55 \times 2,95$ м, который имел в плане фору правильного прямоугольника. Северная и южная длинные стенки сруба были сложены из брёвен. Восточная и западная торцевые стенки - из плоских досок. Эта деревянная гробница, в свою очередь, разделялась пополам перегородкой из досок на две прямоугольные в плане восточную и западную камеры, с оставлением в перегородке довольно широкого прохода. На дне восточной камеры отпечатались следы деревянных жердей, которыми, судя по всему, был устлан пол камеры. Но это предположение, может быть, здесь была перегородка под небольшое отделение для погребального инвентаря. Гробница была перекрыта деревом и камышом, тлен которого зафиксирован на торцевых сторонах ямы.

Вдоль южной стенки погребальной ямы из болотной синей глины с вкраплениями частиц железняка, материала наподобие сырца, была сооружена стенка, толщиной до 0,3 м, которая являлась своеобразной перегородкой между гробницей и отделением с конями. Это отделение представляло собой обширную, не совсем ровную яму, размерами 5,5×3,2 м, примыкающую к южной стороне гробницы. В яме была совершена гекатомба, здесь находились расчленённые кони, части которых лежали на дне без определённой системы, судя по количеству черепов - шесть взрослых особей. Все они без исключения были взнузданы железными удилами со строгими крестовидными насадками. Как и основная гробница, это отделение было перекрыто деревом и камышом.

Теперь о находках (рис. 3). Помимо удил, в набор также входили и псалии. Бронзовый псалий стержневидный, литой, Г-образный, двудырчатый, с 8-образным расширением, с плоским концом-лопастью, украшенным сильно стилизованным ажурным рисунком. Сюжет: головы волков на длинных шеях, с широко раскрытыми пастями в фас и вправо. Детали изображения проработаны гравировкой. Подобные псалии, выполненные в меото-скифском зверином стиле, относятся к довольно редкому типу, так называемого «елизаветинского круга», который начал своё развитие в V в. до н.э. и бытовал на протяжении всего IV в. до н.э. Аналогичный сюжет зафиксирован на экземпляре из курганов станицы Елизаветинской (Канторович, 2010. С. 309. Рис. 64, 1), также он близок псалиям из погребения № 159 Прикубанского могильника, которое надежно датировано набором из трёх амфор второй четвертью IV в. до н.э. (Лимберис, Марченко, 2017). 


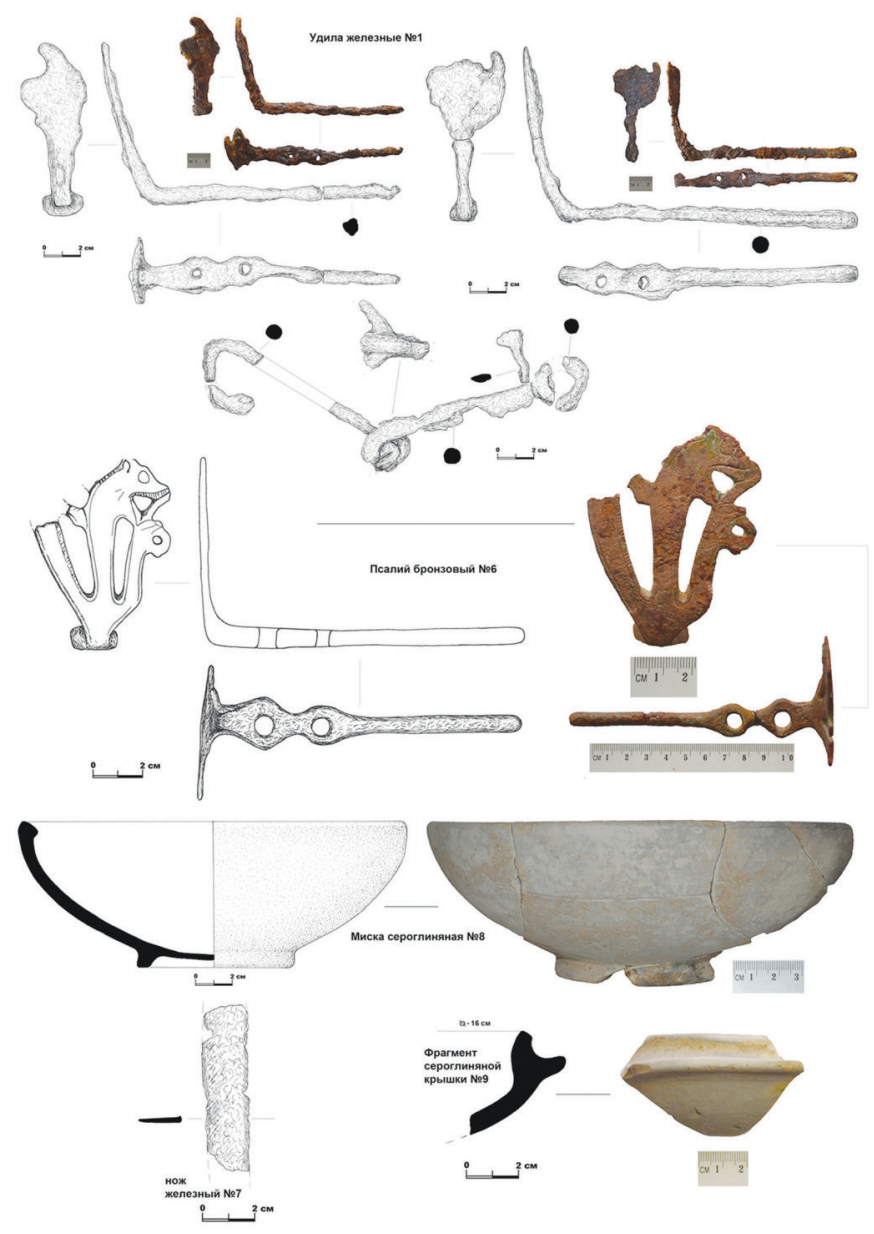

Рис. 3. Материал из отделения для коней

Остальные экземпляры из гекатомбы подобной морфологии, что и описанный выше, только выполненные ковкой из железа. Они также имеют ажурные лопасти, правда, ввиду плохой сохранности сюжет, к сожалению, не разобрать. По мнению В.Р. Эрлиха, работавшего с материалами Уляпских и Тенгинских курганов-святилищ, такая стилистика лопасти, вероятно, является попыткой воспроизвести в железе бронзовые аналоги «елизаветинского стиля» (Эрлих, 2011. С. 55). Среди останков коней, в том числе были найдены фрагмент прямого ножа, фрагмент сероглиняной крышки и фрагментированная сероглиняная миска без выделенного бортика и со скошенным вовнутрь венчиком.

Что же касается основного погребения, то грабителями оставлено очень немногое (рис. 4). В первую очередь, следует отметить части чешуйчатого панциря, разбросанные по всему периметру гробницы. Состоял доспех из не- 


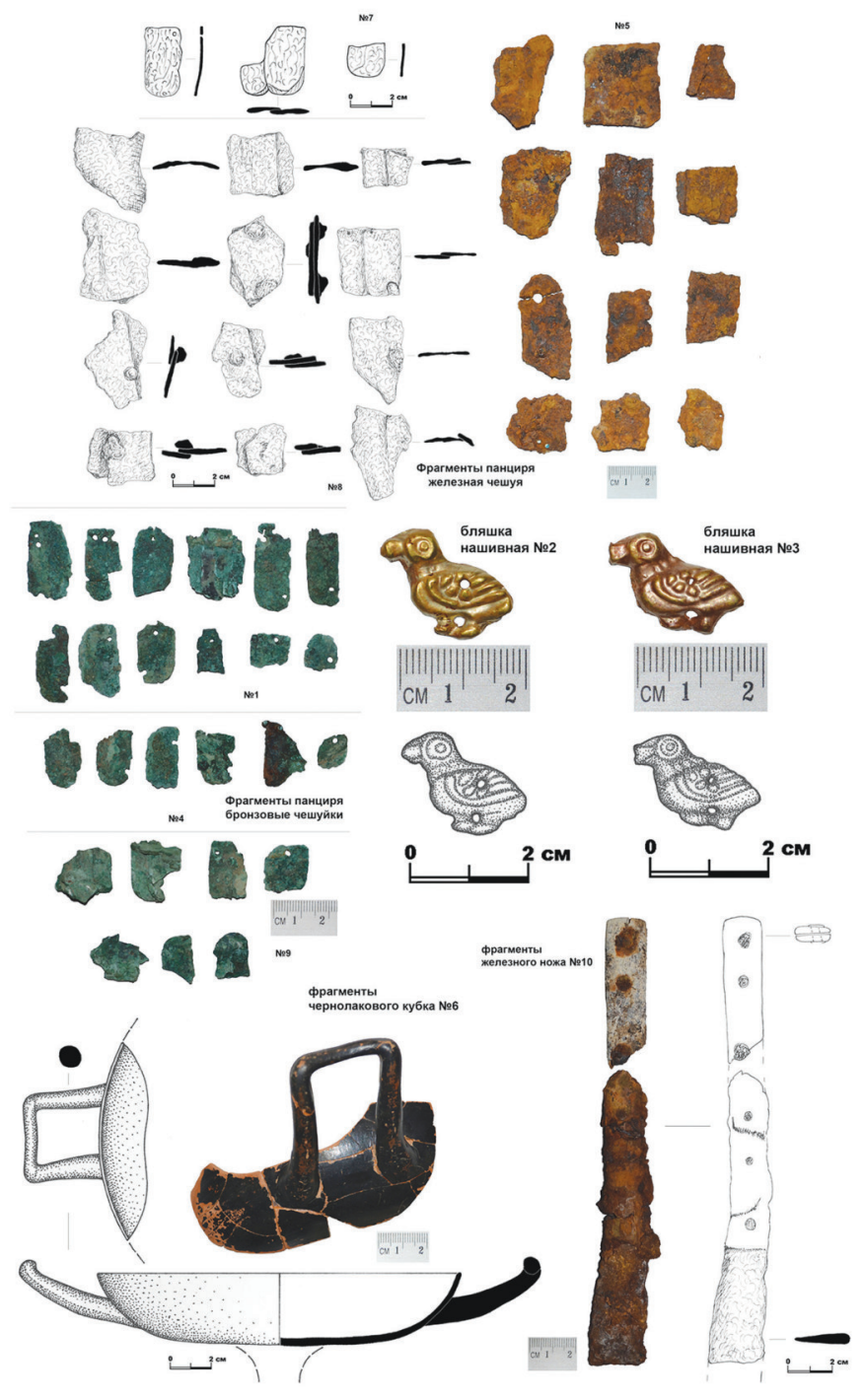

Рис. 4. Материал из гробницы

больших бронзовых и более крупных железных пластин. Железные пластины между собой соединялись железными и бронзовыми скрепками. Эта известная схема, когда для защиты тела применялась крупная железная чешуя, а более мелкие пластинки, в нашем случае бронзовые, составляли металлический набор рукавов (Черненко, 1968. С. 34). Облик доспеха видимо, не особо отличался от образцов панцирей скифского типа, распространённого на обширной территории, в том числе и в Причерноморье. На Кубани подобные панцири встречены практически во всех элитных комплексах V-IV вв. до н.э., а в IV в. 
до н.э. они, правда довольно редко, фиксируются и в воинских погребениях меотских могильников, а также в святилищах (Эрлих, 2011. С. 52).

Помимо остатков панциря, в гробнице найдены крупный нож с костяной рукояткой и фрагменты чернолакового кубка, с низким и широким вместилищем и невысоким заостренным венчиком. Сохранившаяся ручка чуть выше линии венчика, горизонтальная, в сечении округлая. Кубки подобной морфологии по материалам афинской агоры датируются довольно узко - концом V в. до н.э. (Sparkes \& Talcott, 1970. Р. 265. Fig. 4, 433).

Две нашивные штампованные золотые бляшки, встреченные в гробнице, зооморфные, в виде уточек в фас и влево. Тело птиц пропорциональное, шея короткая, рельефно проработан глаз, выполненный в виде точки, окружённой кольцом, и крыло с чёткой обводкой и тремя хорошо различимыми перьями. Ножки две, короткие. Отверстия для крепления округлые, пробитые. Необходимо отметить, что среди образов звериного стиля, наряду с копытными, кошачьими и хищными птицами, утка далеко не самый популярный образ, и встречается крайне редко. Пожалуй, ближайшая аналогия - бляшка в виде уточки из Уляпа. Найдена она в Кургане 4 погребения 44 Уляпского некрополя, вместе с крупным набором импортной посуды, куда входили два килика - чернофигурный и чернолаковый начала IV в. до н.э. и чернолаковый скифос второй половины - конца V в. до н.э. (Лесков, Беглова, Ксенофонтова, Эрлих, 2007. С. 76. Рис. 34).

Таким образом, совокупность данных позволяет датировать комплекс началом IV в. до н.э. Эту позицию подкрепляют и материалы тризны (рис. 5, 1), связанной с гробницей, и откуда происходит амфора Фасоса серии Топраиасара первой половины IV в. до н.э. (Монахов, 2003. С. 76. Таб. 48). Следует обратить внимание и на одно из погребений, найденное в пределах кургана (рис. 5, 2). Здесь погребённый лежал на боку, а из инвентаря находился всего лишь один предмет - ножка мендейской амфоры варианта портичелло, также первой половины IV в. до н.э. Традиция положения в могилу, в составе вещевого набора, ножки амфоры зафиксирована в ближайшем по отношению к кургану меотском могильнике Фурожан, функционировавшем в IV в. до н.э. Не исключен вариант, что это захоронение также связано с гробницей, а скромность инвентаря, возможно, объясняется социальным положением погребённого, - скорее всего, это был раб, сопровождающий своего хозяина.

Безусловно, гробница относится к кругу элитных, статусных погребений. Этот вывод базируется на вполне очевидных позициях - расположение комплекса в кургане, его конструктивная сложность, жертвоприношение коней, а также состав инвентаря, содержавший такие маркеры престижа, как металлический панцирь, золотые предметы и чернолаковую посуду, весьма ценимую варварами. Структура гробницы хоть и находит некоторые параллели среди подобных памятников региона (Иванов, 2016. С. 239), всё же имеет ряд неординарных черт, связанных с особенностями устройства комплекса. В пер- 

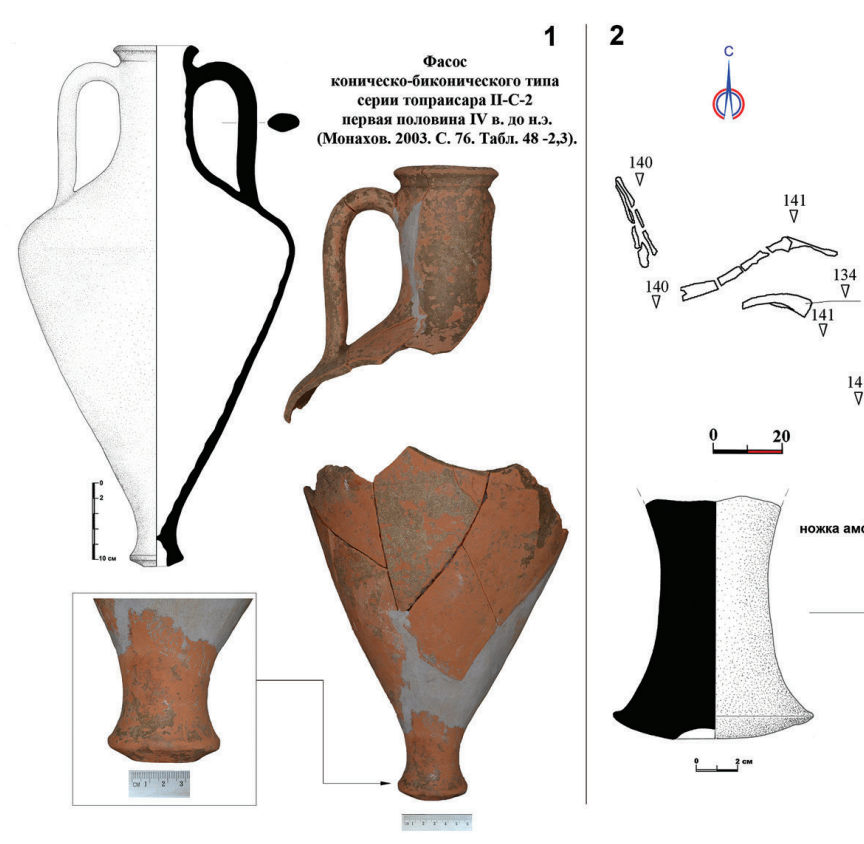

2015

К.Г. Кеслерово4

Курган 1

Погребение №9
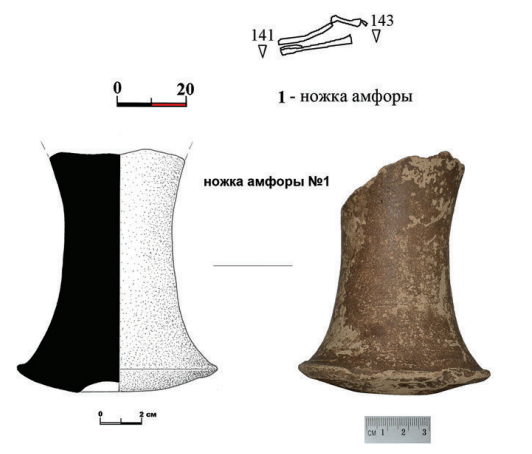

Рис. 5.1 - амфора из тризны; 2 - погребение «раба»

вую очередь отметим использование при сооружении погребения довольно сложной деревянной конструкции - сруба. С другой стороны, трудно найти на Кубани богатые подкурганные комплексы раннежелезного века, где бы не применялось дерево - в данном контексте этот элемент практически всегда выступает как отражение высокого статуса погребённого. Известны обширные деревянные конструкции предскифского времени, особое место они занимали и в памятниках эпохи скифских походов, в Келермесских и Кострамском кургане, в Ульских курганах-святилищах IV - первой половины V в. до н.э. (Ульские курганы, 2015. Рис. 11, 34). В V-IV вв. до н.э. дерево использовалось, в основном, для перекрытия элитных комплексов, и зафиксировано в Семибратних и Елизаветинских курганах, в кургане у х. Начерзий, в кургане Карагодеуашх и в Курджипском кургане конца IV в. до н.э., где двухкамерная гробница также была сложена из дерева (Галанина, 1980. С. 15-30; Анфимов, 1987. С. 136). Но это широкий круг аналогий. На близлежащей к памятнику территории подобных комплексов пока известно не было. Интересна и позиция кургана. Он занимает промежуточное положение между Семибратними курганами и кубанскими знатными комплексами, правда, статус погребённого, думаю, был немного ниже, а сама гробница вряд ли сопоставима с памятниками династического уровня. Впрочем, данный регион в целом исследован очень слабо, и вполне могут возникнуть новые материалы, позволяющие по-другому расставить акценты. 
Напомню, что в одной из своих недавних работ (Иванов, 2016), я рассматривал это погребение в контексте вопроса, связанного с «культурой знати» без каких-либо этнических и культурных привязок. Между тем, даже если отбросить этнический аспект (который в археологии на настоящее время методически оспаривается), данный комплекс стоит рассматривать исключительно в рамках меотской археологической культуры, в границах которой он территориально и находится.

Ко всему прочему следует добавить, что расположение такого уровня памятника фактически у самой окраины меотской территории вряд ли случайно. Для понимания ситуации, наверное, правильным будет сделать отсылку к историческим процессам, протекавшим в регионе. В первую очередь - к событиям в Синдике. Опустим все перипетии войны и усобицы в царском доме Гекатея, лишь акцентируем внимание на итоговом эпизоде этого противостояния. После разорения Синдики язаматами, одним из меотских племён, выступившим на стороне Таргитао, сын Сатира при помощи даров с большим трудом замирил варваров. Мной уже высказывалось предположение о том, что помимо мира, между Спартокидами и меотскими предводителями могли решаться и вопросы иного характера, возможно, торговли (Иванов, 2011. С. 150). Чересчур смело говорить о каких-либо «договорах», но именно после отмеченных выше событий Прикубанье наводняет греческий импорт. Внимательный читатель, конечно же, подметил - ещё в самом начале статьи я акцентировал внимание на территории, на которой расположен курган. С учётом того, что здесь пролегал один из самых удобных сухопутных маршрутов, связывающий Боспор с густо заселёнными равнинами Закубанья, этот участок приобретал воистину стратегическое значение. Его контроль, особенно на фоне развернувшийся активной торговли, всплеск которой приходится как раз на начало IV в. до н.э., мог значительно расширить экономическое и политическое влияние в регионе. Видимо, именно этим и следует объяснять появление статусного комплекса на этих землях.

\section{ЛИТЕРАТУРА}

Анфимов Н.В. Древнее золото Кубани. Краснодар, 1987.

Галанина Л.К. Курджипский курган. Памятник культуры прикубанских племён IV века до н.э. Л., 1980.

Иванов А.В. Боспор. Меоты. IV в. до н.э. // Боспорские чтения. Вып. ХII. Керчь, 2011.

Иванов. А.В. О некоторых параллелях в погребальном обряде «элитных» комплексов Азиатского Боспора, Синдики и Кубани // Элита Боспора и Боспорская элитарная культура. Материалы международного круглого стола. СПб., 2016.

Канторович А.P. Меото-скифское искусство Прикубанья (VII - начало III вв. до н.э.) // Античное наследие Кубани. Т. 1. М., 2010. 
Лесков А.М., Беглова Е.А., Ксенофонтова И.В., Эрлих В.Р. Меоты Закубанья в середине VI - начале III века до н.э. Некрополи аула Уляп: погребальные комплексы. M., 2005.

Лимберис Н.Ю., Марченко М.М. Конская упряжь в меото-скифском зверином стиле из Прикубанского могильника // Новое в исследованиях раннего железного века Евразии: проблемы, открытия, методики. Международная научная конференция. М., 2017. http://scythia-sarmatia.ru/publish

Монахов С.Ю. Греческие амфоры в Причерноморье. Типология амфор ведущих центров - экспортеров товаров в керамической таре: Каталог-определитель. М.; Саратов, 2003.

Ульские курганы. Культово-погребальный комплекс скифского времени на Северном Кавказе. Corpus tumulorum scythicorum et sarmaticorum, 2. Под редакцией А.И. Иванчика и А.М. Лескова. Москва, Берлин, Бордо: Палеограф, 2015.

Черненко Е.В. Скифский доспех. Киев, 1968.

Эрлих В.P. Святилища некрополя Тенгинского городища II, IV в. до н.э. М.: Наука, 2011.

Sparkes B.A., Talcott L. Black and Plain Pottery of the $6^{\text {th }}, 5^{\text {th }}$ and $4^{\text {th }}$ Centuries B.C. $/ /$ The Athenian Agora. Vol.XII. Princeton, New Jersey, 1970. 


\title{
К ВЫДЕЛЕНИЮ ЛОКАЛЬНЫХ ВАРИАНТОВ САКСКОЙ КУЛЬТУРЫ ПРИТЯНЬШАНЬЯ
}

\begin{abstract}
Иванов С.С.
http://10.25681/IARAS.2019.978-5-317-06274-3/71-78

Статья посвящена проблеме выделения локальных вариантов в сакской культуре Притяньшанья, которая в VI - первой половине II вв. до н.э. занимала территорию ЮгоВосточного Казахстана (Семиречье), Северного Кыргызстана и прилегающей части Синьцзяна (верхнее течение р. Или). К настоящему времени можно выделить три локальных варианта данной культуры: семиреченский, тяньшаньский и верхнеилийский. Различия между ними прослеживаются в особенностях погребального обряда и керамического материала при сохранении целостного облика материальной и духовной культуры. Также определённой спецификой обладает группа могильников в западной части Семиречья, образующих особый джамбульский тип захоронений. Причинами возникновения различий внутри сакской культуры Притяньшанья на локальном уровне послужила её исходная многокомпонентность в период формирования.

Ключевые слова: Притяньшанье, скифский (сакский) период, локальные варианты
\end{abstract}

На протяжении VI - первой половины II вв. до н.э. на огромных пространствах Семиречья, Западного и Внутреннего Тянь-Шаня и значительной части Восточного Тянь-Шаня (бассейн верхнего течения р. Или в западной части Синьцзяна) существовала самостоятельная культура скифского облика. Ранее она чаще всего обозначалась как культура саков Семиречья и ТяньШаня (Заднепровский, 1992. С. 73-76). Однако по мере выявления всего ареала распространения данной культуры, которая, как оказалось, охватывала также верхнее течение р. Или на западе Синьцзяна (Иванов, 2015. С. 46-47), встала необходимость уточнения её названия, которое более чётко отражало бы специфику её территориального охвата. По этой причине нами было предложено для неё наименование - сакская культура Притяньшанья (см., напр.: Иванов, 2017).

В настоящее время при изучении этой культуры всё более актуальным становится вопрос выделения в её составе локальных вариантов. Поскольку при всём внешнем единообразии погребальных памятников Притяньшанья в скифское время, в ряде районов её распространения выделяются группы могильников, обладающих своеобразными чертами в погребальном обряде и отчасти в сопроводительном инвентаре захоронений, которые отсутствуют или слабее выражены в других частях ареала сакской культуры Притяньшанья. Это позволяет наметить основные варианты рассматриваемой культуры на локальном уровне.

Однако перед тем, как перейти непосредственно к анализу локальных различий в составе сакской культуры Притяньшанья, необходимо также коснуться ещё одной проблемы - хронологии погребальных памятников данного региона в скифский (сакский) период. Дело в том, что длительное время значительная 
часть погребальных памятников этого периода ошибочно относилась к последующей усуньской культуре гунно-сарматского времени. И только их детальный анализ позволил пересмотреть их хронологию и отнести к собственно сакской культуре Притяньшанья (Иванов, 2016. С. 70-79. Рис. 1-5). Отчасти это и подвело ещё более к необходимости выделения локальных вариантов этой культуры. Так, к примеру, долгое время считалось, что основная часть подбойных захоронений в Семиречье бытует в рамках I в. до н.э. - III в. н.э. (Кушаев, 1963. С. 251-256. Табл. ХІ), но пересмотр их датировок позволил констатировать, что они являлись характерной особенностью данного района на локальном уровне именно в скифский (сакский) период.

Поэтому не только выявление всего ареала распространения сакской культуры Притяньшанья, но и отнесение к ней значительного количества погребальных памятников, ранее датируемых более поздним периодом, позволили увидеть её во всем её сложном многообразии, в том числе на локальном уровне.

При этом мы сознательно несколько абстрагируемся в вопросе выделения локальных вариантов сакской культуры Притяньшанья от проблемы элитарных захоронений, так называемого «царского» типа, которые порой демонстрируют заметное своеобразие в каждом отдельном могильнике, сохраняя при этом базовые характеристики погребального обряда культуры. Объяснить это можно, на наш взгляд, не только социальными или локальными причинами, но и, возможно, также хронологическими, так как погребальные традиции кочевой элиты быстрее и более пластично реагировали на эпохальные веяния в евразийском степном поясе, что достаточно заметно в других синхронных культурах номадического характера от Северного Причерноморья до Саяно-Алтая.

Рядовые захоронения сакской культуры Притяньшанья имеют достаточно устойчивые погребальные традиции. Курганы в могильниках чаще всего вытянуты цепочками с севера на юг, иногда со значительным отклонением от этой оси, отмечены также и отдельные случаи бессистемного расположения. Но последняя планировка по большей части отмечается в том случае, если основу могильника составляют элитарные курганы «царского» типа.

Внешне курганы представляют собой сравнительно небольшие каменноземляные насыпи в среднем высотой до 1 м и диаметром до 20 м. Отличительной особенностью у них является наличие каменных концентрических колец на насыпи или же вокруг неё, в которые в большинстве случаев вписано дополнительное внутреннее кольцо или овал, маркирующий расположение захоронения. Внутримогильные конструкции чаще всего представлены простыми грунтовыми ямами или подбоями, но в ряде случаев встречаются захоронения в каменных ящиках, и крайне редко - на древней поверхности.

Захоронения, независимо от типа внутримогильных сооружений, демонстрируют единообразные погребальные традиции: покойные укладывались на спине в вытянутом положении, головой на запад (иногда с некоторым от- 
клонением от данного направления), руки были уложены вдоль тела или же покоятся в районе таза. Погребальная посуда и пища чаще всего располагалась в изголовье, в том числе, если она находилась в специальных нишах. Остальные предметы сопроводительного инвентаря были помещены в захоронениях согласно их функциональному назначению.

На основании анализа совокупности изученных погребальных памятников сакской культуры Притяньшанья на сегодняшний день можно выделить, по крайней мере, три локальных варианта, отличающихся целым рядом особенностей (рис. 1).

Семиреченский. Выделяется тем, что, при доминировании погребении в грунтовых ямах, достаточно высок процент подбоев (до 20\%), камера которых устроена в северной длинной стенке входной ямы. Большая часть подбойных захоронений сосредоточена в долине реки Или, но спорадически они встречаются по всему Семиречью (Максимова, 1969. С. 136-145). Видимо, к этому варианту культуры можно также отнести захоронения в подбоях в районе о3. Алаколь (Кушаев, 1968. С. 142-145. Рис. 3). Грунтовые могилы имеют в основном деревянное перекрытие, но в ряде случаев для этого использовались каменные плиты, причём чаще всего к югу от Илийской долины. Изредка также встречаются погребения в каменных ящиках, а также в могильных ямах с нишей для погребальной посуды в северной стенке (Акишев, 1963. С. 91-102; Кушаев, 1963. С. 148-221; Нурмуханбетов, Трифонов, 2016. С. 10-19). Имеется также некоторая специфика в керамическом материале, в частности, отмечены сосуды, находящие близкие аналогии в культурах Лесостепного и Горного Алтая (Иванов, 2016. С. 78-79). Спорадически фиксируются также находки
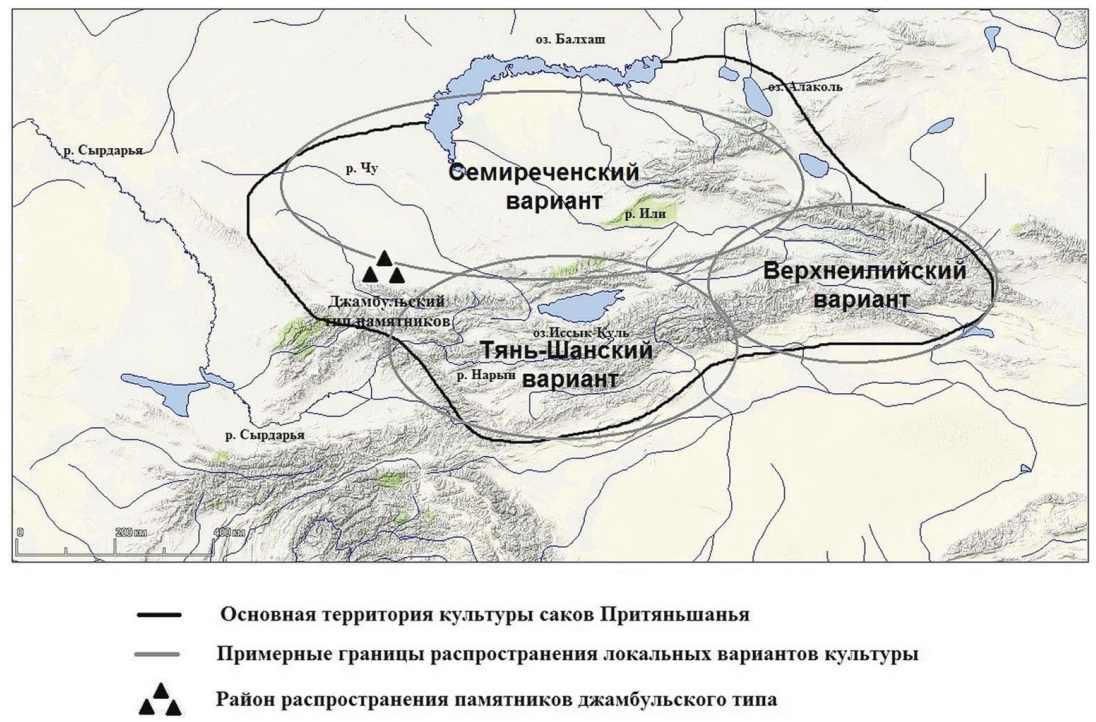

Рис.1. Локальные варианты сакской культуры Притяньшанья 
расписной керамики, имеющей прямые параллели в верхнем течении реки Или (Ташбаева, 1996. С. 69-70. Рис. 1, 4-12). Кроме того, отмечаются находки станковой посуды, имеющей, вероятно, импортное происхождение.

Тяньшаньский. Для него характерно господство погребений в простых грунтовых ямах, значительная часть которых имеет специальную нишу в северной стенке для помещения керамической посуды. Могильные ямы чаще всего перекрыты каменными плитами, но также встречается и деревянный накат, так же как в семиреченском варианте (Ташбаева, 2011. С. 36-50, 97-109). Особенностью тяньшаньского варианта можно считать распространение в территориально ограниченном районе (южное побережье Иссык-Куля и прилегающая к нему Кочкорская долина) каменных ящиков с нишей-пристройкой с северной стороны (ближе к изголовью погребённых), что роднит их с нишами грунтовых могил (Мокрынин, Гаврюшенко, 1975. С. 53-73; Абетеков, 2009. С. 14-18). В западной части данного локального варианта (КетменьТюбинская долина) отмечена заметная специфика в керамической посуде, что связано с наличием здесь значительного количества импортной ферганской керамики, а также подражанием ей местными мастерами (Ташбаева, 2011. С. 81-84). В редких случаях имеется посуда с росписью, характерной для верхнеилийского варианта.

Верхнеилийский. Для него также отмечен высокий процент подбоев (до 30\% и более), которые по конструкции аналогичны семиреченским. Впрочем, доминирующим типом внутримогильных сооружений остаются всё же простые грунтовые ямы, перекрытые в большинстве случаев каменными плитами. Изредка также отмечаются отдельные захоронения в каменных ящиках. Имеется значительное своеобразие в керамическом материале, который при сохранении стандартных сакских форм часто имеет роспись характерного типа, типичного для Синьцзяна в раннем железном веке в целом (Сутягина, 2011. С. 137-143; Иванов, 2015. С. 42-49) ${ }^{1}$.

Надо полагать, что есть некоторые основания для выделения особого джамбульского варианта культуры, отмеченного в ряде могильников в северных предгорьях Киргизского хребта в районе г. Тараз (могильники Караша I и II, Кызыл-Кайнар, Узун-Булак и Шошкала). Данная группа погребальных памятников выделяется наличием специальных ниш для погребальной посуды

${ }^{1}$ Погребальный обряд и особенности памятников ранних кочевников верховьев реки Или были охарактеризованы Н.А. Сутягиной, а также отмечена их значительная близость к погребальным комплексам Семиречья. Однако они были отнесены ею к рубежу эр, несмотря на то, что они содержали целый ряд предметов, характерных для скифского периода. Подобная ошибка возникла в результате некритического принятия дат семиреченских «усуньских» комплексов, которые, как мы показали выше, датируются в основной массе сакским временем (Иванов, 2016. С. 70-79). В настоящее время хронологическая принадлежность могильников верхнего течения Или к VI - первой половине II в. до н.э. не вызывает сомнений (Шульга, 2010. С. 20; Иванов, 2015. С. 46). 
не в северной стенке могильной ямы, а в южной. При этом могилы с подобными нишами составляют от 30 до 85\% от всех погребений в указанных могильниках, в то время как остальные захоронения совершены по стандартному погребальному обряду сакской культуры Притяньшанья, в том числе отмечены отдельные захоронения с нишами в северо-западном углу могильной ямы, что характерно для тяньшаньского варианта (Максимова, 1972; 1975; 1976). Не отличаются эти некрополи от основной части погребальных памятников рассматриваемой культуры и по облику погребального инвентаря. Поэтому, учитывая пока что узколокальный характер джамбульского типа захоронений, можно только предварительно говорить об особом локальном варианте сакской культуры Притяньшанья. Вполне вероятно, что перед нами особая, северозападная, разновидность тяньшаньского локального варианта.

Все отмеченные локальные варианты демонстрируют плавный переход, поэтому их границы во многом условны. При этом погребальный обряд на всей территории распространения сакской культуры Притяньшанья достаточно устойчив и различается лишь второстепенными деталями при сохранении генеральных особенностей.

К особенностям в погребальных традициях можно отнести характер распространения подбойных захоронений, который присущ только для семиреченского и верхнеилийского вариантов и совершенно нетипичен для тяньшаньского. Сходная ситуация и с грунтовыми могильными ямами с нишей в северной стенке, достаточно распространенными в последнем варианте культуры, но малоизвестными в Семиречье. Есть также и узколокальные погребальные особенности: к примеру, захоронения в каменных ящиках с пристройкой, имитирующей нишу, как в рассмотренных грунтовых могилах; они вообще привязаны к небольшому району в тяньшаньском варианте сакской культуры Притяньшанья. Сходная ситуация складывается и с джамбульским типом погребальных памятников, приуроченным только к относительно небольшому предгорному району Киргизского хребта в западной части Семиречья.

Заметен ряд небольших особенностей и в сопроводительном инвентаре погребений. Причем, если основные его категории (предметы вооружения, бытовые вещи, украшения и т.д.) практически не находят различий в зависимости от локального варианта культуры, то керамическая посуда демонстрирует некоторую специфику, которая во многом продиктована контактами с соседними культурами. Это, в первую очередь, ярко проявляется в распространении расписной и станковой керамики. Так, расписная посуда наиболее характерна для верхнеилийского варианта, но её находки также зафиксированы в семиреченском и тяньшаньском вариантах. Причем, если для Восточного Тянь-Шаня (верховьев Или) она местного происхождения, то в других локальных вариантах она появляется именно под воздействием этого района. Заметная специфика отмечается и в распространении посуды станкового изготовления. Она бо- 
лее всего характерна для Западного Тянь-Шаня, возникая здесь в результате контактов с оседлыми областями Средней Азии и прежде всего с Ферганской долиной. Для остальной территории сакской культуры она не типична. Она редко встречается в погребальных памятниках Семиречья и, возможно, представляет собой импорт из Ташкентского оазиса или других среднеазиатских областей, а на Центральном Тянь-Шане она практически не известна. В то же время на всей территории культуры саков Притяньшанья хорошо сохраняется стандартный набор форм и техники изготовления лепной керамической посуды, которая слабо различается на уровне локальных вариантов.

Подобные второстепенные различия на уровне погребальных традиций и керамического материала возникают и сохраняются длительное время, на наш взгляд, в результате сложного процесса формирования самой сакской культуры Притяньшанья. Объединив на начальном этапе своего становления разнородные культурные компоненты при определённом доминировании одного из них, создавшего условия для последующей унификации погребальных традиций и элементов материальной культуры, ряд их исходных особенностей закрепился и продолжил своего существование в рамках единого культурного образования. В последующий период существования сакской культуры в Притяньшанье отдельные элементы локального характера «мигрировали» в соседние районы, обогащая и усиливая единообразие культуры в целом (Иванов, 2017. С. 277279). Причём, это, по-видимому, происходило вместе с перемещением части носителей этих специфических особенностей. Это хорошо заметно на примере распространения подбойных захоронений или же грунтовых могил с нишей. Сомнительно, чтобы эти погребальные традиции распространялись без переселения коллективов людей, для которых они были давно сложившейся частью культуры. Эту ситуацию маркирует также и характер нахождения расписной керамики, большая часть которой, несомненно, имеет исходное распространение из Синьцзяна, где она была характерна ещё в раннескифский период. Поэтому появление такого рода посуды за пределами верхнеилийского варианта - прямой результат влияния последнего. При этом процесс её распространения, видимо, также сопровождался и миграцией групп населения с верхнего течения Или.

Таким образом, современные представления о сакской культуре Притяньшанья позволяют выделить три важнейших локальных варианта: семиреченский, тяньшаньский и верхнеилийский, а также ещё один специфический тип захоронений (джамбульский), который по своим особенностям приближается к особому варианту культуры. Все указанные варианты культуры демонстрируют плавный переход при сохранении генеральных особенностей в погребальных традициях и облике материальной культуры. Различия между ними носят второстепенный характер и в первую очередь проявляются на уровне внутримогильных сооружений и керамическом материале. 


\section{ЛИТЕРАТУРА}

Абетеков А.К. Исследования Шамшинского археологического отряда КИАЭ в 1987-1988 гг. Часть 1. 1987 год // Материалы и исследования по археологии Кыргызстана. Вып. 4. Бишкек: Илим, 2009. С. 9-25.

Акишев К.A. Культура саков долины реки Или (VII-IV вв. до н.э.) // Акишев К.А., Кушаев Г.А. Культура саков и усуней долины реки Или. Алма-Ата: Изд-во АН КазССР, 1963. С. 9-136.

Заднепровский Ю.А. Ранние кочевники Семиречья и Тянь-Шаня // Степная полоса азиатской части СССР в скифо-сарматское время. М.: Наука, 1992. С. 73-87.

Иванов С.С. К проблеме культурных взаимосвязей кочевых культур Кыргызстана и Синьцзяна в I тыс. до н.э. (на примере памятников китайской части долины Или) // Ли Бо и Шёлковый путь. Сборник материалов межд. науч. конф. Бишкек, 2015. C. 42-49.

Иванов С.С. К проблеме культурного разрыва на рубеже сакского и усуньского периодов в Притяньшанье // Stratum plus. 2016. № 3. Третий до ... Потерянное столетие. С. 67-87.

Иванов С.С. Об основных компонентах в формировании сакской культуры Притяньшанья // Наука, нравственность и вера наших отцов: VI Межд. науч.-практ. конф. по истории и культуре Кыргызского и Тюркских каганатов. Бишкек, 2017. C. $276-280$.

Кушаев Г.А. Культура усуней правобережья реки Или (III в. до н.э. - III в. н.э.) // Акишев К.А., Кушаев Г.А. Культура саков и усуней долины реки Или. Алма-Ата: Издво АН КазССР, 1963. С. 139-281.

Кушаев Г.А. Ранние погребения Алакульской впадины // Новое в археологии Казахстана. Алма-Ата: Наука, 1968. С. 136-145.

Максимова А.Г. Подбойные захоронения сакского времени // Культура древних скотоводов и земледельцев Казахстана. Алма-Ата: Наука, 1969. С. 135-145.

Максимова А.Г. Курганные могильники в урочище Кызыл-Кайнар // Поиски раскопки в Казахстане. Алма-Ата: Наука, 1972. С. 123-139.

Максимова А.Г. Узун-Булак и Шошкала - могильники усуньского времени // Древности Казахстана. Алма-Ата: Наука, 1975. С. 141-160.

Максимова А.Г. Курганные могильники Караша I и II // Прошлое Казахстана по археологическим источникам. Алма-Ата: Наука, 1976. С. 163-182.

Мокрынин В.П., Гаврюшенко П.П. Курганы сакского времени длины реки Тон // Археологические памятники Прииссыккулья. Фрунзе: Илим, 1975. С. 52-82.

Мокрынин В.П. Раскопки могильника сакского времени Джель-Арык. Отчет о полевых исследованиях в 1974 г. // Мокрынин В.П. Археология и история древнего и средневекового Кыргызстана. Избранное. Бишкек: Илим, 2010. С. 224-236.

Нурмуханбетов Б.Н., Трифонов Ю.И. Курганные могильники Шубарат и Молалы // Саки и савроматы Казахских степей: контакт культур. Алматы, 2016. С. 10-19.

Сутягина Н.А. Погребальный обряд населения Илийской долины в конце I тыс. до н.э. - начале I тыс. н.э. (по материалам памятников Синьцзяна, КНР) // Маргулановские чтения - 2011. Материалы международной археологической конференции. Астана, 2011. С. 137-143. 
Ташбаева К.И. О расписной керамике ранних кочевников Тянь-Шаня // Древний и средневековый Кыргызстан. Бишкек: Илим, 1996 С. 69-76.

Ташбаева К.И. Культура ранних кочевников Тянь-Шаня и Алая. Бишкек: Илим, 2011.274 c.

Шульга П.И. Синьцзян в VIII-III вв. до н.э. Погребальные комплексы. Хронология и периодизация. Барнаул, 2010. 240 с. 


\section{ПОГРЕБЕНИЕ КОНЦА VII - V В. ДО Н.Э. ИЗ МОГИЛЬНИКА ЗАЮКОВО-3}

\section{Кадиева А.А., Маслов В.Е., Биркина Н.А., Демиденко С.В.}

http://10.25681/IARAS.2019.978-5-317-06274-3/79-88

Статья посвящена женскому погребению 43 могильника Заюково-3. Комплекс содержит украшения (браслеты, перстень и длинную цепь), нож, оселок и керамическую миску. Весь погребальный инвентарь датируется концом VII - рубежом VI-V вв. до н.э. На основе расположения предметов в могиле реконструирован женский убор. Цепь являлась нагрудным украшением, браслеты и перстень надеты на левую руку. Расположение ножа и оселка указывает на наличие пояса. Выявленная система погребального убора характерна для захоронений могильника Заюково-3 скифской эпохи. Аналогии отдельным элементам убора встречаются в могильниках западнокобанской и восточнокобанской культур, а также Закавказья.

Ключевые слова: горная зона Северного Кавказа, Кабардино-Балкарская республика, могильник Заюково-3, кобанская культурно-историческая общность, женский погребальный убор

Погребальный инвентарь населения, оставившего кобанскую культурноисторическую общность, весьма стандартизирован и хорошо известен с XIX в., когда была открыта кобанская археологическая культура. Со времен грабительских раскопок кобанского могильника коллекции кавказских бронз украшают собрания ведущих музеев мира. Благодаря усилиям В.И. Козенковой составлены своды кобанских археологических памятников по локальным вариантам. Тем не менее, из-за малого количества раскопанных на современном научном уровне объектов, основной источниковой базой исследования истории населения горной зоны Северного Кавказа в раннем железном веке до недавнего времени оставались предметы из грабительских раскопок. Этот массив данных имел все характерные для такого рода материалов недостатки, главным из которых была неясность местоположения предметов в погребальных комплексах. Особенно плачевно ситуация сложилась для памятников современной Кабардино-Балкарии.

С 2014 г. Объединённая Северокавказская археологическая экспедиция ГИМ, КБГУ и ИА РАН ведет работы на могильнике Заюково-3. За четыре сезона раскопок было исследовано 113 погребений кобанской, сарматской и аланской эпох. Наиболее представительными находками первого периода являются погребения женщин с уборами из металлических украшений и бус, особенно ценные, поскольку фиксация места находок в погребении позволяет реконструировать погребальный убор и делать обоснованные предположения о структуре костюма. Таким комплексом является погребение 43, публикации которого посвящена предлагаемая вниманию читателя работа.

Погребальная яма захоронения 43 имеет неправильную форму близкую четырехугольнику и ориентирована длинной осью по линии запад - восток (рис. 1, 1). 

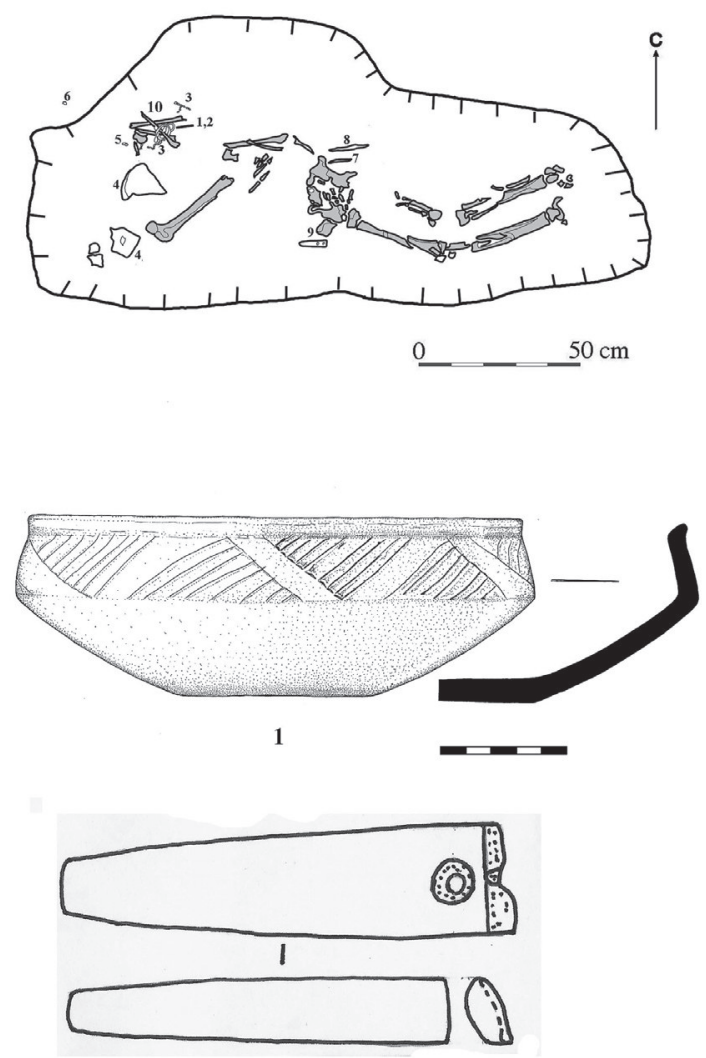

2

Рис. 1. Могильник Заюково-3. Погребение 43 (чертеж Д.А. Бариновой):

1 - план (1, 2 - браслеты, 3 - цепочка, 4 - миска, 5 - бусина, 6 - бисер,

7 - стержень, 8 - нож, 9 - оселок, 10 - перстень); 2 - миска (рис. Е.Ю. Бахаревой);

3 - оселок (рис. А.А. Кадиевой); 2 - керамика, 3 - камень

Скелет имел очень плохую сохранность: верхняя часть практически истлела, кости нижней - фрагментированы. Погребённая была уложена вытянуто на спине со слегка согнутыми в коленях ногами головой на запад. Череп не сохранился. На груди находилась бедренная кость погребённого 2 (других костей от этого скелета не обнаружено). На пальце левой руки был надет перстень. На месте несохранившегося черепа вверх дном находился развал керамической миски. На левой руке были обнаружены два браслета. В районе левой бедренной кости была обнаружена двучастная бронзовая бусина. В районе левой руки, частично обвивая её, лежала бронзовая цепочка. Над головой погребённой находился фрагмент стеклянного бисера, не сохранившийся при зачистке. В районе левого крыла таза были обнаружены железный стрежень и черешковый железный листовидный нож, обращённые остриём 
вверх. У правого крыла таза был обнаружен оселок, обращённый отверстием к ногам погребённой.

На датировку погребения указывают перстень, браслеты и цепь. Перстень (рис. 2, 3) из загнутой в кольцо пластины со щитком из концов, закрученных в спираль. Диаметр шинки перстня 2,1 см, размеры щитка 2,9×1,3 см. Относится к типу I по В.И. Козенковой (Козенкова, 1998. С. 38), который исследовательница датирует VII-VI вв. до н.э. Аналогии этих украшений были обнаружены в могильнике Луговой (Мунчаев, 1963. Рис. 12, 8, 9; Рис. 24, 6-8; Рис. 26, 5), погребения которого суммарно датируются автором первой публикации VI-V вв. до н.э.

Браслет с прямоугольными лопастями, покрытыми ёлочным орнаментом. Диаметр браслета - 5,7 см, ширина лопасти - 0,9 см (Рис. 2, 1).

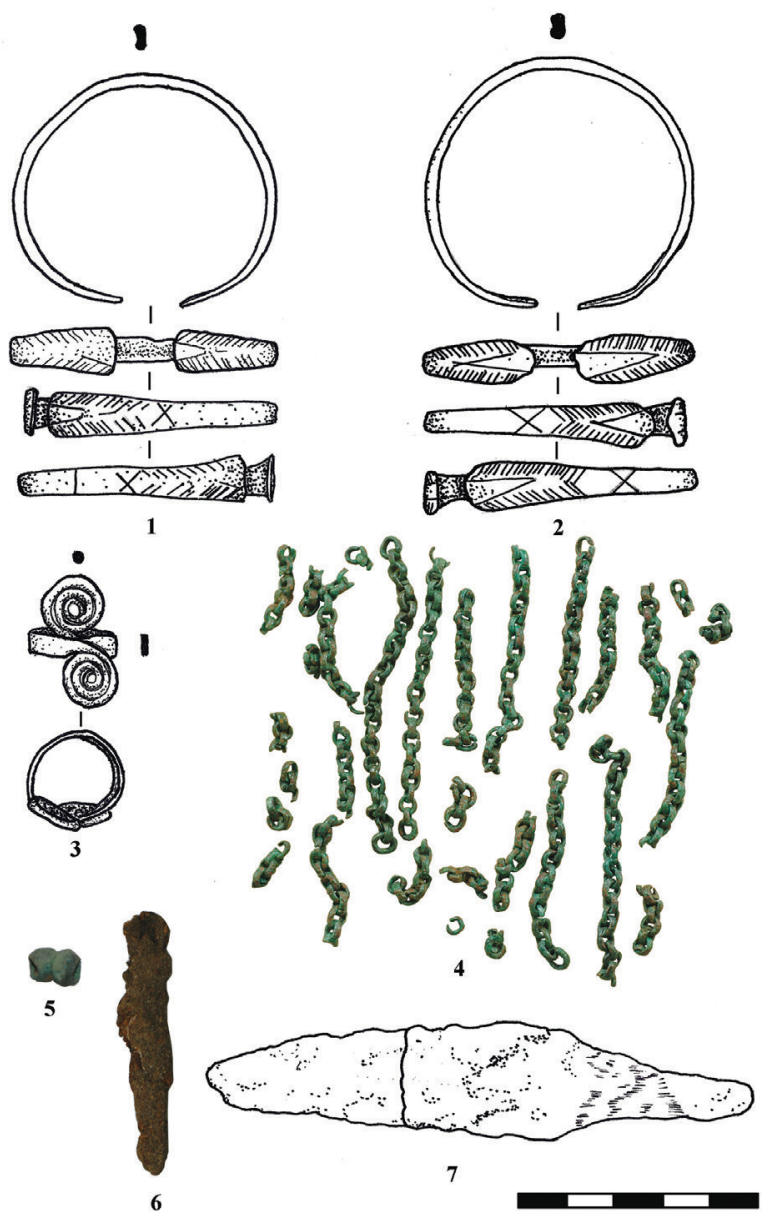

Рис. 2. Могильник Заюково-3. Погребение 43.

Инвентарь: 1, 2 - браслеты, 3 - перстень, 4 - цепь, 5 - бусина, 6 - стержень, 7 - нож (рис. Н.А. Биркиной, фото А.А. Кадиевой); 1 - 5- бронза, 6, 7 - железо 
Браслет с овальными лопастями, покрытыми ёлочным орнаментом. Диаметр браслета - 5,5 см, ширина лопасти - 0,9 см (рис. 2, 2).

Оба браслета относятся к типу XVIII по типологии В.И. Козенковой (Козенкова, 1998. С. 55. Табл. XXVII, 14). Исследовательница датирует этот тип временем не ранее середины VII и не позднее начала VI в. до н.э. В то же время эти браслеты принадлежат к типу 3 отдела I по типологии В.Г. Петренко (Петренко, 1978. С. 53). Появление наиболее ранних браслетов этого типа исследовательница относит к VI в. до н.э. и отмечает, что в степных памятниках они бытуют до IV-III вв. до н.э. При этом В.Г. Петренко видит в этом типе украшений трансформацию браслетов со змеиными головками на окончаниях.

Браслеты с лопастями, украшенными ёлочным орнаментом в сочетании с перстнями с биспиральным щитком для населения, оставившего могильник Заюково-3, являются стандартным набором как женских, так и мужских украшений скифского времени. Именно по мужским погребениям (материалы которых сейчас готовятся к публикации) была установлена дата этого набора.

Так, в воинском погребении 49 браслет и перстень были обнаружены на руке захороненного (Кадиева, Демиденко, 2017. С. 169, фото 8). В этом же погребении у бедра воина лежал короткий меч-акинак с антенным навершием и почковидным перекрестием, относящийся к типу 1 отдела II по А.И. Мелюковой (Мелюкова 1964, С. 53), который исследовательница датирует концом VI - V в. до н.э. В инвентаре погребения 66 перстень и браслет сочетались с акинаком с брусковидным навершием и почковидным перекрестьем, тип 1 отдела I, датированный А.И. Мелюковой VI в. до н.э. (Мелюкова 1964. С. 47). Однако следует отметить, что на сегодняшний день большинство исследователей относит этот тип ко второй половине VII - началу VI в.

Цепь (рис. 2, 4) состоит из овальных сомкнутых звеньев, сегментовидных в сечении. Сохранившаяся длина цепочки составляет 80 см, однако изза хрупкости звеньев часть её была утрачена. Длинные цепи хорошо известны в женских погребениях скифского времени западнокобанской археологической культуры. Длинная цепь была обнаружена на могильнике Султан-Гора III близ Кисловодска (Членова, 1984. С. 239, Рис. 2, 17), датированном автором раскопок VI в. до н.э., но в современной историографии относящемся к концу VII - началу VI вв. до н.э. В состав комплекса входили браслеты с изображением змеиных головок на концах. Две булавки, соединённые цепью, были вложены в руку погребённой 1 из кургана 7 могильника Нартан (Батчаев, 1985. С. 25). Длина цепи составляла 0,6 - 0,7 м. Украшение сочеталось с браслетами с расплющенными концами. Автор раскопок по находке золотой серьги с полыми бубенчиками датирует курган V в. до н.э. (Батчаев, 1985. С. 52). Позднее C.В. Махортых, опираясь на аналогии с изделиями, произведёнными ассирийскими ювелирами, отнёс этот комплекс ко второй половине VII в. до н.э. (Махортых С.В., 1991. С. 76. Рис. 29, 3). 
Нагрудное украшение с длинной цепью принадлежало погребённой из разрушенной женской могилы (обнаруженной в 1985 г.) некрополя Лермонтовская скала (У реки). Здесь погребальный убор состоял из длинной цепи, закреплённой двумя биметаллическими булавками и бронзовой фибулой, а также снабжённой очковидными бронзовыми привесками. Центральная часть цепи располагалась на груди и на шее. Концы украшения спускались по плечам (Березин, Дударев, Фоменко, 1993. С. 147).

В этом же могильнике (погребение 1 раскопок 1994-го года) было обнаружено ещё одно женское погребение с длинной цепью (Березин, Дударев, 1998. С. 171). Погребённый был уложен скорченно на правом боку. Цепь лежала от подбородка вдоль левого предплечья, общая её длина 97 см. Авторы раскопок и публикации комплекса отмечают, что цепь «на большей части своего протяжения была сложена вдвое, местами сбиваясь в комки, и частично была прикрыта грудной костью». Основываясь на этом наблюдении, исследователи предполагают, что цепь служила нагрудным украшением, не надетым на шею, но крепившимся к одежде на груди. В цепь были вставлены три стержневидные железные подвески, концы которых были зажаты в звеньях. Время функционирования подобных цепей авторы определяют в рамках VII-VI вв. до н.э. (Березин, Дударев, 1998. С. 181).

В женском погребении 24 могильника Заюково-3, были обнаружены пять железных стержней, три из которых полностью распались при зачистке. Сохранившиеся стержни аналогичны железным подвескам к цепи из погребения 1 (1994) могильника Лермонтовская скала (Брилева, Кадиева, Демиденко, в печати). Возможно, в погребение была положена и бронзовая цепь, изъятая из могилы или уничтоженная во время постмортальных манипуляций с костяком, от которого сохранились лишь фрагменты. Погребение датируется VII в. до н.э.

Бронзовая цепь была обнаружена на груди погребённой в захоронении 3 могильника Куланурхва (Трапш, 1962. С. 19. Табл. XXXV, 1), которое автор раскопок датирует VII-VI вв. до н.э. (Трапш, 1962. С. 78), но отмечает наличие в инвентаре погребения аналогий материалам из Нестеровского могильника VI-V вв. до н.э. (Трапш, 1962. С. 68). Цепь из Куланурхвы, в отличие от заюковской, крепилась на груди погребённой при помощи очковидной подвески. Украшение с длинной цепью, завершающееся зооморфной подвеской, находилось среди погребального инвентаря коллективного захоронения 1 могильника Эргета III. Этот комплекс Р. Папуашвили относит к группе V, которую датирует концом VII - началом VI в. до н.э. (Папуашвили, 2011. С. 82).

Ещё одна аналогичная цепь длиной 1,85 см была обнаружена в погребении 58 Лугового могильника (Мунчаев, 1963. С. 182, Рис. 25, 3). Здесь цепь находилась на груди погребённой свёрнутой в несколько рядов, один её конец был спущен на грудь и завершался привеской в виде колокольчика. 
Керамическая миска (рис. 1, 2). Поверхность залощена, её цвет варьирует от тёмно-коричневого до чёрного - пятнами, что является результатом неравномерного обжига. Керамическое тесто с примесью известковой крошки. Общие размеры - диаметр устья 20 см, дна - 8 см, высота 7 см. Бортик прямой, наклонённый внутрь, с выделенным венчиком. Бортик и придонную часть разделяет сглаженное ребро. Дно прямое. Бортик декорирован прорезанным орнаментом из двух рядов разнонаправленных треугольников, заполненных косой штриховкой, формирующих не заштрихованный разомкнутый зигзаг.

Данную находку можно включить в группу мисок с различными вариантами пластинчатых бортиков и выделенным ребром, которые появляются в раннескифское время (Абрамова, 1974. Рис. 1, 4; Петренко, 2005. Табл. 73, 143, 146, 230; Петренко и др., 2000. Рис. 2 A; 3). Истоки их происхождения остаются неясными. Как правило, это столовые или туалетные сосуды средних и мелких размеров. У миниатюрных форм обычно выпукло-вогнутое дно.

Сосуды этой группы сосуществуют с крупными мисками с С-видным профилем, которые восходят к мискам круга Змейского поселения финала эпохи бронзы (Крупнов, 1960. Табл. XXII), однако, очевидно, имеют отличный от них генезис.

Декор миски также обычен для керамики раннескифского времени.

Следует учитывать, что набор чернолощёной керамической посуды скифской эпохи нельзя вывести из керамики западнокобанской культуры, которую он сменяет, тогда как его связь с керамикой из предгорных памятников Притеречья представляется очевидной (Абрамова, 1974. С. 211, 212; Маслов, 2015. С. 251, 254-256). Данный набор столовой посуды, постепенно деградируя, просуществовал до финала скифского времени, причем в нём постепенно появлялись черты керамического комплекса «сарматской» эпохи. Так, сходная миска происходит из погребения 91 Нижне-Джулатского могильника, которое М.П. Абрамова датировала V в. до н.э. (Абрамова, 1974. С. 208. Рис. 6, 25).

Бронзовая бусина (рис. 2, 5) представляет собой двучастную пронизь длинной 1 см, состоящую из бронзовых биконических бусин.

Железный стержень (рис. 2, 6) длиной 5,6 см, вероятно, представляет собой фрагмент булавки.

Железный нож (рис. 2, 7) черешковый. Клинок треугольной формы. Длина - 11,8, ширина 2,4 см.

Оселок (рис. 1, 3) подтреугольной формы, прямоугольный в сечении из чёрного плотного камня. Размеры: 9, $1 \times 2$ см. Верхний конец оселка обломан в древности при попытке просверлить отверстие.

Таким образом, погребение 43 могильника Заюково-3 представляется возможным отнести к VII - рубежу VI-V вв. до н.э. Детальное исследование стратиграфии и планиграфии участка захоронений, вероятно, позволит сузить датировку, однако этому вопросу будет посвящена отдельная публикация. 


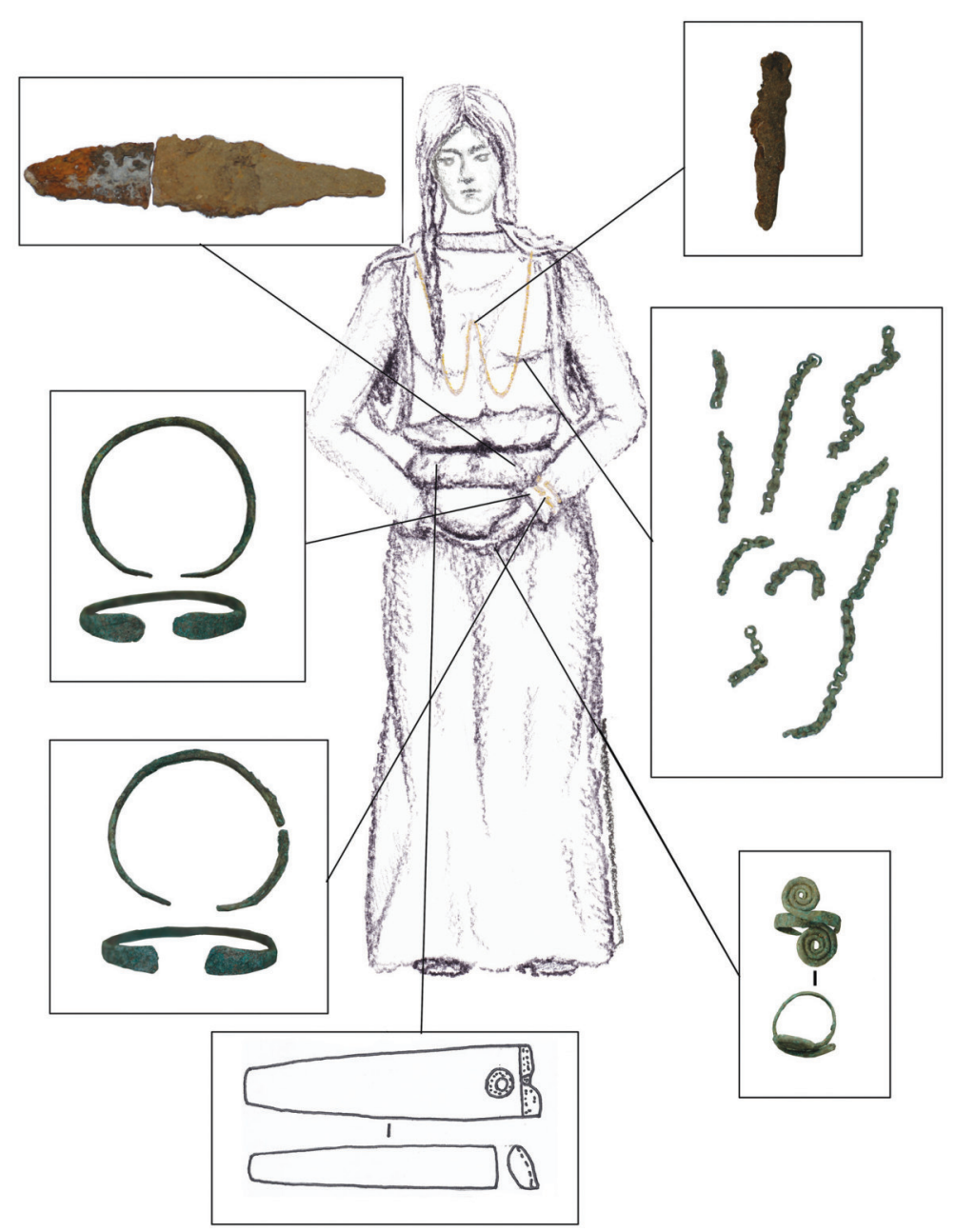

Рис. 3. Могильник Заюково-3. Погребение 43. Погребальный убор. Реконструкция А.А. Кадиевой и Н.А. Биркиной, рисунок Н.А. Биркиной

В захоронении не обнаружено ни одного фрагмента ткани, однако расположение инвентаря позволяет с большой долей вероятности сделать выводы об общем характере костюма и предложить вариант его реконструкции на основании природно-климатических особенностей региона, данных более поздних некрополей, содержащих ткани, и данных этнологии.

Можно предположить, что одежда была многослойной, однако на реконструкции представлена только нижняя плечевая одежда. При использовании шкуры животного крой диктовался формой исходного материала (Орфинская, 2012. С. 77), в отличие от текстиля. Для ткани ограничения были связаны с высотой и шириной ткацкого стана. При создании варианта реконструкции костюма за основу было взято предположение, что значительная часть, а воз- 
можно, и вся одежда погребённой была тканой. Текстильные фрагменты были найдены на Кавказе ещё в погребениях эпохи бронзы Майкопской культуры (Шишлина и др., 2002. С. 253-254).

Самым распространенным вариантом тканой одежды может считаться «туника», получившая распространение и за пределами греко-римского мира. Этот крой одежды является одним из самых простых и функциональных. Именно такой тип нижней плечевой одежды был характерен для женщин, захороненных в могильнике Мощевая Балка - наиболее известном некрополе Северного Кавказа VIII-IX вв., содержащего органические материалы (Иерусалимская, 2012. С. 205). Для удобства «туника» фиксировалась поясом. На основании того, что в районе тазовых костей были зафиксированы оселок и нож, с высокой долей вероятности можно предполагать наличие у погребённой пояса, не содержащего металлических деталей. Оселок и нож, вероятно, подвешивались на пояс с помощью шнуров, хотя могли находиться и в поясной сумке. А.Г. Булатова, С.Ш. Гаджиева и Г.А. Сергеева отмечают, что широкий матерчатый пояс является древним элементам костюма горянок, связанным с туникообразной длинной одеждой. Такие пояса, возможно, выполняли роль карманов, куда женщины, отвернув их спереди, могли класть мелкие предметы (Булатова, Гаджиева, Сергеева, 2001. С. 30-31). В.Х. Тменов также отмечает пояса как неизменный атрибут одежды погребённых могильника Даргавс (Тменов, 1979. С. 126).

Туникообразная одежда в сочетании с парными булавками предполагает отсутствие плечевых швов и фиксацию за счёт скалывания «переда» и «спинки». Учитывая, что в нашем случае парные булавки не зафиксированы, можно предполагать, что фиксация происходила по средствам сшивания или использования органических элементов, которые не сохранились.

Цепь в предлагаемом вниманию читателя варианте реконструкции убора представляет собой нагрудное украшение. При этом необходимо упомянуть мнение В.Ю. Зуева, высказанное в частной беседе, согласно которому такие цепи могут служить застежками шубы. Это предположение находит подтверждение в этнографических материалах Горного Дагестана (Булатова, Гаджиева, Сергеева, 2001. С. 150. Табл. Х, А.), где женская шуба-накидка могла застёгиваться при помощи цепочки. Однако значительная длина цепи из погребения 43 и отсутствие крепления к предполагаемой шубе говорят скорее о том, что это было нагрудное украшение, а намотанной на руку её часть оказалась в результате перемещения тела покойной во время погребальной церемонии. В пользу нагрудного украшения говорят и аналогии из западнокобанских памятников.

Элементы погребального убора женщины, захороненной в погребении 43 могильника Заюково-3, представляют собой детали костюма, характерного для населения, оставившего некрополь в скифскую эпоху. Показательно, что ношение браслетов, перстней и длинной цепи было свойственно как женщинам, так и мужчинам. Расположение инвентаря в погребении 43 могильника 
Заюково-3 указывает на наличие пояса без металлических деталей. Женский убор с длинной цепью в основном был распространен на территории современной Кабардино-Балкарии, Кисловодской котловины, а также в Западном Закавказье. Убор с цепью нередко дополняли браслеты с раскованными концами. Как правило, цепь крепилась к одежде в нескольких местах при помощи булавок. Судя по известным на сегодняшний день аналогиям, не существовало жесткой регламентации способа ношения нагрудного украшения с длинной цепью, однако различные варианты этого убора были распространены среди разнообразных групп населения западных районов кобано-колхидской культурно-исторической общности.

\section{ЛИТЕРАТУРА}

Абрамова М.П. Погребения скифского времени Центрального Предкавказья // CA. 1974. № 2. С. 195-213.

Батчаев В.М. Древности предскифского и скифского периодов // Археологические исследования на новостройках Кабардино-Балкарии в 1972-1979 гг. Т. 2 / Под ред. М.П. Абрамовой и В.И. Козенковой. Нальчик: КБНИИ, 1985. С. 7-115.

Березин Я.Б., Дударев С.Л. Могильник Лермонтовская скала (у реки) - памятник раннего железного века Пятигорья // Материалы по изучению историко-культурного наследия Северного Кавказа. Вып. I / Отв. ред. А.Б. Белинский. Ставрополь: ГУП «Наследие», 1998. С. 168-208.

Березин Я.Б., Дударев С.Л., Фоменко В.А. Жреческий комплекс скифского времени из Пятигорья // Из традиционной этнографии народов Карачаево-Черкесии / Отв. ред. Е.П. Алексеева. Черкесск: КЧНИИ, 1993. С. 145-161.

Брилева О.А., Кадиева А.А., Демиденко С.В. Эволюция образа сидящего божества в бронзовой антропоморфной пластике Кавказа. // КСИА, в печати.

Булатова А.Г., Гаджиева С.Ш., Сергеева Г.А. Одежда народов Дагестана. Пущино: Институт истории, археологии и этнографии ДагНЦ РАН, 2001. 289 с.

Иерусалимская А.А. Мощевая балка. Необычный археологический памятник на северокавказском шёлковом пути. СПб.: Изд-во Государственного Эрмитажа, 2012. $384 \mathrm{c}$.

Кадиева А.А., Демиденко С.В. Раскопки комплекса археологических памятников близ селения Заюково (Кабардино-Балкарская республика) // Вестник РФФИ. Гуманитарные и общественные науки. 2017. № 2. С. 164-171.

Козенкова В.И. Материальная основа быта кобанских племен. Западный вариант. М.: ИА РАН, 1998. 199 с.

Крупнов Е.И. Древняя история Северного Кавказа. М.: Изд-во АН СССР, 1960. $520 \mathrm{c}$.

Маслов B.E. Керамика Центрального Предкавказья в раннескифское время // Современные подходы к изучению древней керамики в археологии. Международный симпозиум (29-31 октября 2013 г.) / Отв. ред. Ю.Б. Цетлин. М.: ИА РАН, 2015. С. 248-257.

Maхортых C.В. Скифы на Северном Кавказе. Киев: Наукова думка, 1991. 136 с.

Мелюкова А.И. Вооружение скифов // Археология СССР. Свод археологических источников. М.: Наука, 1964. 113 с. 
Мунчаев Р.М. Луговой могильник (исследования 1956-1957 гг.) // Древности Чечено-Ингушетии. М.: Изд-во Академии наук СССР, 1963. С. 139-211.

Орфинская O.B. Три источника, или к вопросу о классификации кроя одежд // Женская традиционная культура и костюм в эпоху средневековья и в новое время: Материалы международного научно-образовательного семинара 9-10 ноября 2012 г. Вып. 2. М., СПб., 2012. С. 76-92.

Папуашвили Р. К вопросу об абсолютной хронологии могильников Колхиды эпохи поздней бронзы - раннего железа // Вопросы древней и средневековой археологии Кавказа / Отв. ред. Х.М. Мамаев. М., Грозный: РАН, АН ЧР, 2011. С. 82-94.

Петренко В.Г. Украшения Скифии VII-III вв. до н.э. // Археология СССР. Свод археологических источников. Вып. Д 4-5. М.: Наука, 1978. 144 с.

Петренко В.Г. Краснознаменский могильник. Элитные курганы раннескифской эпохи на Северном Кавказе. М., Берлин, Бордо: Палеограф, 2006. 309 с.

Петренко В.Г., Маслов В.Е., Канторович А.Р. Хронология центральной группы могильника Новозаведенное-II // Скифы и сарматы в VII-III вв. до н.э.: палеоэкология, палеоантропология и археология / Отв. ред. В.И. Гуляев, В.С. Ольховский. М.: ИА РАН, 2000. С. 238-248.

Тменов В.X. «Город мертвых» (Позднесредневековые склеповые сооружения Тагаурии). Орджоникидзе: Ир, 1979. 152 с.

Трапш М.M. Памятники колхидской и скифской культур в селе Куланурхва Абхазской АССР. Сухуми: Абгосиздат, 1962. 130 с.

Членова Н.Л. Могильник VI в. до н.э. Султан-гора III под Кисловодском // Древности Евразии в скифо-сарматское время / Под ред. А.И. Мелюковой, М.Г. Мошковой, В.Г. Петренко. М.: Наука, 1984. С. 235-241.

Шишлина Н.И., Орфинская О.В., Голиков В.П. Текстиль эпохи бронзы Северного Кавказа: проблема происхождения // Степи Евразии в древности и средневековье: Материалы Международной научной конференции, посвящённой 100-летию со дня рождения Михаила Петровича Грязнова. Кн. І. СПб., 2002. С. 253-259. 


\title{
БРОНЗОВЫЙ ЧЕРПАК ИЗ МОГИЛЬНИКА НОВОЗАВЕДЕННОЕ-ІІІ НА СТАВРОПОЛЬЕ
}

(Исследование выполнено в рамках проекта РФФИ № 18-09-00725 «Скифы в Центральном Предкавказье в VII-IV вв. до н.э.»)

\author{
Канторович А.P., Маслов В.Е. \\ (Памяти участника экспедищии Валентина Слатина)
}

http://10.25681/IARAS.2019.978-5-317-06274-3/89-99

Статья посвящена находке бронзового предмета (черпака или жаровни) в кургане № 5 скифского могильника конца V - IV вв. до н.э. Новозаведенное-III на Ставрополье, исследуемого Ставропольской экспедицией кафедры археологии Исторического факультета МГУ. Данный предмет относится к кругу кочевнических древностей и находит аналогии в памятниках V-IV вв. до н.э. скифской и «савроматской» культур от Нижнего Поднепровья до Южного Приуралья. По своим морфологическим параметрам новозаведенский черпак ближе всего к находкам на Нижнем Дону и Северском Донце, происходящим из комплексов, датируемых по объективным показателям в пределах второй половины (скорее, последней трети) IV в. до н.э. При отсутствии единства в литературе по вопросу назначения изделий данной категории, представляется, что для новозаведенского предмета и его ближайших аналогий более вероятна их идентификация как черпаков, а не жаровен или курильниц, учитывая наличие у них втулки для крепления древковой рукояти, а также сочетание их в комплексах в ряде случаев с бронзовыми котлами. Вместе с тем, не следует исключать того, что эти предметы могли быть полифункциональными, а иногда иметь ритуальное назначение.

Ключевые слова: скифы, савроматы, курганный могильник, Новозаведенное-ІІІ, бронзовый черпак/жаровня

В 2015-2017 гг. Ставропольская экспедиция кафедры археологии Исторического факультета МГУ им. М.В. Ломоносова осуществляла раскопки скифского курганного могильника конца V-IV вв. до н.э. НовозаведенноеIII на территории Георгиевского района Ставропольского края (Канторович, 2016. С. 82-84; Канторович, Маслов, 2016. С. 85-87; Канторович, Маслов, 2017. С. 107-139).

В 2016 г. в ходе раскопок кургана № 5 на уровне погребённой почвы на глубине (-64)-(-69) см от $\mathrm{R}(0)$ близ юго-западного угла могильной камеры был найден бронзовый черпак-жаровня(?) с боковой конической втулкой для насадки древка (рис. 1; 2; 3: 1). Длина черпака вместе с втулкой - 22,1 см, максимальный диаметр - 15 см, высота - 7,2 см, толщина стенок - 0,9 см, длина втулки с нижним упором для крепления (не исключено, что это не упор, а результат литейного брака при отливке втулки) - 6,1 см, её диаметр - 3,2 см, длина выступа-упора - 1,6 см. Черпак имеет 16 целых отверстий и ещё два, слитых воедино вследствие облома краёв. Они образуют два концентрических ряда вокруг центрального отверстия. Диаметр сохранившихся отверстий в среднем 2,1 см. Во втулке сверху имеется отверстие для крепления. 


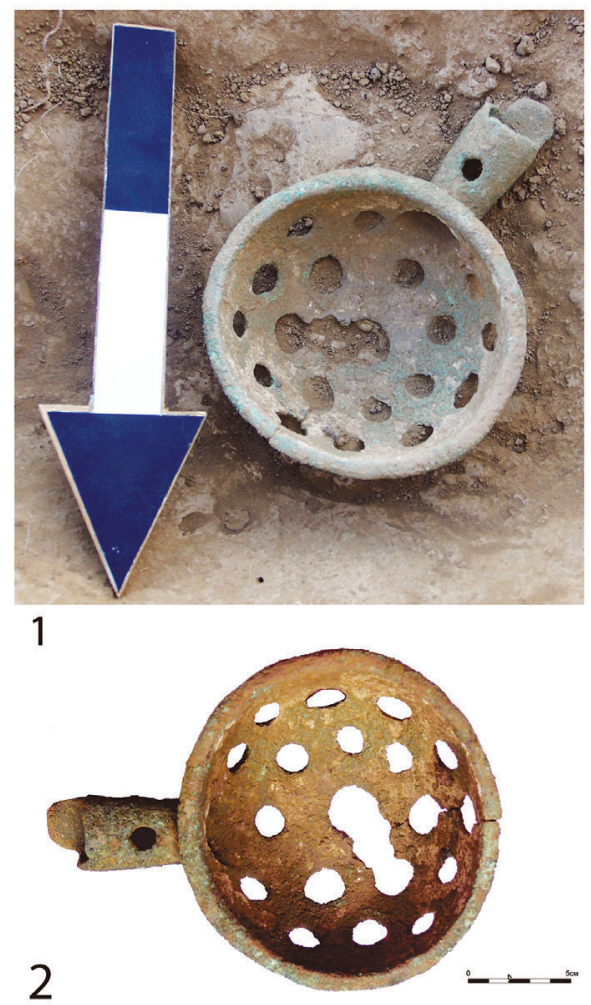

Рис. 1. Черпак из кургана № 5 могильника Новозаведенное-ІІІ. 1 - фото in situ; 2 - фото, вид сверху. Фото А.Р. Канторовича

Вместе с черпаком были найдены невыразительные обломки железа, один из которых прикипел к стенке черпака. Это позволяет осторожно предположить, что черпак был выброшен грабителями из могильной ямы в ходе ограбления. Не исключено, однако, что он был сознательно помещен создателями погребения на край могилы в качестве приношения.

Наиболее ранние параллели бронзовому черпаку содержатся в комплексах с территории «савроматской» культуры - из Волго-Уральского региона. В частности, в Соболевском кургане в бассейне р. Бузулук (Смирнов, 1964. Рис.14, 6) (рис. 3: 12) подобный черпак был найден вместе с двумя котлами - типа I и II по К.Ф. Смирнову (1964. Рис.14, 7, 8), и I и IX по С.В. Демиденко (2008. С. 50, 85,105 , кат. 2; 105).

Материалы из Соболевского кургана, раскопанного крестьянами, привлекли внимание П.Д. Рау, Б.Н. Гракова, а затем К.Ф. Смирнова. По набору наконечников стрел и особенностям стилистики предметов, выполненных в «зверином стиле», имеющих параллели среди материалов Блюменфельдского кургана А 12, данный комплекс был отнесён ко времени не позднее первой половины V в. до н.э. (Смирнов, 1964. С. 45, 46). 


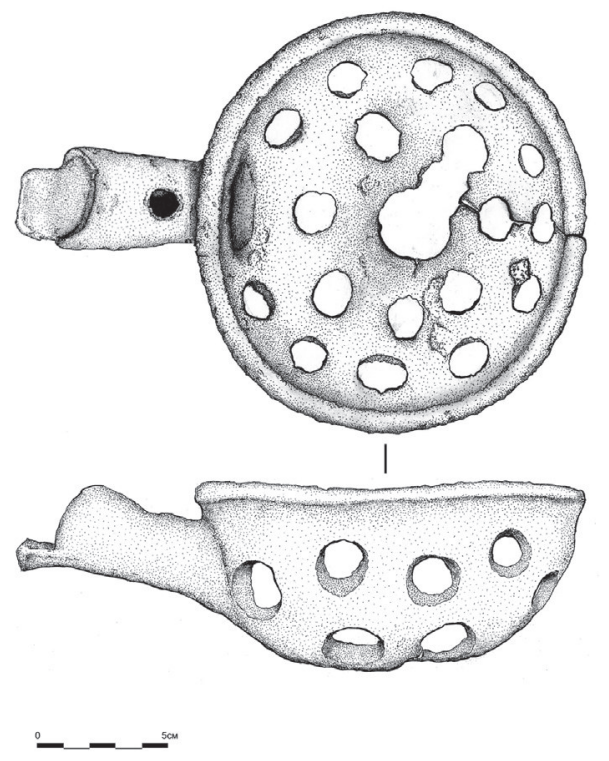

Рис. 2. Черпак из кургана № 5 Новозаведенное-ІІІ. Вид сверху, вид сбоку. Прорисовки Х.В. Штейгер

Резервуар соболевского черпака подпрямоугольный в плане, со скруглёнными углами; он снабжён боковой цилиндрической втулкой. В верхней его части и над переходом тулова в дно расположены рельефные литейные швы, что сближает его с меньшим из котлов. Шесть округлых отверстий на дне, обрамлённых снаружи прямоугольным литейным валиком, расположены двумя параллельными рядами по три.

Аналогичный соболевскому черпак был найден на пашне у с. Алёшкино Кузнецкого уезда Саратовской губернии (территория нынешней Пензенской области) (Смирнов, 1964. С. 136, рис. 70Б, 12) (рис. 3: 11). Черпак имеет округлый в плане резервуар с хорошо выделенной губой, с цилиндрической боковой втулкой, имеющей снизу отверстие для крепления. Четыре округлых отверстия на округлом дне, обрамлённые снаружи литейным валиком, формируют квадрат, в центре которого расположено пятое отверстие. Данный черпак не имеет точной датировки.

Как соболевский, так и алёшкинский черпаки были квалифицированы К.Ф. Смирновым как переносные жаровни: не находя на тот момент прямых аналогий данным предметам, исследователь в качестве отдалённой параллели и основы для их функциональной атрибуции привёл «жаровню» из Чертомлыка, о которой речь пойдет ниже (Смирнов, 1964. С. 136).

Ещё одна аналогия в зоне «савроматской» культуры происходит из кургана № 6 могильника Таксай I в Западном Казахстане: здесь «жаровня» была обнаружена у южной стенки могильной камеры (Сдыков, Лукпанова, 2013. С. 204, 
205, фото 10, рис. 11) (рис. 3: 9). Рядом с ней не было предметов: ближайшая находка - стеклянный сосуд - находилась в 40 см к северо-западу (Сдыков, Лукпанова, 2013. С. 140, 141).

Резервуар «жаровни» в плане имеет форму вытянутого овала, с валикообразной губой и округлым дном, размерами $20,5 \times 15,0 \times 10,5$ см. На скруглённом дне и придонной части чаши имеются 24 отверстия овальной, иногда неправильной формы, разных размеров. Они расположены четырьмя рядами в следующем порядке: $5-7-7-5$ отверстий. С двух длинных сторон чаши были прикреплены утраченные ручки (сохранился фрагмент одной из них) с утолщённым основанием.

Следует отметить, что в погребальной камере также был найден котел, близкий к VI типу котлов по С.В. Демиденко, который, однако, находился в центральной части могилы (Сдыков, Лукпанова, 2013. С. 206-288). Взаимосвязь котла и черпака здесь не очевидна, но допустима.

Комплекс из кургана № 6 могильника Таксай I имеет надёжные основания для датировки в границах первой половины V в. до н.э. Стеклянные сосуды с зигзагообразным декором из белого и жёлтого стекла входят в число сосудов «ахеменидского круга», вероятно, средиземноморского происхождения (Сдыков, Лукпанова, 2013. С. 232-235; Трейстер, 2012. С. 106, 107). На Южном Урале ближайшие аналогии этим находкам представлены в комплексах курганных могильников Пятимары-I и Лебедевка-II.

Из кургана № 6 могильника Таксай I также происходит гребень, вырезанный из тополя. Изображение батальной сцены на этом гребне имеет сюжетные и стилистические соответствия в росписях на бревенчатых стенах погребальной камеры курганной гробницы Татарли во Фригии, которая по образцам дерева на основании радиоуглеродного и дендрохронологического анализа была датирована $451 \mathrm{BC} \pm 22$ или, по другой версии, $478 \mathrm{BC}+4 / \pm 7$ (Сдыков, Лукпанова, 2013. C. 220-225; Summerer, 2007. P. 26, note 99. Fig. II; XI-XIII).

В кургане 1 могильника Покровка-2 на юге Оренбургской области, под насыпью была расчищена погребальная площадка, выстланная камышом, подожженная в центральной части, окруженная невысокой обваловкой, с радиально уложенными брёвнами. Бронзовая литая жаровня с двумя петлевидными ручками была найдена в центральной части погребальной площадки (Веддер и др., 1993. С. 24, рис. 24, 5, 6) (рис. 3: 10). Других находок, кроме одного наконечника стрелы и жертвенных захоронений лошадей, не было. Первоначально Л.Т. Яблонский при датировке этого комплекса опирался почти исключительно на данные погребального обряда, но позднее предположил, что данный курган - это одна из насыпей, исследованных И.А. Кастанье в 1911 г., и из него, вероятно, происходит набор золотых украшений, включавший ахеменидскую печать в золотой оправе, что позволяет достаточно надежно датировать его первой половиной V в. до н.э. (2017. С. 196, 197, рис. 74). Следует отметить, что эти материалы очень близки к находкам из могильника Таксай I. 

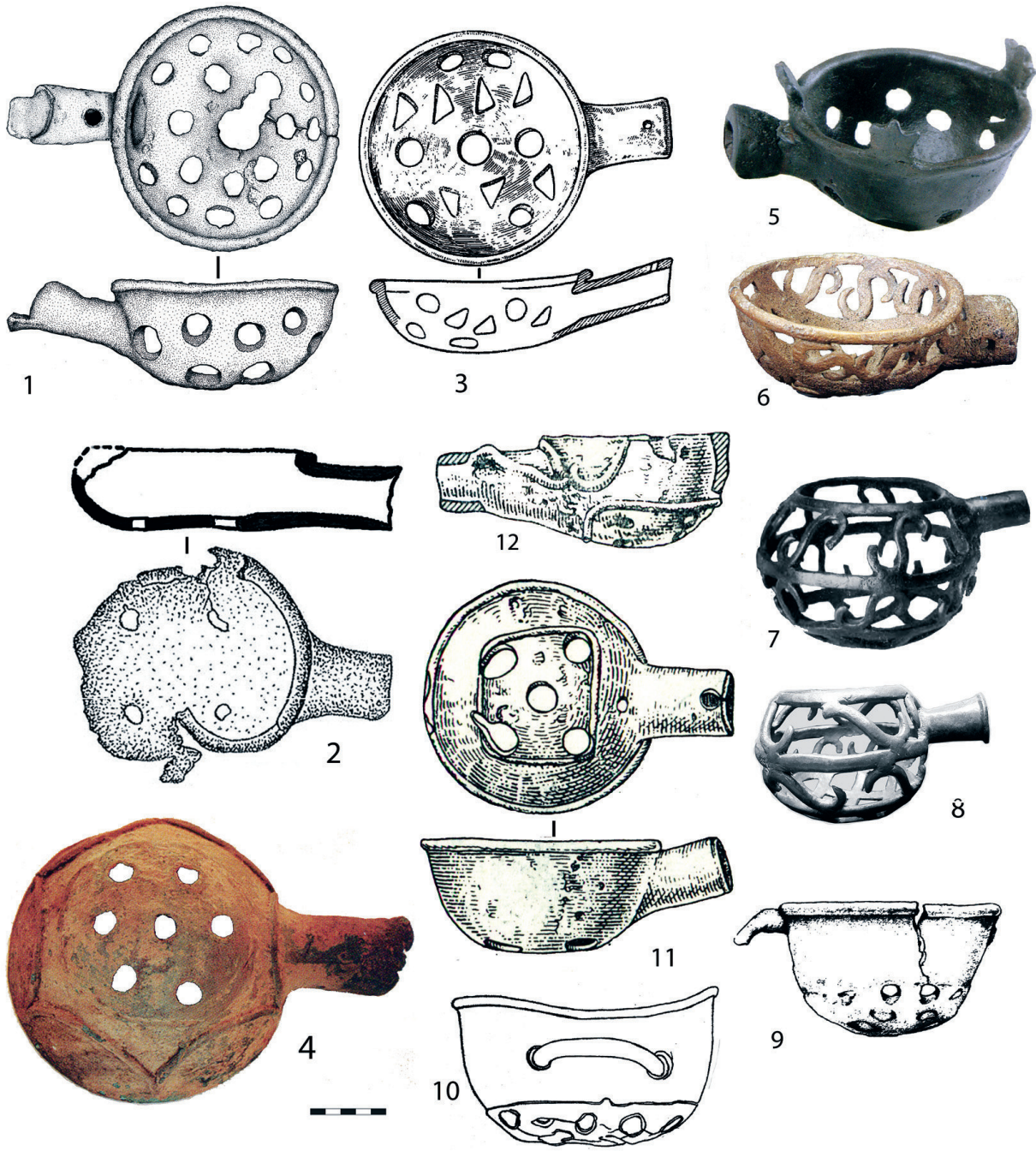

Рис. 3. 1 - Новозаведенное-III; 2 - Веселая Роща III, к. 7, погр. 14 (по: Прокопенко, 2005); 3 - Кащеевка, к. 1 (по: Максименко и др., 1984); 4 - Филипповка (по: Яблонский, 2013); 5 - Частые курганы-ІІ к. 1 (по: Максименко, 2004); 6 - Майкоп, случайная находка (по L'or des Amazones..., 2001); 7 - Чертомлык (по: Алексеев и др., 1991); 8 - Гайманова могила (по: Бидзиля, Полин, 2012); 9 - Таксай I, к. 6 (по: Сдыков, Лукпанова, 2013); 10 - Покровка-2, к. 1 (по: Ведер и др., 1993); 11 - Алешкино (по: Смирнов, 1964); 12 - Соболевский курган (по: Смирнов, 1964)

Жаровня имеет две петельчатые горизонтальные ручки и подквадратный в плане резервуар, размерами $16 \times 13 \times 4$ см. Над переходом тулова в дно расположена граница литейного шва. Не менее 17 отверстий на округлом дне сгруппированы в виде овала. 
Однако наиболее близкие нашей находке аналогии происходят из памятников Нижнего Дона и Южного Приуралья, которые относятся уже к IV в. до н.э.

В могильнике Филипповский $1^{1}$ черпак был обнаружен в межкурганном пространстве, в 200 м к югу от кургана 4 - одного из двух крупнейших курганов могильника с погребениями представителей вождеского клана (Яблонский, 2013. С. 225, кат. 3140) (рис. 3: 4). Датировка этого комплекса в пределах IV в. до н.э., скорее, второй половины - конца этого столетия определяется хронологией всего могильника (Переводчикова, 2013).

Филипповский черпак имеет округлый резервуар диаметром 18 см с боковой цилиндрической втулкой. Семь округлых отверстий на дне (шесть по кругу и одно в центре) обрамлены снаружи шестиугольным арочным литейным валиком.

Две находки происходят из памятников в междуречье Северского Донца и Нижнего Дона.

В кургане 1 у хут. Кащеевка черпак был найден в центре большой квадратной ямы с дромосом и коллективным захоронением (Максименко и др., 1984. С. 155,156 , рис. 70,2 ) (рис. $3: 3$ ). Основанием для уточнения датировки данного комплекса могут послужить поясные крючки, украшенные изображениями медведей (Там же. Рис. $69,10,11)$. Сходные по деталям и стилистике изображения представлены на уздечных бляшках из кургана 10 могильника Горки I на Среднем Дону, где они найдены вместе с амфорой типа Пепарет II, изготовленной в третьей четверти IV в. до н.э. (Гуляев, Шевченко, 2017. С. 30, рис. $9,6,7,15)$.

Черпак имеет округлый в плане резервуар с хорошо выделенной губой, с цилиндрической боковой втулкой, имеющей сверху отверстие для крепления. На округлом дне 14 округлых и треугольных отверстий, сгруппированных в три ряда с обрамлением по бокам.

В кургане 1 могильника Частые курганы-II на Северском Донце в сожжёенной наземной погребальной конструкции в коллективном захоронении были найдены вместе котел (тип V по С.В. Демиденко) и черпак (Максименко и др., 2001. С. 220, 222, рис. 3, 4, 5; 2004. С. 37. РОМК 24522/10) (рис. 3: 5). Погребение датируется благодаря наличию в нем редкого типа блях с сильно стилизованным изображением головок животных, ближайшие аналогии которому происходят из греко-варварской царской гробницы в кургане Карагодеуашх и уже упомянутого кургана 10 могильника Горки I (Лаппо-Данилевский, Мальмберг, 1894. Табл. VII, 3; Максименко, 2004. С. 38. РОМК 24522/9; Гуляев, Шевченко, 2017. Рис. 9, 10, 11). Оба этих комплекса надежно датированы: соответственно четвертой и третьей четвертью IV в. до н.э.

Черпак имеет округлый в плане резервуар, размерами $14,5 \times 10,5$ см, с хорошо выделенной губой, с конической боковой втулкой. На губе радиально

${ }^{1}$ В Филипповском могильнике была встречена также серия ковшей с втулкой, по форме аналогичных нашей находке, но не имеющих отверстий (Яблонский, 2013. Кат. 2621, 3178). 
расположены три пластинчатых выступа, расширяющиеся кверху с расходящимся в стороны трёхзубым завершением. В округлом дне имеются округлые отверстия.

Территориально наиболее близок черпаку из Новозаведенного-ІІІ ковш из впускного погребения 14 кургана 7 могильника Веселая Роща III в Александровском районе Ставропольского края (Прокопенко, 2005. С. 280, рис. 177,4$)^{1}$ (рис. $3: 2$ ). Черпак имеет выделенную губу, низкий корпус с уплощенным дном, переходящим в боковую втулку. В дне имелись четыре неровных отверстия, расположенных в форме квадрата.

Особую группу составляют ковши, имеющие отличия от вышеупомянутых по форме резервуара и в деталях оформления: это ажурные бронзовые черпаки закрытой формы, с широкими прорезями на корпусе, разделенными $\mathrm{S}$-видными завитками, с решетчатым дном. Они происходят из царских и аристократических скифских курганов IV в. до н.э. в Нижнем Поднепровье: курганов Чертомлык, Гайманова могила и Козел.

В Чертомлыке черпак был обнаружен в верхней части насыпи (Толстой, Кондаков, 1889. С. 106, 107, рис. 94; Алексеев и др., 1991. С. 158, 159, кат. 33) (рис. 3: 7). Его корпус, размерами $16,5 \times 11$ см, почти шаровидной формы. Боковая втулка цилиндрическая со сквозным отверстием для крепления.

В Гаймановой могиле черпак был обнаружен в Северной гробнице № 1 в Северной нише № 1. Ковш лежал в перевёрнутом состоянии на краю большой бронзовой жаровни вместе с бронзовыми сосудами - ситечком, ойнохоей, киликом, по соседству с железным черпаком, с большим бронзовым котлом с костями лошади, с малым бронзовым котлом и т.д. (Бидзиля, Полин, 2012. С. 90-92, 342, рис. 115, 473, кат. 137) (Рис. 3: 8). Корпус черпака, размерами $11,5 \times 8,3$ см, почти шаровидной формы. Боковая втулка коническая, глухая, с валиком по краю и сквозным отверстием, для крепления.

Гаймановский черпак в момент его обнаружения был изнутри покрыт кожей, что, по мнению С.В. Полина, изменило его первоначально назначение: вместо «вылавливания кусков мяса в горючем бульоне», он применялся для черпания жидкостей из котлов в ходе «нерядовых событий», поскольку для мяса имелся специальный крюк-тройник, а для обыденных случаев использовали найденный там же «железный ковш-черпак» (Бидзиля, Полин, 2012. С. 90-92. Рис. 115 , с. 342).

Сходный черпак был найден и в катакомбе кургана Козел (не опубликован, фрагменты хранятся в ГИМ) (Алексеев и др., 1991. С. 118).

Наконец, черпак с оформлением стенок, аналогичным стенкам чертомлыцкого и гаймановского черпаков, с решётчатым дном, но открытой полусферической формы, известен в качестве случайной находки в Прикубанье (L'or des Amazones, 2001. P. 90, cat. 25) (рис. 3: 6). Он имеет край с выде-

${ }^{1}$ Вместе с данным ковшом были обнаружены фрагменты костяного изделия с циркульной орнаментацией и бронзовая заклепка. 
ленной губой. Боковая втулка цилиндрическая с горизонтальным отверстием для крепления.

Подведём итоги обзора существующей серии находок.

Для черпаков ранней хронологической группы, датируемых по комплексам находок в пределах первой половины V в. до н.э., характерны, как представляется, вытянутый или подпрямоугольный резервуары. Только один из них имеет боковую втулку, а два - ручки. В двух случаях они встречены в единых комплексах вместе с котлами (Соболевский курган и Таксай I). Один из комплексов относится к воинским (Соболевский курган), два, вероятно, связаны с родовой знатью высшего ранга (Таксай I и Покровка 2).

Хронологический разрыв между черпаками ранней и поздней группы составляет около столетия. Пока его нечем заполнить.

Появление новой группы черпаков на Нижнем Дону и Северском Донце отчетливо связано с культурным импульсом из Южного Приуралья в конце IV в. до н.э. (Максименко и др., 1984. С. 156; Яблонский, 2017. С. 184). Следует подчеркнуть, что этот импульс не был однонаправленным: в раннесарматских памятниках Южного Приуралья также отчетливо просматриваются следы культурных контактов со скифским миром (Переводчикова, 2013).

Исходя из хронологии донецко-донских аналогий черпаку из кургана 5 могильника Новозаведенное-III, наша находка может датироваться в пределах второй половины (скорее, последней трети) IV в. до н.э.

И новозаведенская, и донецко-донские находки достоверно связаны с воинскими комплексами.

Связь ажурных сферических черпаков из царских и аристократических скифских курганов (Чертомлык, Гайманова могила, Козел) с остальными черпаками не очевидна в силу морфологических различий. В её пользу свидетельствует находка из фондов Краснодарского музея, совмещающая черты обоих типов (рис. 3: 6).

Во взглядах на назначение данных находок нет единства.

И.И. Толстой и Н.П. Кондаков, публикуя находку из Чертомлыка, определяли её как жаровню, хотя и с сомнением (1889. С. 106, 107).

В качестве жаровен, использовавшихся в религиозных культах расценивал их и К.Ф. Смирнов (1964. С.136; Максименко и др., 1984. С. 155, 156). Для этого утверждения имеются определённые основания. Все черпаки со сплошными стенками слишком толстостенные и массивные для того, чтобы быть просто черпаками. Не могли быть черпаками двуручные чаши из Покровского и Таксайского могильников. Они вполне могли использоваться в качестве своеобразных курильниц, где снизу находился слой углей, а сверху ароматические вещества, или просто как переносные жаровни.

В пользу небытового использования чаш как будто свидетельствует необычное оформление чаши из Частых курганов - II. Выступы на губе чаши мешали бы её простому утилитарному использованию. 
Однако для большинства подобных изделий предусмотрено наличие толстой (очевидно, длинной) древковой рукояти, крепящейся во втулке. Их сочетание в ряде случаев с бронзовыми котлами, возможно, свидетельствует о том, что это всё же были черпаки, а не жаровни. Другое дело, что черпать ими можно было и угли.

А.Ю. Алексеев, В.Ю. Мурзин и Р. Ролле квалифицировали чертомлыцкое изделие как ковш ${ }^{1}$ и признали функционально близким ему, помимо бронзовых ковшей из Алёшкина и Кащеевки, деревянный ковш из Туэктинского кургана на Алтае 2 , вырезанный из единого нароста кедра, не имеющий отверстий в дне, украшенный резьбой с киноварной окраской и золотой и серебряной пластинами, снятыми грабителями (Алексеев и др., 1991. С. 118; Руденко, 1960. С. 116, 117, рис. 66) (Рис. 3: 13).

Попытка включить туэктинский ковш в круг аналогий бронзовым чашам представляется неудачной. Это совершенно различные предметы в морфологическом и функциональном отношении. Туэктинский сосуд был найден в гробу-колоде (Руденко, 1960. С. 110, рис. 59). Парадный деревянный ковш относится к категории личных вещей, находившихся при владельце, имеющих, очевидно, и сакральный контекст. Возможно, первоначально он имел коленчатую ручку, оканчивающуюся копытом. Гораздо более правомерно будет его сравнение с деревянным ковшом из царского погребения 5 в кургане Аржан 2 в Туве (Cugunov u. а., 2010. Abb. 64. Taf. 81, 1). ${ }^{3}$

C.В. Полин определяет все известные ему аналогии находке из Гаймановой могиле как черпаки (Бидзиля, Полин, 2012. С. 342, 343). Очевидно, определение «черпак» для данных предметов всё же более точное, нежели «ковш», которое косвенно подразумевает использование в застольях, что пока не далеко не очевидно. Вместе с тем, не следует исключать того, что эти предметы могли быть полифункциональными.

\section{ЛИТЕРАТУРА}

Алексеев А.Ю., Мурзин В.Ю., Ролле Р. Чертомлык. (Скифский царский курган IV в. до н.э.). Киев: Наукова думка, 1991. 416 с.

Бидзиля В.И., Полин С.В. Скифский царский курган Гайманова Могила. Киев: Издательский дом «Скиф», 2012. 752 с.

${ }^{1}$ Такая атрибуция, по мнению исследователей, подкрепляется находкой в насыпи Чертомлыка железной ложки, предположительно входившей в единый кухонный набор с черпаком (Алексеев и др., 1991. С. 118).

${ }^{2}$ Из контекста ясно, что исследователи имеют в виду ковш из 1-го Туэктинского кургана.

${ }^{3}$ Сердечно благодарим К.В. Чугунова за консультацию. 
Веддер Д., Егоров В.Л., Дэвис-Кимбол Дж., Моргунова Н.Л., Трунаева Т.Н., Яблонский Л.Т. Раскопки могильников Покровка 2 и Покровка 8 в 1992 г. // Курганы левобережного Илека / Отв. ред. Л.Т. Яблонский. М.: ИА РАН, 1993. С. 18-54.

Гуляев В.И., Шевченко А.А. Новые курганные могильники скифского времени на Среднем Дону: Горки I и Девица V. М.: ИА РАН, 2017. 156 с.

Демиденко С.В. Бронзовые котлы древних племен Нижнего Поволжья и Южного Приуралья (V в. до н.э. - III в. н.э.). М.: Изд-во ЛКИ, 2008. 328 с.

Канторович A.P. Произведения скифского звериного стиля из могильника Новозаведенное-III // Изучение и сохранение археологического наследия народов Кавказа. XXIX Крупновские чтения. Материалы международной научной конференции (Грозный, 18-21 апреля 2016 г.). Грозный: Изд-во ЧГУ, 2016. С. 82-84.

Канторович A.P., Маслов В.Е. Раскопки скифского могильника Новозаведенное-ІІІ на Ставрополье // Изучение и сохранение археологического наследия народов Кавказа. XXIX Крупновские чтения. Материалы международной научной конференции (Грозный, 18-21 апреля 2016 г.). Грозный: Изд-во ЧГУ, 2016. С. 85-87.

Канторович A.P., Маслов B.E. Могильник Новозаведенное-ІІІ как свидетельство пребывания скифов в Центральном Предкавказье в конце V-IV вв. до н.э. // Исторические Исследования. Журнал Исторического факультета МГУ. № 8. 2017. C. $107-139$.

Лаппо-Данилевский А., Мальмберг В. Курган Карагодеуашх. Древности Южной России. МАР. № 13. 1894. 192 с.

Максименко B.E. Нижнедонские «Частые курганы» // Сокровища донских степей из собрания Ростовского областного музея краеведения. Ростов-на-Дону: ОАО КБ «Центр-инвест», 2004. С. 37-39.

Максименко B.Е., Смирнов К.Ф., Косяненко В.М. Курган у хут. Кащеевка // Смирнов К.Ф. Сарматы и утверждение их политического господства в Скифии / Отв. ред. В.В. Кропоткин, М.Г. Мошкова. М.: Наука, 1984. С. 148-156.

Максименко В.Е., Ключников В.В., Гуркин С.В. Исследования могильника «Частые курганы II» на Нижнем Дону (предварительная публикация) // Археология Среднего Дона в скифскую эпоху. ТПАЭ 1993-2000. М.: ИА РАН, 2001. С. 220-225.

Переводчикова E.B. Произведения скифского звериного стиля Прикубанья и дата Филипповских курганов // Шестая международная Кубанская археологическая конференция: Материалы конференции / Отв. ред. И.И. Марченко. Краснодар: Экоинвест, 2013. С. 334-336.

Прокопенко Ю.А. Историко-культурное развитие населения Центрального Предкавказья во второй половине I тыс. до н.э. Ставрополь: Изд-во СГУ, 2005. 819 с.

Руденко С.И. Культура населения Центрального Алтая в скифское время. М.-Л.: Изд-во АН СССР, 1960. 360 с.

Сдыков М.Н., Лукпанова Я.А. Ранние кочевники Западного Казахстана (на примере курганного комплекса Таксай I). Уральск: Полиграфсервис, 2013. 292 с.

Смирнов К.Ф. Савроматы. Ранняя история и культура сарматов. / Отв. ред. М.Г. Мошкова. М.: Наука, 1964. 380 с.

Трейстер М.Ю. Стеклянные сосуды ахеменидского круга из Южного Приуралья // Влияния ахеменидской культуры в южном Приуралье (V-III вв. до н.э.) Т. 1 / Под ред. М.Ю. Трейстера и Л.Т. Яблонского. М.: ТАУС, 2012. С. 50-86.

Толстой И.И., Кондаков Н.П. Русские древности в памятниках искусства. Вып. 2. СПб.: Тип. Министерства путей сообщения, 1889. 161 с. 
Яблонский Л.Т. Золото сарматских вождей. Элитный некрополь Филипповка 1 (по материалам раскопок 2004-2009 гг.). Каталог коллекции. Кн. 1 / Отв. ред. М.Г. Мошкова. М.: ИА РАН, 2013. 232 с.

Яблонский Л.Т. На востоке скифской ойкумены. М.: Грифон, 2017. 400 с.

Cugunov K.V., Parzinger H., Nagler A. Der skythenzeitliche Fürstenkurgan Aržan 2 in Tuva. AE. Bd. 26. 2010. 330 S.; 153 Taf.

Summerer L. Picturing Persian Victory: The Painted Battle Scene on the Munich Wood // Achaemenid Culture and Local Traditions in Anatolia, Southern Caucasus and Iran. New Discoveries / Edited by A. Ivantchik and V. Licheli. ACSS. 13 (1-2). 2007. P. 3-30.

L'or des Amazones: peuples nomades entre Asie et Europe, VIe siècle av. J.-C. IVe siècle apr. J.-C.: Musée Cernuschi Musée des arts de l'Asie de la ville de Paris, 16 mars - 15 juillet 2001. Paris: Éditions Findakly, 2001. 302 p. 


\title{
«СЛОЖНЫЙ ЗАВИТОК» В СКИФСКОМ ЗВЕРИНОМ СТИЛЕ И НАБОРНЫЕ ПОЯСА ДРЕВНИХ КОЧЕВНИКОВ
}

\author{
Кисель В.А. \\ http://10.25681/IARAS.2019.978-5-317-06274-3/100-111
}

В скифском зверином стиле вместе с образами животных присутствуют оригинальные орнаментальные мотивы. Особый интерес вызывает фигура в виде изогнутой капли или буквы «S», дополненная закруглёнными или заострёнными выступами. Обычно она именуется «сложным завитком». Этот мотив встречается в различных вариантах: от слегка изменённых запятых до замысловатых форм с множеством выступов и украшений. Формирование «сложного завитка» происходило в азиатской части древнекочевнического мира около середины VII в. до н.э.

Большинство исследователей считает, что мотив является стилизованным образом хищной птицы. Однако с этим трудно согласиться из-за наличия ненужных выступов, размещённых на якобы орлиной голове, а также схематичного облика «сложного завитка». Как показывают археологические материалы, мотив уже во второй половине VII в. до н.э. украшал различные предметы, но чаще всего выполнялся на пряжках наборных поясов.

Анализ пряжек указывает на то, что «сложный завиток» произошёл от плоского широкого крючка с парой отверстий, внешне напоминавшего запятую. Со временем крючок стал украшаться округлыми и изогнутыми выступами, которые позволяли надежно зацеплять и крепить ремешки пояса. В то же время в древнекочевнической культуре существовал знак в виде запятой или изогнутой капли, возможно, символизировавший звериный или птичий коготь и имевший апотропеическое значение. Ременные пряжки, выполненные в виде «завитка», также играли охранительную роль. В результате усиления значения хищной птицы в репертуаре раннего звериного стиля «сложный завиток» приобрел орнитоморфные черты и стал полноценным орнаментальным мотивом.

Ключевые слова: скифский звериный стиль, мотив «сложный завиток», орнитоморфный образ, наборные пояса

Скифский звериный стиль - ярчайшее явление кочевнического мира. В первую очередь его отличают специфически трактованные образы животных. Вместе с тем в зверином стиле присутствуют и оригинальные декоративные мотивы. Среди них особое внимание вызывает фигура в виде изогнутой капли или буквы «S», дополненная закруглёнными или заострёнными выступами. Её именуют «сложным завитком». Этот мотив встречается в различных вариантах: от слегка изменённых запятых ${ }^{1}$ до замысловатых форм с множеством выступов и дополнительных украшений, состоящих из криволинейных узоров или фигур животных (рис. 1).

Как правило, исследователи видят в «сложном завитке» стилизацию реального художественного образа. На роль прототипа выдвигались растительные побеги (Завитухина, 1983. С. 19). Правда, эта гипотеза основывалась исклю-

1 Упрощённый вариант иногда называется «асимметричным листком». 


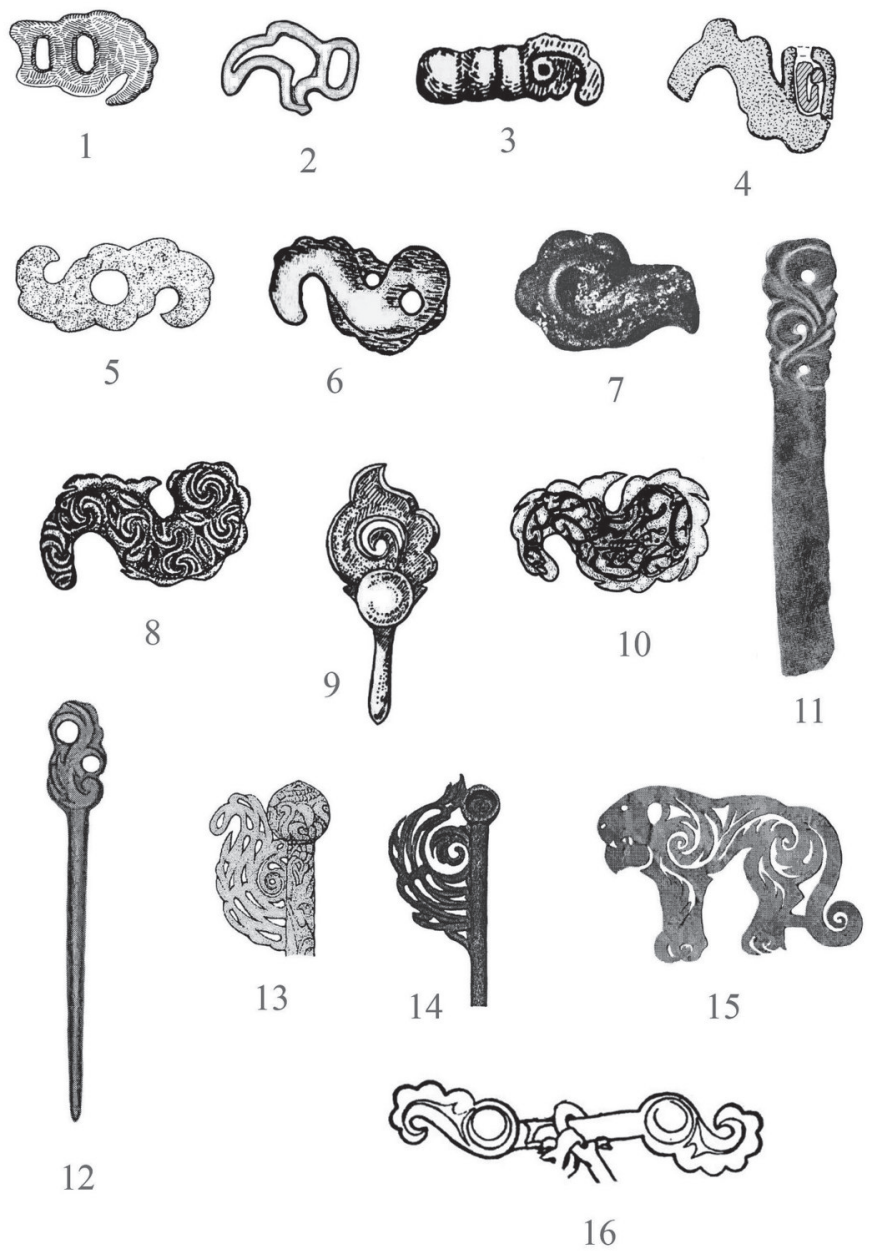

Рис. 1. Примеры мотива «сложный завиток» (масштаб разный):

1. Пряжка. Южный Тагискен, курган 31 (по Итина, Яблонский, 1997. Рис. 12, 1).

2. Сбруйная подвеска. Гилево-10, могила 31 (по Шульга, 2008. Рис. 16, 5, 60, 16).

3. Пряжка. Уйгарак, курган 14 (по Вишневская, 1973. Табл. III, 2, XXVII, 13).

4. Сбруйная подвеска. Гилево-10, могила 16 (по Шульга, 2008. Рис. 8, 60, 15).

5. Сбруйная подвеска. Аржан 2, клад 1 (по Čugunov, Parzinger, Nagler, 2010. T. 142, 5).

6. Бляшка. Карашокы, курган 9 (по Бейсенов и др., 2015. Рис. 9, 2).

7. Сбруйная подвеска. Алматы (по Самашев, Григорьев, Жумабекова, 2005. Рис. на с. 62).

8. Бляшка. Талды-2, курган 5 (по Бейсенов и др., 2015. Рис. 9, 1).

9. Сбруйная подвеска. Северный Китай (по Королькова, 2006. Табл. 24, 5).

10. Бляшка. Аржан 2, могила 5 (по Бейсенов и др., 2015. Рис. 9, 3).

11. Нож. Минусинская котловина (по Завитухина, 1983. Кат. 297).

12. Шпилька. Уйгарак, курган 23 (по Вишневская, 1973. Табл. XXVII, 1).

13. Шпилька. Аржан 2, могила 5 (по Čugunov, Parzinger, Nagler, 2010. Т. 55, 2).

14. Шпилька. Байке-2, курган 7 (по Бейсенов и др., 2015. Рис. 9, 6).

15. Накладка. Карашокы, курган 1 (по Бейсенов, 2013. Рис. 1, 1).

16. Псалий. Пазырык, курган 3 (по Шульга, 2008. Рис. 64, 1).

$1-4,7,9,11,12$ - бронза, 5, 6, 8, 10, 13, 15 - золото, 14 - кость, 16 - дерево 


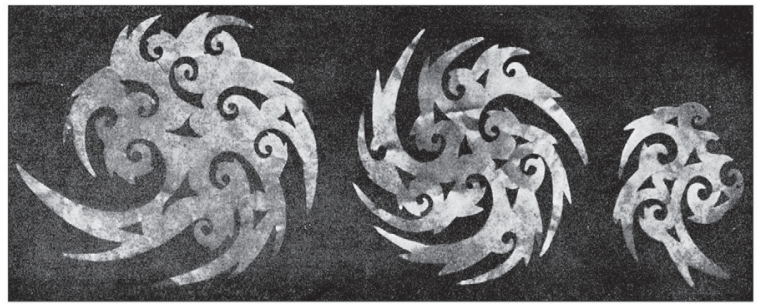

1
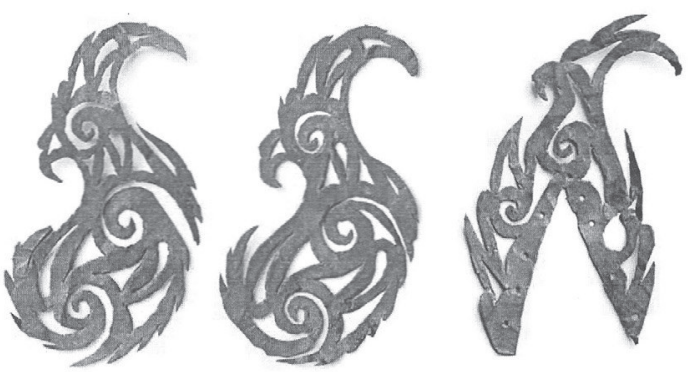

2

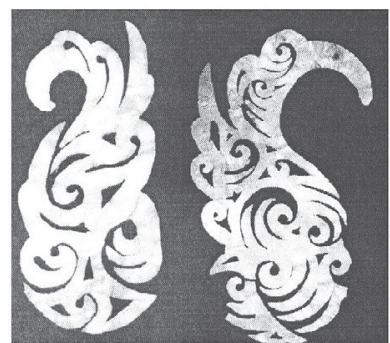

3

Рис. 2. Изысканные образцы мотива «сложный завиток» (масштаб разный):

1. Накладки. Яконур, курган 5 (по Грязнов, 1940. Рис. 3).

2. Накладки. Шерубай, курган 1 (по Unbekanntes Kasachstan, 2013. S. 8. Abb. 16, 17).

3. Накладки. Кичигино I, курган 5 (по Чубаева, 2013. Рис. 1). 1-3 - золото

чительно на памятниках Алтая и Минусинской котловины. Для алтайских «завитков» С.И. Руденко допускал и другой источник - «схематическое воспроизведение» фигуры фантастической птицы и птичьей головы (Руденко, 1952. С. 146, 152). А относительно минусинских образцов Н.Л. Членова отмечала их кажущийся «растительный» характер и утверждала, что «присмотревшись, мы ясно различаем головки грифона, одну... или две» (Членова, 1967. С. 137). 
Е.Ф. Королькова, изучив различные воплощения мотива, происходящие из разных мест, пришла к выводу, что «завитки» являются «вариациями крайне схематизированного и обобщенного изображения головы с мощным клювом..., иногда с небольшим округлым выступом на затылке (грифонье ухо)» (Королькова, 2006. С. 56). Это мнение разделили Г.А. Базарбаева и Г.С. Джумабекова, отметив в мотиве «скрытый орнитоморфный образ». Кроме того, исследовательницы отождествили скопления «завитков» с многофигурными композициями, аналогичными «загадочным картинкам» раннего звериного стиля (Базарбаева, Джумабекова, 2014. С. 5-6).

П.И. Шульга разбил вариации мотива на несколько типов и предположил, что они передают стилизованные изображения орла, головы грифона и «хвостатого существа с головой ушастого орла или грифона». Впрочем, в некоторых случаях исследователь не исключил смешение образов различных животных (Шульга, 1998. С. 35-36; Шульга, 2002. С. 188-189; Шульга, 2008. С. 90-91).

В наиболее изысканных вариантах, представленных на памятниках из Казахстана (Талды-2, курган 5, Шерубай, курган 1), с Алтая (Яконур, курган 5) и Южного Зауралья (Кичигино I, курган 5), большинство учёных увидело фигуры грифонов с тщательно выполненными хвостом, крылом, клювом и даже восковицей (Бейсенов, 2013. С. 15; Переводчикова, 2013. С. 142; Речкалова, 2013. С. 152) (рис. 1, 8, 2). В одной публикации золотая накладка из могильника Кичигино I была описана как изображение не хищной, а водоплавающей птицы (Чубаева, 2013. С. 191-193).

Точку зрения, примиряющую «фитоморфную» и «орнитоморфную» версии, высказал К.В. Чугунов. Он обратил внимание на округлые окончания некоторых «завитков», не имеющих ничего общего с птичьим клювом, и предположил, что в разных кочевых обществах мотив мог восприниматься различно. Кроме того, исследователь высказал мысль об особой значимости количества и направлений изогнутых выступов (Чугунов, 2011. С. 53-54).

Помимо трактовки мотива, археологи проанализировали его конструктивные особенности и установили, что «сложный завиток» является развитием фигуры в виде запятой или изогнутой капли (Руденко, 1960. С. 250; Подольский, 2010. С. 30-31; Бейсенов, 2013. С. 15) ${ }^{1}$. Однако запятая/изогнутая капля близка волюте, которая представляет собой основополагающий элемент большинства древнекочевнических изображений. М.Л. Подольский писал, что голова хищной птицы в виде волюты - «простейший, элементарнейший вариант образного воплощения самой сути скифского звериного стиля», а композиционная основа образов «с необходимостью должна восходить к спиральной линии (волюте)» (Подольский, 2010. С. 32, 65). Такой вывод, безусловно, указывает на большую значимость мотива.

${ }^{1}$ Изогнутая капля в мировой орнаментике обычно носит наименование «бута», «пейсли» или «восточный/турецкий/индийский огурец». 
Обзор мнений демонстрирует, что большинство учёных настаивает на орнитоморфном характере «сложного завитка». Однако особенности иконографии мотива не позволяют принять такой вывод безоговорочно. Недоумение вызывают странные, ненужные выступы и отростки, размещённые на якобы орлиной голове, а также условность облика «завитка». Схематичность резко выделяет мотив из образов звериного стиля, всегда имеющих видовые черты. Наглядным подтверждением служат находки, на которых «завитки» располагаются вместе с изображениями животных. Например, на золотом навершии головного убора из могилы 5 кургана Аржан 2 в Туве, бронзовых элементах пояса из кургана 5 могильника Кичигино I в Южном Зауралье и бронзовой сбруйной бляхе с Алтая гладкие «завитки» резко отличаются от тщательно проработанных деталей звериных образов, таких как круглые или миндалевидные глаза, углублённые ноздри, овальные или заострённые уши, рифлёные гривы лошадей, извивающиеся рога оленя, удлинённые когти пантеры (Королькова, 2006. Табл. 29, 6; Таиров, Боталов, 2010. Рис. 3, 6, 7; Čugunov, Parzinger, Nagler, 2010. Т. 1, 1, 23, 1) (рис. 3). Этот художественный диссонанс позволяет отнестись с недоверием к утверждению, что мотив сформировался на основе образа реального или фантастического животного, и склониться к предположению о знаковом характере «завитка».

По имеющимся на сегодняшний день материалам, формирование «сложного завитка» происходило на азиатских территориях древнекочевнического мира приблизительно в середине VII в. до н.э. Находки показывают, что уже во второй половине столетия мотив украшал различные предметы, но, пожалуй, чаще всего он был представлен на пряжках наборных поясов.

Как можно заключить при изучении оленных камней и каменных изваяний, наборные пояса бытовали в степном мире ещё в период поздней бронзы (Савинов, 1994. С. 104-105; Ковалёв, 2012. С. 136-137). Однако поясные бляшки или обоймы того времени не известны, возможно, по причине изготовления их из органических материалов - дерева, рога, кости, кожи (Добжанский, 1990. С. 17; Шульга, 2007. С. 27). Сохранившиеся фрагменты наборных поясов датируются более поздним временем и принадлежат скотоводческим культурам Синьцзяна, Северного Китая, Тувы, Алтая, Памира, Казахстана, Зауралья и Прикамья (Добжанский, 1990. С. 21; Горелик, 1993. С. 145; Таиров, 2004. С. 140-142; Шульга, 2007. С. 27-39; Шульга, 2008. С. 107-118; Чугунов, 2016. C. 336-356). Наиболее ранние экземпляры относятся ко второй половине VII в. до н.э. и отражают уже полностью сложившуюся категорию вещей, лучшие образцы которой являются настоящими произведениями искусства, как, например, комплект портупеи из могилы 5 кургана Аржан 2 (С̌ugunov, Parzinger, Nagler, 2010. T. 29-32, 51-52).

Из общей массы наборных поясов выделяется группа ранних изделий, найденных в Туве. Все они однотипны. Более того, оформление обойм некоторых поясов идентично. Так, парные фигуры лежащих архаров, заключён- 

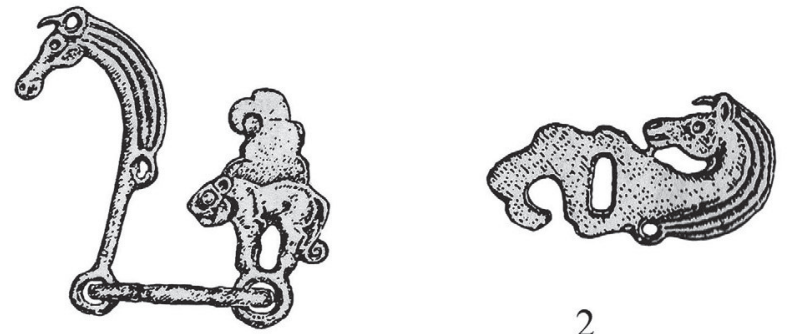

2

1

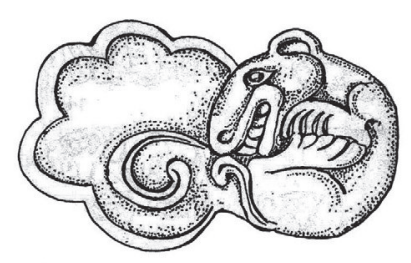

3

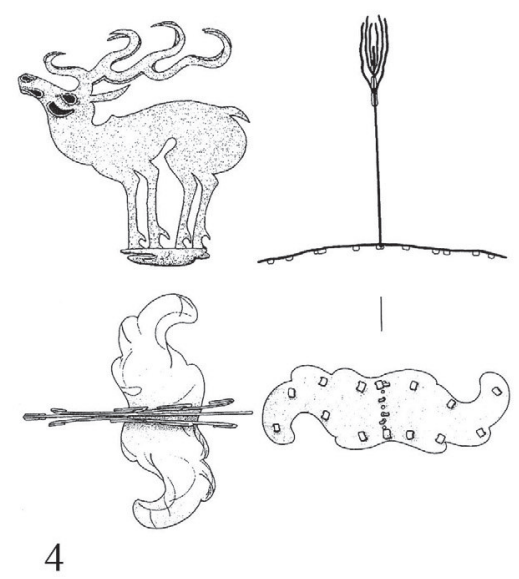

Рис. 3. Сочетания мотива «сложный завиток» и звериных образов (масштаб разный):

1-2. Детали пояса. Кичигино I, курган 5 (по Таиров, Баталов, 2010. Рис. 3, 6, 7).

3. Сбруйная подвеска. Алтай (по Королькова, 2006. Табл. 24, 11, 29, 6).

4. Навершие головного убора. Аржан 2, могила 5

(по Čugunov, Parzinger, Nagler, 2010. T. 1, 1).

1-3 - бронза, 4 - золото

ных в прямоугольную рамку из витого шнура, украшают четыре набора (УстьХадынныг I, курган 4, могила 3; Аржан 2, могила 26; Чинге-Тэй I, могила 5; Сыпучий Яр, курган 4, могила 1) (Семенов, 2001. Рис. 2, 8-10, 12; Чугунов, 2016. Рис. 165 B, 166, 4, 174), сдвоенные пары S-видных фигур декорируют два комплекта (Аржан 2, могила 5; Демир-Суг I, курган 1) (Семёнов, 2001. 
Рис. 2, 13; Чугунов, 2016. Рис. 165 А, 167, 171, 175). А Х-образные ажурные обоймы, найденные в могиле 3 кургана Чинге-Тэй I, находят соответствия в Казахстане (Тасмола II, курган 1; Алыпкаш, курган 2) (Таиров, 2004. Рис. 1, 10, 12; Чугунов, 2016. Рис. 168). Несмотря на такое сходство, существенным отличием поясных наборов являются пряжки. В ряде случаев это «сложный завиток», в других - неправильный овал или подтреугольник с одним-двумя отверстиями.

Благодаря хорошо сохранившемуся поясу из могилы 5 кургана Чинге-Тэй I, К.В. Чугунову удалось восстановить конструкцию подобных вещей. Основной широкий ремень, к которому крепилось оружие и нагайка, был дополнен узким ремешком, пропущенным продольно посередине основного. Ремешок предназначался для фиксации пояса. Обоймы размещались встык на правом конце основного ремня, свисавшего спереди. Завершался этот конец пряжкой. Такая реконструкция позволила К.В. Чугунову определить пряжки как декоративные наконечники (Чугунов, 2016. С. 349-350).

Точное установление способа ношения наборных поясов значительно усложняет тот факт, что все сохранившиеся экземпляры из непотревоженных погребений находились в развязанном состоянии. По всей видимости, в кочевнической среде бытовали представления, согласно которым для перехода души покойного в потусторонний мир пояс нельзя было завязывать. Эти поверья, согласно этнографическим источникам, сохранились до наших дней (Курылёв, 1989. С. 97; Байбурин, 1992. С. 9; Калашникова, 2014. С. 9, 33, 42, 50).

С выводами К.В. Чугунова можно согласиться только отчасти. Действительно, на наборных поясах древних кочевников известны наконечники полуовальной формы, которые не могли играть роль пряжек (Сыпучий Яр, курган 4, могила 1; Чинге-Тэй I, могила 4; Кызык-Телань I, курган 6; с. Вавилонка) (Семёнов, 2001. Рис. 2, 10; Таиров, 2004. Рис. 2, 4, 5; Чугунов, 2016. Рис. 169, 170). Однако подавляющее большинство изделий в виде «сложного завитка», овала или подтреугольника выглядит вполне функционально, так как снабжено отверстиями или незамкнутыми кольцами, сформированными изогнутыми выступами. Наличие отверстий трудно объяснить с декоративной точки зрения, зато они, судя по диаметрам, пригодны для продёргивания ремешков от 5 мм до 1 см шириной. Кроме того, на исходно функциональное назначение пряжек-«завитков» указывает предмет из кургана 1 могильника Демир-Суг II, имеющий наряду с отверстием кнопку-шпенек (Семенов, 2001. Рис. 2, 13) ${ }^{1}$. Это подтверждается близким соответствием этой вещи с уздечной застежкой из кургана 19 могильника Бойтыгем-2 на Алтае (Шульга, 2008. Рис. 46, 2).

Можно заключить, что пряжки в форме «сложного завитка» являлись не только знаковым или декоративным элементом, но и крепёжной деталью. Вероятно, древние кочевники носили наборные пояса со спущенным концом только в тех ситуациях, когда требовалось подчеркнуть и продемонстрировать

${ }^{1}$ Возможность использования данного предмета в качестве пряжки не отрицал и К.В. Чугунов (Чугунов, 2016. С. 350). 
комплект обойм с пряжкой (праздники, проведение обрядов). Во всех остальных случаях этот конец, чтобы не мешать движениям воина, привязывался через пряжку к поясу ${ }^{1}$. Разные размеры парных отверстий или незамкнутых колец пряжек позволяют восстановить способ крепления. Оба конца узкого ремешка сначала пропускались через большое отверстие, затем один из них продевался сквозь малое, после чего они связывались вместе.

Анализ разнотипных пряжек дает возможность гипотетически реконструировать их развитие и проследить превращение простых форм в изысканный «сложный завиток». Скорее всего, «завиток» вёл происхождение от плоского широкого крючка с парой отверстий, внешне напоминавшего запятую. Со временем крючок стал украшаться округлыми выступами, которые в изогнутом варианте, кроме декоративного эффекта, позволяли надежно зацеплять и крепить ремешки (рис. 4).

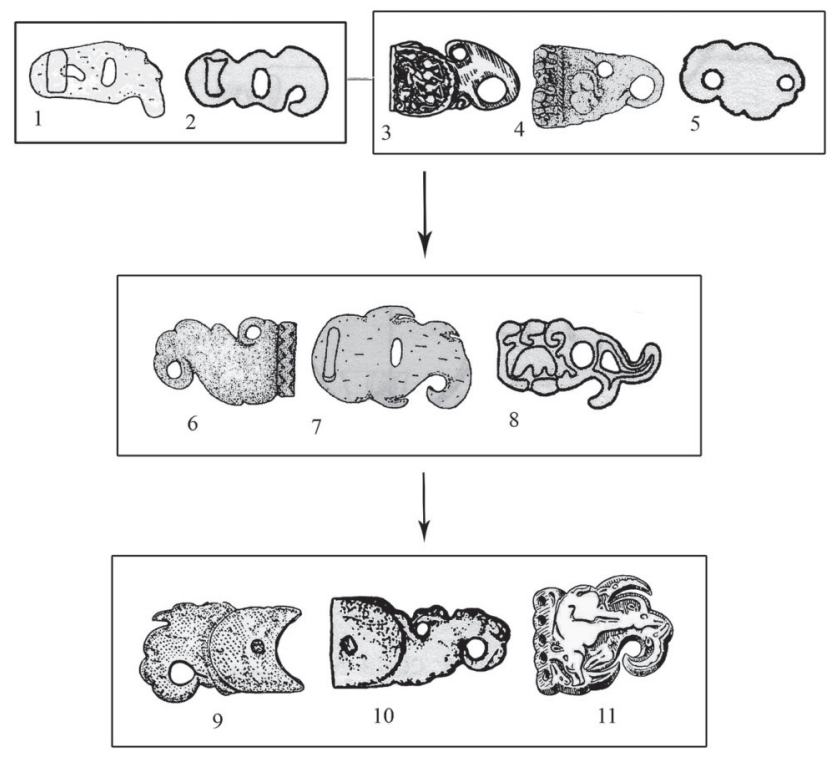

Рис. 4. Условная схема видоизменения пряжек наборных поясов (масштаб разный):

1. Пряжка. Чаухугоу-4 (по Шульга, 2010. Рис. 13, 19).

2. Пряжка. Чаухугоу-1 (по Шульга, 2010. Рис. 19, 13).

3. Пряжка. Усть-Хадынныг І, курган 4, могила 3 (по Семенов, 2001. Рис. 2, 12).

4. Пряжка. Аржан 2, могила 20 (по Чугунов, 2016. Рис. 165 Б).

5. Бляшка. Дунхэйгоу, курган М015 (по Шульга, 2010. Рис. 54, 8).

6. Пряжка. Аржан 2, могила 26 (по Чугунов, 2016. Рис. 165 В).

7. Пряжка. Чаухугоу-1 (по Шульга, 2010. Рис. 19, 12).

8. Пряжка. Дунхэйгоу, курган М015 (по Шульга, 2010. Рис. 54, 5).

9. Пряжка. Кичигино І, курган 5 (по Таиров, Баталов, 2010. Рис. 3, 1).

10. Пряжка. Гилево-10, могила 12 (по Шульга, 2008. Рис. 79, 4, 82, 1).

11. Пряжка. Тасмола V, курган 3. (по Шульга, 2008. Рис. 82, 4б). 1-4, 6-10- бронза, 5, 11 - рог

${ }^{1}$ У современных ремней свободный конец обычно фиксируется тренчиком. 
Перечисленные наблюдения и замечания позволяют усомниться в продуктивности поисков животного прообраза «сложного завитка». В то же время, исходя из распространённого представления о символической и знаковой роли поясных пряжек, вряд ли стоит сомневаться, что первичный вещественный объект всё же существовал. Прототип «завитка»- фигура в виде запятой - в общих чертах напоминает коготь птицы или зверя. Коготь имеет форму дуги, заострённую на конце, и завершается чётко выраженным расширением - наружной фалангой. Когти вместе с зубами часто служили оберегами и нередко размещались на поясах. Это подтверждается находками раннескифского времени и этнографическими материалами (Кирюшин и др., 2003. С. 86. Рис. 53, 7; Ермолова, 2005. С. 188-189, 197, 281; Павлинская, 2005. С. 319, 321; Калашникова, 2014. С. 29, 41, 130, 191; Гуляев, 2017. C. 124).

Не исключено, что амулеты из частей животных воплотились в зверином стиле в мотивах «запятая», «сложный завиток», «дуга» (символ клыка?). Такое могло происходить ещё на ранней стадии становления древнекочевнической культуры, поскольку в кургане Аржан 1 (IX-VIII вв. до н.э.) были найдены не только клыки кабана, использовавшиеся как подвески, но и украшения, вырезанные из кабаньих клыков в виде изогнутой и простой капли (Грязнов, 1980. Рис. 24, 5, 6). Наверное, именно этот процесс описала И.В. Фабрициус, отметившая, что «зубы, клыки, когти, клювы, рога по своему содержанию и форме складываются в комплекс, органически входящий в содержание и оформление звериного стиля» (цит. по: Королькова, 2006. С. 108-109).

«Запятая»-коготь, превратившись в «сложный завиток», сравнительно быстро начала приобретать орнитоморфные черты. Это могло произойти в связи с утратой воспоминаний о прототипе. К тому же процесс преобразования стимулировался усилением значения хищной птицы в репертуаре раннего звериного стиля. Судя по отсутствию на оленных камнях орнитоморфных изображений, птицы не входили в основной состав исходного бестиария древних кочевников.

Таким образом, мотив «сложный завиток» прошёл непростой путь формирования. Его появление было связано с практическими причинами - видоизменением застежки-крючка в форме запятой или изогнутой капли. При этом в древнекочевнической культуре существовал знак сходных очертаний, который, возможно, символизировал коготь и имел апотропеическое значение. Ременные пряжки, выполненные в виде «завитка», унаследовали магическое свойство «запятой». Может быть, оно даже усилилось после дополнения пряжки выступами, которые стали трактоваться как элементы орнитоморфного образа. Именно в таком виде «сложный завиток» вошёл в звериный стиль, превратившись в полноценный орнаментальный мотив. 


\section{ЛИТЕРАТУРА}

Базарбаева Г.А., Джумабекова Г.С. Знаки-символы в раннесакском искусстве // Архаическое и традиционное искусство: проблемы научной и художественной интерпретации: Материалы Всероссийской научной конференции. Новосибирск: ИАЭ СО PAH, 2014. C. 4-6.

Байбурин А.К. Пояс (к семиотике вещей) // Из культурного наследия народов Восточной Европы. Сборник МАЭ. 1992. Т. 45. С. 5-13.

Бейсенов А.3. Предметы искусства ранних саков Сарыарки как свидетельства взаимодействия культур // Вестник КемГУ. 2013. Т. 4, № 3 (55). С. 13-17.

Бейсенов А.З., Исмагулова А.О., Китов Е.П., Китова А.О. Население Центрального Казахстана в I тысячелетии до н.э. Алматы: ИА им. А.Х. Маргулана, 2015. 188 с.

Вишневская O.A. Культура сакских племен низовьев Сырдарьи в VII-V вв. до н.э. М.: Наука, 1973. 160 с.

Горелик M.В. Оружие древнего Востока (IV тысячелетие - IV в. до н.э.). М.: Наука, 1993. 349 с.

Грязнов М.П. Раскопки на Алтае // СГЭ. Л.: Аврора, 1940. С. 17-21.

Грязнов М.П. Аржан. Царский курган раннескифского времени. Л.: Наука, 1980. $64 \mathrm{c}$.

Гуляев В.И. Образ медведя в скифо-сибирском зверином стиле // Эпоха бронзы и ранний железный век: Материалы III международной научной конференции «Ананьинский мир: культурное пространство, связи, традиции и новации». Археология евразийских степей. 2017. № 3. С. 119-140.

Добжанский В.Н. Наборные пояса кочевников Азии. Новосибирск: НГУ, 1990. $164 \mathrm{c}$.

Ермолова Н.В. Пояса у народов Северной Сибири и Дальнего Востока // Украшения народов Сибири. - Сборник МАЭ. 2005. Т. 51. С. 170-301.

Завитухина М.П. Древнее искусство на Енисее. Скифское время. Публикация одной коллекции. Л.: Искусство, 1983. 191 с.

Итина М.А., Яблонский Л.Т. Саки Нижней Сырдарьи (по материалам могильника Южный Тагискен). М.: Российская политическая энциклопедия, 1997. 187 с.

Калашникова Н.М. «Пояса со словесами...» Коллекция поясов из собрания Российского этнографического музея. М.: Северный паломник, 2014. 264 с.

Кирюшин Ю.Ф., Степанова Н.Ф., Тишкин А.А. Скифская эпоха Горного Алтая. Ч. ІІ: Погребально-поминальные комплексы пазырыкской культуры. Барнаул: АлтГУ, 2003. 234 c.

Ковалёв А.А. Древнейшие статуи Чемурчека и прилегающих территорий. СПб.: СПбГБУК МИСР, 2012. 160 с.

Королькова Е.Ф. Звериный стиль Евразии. Искусство племён Нижнего Поволжья и Южного Приуралья в скифскую эпоху (VII-IV вв. до н.э.). Проблемы стиля и этнокультурной принадлежности. СПб.: Петербургское Востоковедение, 2006. 272 с.

Курылёв В.П. Казахские кожаные пояса в собраниях МАЭ // Памятники традиционно-бытовой культуры народов Средней Азии, Казахстана и Кавказа. Сборник МАЭ. 1989. Т. 43. С. 85-97.

Павлинская Л.Р. Наборные пояса в культурах Сибири середины XIX - начала ХХ в. // Украшения народов Сибири. - Сборник МАЭ. 2005. Т. 51. С. 302-341. 
Переводчикова Е.В. Язык звериных образов: Очерки искусства евразийских степей скифской эпохи. М.: Восточная литература, 1994. 206 с.

Переводчикова E.B. Произведения скифского звериного стиля из курганов у села Кичигино как индикатор историко-культурных изменений на Южном Урале в середине I тысячелетия до нашей эры // Этнические взаимодействия на Южном Урале: Сборник научных трудов / Отв. ред. А.Д. Таиров, Н.О. Иванова. Челябинск: Рифей, 2013. С. 139-148.

Подольский М.Л. Зверь, который был сам по себе, или Феноменология скифского звериного стиля. СПб.: ЭлекСис, 2010. 192 с.

Речкалова В.В. Коллекция предметов из кургана 5 могильника Кичигино I // Этнические взаимодействия на Южном Урале: Сборник научных трудов / Отв. ред. А.Д. Таиров, Н.О. Иванова. Челябинск: Рифей, 2013. С. 148-153.

Руденко С.И. Горноалтайские находки и скифы. М.; Л.: АН СССР, 1952. 268 с.

Руденко С.И. Культура населения Центрального Алтая в скифское время. М.; Л.: АН СССР, 1960. $350 \mathrm{c}$.

Савинов Д.Г. Оленные камни в культуре кочевников Евразии. СПб.: СПбГУ, 1994. 208 c.

Самашев 3., Григорьев Ф., Жумабекова Г. Древности Алматы. Алматы: КазИздатKT, 2005. $184 \mathrm{c}$.

Семёнов Вл.А. Сыпучий Яр - могильник алды-бельской культуры в Туве // Евразия сквозь века. СПб.: СПбГУ, 2001. С. 167-172.

Таиров А.Д. Раннесакские боевые пояса // РА. 2004. № 1. С. 140-145.

Таиров А.Д., Боталов С.Г. Погребение сакского времени могильника Кичигино I в Южном Зауралье // Археология и палеоантропология евразийских степей и сопредельных территорий. М.: ТАУС, 2010. С. 339-354.

Членова Н.Л. Происхождение и ранняя история племен тагарской культуры. М.: Наука, 1967. 300 с.

Чубаева М.П. Орнаментальный мотив «сложного завитка» в произведениях скифосибирского звериного стиля // Вестник ЮУрГУ. Серия «Социально-гуманитарные науки». 2013. Т. 13, № 2. С. 191-194.

Чугунов К.В. Искусство Аржана-2: стилистика, композиция, иконография, орнаментальные мотивы // Европейская Сарматия / Отв. ред. Д.А. Мачинский. СПб.: Нестор-История, 2011. С. 39-60.

Чугунов К.В. Парадные пояса кочевников Азии в раннескифское время // Алтай в кругу евразийских древностей / Отв. ред. А.П. Деревянко, В.И. Молодин. Новосибирск: ИАЭТ СО РАН, 2016. С. 336-356.

Шульга П.И. Раннескифская упряжь VII - нач. VI вв. до н.э. по материалам погребения на р. Чарыш // Снаряжение верхового коня на Алтае в раннем железном веке и средневековье: Сборник научных трудов / Отв. ред. Ю.Ф. Кирюшин, А.А. Тишкин. Барнаул: АлтГУ, 1998. С. 25-49.

Шульга П.И. О стилизованных образах орла и грифона VII-IV вв. до н.э. в Южной Сибири // История и культура Востока Азии: Материалы международной научной конференции / Отв. ред. С.В. Алкин. Т. ІІ. Новосибирск: ИАЭ СО РАН, 2002. С. 186-191.

Шульга П.И. О конструкции раннескифских поясов с Алтая и прилегающих территорий // Алтае-Саянская горная страна и соседние территории в древности. Новосибирск: ИАЭТ СО РАН, 2007. С. 27-40. 
Шульга П.И. Снаряжение верховой лошади и воинские пояса на Алтае. Ч. I: Раннескифское время. Барнаул: Азбука, 2008. 276 с.

Шульга П.И. Синьцзян в VIII-III вв. до н.э. (Погребальные комплексы. Хронология и периодизация). Барнаул: АлтГУ, 2010. 238 с.

Čugunov K., Parzinger H., Nagler A. Der skythenzeitliche Fürstenkurgan Aržan 2 in Tuva. Archäologie in Eurasien 26. Steppenvölker Eurasiens 3. Mainz: Verlag Philipp von Zabern, 2010. $330 \mathrm{~S}$.

Unbekanntes Kasachstan. Archäologie im Herzen Asiens. Bochum: Deutsches BergbauMuseum Bochum, 2013. B. II. 


\title{
«КИТЫ» СКИФСКОЙ ХРОНОЛОГИИ И СИСТЕМА ДАТИРОВАНИЯ ПАМЯТНИКОВ
}

\author{
Кузнецова Т.М.
}

http://10.25681/IARAS.2019.978-5-317-06274-3/112-123

В статье представлена сравнительная характеристика вещевых комплексов из скифских захоронений в курганах «Репяховатая Могила», «Червона Могила», «Литой» (Мельгуновский), № 407 у с. Журовка и Келермессского могильника. Сходство предметов позволило датировать памятники от первой четверти (Северный Кавказ) до второй четверти VI в. до н.э. (Правобережье Приднепровской лесостепи). Сопоставление материалов показало, что повышение дат памятников скифской архаики имеет доказательную археологическую базу и возвращает нас к хронологии, разработанной исследователями предшествующего поколения.

Ключевые слова: скифская культура, хронология, письменная традиция, археологические материалы

По мнению исследователей хронология раннескифских древностей стоит на «четырёх китах»: 1) дата гибели Урарту и отдельных её крепостей; 2) хронология Келермесского могильника; 3) раннескифские находки в Малой Азии, соответствующие келермесской ступени раннескифской культуры; 4) датировка античной керамики в раннескифских памятниках (см.: Дараган, 2011. С. 540 и след.).

Однако первый «кит» плавает пока в неопределённом хронологическом пространстве, поскольку, несмотря на то, что урартология за последние десятилетия «не стояла на месте», точная дата этого события остается пока неизвестной (Иванчик, 2006. С. 152-157), а свидетельством взаимодействия урартов со скифами остаются близкие формы предметов, найденных как в Урарту, так и в скифских курганах Северного Кавказа и Причерноморья (Пиотровский, 2011. С. 273-274; Ильинская, Тереножкин, 1983. С. 34).

Второй и третий (по сути один) «киты» были растерзаны после открытия могильника у хутора Красное Знамя на Северном Кавказе, когда произошло удревнение системы всего периода архаики, и у Келермесских курганов возник ряд различных (более десяти) хронологических вариантов (Кузнецова, 2016a. С. 126).

Четвертый «кит» мечется в хронологических водах уточняющих определений, так как античная керамика, используемая в качестве хроноиндикатора при датировке скифской архаики, подвергается постоянной корректировке, не говоря уже о том, что она обнаружена только в двух памятниках, которые безусловно можно определить как «скифские» (см.: Кузнецова, 2017 а. С. 133-134).

Одновременно продолжают набирать силы как 5) европейский («гальштатоидный»), так и 6) азиатский (западно-чжоуский) хронологические «киты», подвергающиеся постояному видоизменению, но обречённые на синхрониза- 
цию с датами скифских памятников периода архаики Северного Причерноморья и Кавказа (Дараган, 2010. С. 99-100; Рябкова, 2016. С. 220; Чугунов, 2017. С. 484-499; Рябкова, 2018. С. 250).

При этом основой для определения продолжительности раннескифского этапа в Северном Причерноморье и на Северном Кавказе всё ещё остаются материалы Келермесского могильника, время сооружения которого ранее базировалось на данных письменных источников (первая половина VI в. до н.э.), а датировка вещевого комплекса, связанного с Ближним Востоком, служила лишь для его подтверждения. В настоящее время дата могильника устанавливается уже по времени сопроводительного инвентаря ближневосточного происхождения, несмотря на то, что хронологические определения для материалов Келермеса всё время обновляются (см., к примеру: Максимова, 1954. С. 281-305; Кисель, 1993. С. 125; Копейкина, 1981; Кисель, 2003. С. 99).

И всё же для ближневосточных предметов из Келермесских курганов, обнаруженных в основном вне археологического контекста, до сих пор не установлено точное определение времени и места их изготовления. Вследствие этого они не могут служить хронологическими реперами даже для одного кургана, не говоря уже о всей системе датирования памятников скифского архаического периода.

Напомню, что в скифологии «архаические» памятники чаще датируются по самым ранним находкам, а «классические» - по наиболее поздним. Такая позиция, как правило, обусловлена концепцией исследователя (см.: Кузнецова, 2015. С. 247-252). Для этого достаточно сравнить подход к датам, предлагаемый исследователями для Келермесских курганов (Галанина, 1997. С. 190-192; Галанина, Алексеев, 2010. С. 187) и кургана «Солоха» (Манцевич, 1987. С. 118, 119; Алексеев, 2003. С. 260; Бидзиля, Полин, 2012. С. 515).

Поэтому, исходя из того, что «загнанные киты» скифской хронологии пока мучаются в сетях научных идей, представилось необходимым выделить среди археологических «хроноиндикаторов» предметы, имеющие стабильную дату, и провести уточнение хронологической системы периода скифской архаики, рассчитав время сооружения памятников от одного репера, сопоставив её с хронологией, полученной в результате работы с письменными источниками.

Археологический материал, имеющий устойчивые даты, был выявлен при изучении кургана «Репяховатая Могила» у с. Матусов (Черкасская область, Шполянский район, Украина), сооруженного в лесостепной зоне Днепровского Правобережья, где в гробнице № 2 находились два зеркала с боковой ручкой (рис. 1, 1-3), датирующиеся не ранее второй четверти VI в. до н.э. (Кузнецова, 2002. С. 79-80; Кузнецова, 2010. С. 238; Кузнецова, 2017б).

Состав сопроводительного инвентаря кургана «Репяховатая Могила», включающего предметы со стабильными датами, позволил рассматривать его в качестве хроноиндикатора для памятников раннескифского периода (Кузнецова, 2017a. С. 100-114). 

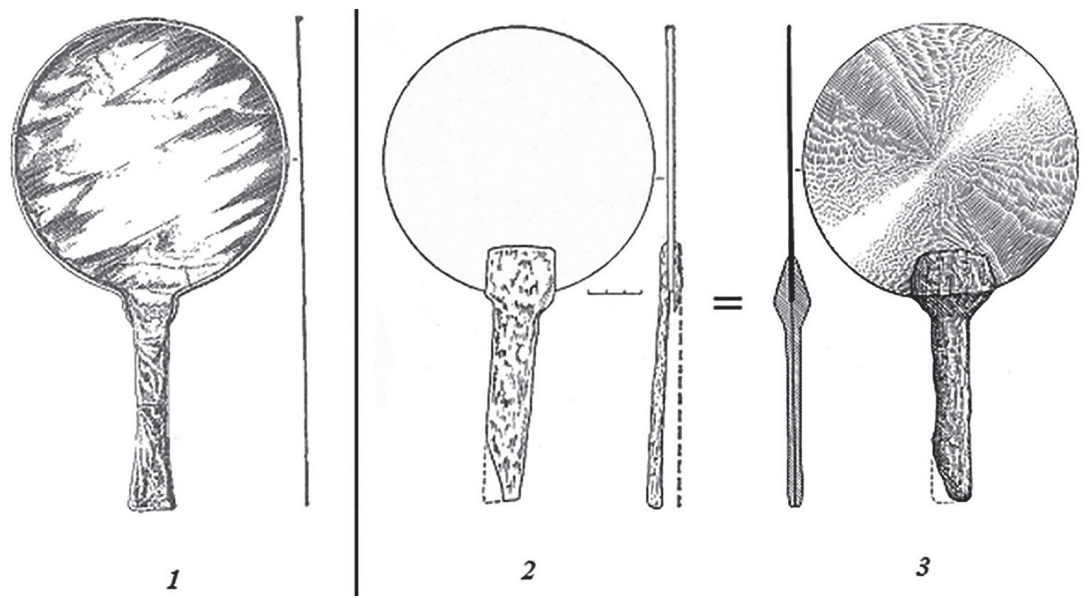

Рис. 1. Хронологические реперы для периода скифской архаики: 1-3: курган «Репяховатая Могила», гробница № 2 (Кузнецова 2002, 81, табл. 29/Б, № 477'; Ильинская, Мозолевский, Тереножкин 1980, 48, рис. 20; Кузнецова 2010, 132, 202, табл. 86: № 476)

Возведение кургана «Репяховатая Могила» (гробница № 1 - первое десятилетие второй четверти VI в. до н.э.: $\approx 575-565$ гг. до н.э.; гробница № 2 ближе к последнему десятилетию второй четверти VI в. до н.э.: $\approx 565-555$ гг. до н.э.) не выходит за рамки второй четверти - середины VI в. до н.э. и связывается по времени с возвращением войска скифов царя Мадия после похода в Переднюю Азию (Кузнецова, 2016а.).

\section{Курган «Репяховатая Могила» и Келермесский могильник.}

Келермесский могильник расположен на левобережье р. Кубань (СевероЗападный Кавказ), где выявлены шесть курганных насыпей и грунтовой могильник скифского времени, наряду с курганами и грунтовым могильником эпохи бронзы (Галанина, 1997). Находится в 8 км к юго-востоку от станицы Келермесская (Адыгея, Гиагинский район, Россия).

Выявленное соответствие сопроводительного инвентаря из кургана «Репяховатая Могила» и курганов Келермеса по десяти категориям предметов показало, что Келермесский могильник также относится к «послепоходному» времени. Он датируется не ранее последнего десятилетия первой четверти VI в. до н.э. $(\approx 585-575$ гг. до н.э.) в силу его территориальной удалённости $(\approx 1200$ км) от кургана «Репяховатая Могила» (Кузнецова, 2016а. С. 126-127).

Близкие по форме предметы и в прикубанских, и в приднепровском курганах представлены железными навершиями, железными (две формы) и бронзовыми удилами, железными и костяными псалиями, каменными блюдами, наконечниками стрел, железными ножами и раквинами каури (рис. 2, 3).

${ }^{1}$ В таблице 29 опечатка (проставлен № 474). 


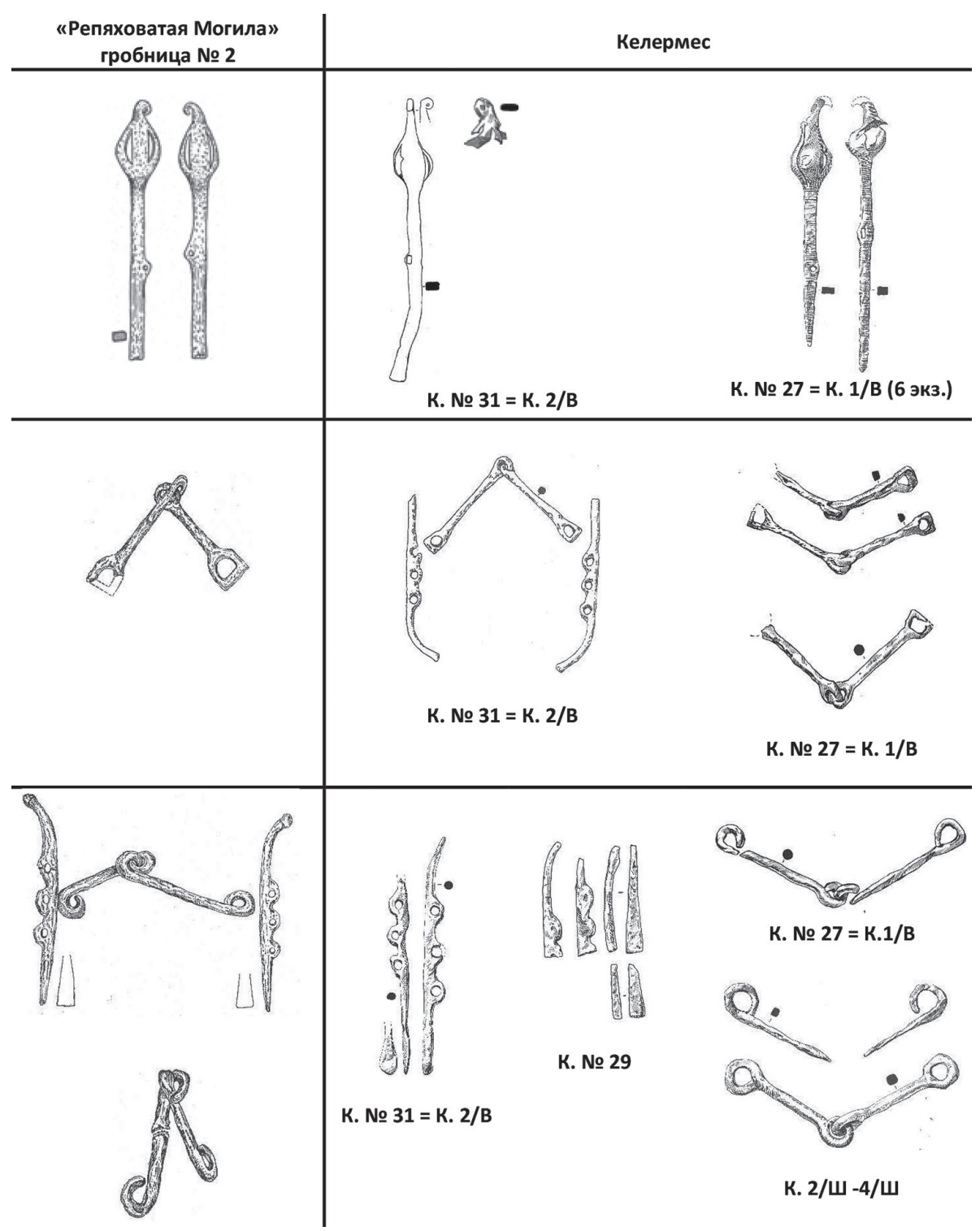

Рис. 2. Сопоставление материала курганов «Репяховатая Могила» (гробница № 2) и Келермеса

\section{Келермесский могильник и «Литой» (Мельгуновский) курган.}

Вещи, обнаруженные в Келермесе: меч в золотых ножнах, близкий по форме и оформлению мечу из «Литого» (Мельгуновского) кургана, и бронзовые наконечники стрел, позволили датировать последнее захоронение (кенотаф) началом второй четверти VI в. до н.э. ( $\approx 575-570$ гг. до н.э.), учитывая его удалённость от Прикубанья и близость (граница степной и лесостепной зон Северного 


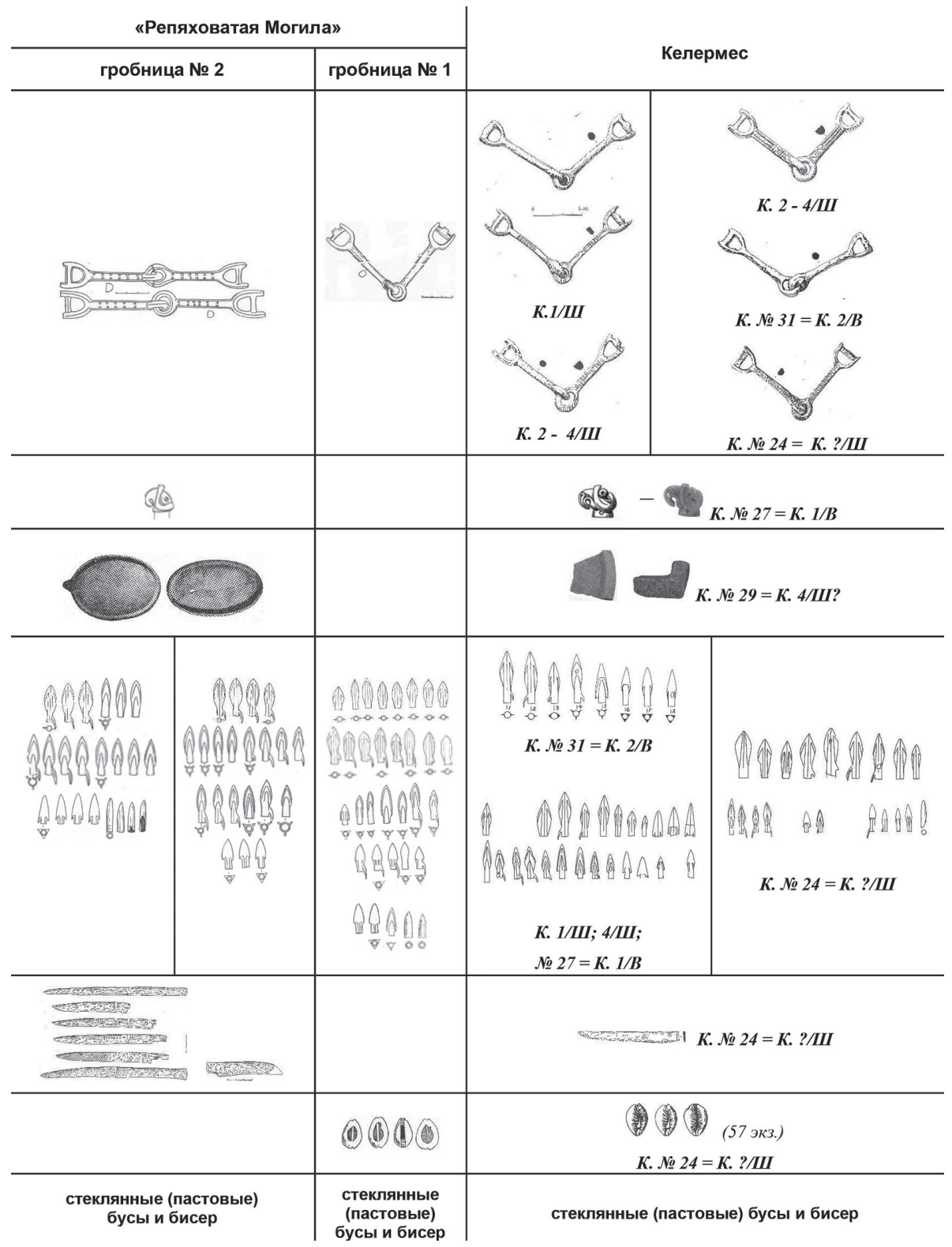

Рис. 3. Сопоставление материала курганов «Репяховатая Могила» и Келермеса

Причерноморья) к кургану «Репяховатая Могила» (Кузнецова, 2017 б. С. 108). От Келермеса до «Литого» (Мельгуновского) кургана $\approx 1080$ км.

«Литой» курган был возведён на правом берегу Днепра, в 30 км к северу от современного г. Кропивницкий (бывш. г. Кировоград, Украина). От «Литого» (Мельгуновского) кургана до с. Матусов $\approx 105-115$ км к северо-западу. 


\section{Курганы «Репяховатая Могила» и «Червона Могила».}

При сравнении сопроводительного инвентаря гробницы № 2 кургана «Репяховатая Могила» (рис. $4,1-17$ ) и кургана «Червонная (Червона) Могила» (рис. 4, 1-25) у с. Флярковка (Черкасская область, Каменский район, Украина) на Правобережье Днепра (Ковпаненко, 1984), сходство устанавливается по восьми категориям предметов, что позволяет датировать курган «Червона Могила» в пределах второй четверти VI в. до н.э. ( $\approx 565-560$ гг. до н.э.). От с. Матусов («Репяховатая Могила») до с. Флярковка («Червона Могила») $\approx 62-67$ км к востоку.

Близкие по форме вещи в сопоставляемых курганах представлены железными навершиями, железными удилами, железными псалиями, каменными блюдами, наконечниками стрел, черпаками, железными ножами и раковинами каури. Сходство вещевого комплекса дало основание предположить близость «Червоной Могилы» и Келермесским курганам.

\section{Курган «Червона Могила» и Келермесский могильник.}

Сопоставление материалов Келермеса (рис. 5, 1-22) и кургана «Червона Могила» (рис. 5, 23-30) показало сходство в семи категориях сопроводительного инвентаря: конское снаряжение (два типа железных удил и псалии), наличие каменных блюд, железных ножей, раковин каури и бус (Кузнецова, 2018).

\section{Курганы «Репяховатая Могила» и № 407 у с. Журовка/ Журавка.}

Сравнение сопроводительного инвентаря гробниц кургана «Репяховатая Могила» (рис. 4, 1-17) и гробницы в кургане № 407 (рис. 4, 27-33) у с. Журовка/ Журавка (Черкасская область, Шполянский район, Украина), сооружённого также на Правобережье Днепра ( $\approx 15-20$ км к югу от «Репяховатой Могилы»), показало безусловное сходство в наличии железных наверший, каменных блюд, высоких черпаков «грушевидной формы», височных колец (серег), «гвоздевидных» булавок и бусин-розеток. Сопоставление состава вещевого комплекса позволило датировать курган № 407 у с. Журовка / Журавка в пределах второй четверти VI в. до н.э. ( $\approx 560-550$ гг. до н.э.).

Плохая сохранность предметов в кургане № 407 у с. Журовка/Журавка не позволила провести полный анализ формы железных удил и ножей. Однако, установленное сходство при сравнении материалов из гробниц кургана «Репяховатая Могила» и кургана № 407 у с. Журовка/Журавка по наличию железных наверший, конского снаряжения, каменных блюд и ножей даёт основание предположить близость последнего памятника и Келермесским курганам.

\section{Курган № 407 у с. Журовка/Журавка и Келермесский могильник.}

Сопоставление сопроводительного инвентаря Келермеса (рис. 5, 1-23) и кургана № 407 у с. Журовка/Журавка (рис. 5, 31-33) показывает сходство в наличии железных наверший, категорий конского снаряжения, каменных блюд, железных ножей, бусин и бисера. 


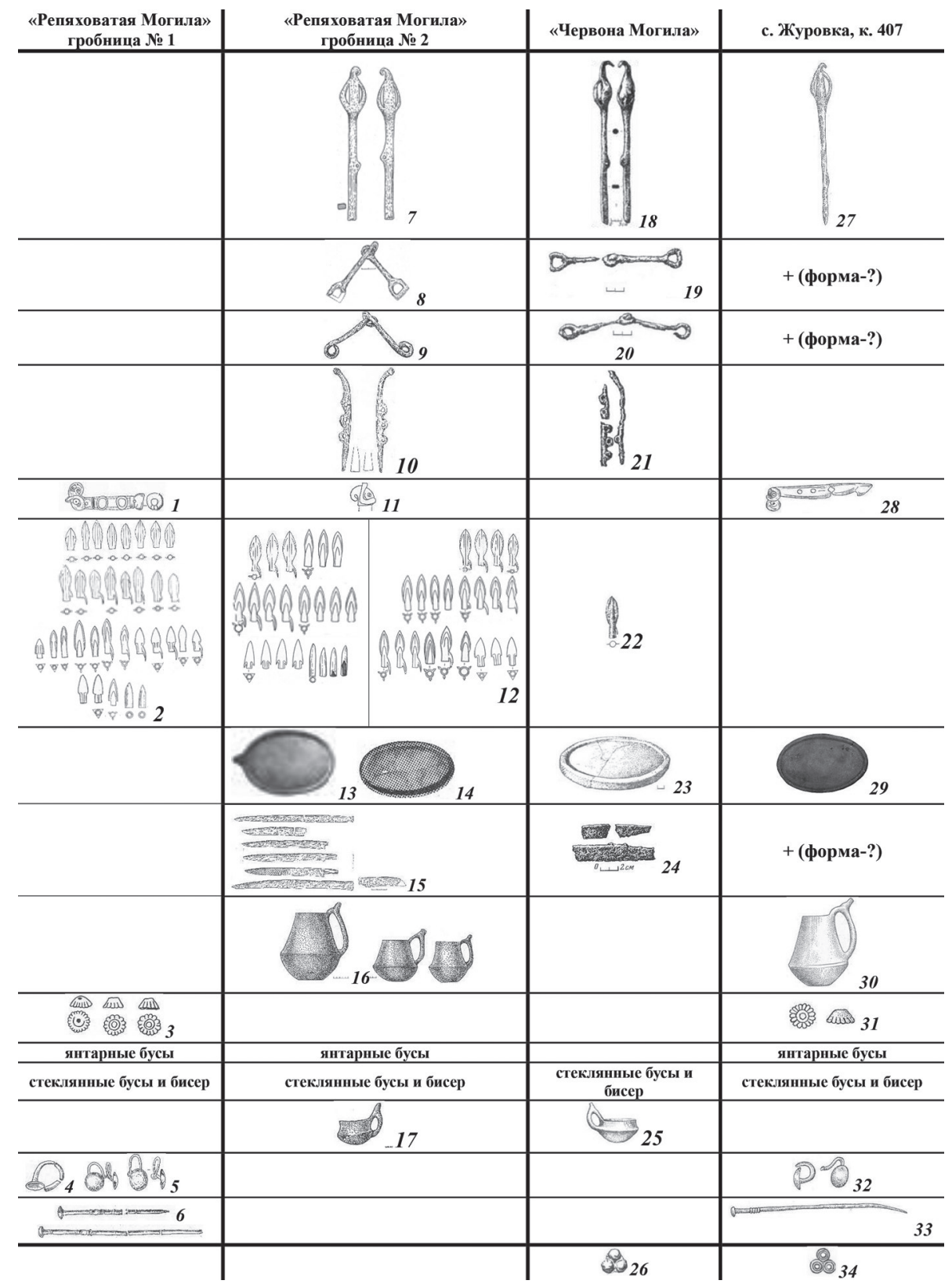

Рис. 4. Сопоставление сопроводительного инвентаря курганов «Репяховатая Могила», «Червона Могила» и № 407 у с. Журовка/Журавка 


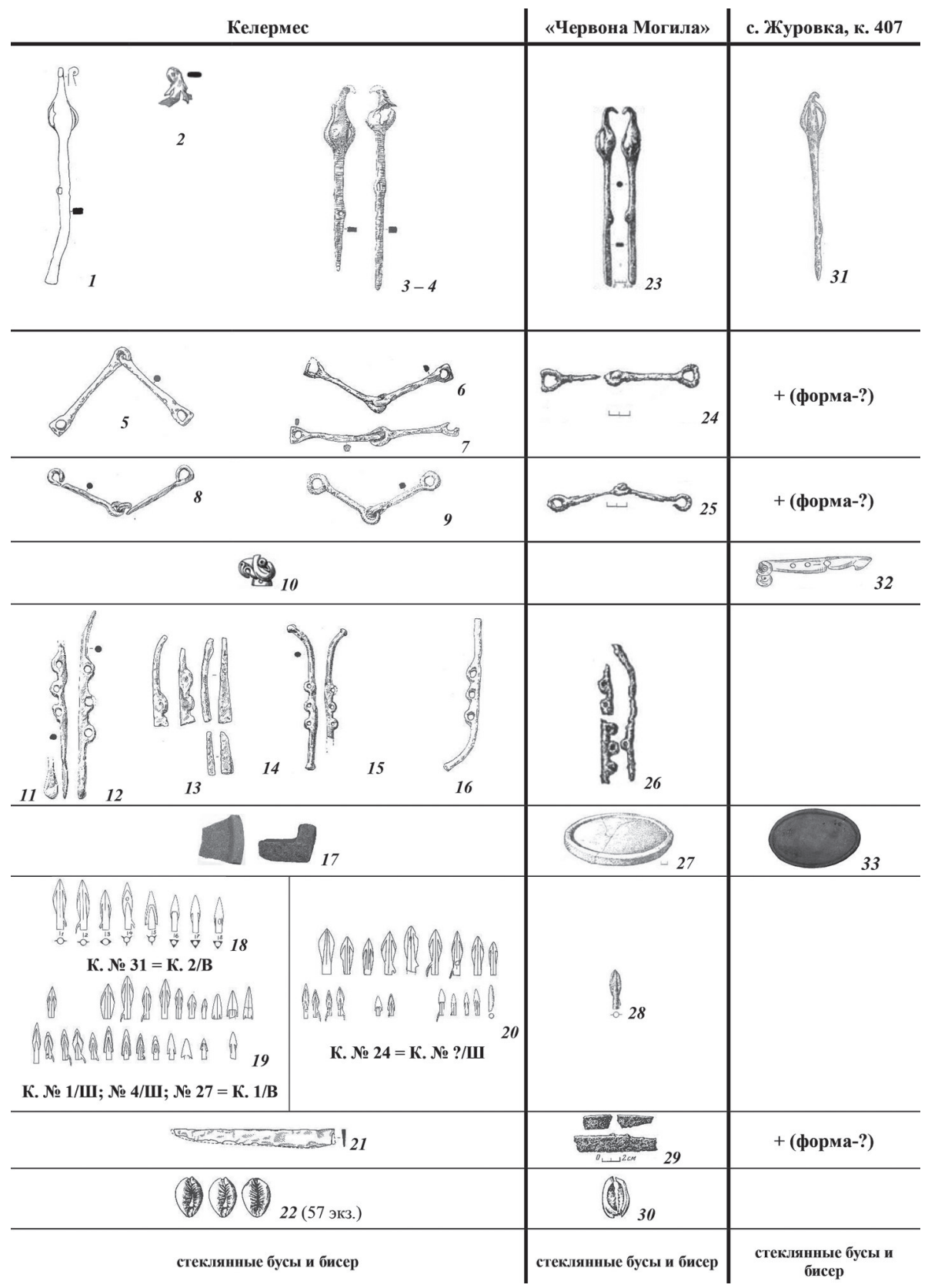

Рис. 5. Сопоставление материала курганов Келермеса, «Червона Могила» и № 407 у с. Журовка/Журавка 


\section{Курганы «Червона Могила» и № 407 у с. Журовка/Журавка.}

При сравнении предметов из курганов «Червона Могила» (рис. 5, 23-30) и № 407 у с. Журовка / Журавка (рис. 5, 31-33) сходство прослежено в наличии железных наверший, каменных блюд, железных удил и ножей.

Помимо этого в обоих памятниках обнаружены близкие, но не идентичные, золотые бляшки треугольной формы с тремя полусферическими выпуклостями, различающиеся по оформлению. Это металлические бляшки-аппликации (рис. 4, 26 и 34), относящиеся как к корчагам, так и к головным уборам (Фиалко, 2006. C. 61-73).

В кургане «Червона Могила» они обнаружены над черепом (4 экз.) и представляют собой треугольник, составленный из трёх гладких полусфер (Ковпаненко, 1984. С. 111. Рис. 2, 11).

В кургане № 407 у с. Журовка/Журавка бляшки в виде треугольников, составленных из трёх кружков, найдены в разных местах западной части могилы (Бобринский 1905. С. 34-35) и представляют собой треугольник, составленный из трёх кружков, украшенных концентрическими окружностями (Ильинская, 1975. Табл. Х, 7).

Поскольку бляшки из «Червоной Могилы» по расположению могут быть связаны с украшением головного убора, а строенные бляшки из кургана № 407 у с. Журовка/Журавка не только отличаются по оформлению, но и обнаружены вне погребального контекста, они, при сравнении вещевого комплекса курганов, не учитываются.

По составу сопроводительного инвентаря наибольшая близость наблюдается между гробницей № 2 «Репяховатой Могилы» и курганами Келермеса, раскопанными Н.И. Веселовским, «Червоной Могилой» и курганом № 407 у с. Журовка / Журавка.

Отмеченные памятники выделяют из общего числа и объединяют между собой близкие по форме железные навершия. Точная функция наверший пока не установлена, за исключением того, что они звенели и были связаны с лошадьми. Их можно было бы рассматривать как маркер клановой структуры скифского сообщества, но против этого свидетельствуют захоронения разных по форме наверший в одной могиле, отмеченные и для прикубанских, и для придепровских курганов (Галанина, 1997; Ильинская, 1968). Однако навершия, по всей видимости, можно считать свидетельством скифского присутствия на Северном Кавказе и в Северном Причерноморье, предположив, что рассмотренные памятники были связаны с представителями одной из воинских группировок скифов.

Сопоставление проанализированных материалов показало, что повышение дат памятников скифской архаики имеет доказательную археологическую базу и в значительной степени возвращает нас к хронологии, разработанной исследователями предшествующего поколения. Пока это только начало работы, связанной с восстановлением хронологической системы, которая 
строится от одного хроноиндикатора и включает весь комплекс скифских древностей.

Поэтому нужно сразу заметить, что она, не причинив вреда, «отпускает на волю» горемычных «китов» раннескифской хронологии, три из которых (скифо-ближневосточные) плавают по кругу, держа друг друга за хвост, а три других (антично-керамические, западноевропейские и китайские) пытаются, разомкнув этот круг, в него внедриться. Безуспешность этих действий обусловлена тем, что каждый из трёх последних «китов» также включён в свою археологическую систему кругового хронологического движения, уже оторванную от основы.

Такой основой являются сведения, содержащиеся в письменных источниках, так как все хронологические «киты» в археологии рождены, в основном, знаниями, сохраненными письменной традицией. Данные эти, правда, тоже довольно часто пытаются корректировать, поскольку они не совпадают с современными хронологическими представлениями.

Да, безусловно, древние ошибались, и этими фактами нельзя пренебрегать. Однако стоит помнить о том, что и мы не безгрешны, поэтому ошибки следует искать не только в работах древних авторов или писцов, но и в собственных хронологических определениях. Исходя из этого, по хронологии Древнего Востока были произведены расчеты исключительно в соответствии с письменными источниками и от одного репера (Кузнецова, 2009; Кузнецова, 2016б. С. 70-93; Кузнецова, 2019), определяющего время вторжения воинства скифского царя Мадия в Переднюю Азию (Herod. I, 103) во время осады столицы Ассирии - Ниневии войсками Вавилонии и Мидии в 14-й год правления вавилонского царя Набопаласара (ВМ 21901, rev. 38-50: Grayson, 1975. P. 9495). Это единственный документ, свидетельствующий о падении Ниневии. По общепринятой хронологии 14-й год правления Набопаласара в Вавилонии определяется 612 г. до н.э. (Бикерман, 1975. С. 106), а по данным Б.А. Тураева (Тураев, 1935. С. 83), опиравшегося на сведения Евсевия (армянский перевод), и моим расчетам это событие произошло в 608 г. до н.э (Кузнецова, 2009. С. 314-317). Однако расхождение в датах не противоречит полученному времени возвращения скифов через Кавказ в Северное Причерноморье после «разгрома» мидийским царем Киаксаром - не ранее 585 г. до н.э. (Кузнецова, 2009. С. 308-328), что соответствует и датам представленного выше вещевого комплекса сопоставлявшихся памятников.

\section{ЛИТЕРАТУРА}

Алексеев А.Ю. Хронография Европейской Скифии VII-IV веков до н.э. СПб.: Изд-во ГЭ, 2003. 416 с.

Бидзиля В.И., Полин С.В. Скифский царский курган Гайманова Могила. Киев: Скиф, 2012. $752 \mathrm{c}$. 
Бикерман Э. Хронология древнего мира. Ближний Восток и античность. М.: Наука, 1975. $336 \mathrm{c}$.

Бобринский А. Отчет, произведённый в 1903 году в Чигиринском уезде Киевской губернии. ИАК. 1905. Вып. 14. С. 1-43.

Галанина Л.К. Келермесские курганы. «Царские» погребения раннескифской эпохи. Степные народы Евразии. Т. 1. М.: Палеограф, 1997. 316 с.

Галанина Л.К., Алексеев А.Ю. Древности скифской эпохи из Прикубанья // Античное наследие Кубани / Ред. Г.М. Бонгард-Левин, В.Д. Кузнецов. М.: Наука, 2010. Т. 3. C. 170-196.

Дараган М. Памятники раннескифского времени Среднего Поднепровья и Гальштатт: поиск хронологических реперов // Revista Arheologică. 2010. Serie nouă. Vol. VI. Nr. 2. C. $85-113$.

Дараган М.Н. Начало раннего железного века в Днепровской Правобережной Лесостепи. Киев: КНТ, 2011. 848 с.

Иванчик А.И. Раннескифская хронология в свете древневосточных данных // Этнокультурное взаимодействие в Евразии. Кн. 1. / Ред. А.П. Деревянко, В.И. Молодин, В.А. Тишков. М.: Наука, 2006. С. 146-161.

Ильинская В.А. Скифы Днепровского лесостепного левобережья. Киев: Наукова думка, 1968. 268 с.

Ильинская В.А. Раннескифские курганы бассейна р. Тясмин. Киев: Наукова Думка, 1975.

Ильинская В.А., Мозолевский Б.Н., Тереножкин А.И. Курганы VI в. до н.э. у с. Матусов // Скифия и Кавказ / Отв. ред. А.И. Тереножкин. Киев: Наукова Думка, 1980. C. 31-63.

Ильинская В А., Тереножкин А.И. Скифия VII-IV вв. до н.э. Киев: Наук. Думка, 1983.

Кисель В.A. Стилистическая и хронологическая атрибуция серебряного зеркала из Келермеса // ВДИ. 1993. № 1. С. 111-125.

Кисель В.А. Шедевры ювелиров Древнего Востока из скифских курганов. СПб.: Петербургское востоковедение, 2003. 192 с.

Ковпаненко Г.Т. «Червона могила» у с. Флярковка // Древности Евразии в скифосарматское время / Ред. А.И. Мелюкова, М.Г. Мошкова, В.Г. Петренко. М.: Наука, 1984. С. $107-113$.

Копейкина Л.В. Келермесское зеркало (к вопросу о датировке и месте его изготовления). Архив отдела Античного мира ГЭ. 1981.

Кузнецова Т.М. Зеркала Скифии VI-III вв. до н.э. Том I. М.: Индрик, 2002. 350 с.

Кузнецова T.M. Хронология скифского присутствия на Ближнем Востоке (по следам Геродота) // Stratum plus. 2009. № 3/2005-2009. С. 308-328.

Кузнецова Т.М. Зеркала Скифии VI-III вв. до н.э. Том II. М.: Таус, 2010. 426 с.

Кузнецова T.M. Серебряный килик из кургана «Солоха» и некоторые аспекты скифской хронологии // Археология без границ: коллекции, проблемы, исследования, гипотезы // ТГЭ. LXXVII. СПб.: Изд-во Государственного Эрмитажа, 2015. C. 240-255, 548.

Кузнецова T.M. Келермесский могильник и система скифской хронологии архаического периода // Материалы международной научной конференции памяти М.Н. Погребовой «Кавказ и степь на рубеже эпохи поздней бронзы и раннего железа» / Отв. ред. С.В. Кулланда, А.С. Балахванцев. М.: ИВ РАН, 2016а. С. 124-134. 
Кузнецова T.M. Скифы и хронология Древнего Востока // Старожитності степового Причерномор'я і Криму. Том. ХІХ / Отв. ред. П.П. Толочко, Г.Н. Тощев. Запоріжжя: Запорізький державний університет, 2016б. С. 70-93.

Кузнецова T.M. Об основах скифской хронологии периода архаики // «И музою его была наука»: Сборник памяти В.А. Кореняко (1952-2016) / Отв. ред. и сост. С.В. Кузьминых, А.А. Горбенко. Азов: Изд-во Азовского музея-заповедника, 2017а. C. $127-142$.

Кузнецова T.M. О времени сооружения кургана «Репяховатая Могила» // РА. 2017б. № 2. C. 100-114.

Кузнецова T.M. 2018. Курганы «Репяховатая Могила», «Червона Могила» и Келермес // Тезисы международной научной конференции «Новое в исследованиях раннего железного века Евразии: проблемы, открытия, методики» (13-14 ноября 2017) / Отв. ред. А.А. Малышев. М.: МАКС Пресс, 2018. С. 97-98. DOI 10.29003/m159.s_et_s

Кузнецова T.M. Дата вторжения скифского царя Мадия в Переднюю Азию // Stratum plus. 2019. № 3. С. 287-319.

Максимова М.И. Серебряное зеркало из Келермеса // СА. 1954. № 21. С. 281-305.

Манцевич А.П. Курган Солоха. Л.: Искусство. 1987. 143 с.

Пиотровский Б.Б. История и культура Урарту. СПб.: Филол. ф-т СПбГУ; Искусство России, 2011. 656 с.

Рябкова Т.В. Шаровидные навершия с прорезными бубенцами из раннескифских памятников Закубанья // Материалы международной научной конференции памяти М.Н. Погребовой «Кавказ и степь на рубеже эпохи поздней бронзы и раннего железа» / Отв. ред. С.В. Кулланда, А.С. Балахванцев. М.: ИВ РАН, 2016. С. 215-221.

Рябкова T.B. Формирование раннескифского культурного комплекса в Закубанье (по материалам старших курганов Келермеса) // Кавказ в системе культурных связей Евразии в древности и средневековье. XXX «Крупновские чтения» по археологии Северного Кавказа». Материалы Международной научной конференции 22-29 апреля 2018 г. / Отв. ред. У.Ю. Кочкаров. Карачаевск, 2018. С. 250-253.

Тураев Б.А. История древнего Востока. Т. ІІ. Л.: ОГИЗ, Соцэкгиз. Ленинградское отделение, 1935. 342 с.

Фиалко E.E. Об одном типе золотых украшений скифского времени (к вопросу об эволюции и происхождении) // Археологічний літопис Лівобережної України. № 1. Полтава, 2006. С. 61-73.

Чугунов К.В. Проблемы датирования азиатских материалов эпохи ранних кочевников и вопросы синхронизации их с древностями восточной Европы // Археологія і давня історія України. Старожитності раннього залізного віку (к 110-летию со дня рождения проф. А.И. Тереножкина). Київ. Вип. 2 (23). С. 484-499.

Grayson A.K. Assyrian and Babylonian Chronicles // Texts from Cuneiform Sources. V. 5. Locust Valley, New York: J. J. Augustin, 1975. 300 p. 


\section{СЛУЧАЙНЫЕ НАХОДКИ ВООРУЖЕНИЯ РАННЕГО ЖЕЛЕЗНОГО ВЕКА ИЗ ЛЕСОСТЕПНОГО АЛТАЯ}

(Работа выполнена при финансовой поддержке РНФ (проект № 16-18-10033 «Формирование и эволюция систем жизнеобеспечения у кочевых социумов Алтая и сопредельных территорий в поздней древности и средневековье: комплексная реконструкция»))

\section{Лихачёва O.C.}

http://10.25681/IARAS.2019.978-5-317-06274-3/124-134

Выявлен и атрибутирован определённый блок информации по случайным находкам средств защиты и нападения из раннего железного века из лесостепного Алтая

Ключевые слова: ранний железный век, вооружение, Лесостепной Алтай, случайные находки

Случайные находки на настоящий момент составляют уже весьма представительную источниковую базу по военному делу племен, населявших Лесостепной Алтай в раннем железном веке. Их учёт начался ещё в конце XIX в., усилиями путешественников и местных краеведов и активно продолжается до настоящего времени. Сейчас они опубликованы в более чем полутора десятке статей, а также ряде монографий, посвящённых изучению данного периода (Иванов, 1993а-б; Могильников, 1997 и др.). В то же время очень часто авторами упускались или очень поверхностно рассматривались вопросы, связанные с их культурной, а порой и хронологической атрибуцией. В каких-то случаях данная информация является уже не актуальной и требует переосмысления.

Несмотря на отсутствие контекста, случайные находки вооружения представляют значительный научный интерес. Это связано с хорошей сохранностью изделий, которая позволяет уточнить морфологические особенности аналогичных образцов. Ряд предметов представляет самостоятельные типы, дающие более подробно проследить эволюцию отдельного вида вооружения на рассматриваемой территории. Некоторое оружие, в частности мечи, расширяет представление о паноплии того времени, поскольку из-за особенностей погребального обряда редко встречается в могилах. Исходя из значимости данных аспектов, сбор и обобщение информации по этому блоку источников представляется нам актуальной задачей.

По материалам VI-I вв. до н.э. на территории Лесостепного Алтая выделено три археологические культуры: каменская, староалейская и быстрянская. Каменская культура локализуется на Приобском плато, Кулундинской равнине, западной части Предалтайской равнины, а также в северной части Бийско-Чумышской возвышенности (Могильников, 1997. С. 7). Памятники староалейской культуры располагаются в Барнаульском Приобье (Абдулганеев, Кунгуров, Фролов, 1994. С. 52-55; Фролов, 2008. С. 53-54). Ареал быстрянской 
культуры соотносится с северными предгорьями Алтая, включая бассейны рек Нижней Катуни и Нижней Бии, начальное течение р. Оби и среднее течение p. Чумыша (Киреев, 1994. С. 118).

Случайные находки вооружения с территории Лесостепного Алтая включают следующие виды: наконечники стрел, мечи, кинжалы, чеканы и панцирную пластину.

Наконечники стрел представлены 27 экземплярами. Из ареала каменской культуры происходит 17 изделий, староалейской - девять, быстрянской - один. Сведения о месте происхождения двух неизвестны.

Наконечники стрел, из ареала каменской культуры найдены в следующих пунктах: с. Чёрная Курья, Завьяловский район, оз. Беленькое, оз. Новенькое, с. Урлапово, Красный Яр (Уманский, 1970. Рис. 8. - 12; Иванов, 1987. Рис. 2. 26-28; Иванов, 1993 б. Рис. 1. - 13, 17, 21-25, 31; Дашковский, Грушин, Симонов, 1998. Рис. 1. - 1). Все они изготовлены из бронзы, по способу насада разделяются на втульчатые и черешковые. У первых втулка может быть выступающей или скрытой. Изделия с выступающей втулкой трёхлопастные с листовидным или треугольным абрисом пера (рис. $1,1-2,11$ ). Один наконечник округлого сечения и килевидного абриса (рис. 1, 4). Экземпляр со скрытой втулкой имеет трёхгранно-трёхлопастное подтреугольной формы перо (рис. 1, 3). Данные изделия находят аналогии среди материалов следующих памятников: Киприно-1, Новообинка, Крестьянское-3, Кабанье, Моховое-3 (Уманский, 1970. Рис. 8. - 8; Иванов, Медникова, 1982. Рис. 1. - 1-4; Иванов, 1987. Рис. 2. - 32; Удодов, 1990. Рис. 3; Иванов, 2000. Рис. 46. - 10). Датируются они VI-V вв. до н.э.

Черешковые наконечники стрел трёхлопастного, трёхгранно-трёхлопастного или трёхгранного сечения с треугольным абрисом (рис. 1, 5-10, 12-16). Аналогичные образцы известны по колчанным наборам могильника Новотроицкий-2 (к. 15, м. 3; к. 18, м. 9 и м. 10) и поселений Крестьянское-3, Моховое-5, Первомайское (Иванов, 2000. Рис. 5. - 10-11. Рис. 46. - 8-9; Шульга, Уманский, Могильников, 2009. Рис. 78. - 1-9. Рис. 88. - 12. Рис. 93. - 4). Трёхгранно-трёхлопастные наконечники известны по памятникам Михайловский-VI и Моховое-5 (Шамшин, Демин, Навротский, 1992. С. 197; Иванов, 2000. Рис. 46. - 7). Трёхгранному пока не известно точных аналогий. Такие изделия применялись с V по III в. до н.э.

Типологически близки рассмотренным образцам два наконечника стрел с неизвестным местонахождением, что позволяет рассматривать их в рамках данной культуры. Они находят аналогии в материалах Новотроицкого некрополя (Шульга, Уманский, Могильников, 2009. Рис. 110. - 1-9).

К ареалу староалейской культуры принадлежит девять экземпляров. Они происходят из окрестностей оз. Телеутское и с. Бобровка (Иванов, 1993 а. Рис. 1. - 15-17, 24-29). Среди них есть как втульчатые, так и черешковые. У первых втулка может быть выделенной или скрытой. Изделия с выделенной втулкой имеют трёхлопастное перо треугольной формы, экземпляр со скры- 

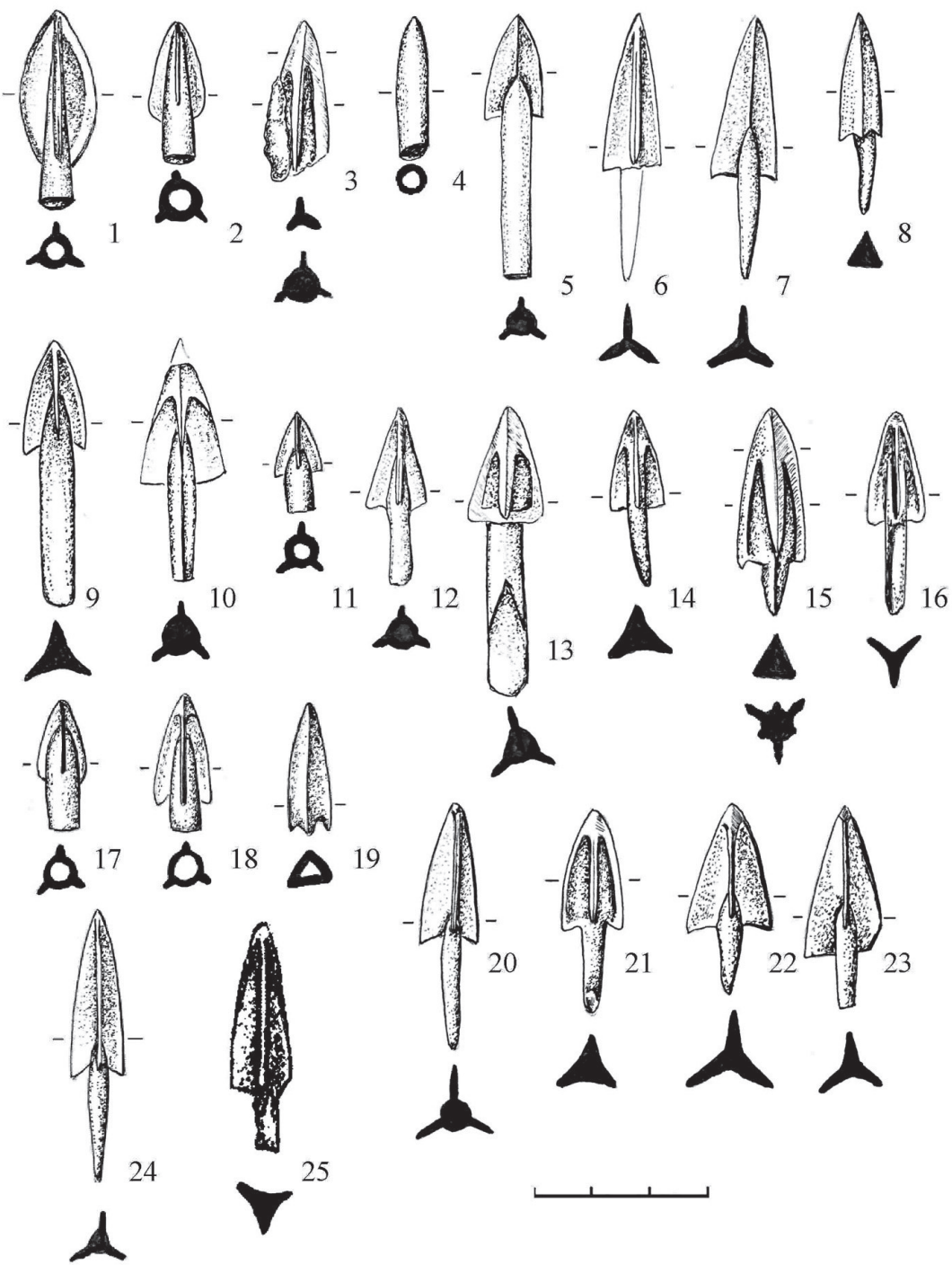

Рис. 1. Наконечники стрел с территории Лесостепного Алтая.

1-3 - с. Чёрная Курья; 4-8 - Завьяловский район; 9-10 - оз. Новенькое,

11 - оз. Беленькое; 12 - с. Урлапово; 13 - Красный Яр; 14-16 - Лесостепной Алтай;

17-23 - оз. Телеутское; 24 - с. Бобровка; 25 - с. Верх-Озерное.

1-16 - каменская культура; 17-24 - староалейская культура; 25 - быстрянская культура. 1-25 - бронза

той - трёхгранного сечения и треугольного абриса (рис. 1, 17-19). Наконечники стрел таких типов есть в следующих памятниках староалейской культуры: Малый Гоньбинский Кордон-1, могильник 3, м. 13 и Клепиков-I (Фролов, 1996. Рис. 1. - 3; Кунгуров, 1999. Рис. 1. - 4). Их датировка укладывается во вторую половину VI - начало V в. до н.э. 


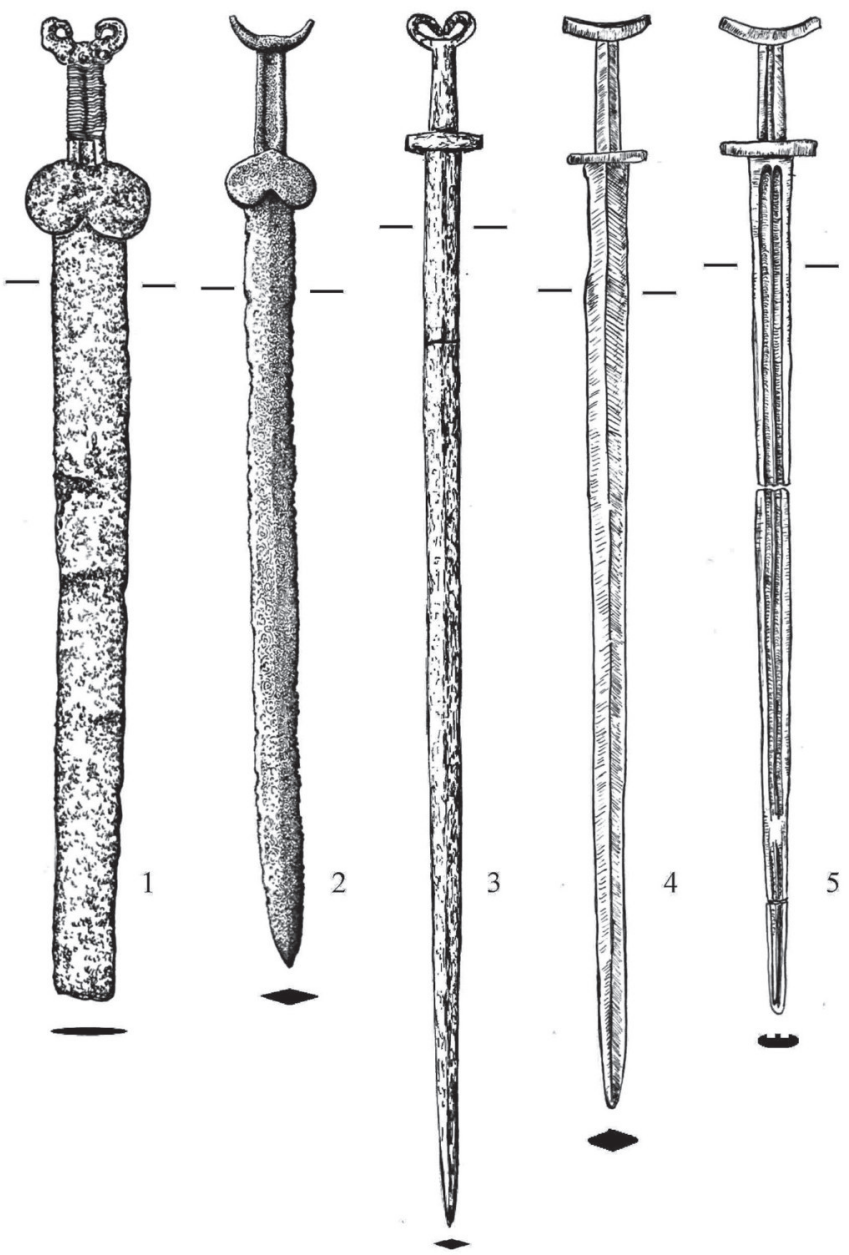

Рис. 2. Мечи с территории Лесостепного Алтая.

1 - Тюменцевский район; 2 - с. Горьковское; 3 - с. Солоновка; 4 - с. Шипуново;

5 - с. Ключи. 1-5 - каменская культура. [По: 2 - Фролов, 2016.] 1-5 - железо

Черешковые изделия имеют перо трёхлопастного сечения и треугольного абриса (рис. 1, 20-24). Они могут быть соотнесены с образцами из памятников Клепиково-I и Телеутский Взвоз-1 и датироваться с V по III в. до н.э. (Фролов, 1996. Рис. 1. - 5; Кирюшин, Фролов, 1998. Рис. 2. - 3).

Из ареала быстрянской культуры происходит только один наконечник стерлы из окрестностей с. Верх-Озерное с пером трёхлопастного сечения и треугольного абриса (рис. 1, 25) (Лихачева, 2007. С. 178). Пока находок такого типа из закрытых комплексов не известно. Такие образцы бытуют с VI по ІІІ в. до н.э.

Клинковое оружие раннего железного века с территории Лесостепного Алтая представлено мечами и кинжалами. Первые известны на настоящий мо- 
мент только по памятникам каменской культуры. Из её же ареала происходит пять случайных находок этих изделий. (Ранее нами в эту группу включался также меч из с. Калистратиха (Лихачева, 2017б), но, поскольку в месте его обнаружения частично фиксировались остатки погребения, он был исключен из разряда случайных находок). Мечи найдены в следующих пунктах: с. Горьковское, с. Ключи, с. Шипуново, с. Солоновка, Тюменцевкий район (Уманский, 1970. Рис. 7; Кирюшин, Иванов, Бородаев, 1995. Рис. 1; Фролов, 2016. Рис. 1. - 1; Худяков, 2017. Рис. 1). Они изготовлены из железа, имеют клинки килевидной или треугольной формы. Образцы с килевидными клинками обладают следующими признаками: почковидное перекрестие и волютообразное навершие, трактованное в зверином стиле, либо сердцевидное перекрестие и дуговидное навершие (рис. 1, 1-2). Они соотносятся с экземплярами из могильника Гилево-Х (к. 3) и Новообинского «кургана» (Иванов, Медникова, 1982. С. 91. Рис. 1. - 14; Могильников, 1990. Рис. 1. - 6). Их датировка определяется VI-IV вв. до н.э. Все мечи с треугольным клинком имеют брусковидное перекрестие и дуговидное или волютообразное навершие (рис. 1, 3-5). Наиболее близок им меч из разрушенного погребения у с. Калистратиха (Уманский, 1970. Рис. 6. - 1). Применялись такие изделия во II-I вв. до н.э.

С рассматриваемой территории происходит 14 случайно найденных кинжалов. Из них девять зафиксировано в ареале каменской культуры, один кинжал в ареале староалейской и три - в ареале быстрянской.

Кинжалы, относящиеся к каменской культуре, изготовлены как из бронзы, так и из железа. Они найдены в следующих пунктах: г. Змеиногорск, с. Чернопятово, с. Новообинцево, с. Ильинка, с. Кочки, с. Рогозиха, г. Барнаул, с. Шадрино (Могильников, 1997. Рис. 36. - 3, 5, 7. Рис. 40. - 8; Уманский, Тишкин, Горбунов, 2001. Рис. 14; Чекрыжова, Шамшин, 2001. Рис. 1; Кирюшин, Кирюшин, Лихачёва, 2014. С. 127-128. Рис. 1; Тишкин, 2006. С. 250-251). Бронзовые изделия имеют треугольные клинки и бабочковидные перекрестия (рис. 3, 1). У одного кинжала навершие полусферическое, у второго эта деталь не сохранилась. Два данных экземпляра, а также железный образец с килевидным клинком, бабочковидным перекрестием с зооморфным изображением и брусковидным навершием (рис. 3,2 ) пока не имеют прямых аналогий и отнесены к рассматриваемой культуре на основе своей локализации. Четыре изделия имеют треугольные клинки и дуговидное перекрестие. Форма их наверший волютообразная, трактованная в зверином стиле, дуговидная или кольцевая. Кинжал с волютообразным навершием в виде голов грифонов и зооморфными мотивами на черене (рис. 3,3 ) происходит из с. Рогозиха и, скорее всего, связан с материалами могильника Рогозиха-1 (Уманский, Шамшин, Шульга, 2005. С. 15). Датируется он VI-IV вв. до н.э.

Изделие с дуговидным навершием и дуговидным перекрестием (рис. 3, 6) аналогично образцу из памятника Новотроицкий-1 (к. 5, м. 5), что позволяет датировать его IV-III вв. до н.э. (Шульга, Уманский, Могильников, 2009. 


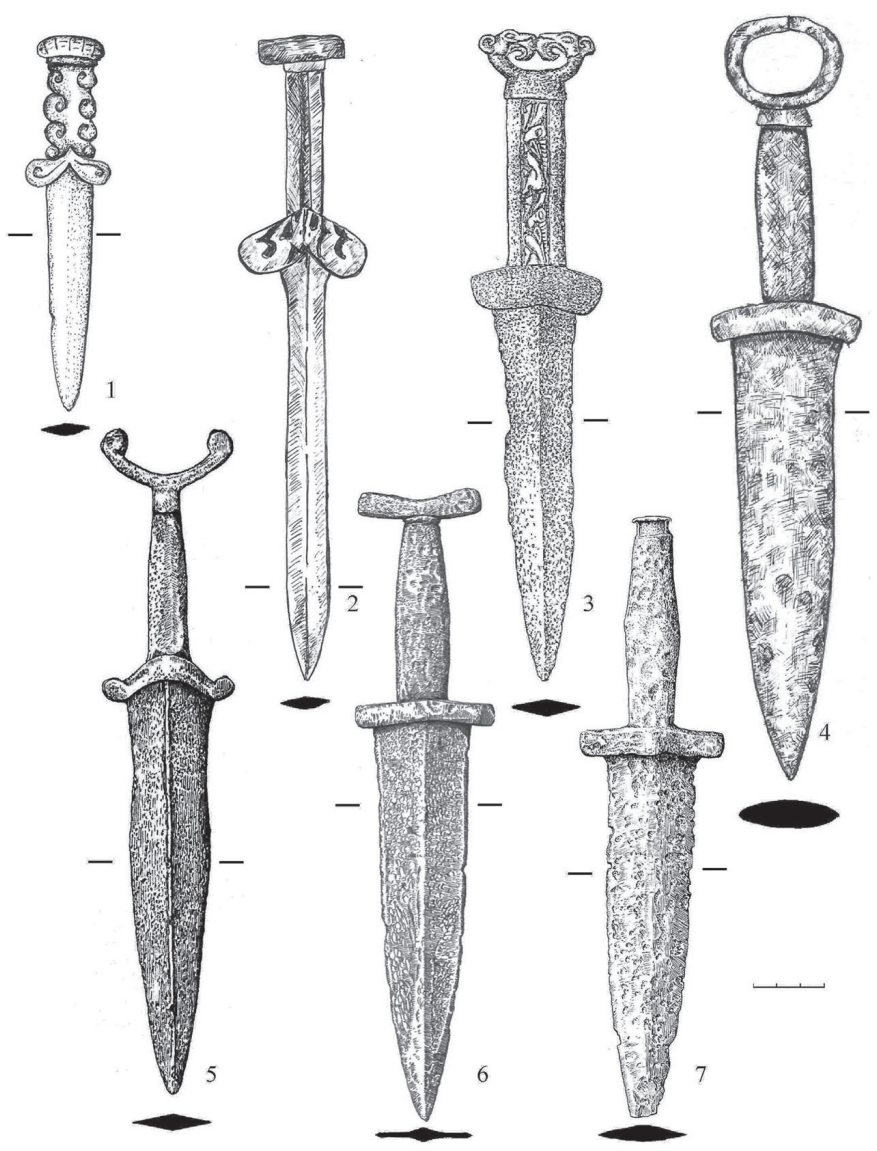

Рис. 3. Кинжалы с территории Лесостепного Алтая.

1 - г. Змеиногорск; 2 - с. Кочки; 3 - с. Рогозиха; 4 - с. Новобинцево;

5 - Лесостепной Алтай; 6 - с. Чернопятово; 7 - с. Ильинка. 1-7 - каменская культура. 1 - бронза; 2-7 - железо

Рис. 4. - 8). Экземпляр с кольцевым навершием и сходный с ним образец (рис. $3,4,7$ ), относятся к рассматриваемой культуре, исходя из картографирования, и бытуют в III-I вв. до н.э.

Помимо указанных образцов, в рамках каменской культуры нами рассматривается кинжал, точное место происхождения которого не известно. Он хранится в музее «Мир времени» и имеет специфичные признаки: клинок с прогибом в верхней части и «коромысловидное» перекрестие. Навершие его волютообразное (рис. 3,5 ). Подобные изделия составляют особую серию и пока встречаются только в материалах каменской культуры (Горбунов, Лихачева, 2015. С. 70, 73-74). Ещё два таких же кинжала происходят из могильника Новотроицкий-2 (к. 7, м. 6 и к. 5, м. 3) (Шульга, Уманский, Могильников, 2009. С. 181. Рис. 57. - 2, 63. - 5). Датируются они IV-III вв. до н.э. 
Из ареала староалейской культуры (ст. Укладочая) происходит железный кинжал с обломанным клинком (по всей вероятности треугольным), на навершии и перекрестии которого изображены повёрнутые в противоположные стороны головы баранов (рис. 4,1 ). Он может быть отнесён к данной культуре лишь по местонахождению и датироваться VI-IV ввдо н.э. (Могильников, 1997. Рис. 36. - 6). К этой же культуре относится, на наш взгляд, бронзовый образец из Бийского краеведческого музея им. Бианки (далее БКМ). Такие его признаки, как бабочковидное перекрестие, парное изображение голов животных (рис. 4, 2), наиболее характерны для клинкового оружия данной культуры. Датируется рассматриваемый экземпляр в рамках VI-V вв. до н.э. (Лихачёва, 2017a. С. 121-122).

С быстрянской культурой связано три железных кинжала, найденные на г. Пикет и у р. Сухая Чемровка (Кирюшин, Кунгуров, Казаков, 1992. Рис. 10. - 1-2, 5). Они имеют дуговидное перекрестие. Навершие волютообразное или дисковидное (рис. 4, 3-5). Полностью идентичных аналогий им пока не известно, но ряд их признаков есть у образцов из закрытых комплексов этой культуры (Казаков, Семибратов, Ситников, Матренин, Григоров, 2016. Рис. 1. - 1).

Следующим видом оружия, встречающимся среди случайных находок, являются чеканы. Они представлены тремя экземплярами, изготовленным

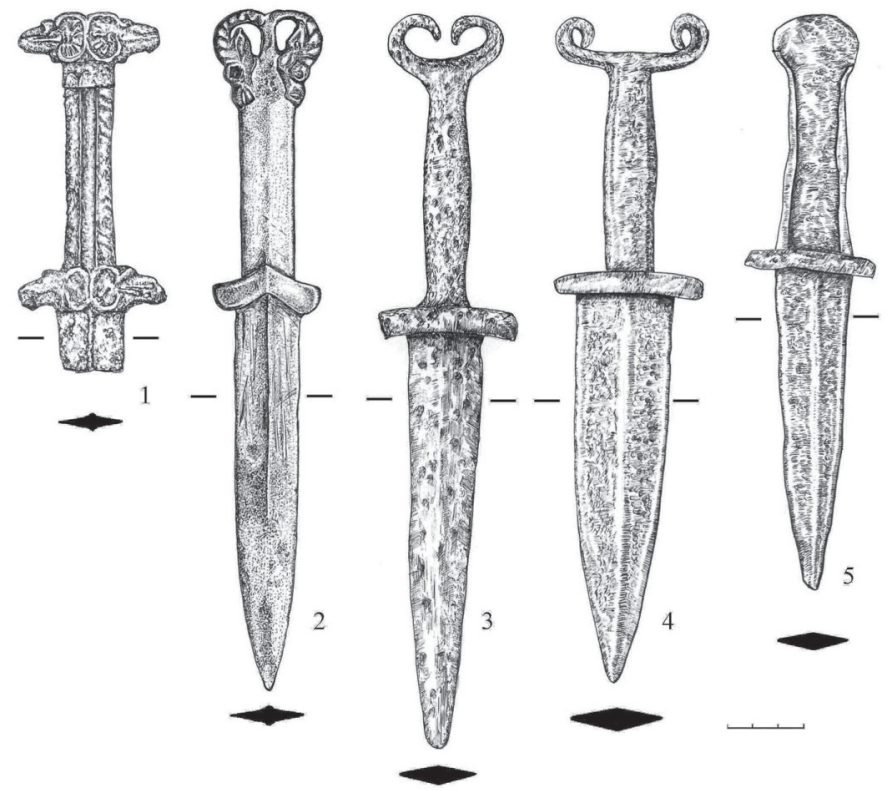

Рис. 4. Кинжалы с территории Лесостепного Алтая.

1 - ст. Укладочная; 2 - Лесостепной Алтай; 3, 5 - г. Пикет;

4 - р. Сухая Чемровка. 1-2 - староалейская культура; 3-5 - быстрянская культура.

1, 3-5 - железо; 2 - бронза 
из бронзы. Из них один происходит из ареала каменской культуры, а два из ареала быстрянской. Чекан из окрестностей с. Новосклюиха имеет прямые обух и боёк (Могильников, 1997. Рис. 43. - 8). Боёк килевидного абриса и состоит из двух элементов: округлого стержня и отходящей от него лопасти. Втулка его имеет широкий выпуклый валик в верхней части, отверстие, а между ней и бойком располагается петля (рис. 5,1 ). Данное изделие относится к рассматриваемой культуре на основании картографирования. Но, стоит отметить, что прямое расположение обуха и бойка и художественное оформление данного вида оружия наиболее характерно для материалов каменской культуры (Шульга, Уманский, Могильников, 2009. Рис. 117. - 2-3). Типологически этот чекан датируется VI - второй половиной V в. до н.э.

Чекан, относящийся нами к быстрянской культуре, имеет наклонные обух и боёк (Иванов, 1987. Рис. 6. - 1). Обух простой формы, скруглённый, боёк стержневидный без дополнительных элементов. Между бойком и обухом имеется орнитоморфное изображение (рис. 5, 2). Он хранится в БКМ и может
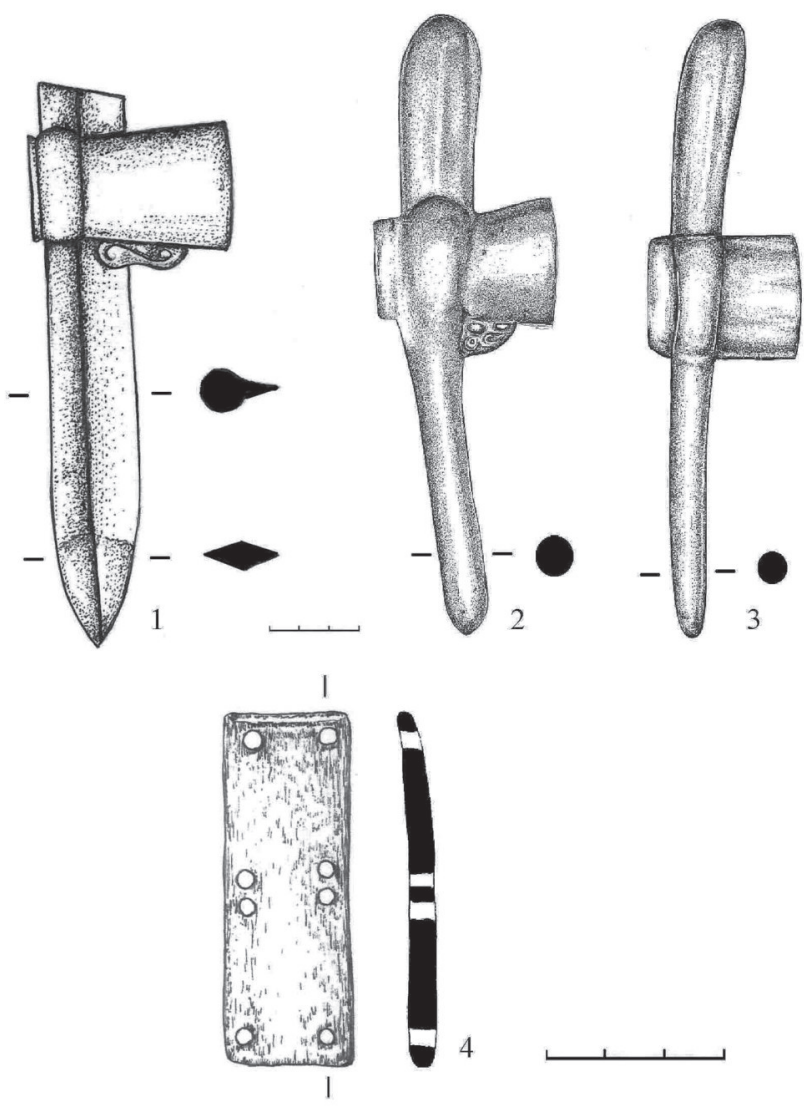

Рис. 5. Чеканы и панцирная пластина с территории Лесостепного Алтая. 1 - с. Новосклюиха; 2 - г. Бийск; 3 - Лесостепной Алтай; 4 - ур. Соловьиная Лука.

1, 4 - каменская культура; 2-3 - быстрянская культура. 1-3 - бронза; 4 - кость 
быть отнесен к быстрянской культуре, так как схож по признакам с вотивными чеканами из могильника Каменка (Казаков, Семибратов, Ситников, Матренин, Григоров, 2016. Рис. 1. - 2). К этой же культуре относится и экземпляр без точного местонахождения, но аналогичный типологически (рис. 5, 3) (Иванов, 1987. Рис. 6. - 2). Датируются эти образцы VI-V вв. до н.э.

Панцирная пластина обнаружена в ареале каменской культуры - урочище Соловьиная Лука (Горбунов, Кирюшин, Лихачёва, 2013. Рис. 1. - 1). Она имеет прямоугольный абрис и восемь отверстий. Боковых отверстий - четыре: по одной паре, на каждом из боковых краев, угловых также четыре - по одному возле каждого угла пластины (рис. 5, 4). Аналогиями ей являются экземпляры из могильника Масляха-I (к. 6, м. 7). Панцирные пластины такого типа бытовали на рассматриваемой территории с IV по I в. до н.э. (Горбунов, Кирюшин, Лихачёва, 2013. С. 57-60).

Таким образом, нами выявлен и атрибутирован блок информации по случайным находкам средств защиты и нападения. Эта работа, безусловно, не является окончательной и лишь обобщает материал за определённый период времени. Предполагается дальнейший сбор сведений и составление на его основе развёрнутой, регулярно пополняющейся базы данных.

\section{ЛИТЕРАТУРА}

Абдулганеев М.Т., Кунгуров А.Л., Фролов Я.В. Староалейская культура // Проблемы изучения культурно-исторического наследия Алтайского края. Горно-Алтайск, 1994. C. $52-55$.

Горбунов В.В., Кирюшин Ю.Ф., Лихачёва О.С. Об одном типе костяных панцирных пластин, используемом населением Алтая в раннем железном веке // Древности Сибири и Центральной Азии. № 5(17). Горно-Алтайск: ГАГУ, 2013. С. 58-63.

Горбунов В.В., Лихачёва О.С. Кинжал редкого типа с Алтая // Сохранение и изучение культурного наследия Алтайского края. Вып. ХХІ. Барнаул: Изд-во Алт. ун-та, 2015. С. 70-75.

Дашковский П.К., Грушин С.П., Симонов Е.В. Новые могильники Угловского района Алтайского края // Сохранение и изучение культурного наследия Алтайского края. Вып. ІХ. Барнаул: Изд-во Алт. ун-та, 1998. С. 137-141.

Иванов Г.Е. Бронзовый наконечник дротика с поселения Курейка-III (Степной Алтай) // Археологические исследования на Алтае. Барнаул, 1987. С. 126-136.

Иванов Г.Е. Новые находки оружия раннего железного века в степном Алтае // Военное дело населения юга Сибири и Дальнего Востока. Новосибирск: ВО «Наука», 1993 a. C. 95-106.

Иванов Г.Е. Новые находки оружия раннего железного века в лесостепном Алтае // Культура древних народов Южной Сибири. Барнаул: Изд-во Алт. ун-та, 1993 б. C. 56-62.

Иванов Г.Е. Свод памятников истории и культуры Мамонтовского района. Барнаул: Алтайский полиграфический комбинат, 2000. 160 с. 
Иванов Г.Е., Медникова Э.М. Новообинский курган // Археология и этнография Алтая. Барнаул: Изд-во Алт. ун-та, 1982. С. 89-95.

Казаков А.А., Семибратов В.П., Ситников С.М., Матрёнин С.С., Григоров Е.В. Новые исследования погребений быстрянской культуры на могильнике Каменка в Советском районе Алтайского края // Сохранение и изучение культурного наследия Алтайского края. Вып. ХХІІ. Барнаул: Изд-во Алт. ун-та, 2016. С. 126-132.

Киреев С.М. Роль миграционных процессов в сложении быстрянской культуры // Палеодемография и миграционные процессы в Западной Сибири в древности и средневековье. Барнаул: Изд-во Алт. ун-та, 1994. С. 118-120.

Кирюшин Ю.Ф., Иванов Г.Е., Бородаев В.П. Мечи из собрания Шипуновского музея // Проблемы охраны, изучения и использования культурного наследия Алтая. Барнаул: Изд-во Алт. ун-та, 1995. С. 99-103.

Кирюшин Ю.Ф., Кирюшин К.Ю., Лихачева О.С. Кинжал раннего железного века из Чернопятово // Сохранение и изучение культурного наследия Алтайского края. Вып. ХХ. Барнаул: Изд-во Алт. ун-та, 2014. С. 127-132.

Кирюшин Ю.Ф., Кунгуров А.Л., Казаков А.А. Город Бийск. Памятники археологии // Бийск, Бийский район. Памятники истории и культуры. Бийск, 1992. С. 7-47.

Кирюшин Ю.Ф., Фролов Я.В. Комплекс памятников эпохи раннего железа в районе с. Елунино // Древние поселения Алтая. Барнаул: Изд-во Алт. ун-та, 1998. C. $110-136$.

Кунгуров А.Л. Погребальный комплекс раннескифского времени МГК-І в Приобье // Итоги изучения скифской эпохи Алтая и сопредельных территорий. Барнаул: Изд-во Алт. ун-та, 1999. С. 92-98.

Лихачёва О.С. Предметы вооружения и быта из археологической коллекции Верхозернинского музея Быстроистокского района Алтайского края // Сохранение и изучение культурного наследия Алтайского края. Вып. XVII. Барнаул: Изд-во Алт. ун-та, 2007. С. 175-180.

Лихачёва О.С. Бронзовый кинжал с зооморфным навершием из Бийского краеведческого музея // Сохранение и изучение культурного наследия Алтайского края. Вып. ХХІІІ. Барнаул: Изд-во Алт. ун-та, 2017 а. С. 118-123.

Лихачёва О.С. Случайные находки вооружения VI-I вв. до н.э. из Лесостепного Алтая // Новое в исследованиях раннего железного века Евразии: проблемы, открытия, методики. [Электронный ресурс.] М.: Институт археологии РАН, 2017 б. Режим доступа: http:/scythia-sarmatia.ru/лихачева-тезисы-иа-2017/

Могильников B.A. Население Верхнего Приобья в середине - второй половине І тысячелетия до н.э. М., 1997. 195 с.

Могильников В.A. Памятники раннего железного века на Верхнем Алее // Охрана и использование археологических памятников Алтая. Барнаул, 1990. С. 78-83.

Тишкин A.A. Теория и практика археологических исследований. Вып. 2. Барнаул: Изд-во Алт. ун-та, 2006. С. 250-253.

Удодов В.С. Некоторые результаты археологических исследований на р. Бурле // Охрана и использование археологических памятников Алтая. Барнаул, 1990. С. 39-43.

Уманский А.П. Случайные находки предметов скифо-сарматского времени в Верхнем Приобье // СА. 1970. № 2. С. 169-179. 
Уманский А.П., Тишкин А.А., Горбунов В.В. Погребения первой половины II тыс. до н.э. на могильнике Ильинка в Алтайском крае // Алтай и сопредельные территории в эпоху средневековья. Барнаул: Изд-во Алт. ун-та, 1996. С. 146-161.

Уманский А.П., Шамшин А.Б., Шульга П.И. Могильник скифского времени Рогозиха-1 на левобережье Оби. Барнаул: Изд-во Алт. ун-та, 2005. 204 с.

Фролов Я.В. Грунтовый могильник раннего железного века Клепиково I (по материалам М.Д. Копытова и С.М. Сергеева 1925, 1928 гг.) // Погребальный обряд древних племен Алтая. Барнаул: Изд-во Алт. ун-та, 1996. С. 135-143.

Фролов Я.В. Погребальный обряд населения Барнаульского Приобья в VI в. до н.э. - II в. н.э. (по данным грунтовых могильников). Барнаул: Азбука, 2008. 479 с.

Фролов Я.В. Меч скифского времени - новая находка с территории лесостепного Алтая // Археология, этнография и антропология Евразии. 2016. Т. 44. № 3. C. $56-62$.

Худяков Ю.С. Железный меч скифо-сарматского времени из Степного Алтая // Вестник НГУ. 2017. Т. 16. № 5. Изд-во: Новосибирского гос. ун-та, 2017. С. 50-54.

Чекрыжова О.И., Шамшин А.Б. Случайная находка зооморфного кинжала из Рогозихи // Сохранение и изучение культурного наследия Алтайского края. Вып. ХІІ. Барнаул: Изд-во Алт. ун-та, 2001. С. 172-176.

Шамшин А.Б., Демин М.А., Навротский П.И. Раскопки курганного могильника раннего железного века Михайловский-VI на юге Кулунды // Вопросы археологии Алтая и Западной Сибири эпохи металла. Барнаул: Изд-во БГПИ, 1992. С. 60-68, 195-197.

Шульга П.И., Уманский А.П., Могильников В.А. Новотроицкий некрополь. Барнаул: Изд-во Алт. ун-та, 2009. 329 с. 


\section{САКРАЛЬНАЯ ОРИЕНТИРОВКА «ЦЕПОЧЕК» КУРГАНОВ КОЧЕВНИКОВ САЯНО-АЛТАЯ І ТЫС. ДО Н.Э. КАК ЭТНОКУЛЬТУРНЫЙ ПРИЗНАК}

\section{Марсадолов Л.С.}

http://10.25681/IARAS.2019.978-5-317-06274-3/135-143

В статье анализируются ориентировки «цепочек» больших курганов вождей из Тувы, Хакасии и Алтая I тысячелетия до н.э. В каждом из этих регионов древние кочевники практиковали разные типы расположения групп курганов, что может служить для археологов одними из важных этнокультурных признаков. При последовательном сооружении «цепочки» курганов древние кочевники Саяно-Алтая учитывали глубинные мировоззренческие идеи, основанные на осознании целого ряда как социальных, так и природно-географических факторов, базирующихся на длительных наблюдениях. В Туве ряд больших курганов расположен по линии СВ-Ю3, в Хакасии - С3-ЮВ, а на Алтае - Ю-С. Наиболее крупные, социально и сакрально важные объекты расположены в центре курганного поля или у южного края невысоких террас, на доминирующем месте в долине. Ориентировка «цепочек» курганов и форма их наружных насыпей/оград, наряду с другими признаками, может служить важным дополнительным критерием для этнокультурного подразделения крупных регионов археологических памятников.

Ключевые слова: пазырыкская культура, сакральное ориентирование, планиграфия, курган, скифское время

В своей социальной и сакрально-культурной деятельности жрецы и вожди кочевников Саяно-Алтая чётко сознавали и использовали основные доминанты, вытекающие из координат пространственно-временной структуры: центр и вертикальная, а также горизонтальная периферия; верх и низ, высокое положение вождя и низкое рядовых кочевников; восход - полдень - заход; 4 основных и 4 промежуточных стороны света, 4 сезона года; высокое летнее и низкое зимнее Солнце и т.д. Эти доминанты нашли своё отражение, как в социальной структуре общества и календарных представлениях, так и общей организации пространства на Саяно-Алтае, планировке жилых посёлков, погребальных объектов и святилищ.

Центр как сокральная, социальная и культурно-политическая доминанта. Проблема центра, границ и периферии всегда была важна для жизнедеятельности каждого отдельного человека и общества в целом. Геополитическая сфера предполагала умение правителей и их помощников оперативно и правильно ориентироваться в быстро меняющейся обстановке не только в своём и в соседних районах, но и в стратегически важных удалённых регионах. Не только интуитивно, но и осознано древние кочевники под руководством и контролем своих вождей прокладывали наиболее рациональные транспортные и хозяйственные пути, искали наиболее значимые точки в данном регионе - районе - долине - урочище и т.д. Например, как большие современные 
поселки Саяно-Алтая располагаются в наиболее важных узловых точках дорог, так и в древности наиболее крупные курганы воздвигали вдоль таких же путей. Они свидетельствовали о «праве предков» на занятую территорию и служили путевыми ориентирами для проводников.

Древний Центр Азии расположен в Турано-Уюкской котловине в Туве, геополитически важной и удобной для хозяйственной деятельности обширной долине, на пограничье с другими природно-культурными регионами. Аржан крайний северо-восточный форпост кочевников Саяно-Алтая, находится в пограничье горных, таёжных и степных регионов, на юге от тагарской культуры в Хакасии и к западу от Прибайкалья. В аржанской долине расположено около
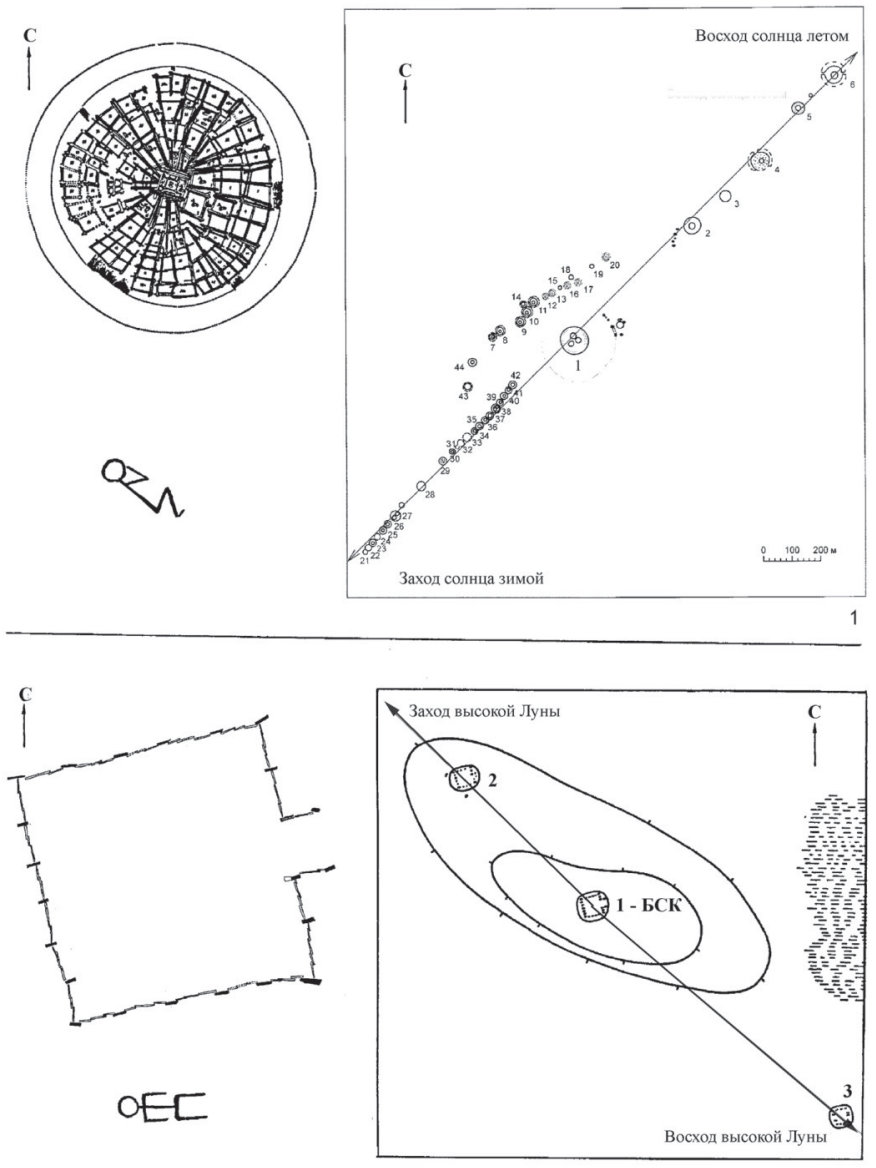

Рис. 1. Региональные различия в ориентации курганов и людей, погребённых в них:

1 - Тува, курган Аржан-1 и курганный могильник Аржан-ІІ

(ориентация по Солнцу «цепочки» курганов [по линии восхода летнего высокого солнца на СВ и захода низкого зимнего солнца на Ю3];

2 - Хакасия, Большой Салбыкский курган (№ 1) и часть курганного поля в Салбыке (ориентация по Луне углов кургана и «цепочки» объектов).

По материалам М.П. Грязнова, С.В. Киселёва и Л.С. Марсадолова 
десяти «цепочек» больших курганов племенных вождей кочевых народов I тыс. до н.э. - это самое грандиозное курганное поле в Саяно-Алтае (рис. 1: 1).

Диаметр каменной насыпи кургана Аржан-1, раскопанного экспедицией М.П. Грязнова и М.Х. Маннай-оола в 1971-1974 гг., достигал 120 м, а высота до 4 м (Грязнов, 1980). «Царь и царица» (вождь союза племён разных регионов Саяно-Алтая и его жена или наложница) и ещё восемь человек были захоронены в центральной, наиболее сакральной части кургана. Углы внутреннего и внешнего срубов в центре кургана были связаны с направлениями восходазахода Солнца и Луны в астрономически значимые дни. В кургане Аржан-1 довольно чётко прослеживается трёхчленная вертикальная пространственная структура - верхний мир (Небо = каменная насыпь), средний (Центр, погребения людей и коней, деревянная конструкция) и нижний мир (подстилающая земля и ниже). Число коней, погребённых в отдельных камерах кургана Аржан, также отражает определённую календарную символику. Наибольшее количество захороненных коней находится в восточной части кургана: $30+30+15+3+12=$ $=90$ коней $=3$ месяца. В целом курган Аржан-1 не только сложный погребальнопоминальный объект, но и своеобразная сакральная «модель мира» (мандала) древних кочевников Центральной Азии (Марсадолов, 2009).

В Центре Хакасии расположен Большой Салбыкский курган (рис. 1: 2), VII в. до н.э., раскопанный экспедицией С.В. Киселёва в 1954-1956 гг. - самый крупный мегалитический объект в Сибири, для сооружения которого были использованы и огромные камни из более древних святилищ. В Салбыкской долине находятся более 100 разных по размерам курганов тагарской культуры, из них 5 курганов по своим размерам почти не уступают Большому (Киселёв, 1956; Дэвлет, 1976; Марсадолов, 2010).

В Центре Алтая находятся изученные экспедицией С.И. Руденко в 1954 г. широко известные большие Туэктинские курганы VI в. до н.э. (Руденко, 1960) самые ранние объекты пазырыкской культуры, по материалам которых прослежены связи кочевников Алтая с Гордионом в Анатолии (Марсадолов, 2006).

Интересно отметить, что раскопки больших курганов в центрах двух соседних регионов были начаты в один год - в 1954 г., на Алтае в Туэкте-1 и в Хакасии в Салбыке.

Центр Восточного Алтая маркируют знаменитые Пазырыкские курганы, относящиеся ко 2-й пол. V в. до н.э., исследованные С.И. Руденко и М.П. Грязновым в 1929, 1947-1949 гг. Вождь из самого раннего большого кургана Пазырык-2 был человеком высокого роста и огромной физической силы, настоящим богатырём-батыром, его тело было украшено сакральной татуировкой (Грязнов, 1950; Руденко, 1953).

Микрохронология и ориентация больших курганов в Пазырыке. При рассмотрении социальных, мировоззренческих и хронологических проблем важно установить не только время функционирования отдельных предметов, курганов и могильника в целом, но также и определить направление форми- 
рования в пространстве «цепочки» из ряда курганов, что может дать новые данные по микрохронологии объектов и найденных в них вещей, а также более обоснованные выводы по социальной организации древних кочевников и «моделям мира» в разных регионах.

Курганы пазырыкской культуры, как правило, расположены «цепочкой», вытянутой по линии С-Ю (Туэкта, Пазырык, Юстыд и др.). Самые ранние курганы в могильниках обычно занимали господствующее положение на местности и, если позволял рельеф, они сооружались у южного края надпойменной террасы. Большие курганы, возможно, были не только местами погребения, но и своеобразными родовыми знаками и топографическими ориентирами на торговых путях (Марсадолов, 1984). Могильник - «небольшая группа однокультурных курганов» формировался в течение определённого отрезка времени (Сорокин, 1974).

При последовательном сооружении «цепочки» курганов древними народами Азии, на наш взгляд, должна была учитываться глубинная мировоззренческая идея, основанная на длительных наблюдениях и осознании следующих фактов: 1) наиболее высокое положение полуденного солнца бывает в южной стороне горизонта; 2) южная часть ночного неба весьма подвижна и удобна для астрономических наблюдений за движением планет и созвездий, а на севере находится участок неподвижных звёзд; 3) южные склоны гор покрыты растительностью, а северные, в основном, безлесные; 4) в лесу деревья имеют более густые ветви с южной стороны, чем с северной; 5) стволы берёз с южной стороны значительно светлее, чем с северной; 6) с северной стороны стволы деревьев после дождя дольше остаются тёмными и влажными, а кора деревьев значительно грубее, мхи и лишайники у основания деревьев также растут преимущественно в северной части; 7) муравейники обычно находятся с южной стороны деревьев, пней, камней; 8) перед наступлением холодов осенью птицы улетают в более тёплые южные страны; 9) весной и летом природа и деревья оживают и расцветают, а зимой - засыпают и замирают; 10) южный ветер, прогретый солнцем, более тёплый, чем северный и т.д.

Эти или другие близкие ассоциации юга с летом, а севера с зимой могли лечь в основу представлений о более благоприятной для человека роли южной стороны света, чем северной. Юг - дерево - тепло - жизнь были противопоставлены северу - холоду - камню - смерти. Не исключено, эта концепция имеет универсальный характер у многих народов. Сходные представления отмечены и в Китае, где они были связаны с Небом и соотнесены со сторонами света: южная красная птица - тепло и северный чёрный воитель - холод.

Вероятно, не случайно на Алтае в скифское время в надежде на будущее возрождение сначала в южной, более глубокой части могильной ямы, в деревянном срубе укладывали тело человека, а затем коня в северной части ямы. С большей долей вероятности можно предположить, что и первый наиболее ранний курган в «цепочке», ориентированной по линии север - юг, - южный, 

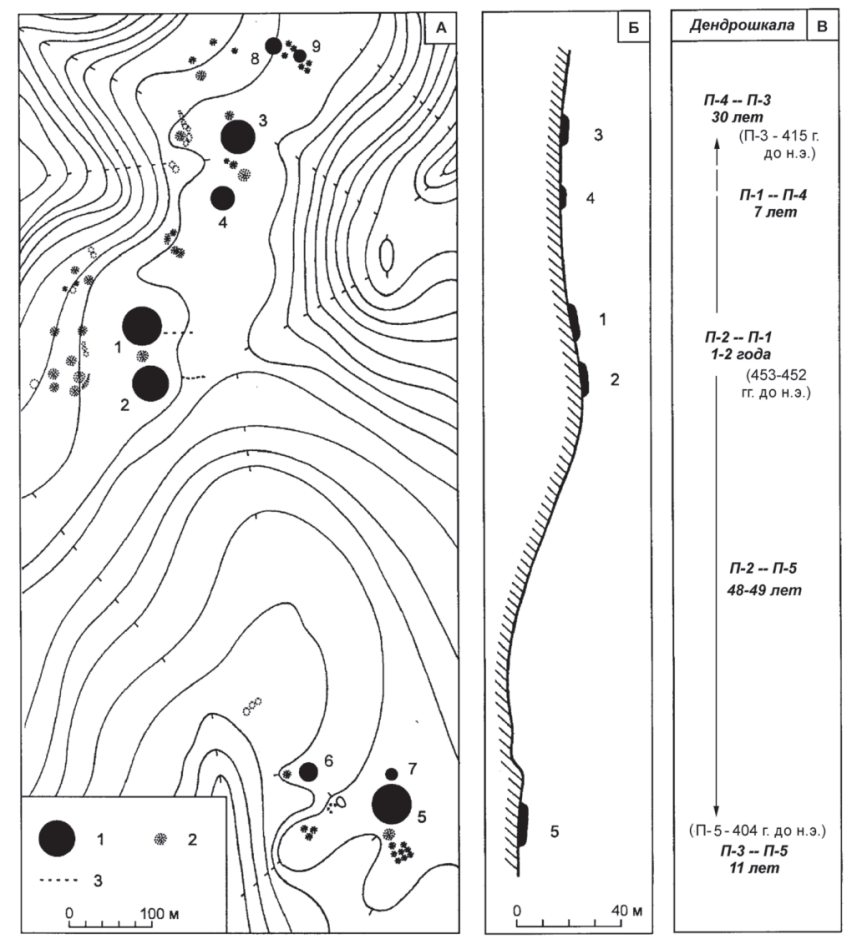

Рис. 2. Алтай. План группы курганов в урочище Пазырык:

$A$ - план урочища; $Б$ - разрез урочища (вертикальный масштаб увеличен);

$B$ - дендрохронологическая шкала и очерёдность сооружения больших курганов.

Очерёдность сооружения объектов в Пазырыке: 2 - 1-4-3-5 курганы.

Первым в урочище был воздвигнут курган № 2, затем через 1-2 года курган № 1, ещё через 7 лет - курган № 4, а после него через 30 лет курган № 3

и последним на нижней площадке сооружён курган № 5, через 11 лет после № 3.

Условные обозначения: 1 - курганы с насыпью из камней;

2 - выкладки из камней; 3 - вертикальные камни-стелы.

По материалам М.П. Грязнова, С.И. Руденко (А) и Л.С. Марсадолова (A-B)

а сама семейная «цепочка» в большинстве случаев формировалась с юга на север (рис. 2). Это предположение подтверждается различными данными.

Во-первых, дендрохронологией и топографией: в Пазырыке первым воздвигли курган № 2, самый южный на верхней террасе (рис. 2; Марсадолов, 1984. С. 92).

Во-вторых, стратиграфическими наблюдениями. В Туэкте южные края каменной выкладки и кольцо 2-го кургана перекрывают кольцо из плит 1-го кургана, то есть более южный и более крупный 1-й Туэктинский курган сооружён раньше 2-го, расположенного севернее (Руденко, 1960. С. 94. Рис. 52; 106). На могильном поле в Башадаре в процессе раскопок автора было выявлено, что насыпи трёх малых курганов (№ 8, 9 и 10) последовательно перекрывают одна другую с юга на север (Марсадолов, 1997. С. 30. Рис. 5). 
В-третьих, сравнительным анализом археологических находок - предметов из могильников Пазырык и Кок-су 1 и др. В могильнике Кок-су 1 весьма архаичные предметы найдены в курганах № 31 и 17, а эти курганы самые южные в небольших самостоятельных курганных группах (Марсадолов, 1984; Сорокин, 1974. С. 90-91).

Пазырыкская «цепочка» курганов - единственная в Евразии полностью раскопанная группа больших курганов, очерёдность которых определена с точностью до года и даже сезона года. В урочище Пазырык первым был сооружён курган 2-й, самый южный на верхней террасе, а затем курганы 1, 4 и 3-й, расположенные севернее. Хотя в Пазырыке топографические условия позволяли соорудить ещё несколько курганов севернее 3-го, наиболее поздний по времени 5-й курган был воздвигнут южнее самого раннего 2-го кургана, но на нижней террасе урочища (рис. 2; Марсадолов, 1984, 1988).

Звёздная (Алтай), солнечная (Тува) и лунная (Хакасия) ориентация сакральных направлений при сооружении «цепочек» курганов. В ходе детальных палеоастрономических исследований Саяно-Алтайской археологической экспедиции Государственного Эрмитажа в 1980-2000-е годы на ряде больших курганов было выяснено, что расположение курганов в разных регионах Саяно-Алтая принципиально отличается по планиграфии объектов.

В Туве около поселка Аржан большие курганы (VI-V вв. до н.э.) ориентированы по Солниу, в противоположную сторону - по линии $\boldsymbol{C B}-\boldsymbol{H O}$ - на высокую точку восхода в день летнего солнцестояния и низкую точку захода солнца в день зимнего солнцестояния (рис. 1: 1). На могильном поле Аржан-IV от доминантного центра - самого большого кургана диаметром около 100 м, в соответствии с высоким летним положением восхода Солнца на СВ размещали только большие курганы вождей и знати с насыпью диаметром от 40 до 65 м, а степной участок, находящийся на линии низкого положения захода Солнияа зимою на ЮЗ, был отведён для погребений людей в средних по размерам курганах, относящихся к более низкому социальному рангу, с насыпями диаметром om 16 до 35 м. В Аржане-IV почти нет малых курганов, что в целом свидетельствует об элитарном социальном ранге погребённых там людей. Следует отметить, что разрывы на ЮB и СЗ у ряда выкладок и ровиков курганов, противоположны по своей направленности общей линии «цепочек» курганов - с ЮЗ на СВ. В целом это связано с тем, что выкладки и ровики с низкой точки восхода солнца в день зимнего солнцестояния на ЮВ ориентировали на высокую точку захода в день летнего солнцестояния на СЗ. Погребённых в таких курганах также в большинстве случаев ориентировали головой на С3, лицом на восток (Марсадолов, 2004, 2009).

На Салбыкском курганном поле в Хакасии прослеживается несколько «цепочек» курганов, ориентированных по линиям С3-ЮВ. Как и в Туве, в Салбыке также можно планиграфически выявить расположение разных по размерам и социальному рангу объектов: на C3 в основном находятся крупные, а на ЮВ - 
средние и малье тагарские курганы (рис. 1: 2). Большой Салбыкский курган доминирует на местности, в её более высокой северо-западной части, что особенно заметно с более низкой южной стороны долины. В Салбыке «цепочка» курганов ориентирована по линии $\boldsymbol{C}$ 3-ЮВ - линии восхода и захода Луньл (рис. 1:2).

Курганы Тувы и Алтая имеют круглую форму каменной насыпи и крепиды, а в Хакасии - подквадратную ограду из горизонтальных плит и вертикальных стел.

Курганы пазырыкской культуры Алтая, как правило, расположены «цепочкой», ориентированной по линии юг - север, и южный курган является наиболее ранним (Туэкта, Пазырык и др.). Но есть и могильники, в которых «цепочка» курганов вытянута по линии запад - восток.

Возможно, в ряде случаев ориентировка «цепочки» курганов зависела от доминирующего окружающего ландшафта - направлений горных хребтов, межгорной долины, наиболее почитаемой в этом районе горы, бассейна реки и т.п.

Сакральное ориентирование объектов. На материалах из археологических памятников Саяно-Алтая I тыс. до н.э. можно проследить пространственные и временные представления о 4 направлениях «путей-дорог», в основном ведущих от Земли на Небо. Эти направления, разные по своей ориентации, вероятно, были связаны с идей суточного, годового и многолетнего движения Солнца, Луны и Созвездий. Сакрально-навигационные идеи основывались на осознании объёмных пространственных координат - вертикальной (верх - низ), горизонтальной (вперёд - назад или право - лево) и двух диагональных:

1) с востока на запад, линия ежедневного восхода - захода Солнца, а также весеннего и осеннего равноденствия (горизонтальная линия);

2) с юга на север, от ежедневной высокой точки Солнца в полдень на юге к наивысшей неподвижной ночной точке в области незаходящих звёзд на севере, из тепла в холод (вертикальная линия);

3) с юга-запада на северо-восток, из низшей точки захода Солнца в день зимнего солнцестояния до высшей точки восхода солнца в день летнего солнцестояния, из холода к теплу (диагональная линия);

4) с юго-востока на северо-запад, из точки восхода низкой Луны на ЮВ к точке захода высокой Луны на С3 (диагональная линия в Салбыке) и т.д.

Все вышеуказанные направления, зафиксированные в планиграфии погребальных объектов древних кочевников Саяно-Алтая и отражали основную сакральную цель - через Смерть - к новому Возрождению (Марсадолов, 2009; 2010).

Таким образом, ориентировка «цепочек» курганов и форма их наружных насыпей/оград, наряду с другими признаками, может служить важным дополнительным критерием для этнокультурного подразделения крупных регионов археологических памятников. 


\section{ЛИТЕРАТУРА}

Грязнов М.П. Первый Пазырыкский курган. Л.: Изд-во Гос. Эрмитажа, 1950. 90 с.

Грязнов М.П. Аржан. Царский курган раннескифского времени. Л.: Наука, 1980. $64 \mathrm{c}$.

Дэвлет М.А. Большой Салбыкский курган - могила племенного вождя // Из истории Сибири. Вып. 21. Томск: Изд-во Томского ун-та, 1976. С. 146-154.

Замоторин И.М. Относительная хронология Пазырыкских курганов // Советская археология. М.: Изд-во АН СССР, 1959, № 1. С. 21-30.

Киселёв С.В. Исследование Большого Салбыкского кургана в 1954 и 1955 гг. // Тезисы докладов на сессии Отделения исторических наук и пленуме ИИМК, посвящённых итогам археологических исследований 1955 г. М., 1956. С. 56-58.

Марсадолов Л.С. О последовательности сооружения пяти больших курганов в Пазырыке на Алтае // АСГЭ. Л.: Искусство, 1984. Вып. 25. С. 90-98.

Марсадолов Л.С. Хронологическое соотношение Пазырыкских и Семибратних курганов // АСГЭ. Л.: Искусство, 1987. Вып. 28. С. 30-37.

Марсадолов Л.С. Дендрохронология больших курганов Саяно-Алтая I тысячелетия до н.э. // АСГЭ. Л.: Искусство, 1988. Вып. 29. С. 65-81.

Марсадолов Л.С. История и итоги изучения археологических памятников Алтая VIII-IV веков до н.э. (от истоков до начала 80-х годов XX века). СПб.: Вичи, 1996. $100 \mathrm{c}$.

Марсадолов Л.С. Исследования в Центральном Алтае (Башадар, Талда). СаяноАлтайская экспедиция Государственного Эрмитажа. Вып. 1. СПб.: Com Mark Nord, 1997. $56 \mathrm{c}$.

Марсадолов Л.С. Пазырыкский феномен и попытки его объяснения // Итоги изучения скифской эпохи Алтая и сопредельных территорий. Барнаул: Изд-во Алтайского гос. ун-та, 1999. С. 104-107.

Марсадолов Л.С. Археологические памятники IX-III вв. до н.э. горных районов Алтая как культурно-исторический источник (феномен пазырыкской культуры). Автореф. дисс. ... к.и.н. докт. культурологии. СПб.: Изд-во Гос. Эрмитажа, 2000. $56 \mathrm{c}$.

Марсадолов Л.С. Проблемы уточнения абсолютной хронологии больших курганов Саяно-Алтая I тыс. до н.э. // Радиоуглерод и археология. Вып. 2. СПб., 1997. C. $45-51$.

Марсадолов Л.С. Памятник Аржан IV в Туве // Центральная Азия и Прибайкалье в древности: Сборник научных трудов. Выпуск 2. Улан-Удэ: Изд-во Бурятского гос. университета, 2004. С. 121-133.

Марсадолов Л.С. Гордион в Анатолии (Турция) - военная база кочевников Евразии в VIII-VI веках до н.э. // Современные проблемы археологии России. Материалы Всероссийского археологического съезда (23-28 октября 2006 года). Том II. Новосибирск: Изд-во ИА и Э СО РАН, 2006. С. 40-42.

Марсадолов Л.С. Курган Аржан-1 в Центре Азии (геополитический и астрономический аспекты) // Наследие народов Центральной Азии и сопредельных территорий: изучение, сохранение и использование. Материалы Международной научнопрактической конференции, г. Кызыл, 9-10 сентября 2009 г. В 2 частях. Часть І. Кызыл, 2009. С. 59-63. 
Марсадолов Л.С. Большой Салбыкский курган в Хакасии. Абакан: Хакасское книжное изд-во, 2010. 128 с.

Марсадолов Л.С. Жертвоприношения на сакральных путях-направлениях у древних кочевников Саяно-Алтая // Жертвоприношение в архаике: атрибуция, назначение, цель. Сборник научных трудов семинара «Теория и методология архаики». СПб., 2012. C. $87-115$.

Руденко С.И. Культура населения Горного Алтая в скифское время. М.-Л.: Издво АН СССР, 1953. 403 с.

Руденко С.И. Культура населения Центрального Алтая в скифское время. М.-Л.: Изд-во АН СССР, 1960. 359 с.

Сорокин С.С. Цепочка курганов времени ранних кочевников на правом берегу Кок-су (Южный Алтай) // АСГЭ. Л.: Искусство, 1974. Вып. 16. С. 62-91. 


\section{ПОГРЕБАЛЬНЫЕ КОМПЛЕКСЫ С МЕРЗЛОТОЙ НА СЕВЕРО-ЗАПАДЕ МОНГОЛИИ (ПАЗЫРЫКСКАЯ КУЛЬТУРА)}

(Работа выполнена в рамках проекта № 0329-2016-0003 «Историко-культурные процессы в Сибири и на сопредельных территориях»)

\section{Молодин В.И., Парцингер Г.}

http://10.25681/IARAS.2019.978-5-317-06274-3/144-158

В начале нашего столетия успешно реализован международный (российскогерманско-монгольский) мультидисциплинарный проект по изучению погребальных комплексов пазырыкской культуры с мерзлотой в Северо-Западной части Монголии. В результате разведок и геофизического мониторинга было выявлено три объекта с мерзлотой, на которых и произведены раскопки. Наиболее информативным оказался курган № 1 памятника Олон-Курин-Гол-10. Погребальная камера и помещённый в неё бревенчатый сруб оказались не потревоженными и благодаря образовавшейся над ней линзе мерзлоты содержали предметы из органики. Сохранились кости двух сопровождающих лошадей с набором деревянных украшений. В погребальной камере сохранился почти весь сопроводительный набор предметов, хуже - органические остатки самого человека. Прекрасно сохранилась одежда погребённого, а также оружие, поясной набор, посуда, украшения, предметы туалета. Проведены мультидисциплинарные исследования комплексов, среди которых особо отмечаются дендрохронологические и палеогенетические.

Ключевые слова: Северо-Западная Монголия, пазырыкская культура, Олон-КуринГол-10

В 2004-2006 гг. был реализован международный (российско-германскомонгольский) мультидисциплинарный проект по нахождению, геофизическому мониторингу и раскопкам курганов пазырыкской культуры с мерзлотой в северо-западной части Монголии (рис. 1). Выбор территории, конечно же, был не случаен. Здесь, по Сайлюгемскому хребту, проходит граница Монгольской народной республики с Россией, где на плато Укок в начале девяностых годов прошлого века российскими археологами Института археологии и этнографии СО РАН под руководством Н.В. Полосьмак и В.И. Молодина были проведены многоплановые исследования, в том числе памятников пазырыкской культуры с мерзлотой, обогативших мировую науку уникальными данными; при этом, мультидисциплинарные исследования позволили вывести интерпретацию источников вообще на качественно новый уровень (См. напр: Полосьмак, 1994; 2001; Полосьмак, Молодин, 2000; Молодин, Полосьмак, Чикишева и др., 2000).

Перед нашей совместной экспедицией, руководителями которой были авторы этих строк, а также профессор Д. Цэвээндорж, стояли непростые задачи - провести фронтальные разведки в избранном районе, где главной целью 


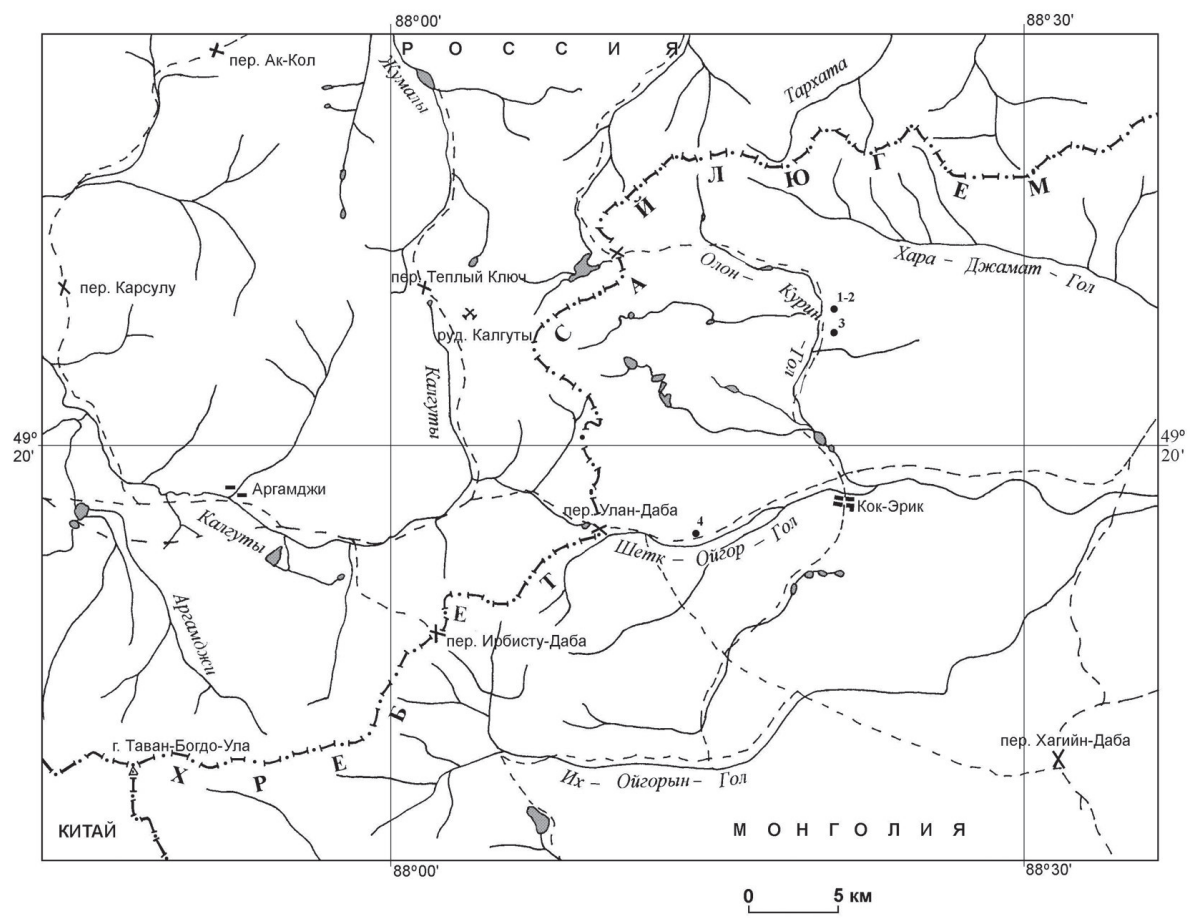

Рис. 1. Карта-схема расположения археологических памятников, исследованных в 2006 году.

1 - Олон-Курин-Гол-6; 2 - Олон-Курин-Гол-7;

3 - Олон-Курин-Гол-10; 4 - Улан-Даба-1

было обнаружение памятников пазырыкской культуры; осуществление геофизического мониторинга максимально большого количества курганов, направленного на обнаружение мерзлотных образований; наконец, третье и самое главное - провести раскопки избранных объектов, сочетаемые с максимально широким спектром мультидисциплинарных исследований. Не менее масштабны были и последующие задачи, связанные с реставрацией и консервацией полученных реалий, а также монографическими изданием сформированного корпуса источников и их интерпретации.

В общей сложности на реализацию проекта потребовалось четыре месяца (на протяжении трёх лет) - один на разведки, один на геодезические исследования и два на раскопки. Забегая вперёд, следует констатировать, что программа была завершена триумфально.

В результате разведок, проведённых в долинах, примыкающих к границе и далее к плоскогорью Укок, было открыто и документировано 93 объекта, среди которых можно, судя по всему, говорить о 15 могильниках, которые по своей планиграфии и специфическим особенностям с большой долей вероятности можно было относить к пазырыкской культуре (Молодин, Слюсаренко, Гаркуша и др., 2012). 
Последующий геофизический мониторинг был произведён на 12 объектах, позиционируемых нами как курганы пазырыкской культуры. В результате этих исследований выяснилось, что только три объекта на разных могильниках содержали мерзлотные аномалии (Эпов, Чемякина, Манштейн и др., 2012), на них-то и были произведены раскопки.

Памятники Олон-Курин-Гол-6 (курган №2) и Олон-Курин-Гол-10 (курган № 1) представляли классические образцы могильников и курганов пазырыкской культуры, хорошо изученных на юге российского Алтая, в том числе на плато Укок (См. напр: Полосьмак, Молодин, 2000; Кубарев, 1992). Исследование этих объектов велось по общепринятой методике, применяемой в российской и мировой археологии. Подробное описание полевых исследований заинтересованный читатель может найти в обобщающих монографиях, вышедших в Европе, России и Монголии (Parzinger, Molodin, Cevendorzž, 2008; Молодин, Парцингер, Цэвээндорж, 2012; Цэвээндорж, Молодин, Парцингер, 2016; Молодин, 2013).

Курган № 2 памятника Олон-Курин-Гол-6 был, к сожалению, сильно потревожен при ограблении, и, хотя в нем благодаря мерзлоте сохранились отдельные предметы из дерева и даже фрагменты тканей, а также остатки сруба, тем не менее, он не шёл ни в какое сравнение с курганом могильника ОлонКурин-Гол-10, в котором, в силу ряда обстоятельств, погребальная камера (как и всё её содержимое) сохранились лучше, чем где-либо на Алтае. К тому же, эта могила не была подвергнута каким-либо проникновениям, благодаря чему до нашего времени дошли почти все нюансы погребальной практики, кроме того, очень хорошо сохранились и сами предметы, в неё помещённые. В силу ряда сложившихся при захоронении обстоятельств (а именно: характера глинистой почвы, прекрасно выполненный из лиственничных бревен погребальный сруб, ставший герметически закрытым сооружением, в который после его изоляции ничего, кроме воды, не проникало; наконец, плотное глиняное перекрытие верхней части погребальной камеры, не только препятствующее визуальному восприятию контуров могильной ямы, но и вообще всяческому проникновению), мы имели дело с объектом, весьма близким к тому, каким он был почти две с половиной тысячи лет тому назад!

Итак, после исследования надмогильного сооружения, кургана № 1 памятника Олон-Курин-Гол-10, верхняя часть которого сильно пострадала от действия современного населения, разобравшего каменную наброску насыпи на хозяйственные нужды, мы определили контур могильной ямы, расположенной в центральной части конструкции. Как оказалось, яма имела размеры $3 \times 2,4$ м и была углублена в материк на 1,8 м. На дне могилы был возведён сруб, в 3 венца, выполненный из массивных лиственничных полубрёвен диаметром до 30 см. Конструкция сооружена, что называется, «в обло», и как оказалось, не имела пола. В качестве перекрытия сруба служили ещё 6 брёвен, плотно подогнанных одно к другому. Это привело к тому, что в камеру проникло лишь небольшое 
количество воды, и она оказалась внутри практически свободной ото льда, однако то, что проникло и было аккумулировано на дне могилы - замёрзло и, таким образом, образовало своего рода термос-холодильник со всеми вытекающими последствиями. Минусовой температуры внутри сруба вполне хватило для сохранения в нем органических остатков, однако было недостаточно, чтобы воспрепятствовать разложению двух лошадей, уложенных на крышку погребального сруба. При этом до нашего времени, помимо костяков, всё-таки сохранились отдельные деревянные украшения конской упряжи, среди которых особенно эффектны подвески в виде парных головок грифонов, первоначально покрытые серебристой фольгой (олово?) (рис. 2). Перед нами типичные произведения, характерные для памятников пазырыкской культуры с мерзлотой данного региона. Их количество было не менее 15. Почти абсолютные аналогии данным изделиям мы находим на памятниках Bepx-Кальджин-II (Molodin, 1996. Fig. 41) и Ак-Алаха-1 (Полосьмак, 1994. С. 51. Рис. 58-1), а также в соседствующих с Укоком курганах Уландрыка и Юстыда (Кубарев, 1987. С. 36. Рис. 13 (6, 7); 1991. Табл. XLV-3). К числу других деревянных украшений, сохранившихся на лошадях, являются также конусовидные подвески, серия имитаций кабаньих клыков, окрашенных чёрной краской. Составляющими элементами удил являются частично сохранившиеся деревянные, художественно оформленные развилки, а также двудырчатые псалии с симметрично изогнутыми лопаточковыгнутыми навершиями (рис. 3). Перед нами явная имитация металлических псалий, относящихся к раннегуннскому времени и датируемых III в. до н.э. (The Subterranean Army, 2005. Р. 90). Наличие данных изделий позволяет предложить наиболее позднюю датировку изученного комплекса в пределах пазырыкской

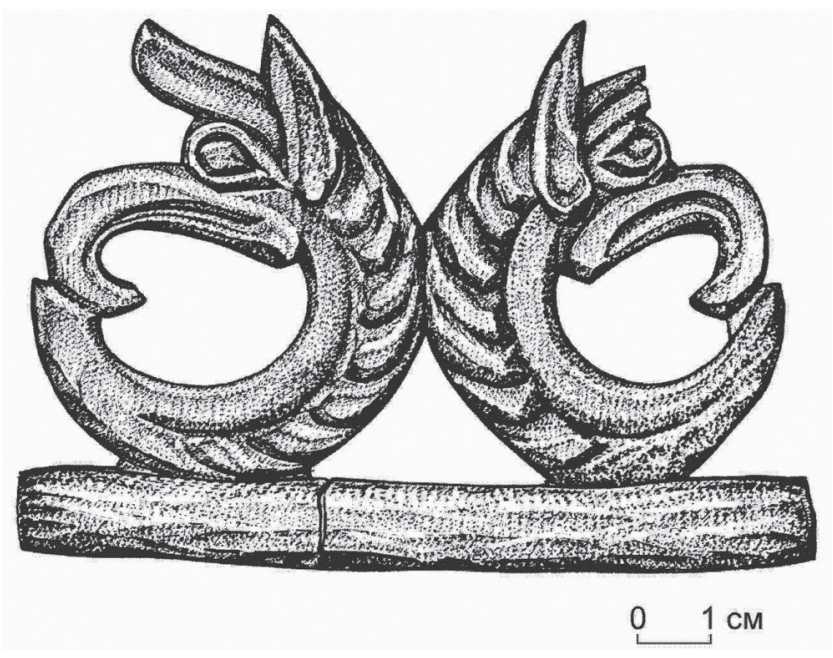

Рис. 2. Подвеска.

Деревянное украшение конской упряжи. Памятник Олон-Курин-Гол-10 (лошадь № 2)

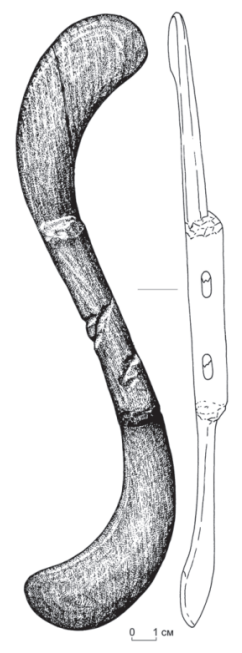

Рис. 3. Деревянный псалий. Памятник Олон-Курин-Гол-10 (лошадь № 1) 
культуры. Кроме того, на лошади 2 сохранился войлочный фрагмент седла и деревянные седельные дуги, а также застежки-ворворки.

Особенностью почти всех деревянных изделий, обнаруженных на обеих лошадях, является наличие на них серебристого налёта, по-видимому, олова. Очевидно, что украшенная таким образом амуниция была весьма эффектна, производя ассоциацию с массивными серебряными предметами.

К иным атрибутам, которые можно относить к конской упряжи, принадлежат застежки для пут «цурки», а также рукоять плети.

Кроме перечисленных изделий, к седлу одной из лошадей был приторочен деревянный щит - традиция, характерная для носителей пазырыкской культуры. Щит был подпрямоугольной формы с закруглёнными углами. Внешняя поверхность украшена резным орнаментом.

После вскрытия брёвен перекрытия перед нами оказалось практически пустая погребальная камера с промёрзшим дном. Сохранность почти всех артефактов (за исключением отдельных механических нарушений) была очень хорошей. Хуже сохранился сам погребённый, от которого, однако, уцелели ноги, рыжеватые волосы и фрагмент кожи с татуировкой.

Умерший был положен по классическим для рядовых носителей культуры канонам - на слегка приподнятым над дном могилы помосте из лиственничных плах, покрытых чёрным войлоком. Он лежал на правом боку, в скорченном положении, головой на ЮВ. Особое место в погребальных аксессуарах занимала одежда, обувь и головной убор. Сохранность их была вполне удовлетворительной, однако, после проведённых в лаборатории Института археологии и этнографии СО РАН реставрационных работ - они выглядят великолепно.

Погребённый был одет в короткие шерстяные штаны, сшитые по бокам с вшитой спереди мотнёй. Штаны не имели приспособлений для крепления на поясе при носке, поэтому, возможно, были изготовлены для захоронения. Укороченная длина, вероятно, говорит о моде, характерной уже для гуннского времени, что было прослежено С.И. Руденко для Ноин-Улинских курганов этого времени в Монголии (Руденко, 1962. С. 39. Рис. 32. Табл. Х, ХI).

Замечательным изделием является меховая шуба (рис. 4 а, б, в), надетая на голое тело погребённого, что, по наблюдениям в пазырыкских курганах Укока, где были найдены первые две шубы in situ, являлось обычным явлением. Специальные определения меха, впервые выполненные профессиональными биологами и генетиками, позволяют однозначно говорить, из меха каких животных было выполнено данное изделие (Молодин и др., 2009). Верхняя наружная часть шубы и подбортовка выполнены из шкурок соболя (рис. 4 a, б); нижняя наружная часть из меха белки (рис. 4 а, б), внутренняя часть шубы и окантовка выполнены из меха грубошёрстной овцы, а апплицированный орнамент - из меха домашней лошади; кисточки, украшающие спину шубы выполнены из крашенного конского волоса (рис. 4 б, в). 

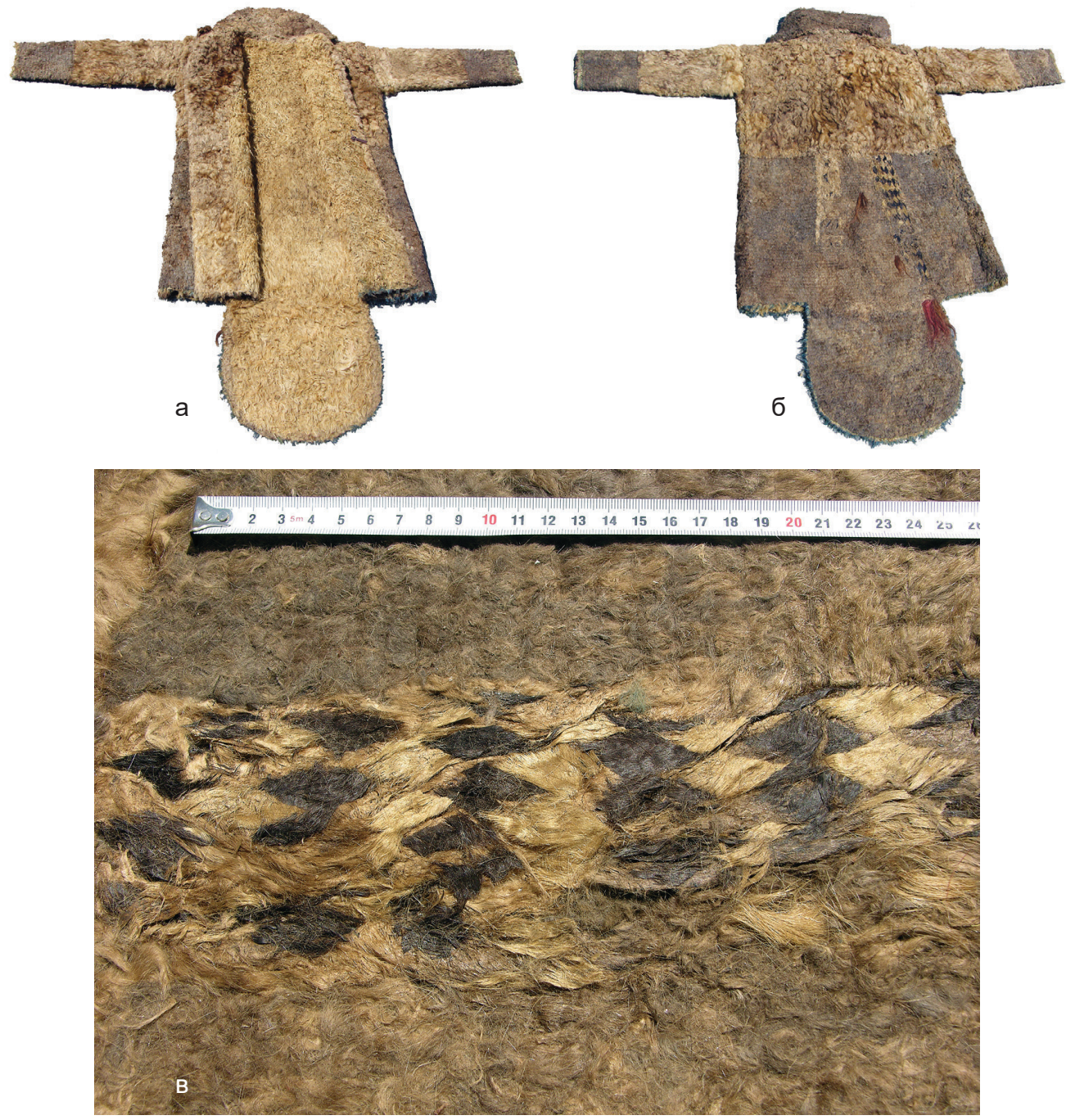

Рис. 4. Меховая шуба. Памятник Олон-Курин-Гол-10.

а) вид спереди; б) вид сзади; в) меховая аппликация

Замечателен и крой шубы, имеющий в нижней задней поле своеобразный, длинный и широкий хвост. Абсолютные аналоги фасона шубы имеются с шубой-дублёнкой из пазырыкского могильника Верх-Кальджин-II (Молодин, 2000. С. 102), причём их сближает не только наличие хвоста, но и украшение из крашенного конского волоса. Уместно отметить, что шубы с хвостами зафиксированы этнографами у ряда коренных сибирских народов (Васильевич, 1958). По мнению Н.В. Полосьмак и Л.Л. Барковой (2005), хвост у пазырыкских шуб мог быть заимствован из нарядов сакских шуб (кандисов).

На голове погребённого был надет типичный для носителей пазырыкской культуры войлочный шлемовидный головной убор, украшенный в верхней ча- 
сти стилизованным деревянным изображением птицы. Макушку и налобную часть шлема венчали деревянные фигурки лошадок, с оленьими рогами из кожи, покрытые золотой фольгой. Более крупная, составная фигурка оленя украшала одну из боковых сторон шапки (рис. 5). Аналогии такому головному убору широко известны в замерзших комплексах пазырыкской культуры, в условиях, где они могли сохраняться (См., напр.: Молодин, 2000. С. 104. Рис. 125; Полосьмак, 1994. С. 40. Рис. 34). Как справедливо утверждают Н.В. Полосьмак и Л.Л. Баркова - такие головные уборы являлись одним из главных символов пазырыкского сообщества (Полосьмак, Баркова, 2005. С. 82-84).

На ногах погребённого были надеты войлочные сапоги-чулки. Изделия изготовлены из целого куска войлока и прошиты сзади по всей длине. Отдельно была пришита войлочная подошва. В районе голеностопа сапоги были обшиты шерстяными лентами, окрашенными в малиновый цвет.

Аналогичные сапоги-чулки были обнаружены в целом ряде захоронений пазырыкской культуры, исследованных на плато Укок (Молодин, 2000. С. 101. Рис. 117, 118). Помимо трёх прекрасно сохранившихся пар и многочисленных фрагментов, такая обувь была обнаружена во втором Пазырыкском кургане (Руденко, 1953. С. 111).

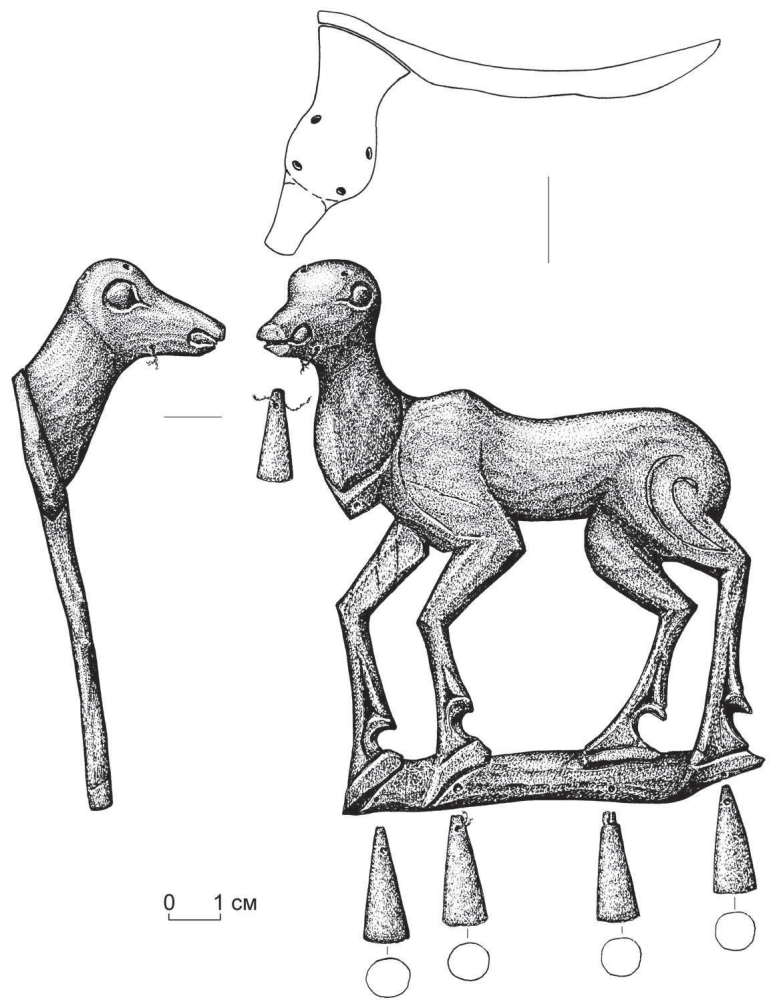

Рис. 5. Деревянное украшение боковой части головного убора.

Памятник Олон-Курин-Гол-10 
Таким образом, обнаруженная в пазырыкском кургане Монголии одежда полностью соответствует традициям, которые были присущи носителям пазырыкской культуры на всей территории её существования.

Одним из главных атрибутов, сопровождающих умершего в иной мир, был оружейный набор, по-видимому, одна из главных (если не главная!) составляющая орудийного набора мужчины в пазырыкском сообществе.

К числу оборонительного оружия следует отнести деревянный щит, о котором речь уже шла выше. Остальной набор следует отнести к наступательному оружию ближнего и дальнего боя. На бедре погребённого обнаружен железный боевой кинжал в деревянных ножнах с выраженным перекрестием и брусковидным навершием (рис. 6). Несмотря на, казалось бы, простейшую форму, характеризуемый кинжал не имеет полных аналогий. Ножны односторонние, в верхней части имеют два симметрично поставленных, слегка приостренных выступа. В средней части ножен имеет место ещё одна горизонтальная лопасть. Лопасти имеют функциональное значение, поскольку за отверстия, в них проделанные, ножны с кинжалом фиксировались к бедру человека. На ножнах прослежены следы красной краски, в которую они и были окрашены.

И кинжал, и ножны являются типичными образцами пазырыкской культуры (Molodin, 1996; Кубарев, 1981).

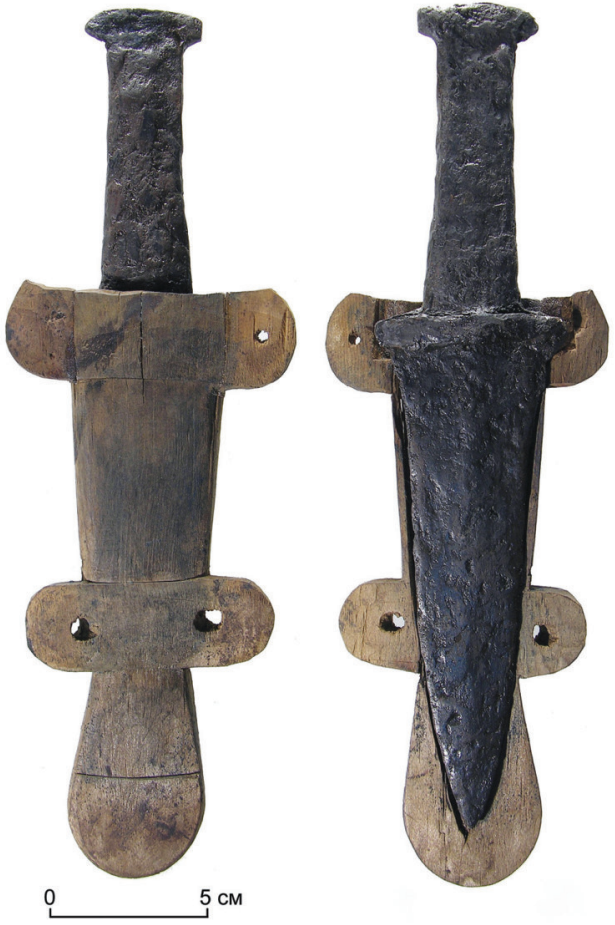

Рис. 6. Железный кинжал в деревянных ножнах. Памятник Олон-Курин-Гол-10
К поясу погребённого, у левого бедра был подвешен железный клевец; на прекрасно сохранившейся деревянной рукояти, с выраженным на конце втоком. Рукоять была прокрашена зонами чёрного цвета. Боевая часть клевца стержневидная, округлая в разрезе. Ударная часть оформлена в форме четырёхгранного бойка. Обушок выполнен в виде топорика.

Боевые клевцы, как и кинжалы, были типичными в оружейном наборе носителей пазырыкской культуры. Интересно отметить, что довольно существенный процент боевых железных изделий был обнаружен в пазырыкских захоронениях Укока (Молодин, 2000. С. 107. Рис. 132).

Оружие дальнего боя представлено луком, набором деревянных стрел и сохранившихся частей колчана. Следует сказать, что обнаруженный в захоронении лук является одним 
из лучших находок в комплексе, и впервые был обнаружен целым на пазырыкских памятниках. Тело лука было сложносоставным, склеенным из восьми основных деталей, а также четырёх дополнительных накладок. Общая длина его составляла 119 см. Тело ассиметрично. Детальное его описание было дано нами в специальной монографии, к которой мы и отсылаем заинтересованного читателя (См.: Молодин, Парцингер, Цэвээндорж, 2012. С. 41). Следует добавить, что не раз обнаруженные детали луков в пазырыкских комплексах российского Алтая (См.: Кубарев, 1987; Молодин, 2000), а также соседних районах Центральной Азии (Новгородова, 1989. С. 334-335) свидетельствуют об их конструктивной близости. Несомненное сходство демонстрируют и конструкции савроматских луков (Смирнов, 1961. С. 32).

Вместе с луком лежали пять деревянных стрел с имитированными наконечниками. Эти изделия также типичны для погребальных комплексов пазырыкской культуры практически на всей территории существования последней.

Сохранившийся горит, в котором и были помещены в могилу лук и стрелы, традиционно был выполнен из шкур лошади и оленя мехом наружу. Футляр был снабжен деревянной пластиной жёсткости. Прекрасно сохранилась войлочная съемная крышка горита, выполненная в виде двухцветного колпака с кистями (рис. 7). Абсолютные аналогии подобным крышкам обнаружены одним из авторов в пазырыкском погребальном комплексе памятника Верх-Кальджин-II на плато Укок (Молодин, 2000; Molodin, 1996).

Несомненно, особенно значимым атрибутом, сопровождающим воина в иной мир, был поясной набор, который имел как практическое, так, вероятно, и семантическое значение. В исследуемом захоронении, сам пояс, к сожалению, не сохранился, однако о его присутствии свидетельствуют деревянные прямоугольные и квадратные бляхинакладки (всего 7 штук), украшенные по периметру резной окантовкой и первоначально окрашенные в красный и чёрный цвет (рис. 8). Очевидно, что к поясной гарнитуре относятся 6 деревянных пуговиц. Изделия имели конусовидную форму, они были круглые в плане, различного диаметра с отверстием в центре и окрашены в чёрный цвет.

Аналогии поясам и аксессуарам портупеи в виде фрагментов и деревянных составляющих не раз встречены в погребальных комплексах с мерз-

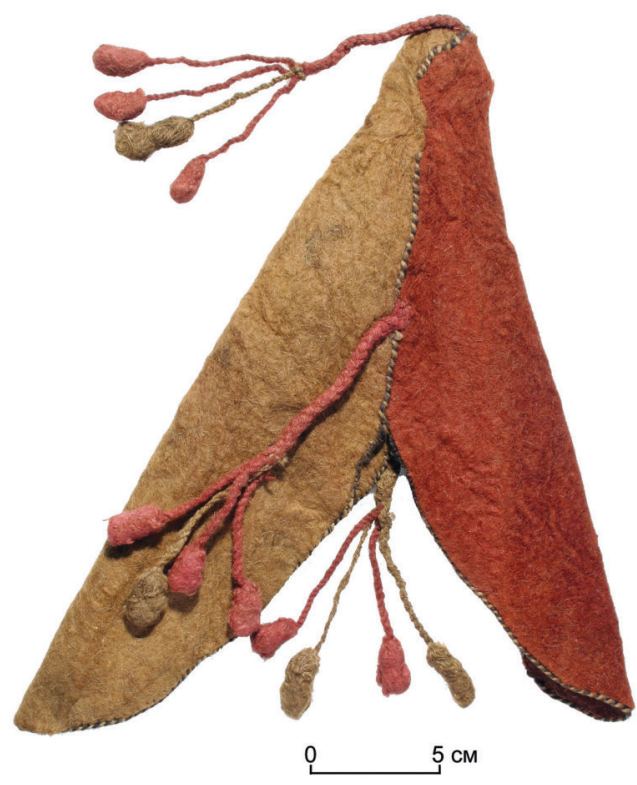

Рис. 7. Войлочная крышка горита. Памятник Олон-Курин-Гол-10 

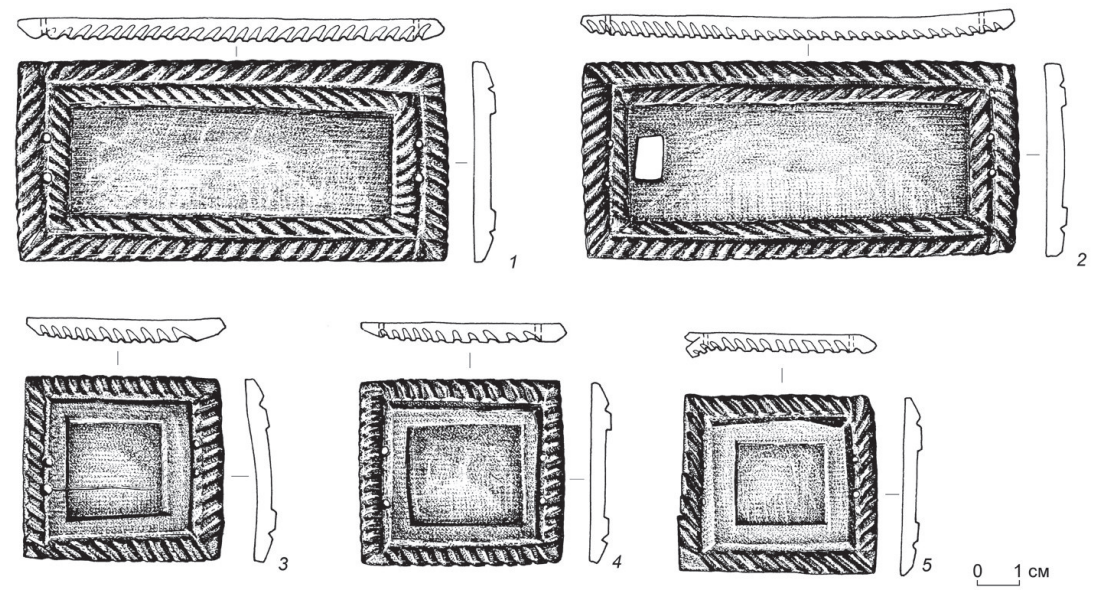

Рис. 8. Деревянные накладки на пояс. Памятник Олон-Курин-Гоол-10

лотой Южной части российского Горного Алтая (Кубарев, 1987; 1991; 1992; Молодин, 2000; Molodin, 1996).

Особое место среди погребального инвентаря занимала посуда и предметы быта, в целом типичные для пазырыкских памятников. В характеризуемом

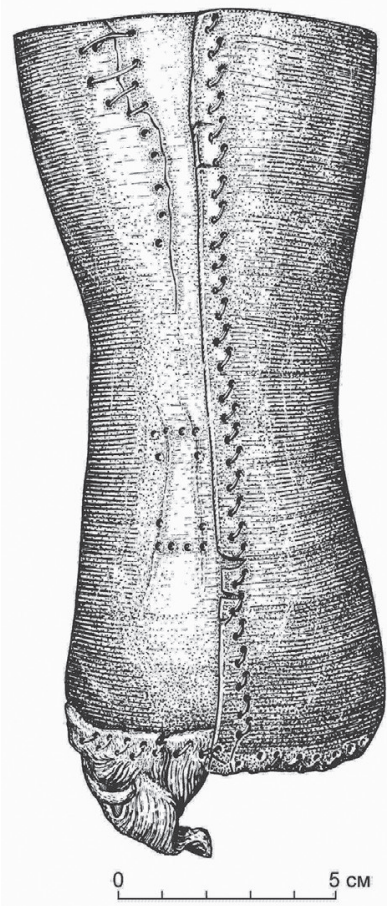

Рис. 9. Сосуд из рога. Памятник Олон-Курин-Гол-10 комплексе обнаружен полный набор ритуальной посуды, характерный, по крайней мере, для рядовых членов пазырыкского сообщества. Он состоит из трёх емкостей - деревянного, глиняного и рогового сосудов, стоящих на специальных войлочных подставках, а также деревянного блюда на ножках. Вероятно, что в три различные по качеству емкости наливалась различная жидкая пища, а на деревянное блюдо помещались мясо и нож для его разделки. Глиняный сосуд как индикатор культурной принадлежности был типичен для погребальных памятников пазырыкской культуры (См.: Суразаков, 1989; Степанова, 1998; Кирюшин, Степанова, 2004).

Особый интерес, конечно, представляет своеобразный сосуд из рога (рис. 9), который лишь шестой, обнаруженный в многочисленных погребальных комплексах пазырыкской культуры. Абсолютно аналогичный сосуд был найден в кургане № 3 памятника Верх-Кальджин-II на соседнем Укоке (Молодин, 2000. С. 113. Рис. 142).

Следует обратить внимание на особые войлочные подставки под каждый из сосудов. На уже упомянутом выше могильнике Верх-Кальджин-II, анало- 
гичные подставки были даже связанными между собой (Молодин, 2000. С. 98. Рис. 203). Отсутствие практической необходимости для постановки плоскодонных ёмкостей свидетельствует скорее о сакральной, нежели практической роли таких подставок в погребальных комплексах.

К посуде относится и деревянное блюдо с мясной пищей, которое сопутствует кочевникам-скотоводам на протяжении веков, вплоть до современности. Характерной чертой погребальной практики носителей пазырыкской культуры является помещение на блюде курдючной части барана и железного ножа.

Значимое место в погребальной практике носителей пазырыкской культуры, обнаруженное также и в Монголии, имеют украшения и предметы туалета. Наиболее яркими изделиями декоративно-прикладного искусства является шейная гривна (рис.10 а, б). Гривна выполнена из целого куска дерева, изогнутого в замыкающееся кольцо. Центральную часть изделия занимает композиция в виде двух хищников (волков?). Животные переданы в характерной для скифо-сибирского искусства манере (рис. 10 a, б). Гривна, вероятно, была покрыта золотой фольгой, от которой сохранились лишь небольшие фрагменты. Данный атрибут, по-видимому, клановой принадлежности, был характерен как для носителей пазырыкской культуры (Кубарев, 2005) так и для целой свиты культур скифо-сарматского времени Евразии (см.: Смирнов, 1964; Артамонов, 1973; Грач, 1980; Мартынов, 1979).

К предметам туалета относится бронзовое зеркало в войлочном чехле, которое крепилось к поясу умершего. Помещение бронзовых зеркал, как и их имитаций, в захоронение было также характерной чертой погребальной практики носителей пазырыкской культуры. Традиция эта, несомненно, эпохальная и характерна для культур скифского времени. Абсолютный аналог как зеркала, так и чехла имеет место опять-таки на памятнике Верх-Кальджин-II на соседнем Укоке (Молодин, 2000).

Ещё одним предметом, являющимся обязательным в захоронениях носителей пазырыкской культуры, является гребень из рога или дерева. Роговой гребень, обнаруженный в характеризуемом захоронении, имел полукруглое основание и отходящие от него зубцы. Гребень был положен в специальный меховой мешочек, имеющий клапан, фиксируемый деревянной пуговицей.

Таковы предметы, обнаруженные в наиболее южном, несомненно, пазырыкском памятнике Олон-Курин-Гол-10. Как мы видим, все они находят прямые аналогии в пазырыкских комплексах более северных территорий российского Алтая. Интересно, что исследуемый памятник до тождества сопоставим с могильником Верх-Кальджин-II на соседнем Укоке. Об этом же свидетельствуют результаты палеогенетического и дендрохронологического анализов.

Палеогенетический анализ мужчины (Олон-Курин-Гол-10), женщины и ребёнка (Олон-Курин-Гол-6), показал, что их мтДНК, во-первых, относятся к гаплогруппам U5a1 и HV2 и принадлежат западно-евразийскому кластеру 

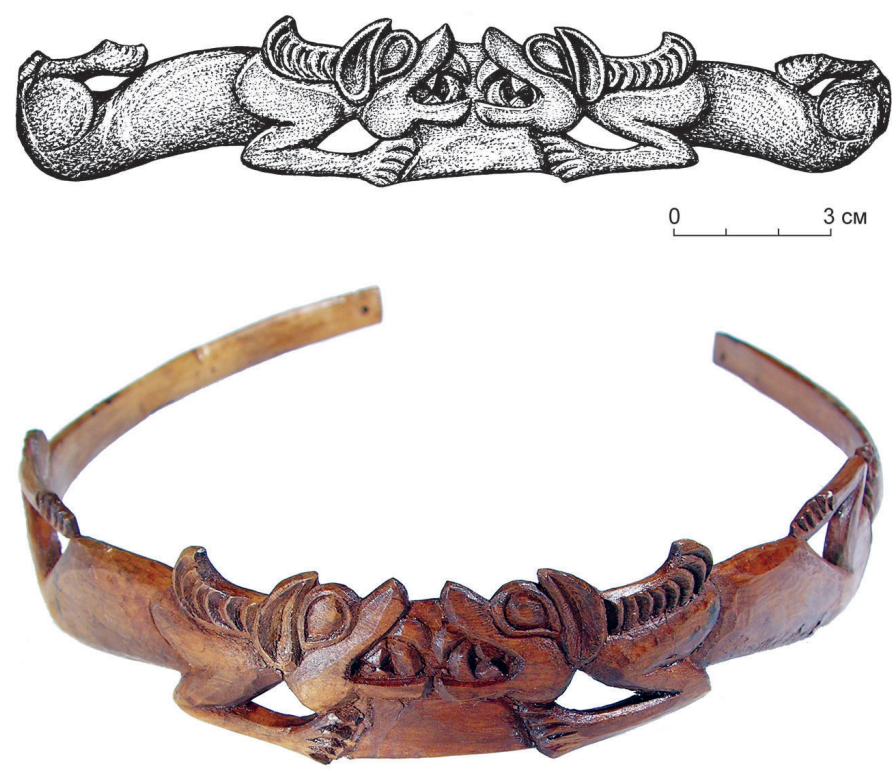

Рис. 10. Шейная гривна. А) прорисовка; Б) фото центрального сюжета. Памятник Олон-Курин-Гол-10

(Пилипенко, Молодин, Ромащенко, 2012), во-вторых, они имеют генетическую близость с пазырыкскими особями Укока. В-третьих, гаплогруппа HV2 была впервые выделена среди пазырыкских особей и, вероятно, принадлежала матери и сыну. Принципиально значимым является вывод о том, что гаплогруппа HV2 демонстрирует Переднеазиатский и Южноазиатский векторы распространения. С учетом данных палеогенетики, антропологии (Чикишева, 2000) и археологии (Руденко, 1968; Полосьмак и др., 2006) можно говорить о проникновении этнокультурных импульсов на Алтай из восточных окраин Ахеменидской империи (Pilipenko and all, 2010).

Анализ инвентаря, а также данные, полученные в результате дендрохронологических исследований (Мыглан, Слюсаренко, Хайснер, 2012) монгольских курганов, их корреляция с образцами российского Алтая (Слюсаренко, 2000; Heussner, Sljusarenko, 2007) демонстрируют, во-первых, возраст кургана памятника Олон-Курин-Гол-10 - 393 г. до н.э., кургана памятника Олон-КуринГол-6 - 388 г. до н.э. Во-вторых, учитывая календарный возраст, определённый для пазырыкских курганов Укока по радиоуглеродному датированию (Слюсаренко и др., 2002), следует констатировать, что монгольские курганы принадлежат тому же короткому интервалу, что и укокские, который приходится на конец IV - первую треть Ш тыс. до н.э., в пределах 39 лет.

Скорее всего, носители пазырыкской культуры проникали в этот район Монголии через Сайлюгемский хребет, со своими стадами мигрируя на юг, по существу, уже в Центральную Азию. 
Как глубоко на юг проникали носители пазырыкской культуры - ещё предстоит выяснить. Исследованный монголо-французской экспедицией могильник Бага-Турчен-Гол-6, расположенный примерно на 200 км южнее пограничного с Россией региона (Торбат и др., 2007), не является исключительно пазырыкским, хотя черты последней культуры и имеют место. В погребальной практике оставившего его населения присутствуют черты чандоманьской культуры Центральной Азии.

Данное обстоятельство лишний раз свидетельствует об интенсивных контактах между обитателями этого района Южной Сибири и Центральной Азии, имеющих место в скифское время.

\section{ЛИТЕРАТУРА}

Артамонов М.И. Сокровища саков. М.: Наука, 1973. 280 с.

Василевич Г.М. Тунгусский кафтан // Сборник Музея антропологии и этнографии. 1958. T. 18. C. $122-178$.

Грач А.Д. Древние кочевники в центре Азии. М.: Восточная литература, 1980. $256 \mathrm{c}$.

Кирюшин Ю.Ф., Степанова Н.Ф. Скифская эпоха Горного Алтая. Часть III: Погребальные комплексы скифского времени средней Катуни. Барнаул: Изд-во АГУ, 2004. 292 c.

Кубарев В.Д. Кинжалы из Горного Алтая// Военное дело древних племен Сибири и Центральной Азии. Новосибирск: Наука, 1981. С. 29-53.

Кубарев В.Д. Курганы Уландрыка. Новосибирск: Наука, 1987. 190 с.

Кубарев В.Д. Курганы Юстыда. Новосибирск: Наука, 1991. 190 с.

Кубарев В.Д. Диадемы и гривны из курганов Алтая // Археология, этнография и антропология Евразии. 2005. № 1. С. 55-69.

Мартынов А.И. Лесостепная тагарская культура. Новосибирск: Наука, 1979. 208 с.

Мыглан В.С., Слюсаренко И.Ю., Хойсснер К.У. Дендрохронологический анализ древесины из пазырыкских курганов Северо-Западной Монголии // Молодин В.И., Парцингер Г., Цэвээндорж Д. Замерзшие погребальные комплексы пазырыкской культуры на южных склонах Сайлюгема (Монгольский Алтай). М.: ИД «Триумф-принт», 2012. C. 507-523.

Молодин В.И. Культурно-историческая характеристика погребённого комплекса кургана № 3 памятника Верх-Кальджин-II // Феномен алтайских мумий. Новосибирск: Изд-во ИАЭТ СО РАН, 2000. С. 86-119.

Молодин В.И. За перевалом Сайлюгем. Новосибирск: ИНФОЛИО, 2013. 168 с.

Молодин В.И., Париингер Г., Цэвээндорж Д. Замёрзшие погребальные комплексы пазырыкской культуры на южных склонах Сайлюгема (Монгольский Алтай). М.: ИД «Триумф-принт», 2012. 565 с.

Молодин В.И., Полосьмак Н.В. Чикишева Т.А. и др. Феномен алтайских мумий. Новосибирск: Изд-во ИАЭТ СО РАН, 2000. 320 с.

Молодин В.И. Прасолова Л.А., Потапов М.А., Евсиков В.И., Парцингер Г., Цэвээндорж Д. Видовая идентификация меха шубы пазырыкца из могильника Олон-Курин- 
Гол-10 (Монголия) на основе морфологического анализа волос // Археология, этнография и антропология Евразии. 2009. № 2. С. 59-66.

Молодин В.И., Слюсаренко И.Ю., Гаркуша Ю.Н., Мыльников В.П., Цэвээндорж Д., Парциингер $Г$. Археологические памятники на северо-западе Монголии. Результаты разведки российско-германско-монгольской экспедиции в 2004 году // Молодин В.И., Парцингер Г., Цэвээндорж Д. Замёрзшие погребальные комплексы пазырыкской культуры на южных склонах Сайлюгема (Монгольский Алтай). М.: ИД «Триумф-принт», 2012. C. 204-266.

Новгородова Э.А. Древняя Монголия. М.: Восточная литература, 1989. 384 с.

Пилипенко А.С., Молодин В.И., Ромащенко А.Г. Палеогенетический анализ останков носителей пазырыкской культуры из памятников Олон-Курин-Гоол-6 и Олон-КуринГол-10 в Северо-Западной Монголии // Молодин В.И., Парцингер Г., Цэвээндорж Д. Замерзшие погребальные комплексы пазырыкской культуры на южных склонах Сайлюгема (Монгольский Алтай). М.: ИД «Триумф-принт», 2012. С. 347-357.

Полосьмак Н.В. «Стерегущие золото грифы» (Ак-Алахинские курганы). Новосибирск: Наука, 1994. 125 с.

Полосьмак Н.В. Всадники Укока. Новосибирск: ИНФОЛИО, 2001.

Полосьмак Н.В., Балакина Г.Г., Васильев В.Г., Власов А.А., Довлитова Л.С., Карпова Е.В., Краевская И.Л., Королюк Е.А., Кундо Л.П., Мылахов В.В., Маматюк В.И., Царева Е.Г. Текстиль из «замерзших могил Горного Алтая IV-I вв. до н.э. (опыт междисциплинарного исследования). Интеграционные проекты СО РАН. Вып. 5. Новосибирск: Изд-во СО РАН, 2006. 267 с.

Полосьмак Н.В., Баркова Л.Л. Костюм и текстиль пазырыкцев Алтая (IV-Ш вв. до н.э.). Новосибирск: ИНФОЛИО, 2005.

Полосьмак Н.В., Молодин В.И. Памятники пазырыкской культуры на плоскогорье Укок // Археология, этнография и антропология Евразии. 2000. № 4. С. 66-86.

Руденко С.И. Культура населения Горного Алтая в скифское время. М.-Л.: Издво АН СССР, 1953. 402 с.

Руденко С.И. Культура хуннов и Ноинулинские курганы. М.-Л.: Наука, 1962. $206 \mathrm{c}$.

Руденко С.И. Древнейшие в мире художественные ковры и ткани. М.: Искусство, 1968. $136 \mathrm{c}$.

Слюсаренко И.Ю. Дендрохронологический анализ дерева из памятников пазырыкской культуры Горного Алтая // Археология, этнография и антропология Евразии. 2000. № 4. C. 122-130.

Слюсаренко И.Ю., Кузьмин Я.В., Кристен Дж.А., Орлова Л.А., Бурр Дж.С. Анализ результатов радиоуглеродной «привязки» древесно-кольцевой хронологии курганов пазырыкской культуры Алтая // Проблемы археологии, этнографии, антропологии Сибири и сопредельных территорий. Новосибирск: Изд-во ИАЭТ СО РАН, 2002. Т. VIII. С. 436-440.

Смирнов К.Ф. Вооружение савроматов. М.: Наука, 1961. 162 с.

Смирнов К.Ф. Савроматы. М.: Наука, 1964. 380 с.

Степанова Н.Ф. К вопросу о терминологии и типологии керамики раннего железного века Горного Алтая // Древние поселения Алтая. Барнаул: Изд-во АГУ, 1998. C. 137-145. 
Суразаков А.С. Горный Алтая и его северные предгорья в эпоху раннего железа. Проблемы хронологии и культурного разграничения. Горно-Алтайск: Алт. кн. изд-во, 1989.214 c.

Чикишева T.A. Вопросы происхождения кочевников Горного Алтая эпохи раннего железа по данным антропологии // Археология, этнография и антропология Евразии. 2000. № 4. C. 107-121.

Эпов М.И., Чемякина М.А., Манштейн А.К., Балков Е.В., Майнштейн Ю.А., Ковбасов К.В. Непреев Д.В. Геофизические исследования «замёрзших» курганов Алтая // Молодин В.И., Парцингер Г., Цэвээндорж Д. Замёрзшие погребальные комплексы пазырыкской культуры на южных склонах Сайлюгема (Монгольский Алтай). М.: ИД «Триумф-принт», 2012. С. 324-346.

Heussner K.-U., Sljusarenko I. Die Dendrochronologie von Aržan 2 // Im Zeichen des Goldenen Greifen: Kőnigsgräber der Skythen. Műnchen, Berlin, London, New York: Prestel, 2007. S. 83-84.

Molodin V.I. Un kourgane gelé d'époque scythe dans le sud-ouest de l'Altai // Les Dossiers d l'Archéologie. Paris, 1996. N 212. P. 36-41.

Parzinger H. Molodin V., Ceveendorzž D. Der Skythenzeitlice krieger aus dem Eis: Neue Entdeckungen im Mongolischen Altaj. Amsterdam, 2008. S.65.

Pilipenko A.S., Romaschenko A.G., Molodin V.I., Parzinger H., Kobzev V.F. Mitochondrial DNA studies of the Pazyryk people ( $4^{\text {th }}$ to $3^{\text {rd }}$ centuries BC) from northwestern Mongolia // Archaeological and Anthropological Sciences. 2010. N 4. P. 231-236.

The Subterranean Army of Emperor Qin Shi Huang. 2005.

Торбат Ц., Батсух Д., Батбаяр Н., Баярхуу Н., Жордана Х., Жискар П. Х БагаТургени-Гол-VI пазырыкийн уейн цогцолборын археоги, палеоантропологийн судалгаa // Археологийн судлал. Том (IV) XXIV. Улаанбаатар, 2007. С. 188-215.

Цэвээндорж Д., Молодин В.И., Парцингер Г. Монгол Алтайн Пазырыкийн соёлын цэвдэгт булш. Улаанбаатар: ШУА- Түүх, археологийн хүрээлэн, 2016. 256 с. (на монгольском яз.). 


\section{МОДЕЛЬ КОММУНИКАЦИИ РАННИХ КОЧЕВНИКОВ ЦЕНТРАЛЬНОЙ АЗИИ}

(Работа выполнена по гранту Министерства образования и науки РК АР05131564: «Разработка модели коммуникаций населения Центральной Азии в древности и средневековье: взаимодействие традиций и диалог культур»)

\section{Новожёнов В.А.}

http://10.25681/IARAS.2019.978-5-317-06274-3/159-180

Статья представляет собой историографический обзор основных концепций по теме и посвящена очередному периоду глобализации в Евразийских степях - периоду становления и господства элитных кланов ранних кочевников. На основании анализа письменных и изобразительных источников автор обосновывает модель взаимодействия ранних кочевников в Сарыарке, Туркестане и на северных границах Китая. На базе известных инноваций конского снаряжения, повозок, иных средств транспорта и успехов в верховом использовании лошади рассмотрены основные векторы коммуникаций населения и общие тенденции развития этнокультурной ситуации в Центральной Азии.

Ключевые слова: Сарыарка (Казахская степь), Туркестан, жуны, хьянъюны, туры, бегазы-дандыбаевская (карасукская) изобразительная традиция, ди, (динлины), юэчжи, хунну (сюнну), коммуникации, взаимодействие культур, скифо-сакский звериный стиль и традиция, оленные камни, миграции, повозки, колесницы

Конфронтационная модель постоянного противостояния кочевого мира «варваров» и первых китайских и других оседлых государств длительное время оставалась в историографии единственной объяснительной концепцией взаимодействия народов в Туркестане и Центральной Азии в целом, объясняя такое взаимодействие исключительно с позиций военной экспансии и грабежей. В последние годы новые археологические материалы и исследования заставили в значительной мере пересмотреть такой подход.

Постановка проблемы. Новые коммуникации номадов с конца XI в. до н.э., а может и гораздо раньше - начиная с XV в. до н.э. и вплоть до раннего средневековья, возникали изначально как закономерный результат длительного формирования и успешного функционирования на обширных территориях бюрократических имперских инфраструктур и окончательно оформились во времена сложившихся на западе империи Ахеменидов и китайской империи Цинь Шихуана (ди) - на востоке. На огромных степных пространствах меж ними, в среде ранних кочевников Евразии, рождались новые племенные союзы, обычаи и традиции, способы коммуникации, включая прежде всего визуальные и только в очень редких случаях - письменные или знаковые (созданные на иероглифическом силлабарии или ином сочетании специальных символовизображений, но никак не на основе алфавита).

Яркие артефакты, выполненные в знаменитом скифо-сибирском зверином стиле, в большом количестве обнаруженные повсюду в памятниках Великого 
пояса степей Евразии, убедительно доказывают наличие таких трансконтинентальных изобразительных коммуникаций, которые позволяли таким разным по языкам, этническому происхождению и менталитету кланам общаться между собой, торговать, обмениваться товарами, идеями, информацией, своими культурными достижениями и находить общий «язык», успешно развиваться, в том числе и посредством понятных им визуальных анималистических образов. Очевидно, что этот некий универсальный «язык» общения ранних кочевников, смысловое содержание его знаков-образов, их тайный смысл, были хорошо понятны всем степнякам и на западе и на востоке, независимо от их этнического происхождения.

Приоритет в кочевых социумах вербальной и образной (изобразительной) коммуникативной традиции, в противоположность письменной, объясняется мобильным способом повседневной жизнедеятельности, притом, что уже существовали достаточно сложные образцы знаковой коммуникации. Так, письменность ранних кочевников (иссыкское письмо) зафиксирована в сакских памятниках Жетысу - на дне чаши из погребения в кургане Иссык, например. Скифо-сакский звериный стиль, его причудливые, фантасмагоричные образы и их территориальное распространение в синхронных памятниках на огромной территории континента - яркое свидетельство развитых трансконтинентальных изобразительных, а по сути - знаковых и образных коммуникаций ранних кочевников в этот период.

Складывающиеся в этой среде коммуникации определялись различными внутренними факторами формирующихся на этих пространствах кочевых социумов (кланов), их уникальной идентичностью и внешними, в том числе - брачно-семейными связями, прежде всего - в среде элиты. Как полагают некоторые исследователи, в степных и предгорных районах Казахстана, Алтая, Хакасии и Тувы на основании общих хозяйственных потребностей и религиозно-мифологических представлений в этот период сложилось могущественное объединение местных кланов - Аржанский племенной союз (Чугунов, 2015. С. 389-404; Худяков, 2014. С. 700-714).

Очевидно, что в основе происходящих в этот период исторических процессов лежали факторы, которые обусловили довольно быстрое распространение некоторых элитных кланов ранних кочевников из глубин Центральной Азии, а точнее - из сопредельных с Великой китайской равниной степных просторов, на запад континента до Причерноморских степей и Карпатских гор. Инициаторами таких передвижений были, видимо, большей частью не народы или даже некие племена, а сравнительно немногочисленные группы - элитные и самодостаточные кланы кровных родственников, быстро растворявшиеся в среде автохтонного населения и, надо думать, подчинявшие их себе в силу обладания самыми передовыми и прогрессивными инновациями. Из китайских источников выясняется, что эти кочевнические волны миграций, фиксируемые археологическими находками, удивительно точно совпадают с периодами акти- 
визации и широкого расселения племён, известных в китайской историографии как жун и ди (Пьянков, 2015. С. 233-243; Ковалёв, 1998; 2008; Ковалёв, 2014. С. 124-136; Таиров, 2003; 2007; Новожёнов, 2013; 2014).

Как правило, синхронизация глобальных процессов на значительно удалённых друг от друга территориях вызывает затруднения без анализа значительных серий радиоуглеродных калиброванных датировок. Недавно опубликована серия из 24 радиоуглеродных калиброванных AMS дат, полученных из 16 памятников ранних кочевников, расположенных на территории Сарыарки и принадлежащих погребениям людей тасмолинской сакской культуры, датированных в пределах конца IX-V вв. до н.э., а также из памятников коргантасского этапа, относящихся в Сарыарке к раннему периоду истории хунну и датированных IV-II вв. до н.э. (Beisenov et al., 2016. Р. 179-191). Полученные даты удревняют время начала эпохи ранних кочевников в Казахской степи, однако хорошо согласуются с датировками аналогичных материалов из сопредельных регионов и делают более надёжной их синхронизацию, а главное - устанавливают хронологические рамки описываемых здесь исторических процессов.

Этнокультурная ситуация. При всей сложности и дискуссионности определения времени перехода от бронзового к железному веку в Северном Китае (Молодин и др., 2015. С. 5-12), где великолепная бронзолитейная, а не железоплавильная, традиция прекрасно развивалась до рубежа новой эры и даже позднее, именно переходный «предскифский или древнескифский» период с XI по VII в. до н.э. является тем рубежом, который стал переломным и определяющим глобальные процессы культурогенеза и продолжительных миграций местных кланов в направлении западных степных просторов континента, предопределивших в свою очередь формирование многих новых этнических и культурных образований ранних кочевников по всему Великому поясу степей, включая степи Сарыарки, за многие тысячи километров от своих исходных территорий. Обычно этническую природу этих первых элитных кланов, предпринявших такие значительные трансконтинентальные инвазии или диффузии, определяют как индоиранскую, «протоскифскую», «сакскую» или напрямую связывают собственно со скифскими племенами, что несомненно требует уточнений и конкретизации.

Возможно, для защиты от этих воинственных кочевых кланов на востоке континента строил Великую стену первый китайский император-объединитель Ичжен (Цин Шихуан), а его предшественники - ваны северных государств постоянно воевали, что с большой долей вероятности подтверждают более ранние, времен династий Ся и Шан, древнекитайские надписи на гадальных костях (бараньих лопатках и черепашьих панцирях), обнаруженных в количестве уже нескольких тысяч в северных и западных провинциях Китая. Они недвусмысленно свидетельствуют о постоянной и реальной «северной угрозе»; об активных контактах со степным населением, приходившим с севера и с северо-запада. 
Этими степными кланами кочевников могли быть племена, обитавшие на территориях гуй-фан, my-фан, гун-фан, жившие в государстве Янь (одном из княжеств Западной Чжоу, в районе современного Пекина), и с которыми шан-инские и чжоуские правители постоянно вели войны (Малявкин, 1981; Ходжаев, 2010. С. 38-40; см.: Ковалёв, 2008; 2014; 2015. С. 229-241; Ковалёв, Эрденбатаар, 2010. С. 104-117). Примечательно, что наиболее ранние источники называют всех северных соседей древних китайцев - riwem (rong), они же в русской транскрипции - жун (северныле жуны; иююаньжуны - «пёсьеголовые» и горные - «шаньжуны»), что в дословном переводе означает: воин, боевая колесница, большой военный поход. При этом отмечается, что указанный термин не является этнонимом, а является общим названием для всех северных соседей (Ходжаев, 2010. С. 33, 38-46).

Л.С. Клейн полагает, что древние китайцы знали на север от себя три европеоидных народа: усуни (асии), юэджи (яду) и ди (льок), при этом он допускает на основании заимствованных в китайский язык терминов, что кто-то из них может оказаться тохарами (2000. С. 180; 2012. С. 30). Данные лингвистов подтверждают использование в Центральной Азии древнейших языков индоевропейского корня - дардского, кафирского, тохарского, а также индоиранских языков Ригведы и Авесты. Вполне вероятно, что предками усуней и юэджей могут оказаться андроновцы - потомки некоторых кланов тохаров, а ди (динлинов, тиеков) и загадочных туров - карасукцы.

Р.Х. Сулейманов поддерживает мнение (Киселёв, 1951) о тюркоязычности $m u$-(дu) - (динлинов) - прямых наследников традиций карасукской культуры

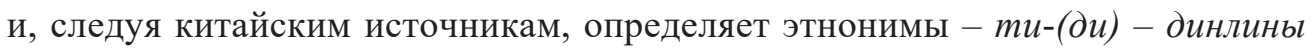
и более поздние - теле, как разные формы этнонимов древнейших тюркоязычных племён (Сулейманов, 2011. С. 406). Эта идея активно разрабатывается некоторыми тюркологами (Tasagil, 2004. Р. 7-13; см.: ЗТКА, 2013. С. 123-128).

В своих исследованиях К.М. Линдафф (Lindaff, 1996. Р. 12-48; 2006. Р. 358-370; 2014. С. 300-307) на основании территориального распространения из Сибири, Казахстана и Алтая оружия и металлургической традиции, последовательно доказывает существование значительных и развитых коммуникаций между степными племенами севера и населением Центральной равнины Китая в течение длительного исторического периода. По всей северной и северо-западной границе возникали новые поселения - торговые фактории; женщины степняков становились жёнами, приходили в дома местных китайцев (китайцев ли?), принося с собой предметы обихода, свои традиции и обычаи. Многие такие фактории сохранили в течение нескольких столетий материальную культуру северных кочевников практически неизменной, без каких бы то ни было заметных влияний традиционной китайской культуры (Линдафф, 2012. С. 412-420; Ковалёв, 2015. С. 229-241). Ярким эталонным примером таких взаимодействий являются многолетние раскопки могильников Наньшангэнь и Юйхуанмяо (VIII-VI вв. до н.э., см.: Шульга, 2015 a). 
Инновации. Традиционно считается, что в эпоху ранних кочевников наступает время тотального господства и триумфа Великих кентавров степей всадников на верховой лошади. Такое новшество стало революционным во времена усиления в степи ранних кочевников, в отличие от предшествующей эпохи бронзы, когда в военной, хозяйственной и культовой практиках активно использовалась пароконная колесница и иные типы колесных повозок. Этот тезис, однако, требует некоторого уточнения. Традиция строительства колесных повозок на завершающих этапах эпохи бронзы продолжилась в местных социумах и в карасукское время, и позднее, о чём с большой долей вероятности свидетельствуют изображения колесниц на стенках карасукских могил, на оградке кургана Аржан 2, «имитации» погребений с колесницами в кургане Аржан 1, изображения колесницы, карасукского оружия и предметов колесничного комплекса на оленных камнях Восточного Казахстана и Монголии и конечно же - колесничная упряжь в могилах (Шульга, 2015 б) и собственно повозки, найденные в Пазырыкских курганах; деревянный гребень с колесницей и специальной упряжью в раннесарматском кургане Таксай I (Сдыков, Лукпанова, 2013; Лукпанова, 2014; Алтынбеков, 2013; 2014; Новожёнов, 2015 б. С. 57-88) и на росписях склепа в Татарлы (Summerer, 2007 a. P. 129-156; 2007 b. P. 3-30) или фракийской гробницы в Казанлыке (Болгария).

А.А. Ковалёв (1998. С. 122-131) приводит материалы памятников «типа Наньшаньгень» в качестве примера зарождения искусства звериного стиля ранних кочевников. Материалы этих памятников в основном датируются VIII в. до н.э., расположены к северо-востоку от излучины Хуанхэ, в провинции Хэбэй и в китайской историографии связаны с горныли жунами (щань-жунами). Отметим, что в материалах могильника Наньшаньгэнь (мог. 102) обнаружена костяная пластина с пароконной колесницей (двуколкой), выполненная в проекции «вид сверху», в манере, абсолютно аналогичной наскальной изобразительной традиции эпохи бронзы, хорошо известной в петроглифах Центральной Азии (Комиссаров, 1988; Новожёнов, 2012). Этот факт наглядно свидетельствует в пользу преемственности изобразительных традиций в кочевой среде ещё с эпохи бронзы и полном восприятии местным населением визуальных коммуникаций, представленных такими сложными полисемантическими мифологическими образами. Материалы хорошо раскопанного, эталонного для этих же мест и более позднего (VII-VI вв. до н.э.) некрополя Юйхуанмяо (Шульга, 2015 a. C. 419-428) дают дополнительные аргументы в пользу этой версии.

Уникальность этого памятника, а именно его археологическая целостность и беспрецендентная сохранность, а также особенности микротопографии, когда новые погребения совершались сначала строго в восточном, а позднее в южном направлениях в течение более полутора-двух сотен лет или даже более, позволили наглядно проследить эволюцию, развитие во времени, форм и типов очень многих предметов, известных в кочевой среде далеко на западе континента. 
Кроме уникальной по количеству коллекции оружия, статусных поясов воинов и предметов украшения в зверином стиле, находки этого могильника демонстрируют поступательную линию развития и эволюции конского снаряжения, наглядно фиксируют факт важнейшего изобретения, а именно - инновационного, не известного ранее в кочевой среде крепления удил к двудырчатым псалиям, посредством металлических «пешек» или колец соответствующего диаметра на концах удил, в том числе и «стремечковидной» формы или с использованием специальной рамки. Заимствование такого технического решения из колесничной упряжи способствовало значительному конструктивному усилению деревянных или роговых псалиев и повлекло за собой конкретное улучшение эффективности управления верховой лошадью (Шульга, 2015 а. С. 419-428, прим. 4).

Очевидно, что такие инновации конского снаряжения, зафиксированные также в материалах более раннего мог. Байфy, где роговые псалии укреплялись специальными накладками с шипами, существенно расширяли возможности жунов в использовании ими верховой лошади и давали им явные преимущества в сравнении с другими кланами кочевников. Другие принадлежности конской упряжи, найденные в погребениях мог. Юйхуанмяо - бронзовые распределители ремней-«тройники» появляются в тасмолинских памятниках Сарыарки, в материалах южно-уральских раннесарматских могильников Kырык-оба 2 и Таксай I и функционально реконструируются нами как распределители вожжей в пароконной повозке или квадриге, либо как силовые детали комбинированного ярма-рогатки в таких повозках, но в любом случае - как необходимый элемент исключительно колесничной упряжи (Алтынбеков, 2014; Алтынбеков, Новожёнов, 2014).

Найденные в материалах Юйхуанмяо кинжалы с бабочковидным перекрестием и кинжалы с навершием в виде двух противопоставленных существ также появляются здесь раньше их западных аналогов, равно как и накладки на лук с характерным вырезом и костяные свистунки с наконечниками стрел, только через несколько столетий появившиеся в степных памятниках во времена экспансии хуннских кланов на запад (Шульга, 2015 a. С. 427-428).

Рядом с этими удивительным памятниками в излучине Хуанхэ и несколько восточнее - до верховий Янцзыцзяна, несколько позднее горных жунов, обитали племена $\partial u$, которые также имели собственное развитое производство изящных предметов и с кланами которых образцы этого элитного искусства знати, очевидно, распространялись далеко на запад континента, подобно шёлку в эти и более поздние времена.

Tри волны миграций элитарных кланов. Наиболее достоверно на наш взгляд этнокультурная и историческая ситуация этого периода, применительно к древним насельникам Сарыарки, реконструирована в ряде работ профессора В.И. Пьянкова (1994; 1995; 2006; 2015. С. 233-243). Однако в связи с новыми датировками бегазы-дандыбаевских памятников в Казахской степи эта ситуация должна быть скорректирована в пользу удревнения рассматриваемых здесь 
процессов, вплоть до середины второго тыс. до н.э., когда очевидно начались первые попытки проникновения карасукских кланов на запад и их цикличное возвратно-поступательное движение по степным просторам Северной Азии.

Всего таких волн на раннем этапе этого процесса прослеживается три. Одна из них увязывается ещё с карасукской эпохой (XV(?)-X вв. до н.э.), когда из юго-восточной части Центральной Азии, включающей Ордос, Ганьсу, верховья Хуанхэ и Янцзыцзяна, произошла первая активизация племён жун и началась карасукская экспансия на запад (Novozhenov, 2018). Вторая волна (X(?)-VIII вв. до н.э.): новая активизация племен жун, выступление племен хьянъюн и первая «скифо-сибирская» инвазия. Третья волна (VIII(?)-VII вв. до н.э.): расселение на запад племен ди и вторая «скифо-сибирская» миграция (Пьянков, 2015. С. 233-234).

В XIII-XII вв. до н.э., как и в более ранние периоды, степные кочевники на территории Синьцзяна и в прилегающих северных степных районах активно взаимодействуют с древними китайцами на Великой равнине: чжоусцы отступают под их натиском, иньцы совершают походы на эти же племена, называя их в своих хрониках «иян». Новый подъем активности степных соседей Китая начинается с конца IX в. до н.э. Вновь на Китай с запада, в основном из Ганьсу, наступают жуны, и в том числе опять-таки ц̧юань-жуны, которые уже расселились во многих центральных областях Китая. Основная тяжесть борьбы с жунами выпала на долю самого западного китайского княжества Цинь, и его гуны с конца VII в. до н.э. постепенно вытесняют жунов из занятых ими земель. Несколько позже жунов, с середины VII в. до н.э., из Ордоса наступают степные племена $\partial и$ и тоже расселяются на Китайской равнине, разделившись на две части: красных $\partial и$ и бельх $\partial u$.

Скорее всего, именно тогда, в VII-VI вв. до н.э. или несколько ранее, происходит распространение красных ди, они же дили (-тили-дулу?) по Великому степному поясу Евразии, где они стали известны как динлины. Позднее, co II в. до н.э., китайские источники знают их в основном в центральной, вплоть до Хангая на западе, и восточной частях Внешней Монголии, включая Забайкалье, а кроме того, в Западной Монголии и верховьях Енисея, где они жили смешанно с древними кыргызами; отдельная группа их обитала на западе, в Центральном и Северо-Восточном Казахстане (в Сарыарке. - B.H.), к северу и северо-востоку от древнего Кангха (Пьянков, 2015. С. 235-237).

Археологическая идентификация племен жун как карасукцев дает возможность реконструировать ход этих инвазий. В конце IX - начале VIII вв. до н.э. среди жунов, оставшихся в степях к западу и северу от коренного Китая, вновь начинается брожение, возможно, под влиянием климатических изменений. Разные кланы жунов всё больше напирают на Китай, расселяются на Китайской равнине, так что чжоуские ваны в конце концов вынуждены перенести свою столицу на восток, в город Лои (771 г. до н.э.). Видимо, ведущую роль среди жунов в это время играл клан хьянъюнов (xianyun) - предков хуннов. Ещё 
в эпоху ордосских бронз предки хуннов, именовавшиеся тогда племенем гунфан или гуйфан, обитали в Ордосе вместе с жунами, а после их ухода заняли их место, расселяясь в Шаньси (Тайюань), а может быть и далее, вплоть до Южной Маньчжурии. Расселяясь также и на запад и увлекая за собой другие кланы хьянъюны, видимо, оказались создателями нового мощного союза племен. В Сарыарке эти новые кланы создали на основе алакульской новую культуру карасукоидного облика - бегазы-дандыбаевскую и её дериват - донгальскую. Предшествовавшую ей саргаринскую культуру она частично поглотила, но западнее, на Южном Урале, саргаринская (замараевская) культура, видимо, продолжала существовать самостоятельно, сменив здесь позднеалакульскую. Возможно, что с этим движением связана первая «скифо-сибирская» инвазия на запад - распространение памятников черногоровского круга в степях Поволжья, Северного Кавказа и Северного Причерноморья (Пьянков, 2015. С. 237-238; Новожёнов, 2013. С. 321-329; 2015. С. 171-193: 2018) и некоторые элитарные кланы жунов-хьянъюнов вошли в состав причерноморских киммерийцев (Novozhenov, 2018).

О соответствующих исторических событиях как о недавних и рассказал в VII в. до н.э. Аристей Проконнесский в своей поэме, где apuмacnbl, «самые могучие из всех мужей», явились инициаторами такого передвижения народов. В них нетрудно узнать жунов во главе $c$ хьянъюнами, создателей бегазы-дандыбаевской культуры. В таком случае исседонами будут саргаринцы, а древнейшими скифами (отдельными кланами сакского круга. - B.H.) - носители алакульской культуры. В это время, по-видимому, скифы и были сначала сдвинуты на запад с исконных мест своего обитания, - а таковыми были, судя по рассказу Аристея, степи Южного Урала и Зауралья, - их восточными соседями исседонами, а затем окончательно вытеснены за реку Аракс (Волгу) массагетами (Пьянков, 2015. С. 237-239).

Характерной чертой возникших новых карасукоидных культур в Казахской степи стали своеобразные инновационные погребальные конструкции - херексуры, поминальные кенотафы - комплексы с оленными камнями или менгирами и мавзолеи их элиты типа Бегазы, Сангру (Маргулан, 1979), «сарыаркинская пирамида», недавно найденная недалеко от Караганды (рис. 1-3), или мавзолей Тагискен в низовьях Сырдарьи. По мнению В.И. Пьянкова и эта черта их культуры нашла отражение в письменных источниках. В древнейшем цикле сказаний иранской «Книги царей» повествуется о войне арийского кави Хаусравы с предводителем туров Франграсьяном (Афрасиабом). Событие это датируется первой половиной VIII в. до н.э. (Пьянков, 2001. С. 337, 338; 2015. С. 236-240). Особенно воспевается взятие арьями замка Хшатросаука в турской стране Кангха (т.е. в низовьях Сырдарьи). Возможно, что этим замком и является Тагискенский мавзолей. Это позволяет считать название «туры» иранским обозначением тех же жунов-хьянъюнов-карасукцев (Пьянков, 2015. С. 237-238). 

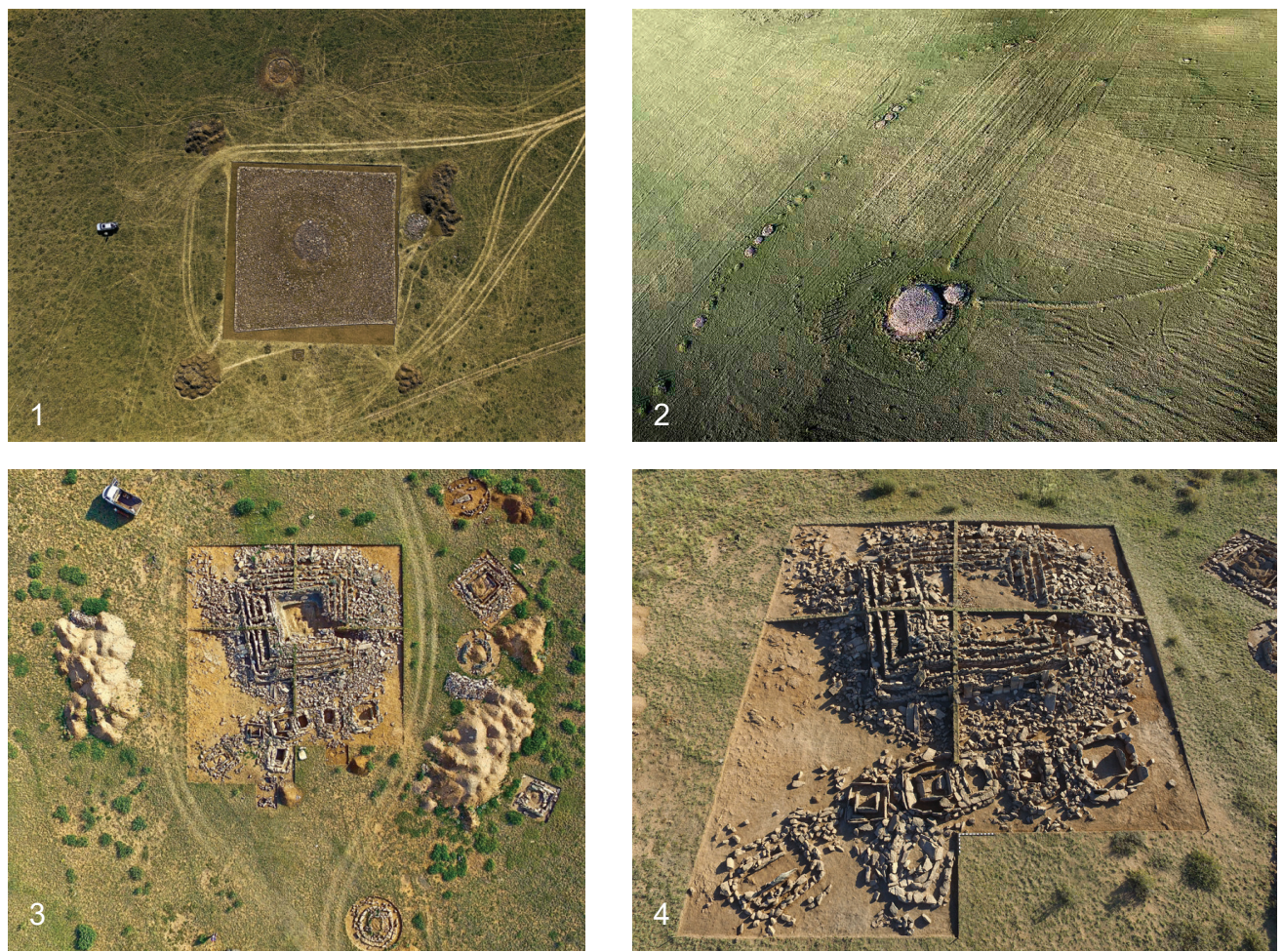

Рис. 1. Сарыарка. Виды погребальных памятников эпохи фринальной бронзы и ранних кочевников. Аэрофото автора.

1 - Карагандинская область, могильник Шантемес.

Курган с прямоугольной каменной выкладкой 43×41 м, вид с высоты 100 метров;

2 - Карагандинская область, погребальный комплекс 37 воинов.

Курган с «усами», каменные курганы различных размеров и цепочка каменных изваяний; 3, 4 - Карагандинская область, могильник Каражартас, «Сарыаркинская пирамида» - бегазы-дандыбаевский мавзолей, 15 в. до н.э.

С этой их мегалитической традицией возведения мавзолеев для своих вождей и элиты, ставшей, кстати, господствующей в Сарыарке с тех пор на очень долгие годы (вплоть до современности), следует объединить обычай установки поминальных антропоморфных стел-кенотафов, более известных как оленные камни (Членова, 1984; 1996; Ковалёв и др., 2010; 2014. C. 41-54; Kovaliov et al, 2016. Р. 82-92), которые стали также на долгие годы здесь весьма распространённой традицией, а многочисленные каменные антропоморфные скульптуры в память о своих первопредках-аруахах маркировали наиболее удобные и значимые урочища и пастбища в Сарыарке и в сакские, и в тюркские времена (рис. 4).

C конца VII - VI в. до н.э. китайские источники активно начинают упоминать другой степной народ - $u$, который также активно вмешивается в китайские дела: они фактически овладевают новой столицей Китая, городом Лои, 

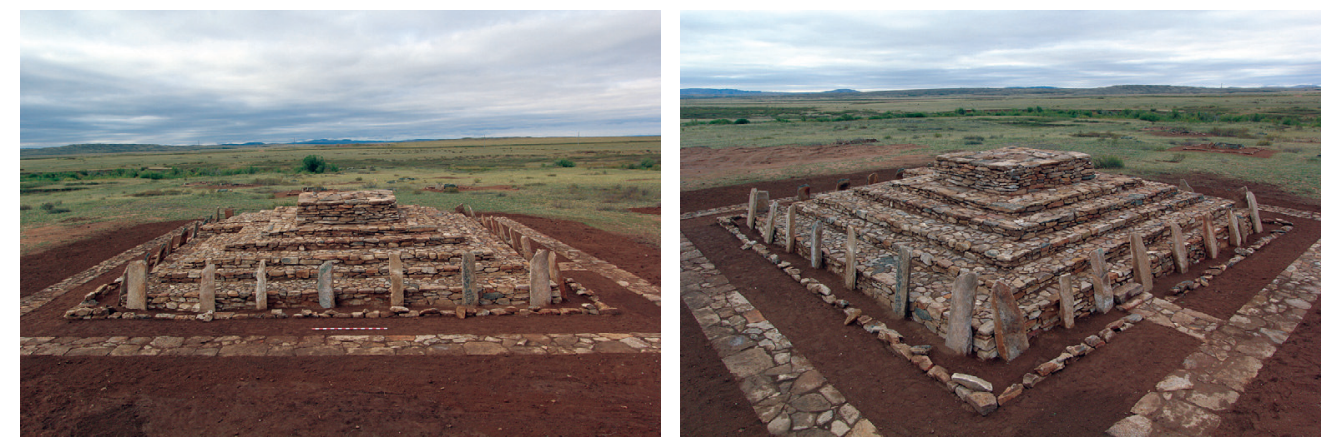

Рис. 2. «Сарыаркинская пирамида», реконструкция А.З. Бейсенова и И.А. Кукушкина
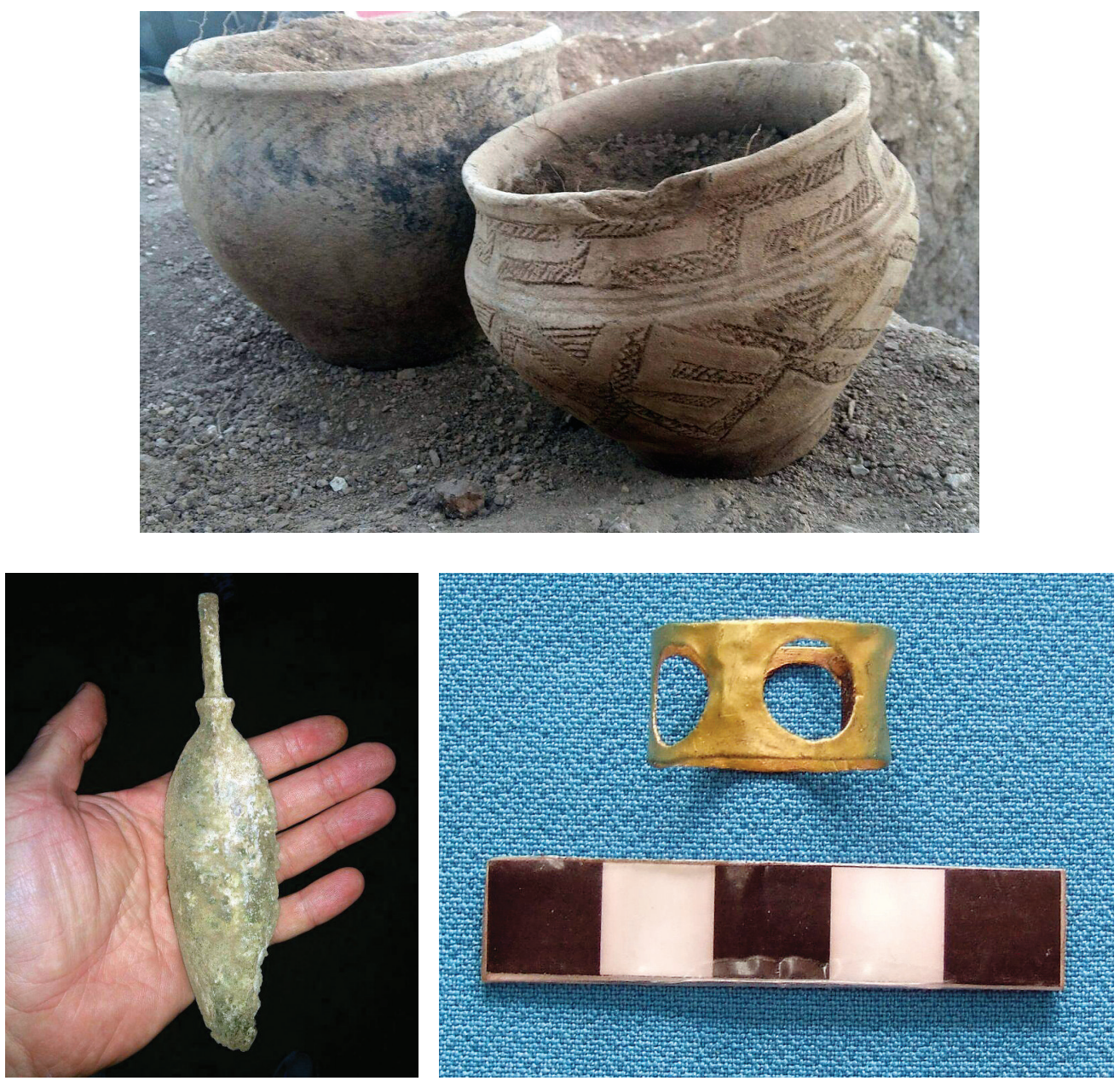

Рис. 3. «Сарыаркинская пирамида». Находки.

1 - сосуды; 2 - бронзовый нож; 3 - золотое кольцо 

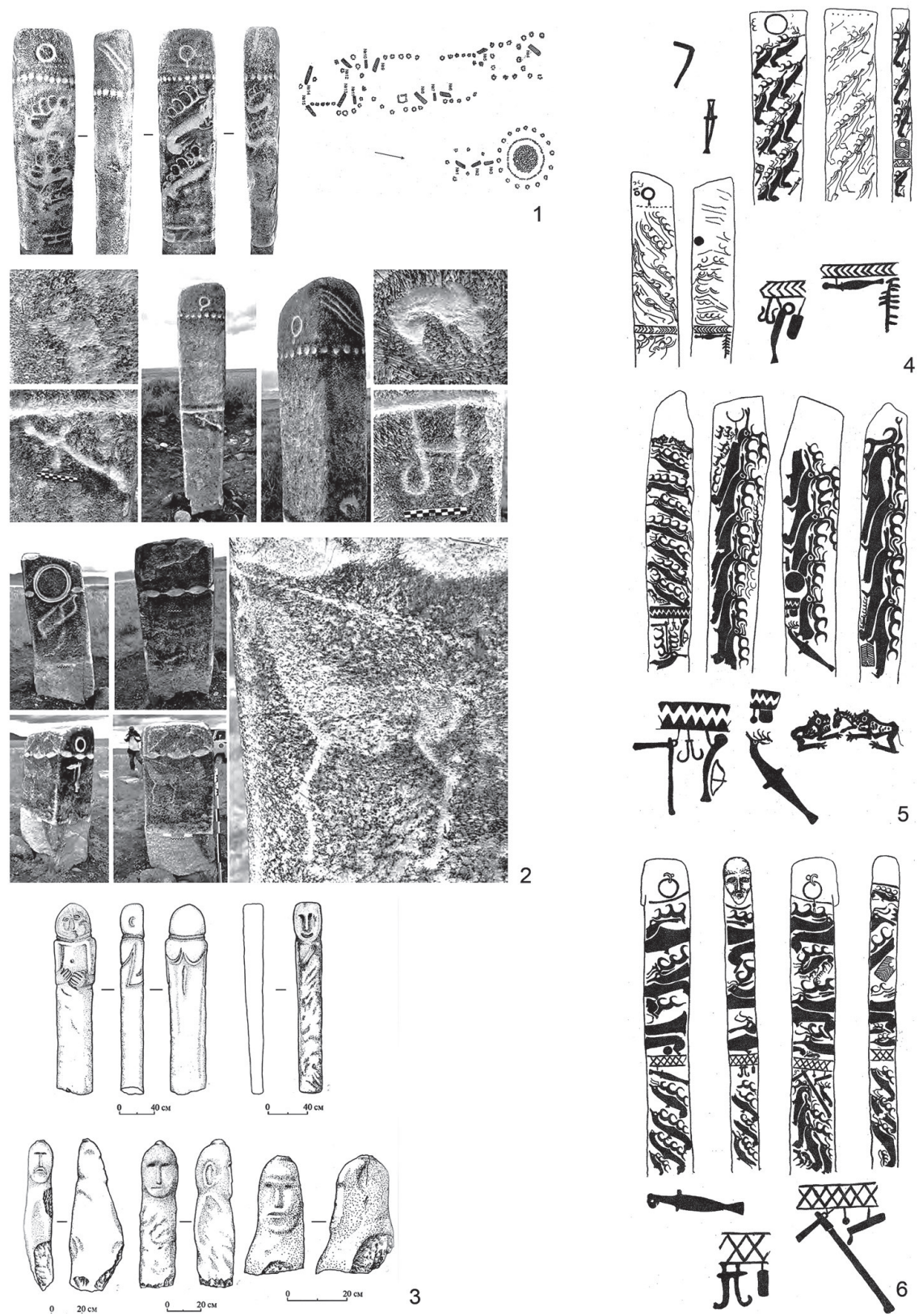

Рис. 4. Две линии развития статуарных памятников в Казахской степи (Самашев, 2013. С. 44-46; Бейсенов, 2015. С. 33; Волков, 2002. С. 187-194).

$1,4,5,6$ - оленные камни Уушкийн-увэра: план могильника (1) и «абстрактная» - $(4,5)$

и «реалистическая» (6) линии развития статуарной традиции оленных камней забайкальско-монгольского типа; 2 - оленные камни «абстрактного» типа в предгорьях Казахского Алтая: у села Ойшилик (вверху) и у села Жартас (в середине и внизу); 3 - сакские изваяния из могильников Кособа, Бегазы, Байдалы, Талды и Жыланды (слева направо) 
и, как и жуны, расселяются по Китайской равнине. Китайские источники помещают динлинов в двух местах: в Центральной и Восточной Монголии (Пьянков, 2002. С. 199-203) и в Сарыарке (Пьянков, 2006. С. 13-18). Археологически первым динлинам будет соответствовать культура плиточных могил (? - B.H.), вторым - тасмолинская культура. Продвижение $\partial u$ на запад и сложение западной их группы в VII в. до н.э. стало причиной вытеснения бегазы-дандыбаевских кланов (жунов-хьянъюнов) из Сарыарки; во всяком случае, здесь их сменяют носители тасмолинской культуры. Вытесненные кланы устремляются на юг, в степи Приаралья, Жетысу и Тянь-Шаня, где участвуют в сложении культуры исторических массагетов и саков (Пьянков, 2015. С. 235-241).

Если ведущей силой жунского союза племен были хьянъюныl, то, очевидно, их имя в те или иные моменты могло прилагаться и к массагетам (тасмолинцุам), и к сакам как их наследникам. Действительно, в конце VII в. до н.э. враги авестийского кави Bummacnы (Гoumacnы) в Приаралье именовались как «хьяона» (hyaona, hyaonina), и к ним же прилагалось прозвище «острошапочные» - так в более поздних источниках назывались именно массагеты. В конце III в. до н.э. загадочный народ, обитавший, видимо, где-то к западу от Алтая, именовался древним названием хуннов - «хуньюй» и входил в состав хуннской державы. Возможно, что поздние гунны так называли саков (Ibid. C. 235-241).

Расселение $\partial u$ на запад в середине VII в. до н.э. в эпоху третьей кочевнической волны должно быть связано с экспансией легендарных амазонок - «храбрых охотниц-прорицательниц» в китайских источниках. Действительно, «амазонки» появляются в Причерноморье, что приводит к сложению, видимо, в VI в. до н.э. нового народа - «гинекократических» («женоуправляемых») савроматов. Заметим, что предания о вытеснении скифов исседонами и массагетами как их непосредственными соседями в эпоху второй кочевнической волны подразумевают, что савроматов, позднее отделявших скифов и от исседонов, и от массагетов, тогда ещё не существовало. Аристей, излагавший предания исседонов, был современником третьей волны переселений и застал лишь самое начало событий, приведших к сложению савроматов (Ibid. C. 238-241).

Скифские амазонки - полумифический народ, сведения о котором связаны с продвижением на запад центральноазиатских кочевых кланов. Сведения эти собрал и пронализировал Б.Н. Граков, показав, что в основе их могут лежать воспоминания о действительных событиях: движении кочевников в причерноморские степи с востока на запад, к Дунаю и далее, в период с рубежа II-I тыс. до н.э. и до VII в. до н.э. (Граков, 1977. С. 103-109, 152, 153). Эти кочевники ассоциировались в представлении греков с весьма популярным среди них сказочным образом амазонок, несомненно, по причине особого положения женщин у кочевников. В китайских мифах также фигурируют «храбрые охотницы-прорицательницы», упоминаются горы и реки этих дев - «охотницпрорицательниц» - все они локализуются в провинции Шаньси по течению реки Фэнь, где чаще всего оседали красные ди (Пьянков, 2015. С. 238). 
Модель коммуникации. Как видим, такое быстрое расселение немногочисленных кланов по огромным степным пространствам могло приводить лишь к частичному вытеснению местного населения, а в остальном - к перегруппировке его, к разрушению старых племенных союзов и созданию новых, во главе которых становились пришельцы, образовывавшие тонкий суперстратный слой племенной знати, при том, что этническая основа этих союзов оставалась прежней. Новые племенные объединения могли принимать новые имена из племенной номенклатуры пришельцев, внедрять в свою среду какие-то традиции победителей, но языком их оказывался, в конечном счете, язык местных племен - основной массы населения так, как это произошло при взаимодействии кланов динлинов и туров.

Полученные в последнее время новые данные по истории, хозяйству и изобразительной деятельности ранних номадов Сарыарки позволяют сегодня по-новому взглянуть на роль носителей бегазы-дандыбаевской культуры в глобальных процессах формирования цивилизации ранних номадов и её распространении по степным просторам Евразии (Новожёнов, 2013. С. 321-329; 2014; 2015. С. 171-193; Novozhenov, 2018).

В серии работ уральский исследователь профессор А.Д. Таиров разрабатывет модель взаимодействия различных кланов ранних кочевников в условиях аридизации климата в степных районах Северной Евразии, на основании которой он реконструирует основные культурно-исторические и этногенетические процессы в этом регионе (Таиров, 2003; 2007. С. 52-64; 2015. С. 68-71).

В период около рубежа II-I тыс. до н.э. согласно данным климатологов, во всех степных регионах, прилегающих к Великой китайской равнине, произошла значительная аридизация климата. Климатические условия оставались более оптимальными только в Южном Зауралье, в Сарыарке, и в Южном Приаралье. В этих засушливых условиях другой альтернативой выживания кочевников стало освоение предгорных и горных долин-жайляу, богатых травой, что приводило к формированию нового культурно-хозяйственного типа, связанного с вертикальным кочеванием и активным освоением, кроме степных равнинных пространств, и долин рек, ещё и предгорных и горных районов.

Подробный анализ этих климатических данных по всем рассматриваемым здесь степным регионам приводит А.Д. Таирова к важным выводам о том, что миграции центральноазиатских кочевников на территорию Сарыарки, Южного Урала и Южного Приаралья обусловлены конкретными экологическими причинами и произойти они могли не ранее конца IX в. до н.э. (Таиров, 2007. С. 56). Этот вывод подтверждается и новыми радиоуглеродными датировками по памятникам тасмолинской культуры, приведёнными в начале этой статьи.

Далее автор на основании подробного сравнительного анализа погребальных памятников приходит к заключению о «невозможности выведения культур 
ранних кочевников региона из предшествующих им по времени культур эпохи поздней бронзы», а исходной территорией, откуда происходило движение этих волн кочевников, были районы Северного, Северо-Западного Китая (Восточный Туркестан) и Монголии (Таиров, 2007. С. 62; ср.: Итина, Яблонский, 2001. С. 108; Маргулан, 1979).

А.Д. Таиров также выделяет наиболее заметные этапы этих миграций, которые совпадают с вышеизложенными с той разницей, что эти миграционные процессы начались несколько раньше. Так, первая волна, по А.Д. Таирову, началась только в конце IX - начале VIII в. до н.э., очевидно, была направлена, главным образом, в Тыву, Минусинскую котловину, а также в горные районы Алтая. Вторая, более массовая, волна миграций произошла, по всей вероятности, в конце VIII в. до н.э. или на рубеже VIII-VII вв. до н.э. Одна группа кочевников этой волны, пройдя через Джунгарские ворота и Алакольскую впадину, устремилась через Сарыарку и Семиречье в Приаралье. Путь другой группы, согласно намеченной модели движения кочевников в Урало-Казахстанских степях, пролегал через Джунгарскую впадину и долину Чёрного Иртыша, вдоль западных (Восточный Казахстан) и северо-западных предгорий Алтая в Центральный и Северный Казахстан и далее в степи Южного Зауралья. Отдельные, очевидно небольшие, группы мигрантов этой волны проникли и в горные районы Алтая (Таиров, 2007. С. 62) и очевидно - в Южное Приаралье.

Причина этих миграций кроется, по мнению А.Д. Таирова, не столько в политических событиях на границе Китая и кочевого мира, сколько в изменении экологических условий в степях Монголии и Восточного Туркестана, а именно - случившейся там жесточайшей засухи. Основой же сложения и функционирования общности культур ранних кочевников Сарыарки и, в том числе тасмолинской общности, явилась пастбищно-кочевая система, или система посезонного распределения пастбищ и водных источников. Оформившись ещё в эпоху поздней бронзы, она просуществовала в ряде районов без каких-либо кардинальных изменений вплоть до начала XX века (Ibid. C. 62).

Некоторые исследователи, опираясь на сходство материалов могильника Саэнсаи близ Урумчи с тасмолинскими, предполагают обратное продвижение ранне-кочевнического населения из Сарыарки в Восточный Туркестан (Шульга, Шульга, 2015. С. 532). Такое предположение вполне имеет право на существование, поскольку не противоречит кочевой модели их хозяйства, имеющей возвратно-поступательный, циклический характер, и в целом никак не может противоречить возможности продвижения отдельных монголоидных кланов на запад, как и в обратном направлении, при совершенно недостаточной изученности археологических памятников синхронного периода в Джунгарии. Выявленное сходство этих материалов, на наш взгляд, никак не может быть надежным аргументом против возможности более глубоких и дальних связей тасмолинского населения Сарыарки с некоторыми кланами на Севере Китая или в Ордосе - слишком много имеется аргументов, происходящих из других 
видов источников, включая письменные. Представляется, что современное состояние и степень изученности археологических памятников Восточного Туркестана и даже находки уникальных отдельных памятников на современном этапе исследований не позволяют конкретизировать многие детали проходивших здесь исторических процессов, однако несомненно позволяют выявить некоторые общие или глобальные тенденции при комплексном анализе всех типов источников.

В этом смысле выводы А.Д. Таирова и предложенная им модель в основном совпадают с реконструкциями этно-культурных процессов, изложенным здесь ранее, и раскрывают «механизм», позволивший осуществить рассмотренные выше значительные передвижения кланов жунов и ди. В целом, соглашаясь с выводами автора, добавим, что не менее важным, чем климатический, очевидно в такой модели выступали другие глобальные факторы, и в том числе - внутренний социальный конфликт в социумах кочевников и фактор лошади, а хронологические рамки этих процессов были более значительными.

Bbыводы. На наш взгляд, в основе рассмотренных миграций стоят глобальные процессы, произошедшие на заключительном этапе эпохи бронзы в XV(?) XII-X вв. до н.э. повсюду на Евразийском континенте и известные как «тёмные века». Это был период глобального «слома» стабильных ранее археологических культур и даже передовых цивилизаций Средиземноморья. Причина этого вселенского кризиса, возможно, кроется в глобальных природных катаклизмах, в значительной аридизации климата, усугубившейся в южных регионах наводнениями и извержениями вулканов, но и по нашему убеждению причина этого также находится внутри самих, сложившихся в это время догосударственных социальных и общественных структур в степной среде и их производственных единиц - самодостаточных кланов кровных родственников, находящихся в социальном плане на уровне вождеств и начинавших борьбу за передел сложившейся ранее системы пастбищ и водопользования, за контроль за господствующими в степи традиционными коммуникациями.

Многие предводители этих кланов начали понимать, что ресурсов экологических ниш, в которых их социумы до этого времени благополучно развивались и плодились, в условиях демографического роста, оказывалось совершенно недостаточно. Естественным образом они пришли к мысли, что благополучие и светлое будущее новых поколений, кроется в расширении пастбищ и «жизненного пространства» для их соплеменников. Осознание экстенсивного, а точнее экспансионистского, способа развития и продолжения рода - есть важная побуждающая причина этих миграций и продвижения на запад отдельных воинственных и безусловно элитарных кланов, обладающих самыми передовыми инновациями. Такая воинственная, экспансионистская идеология ранних кочевников в основе своей происходит из глубин кочевого способа хозяйствен- 
ной деятельности этих социумов. Но такая экспансия, которую мы наблюдаем в это время, была невозможна без активного использования прогрессивных инноваций.

Обеспечить такую экспансию могли революционные инновации прежде всего в коммуникациях - универсальная знаковая система - звериный стиль в социальной структуре социума, а также - в конском снаряжении и в новых типах вооружения ранних кочевников. Гарантировать такое революционное превосходство могла только верховая лошадь и обладание передовыми навыками её использования, прежде всего, в военном деле. На смену ушедшей в «тёмные века» эпохи бронзы боевой колесницы, приходит время тотального господства и триумфа Великих кентавров степей - всадников на верховой лошади - прообраза будущей кавалерии.

Традиционное коневодство в Сарыарке в эпоху ранних кочевников очевидно стало наиболее передовым видом хозяйственной деятельности, пожалуй, во всей Центральной Азии в то время и в этом смысле несомненно представляло значительный интерес для воинственных соседей, как регион, обеспечивающий массовые поставки превосходных и обученных лошадей. Здесь проходили самые ранние этапы приручения лошади, местное население добилось существенных успехов в селекции казахской породы лошади в коренном ареале её обитания - в Сарыарке и массово поставляло обученных верховых лошадей всем своим соседям и не только. Коней из Золотой степи активно использовали ранние кочевники Алтая, традиционно, на протяжении многих столетий местные лошади поставлялись в Китай, о чём повествуют многочисленные китайские письменные источники и данные остеологии (Гайдученко, 2014; Косинцев, Самашев, 2014; Зуев, 1960; 2002). Вероятно, задолго до Великого Шёлкового возник «Оловянный», а чуть позже и «Конский» Великие пути, основной вектор которых скорее был направлен не из Китая на запад, а напротив - с запада, из степи - на восток, на территорию Великой Китайской равнины. И контроль за такими стратегически важными территориями несомненно обеспечивал геополитическое превосходство именно тем элитарным кланам, которые могли возглавить этот процесс и гарантированно получать превосходных коней для своих военных походов в нужном количестве. В этом смысле, потребности «китайских» степных кланов в быстрых, надёжных, обученных лошадях вполне могли быть побуждающей причиной описанных выше инвазий, тем более, что с самым передовым на тот момент вооружением и технологиями они были прекрасно знакомы.

\section{ЛИТЕРАТУРА}

Алтынбеков К. Возрождённая из пепла. Реконструкция жрицы по материалам погребения в могильнике Таксай I / Новожёнов В.А. (отв. ред.). Алматы: Остров Крым, 2013. $64 \mathrm{c}$. 
Алтынбеков К. Возрожденные сокровища Казахстана: опыт научной реставрации / Новожёнов В.А. (отв. ред.). Алматы: Остров Крым, 2014. 364 с.

Алтынбеков К., Новожёнов В.А. Повозки ранних кочевников в центре Евразии // Таинство этнической истории древнейших номадов степной Евразии. Коллект. моногр. памяти Е.Е. Кузьминой. Алматы: Остров Крым, 2014. С. 308-344.

Бедельбаева М.В., Новожёнов В.А., Новожёнова Н.В. Изобразительные памятники Казахского мелкосопочника. Караганда: Сарыаркинский археологический институт, 2015. 252 c.

Бейсенов А.3. Поселения и могильники сакской эпохи Центрального Казахстана // Бейсенов А.3. (ред). Сакская культура Сарыарки в контексте изучения этносоциокультурных процессов степной Евразии. Алматы: ИА им. А.Х. Маргулана, 2015. C. 11-38.

Бейсенов А.З., Ермоленко Л.Н. Новые каменные изваяния сакского времени из Сарыарки // Вестник КемГУ. 2014. № 3(59). Т. 3. С. 36-40.

Бичурин Н.Я. Собрание сведений о народах, обитавших в Средней Азии в древние времена. М.-Л., 1953. Т. III.

Волков В.В. Оленные камни Монголии. М.: Научный мир, 2002. 248 с.

Гайдученко Л.Л. Семь тысячелетий истории казахской лошади // Онгар А. (ред.). Всадники Великой степи: традиции и новации. Труды филиала ИА им. А.Х. Маргулана. Вып. IV. Астана, 2014. С. 300-310.

Граков Б.Н. Ранний железный век. Культуры Западной и Юго-Восточной Европы. M., 1977.

Ермоленко Л.Н. Изобразительные памятники и эпическая традиция: по материалам культуры древних и средневековых кочевников Евразии. Томск: Томский гос. пед. ун-т, 2008. 278 с.

Ермоленко Л.Н., Курманкулов Ж.К., Касенова А.Д. Новые данные о специфической разновидности изваяний сакской эпохи // Вестник КемГУ. 2015. Вып. 1(61). Т. 3. C. 26-32.

ЗТКА, Западный Тюркский каганат. Атлас / Досымбаева А., Жолдасбеков М. (гл. ред.) / Новожёнов В. (ред.). Астана: Назарбаев Центр, Service Press, 2013. 848 с.

Зуев Ю.А. Тамги лошадей из вассальных княжеств (перевод из китайского сочинения 8-10 вв. Таньхуйяо, т. III, цзюань 72, с. 1305-1308) // Труды Института истории, археологии и этнографии АН КазССР. № 8. 1960. С.87-96.

Зуев Ю.А. Ранние тюрки: очерки истории и идеологии. Алматы: Дайк-Пресс, 2002. $333 \mathrm{c}$.

Иванчик А.И. Киммерийцы и скифы. Культурно-исторические и хронологические проблемы археологии восточноевропейских степей и Кавказа пред- и раннескифского времени. Степные народы Евразии. Т. ІІ. М.: Палеограф, 2001. 324 с.

Итина М.А., Яблонский Л.Т. Мавзолеи Северного Тагискена. Поздний бронзовый век Нижней Сырдарьи. М.: Восточная литература РАН, 2001. 295 с.

Киселев С.В. Древняя история Южной Сибири. М.: Изд-во АН СССР, 1951. 642 c.

Клейн Л.С. Миграция тохаров в свете археологии // Stratum plus. № 2. 2000. C. $178-187$.

Клейн Л.С. Происхождение индоевропейцев и археология // В.А. Алёкшин, Е.В. Бобровская (отв. ред.). Культуры степной Евразии и их взаимодействие с древ- 
ними цивилизациями. Материалы международной научной конференции, посвящённой 110-летию со дня рождения выдающегося российского археолога М.П. Грязнова. Т. 2. СПб.: ИИМК РАН, 2012. С. 25-34.

Ковалёв А.А. Древнейшие датированные памятники скифо-сибирского звериного стиля (тип Наньшаньгэнь) // Самбу И.У., Решетов А.М. (ред.). Древние культуры Центральной Азии и Санкт-Петербурга. Мат-лы конф. СПб.: Культинформпресс, 1998. C. $122-131$.

Ковалёв А.А. Локализация народов VI-III вв. до н.э. на северных границах китайских государств (по археологическим и письменным источникам) // Записки ИИМК РАН. № 3. 2008. С. 181-202.

Ковалёв А.А. Происхождение скифов из Джунгарии: основания гипотезы и её современное состояние // Арии степей Евразии: эпоха бронзы и раннего железа в степях Евразии и на сопредельных территориях: сб. памяти Е.Е. Кузьминой / Ред. кол.: К.Э. Разлогов (председатель); Е.В. Антонова и др. / Молодин В.И., Епимахов А.В. (ред.). Барнаул: Изд-во Алт. гос. ун-та, 2014. С.124-137.

Ковалёв А.А. Синьчжуантоу М30 - погребение знатного представителя пазырыкцев-«лоуфаней» на службе вана китайского царства Янь (серед. III в. до н.э.) // КСИА. Вып. 238. ИА РАН, ред. Н.А. Макаров. М.: Языки славянской культуры, 2015. C. 229-241.

Ковалёв А.А., Эрденбаатар Д. Две традиции использования оленных камней Монголии // Тишкин А.А. (ред.). Каменная скульптура и мелкая пластика древних и средневековых народов Евразии. Барнаул: Изд-во Алт. ун-та, 2007. С. 99-105.

Ковалёв А.А., Эрденбаатар Д. Поздний бронзовый век и начало раннего железного века Монголии в свете открытий Международной Центрально-Азиатской археологической экспедиции // Древние культуры Монголии и Байкальской Сибири. Материалы международной научной конференции. Улан-Удэ: Изд-во Бурятского университета, 2010. С. 104-117.

Ковалёв А.А., Рукавишникова И.В., Эрденбаатар Д. Оленные камни - это памятники - кенотафы (по материалам новейших исследований в Монголии и Туве) // Древнейшие и средневековые изваяния Центральной Азии. Барнаул: Изд-во Алт. унта, 2014. С. 41-54.

Комиссаров С.A. Комплекс вооружения древнего Китая. Эпоха поздней бронзы. Новосибирск: Наука, 1988. 178 с.

Косинцев П.А., Самашев 3.С. Берельские лошади. Морфологическое исследование // Материалы и исследования по археологии Казахстана. Т. V. Астана: фил. ИА им. А.Х. Маргулана, 2014. 400 с.

Линдафф К.М. Торговля и обмен товарами в конце I тыс. до н.э. после исследований М.П. Грязнова // Культуры степной Евразии и их взаимодействие с древними цивилизациями. Материалы международной научной конференции, посвящённой 110-летию со дня рождения выдающегося российского археолога М.П. Грязнова. Т. 2. СПб.: изд-во ИИМК РАН, 2012. С. 412-420.

Линдафф К.М. Почему сибирские артефакты найдены в пределах границ китайского государства? // Таинство этнической истории древнейших номадов степной Евразии. Алматы: Остров Крым, 2014. С. 300-307.

Лукпанова Я.А. Костюм женщины сарматской эпохи: опыт реконструкции // Диалог культур Евразии в археологии Казахстана. Сборник научных статей, посвя- 
щённых 90-летию со дня рождения выдающегося археолога К.А. Акишева. Астана: Сарыарка, 2014. С. 430-440.

Малявкин И.Г. Историческая география Центральной Азии. Новосибирск, 1981.

Маргулан А.Х. Бегазы-дандыбаевская культура Центрального Казахстана. АлмаАта: Наука, 1979. 336 с.

Молодин В.И., Кожин П.М., Комиссаров С.А. Особенности перехода к раннему железному веку на территории Северного Китая // Вестн. Новосиб. гос. ун-та. Серия: История, филология. 2015. Т. XIV, вып. 4: Востоковедение. С. 5-12.

Новгородова Э.А. Центральная Азия и карасукская проблема. М.: Наука, 1970. $176 \mathrm{c}$.

Новгородова Э.А. Древняя Монголия. М.: Наука, 1989. 384 с.

Новожёнов B.A. Чудо коммуникации и древнейший колёсный транспорт Евразии. M.: Tayc, 2012. 500 c.

Новожёнов В.A. Древнейшие кузнецы Евразийской степи (карасукская культура и происхождение бегазы-дандыбаевского феномена) // Бегазы-дандыбаевская культура степной Евразии / Бейсенов А.3. (ред.). Алматы: Бегазы-Тасмола, 2013. С. 321-329.

Новожёнов В.A. Великая степь: человек в системе древних коммуникаций // Таинство этнической истории древнейших номадов степной Евразии / Епимахов А.В. (ред.). Кол. моногр. памяти Е.Е. Кузьминой. Алматы: Остров Крым, 2014. С. 18-267.

Новожёнов В.A. Трансконтинентальные связи ранних кочевников (к проблеме происхождения киммерийцев) // А.З. Бейсенов (ред.). Сакская культура Сарыарки в контексте изучения этносоциокультурных процессов в степной Евразии. Алматы: ИА им. А.Х. Маргулана, 2015. С. 171-193.

Пьянков И.В. Кочевники Казахстана VII в. до н.э. и античная литературная традиция // Античность и античные традиции в культуре и искусстве народов Советского Востока. М., 1978.

Пьянков И.В. Античные авторы о Средней Азии и Скифии // ВДИ. № 4. 1994.

Пьянков И.В. Некоторые вопросы этнической истории древней Средней Азии // Восток. Orient. № 6. 1995. С. 3-27.

Пьянков И.В. Древнейшие государственные образования Средней Азии // Древние цивилизации Евразии. История и культура. М., 2001.

Пьянков И.В. Ещё раз к вопросу о динлинах // Лев Николаевич Гумилёв: теория этногенеза и исторические судьбы Евразии. СПб., 2002. Т. І.

Пьянков И.В. Аристей: путешествие к исседонам // Исседон. Альманах по древней истории и культуре. Екатеринбург, 2005. Т. III.

Пьянков И.В. Жуны и ди, аримаспы и амазонки // ЗВОРАО. СПб., 2006а. Т. II (XXVII).

Пьянков И.В. Западные динлины - первый тюркоязычный народ на территории Казахстана // Арало-Каспийский регион в истории и культуре Евразии. Актобе, $2006 б$. Ч. II.

Пьянков И.В. По поводу киммерийской проблемы // Восток, Европа, Америка в древности // XVI Сергеевские чтения: сб. научн. тр. М., 2010.

Пьянков И.В. Этнокультурные процессы в евразийских степях (конца II - первой пол. І тыс. до н.э.) // А.З. Бейсенов (ред.). Сакская культура Сарыарки в контексте изучения этносоциокультурных процессов в степной Евразии. Алматы: ИА им. А.Х. Маргулана, 2015. С. 233-243. 
Савинов Д.Г. Оленные камни в культуре кочевников Евразии. СПб., 1994.

Савинов Д.Г. Карасукские традиции и аржано-майэмирский стиль // Древние культуры Центральной Азии и Санкт-Петербург. СПб., 1998.

Самашев 3. Древнее искусство. Т. І. Алматы: Елнур, 2013. 240 с.

Сдыков М.Н., Лукпанова Я.А. Ранние кочевники Западного Казахстана (на примере комплекса Таксай I). Уральск: Полиграфсервис, 2013. 292 с.

Сулейманов P.X. К вопросу об этнической атрибуции некоторых археологических культур эпохи бронзы севера Центральной Азии // Байтанаев Б.А. (отв. ред.). Археология Казахстана в эпоху независимости: итоги и перспективы. Материалы международной научной конференции, посвящённой 20-летию независимости Республики Казахстан и 20-летию Института археологии им. А.Х. Маргулана КН МОН РК. Т. 1. Алматы: Институт археологии, 2011. С. 404-407.

Сунь Цзы. Трактат о военном искусстве. Пер., предисл. и комм. Н. И. Конрада. СПб.: Азбука-Аттикус, 2014. 480 с.

Сыма Цянь. Исторические записки. Пер. Р.В. Вяткина и В.С. Таскина. М., 1972. T. I.

Тасмагамбетов И.Н. Кулпытас. Астана: Берел, 2001. 392 с.

Тасмагамбетов И.Н. Кентавры Великой степи. Алматы: Берел, 2003. 487 с.

Таиров А.Д. Изменения климата степей и лесостепей Центральной Евразии во II-I тыс. до н.э.: Материалы к историческим реконструкциям. Челябинск: Рифей, 2003. $68 \mathrm{c}$.

Таиров А.Д. Кочевники Урало-Казахстанских степей в VII-VI вв. до н.э. Челябинск: Изд-во ЮУрГУ, 2007. 274 с.

Таиров А.Д. Кочевники Южного Урала, Северного и Центрального Казахстана (VII-V вв. до н.э.) // Мат-лы конф. Петропавловск: СКГУ им. М. Козыбаева, 2015. C. $68-71$.

Хабдулина. М.К. Каменное изваяние сакского времени из Центрального Казахстана // А.3. Бейсенов (ред.). Сакская культура Сарыарки в контексте изучения этносоциокультурных процессов в степной Евразии. Алматы: ИА им. А.Х. Маргулана, 2015. C. 372-375.

Ходжаев А. Из истории древних тюрков. Ташкент: изд-во АН Узбекистана, 2010. $238 \mathrm{c}$.

Худяков Ю.С. Военное дело древних кочевников Южной Сибири и Центральной Азии. Новосибирск: Новосибирский гос. университет, 1995. 138 с.

Худяков Ю.С. Древние тюрки на Енисее. Институт археологии и этнографии СО РАН. Новосибирск, 2004. 150 с.

Худяков Ю.С. Особенности формирования комплексов вооружения древних номадов Саяно-Алтая в ранний скифский период // Диалог культур Евразии в археологии Казахстана. Сборник научных статей, посвящённых 90-летию со дня рождения выдающегося археолога К.А. Акишева. Астана: Сарыарка, 2014. С. 704-714.

Членова Н.Л. Оленные камни как исторический источник. Новосибирск: Наука, 1984.

Членова Н.Л. К вопросу о центральноазиатской гипотезе происхождения скифов: дата оленных камней Монголии // Древность: историческое значение и специфика источника. Тезисы докладов конференции, посв. памяти Э.А. Грантовского. М., 1996. C. $125-127$. 
Чугунов К.В. Искусство раннесакского времени Тывы и Казахстана: опыт сравнительного анализа и хронологии // А.З. Бейсенов (ред.). Сакская культура Сарыарки в контексте изучения этносоциокультурных процессов в степной Евразии. Алматы: ИА им. А.Х. Маргулана, 2015. С. 389-404.

Шер Я.А. Ранний этап скифо-сибирского звериного стиля // Скифо-сибирское культурно-историческое единство / ред. А.И. Мартынов и др. Кемерово: КемГУ, 1980. С. 344-346.

Шульга П.И. Особенности расположения оружия на оленных камнях и в погребениях могильника Юйхуанмяо // Древние культуры Монголии и Байкальской Сибири. Улан-Батор: изд-во Монг. гос. ун-та, 2012. Вып.3. С. 298-306.

Шульга П.И. Могильник Юйхуанмяо в северном Китае (VII-VI века до н.э.). Новосибирск: ИАЭТ СО РАН, 2015 а. 304 с.

Шульга П.И. Скифоидные культуры на территории Китая в VIII-VI вв. до н.э. // А.3. Бейсенов (ред.). Сакская культура Сарыарки в контексте изучения этносоциокультурных процессов в степной Евразии. Алматы: ИА им. А.Х. Маргулана, 2015 б. C. 419-428.

Шульга П.И., Шульга Д.П. Могильник Саэнсаи раннескифского времени у г. Урумчи (Синьцзян, Китай) // Труды Государственного Эрмитажа: Археология без границ: коллекции, проблемы, исследования, гипотезы. СПб.: Гос. Эрмитаж, 2015. C. 512-533.

Beisenov A.Z., Svyatko S.V., Kassenalin A.E., Zhambulatov K.A., Duisenbai D., Reimer P.J. First Radiocarbon Chronology for the Early Iron Age Sites of Central Kazakhstan (Tasmola Culture and Korgantas Period) // Radiocarbon. 2016. № 58. P. 179-191.

Kovalev A.A., Erdenebaatar D., Rukavishnikova I.V. A Ritual Complex with Deer Stones at Uushigiin Uvur, Mongolia: composition and construction stages (Based on the 2013 Excavations) // Archaeology, Ethnology \& Anthropology of Eurasia. 44/1. 2016. P. 82-92.

Legrand S. Karasuk Metallurgy: Technological Development and Regional Influence // Linduff K. M. (ed.) Metallurgy in Ancient Eurasia from the Urals to the Yellow River. Lewiston-Queenston-Lampeter: E.Mellen Press, 2004. P. 340-357.

Legrand S. The emergence of the Scythians: Bronze Age to Iron Age in southern Siberia // Antiquity. № 80/310. 2006. P. 843-879.

Linduff K.M. Zhukaigou: Steppe Culture and the Rise of Chineese Civilization // Antiquity. № 69. 1995. P. 132-147.

Linduff K.M. Art and Identity: The Chinese and Their «Significant Others» in the Shang // Gervers, M. and Schlepp (eds.). Cultural Contact, History and Ethnicity in Inner Asia: Papers presented at the Central and Inner Asian Seminar, University of Toronto, March 4, 1994 and March 3, 1995. Toronto: Toronto Univ. Press, 1996. P. 12-48.

Linduff K. Metalurgy in Ancient Eastern Eurasia from the Urals to the Yellow River // Chainese Studies. № 31. 2004. P. 231-297.

Linduff K.M. Beyond the Steppe and the Sown // Lindaff K.M. (ed) Proceedings of the 2002 University of Chicago Conference on Eurasian Archaeology. Leiden - Boston: Chicago Univ. Press / E. Brill, 2006. P. 358-370.

Novozhenov V.A. Whence the Cimmerians Came? Transcontinental Communications of the Early Nomads in the Lights of the Origin of the Cimmerians // Journal of Historical Archaeology \& Anthropological Science, 2018, 3(1): 00058. On-line: http://dx.doi.org/ 
10.15406/ jhaas.2018.03.00058. http://medcraveonline.com/JHAAS/volume_issues?issueI $\mathrm{d}=1974 \&$ volumeId $=563$

Summerer L. From Tatarl1 to Munich. The recovery of a painted wooden tomb chamber in Phrygia / Casabonne O., Delemen I. (eds.). The Achaemenid Impact on Local Population and Cultures in Anatolia $\left(6^{\text {th }}-4^{\text {th }}\right.$ centuries B.C.) // Proceedings of the International Workshop in Istanbul. 19-22 May 2005. Istanbul: Turkish Institute of Archaeology, 2007 a. P. 129-156.

Summerer L. Picturing Persian victory: the painted battle scene on the Munich wood / Ivantchik A., Licheli V. (eds.). Achaemenid Culture and Local Traditions in Anatolia, Southern Caucasus and Iran. New Discoveries // Ancient Civilizations from Scythia to Siberia. № 13. Leiden: Brill, 2007 b. P. 3-30.

Taşağil A. Gök-Türkler. III. Baski. - Ankara: Türk Tarih Kurumu Basimevi, 2004. 217 c. 


\section{РАСКОПКИ АЛЕКСАНДРОПОЛЬСКОГО КУРГАНА В 2004-2009 гг.}

\section{Полин С.В., Дараган М.Н.}

http://10.25681/IARAS.2019.978-5-317-06274-3/181-206

Александропольский курган, благодаря его громадным размерам, многочисленности и сложности подземных погребальных сооружений и разветвлённой системе подземных ходов, многочисленности и разнообразию находок, играет важнейшую роль в скифоведении в качестве памятника, иллюстрирующего и фиксирующего финальный этап существования степной Скифии Северного Причерноморья. От его датировки зависит определение даты завершения существования Причерноморской Скифии. Важность Александропольского кургана для дальнейшего развития скифоведения привела к его повторному исследованию, осуществлённому в 2004-2009 гг. первоначально в рамках украинско-американского проекта совместно с университетом штата Флорида (2004-2006 гг.), позднее самостоятельно силами Скифской Степной экспедиции ИА НАНУ под руководством С.В. Полина. В процессе новых раскопок были получены очень важные новые данные, позволяющие по-новому представить структуру кургана и окончательно уточнить его датировку.

Ключевые слова: скифская культура, погребальный обряд, хронология, царский курган, гробница, ритуал, катакомба

Скифский царский Александропольский курган ${ }^{1}$ входил в четверку крупнейших степных скифских царских курганов-гигантов Северного Причерноморья, наряду с курганами Солоха, Чертомлык и Огуз. Все они были исследованы во второй половине XIX - начале XX в. Александропольский курган был первым скифским царским курганом, специально раскопанным с научными целями (рис. 1). На протяжении 1852-1855 гг. М. Бухтеев, А.В. Терещенко и А.Е. Люценко полностью раскопали громадную насыпь, а в 1855-1856 гг. А.Е. Люценко обнаружил и исследовал многочисленные подземные сооружения кургана - гробницы и различные подземные ходы (рис. 2) (Древности..., 1866 а. С. 1-25; Древности..., 1866 б. Табл. «А», I-XXI; Лазаревский, 1894).

Александропольский курган, благодаря его громадным размерам, многочисленности и сложности подземных погребальных сооружений и разветвленной системе подземных ходов, многочисленности и разнообразию находок, играет важнейшую роль в скифоведении в качестве памятника, иллюстрирующего и фиксирующего финальный этап существования степной Скифии Северного Причерноморья. От его датировки зависит определение даты завершения существования Причерноморской Скифии. Важность Александропольского кургана для дальнейшего развития скифоведения привела к его повторному исследованию, осуществлённому в 2004-2009 гг. первоначально в рамках украинско-американского проекта совместно с университетом штата Флорида (2004-2006 гг.), позднее самостоятельно силами Скифской Степной экспедиции ИА НАНУ под руководством С.В. Полина (рис. 3). В процессе новых раскопок

\footnotetext{
${ }^{1}$ Находится у с. Петриковка Солонянского р-на Днепропетровской обл.
} 


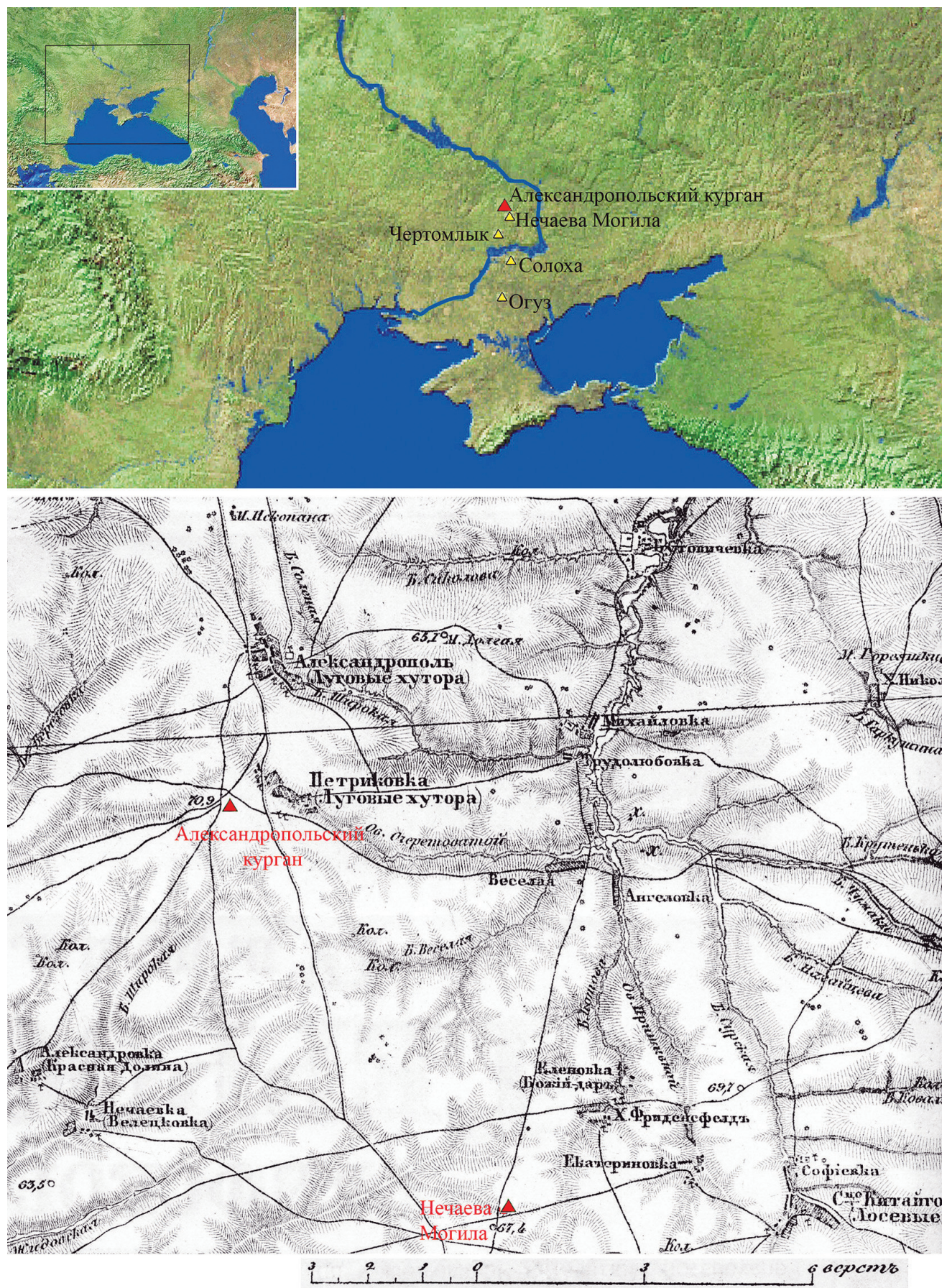

Рис. 1. Александропольский курган на карте.

1 - современная карта.

2 - Трёхвёрстная «Военно-топографрическая карта России» 1868 г.

(ряд XXVII, лист 13) 


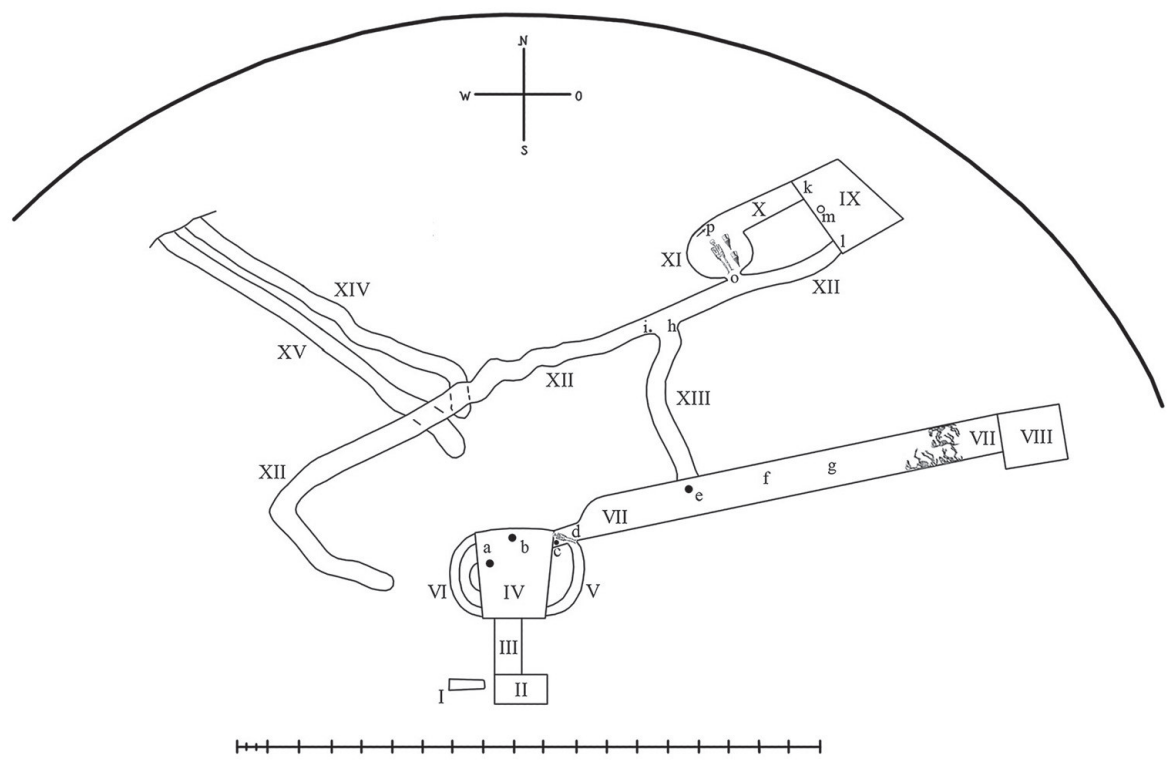

Рис. 2. Общий план Александропольского кургана по И.Е. Забелину (ДГС-І: табл. А).

Обозначения: Погребальные сооружения кургана:

I - Захоронение коня возле Центральной гробницы кургана;

II - Входная яма Центральной гробницы;

III - Дромос, соединявший входную яму с катакомбой Центральной гробницы;

IV - Катакомба Центральной гробницы кургана;

VII - Восточный дромос подзахоронения в Центральную гробницу

с восточного края кургана («подземная конюшня» по А.Е. Люценко);

VIII - Входная яма Восточного дромоса подзахоронения в Центральную гробницу;

$I X-$ Входная яма боковой Северо-восточной гробницы;

$X-$ Дромос, соединявший входную яму

и катакомбу боковой Северо-восточной гробницы;

$X I$ - Катакомба боковой Северо-восточной гробницы

были получены очень важные новые данные, позволяющие по-новому представить структуру кургана и окончательно уточнить его датировку.

К началу раскопок в 2004 г. Александропольский курган представлял собой круглую в плане площадку диаметром около 100 м, изрытую большими и малыми ямами. Её окружало кольцо отвалов грунта, вывезенного с кургана при раскопках 1852-1856 гг., высотой до 5 м (рис. 4). В первый год работ были определены границы кургана - найден кольцевой ров, окружавший курган, и определён его диаметр 110 м. Ров имел ширину 4-5,7 м на уровне материка и глубину 1,7-3,2 м от уровня материка, не менее 2,2-3,3 м от уровня древнего горизонта. С западной и восточной сторон во рву имелись проходы шириной 3,6-4,1 м. В заполнении рва были обнаружены большое количество мелких камней, оплывших в ров вместе с грунтом из крепиды кургана, и в небольшом количестве остатки тризны - обломки амфор и кости животных. 


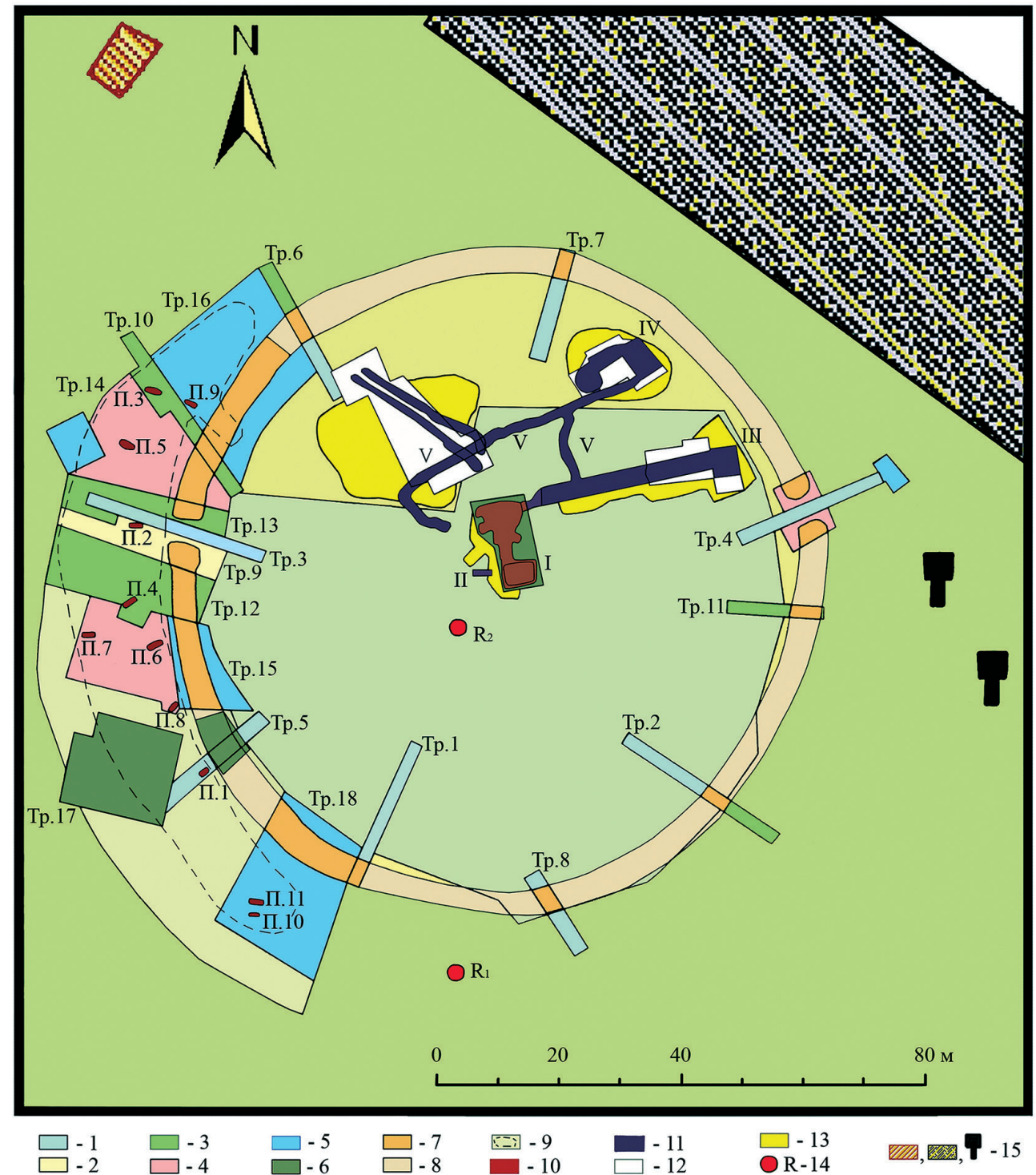

Рис. 3. Общий план раскопок Александропольского кургана в 2004-2009 гг. (1 - раскопы 2004 г.; 2 - раскопы 2005 г.; 3 - раскопы 2006 г.; 4 - раскопы 2007 г.;

5 - раскопы 2008 г.; 6 - раскопы 2009 г.; 7 - раскопанные участки рва;

8 - нераскопанная часть рва; 9 - пределы распространения околокурганной тризны; 10 - жертвенные погребения № 1-11 в околокурганной тризне;

11 - гробницы и подземные ходы, исследованные А.Е. Люценко в 1855-1856 гг.

(I - Центральная гробница. II - захоронение лошади. III - восточный дромос подзахоронения в Центральную гробницу. IV - боковая Северо-восточная гробница.

$V$ - подземные ходы);12 - контуры раскопов А.Е. Люценко 1855-1856 гг.;

13 - современные контуры раскопов А.Е. Люценко; 14 - наши реперы; 15 - современные строения (скотобойня,

бетонированная силосная траншея, водонапорные башни) 

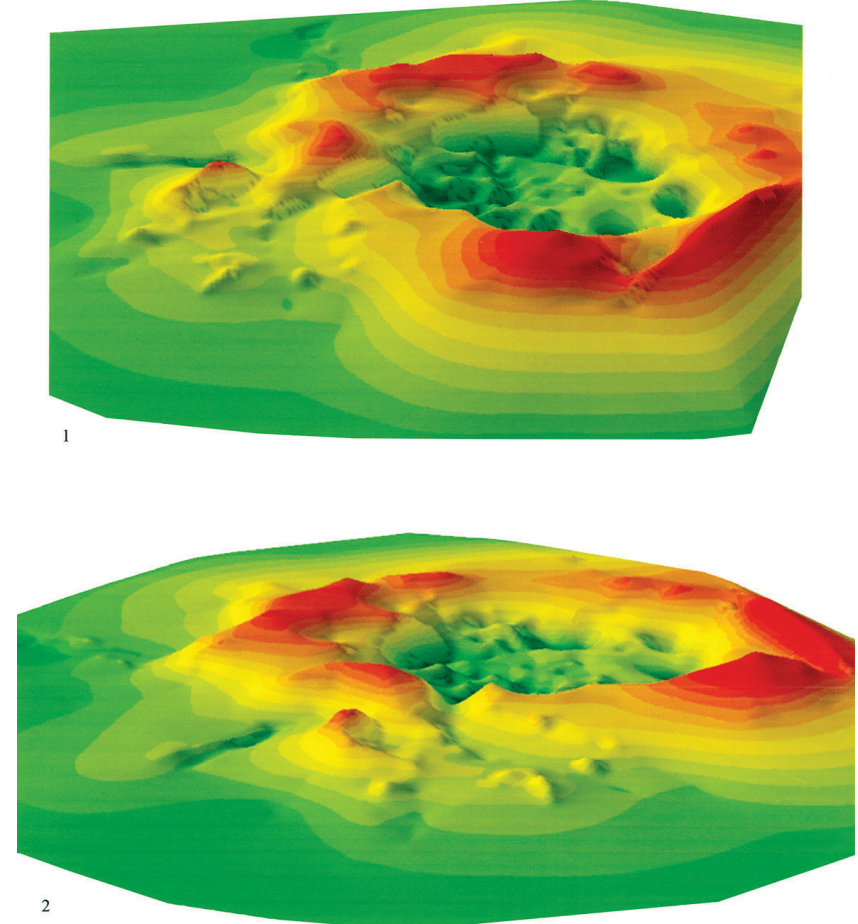

Рис. 4. Александропольский курган. Тахеометрическая съемка 2004 г. 1 - вид с востока. 2 - вид с юга, со стороны прохода в отвалах (съемка М.Н. Дараган)

В большинстве скифских курганов остатки тризны обычно укладываются в ров. В Александропольском кургане это правило нарушено - ров содержал очень незначительное количество остатков тризны.

На внешнем склоне рва в северо-западном секторе были найдены средневековые вещи, - железные наконечник стрелы и псалии, - связанные с жертвоприношениями средневековых кочевников каменной статуе, некогда стоявшей на вершине Александропольского кургана.

За пределами рва с западной стороны кургана на большой площади были открыты остатки околокурганной поминальной тризны, произведённой после завершения похорон скифских царя и царицы в Александропольском кургане (рис. 3). Это было очень важное открытие. В Александропольском кургане, благодаря уникальным условиям, - здесь остатки тризны были засыпаны отвалами грунта при раскопках 1852-1856 гг., - и вся огромная площадка, где происходили поминальные действия, сохранилась полностью. В других курганах Скифии, которые располагаются на пахотных полях, такие площадки разрушены постоянной распашкой территорий, окружающих курганы (Полин, 2011. С. 214). Впервые в истории скифской археологии на Александропольском кургане появилась возможность исследования околокурганной тризны скиф- 
ского царского кургана. Поэтому все шесть лет раскопок 2004-2009 гг. были посвящены, прежде всего, исследованию этой тризны (Де Груммонд и др., 2005; Полин и др., Дараган, 2005; Полин, Дараган, 2007; 2008; 2010 а; Полин, 2010 б). В результате вдоль западной стороны кургана за пределами рва была полностью исследована площадка тризны размерами около $120 \times 15$ м об-

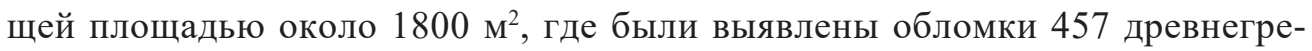
ческих амфор ${ }^{1}$ с 52 клеймами, произведённых в девяти центрах - Гераклея Понтийская (рис. 5; 6), Икос (рис. 7), Херсонес Таврический (рис. 8), Фасос (рис. 9), Хиос (рис. 10), Менда (рис. 11, 4), Синопа (рис. 11, 1-3), в одном из центров Восточного Средиземноморья (рис. 12), других пока ещё нелокализованных греческих центрах (рис. 13; 14; 15), амфоры типа Муригиоль (рис. 16) и Солоха-I (рис. 11, 5). Найдены также кости животных, которые были съедены во время отправления тризны - 99 особей, преимущественно домашних животных: быков, коней, овец, коз, собак, свиней, и в незначительной степени диких: зайца и оленя ${ }^{2}$. Также были найдены фрагменты скифских лепных сосудов, бронзовые и железные наконечники стрел, фрагменты чешуйчатого панциря (рис. 20, Кат. 33), детали конской узды, личные украшения (бусы, серьга), железные гвозди и скобы, орудия труда и скопление золотых нашивных бляшек, украшавших женскую одежду (рис. 19. Кат. 51-54).

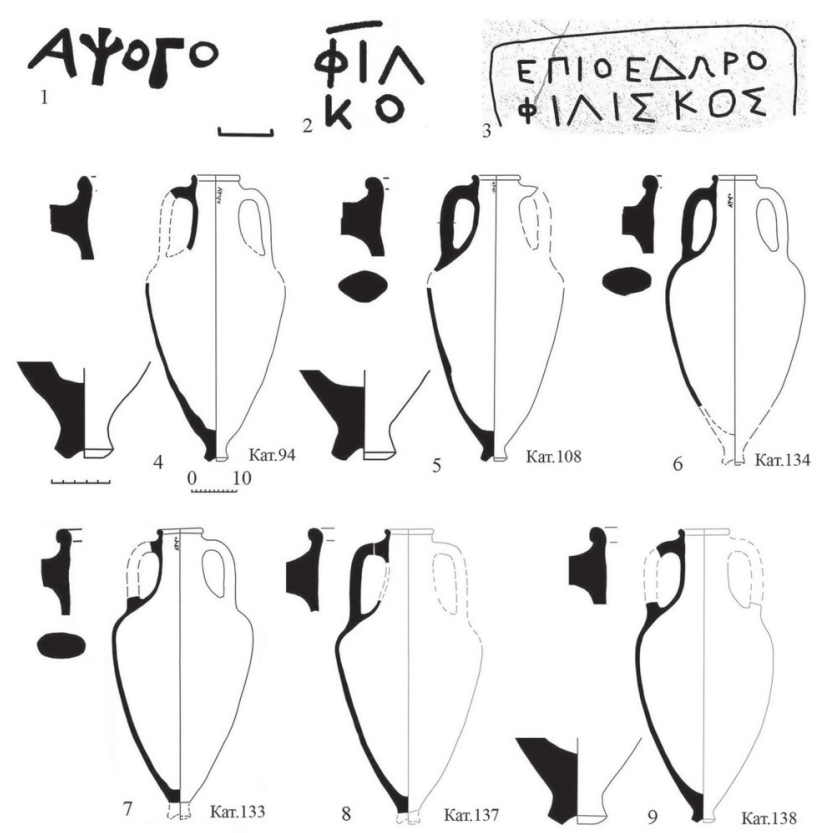

Рис. 5. Амфоры из Александропольского кургана. Гераклея пифоидного типа

${ }^{1}$ По последним полным подсчётам. В предварительной публикации указывалось 389 амфор (Полин, 2010. С. 273).

${ }^{2}$ Определения О.П. Журавлева (ИА НАНУ). 

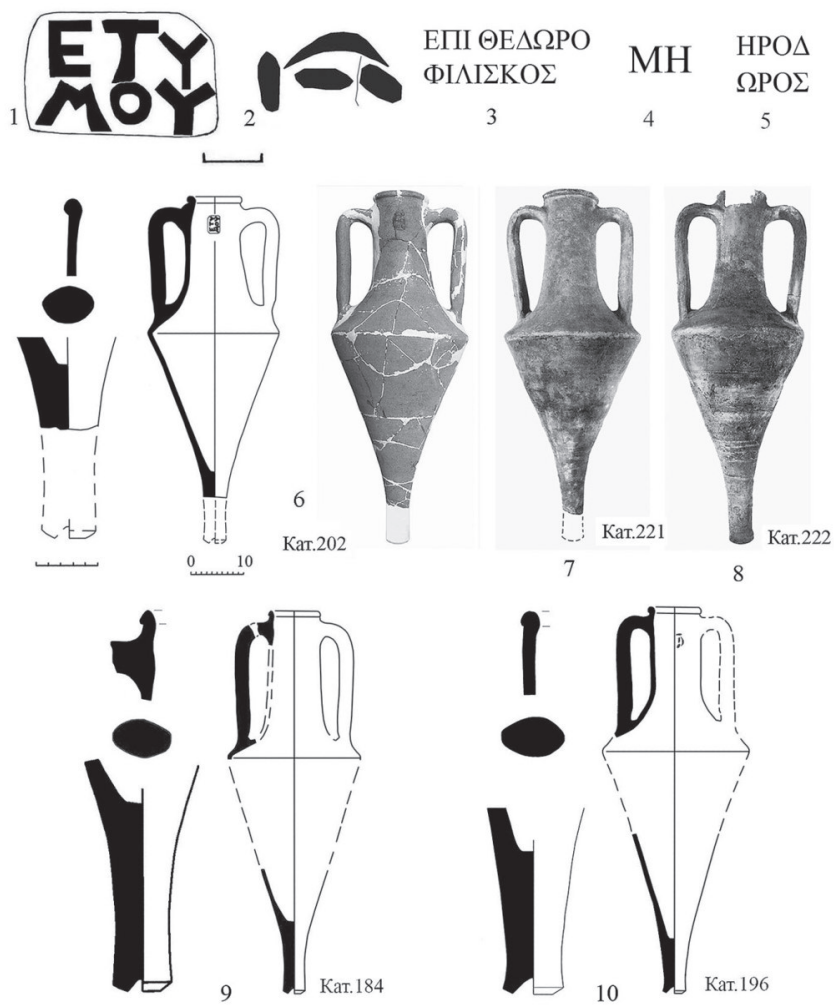

Рис. 6. Амфоры из Александропольского кургана. Гераклея конического типа
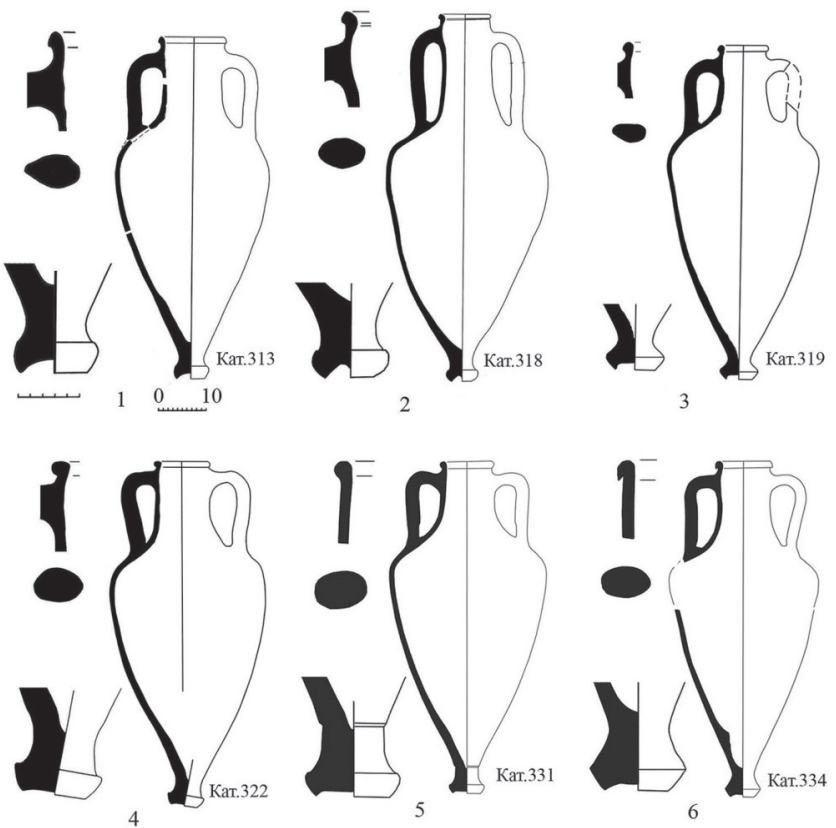

Рис. 7. Амфоры из Александропольского кургана. Икос красноглиняный 


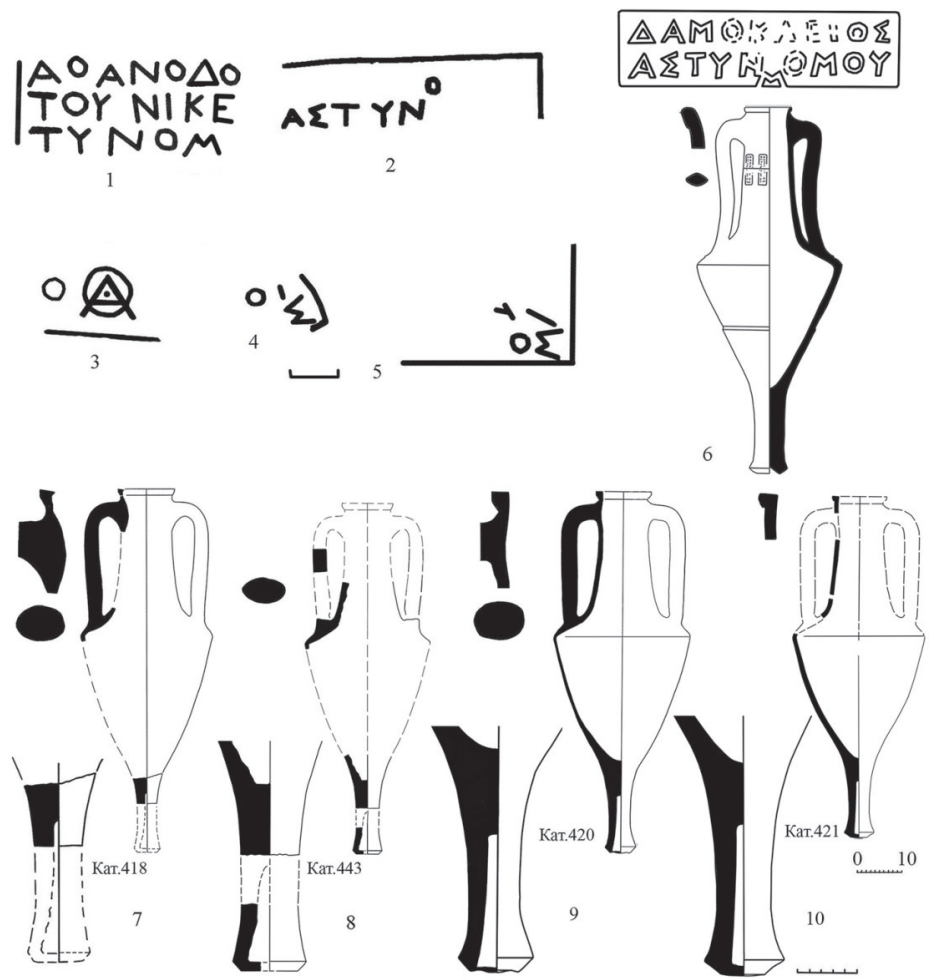

Рис. 8. Амфоры из Александропольского кургана.

Херсонес Таврический (1-5, 7-10 - Александропольский курган, 6 - Запорожье, рис. по: Нефедов, 1992)

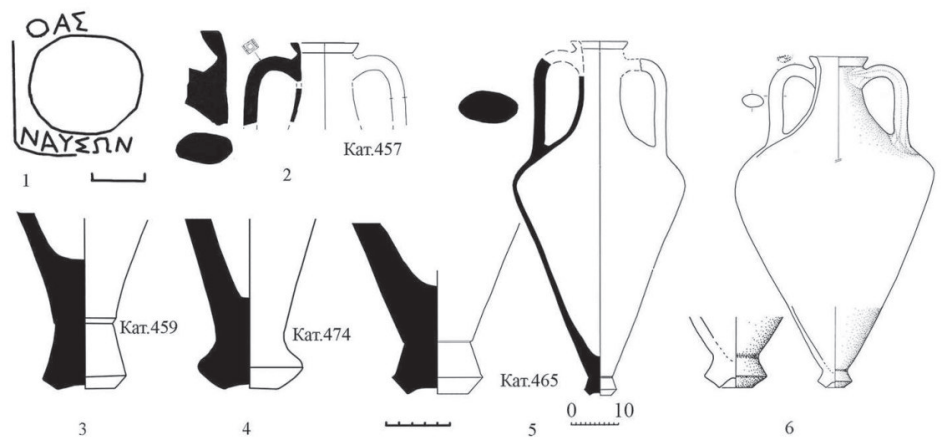

Рис. 9. Амфоры из Александропольского кургана. Фасос 


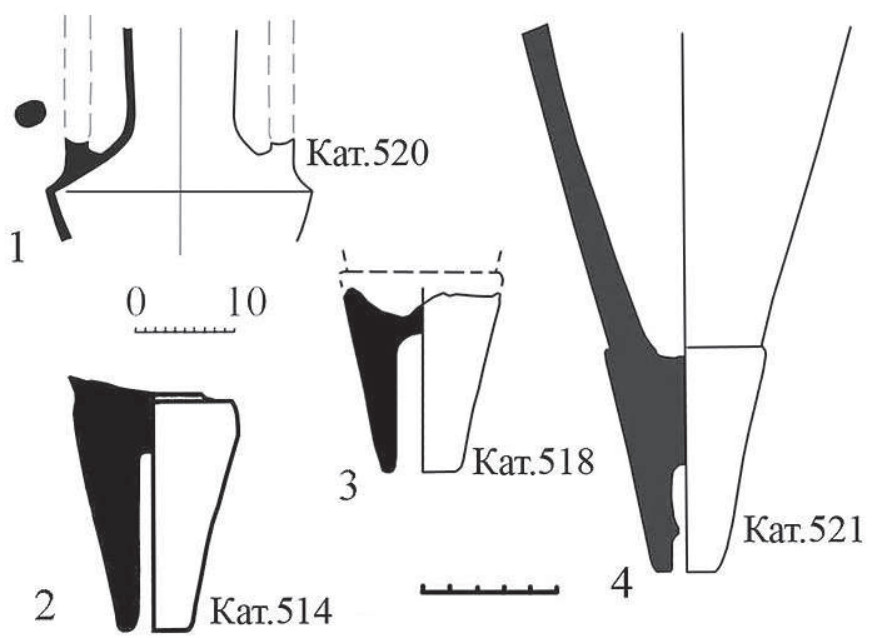

Рис. 10. Амфоры из Александропольского кургана. Хиос
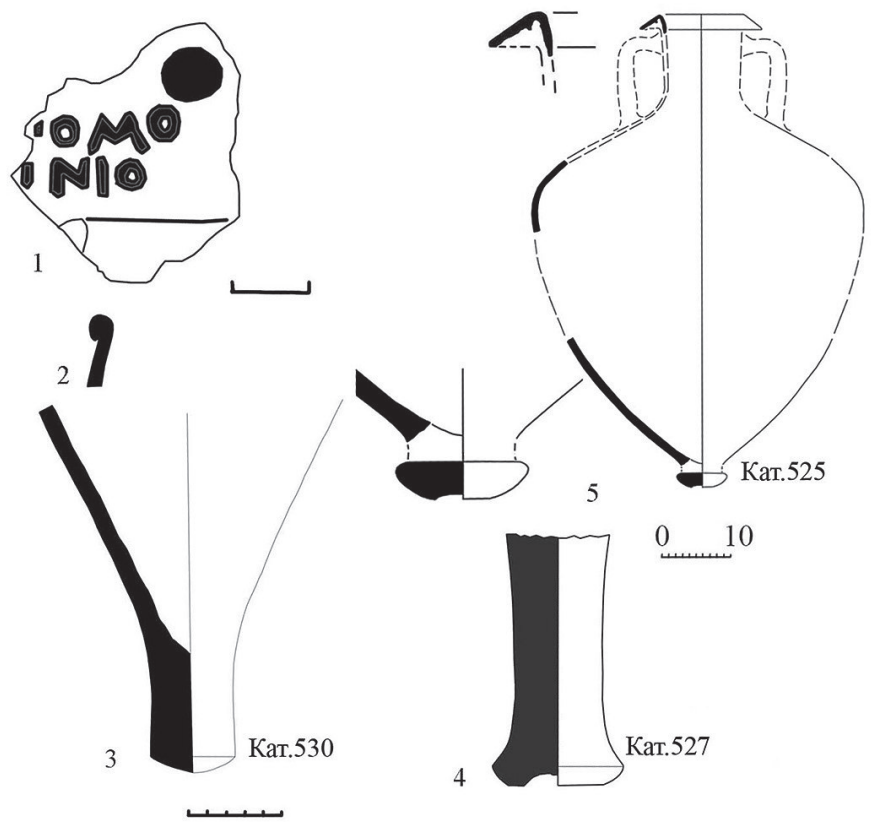

Рис. 11. Амфоры из Александропольского кургана. Амфоры Синопы, Менды и типа Солоха-І 

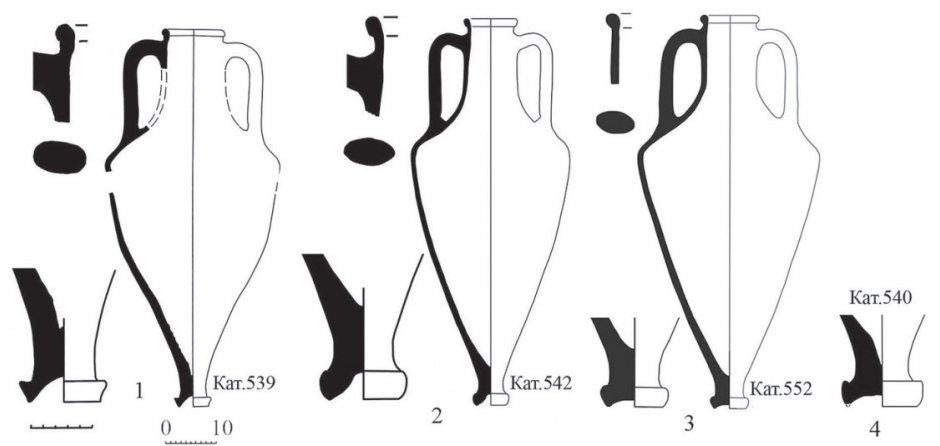

Рис. 12. Амфоры из Александропольского кургана.

Восточное Средиземноморье, неустановленный центр
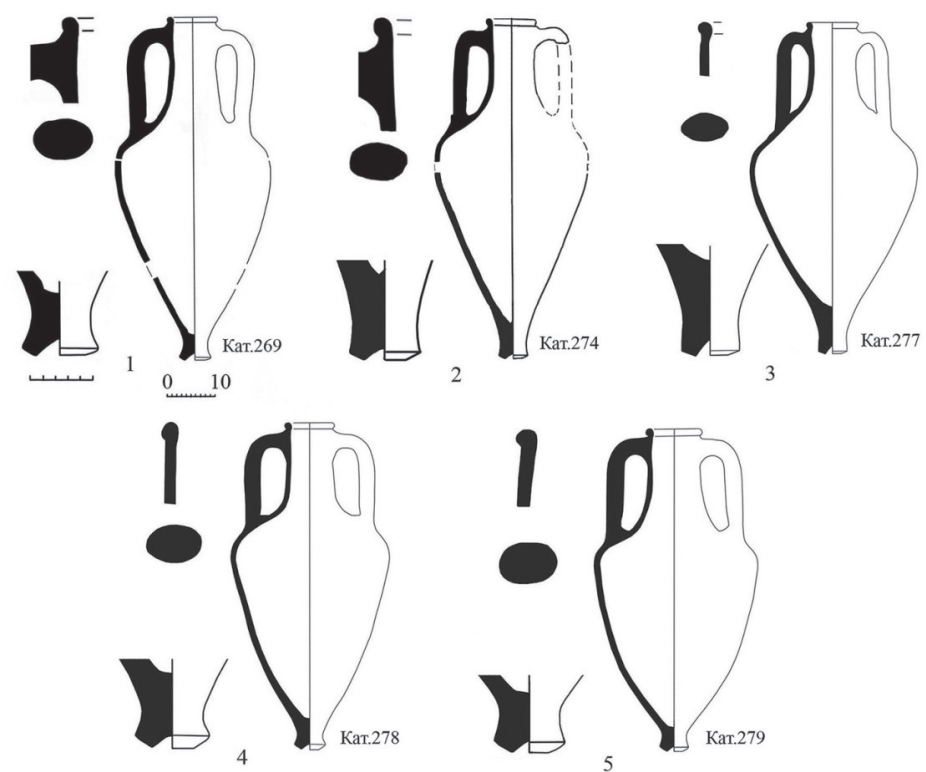

Рис. 13. Амфоры из Александропольского кургана. Круг Гераклеи. Оранжевая серия
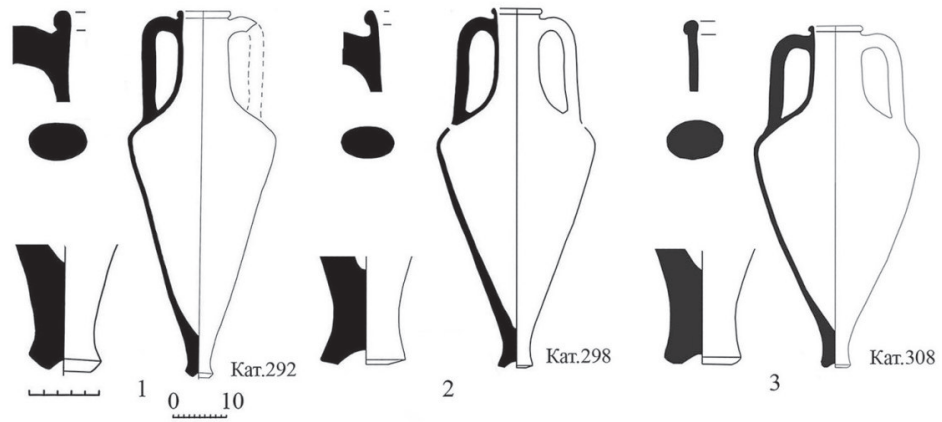

Рис. 14. Амфоры из Александропольского кургана. Круг Гераклеи. Коричневая серия 


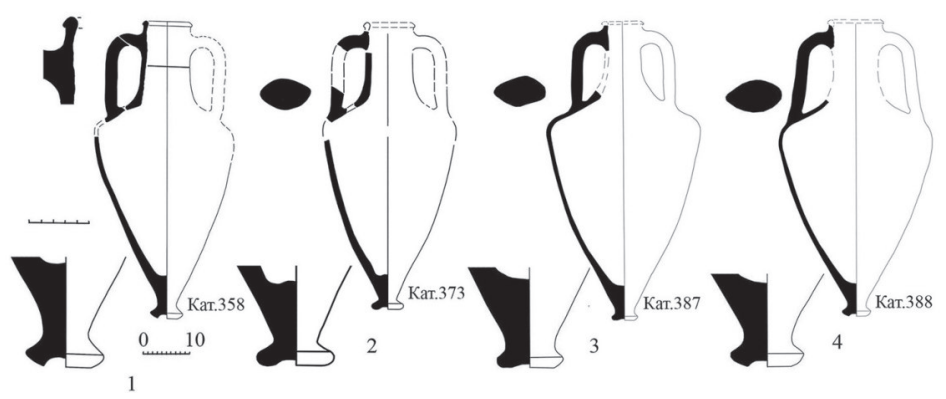

Рис. 15. Амфоры из Александропольского кургана. Икос-2 коричневоглиняный
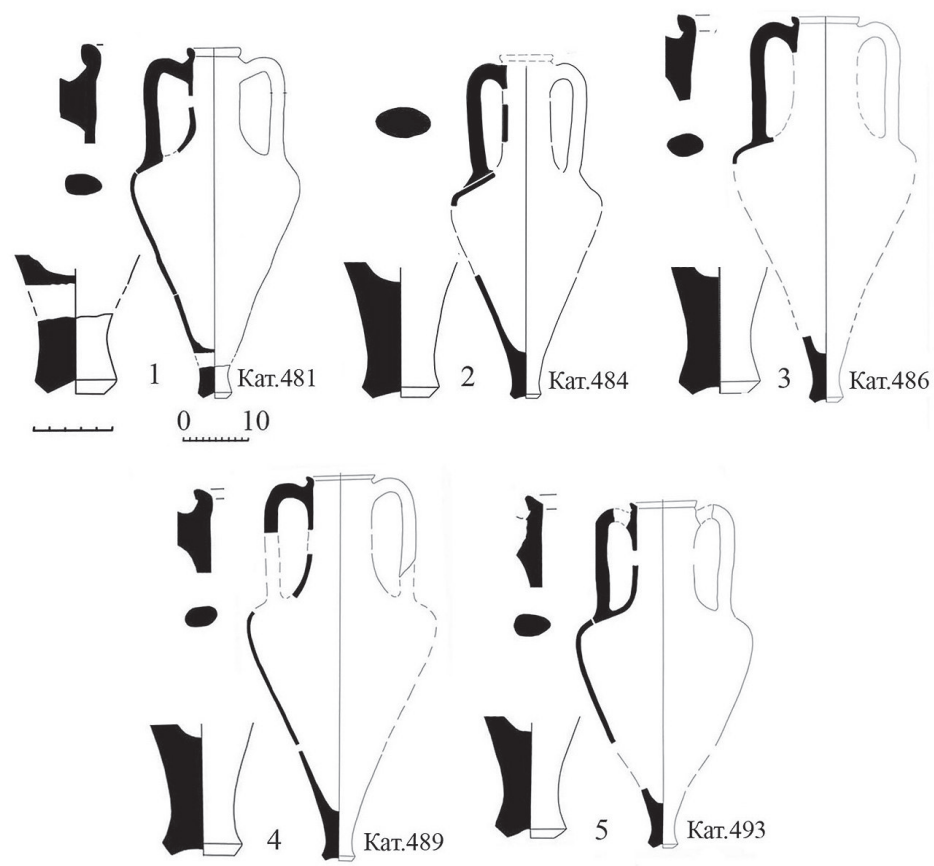

Рис. 16. Амфоры из Александропольского кургана. Амфроры типа Муригиоль

Среди остатков тризны также были найдены несколько обломков человеческих костей, что, возможно, может свидетельствовать о существовании ритуального каннибализма у скифов. Кроме того, в пределах площадки тризны были открыты 11 сопровождающих захоронений людей разного пола и возраста (рис. 3): № 1 - мужчина 20-30 лет, № 2 - мужчина 35-45 лет, № 3 - мужчина (20) 25-30 лет, № 4 - мужчина 18-20 (25) лет, № 5 - молодой/взрослый мужчина, № 6 - мужчина молодого возраста (20-25 лет), № 7 - ребёнок 10-14 лет, № 8 - зрелый мужчина 45-55 лет, № 9 - мужчина 30-40 лет, № 10 - ребёнок 
3-5 лет, № 11 - женщина 25-30(35) лет1․ Эти захоронения открывают страшную сторону скифского погребального ритуала: все эти люди, мужчины и женщины разного возраста, а также подростки и дети, были убиты в процессе отправления поминок и здесь же были похоронены.

При исследовании околокурганной тризны и рва были собраны образцы камней, из которых была построена грандиозная крепида кургана, - всего 11 разновидностей камней. Их исследование и определение показало, что они происходят из различных месторождений, расположенных на расстоянии от 40 до 80 км по прямой от Александропольского кургана. С учётом необходимости объездов через броды через мелкие степные речки, а также необходимости выбора объездных дорог с наименьшей крутизной подъёмов/спусков для удобного переезда степных балок повозками, тяжело нагруженными камнями, эти расстояния как минимум нужно удвоить, что составляет от 80 до 170 км. Для одного образца предполагается происхождение из Крыма². Для строительства крепиды вовсе не требовалось 11 видов камня. Такое разнообразие было вызвано совсем другими причинами. Необходимо рассматривать камни из крепиды не только как строительный материал, но и своего рода приношения от подвластного населения с различных территорий.

В 2004 г. также предполагалось повторное исследование всех гробниц кургана и подземных ходов, открытых при раскопках 1855-1856 гг. Но после получения информации о захоронениях на протяжении второй половины XIX - первой половины XX вв. почти во всех подземельях кургана животных, погибших от различных болезней вплоть до сибирской язвы, мы ограничились зачисткой подкурганной поверхности для проверки отсутствия других гробниц, кроме обнаруженных в 1855-1856 гг., и повторным исследованием только Центральной гробницы кургана. От исследования остальных гробниц и многочисленных подземных ходов Александропольского кургана по вышеуказанным причинам пришлось отказаться. При зачистке подкурганной поверхности также были получены стратиграфические данные об одновременности сооружения Центральной гробницы кургана и Восточного дромоса подзахоронения в неё.

В 2009 г. за два месяца непрерывной упорной работы были повторно открыты и расчищены входная яма, дромос и катакомба Центральной гробницы Александропольского кургана (рис. 17-18). Наши находки не были щедрыми. При самой тщательной расчистке с применением металлоискателя в Центральной гробнице было обнаружено около 60 золотых штампованных бляшек, бусин и пронизей разных типов, в том числе несколько новых типов, неизвестных по раскопкам 1855-1856 гг., покрытые золотом панцирные пластинки (рис. 19, Кат. 55-62; 20; 21) (Polin, Daragan, 2011 b; Полин, 2016),

\footnotetext{
${ }^{1}$ Определения А.Д. Козак (ИА НАНУ).

${ }^{2}$ Определения И.С. Никитенко (Днепропетровский горный университет).
} 


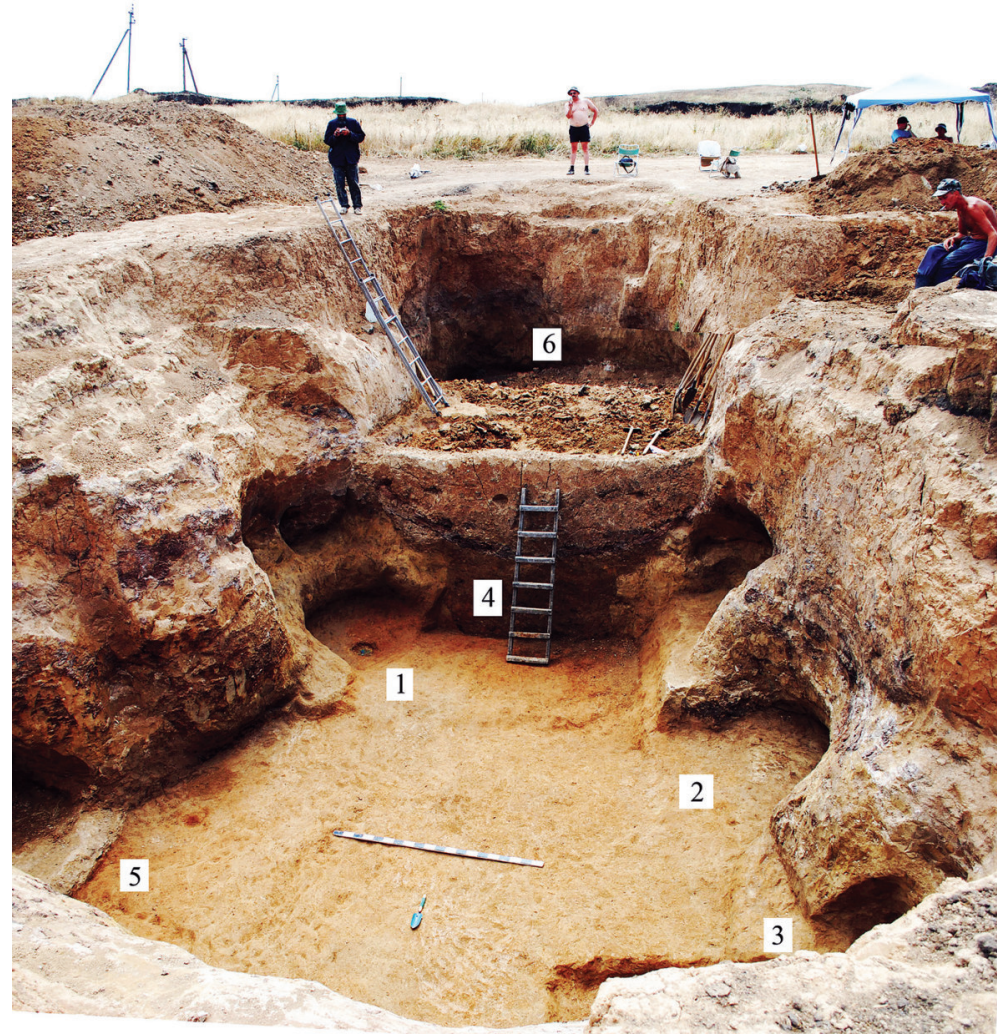

Рис. 17. Александропольский курган. Раскопки Центральной гробницы. Поиски границ. Вид с востока

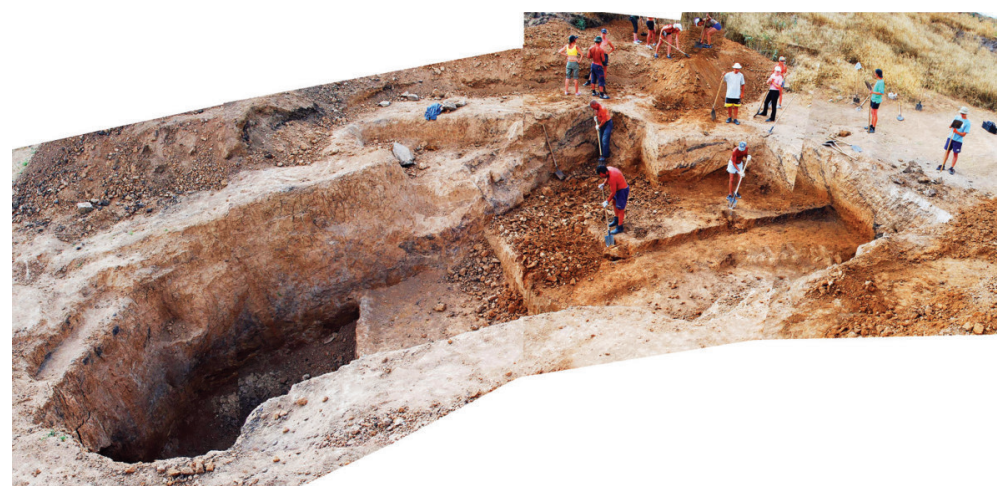

Рис. 18. Александропольский курган. Центральная гробница. Общий вид гробницы с расчищенной катакомбой. Вид с севера. Цифровые обозначения см. рис. 24 

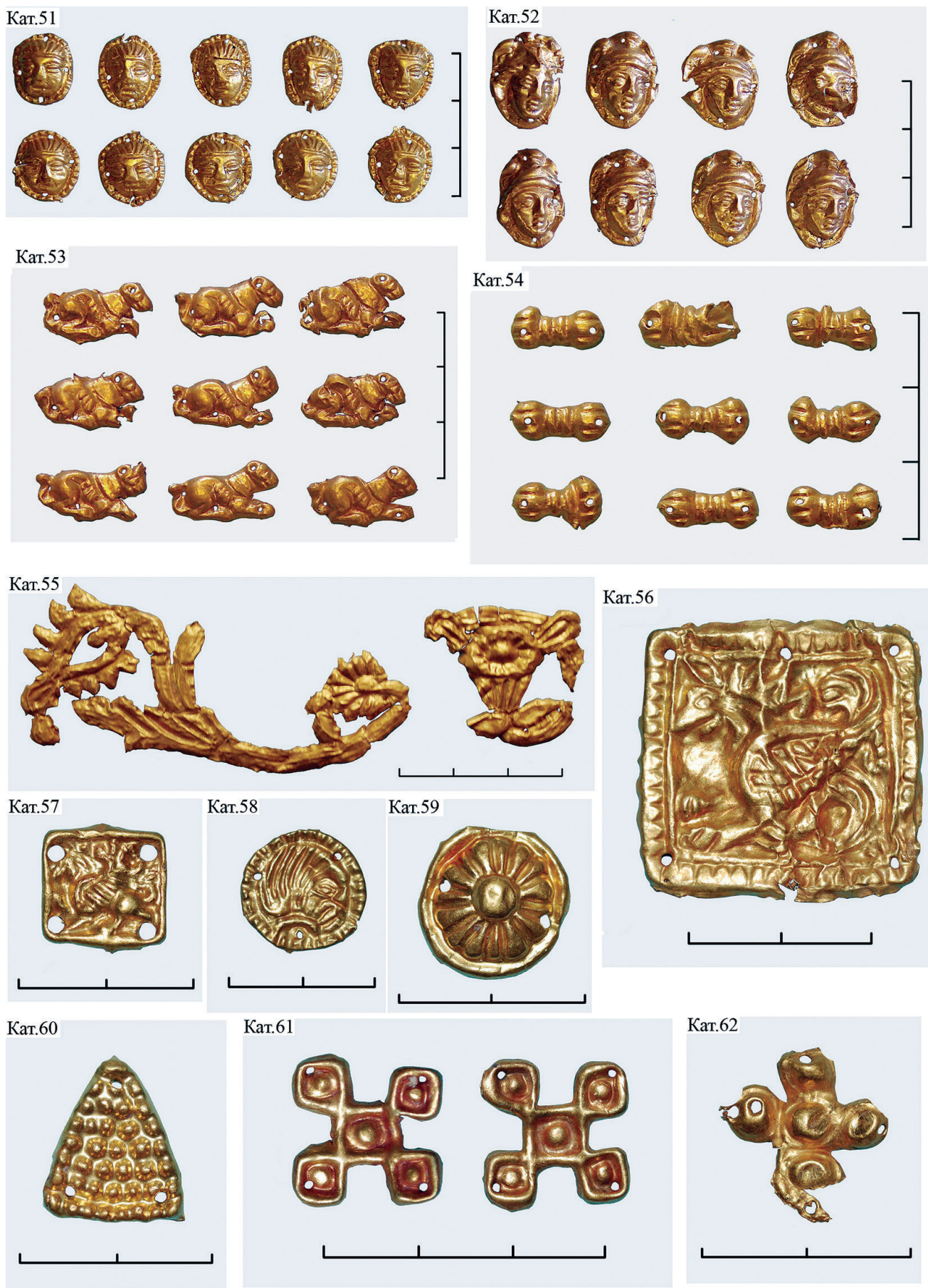

Рис.19. Золотые бляшки из раскопок околокурганной тризны 2006-2008 гг. (Кат. 51 - Кат. 54) и Центральной гробницы в 2009 г. 

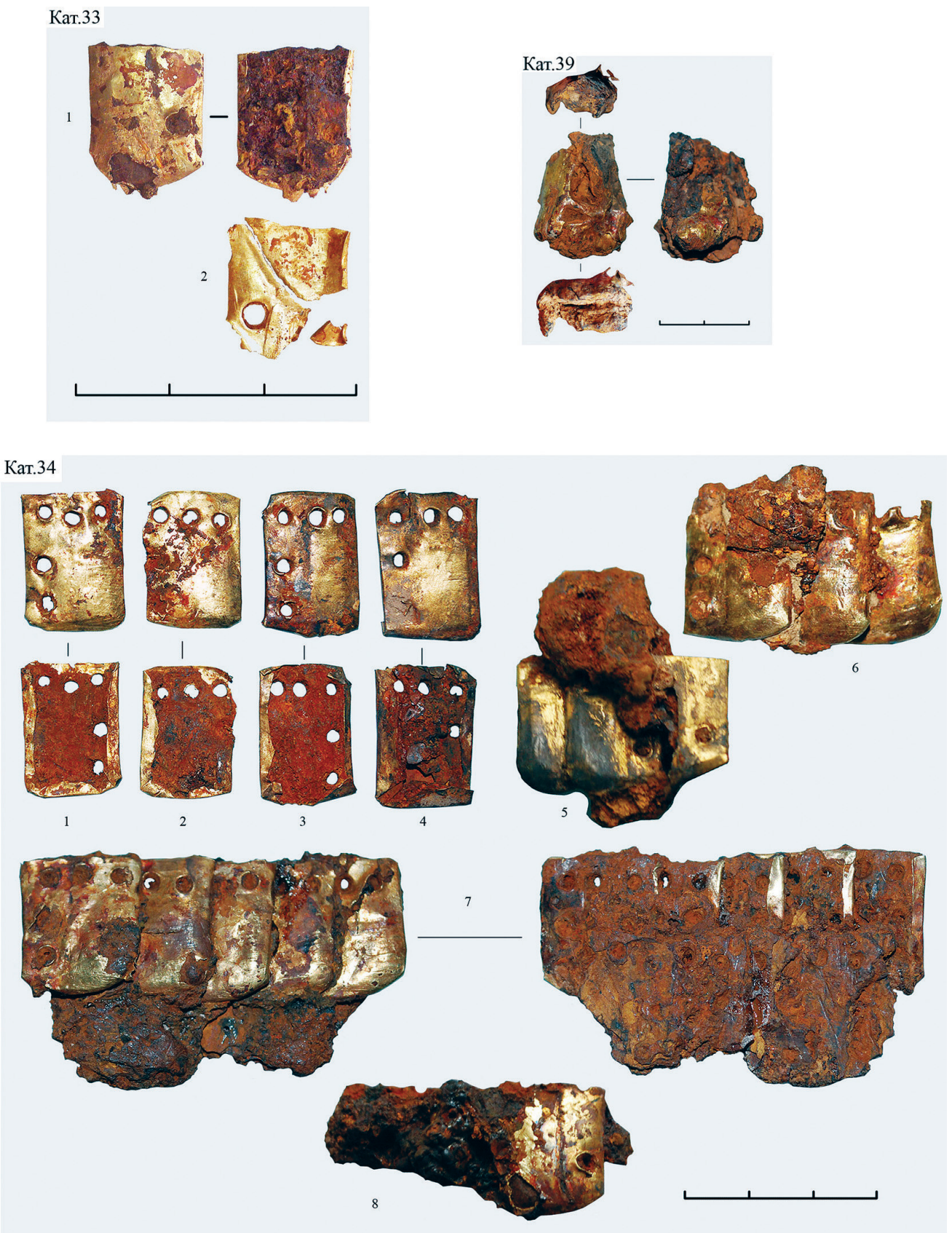

Рис. 20. Обломки чешуйчатого панциря из тризны и Центральной гробницы

(Кат. 33 - Кат. 34), а также фрагмент псалия (?), плакированного золотом из Центральной гробницы (Кат. 39) 

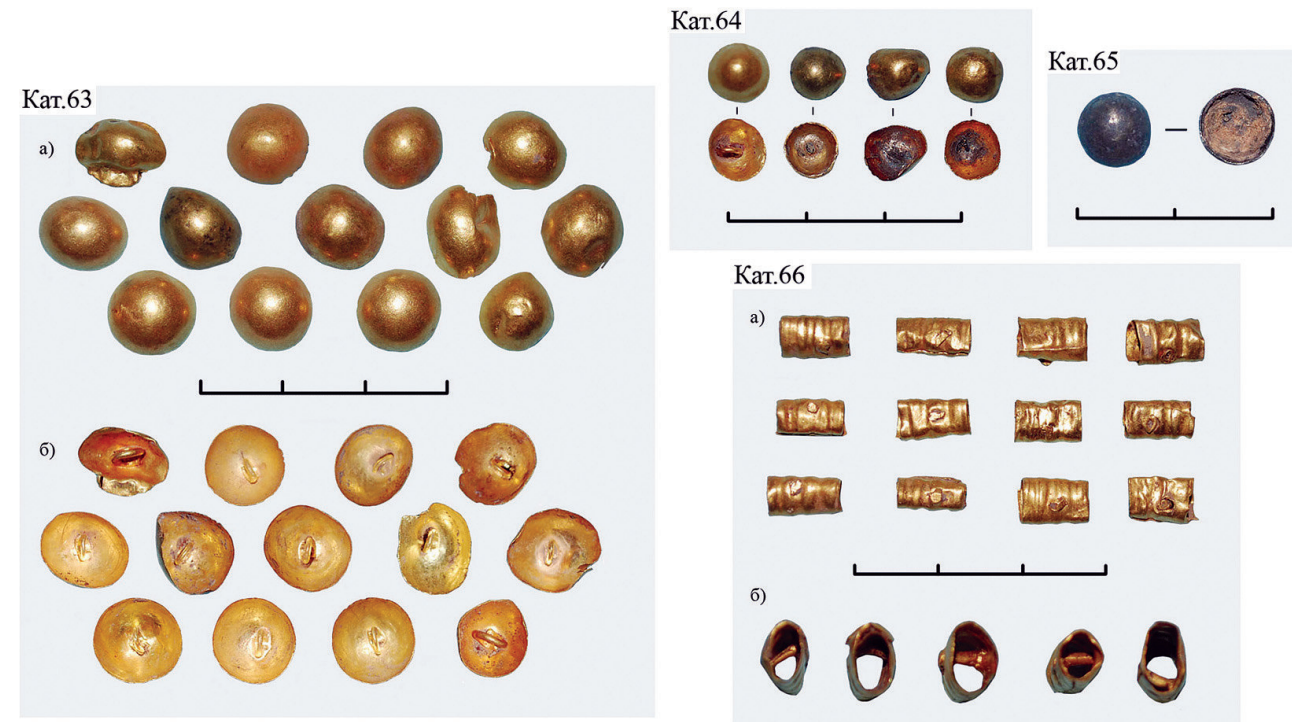

Кат.66

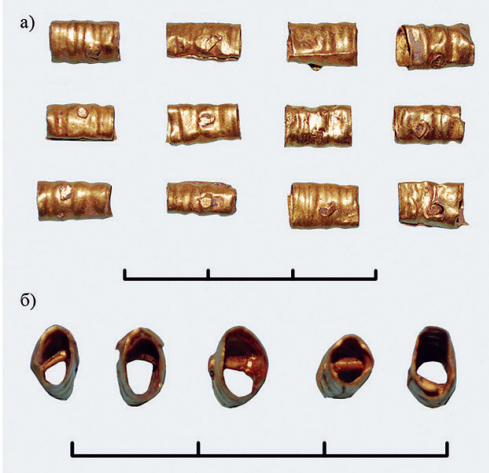

Кат. 67
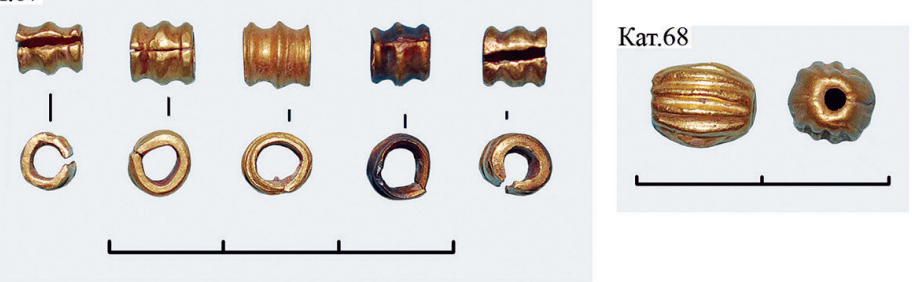

Кат.69

Кат. 70

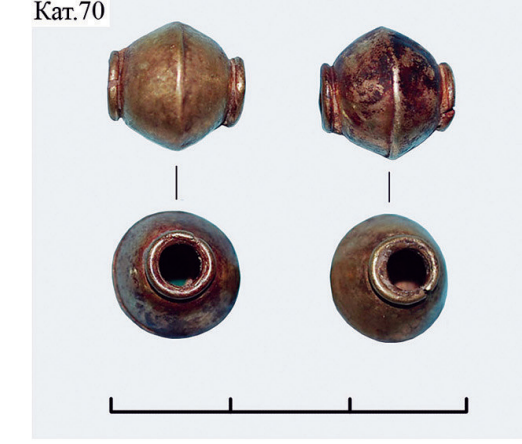

Кат.71
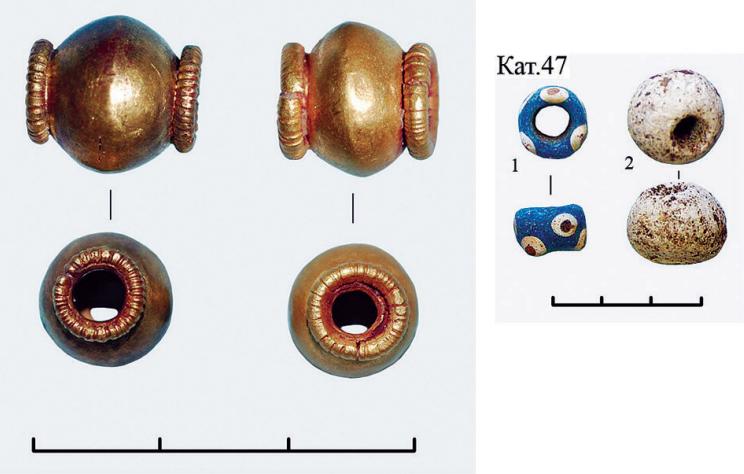

Рис. 21. Золотые бляшки и бусы из раскопок Центральной гробницы в 2009 г.

(Кат. 63 - Кат. 71) и бусы из погребения № 4/2006 г.

в околокурганной тризне (Кат. 47) 
обломки железных панцирных пластинок - ?, фрагмент железного псалия (?), обтянутого золотым листом (Кат. 39), серебряная ворворка, серебряная пуговица, мелкие обломки серебряных изделий, фрагмент знаменитой чернолаковой Александропольской пиксиды, бронзовый шарик, железные гвозди, множество мельчайших обломков тонкой листовой бронзы, фрагменты железных скоб, мелкие обломки бронзовых изделий, два обломка бронзовых наконечников стрел, фрагмент скифского лепного сосуда, фрагмент лутерия (?) (Кат. 73), около 60 фрагментов амфор семи типов - Гераклея, Икос, Икос-2, типа Муригиоль, Хиос, Восточное Средиземноморье, тех же типов, что были обнаружены в околокурганной тризне.

Повторные раскопки Центральной гробницы кургана позволили уточнить её конструкцию и размеры, несколько иную конфигурацию камеры, наличие двух новых ниш в боковых стенках камеры (котловой - здесь обнаружен отпечаток ножки гигантского котла, и второй неизвестного назначения), отсутствие боковых обходных грабительских ходов - таких ходов никогда не существовало и они не были открыты и не были исследованы в 1855 г. (рис. 22).

В результате повторных исследований Александропольского кургана в 2004-2009 гг. были получены серьёзные научные результаты, позволившие по-новому понять этот фундаментальный памятник Причерноморской Скифии. Все имеющиеся данные о конструкции кургана, однотипность золотых бляшек, амфор и амфорных клейм из всех гробниц кургана, его насыпи, рва и околокурганной тризны свидетельствуют о полной синхронности всех гробниц
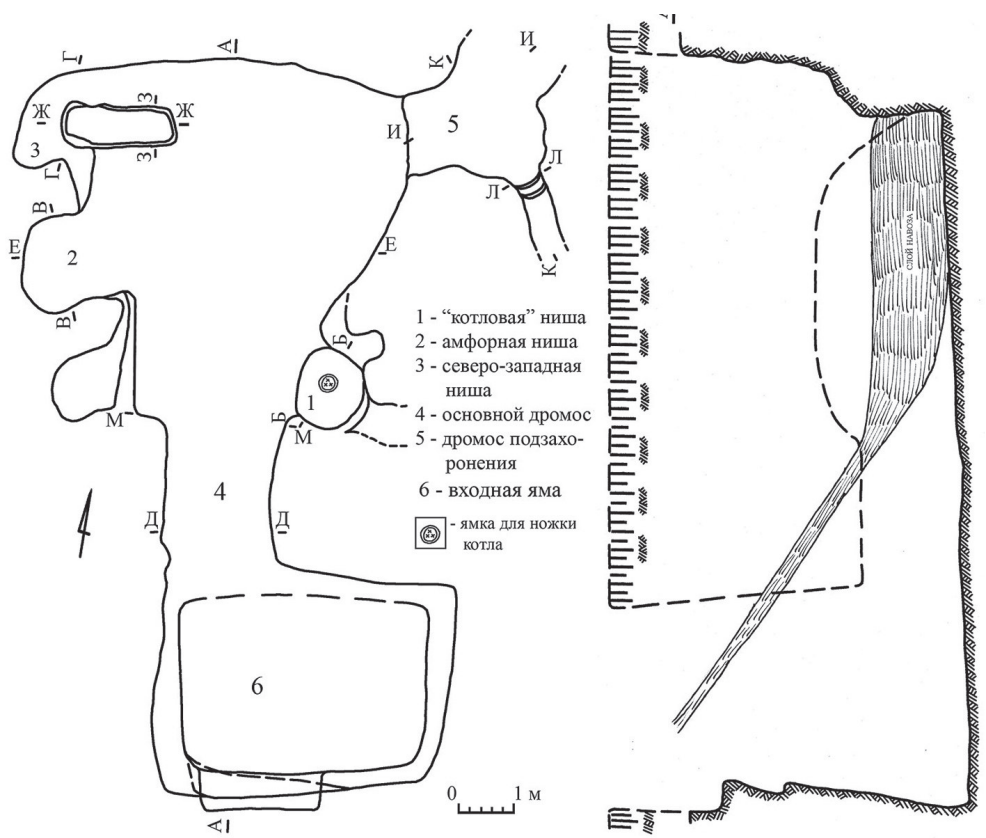

Рис. 22. Александропольский курган. Центральная гробница. Общий план и разрез 
и конструктивных элементов Александропольского кургана. Синхронизация всех типов амфор, найденных в гробницах, насыпи, во рву и в околокурганной тризне, наиболее вероятна в пределах третьей четверти IV в. до н.э. около 340-330 гг. до н.э.

Конструкция Александропольского кургана по данным раскопок 18521856 и 2004-2009 гг. В результате новых раскопок Александропольского кургана в 2004-2009 гг. была получена новая информация, благодаря которой удалось понять и уточнить некоторые данные по раскопкам 1852-1856 гг. По данным раскопок 1852-1856 гг. и 2004-2009 гг., Александропольский курган выглядит так.

Наиболее вероятная высота Александропольского кургана составляла 23-24 м при диаметре крепиды около 80 м и диаметре рва 110 м. Такой высоте соответствует объём грунта в отвалах, вывезенных при раскопках насыпи кургана в 1852-1856 гг. - около 130000 м куб. ${ }^{1}$ Александропольский курган представлял собой усечённый конус с широкой плоской вершиной диаметром около 19 м. Наиболее точно форма насыпи Александропольского кургана запечатлена на эскизном рисунке князя А.А. Сибирского 1852 г., сделанном в самом начале раскопок кургана (рис. 23).

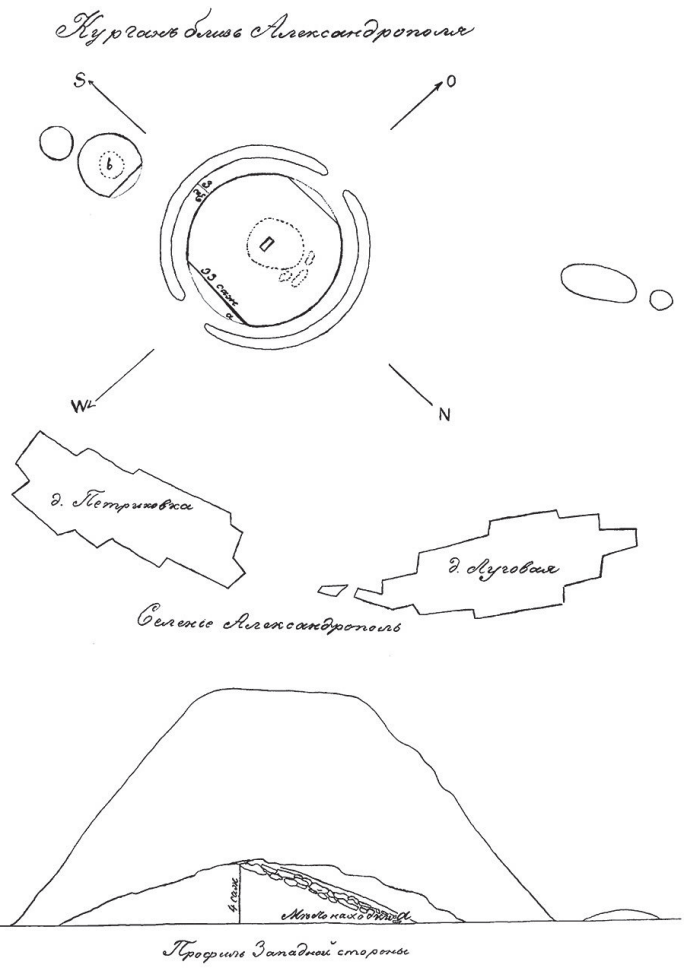

Рис. 23. Александропольский курган и его ближняя курганная свита на схематическом рисунке князя А.А. Сибирского (10 сентября 1852 г.)

${ }^{1}$ Тахеометрические обмеры и расчёты М.Н. Дараган. 
Поверхность кургана была полностью покрыта каменным панцирем.

На вершине Александропольского кургана некогда стояла каменная баба неизвестной принадлежности, скифская или половецкая.

Курган окружал земляной вал высотой 0,9-1,1 м. Ширина вала различная - от 6,5 до 18-20 м. Через вал и ров существовали проходы шириной 3,6 м с западной и 4,1 м с восточной сторон. Вал был сооружён после проведения поминальной тризны и своей толщей перекрыл слой околокурганной тризны.

Между валом и курганом находился кольцевой ров диаметром 110 м, шириной на уровне материка на разных участках 4,0-5,7 м, глубиной 1,7-3,2 м от уровня материка или от уровня древнего горизонта не менее 2,2-3,3 м. Как показывают раскопки скифских курганов в Северном Причерноморье, сооружение кургана начиналось с выкапывания рва. Таким образом, выделялась подкурганная площадка, - территорию мёртвых ров отделял от мира живых. Только после этого начиналось выкапывание могил. Следует отметить весьма незначительное количество находок остатков тризны во рву для кургана такого уровня, как Александропольский. Только на участках рва возле западного прохода с обеих сторон их концентрация была достаточно высокой. В скифских курганах значительно меньших размеров высотой 2-5 м и менее во рвах нередко обнаруживаются настоящие завалы остатков тризны из обломков амфор и костей животных. В Александропольском кургане основная часть тризны находилась за пределами его рва, с западной стороны на огромной площадке.

Каменная крепида, окружавшая Александропольский курган по основанию, имела весьма грандиозные размеры и, по-видимому, представляла собой вертикальную кольцевую стену высотой более 4 м и диаметром около 80 м, сложенную из огромных каменных плит, которые, по словам А.В. Терещенко, то ли 5 человек, то ли 8, то ли 12, или даже 15 человек, не могли сдвинуть с места. Данное свидетельство, безусловно относящееся к разряду эмоциональных, тем не менее, отражает циклопический характер камней, из которых была сложена крепида Александропольского кургана. Для строительства крепиды были использованы 11 пород камня из различных месторождений, расположенных от 40 до 80 км от кургана по прямой или от 80 до 160 км реальных расстояний по дорогам.

После завершения похорон царских особ, возведения насыпи Александропольского кургана, строительства крепиды вокруг неё и каменного панциря, покрывшего всю поверхность кургана, была проведена поминальная тризна с западной стороны кургана. Находки обломков амфор были отмечены и среди камней крепиды при раскопках 1852-1856 гг., кроме того, именно среди камней крепиды были найдены крестьянами в 1851 г. многочисленные золотые, серебряные и бронзовые вещи скифского типа. Часть остатков тризны находилась и между рвом и крепидой кургана. Незначительные остатки тризны были обнаружены и во рву кургана при раскопках 2004-2009 гг. 
Основные остатки тризны были открыты вдоль западной стороны кургана

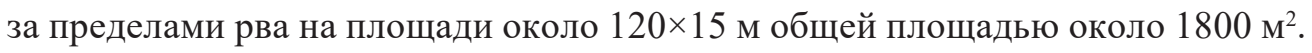
Как уже упоминалось выше, здесь были найдены обломки 457 древнегреческих амфор с 52 клеймами, произведённых в девяти установленных центрах Гераклея Понтийская, Икос, Херсонес Таврический, Фасос, Хиос, Синопа, Менда, в одном из центров Восточного Средиземноморья и других, пока ещё нелокализованных, греческих центрах, амфоры типа Муригиоль и Солоха-I. Найдены также кости животных, которые были съедены во время тризны, 99 особей, преимущественно домашних: быков, коней, овец, коз, собак, свиней, и в незначительной степени диких: зайца и оленя. Также были найдены фрагменты скифских лепных сосудов, бронзовые и железные наконечники стрел, фрагменты чешуйчатого панциря, детали конской узды, личные украшения, железные гвозди и скобы, орудия труда и скопление золотых нашивных бляшек, украшавших женскую одежду. Также были найдены несколько обломков человеческих костей, что может свидетельствовать о существовании ритуального каннибализма у скифов. В пределах площадки тризны были открыты 11 сопровождающих захоронений мужчин, женщины и детей разного возраста, умерщвленных насильственно.

Повторное исследование Центральной гробницы кургана подтвердило её смещение к северу от геометрического центра кургана, что нехарактерно для скифских курганов, в которых первичные погребения располагаются в геометрическом центре кургана. Причины этого неизвестны. Повторные раскопки позволили уточнить её размеры и детали конструкции (рис. 22). Входная яма, дромос и катакомбы имели несколько иные размеры и конфигурацию. Из главных отличий нужно указать более вытянутую форму катакомбы, отсутствие боковых грабительских ходов вдоль продольных стенок катакомбы и наличие ещё двух ниш в стенках камеры, сверх одной, открытой в 1855 г. Кроме того, при зачистке подкурганной поверхности были получены стратиграфические свидетельства синхронности сооружения Центральной гробницы и Восточного дромоса подзахоронения в неё.

Определение достоверных достаточно скромных размеров и истинной конфигурации катакомбы Центральной гробницы Александропольского кургана, состав вещей, найденных в ней, позволяют утверждать, что в камере Центральной гробницы было захоронено не более двух человек, а именно мужчина и женщина (рис. 24) ${ }^{1}$. Существуют старые антропологические опреде-

${ }^{1}$ Для реконструкции захоронений в Центральной гробнице Александропольского кургана использованы планы неграбленных мужского воинского захоронения в кургане Соболева Могила (Мозолевский, Полин, 2005. Рис. 91) и женского захоронения в Толстой Могиле (Мозолевський, 1979. Рис. 30). Безусловно, эти захоронения более низкого социального уровня и в Центральной гробнице Александрополя было значительно больше сопровождающих вещей, соответствующих высочайшему царскому уровню, что только подчеркивает невозможность размещения более 2 погребённых в камере Центральной гробницы. 


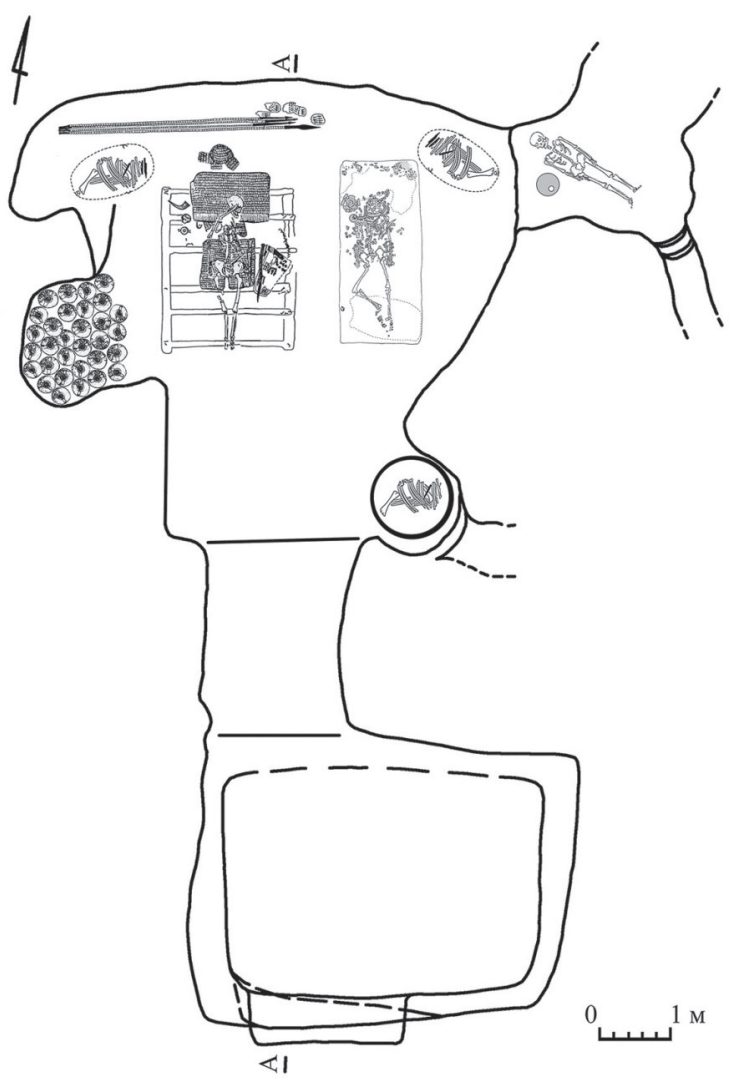

Рис. 24. Александропольский курган, Центральная гробница.

Реконструкция по данным раскопок 2009 г.

ления двух черепов, найденных в катакомбе Центральной гробницы в 1855 г. Согласно этим определениям черепа принадлежали мужчине до 40 лет и весьма пожилому мужчине в возрасте за 60-70 лет. Но состав вещей настойчиво указывает на захоронение здесь мужчины и женщины. Согласно новейшим антропологическим определениям черепов из Центральной гробницы В.Г. Моисеева и А.Г. Козинцева ${ }^{1}$ черепа, найденные здесь, принадлежат женщине 20-35 лет и мужчине в возрасте более 50 лет. Таким образом, состав сопровождающих вещей полностью соответствует половому составу погребённых. Было подтверждено определение черепа из боковой Северо-восточной гробницы - мужчина в возрасте около 30 лет.

Накопление информации об ограблении скифских курганов в Северном Причерноморье за прошедшие 150 лет их раскопок позволяет иначе оценить подземные ходы, открытые в Александропольском кургане. Из их числа необходимо исключить «обходные грабительские мины» вдоль продольных стен

${ }^{1}$ Искренне признательны за определения В.Г. Моисееву и А.Г. Козинцеву (Музей антропологии и этнографии РАН им. Петра Великого). 
катакомбы Центральной гробницы (рис. 2, V; VI), которые, как установлено при повторных раскопках в 2009 г., никогда не существовали, никем и никогда не исследовались. За них ошибочно были приняты норы животных в стенках камеры, которые не являются творением человеческих рук и, следовательно, не могут иметь ни малейшего отношения ни к гробнице, ни к её ограблению. Другие абсолютно достоверные ходы, которые были полностью исследованы А.Е. Люценко в 1855-1856 гг., ходы XII, XIII (рис. 2) сразу после их исследования было принято считать грабительскими. Безусловно, эти ходы впоследствии могли частично использоваться грабителями. Но их создание было продиктовано ритуальными целями. Это также справедливо и для загадочных подземных ходов XIV и XV (рис. 2), которые не имеют ни малейшего отношения к грабителям и носят исключительно ритуальный характер.

Имеющиеся данные свидетельствуют о том, что на протяжении существования Александропольского кургана произошло два проникновения в его гробницы. Первое проникновение с ритуальными целями произошло вскоре после завершения строительства кургана и было совершено через подземный ход, вырытый из входной ямы боковой Северо-восточной гробницы (рис. 2, IX, 1). При этом был пробит ход в камеру Северо-восточной гробницы, после этого тщательно замазанный глиной (рис. 2, XII, о). Видимых последствий это посещение для Северо-восточной гробницы как будто не имело. Однако, исключительно скромный характер набора вещей в боковой Северо-восточной гробнице царского уровня дает основания предполагать, что при этом посещении наиболее крупные ценные вещи были аккуратно изъяты без нарушения скелета. В это же время также имело место посещение катакомбы Центральной гробницы, однако, судить о последствиях которого мы не можем, поскольку при втором более позднем ограблении захоронения в камере Центральной гробницы были полностью разрушены. Второе ограбление было совершено через вертикальный колодец, вырытый с вершины кургана через входную яму Центральной гробницы. Такой тип ограбления вертикальным колодцем с вершины кургана наиболее характерен для XIX-XX вв., но изредка применялся и в древности. Имеющиеся данные ограничивает вероятный период второго ограбления Центральной гробницы Александропольского кургана от скифского времени до средневековья (это ограбление предшествовало установке на вершине кургана антропоморфной стелы, перекрывшей место грабительского колодца). К этому времени камера Центральной гробницы давно обвалилась, и грабителям пришлось механически перекапывать завалы материковой глины. По-видимому, им удалось извлечь наиболее крупные вещи, но при этом тысячи мелких вещей остались в грунте. Поздние грабители также вышли в Восточный дромос и ограбили половину захоронений лошадей на участке, прилегающем к камере Центральной гробницы. Вторая половина Восточного дромоса осталась непотревоженной, поскольку к тому времени здесь произошёл обвал потолка, и эта часть дромоса оказалась недоступной. Поздние грабители также 
вышли в подземные ходы XII, XIII, о чём свидетельствует вынесенный сюда грунт вместе с мелкими находками. Однако, при втором ограблении боковая Северо-восточная гробница не была обнаружена.

Таким образом, доисследование Александропольского кургана в 20042009 гг. позволило установить точную дату кургана, уточнить конструкцию Центральной гробницы кургана, провести метрические замеры рва и вала, окружавших курган, а также его Центральной гробницы. Но самое главное, это открытие мощной околокурганной тризны Александропольского кургана, меняющее концепцию скифского кургана и его периферии, а также предъявляющее новые требования к методике исследования скифских курганов.

Все наши представления о погребальной обрядности и о многих других сферах жизни скифов напрямую зависят от качества и характера исследования собственно курганов. Это касается как исследования подкурганных захоронений, собственно насыпи кургана, так и окружающего его пространства - курганной периферии. И в первую очередь это относится к курганам скифской знати, представляющим собой сложные погребально-поминальные комплексы и являющимся своеобразной квинтэссенцией мировоззрения оставившего их общества.

За последние полвека интенсивных раскопок скифских курганов в Северном Причерноморье была получена огромная информация, дающая представление о структуре кургана, строительных материалов, из которых он построен, и собственно его конструкции. На этих материалах основываются построения, касающиеся политического устройства, социальной структуры и идеологии скифского социума. Однако при раскопках курганов долгое время не считались нужными раскопки кольцевых рвов в курганах, не уделялось внимания изучению тризн. Только постепенно утвердилось представление о высокой информативной ценности всех элементов скифского кургана и необходимости тщательнейшего исследования не только насыпи и погребений, но рва и тризны.

Совершенно новое представление о структуре погребального обряда получено после исследования тризны Александропольского кургана.

Исследование околокурганной тризны скифского царского Александропольского кургана впервые в истории раскопок скифских курганов было проведено в полном объёме. Остатки околокурганной тризны обнаружены вдоль западной стороны кургана за пределами рва на уровне древней околокурганной поверхности в полосе шириной до 15 м на протяжении около 120 м, до 40 м к северу от западного прохода и около 80 м к югу от него. О существовании околокурганных тризн возле больших скифских курганов, в общем-то, было известно и раньше. Они были зафиксированы возле курганов Бабина, Водяна, Гайманова и Желтокаменская Толстая могилы. Однако тризны возле всех этих курганов были разрушены распашкой, фиксировались только по рассеянным 
находкам обломков амфор и костей животных на дневной поверхности и ни в одном случае не были исследованы (Полин, 2011. С. 206-222).

Тем самым после открытия в Александропольском кургане приходится сделать печальный вывод о том, что ни один скифский царский курган или высшей знати в Северном Причерноморье не исследован в полном объёме, поскольку нигде исследование кургана не выходило за пределы рва, а иногда и рвы оставались неисследованными.

Таким образом, периферия скифских курганов в Северном Причерноморье остается для нас практически неизвестной. С большим сожалением приходится констатировать, что и сейчас при раскопках скифских курганов, как правило, изучается только пространство в пределах рва кургана. Примыкающая к кургану территория, содержащая культурные остатки, связанные как со строительством кургана, так и с поминальными ритуальными действиями, не исследуется и тем самым становится потерянной для науки. Все эти свидетельства не всегда видны на поверхности, но исключить их присутствие заведомо нельзя, особенно в случае больших курганов. Это приводит к необходимости пересмотра методических подходов к исследованию скифских курганов, к обязательному включению в программу раскопок кургана исследование его курганной периферии.

Благодаря результатам крупномасштабных раскопок и обследований курганов скифского времени, проведённых по совместным проектам экспедициями Евроазиатского отдела Германского археологического Института, Северо-Казахстанского университета, Хакасского государственного университета, Государственного Эрмитажа и Института археологии Казахстана на территории Казахстана, Сибири, Тувы на протяжении последних двадцати лет интерпретация кургана как разрушенного архитектурного сооружения, предложенная в свое время М.П. Грязновым (Грязнов, 1961. С. 22-25), получает дальнейшее развитие и значительно более насыщенное содержание. А. Наглер на основе этих данных, а также с учетом информации по курганам Северного Причерноморья, Северного Кавказа и Южного Приуралья, предложил следующую характеристику кургана как археологического памятника: «Курган является поминально-погребальным комплексом, состоящим из связанных в единое целое трёх частей: 1 - захоронений, кладов, жертвенных комплексов; 2 - построенных над ними сооружений, порой сложных и монументальных, являющихся памятниками своеобразной архитектуры. Намечаются три строительных традиции их возведения - каменные платформы, сооружения из кусков дерна, глинобитные сооружения. Все они существовали уже в раннесакское время и, возможно, складывались и получили свое развитие в разных регионах Азии; 3 - территория, прилегающая к сооружению или курганная периферия. Она содержит культурные остатки, связанные как со строительством комплекса, так и с проводившимися здесь ритуальными действами, артефакты и даже могилы. При исследовании подобных памятников необходимо изучать 
их полностью и начинать именно с этой территории, с проведения там геофизической разведки. В противном случае огромное количество информации, содержащейся в объекте, будет безвозвратно утеряно» (Nagler, 2013. C. 609-620; Наглер, 2015. С. 79-85).

\section{ЛИТЕРАТУРА}

Грязнов М.П. Курган как архитектурный памятник // Тезисы докладов на заседаниях, посвящённых итогам полевых исследований в 1960 г. М., 1961. С. 22-25.

Древности Геродотовой Скифии. Сборник описаний археологических раскопок и находок в Черноморских степях. СПб.: Типография Императорской Академии наук, 1866 a. Вып. I. 28 с. + Приложение C. I-XVI.

Древности Геродотовой Скифии. Сборник описаний археологических раскопок и находок в Черноморских степях. СПб.: Типография Императорской Академии наук, 1866 б. Вып. І. Атлас. Табл. I-XXI.

Де Груммонд Н., Полин С.В., Черных Л.А., Глеба М., Дараган М.Н. Первый год доисследования Александропольского кургана // Боспорский феномен: проблемы соотношения письменных и археологических источников. СПб., 2005. С. 272-282.

Лазаревский Я. Александропольский курган. Могила скифского царя // ЗРАО. 1894. Т. 7. Вып. 1-2. С. 24-46 + 16 табл.

Мозолевський Б.М. Товста Могила. К: Наукова думка, 1979. 248 с.

Мозолевский Б.Н., Полин С.В. Курганы скифского Герроса IV в. до н.э. (Бабина, Водяна и Соболева могилы). Киев: Стилос, 2005. 599 с.

Наглер А. Курганы Большой степи как архитектурное сооружение // Археология, этнография и антропология Евразии. Новосибирск, 2015. № 4(64). С. 70-85.

Полин С.В. Исследования скифского царского Александропольского кургана в 2009 г. // Археологічні дослідження в Україні 2009 р. Київ-Луцьк: ВД «Академперіодика», 2010 a. C. 332-334.

Полин С.В. Амфоры Александропольского кургана (по материалам раскопок 2004-2009 гг.) // АМА. Саратов, 2010. Вып. 14. С. 262-307.

Полин С.В. К истории развития методики раскопок больших скифских курганов // Методика полевых археологических исследований. Вып. 4. Греческие и варварские памятники Северного Причерноморья. Опыт методики российских и украинских полевых исследований. М.: ИА РАН, 2011. С. 206-222.

Полин С.В. Александропольский дракон // Археологія та етнологія півдня Східної Європи. Дніпро: Ліра, 2016. С. 278-286.

Полин С.В., Дараган М.Н. Продолжение исследований Александропольского кургана в 2005 г. // АДУ 2005-2007 pр. Київ-Запоріжжя: Дике Поле, 2007. С. 45-59.

Полин С., Дараган М. Проблемы датировки скифского царского кургана Александрополь // Revista Arheologica. Serie noua. 2008. Vol. IV. Nr. 2. C. 146-163.

Полин С.В., Дараган М.Н. Работы на Александропольском кургане в 2008 г. // $\Sigma \mathrm{YMBO \Lambda A} \mathrm{1.} \mathrm{Античный} \mathrm{мир} \mathrm{Северного} \mathrm{Причерноморья.} \mathrm{Новейшие} \mathrm{находки} \mathrm{и} \mathrm{откры-}$ тия. Москва-Киев: ИД «Триумф принт», 2010. Вып. 1. С. 191-209.

Полин С.В., Де Граммонд Н., Глеба М., Черных Л.А., Дараган М.Н. Украинско-американский скифский курганный проект. Первый год работы // Археологічні дослідження в Україні 2003-2004 р. Запоріжжя: Дике Поле, 2005. С. 252-256. 
Nagler A. Grabanlagen der frühen Nomaden in der eurasischen Steppe im 1. Jt. v. Chr. // Unbekanntes Kasachstan. Archäologie im Herzen Eurasiens. Katalog der Ausstellung des Deutschen Bergbaumuseums Bochum. Band 2. Bochum, 2013. S. 609-620.

Polin S., Daragan M. Das Prunkgrab Alexandropol-kurgan. Verbericht über die Untersuchungen in den Jahren 2004-2009 // Eurasia Antiqua. 17. 2011 a. S. 189-214.

Polin S., Daragan M. New type of gold application with the image of a dragon from a Scythian royal Aleksandropol'sky kurgan / Herausgegeben von Sava E., Govedarica B. und Hansel B. // Der Schwarzmeerraum vom Aneolithikum bis in die Früheisenzeit (500-500 V., chr.). Band 2. Globale Entwicklung versus Lokalgeschehen. 2011 b. P. 273-278. 


\title{
ОРНАМЕНТИРОВАННЫЕ ЛЕПНЫЕ КУРИЛЬНИЦЫ С ГОРОДИЩА «ЧАЙКА» В СЕВЕРО-ЗАПАДНОМ КРЫМУ
}

\author{
Попова E. A. \\ http://10.25681/IARAS.2019.978-5-317-06274-3/207-212 \\ Наследие древности, подобно самой природе, - \\ это обширное пространство, взывающее к истолкованию; \\ как здесь, так и там нужно обнаружить знаки \\ и мало-помалу заставить их говорить.
}

Мищель Фуко «Слова и вещи»

На городище «Чайка» в Северо-Западном Крыму в контекстах III в. до н.э. I в. н.э. были найдены фрагменты и две целых лепных курильницы. Все сосуды орнаментированы. Техники нанесения орнаментов различны: прочерченный по сырой глине, рельефный и резной, заполненный белой краской. В основном курильницы находятся в могильниках близ поселений. Можно предположить, что ритуалы, связанные с обрядами в святилищах на поселениях, были связаны с земледельческими культами и культом плодородия.

Ключевые слова: городище, курильница, кизил-кобинская культура, тавры, орнамент

На городище «Чайка» в Северо-Западном Крыму в разные годы были найдены фрагменты и две целых лепных курильницы (рис. 1). Они датируются по местам находок. Одна, почти целая, собранная из фрагментов, курильница находилась в вымостке греческого комплекса конца III-II вв. до н.э. (рис. 1,1$)$. Второй целый сосуд лежал на полу помещения типа мегарон позднескифского поселения (рис. 1, 2). Фрагменты третьей курильницы обнаружились в пожарном слое позднескифского помещения 12 в здании III в. до н.э. (рис. 1, 3). Курильницы из позднескифских слоев датируются I в. до н.э. - началом I в. н.э. Все сосуды орнаментированы. Техники нанесения орнаментов различны: прочерченный по сырой глине, рельефный и резной, заполненный белой краской.

Сосуд из греческой вымостки разделён на четыре горизонтальных пояса: верхний обрамляет горло горизонтальной «ёлочкой» и отделяется от следующего пояса ямками, в среднем расположены треугольники вершинами вверх, опирающиеся на сплошную линию, отделяющую этот пояс от третьего, гладкого, с двумя горизонтальными простыми линиями, отделяющими четвёртый пояс, состоящий из косых полос, направленных к дну и не доходящих до него. На венчик нанесены ямки.

Одна курильница с позднескифского поселения орнаментирована рельефом: с двух сторон от обрамляющей горло «косички» спускаются доходящие до половины высоты тулова прямые линии с закругляющимися концами (их 4). Между каждой парой этих линий, в центре расположены линии с окончаниями 

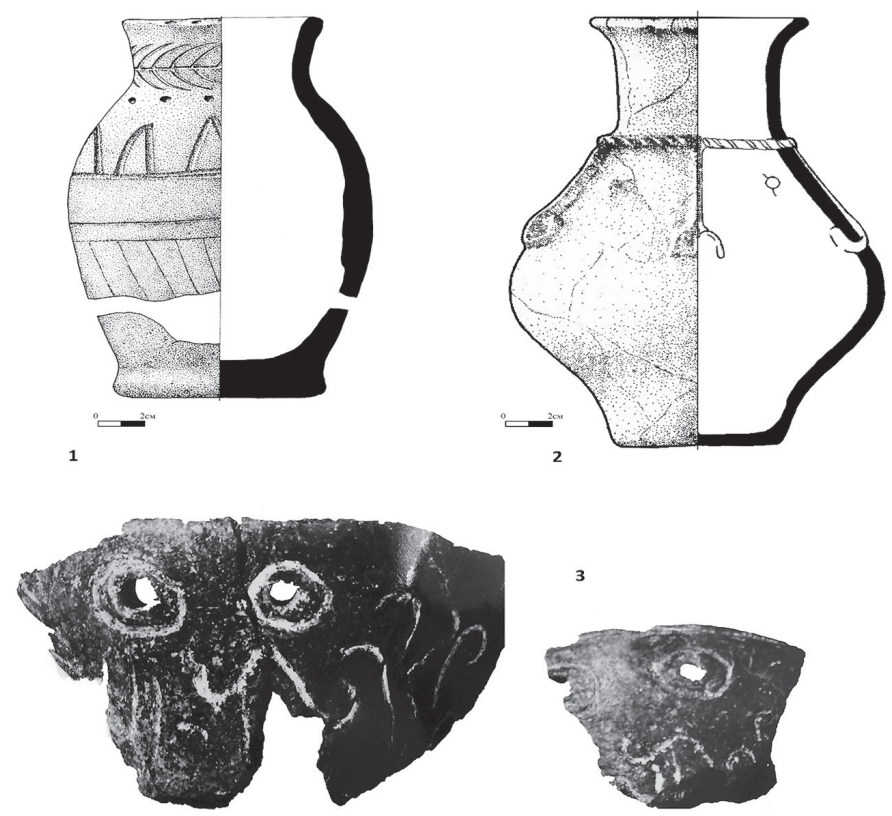

Рис. 1.

1 - курильница из греческой вымостки; 2 - сосуд из здания типа мегарон; 3 - фррагменты курильницы из позднескифского помещения 12

в виде «вилок» с тремя зубцами. В верхней части поля с двух сторон от «вилки» находятся небольшие округлые выступы. В целом орнамент напоминает стилизованное изображение дважды повторенного лица.

На третьей курильнице орнамент резной, заполненный белой пастой, имеются сквозные отверстия, обведенные белой краской. Ниже нанесены волнообразные линии. От одного из отверстий идут вниз две вертикальные линии с несомкнутыми округлыми концами. На том же фрагменте рядом с отверстием изображена «ёлочка» «ветвями» вверх. На втором фрагменте видны одно отверстие, также обведённое белой краской и часть соседнего с ним второго отверстия. Судя по этим фрагментам, отверстия на тулове сосуда располагались попарно.

На городище «Чайка» в 1965 г. были найдены фрагменты ещё одной курильницы с орнаментом (Гаврилюк, 2016. С. 228, рис. 18, 3). Орнамент «в виде волнистой линии» из круглых ямок, в основании шейки ограниченной прочерченной линией, от линии ямок вниз спускаются «пары коротких прочерченных линий» (Гаврилюк, 2016. С. 228). Найдена курильница в слое IV-III вв. до н.э.

Лепные курильницы давно привлекали внимание исследователей, но обобщающая работа появилась только сравнительно недавно (Синика, Меньшикова, Тельнов, 2014. С. 65-101). До этого в литературе к этой категории материала 
обращались в связи с публикациями новых сосудов. Самой обстоятельной и концептуальной была статья О.Д. Дашевской (Дашевская, 1980. С. 18-29). Она затрагивает вопрос о происхождении курильниц, приводя точки зрения на эту проблему других исследователей. П.Н. Шульц считал прототипом орнаментов курильниц керамику кизил-кобинской культуры (Шульц, 1953. С. 62). Н.Н. Погребова аналогии формам курильниц Крыма находила в Поднестровье (Погребова, 1961. С. 111). А.И. Мелюкова считала возникновение таких сосудов в Крыму, Нижнем Поднепровье, Поднестровье или Побужье, и О.Д. Дашевская приветствовала эту точку зрения как наиболее плодотворную (Дашевская, 1980. С. 26). Здесь же она выступила против идеи Э.В. Яковенко видеть прототипы таких курильниц в сосудах из Кармир-Блура (Дашевская, 1980. С. 26, 27). Сама О.Д. Дашевская уже названием статьи утверждала принадлежность идеи подобных культовых сосудов скифам. В.С. Синикой с соавторами был разобран весь спектр мнений относительно проблемы происхождения курильниц IV-I вв. до н.э. Причем исследователи пришли к выводу, что этот вопрос до сих пор остается наиболее сложным (Синика, Меньшикова, Тельнов, 2014. С. 91). Авторы предлагают типологию курильниц по формам, называя все приводимые сосуды «курильницами с раздутым туловом» (Синика, Меньшикова, Тельнов, 2014. С. 65). Орнамент не учитывается ими при создании типологии, т.к. «ни в одном случае не может являться типо- или вариантообразующим признаком» (Синика, Меньшикова, Тельнов, 2014. С. 91). Однако именно орнаменты привлекаются при определении беспаспортных находок, например, курильниц из Одесского музея, происхождение которых, «судя по орнаменту, с большой степенью достоверности может быть связано с Крымом» (Синика, Меньшикова, Тельнов, 2014. С. 77). Решение исследователей не использовать орнаменты в качестве типообразующего признака продиктовано, безусловно, тем, что одинаково орнаментированных курильниц нет. Но, тем не менее, в определённых районах орнаменты составляются из похожих символических изображений, а отдельные мотивы встречаются и в разных районах. Находки курильниц и на античных памятниках, и в позднескифских некрополях и поселениях, и датирующиеся по-разному, уже представляют трудности в определении их культурной принадлежности. Чайкинские курильницы не являются исключением. Самая ранняя из них - курильница 1965 г., найденная в слое IV-III вв. до н.э., представляет трудности для определения культурной принадлежности, также как и курильница из греческой вымостки, датирующаяся концом III - II в. до н.э. Наличие таких сосудов на античном поселении свидетельствует о присутствии негреческого населения. О том, что на греческом поселении «Чайки» были представители тавров, говорило наличие в нижних слоях фрагментов кизил-кобинской керамики (Беловинцева, Попова, 2007. C. 131-154). Во второй половине II в. до н.э. на месте греческого поселения возникает позднескифское. Возможно, курильница из греческой вымостки была изготовлена в это время. Орнаментация её не имеет аналогий, так же, как и раз- 
деление на четыре горизонтальных пояса, но отдельные мотивы встречаются и на других культовых сосудах. Это изображение «ёлочки» и треугольников. «Ёлочка» встречается в самых разных районах: в Добрудже, в Поднепровье, на азиатском Боспоре, в Крыму (Синика, Меньшикова, Тельнов, 2014. Рис. 1, 1; Рис. 14, 6; Рис. 17, 7; Рис. 12, 1, 12). «Ёлочка» такой формы интерпретируется как изображение мирового древа, дерева жизни. На упомянутых курильницах «ёлочки» изображены ветвями вниз, что считается символом перевёрнутого мирового древа, то есть показывается связь с подземным миром. На нашей курильнице «ёлочка» расположена горизонтально, вокруг горловины. Горизонтальная структура мирового древа указывает на его непосредственную связь с ритуалом, причем сосуд является субъектом ритуала. Треугольники традиционно рассматривают как изображение гор. Этот мотив мы находим на курильнице из склепа № 17 кургана 1 некрополя Пантикапея и на фрагменте с городища Беляус (Синика, Меньшикова, Тельнов, 2014. Рис. 12, 9, 10).

Орнаментацию курильницы 1965 г. с «Чайки» можно сравнить с сосудом из некрополя Ольвии (Синика, Меньшикова, Тельнов, 2014. Рис. 10, 1). Здесь также от прочерченной под горлом линии спускаются попарно короткие вертикальные линии, сочетающиеся с округлыми ямками.

Наиболее близкой к крымским сосудам является курильница из позднескифского помещения 12, от которой остались лишь два фрагмента. Орнамент на них демонстрирует сочетание растительных и солярных мотивов. Растительный орнамент выполнен в виде линий с волютообразными окончаниями. Этот мотив перекликается с курильницами из кургана 12 у с. Кринички и из склепа 1979 г. Битакского могильника (Синика, Меньшикова, Тельнов, 2014. Рис. 12, 7, 8). Солярный символ на чайкинской курильнице - круглые отверстия, обрамленные кругом с белой краской. Такого типа солярные символы, сквозные отверстия с обводкой, присутствуют на двух курильницах из Одесского музея и из склепа 1926 г. Неаполя (Синика, Меньшикова, Тельнов, 2014. Рис. 12, 12, 13; Рис. 12,2$)$. Около одного из отверстий на чайкинской курильнице изображена «ёлочка», но ветвями вверх, то есть традиционное изображение мирового древа. Интересно вспомнить роспись склепа № 1 некрополя Неаполя скифского (Попова, 1987. С. 139-151). Роспись состоит, в основном, из растительных мотивов, воспроизводимых в виде волютообразно загнутых линий, внизу нарисован солнечный диск, т.е. здесь мы видим сочетание растительных мотивов с солярным символом (Попова, 1987. Рис. 1). Это указывает на традиционность подобной символики для объектов, связанных с погребальным культом. В том, что курильницы были связаны с ритуалами при совершении захоронения, сомневаться не приходится.

Таким образом, рассмотренные курильницы с геометрическим орнаментом находят аналогии по отдельным мотивам в основном на сосудах из Крыма, Побужья, а мотив «ёлочки» имеет и более широкий ареал. 
Самой необычной является курильница из позднескифского здания типа мегарон. В свое время орнамент в виде двух «личин» был проанализирован и интерпретирован как оформление сосуда антропоморфным кодом (Попова, 1996. С. 76-79. Рис. 4). Н.А. Гаврилюк в качестве аналогии привела орнамент с сосуда из кургана у с. Пионерское в Приазовье (Гаврилюк, 2016. Рис. 18, 2). Однако согласиться с этой аналогией не представляется возможным, поскольку на сосуде из Приазовья присутствует просто растительный орнамент, возможно, «ёлочки». На нашем сосуде совершенно очевидно даны стилизованные изображения человеческого лица. Полных аналогий ему не было найдено, наиболее близкой оказалась корчага с городища Золотая Балка с два раза повторенным лицом, показанным врезным орнаментом (Вязьмітіна, 1962. С. 125, 64, 14). Поскольку очевидно, что чайкинский сосуд был культовым, такая орнаментация свидетельствует о том, что он был связан с культом предков, который взаимосвязан с аграрными культами, так как предков представляли воздействующими на земную жизнь, покровительствующими живым, от чего зависело благополучие потомков (Попова, 1996. С. 78).

Функцией курильниц было очищение пространства. Поскольку значительная часть культовых сосудов была найдена в погребениях, видимо, они использовались в ритуале очищения пространства могилы перед следующим захоронением. Однако и на поселениях курильницы встречаются довольно часто. В Крыму - на городищах Калос-Лимен и Беляус. На городище «Чайка», кроме описанных орнаментированных курильниц, был найден фрагмент сосуда с шаровидным туловом, на ножке, лощёного, и целая курильница, также типа сосудов «с раздутым туловом», с отверстиями на горле, обе без орнамента (Гаврилюк, 2016. С. 228, Рис. 18, 5,6). Находки курильниц на поселениях не удивительны: если они присутствуют в погребениях, их где-то изготовляли, и, скорее всего, на близких к могильникам городищах. Но случаи находок их на поселениях Крыма увеличиваются, о чем свидетельствуют материалы «Чайки». Использование подобных культовых сосудов и на поселениях подтверждается находкой в здании типа мегарон. О том же, по-видимому, свидетельствует большое количество найденных курильниц на Елизаветовском городище на Нижнем Дону (Синика, Меньшикова, Тельнов, 2014. С. 84). Причем датируются подобные сосуды от IV в. до н.э. до I в. н.э. Таким образом, как отмечают В.С. Синика с соавторами, ритуальные сосуды такого типа, орнаментированные и без орнамента, получили широкое распространение в Северном Причерноморье и представляют собой общее явление, а не локальную особенность материальной культуры скифов Поднестровья, Крыма или любого другого региона (Синика, Меньшикова, Тельнов, 2014. С. 95). Действительно, как писала в свое время О.Д. Дашевская, «курильницы играли заметную роль и в культах северопричерноморских греков» (Дашевская, 1980. C. 27). Однако появление курильниц с шаровидным туловом она приписала 
скифам. Исследование В.С. Синики с соавторами убедительно доказывает более широкую атрибуцию таких сосудов.

Интересно, что в основном курильницы находятся в могильниках близ поселений. Можно предположить, что ритуалы, связанные с обрядами в святилищах на поселениях, были связаны с земледельческими культами и культом плодородия. Это подтверждается большим количеством домашних жертвенников на городище «Чайка» (Попова, 1990. С. 196-203). Об этом же пишут и В.С. Синика с соавторами, причем первичным считают использование курильниц именно при отправлении домашних культов, а затем и при погребениях (Синика, Меньшикова, Тельнов, 2014. С. 95).

Поскольку мы говорили об орнаментированных лепных курильницах, представляется возможным предложить включить орнамент в типологические схемы подобной керамики. Тем более, что первые шаги в этом направлении уже сделаны (Синика, Меньшикова, Тельнов, 2014. С. 95). Необходим анализ орнаментальных мотивов и их сочетаний, в совокупности с формами сосудов. Это станет возможным при дальнейшем накоплении материалов, как это произошло в случае с материалами из могильника у с. Глиное, где именно орнамент из каннелюр позволил найти прототипы курильниц.

Чайкинское городище и некрополь у пос. Заозерное при дальнейших исследованиях, возможно, дадут новые материалы этой категории керамики.

\section{ЛИТЕРАТУРА}

Беловинцева Н.И., Попова Е.А. Находки Кизил-Кобинской керамики с городища «Чайка» // Материалы исследований городища «Чайка» в Северо-Западном Крыму. Сб. научных трудов. Отв. ред. В.Л. Янин, Ю.Л. Щапова. М.: МГУ, 2007. С. 131-154.

Вязьмітіна М. І. Золота Балка. Киів, 1962. 239 с.

Гаврилюк Н.А. Лепная керамика городища «Чайка» // Очерки археологии СевероЗападного Крыма (по материалам городища «Чайка» и некрополя у поселка Заозерное). Сб. научных статей. Отв. ред. Е.А. Попова. М.: МГУ, 2016. С. 179-271.

Дашевская О.Д. О скифских курильницах // СА. 1980. № 1. С. 18-29.

Погребова Н.Н. Находки в мавзолее Неаполя скифского // МИА. 1961. № 96. C. 103-213.

Попова Е.А. Роспись склепа № 1 некрополя позднескифской столицы // ВДИ, 1987. № 2. C. 139-151.

Попова E.A. Позднескифские жертвенники с городища «Чайка» // СА. 1990. № 3. C. 196-203.

Попова Е.A. Здание типа мегарон с городища Чайка // Вестник МГУ. Серия 8. История. 1996. № 1. С. 71-80.

Синика В.С., Меньшикова В.А., Тельнов Н.П. Лепные курильницы из памятников Северного Причерноморья IV-I вв. до н.э. // Stratum plus, 2014. № 3. С. 65-101.

Шульи П.Н. Мавзолей Неаполя Скифского. М., 1953. 124 с. 


\section{БРОНЗОВЫЕ ПРЕДМЕТЫ СКИФСКОГО ВРЕМЕНИ С ВЕРХНЕДОНСКОГО ГОРОДИЩА У С. ВЕРХНЕЕ КАЗАЧЬЕ}

(Исследование выполнено при финансовой поддержке РФФИ в рамках проекта № 20-39-70001)

Разуваев Ю.Д.

http://10.25681/IARAS.2019.978-5-317-06274-3/213-217

В статье публикуются предметы VI-III вв. до н.э., найденные при раскопках многослойного городища у с. Верхнее Казачье в Липецкой области. Коллекция находок включает двенадцать изделий. Две коньковые подвески относятся к городецкой культуре, ворворки, пронизи, булавки, зеркало и серьга - к скифоидной. Предметы изготовлены из оловянистых, свинцовистых, а также оловянисто-свинцовистых бронз, и имели, очевидно, различное происхождение. На городище открыты свидетельства собственного бронзолитейного производства: остатки печи-горна и фрагменты глиняных тиглей.

Ключевые слова: Верхнее Подонье, скифское время, городище, бронзовые изделия, химический состав

Самое северное из городищ, входящих в среднедонскую группу памятников Лесостепной Скифии, расположено у с. Верхнее Казачье в Задонском районе Липецкой области. Это показали раскопки 2015 и 2016 гг., проведённые совместной экспедицией Воронежского государственного педагогического университета и общественной организации «Фонд научного краеведения Липецкой области». В раскопах площадью 1299 кв. м были получены материалы широкого хронологического диапазона: от эпохи ранней бронзы до древнерусского времени (Разуваев, Козмирчук, 2016; 2017 а; 2017 б). Из них примерно половина относится к скифской эпохе, в том числе небольшая серия бронзовых изделий (заметим в скобках, что памятник сильно пострадал от деятельности грабителей с металлоискателями), которой посвящена данная статья. Двенадцать оставляющих её предметов отчасти интересны сами по себе, но ещё и тем обстоятельством, что в большинстве своём были подвергнуты рентгеноспектральному анализу (Меркулов, 2018).

Значительная часть сделанных на городище находок связана с уничтоженным пожарами укреплённым поселением, предварительно датированным VII-VI вв. до н.э. (Разуваев, 2018а). Однако публикуемые вещи, за одним исключением, едва ли входят в их число, принадлежа, скорее, последующему времени.

Любопытны две подвески, представляющие собой стилизованные лошадиные фигурки с петелькой для подвешивания на спине. Размеры одной из них, обломанной сзади, составляли $3,1 \times 2,3$ см. Фигурка, отлитая в двусторонней форме и имевшая вследствие этого заплывы металла, обладала одной передней ногой и, по-видимому, двумя задними (рис. 1, 1). Вторая подвеска имела размеры 3,1×2,1 см (видимо, задняя часть у неё тоже обломана). У лошадки 


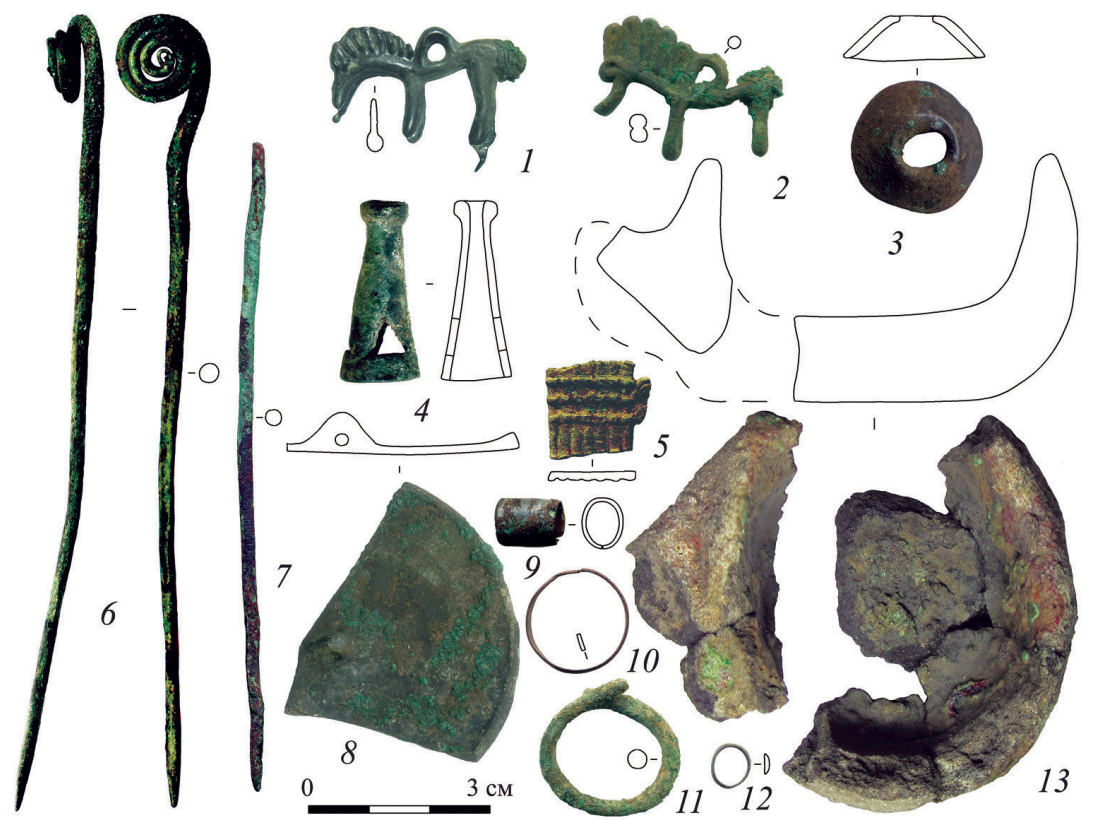

Рис. 1. Бронзовые изделия (1-12) и глиняный тигель с городища у с. Верхнее Казачье

по одной передней и задней конечности, выполненной из согнутого вдвое прутика; завитками прутика сформованы также уши и грива (рис. 1, 2). Скорее всего, этот предмет был отлит по выплавляемой модели.

Обе фигурки изготовлены из оловянистой бронзы, но разнятся рецептурами сплава (табл.): в первой больше олова и присутствует кремний. Они относятся к кругу коньковых подвесок, которые исследователи недавно соотнесли с археологическими культурами лесного круга, ориентировочно датировав IV-III вв. до н.э. (Обломский, Сыроватко, Сапрыкина, 2012). Скорее всего, в лесостепном Подонье такого рода предметы связаны с населением городецкой культуры (Разуваев, 2017).

На городище встречается характерная «рогожная» керамика, скорее всего, предшествовавшая появлению здесь материалов ярко выраженного скифоидного облика. Связанный с последними поселок IV-III вв. до н.э. представлен новыми фортификациями, примыкающей к ним длинной наземной постройкой, а также несколькими хозяйственными сооружениями на городищенской площадке.

В насыпи вала были найдены две ворворки усечённо-конической формы. Вряд ли случайно, что эти принадлежности конской узды встречены именно здесь - на линии обороны городища, где нельзя исключать вооружённых столкновений. 


\section{Химический состав предметов с городища у с.Верхнее Казачье} (массовая доля элементов указана в \%)

\begin{tabular}{|c|l|c|c|c|c|c|c|c|}
\hline $\begin{array}{c}\text { № } \\
\text { на рис. 1 }\end{array}$ & \multicolumn{1}{|c|}{ Образец } & $\mathrm{Cu}$ & $\mathrm{Sn}$ & $\mathrm{Pb}$ & $\mathrm{Si}$ & $\mathrm{As}$ & $\mathrm{Fe}$ & $\mathrm{Ni}$ \\
\hline 1. & Подвеска & 79,0 & 16,6 & - & 4,0 & - & - & - \\
\hline 2. & Подвеска & 92,6 & 7,4 & - & - & - & - & - \\
\hline 5. & Пластина & 92,5 & 7,5 & - & - & - & - & - \\
\hline 6. & Булавка & 83,6 & 10,5 & - & 3,1 & 1,5 & 0,8 & - \\
\hline 7. & Булавка & 97,5 & 0,3 & 2,1 & - & - & - & 0,1 \\
\hline 8. & Зеркало & 69,5 & 24,6 & - & - & - & 1,6 & - \\
\hline 11. & Серьга & 98 & - & 2 & - & - & - & - \\
\hline 12. & Пронизь & 78 & 18,2 & 3,8 & - & - & - & - \\
\hline 13. & Тигель & 77,8 & 0,6 & 16,4 & 3,5 & - & 1,3 & - \\
\hline
\end{tabular}

Одна ворворка, широких пропорций, имела размеры 2,3×1,1×2,1 см и отверстие, расточенное до овальных очертаний (рис. 1, 3). Аналогичные предметы были широко распространены в лесостепи, в том числе и на Среднем Дону, в V-IV вв. до н.э. (Могилов, 2008. С. 76-77; Савченко, 2009. С. 283).

Другая ворворка обладала удлинёнными пропорциями и утолщением на узком конце (рис. 1, 4). Её размеры $2,9 \times 1,2 \times 1,3$ см. В расширенной части изделия в стенках имелись три треугольных прорези, причем, одно несквозное. Ворворки этого типа локализуются в восточной части скифской лесостепи (Могилов, 2008. С. 75). Так, подобные предметы были найдены в кургане второй половины V в. до н.э. группы Частых (Либеров, 1965. Табл. 22, 11).

В слое на площадке городища найден обломок какого-то украшения в виде пластинки размерами $1,7 \times 1,5 \times 0,2$ см (рис. 1, 5). Одна сторона изделия гладкая, другая - гофрированная. Сбоку частично сохранилась S-видная волюта - орнаментальный мотив, характерный для скифского времени. Для изготовления предмета использовалась оловянистая бронза (табл.). Причем, по химическому составу сплав практически идентичен тому, что был применён при отливке второй коньковой подвески.

Также в слое найдена булавка длиной 13,6 см (рис. 1, б). Она изготовлена из круглой в сечении проволоки, один конец которой заострён, а другой загнут в три оборота, образуя спиралевидную головку. Ещё от одной явно такой же булавки сохранилась только игла (рис. 1, 7). Оба предмета сильно различаются по химическому составу (табл.).

Сами по себе булавки со спиралевидной головкой были достаточно широко распространены в скифскую эпоху. В Подонье такие изделия найдены в погребениях IV-III вв. до н.э. грунтового могильника у с. Ксизово, расположен- 
ного неподалеку от Верхнего Казачьего ниже по Дону (Обломский, Разуваев, 2013. Рис. 2, 7; 4, 2,6), а также в слое Пекшевского городища (Медведев, 1999. Рис. 36, 1, 2).

Из нижнего пласта городищенского слоя происходит обломок зеркала размерами 4,5×3,6×0,7 см (рис. 1,8 ). Это был изготовленный из оловянистой бронзы диск диаметром 6 м, имевший бортик по краю и ручку-петельку треугольной формы в центре. По классификации Т.М. Кузнецовой зеркало относится ко 2-му варианту I вида I типа, известному в приднепровских погребальных комплексах середины VI в. до н.э. (Кузнецова, 2002. С. 39).

К деталям конской узды, очевидно, относятся две изготовленные из тонких пластинок пронизи, найденные в городищенском слое. Одна - цилиндрической формы размерами $1 \times 0,8 \times 0,7$ см (рис. 1,9$)$. Другая имела вид маленького колечка размерами $0,7 \times 0,6 \times 0,2$ см (рис. 1, 12).

К украшениям относятся два предмета. Это изготовленное из тонкой пластинки кольцо диаметром около 1,7 см, толщиной 0,2 см (рис. 1, 10). Со скифским временем оно соотнесено предположительно. Иное дело - серьга, согнутая из круглого в сечении прутка таким образом, что концы накладывались друг на друга (рис. 1, 11). Размеры предмета 2,37×2,3 см, диаметр прутка 0,3 см. Он изготовлен из сплава меди и небольшого количества свинца (табл.). Серьги данного типа известны среди скифских украшений (Петренко, 1978. С. 37).

Публикуемые предметы изготовлены из оловянистых, свинцовистых и оловянисто-свинцовистых бронз (табл.). Такое разнообразие лигатур вполне типично для донской лесостепи (Меркулов, 2018).

Любопытно, что на городище у с. Верхнее Казачье открыты свидетельства собственного бронзолитейного производства. В упомянутой постройке одна из углублённых в материк ям представляла собой, видимо, основание печигорна (Разуваев, 2018б). В ней были найдены обломки двух глиняных тиглей со следами воздействия высокой температуры на стенках, к которым прикипел шлак с корольками медного сплава (рис. 1, 13). Анализ металла из одного тигля показал высокое содержание свинца (табл.). Такая лигатура относительно редка для скифской эпохи (Барцева, 1981. С. 17). Интересно, что она несхожа с металлом тех из предметов, что подверглись рентгеноспектральному исследованию. Надо полагать, набор найденных на городище бронзовых изделий включает разные по происхождению вещи.

\section{ЛИТЕРАТУРА}

Барцева Т.Б. Цветная металлообработка скифского времени. Лесостепное днепровское левобережье. М.: Наука, 1981. 127 с.

Кузнецова T.М. Зеркала Скифии VII-III вв. до н.э.. М.: Индрик, 2002. Т. I. 352 с.

Либеров П.Д. Памятники скифского времени на Среднем Дону // САИ. Вып. Д131. $1965.110 \mathrm{c}$. 
Медведев А.П. Ранний железный век лесостепного Подонья. Археология и этнокультурная история І тысячелетия до н.э. М.: Наука, 1999. 160 с.

Меркулов А.Н. Результаты рентгеноспектральных исследований бронзовых изделий скифского времени из лесостепного Подонья // Известия Воронежского государственного педагогического университета. 2018. № 1 (278). С. 100-103.

Могилов О.Д. Спорядження коня скіфської доби у лісостепу східної Свропи. Київ; Кам'янець-Подільский: ИА НАНУ, 2008. 439 с.

Обломский А.М., Разуваев Ю.Д. Грунтовые погребения скифского времени у с. Ксизово на Верхнем Дону // КСИА. 2013. Вып. 231. С. 183-195.

Обломский А.М., Сыроватко А.С., Сапрыкина И.А. Об одном типе подвесокконьков на территории лесной и лесостепной зон Восточной Европы // КСИА. 2012. Вып. 226. С. 169-178.

Петренко В.Г. Украшения Скифии VII-III вв. до н.э. // САИ. Вып. Д4-5. 1978. $144 \mathrm{c}$.

Разуваев Ю.Д. Бронзовые коньковые подвески скифского времени на Верхнем Дону // КСИА. 2017. Вып. 247. С. 267-273.

Разуваев Ю.Д. Новые поселенческие материалы начала раннего железного века на Верхнем Дону // РА. 2018 а. № 1. С. 93-104.

Разуваев Ю.Д. Постройка IV-III вв. до н.э. с бронзолитейным комплексом на верхнедонском городище у с. Верхнее Казачье // КСИА. 2018 б. С. 181-192.

Разуваев Ю.Д., Козмирчук И.А. Раскопки городищ в Верхнем Подонье // Археологические исследования в Центральном Черноземье 2015 / Отв. ред.-сост. Н.Е. Чалых. Липецк, 2016. С. 117-121.

Разуваев Ю.Д., Козмирчук И.Е. Материалы гуннского времени с городища у с. Верхнее Казачье на Острой Луке Дона (раскопки 2015 г.) // Верхнедонской археологический сборник / Отв.ред. А.Н. Бессуднов. Липецк: ЛГПУ, 2017 а. С. 156-161.

Разуваев Ю.Д., Козмирчук И.А. Раскопки городищ в Задонском районе Липецкой области // Археологические исследования в Центральном Черноземье 2016 / Отв. ред.сост. Н.Е. Чалых. Липецк; Воронеж: Новый взгляд, 2017 б. С. 133-135.

Савченко Е.И. Снаряжения коня скифского времени на Среднем Дону, как археологический источник // Археология Среднего Дона в скифскую эпоху: Труды Донской археологической экспедиции ИА РАН, 2004-2008 / Отв. ред. В.И. Гуляев. М.: ИА РАН, 2009. C. 221-325. 


\section{ДВА «МИРА» ТАГАРСКОГО ИСКУССТВА: ПЕТРОГЛИФЫ И МЕЛКАЯ ПЛАСТИКА}

(Работа выполнена в рамках государственного задания

Министерства образования и науки РФ

(проект № 33.2597.2017/ПЧ))

\section{Советова О.С., Моop Н.H.}

http://10.25681/IARAS.2019.978-5-317-06274-3/218-229

Объединённые общим понятием «тагарское искусство», два отдельных, дошедших до нашего времени раздела большого многокомпонентного явления - петроглифы и пластика гармонично дополняют друг друга. О других составляющих «мира» тагарского искусства можно только догадываться. Сходство в изображениях на портативных предметах и в наскальном искусстве скифской эпохи, подмеченное исследователями уже давно, закономерно приводит к вопросу, что же было первичным: петроглифы или пластика. Несмотря на значительное сходство изображений в декоре вещей и в наскальном искусстве, между ними наблюдаются и существенные «разночтения».

Ключевые слова: петроглифика, тагарская культура, зооморфные и антропоморфные изображения, мелкая пластика

Искусство тагарской культуры (VIII-II/I вв. до н.э.), казалось бы, хорошо известно по великолепным образцам мелкой пластики и изображениям на предметах прикладного искусства. Н.Л. Членова совершенно справедливо назвала Минусинскую котловину «...гигантской кладовой археологических находок из бронзы» (Членова, 1981. С. 16). К сожалению, до нас не дошли предметы из органических материалов, бытовавших в эту эпоху, а ведь в них наверняка могли быть воплощены какие-то популярные сюжеты и образы, для них характерные. Эту «пустоту», очевидно, отчасти заполняет наскальное искусство, чрезвычайно популярное в то время, поскольку и ещё сегодня петроглифы покрывают скальные выходы горных массивов, отдельные плиты и курганные камни Минусинской степи. Они достаточно хорошо узнаваемы по характерным персонажам, композициям и стилистическим особенностям (Шер, 1980. C. 122-124; Советова, 2005; и др.), но, несмотря на вполне продолжительную историю изучения, ещё хранят в себе множество загадок. Этот «открытый» тип памятников совсем не прост для понимания и на многие вопросы пока так и не получены вразумительные ответы. Исследователи применяют множество методов для датирования наскальных изображений, но, пожалуй, главным из них до сих пор остается метод аналогий. Эталонными можно считать изображения, выполненные в «скифо-сибирском зверином стиле» - это огромная и наиболее яркая серия наскальных рисунков, имеющая стилистическую и сюжетную перекличку с искусством скифской эпохи в широком смысле слова. Другие изображения датируются по аналогии с рисунками из закрытых комплексов - нанесённых на могильные плиты и укрытых в погребениях. Такие рисунки бывают не только реалистичными, умело выполненными, но и весьма 
упрощенными, маловыразительными, не имеющими особых датирующих признаков, тем не менее, и они расширяют репертуар наскального искусства этого времени. Изредка удается датировать изображения по реалиям эпохи, которые бывают включены в наскальные композиции - это изображения котлов, домов, оружия и иные предметы (в качестве примера можно назвать Боярскую писаницу). И ещё одним методом датирования наскальных рисунков является метод аналогий с предметными сериями эпохи.

Сходство в изображениях на портативных предметах и в наскальном искусстве скифской эпохи, подмеченное исследователями уже давно, закономерно приводит к вопросу, что же было первичным: петроглифы или пластика? Так, В.В. Бобровым было высказано предположение о возможности влияния на возникновение кулайского ажурного литья наскальных изображений Саяно-Алтая и Среднего Енисея (Бобров, 2004. С. 309-313). С.А. Зинченко также отмечает, что изображения кабанов из золотой фольги, обнаруженные в Чиликтинских курганах, могли быть созданы под влиянием наскального искусства (Зинченко, 2005. С. 116-117). Существует и противоположная точка зрения, что именно портативные предметы оказывали воздействие на развитие стилей наскального искусства (Миклашевич, 2010. С. 143; Чемякин, 2015. С. 178). О возможности воспроизведения древним тагарским художником бронзовых объёмных образцов на скалах писал Я.А. Шер (Шер, 1980. С. 123). Однако, нельзя не признать, что несмотря на значительное сходство изображений в декоре вещей и в наскальном искусстве, между ними наблюдаются и существенные «разночтения». В качестве одной из основных причин различий Д.Г. Савинов указал на их принадлежность к разным формам изобразительной деятельности (Савинов, 2009. С. 95-96).

Penepmyap зооморфных образов в тагарской мелкой пластике и в наскальном искусстве в целом общий. Вместе с тем заметны и отличия: так, в наскальном искусстве наиболее многочисленны изображения оленей, коней, козлов, косуль, баранов, неопределённых в видовом отношении животных, выполненных в общей стилистике. Характерны также изображения хищников - представителей местной фауны (кабанов, волков, кошачьих), фантастических персонажей с «хищными» признаками (когтями, зубами, кошачьими хвостами), птиц. В прикладном творчестве, казалось бы, присутствуют все те же образы - олени, козлы, довольно часто встречаются кабаны, кошачьи хищники и хищные птицы. Дополняют картину немногочисленные изделия с изображениями водоплавающих птиц, баранов, лосей, коней, изредка рыб. Можно отметить и такую особенность прикладного творчества: в декоре предметов реализованы не только полнофигурные, но и парциальные изображения зверей. Особенно много изображений голов хищных птиц, копытных (лосей? лошадей?), грифонов («мифических орлов»). Ими украшались, как правило, ножи, кинжалы и так называемые «ПНН», и они были полностью подчинены форме декорируемой части предмета. Для тагарского наскального искусства 
парциальные изображения в целом нехарактерны, хотя в более ранние эпохи на скалах такие случае зафиксированы. Конечно, истинную степень популярности тех или иных персонажей определить сложно, поскольку мы судим о репертуаре тагарского искусства лишь исключительно по дошедшим до нас предметам и изображениям, но это не означает, что только ими он и ограничивался, о чем свидетельствуют открытия последнего времени (примеры будут приведены ниже). Проследим общее и особенное в образах, представленных в двух разделах древнего творчества.

Олень - пожалуй, основной персонаж скифо-сибирского звериного стиля, популярный и в тагарской пластике, и в наскальном искусстве. В пластике это, как правило, олени в позе с подогнутыми под брюхо ногами (Завитухина, 1983. Кат. 95-145; Кузьмин, 1994 (а). Рис. 18.5, 6; и др.). Изредка встречаются олени «на цыпочках» (Завитухина, 1983. Кат. 93; Клеменц, 1886. Рис. 2 а, б), стоящие на прямых ногах, либо на ногах, соединённых в одной точке (Завитухина, 1983. Кат. 92; Merchart, 1926. Taf. IX, 3; и др.); с вывернутым крупом (МКМ, инв. № 8681) ${ }^{1}$, а также в позе «внезапной остановки» (Макаров, 2012. Рис. V.1; и др.) (рис. 1. 39-43). Не все они находят точные аналогии в наскальном искусстве, хотя имеются и исключения. Так, наиболее близко наскальным рисункам гравированное изображение оленёнка (?), размещённое на плоскости втулки тагарского бронзового чекана (местонахождение неизвестно) (Макаров, 2012. Рис. V.1) (рис. 1, 38). Контур тела животного заполнен, подобно наскальным силуэтным изображениям, имитацией выбивки.

В наскальном искусстве рисунков оленей, аналогичных тагарским бляшкам, исключительно мало, да и в целом поза с подогнутыми ногами в тагарском наскальном искусстве не была преобладающей, хотя и олени, и другие копытные, представленные в такой манере, явление обычное. Но всё же представляется, что более популярной на протяжении всей эпохи была поза «внезапной остановки», но встречаются также бегущие животные и находящиеся в спокойном состоянии (рис. 1, 18-24). Олени нередко представлены в различных многофигурных композициях, пожалуй, чаще всего, в сценах охоты или преследования хищником. Как и все зооморфные персонажи, они входят в две группы контурных и силуэтных изображений (когда контур заполнялся выбивкой), есть ещё относительно немногочисленная группа гравированных фигур.

Кони. В наскальном искусстве конь - один из самых популярных персонажей, представленных как самостоятельно, так со всадником, нередко в композициях. Сегодня уже известны целые серии таких изображений: например, кони с орнаментированными корпусами - серия реалистичных, контурно вы-

${ }^{1}$ Авторы выражают глубокую признательность Минусинскому краеведческому музею им. Н.М. Мартьянова за предоставленную возможность ознакомления с материалами из собрания музея. 


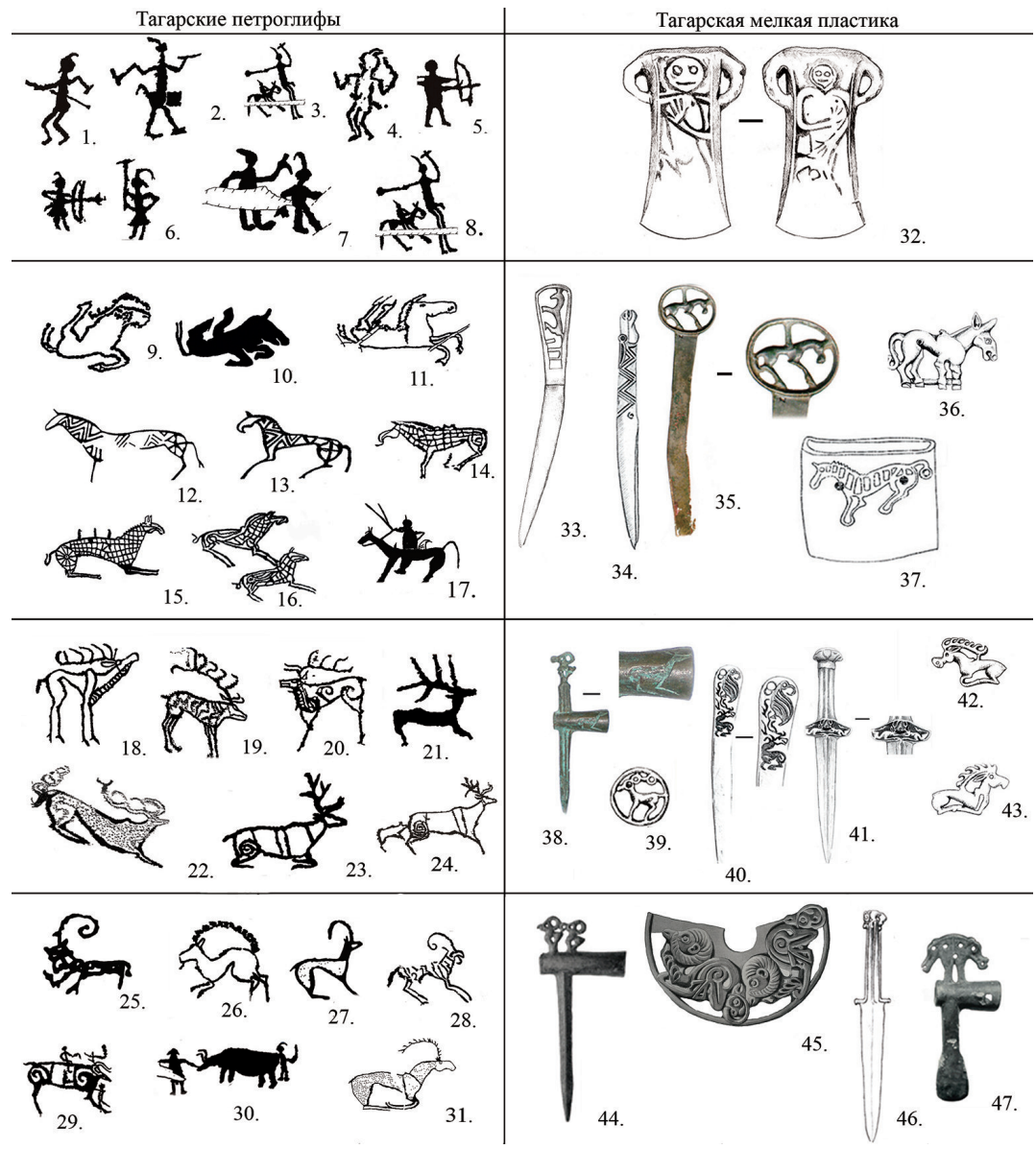

Рис. 1. Тагарское искусство: петроглифы и мелкая пластика (антропоморфные изображения, изображения копытных):

1-2 - Куня (по: Советова, 2005); 3 - Тепсей (по: Советова, 2005); 4 - гора Сосниха (по: Миклашевич, 2012); 5 - Абакано-Перевоз (по: Русакова, 1997); 6 - Оглахты (по: Миклашевич, 2015); 7 - Тепсей (по: Советова, 2005); 8 - Тепсей (Советова, 2005);

9-11 - Абакано-Перевоз (по: Русакова, 1997); 12-13 - Апкашево, Оглахты

(по: Членова, 1981); 14 - Оглахты (по: Шер, 1980); 15 - Оглахты (по: Шер, 1980);

16 - Оглахты (по: Советова, 2005); 17 - Усть-Туба III (по: Шер, 1980);

18 - гора Сульфатная (по: Миклашевич, 2012); 19 - Суханиха (по: Советова, 2005);

20 - Усть-Туба III (по: Шер, 1980); 21 - гора Кедровая (по: Семенов и др., 2003);

22 - Тепсей II (по: Советова, 2005); 23 - Оглахты (по: Советова, 2005);

24 - Оглахты (по: Советова, 2005); 25, 28 - Бычиха (по: Советова, 2005);

26, 27 - Оглахты (по: Шер, 1980); 29-30 - Тепсей (по: Советова, 2005);

31 - Оглахты (по: Грязнов, 1980); 32 - у с. Усинское (МКМ, инв. № 155);

33 - Ключи (МКМ, инв. № 4064); 34 - Большая Ничка (МКМ, инв. № 3980);

35 - Малая Минуса (по: Макаров, 2012); 36 - местонахождение неизвестно

(МКМ, инв. № 9105); 37 - Шунеры (по: Членова, 1967);

38 - местонахождение неизвестно (по: Макаров, 2012); 39 - Иджа (МКМ, инв. № 9210);

40 - Аешка (МКМ, инв. № 3776); 41 - Малая Иня (МКМ, инв. № 868);

42 - Восточное (МКМ, инв. № 9738); 43 - Минусинский край (МКМ, инв. № 9153); 44 - Барсучиха І, могила 2 (по: Завитухина, 1983);

45 - Минусинский край (по: Завитухина, 1983); 46 - Татарка (МКМ, инв. № 467); 47 - могильник у Подгорного озера, курган 1 (по: Завитухина, 1983) 
полненных животных, «разрисованных» клеткой или ломаными, поперечными или извилистыми линями (Советова, 2005. Табл. 8); кони с необычными реалистичными всадниками (Миклашевич, 2012. Табл. I, II) и менее реалистичными (Советова, 2005. Табл. 20-22); «жертвенные»- с вывернутым крупом, и др. (рис. 1, 12-17). Изредка встречаются кони в лежачей позе: в одном случае оглахтинский конь представлен в противоестественной позе с вытянутыми вперед передними и задними ногами, а также кони с подогнутыми под живот ногами (рис. 1, 9-11); и др. Техника их исполнения разнообразна: есть фигуры, выполненные контурной выбивкой или гравировкой, с проработкой различных элементов, много рисунков упрощённых, силуэтных или линейных (Советова, 2005. Рис. 12, 13; Табл. 9. 7-11; 10). Любопытно, что корпусы некоторых коней из улуса Апкашева из горного массива Оглахты (а именно здесь представлена многочисленная группа коней с орнаментированными корпусами) (рис. 1, $12-$ 13 ) заполнены ломаными зигзагообразными линиями, аналогичными орнаменту на рукоятях некоторых тагарских ножей (Членова, 1981. Рис. 6). Не исключено, что это не простое совпадение.

А вот в тагарской мелкой пластике конь далеко не самый популярный персонаж, он реализован, в основном, в скульптуре и представлен в тех же позах, что и в наскальном искусстве: в позе «внезапной остановки» (Макаров, 2012. Рис. IV.10; МКМ, инв. № 4064), стоящим или идущим (Членова, 1967. Табл. 25.1, 20- 22) и с подогнутыми под живот ногами (Завитухина, 1983. Кат. 153) (рис. 1, 33-37). Декор тела отсутствует, за исключением одного гравированного изображения, выполненного на бронзовом кельте из Шунеры практически полной аналогии некоторых рисунков со скал Оглахты (Членова, 1967. Табл. 25.18; Миклашевич, 2010. Табл. II.36) (рис. 1, 37).

Козльл и бараны. В целом козёл - один из самых популярных персонажей в наскальном искусстве, не потерял он своей популярности и в тагарскую эпоху. Наряду с бесчисленным количеством самых простых изображений встречаются и экземпляры, мастерски выполненные в скифо-сибирском стиле (рис. 1, 25-28, 31, 44). В декоре тагарских вещей козлы воплощены в разнообразных позах: стоящими на прямых ногах; стоящими на ногах, соединённых в одной точке; лежащими, с повернутой назад головой; с подогнутыми под живот ногами и др. (Завитухина, 1983. Кат. 14-39). В тагарском наскальном искусстве очень популярны также изображения косуль, особенно часты сцены с ними в конце эпохи, в тесинское время. Изредка встречаются изображения баранов, которые легко распознаются по закрученным рогам. На Боярской писанице имеются выразительные фигуры лежащих баранов (Дэвлет, 1976). В мелкой пластике они также встречаются не часто (Завитухина, 1983. Кат. 47; Членова, 1967. Табл. 34.29, 30, 40) (рис. 1, 46).

Также в тагарском искусстве известны фигуры и других копытных, например, быков (рис. 1, 29, 30) и животных, видовое определение которых затруднительно. 
Хищники. И в тагарской мелкой пластике, и в наскальном искусстве известны изображения реалистичных хищников, представителей местной фауны - волков, кабанов, кошачьих. Их не так много, но они хорошо узнаваемы по оскаленным пастям, когтям, иной детализации (Советова, 2005. Табл. 11, 12, 14; Членова, 1967. Табл. 11. 19; Завитухина, 1983. Кат. 198-213 и др.). Примечательно отсутствие в наскальном искусстве изображений хищников с кольчатыми окончаниями лап, столь характерных для пластики (Кузьмин, 1994 (б). Рис. 1.1; Завитухина, 1983. Кат. 93) (рис. 2. 20, 22, 25). Однако, в петроглифах и в пластике нашли воплощение изображения хищников, напоминающих «барсов», с когтистыми лапами (Завитухина, 1983. Кат. 191-193; Миклашевич, 2016. Рис. 6). Для тагарской металлопластики характерно большее разнообразие в реализации образа хищника: это и припавшие звери, и идущие, стоящие, свернувшиеся в кольцо, изогнутые дугой, парциальные изображения голов хищных животных (рис. 2, 19-27). В металле реализованы изображения зверей, которых по некоторым признакам мы можем соотнести с хищниками семейства канисовых (рис. 2. 21-23).

Нечасты, но очень выразительны в тагарском наскальном искусстве изображения кабанов (Сыдинская писаница, Усть-Туба II, Подкамень и др.), особенно популярных в мелкой пластике (рис. 1, 46-47). Но, если в металлопластике изображения кабанов довольно статичны (это спокойно стоящие звери с низко опущенной головой, либо изображения их голов) (Завитухина, 1983. Кат. 50-89, 86-91 и др.), то в наскальном искусстве этот персонаж передан более экспрессивно: с оскаленными пастями, с зубами и заострённым языком, вздыбленной холкой, хотя встречаются и изображения спокойно стоящих животных с опущенными головами.

Фантастические персонажи. Достоверно в наскальном искусстве не выявлено ни одного изображения грифона («мифического орла»), хотя в пластике этот образ нашёл яркое воплощение в декоре ножей, чеканов, бляшек, а особенно ярко проявился в декоре бронзовых, железных и биметаллических кинжалов (рис. 2, 36-39). Основная часть «грифовых» кинжалов, имеющих большую степень близости с тагарскими, обнаружена на Алтае, гораздо меньше они известны на территории Казахстана и Тувы. Для искусства мелкой пластики образ «мифического орла» - практически единственное известное воплощение представлений о фантастических существах, в то время как в петроглифах изображения таких существ многообразны и многочисленны. Среди наскальных изображений встречаются самые разнообразные синкретические (фантастические) персонажи (рис. 2, 15-18). Характерно, что они не столь пугающе чудовищны, как, например, в окуневском искусстве, и чаще всего собирают в единый образ отдельные черты разных животных: это, например, «конизвери» (Советова, 2013) - кони с длинными закрученными хвостами кошачьих; иногда кони бывают с рудиментами крыльев (Миклашевич, 2010. Табл. IV). Нередко необычные признаки едва уловимы - например, у коней из Оглахты 


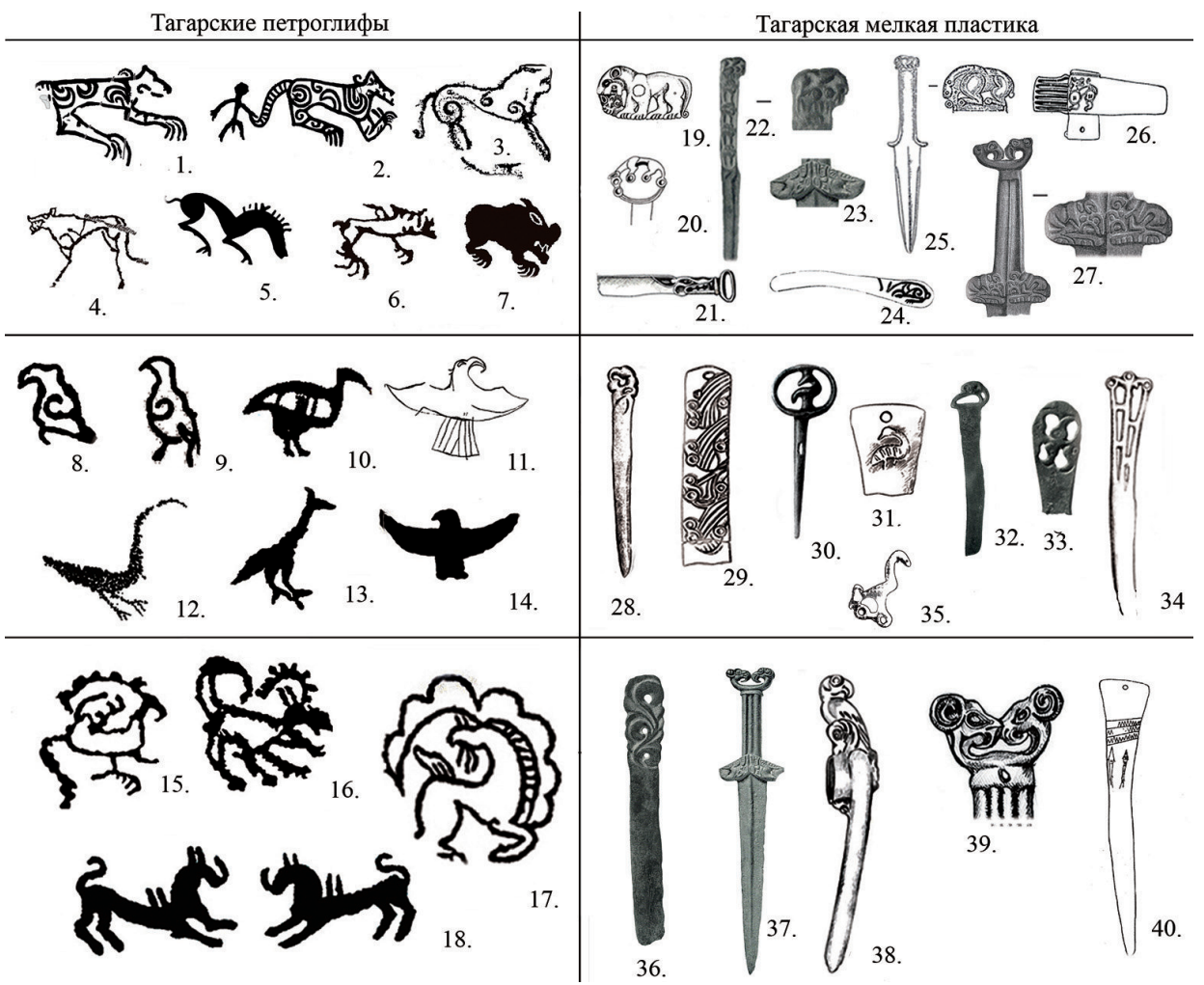

Рис. 2. Тагарское искусство: петроглифы и мелкая пластика (изображения хищников, птиц, франтастических существ): 1-2 - Сыдинская писаница (прорисовка Е.А. Миклашевич);

3 - Абрашкин Лог. Оглахты (по: Миклашевич, 2016); 4 - Усть-Туба III (по: Шер, 1980); 5 - Тигей (по: Седых, 2001); 6 - Абакано-Перевоз (по: Русакова, 1997);

7 - Ураки (по: Семенов и др., 2003); 8 - Бейская стела (по: Дэвлет, 1990);

9 - Новоселово (по: Боковенко, 2000); 10 - Бейская стела (по: Дэвлет, 1990);

11 - Тепсей, рисунок на камне оградки (прорисовка И.В. Аболонковой);

12 - гора Сульфатная (по Е.А. Миклашевич, 2012); 13-14 - Куня (по: Советова, 2005);

15 - Абакано-Перевоз (по: Русакова, 1997); 16 - Усть-Туба (по: Шер, 1980);

17 - Тепсей (по: Шер, 1980); 18 - Куня (по: Миклашевич, 2004); 19 - местонахождение неизвестно (МКМ, инв. № 9108);

20 - Шунеры (по: Членова, 1967); 21 - Байкалово (МКМ, инв. № 3967);

22 - Красноярский край (по: Завитухина, 1983); 23 - Батой (по: Завитухина, 1983);

24 - местонахождение неизвестно (МКМ, инв. № 9993/1);

25 - курган у горы Багульной (по: Кузьмин (б), 1994);

26 - близ Канска (по: Членова, 1967); 27 - около д. Бородино (по: Радлов, 1891);

28 - Сагайское (МКМ, инв. № 3939); 29 - Шошино (по: Завитухина, 1983); 30 - Койча (по: Завитухина, 1983);

31 - могильник Туран II, курган 2, могила 1 (по: Завитухина, 1983);

32 - Минусинский край (по: Завитухина, 1983); 33 - Калы (по: Завитухина, 1983); 34 - Минусинский край (МКМ, инв. № 3892); $35-$ у д. Колмакова (МКМ, инв. № 9178); 36 - Минусинский округ (по: Завитухина, 1983); 37 - с. Батой (по: Завитухина, 1983); 38 - Колмакова (МКМ, инв. № 581); 39 - Чернавка (МКМ, инв. № 863), 40 - д. Калы (по: Филиппова, 1990) 
морды загнуты как птичий клюв (несколько аналогичных экземпляров известны и в мелкой пластике: в Государственном Эрмитаже имеется изображение стоящего козла с длинным рогом и клювовидной мордой (Завитухина, 1983. Кат. 28, 37). Известен фантастический персонаж на скалах Тепсея с корпусом копытного, огромным козлиным рогом с годичными кольцами, клювом птицы, усами (Шер, 1980. Рис. 73) (рис. 2, 17). Подобные существа, воплощенные в дереве, металле и других материалах близкого времени, встречаются и на соседних территориях Алтая и Тувы (Грач, 1980. С. 251. Рис. 113. 1), в Казахстане (Акишев, 1984. С. 8-9, 28. Табл. 1.). На скалах зафиксированы также изображения «единорогов» (Миклашевич, 2004) (рис. 2, 18), крупноголовых хищников, покрытых спиральными завитками (Appelgren-Kivalo, 1931. Abb. 266; Миклашевич, 2016. Рис. 6) и др.

Недавно на скалах горы Тепсей был обнаружен ещё один удивительный персонаж, представляющий фигуру оленя с двумя головами, одна из которых находится на анатомически правильном месте, вторая как бы вырастает из крупа (Советова, 2015. Рис. 1-1) (рис. 1, 22). В наскальном искусстве других территорий двухголовые персонажи тоже изредка встречаются, но всегда более упрощённые. В тагарской мелкой пластике также можно встретить этот мотив, воплощённый на зеркалах, секирах, ножах и т.д. (Завитухина, 1983. Кат. 41a, 41-44, 83, 84a, 84-86, 157, 168-178 и др.) (рис. 1, 47).

Птищьы. И в пластике, и в наскальном искусстве имеются изображения птиц, но различия в них кардинальны. Например, в наскальном искусстве водоплавающие исключительно редки, не обнаружено изображений птиц с повёрнутой назад головой, или таких деталей, как кольчатое окончание лап, а также переданное штрихами оперение - хорошо знакомых по мелкой пластике (Завитухина, 1983. Кат. 222- 225) (рис. 2, 28, 29, 31, 32). Особенно много в декоре вещей изображений голов хищных птиц, отсутствующих в наскальном искусстве (Там же. Кат. 229, 231, 241-248 и др.) (рис. 2, 33-34). В петроглифах в большом количестве зафиксированы изображения птиц с распластанными крыльями - «парящих орлов», а также воронов, водоплавающих, дроф. В последнее время среди позднетегарских изображений (хунно-сяньбийский пласт) на Кавказской писанице и горе Полосатой выявлены сцены со всадником, сидящим на лошади, развернутым анфас и держащим в правой руке ловчую птицу (беркута?) над головой (Миклашевич, Солодейников, 2013. Рис. 12).

$P$ blбы. Их практически невозможно атрибутировать в тагарском наскальном искусстве, но схематичные изображения рыб изредка встречаются в декоре тагарских предметов (Завитухина, 1983. Кат. 64, 325; Филиппова, 1990. Рис. 1, 2; МКМ, инв. № 10622; МКМ, инв. № 3761). Декор тела рыб различен: это зигзаги, косые или горизонтальные линии, разделяющие тело на сегменты (рис. 2, 40).

Антропоморфные персонажи. Любопытно, но в пластике практически полностью отсутствуют антропоморфные персонажи, чего не скажешь о на- 
скальном искусстве. «Тагарские человечки» - это маркер огромного множества наскальных композиций Минусинского края. Главный, но не основной их признак - султан на голове. Антропоморфные персонажи в петроглифах многочисленны, нередко динамичны; они активно участвуют в действии: скачут на конях с поднятым в руках оружием, участвуют в батальных сценах сражаясь то с «великанами», то с другими врагами, порой побеждая - ставя противника на колени или нанося ему удар чеканом, топором, поражая стрелой из лука, а то и умирая (перевёрнутые фигурки) и т.д. (рис. 1, 1-8). Нередко они вписаны в сюжетные картины предшествующих эпох, таким образом, очевидно, преобразуя их смысл. «Тагарские человечки» бывают очень разными: есть персонажи, выполненные относительно реалистично, как правило, с присогнутыми в коленях ногами, с бородками клинышком, нередко в головных уборах типа колпака или в раскидистом уборе, часто с растопыренными пальцами рук и т.д. Нередко такие персонажи сопровождают коней (сюжет «Господин коней») (Шер, 1993). Встречаются лыжники, лучники, охотники и проч., но огромное количество человечков выполнено предельно схематично.

В прикладном творчестве к настоящему времени известно всего лишь два антропоморфных изображения, но они значительно отличаются от «тагарских человечков». Они украшают противоположные стенки одного бронзового тагарского кельта, обнаруженного у с. Усинское (Ненахов, 2011. Рис. 1. С. 127-131) (рис. 1, 32). Выполнены они по канонам скифских антропоморфных изваяний. Персонажи представлены в фас, их головы имеют каплевидную форму, глаза круглые и крупные, рот в виде углублённой черты. У одного из них правая рука согнута в локте, кисть прижата к левой груди, левая согнута и находится на уровне талии, пальцы растопырены. У человека с противоположной стороны кельта руки расположены зеркально по отношению к описанному выше. Аналогичных изображений среди «тагарских человечков» не выявлено, известен лишь иконографически близкий этнографический рисунок на скалах Оглахты (Миклашевич, 2015. Рис. 16).

Таким образом, в репертуаре тагарского искусства отображено огромное количество различных персонажей, очевидно, очень значимых в жизни тагарского населения. Накопление новых материалов лишний раз свидетельствует о том, что он вполне может пополняться новыми образами и сюжетами, причем, не только в наскальном искусстве периодически открываются новые образы, но также открываются новые нюансы и в мелкой пластике. Так, например, нами зафиксирован один любопытный сюжет, когда на спине одного существа располагается другой, но меньших размеров: например, на обушке чекана из Шестаковского кургана 10 помещены изображения стоящих козлов (Мартынов, Кулемзин, Мартынова, 2017. Рис. 85.18). Не менее интересен сюжет, представляющий собой изображение крупной птицы и маленького птенца, примкнувшего к ней, представленный на бляшке, обнаруженной у с. Колмакова 
(МКМ, инв. № 9178) (рис. 2, 35). Так и в наскальном искусстве нередко открываются совсем новые воплощения универсальных тем, например, на позднем этапе тагарской культуры получил широкое распространение сюжет с самкой, укрывающей под животом своего детёныша. Не исключено, что это список может быть продолжен.

Что касается вопроса композиции в тагарском искусстве, то можно отметить самое основное. Тагарские изображения в декоре предметов прикладного творчества хоть и отличаются статичностью, небольшим набором персонажей, однако вполне могут представлять конкретный сюжет. Д.Г. Савинов справедливо заметил, что совместное расположение фигур уже представляет собой композицию, а совместное нахождение фигур в одном пространстве и характер их расположения уже являются знаковым определением такого действия (Савинов, 2012. С. 35-38). В предметах поле размещения фигур было ограничено, мастер знал точно заданные границы, все позиции и места размещения изображений были четко выверены. Выбор образа был органично привязан к типу украшаемого предмета, закреплены возможные сочетания образов. Вероятно, именно поэтому изображения в металле более каноничны и серийны, чем в искусстве петроглифов. Не стоит забывать, что в наскальном плоскостном - искусстве не было столько возможностей для той детализации объекта, которая была присуща пластике. На скалах повествование вообще развертывалось иначе: фигуры размещались более свободно, их пропорции часто варьировались в зависимости от замысла художника, не ограничивавшего себя размерами используемого поля, а от степени его мастерства зависело и качество воплощаемого сюжета. Наскальные композиции часто содержат от нескольких до десятков персонажей, в них разворачиваются батальные и ритуальные действия, охота и иного рода события, активным участником которых является человек: пеший, всадник, воин, участник ритуалов, нагой, «одетый» и т.д., это активный, разный, но узнаваемый «тагарский человечек». Вместе с тем, несмотря на то, что наскальное искусство не слишком ограничивало свободу творчества художника, нередки и канонизированные сюжеты, повторяемые на скалах многократно - напомним лишь сюжет «Господин коней» (Оглахты, Куня) с многочисленными вариациями.

Безусловно, петроглифы и пластика, гармонично дополняя друг друга, объединённые общим понятием «тагарское искусство», представляют лишь два отдельных, дошедших до нашего времени раздела большого многокомпонентного искусства, о других составляющих которого можно только догадываться.

\section{ЛИТЕРАТУРА}

Акишев К.А. Искусство и мифология саков. Алма-Ата: Наука, 1984. 176 с.

Бобров В.В. Петроглифы Сибири и кулайская металлопластика // Изобразительные памятники. Стиль. Эпоха. Композиции. СПб.: Изд-во СПбГУ, 2004. С. 309-313. 
Боковенко Н.А. Новые памятники наскального искусства скифской эпохи на Енисее // Мировоззрение. Археология. Ритуал. Культура. Сб. статей к 60-летию М.Л. Подольского. СПб., 2000. С. 11-19.

Грач А.Д. Древние кочевники в центре Азии. М.: Наука, 1980. 256 с.

Завитухина М.П. Древнее искусство на Енисее. Скифское время. Публикация одной коллекции. Л.: Искусство, 1983. 192 с.

Зинченко С.A. Петроглифы как возможный стилистический прототип для формирования памятников раннескифского искусства // Мир наскального искусства: Сб. докл. Междунар. конф. М.: Изд-во ИА РАН, 2005. С. 116-117.

Клемени Д.А. Древности Минусинского музея. Памятники металлической эпохи. Атлас. Томск: Типография сибирской газеты, 1886. 185 с.

Кузьмин Н.Ю. Курган у деревни Новомихайловка. Археологические изыскания. СПб.: РАН ИИМК, 1994 (а). 60 с.

Кузьмин Н.Ю. Некоторые итоги охранных раскопок в долине р. Уйбат в Хакасии // Изучение древних культур и цивилизаций. Археологические изыскания. Вып. 14. СПб.: 1994 (б). С. 24-28.

Макаров Н.П. Художественная бронза раннего железного века в фондах Красноярского краевого краеведческого музея // Археология южной Сибири. Кемерово: Кузбассвузиздат, 2012. С. 68-77.

Мартынов А.И., Кулемзин А.М., Мартынова Г.С. Тайны Шестаковских курганов. Кемерово: КемГУ, 2017. 118 с.

Миклашевич E.A. Племя единорога на Енисее (сяньбийские мотивы в наскальном искусстве Минусинской котловины) // Изобразительные памятники: стиль, эпоха, композиции: Материалы тематической научной конференции. Санкт-Петербург, 1-4 декабря 2004 г. СПб.: Изд-во СПбГУ, 2004. С. 320-325.

Миклашевич E.A. Влияние торевтики на формирование стилей наскального искусства Южной Сибири, Средней, Центральной Азии // Торевтика в древних и средневековых культурах Евразии. Барнаул: Азбука, 2010. С. 135-144.

Миклашевич E.A. Льнищенская писаница // Памятники наскального искусства Минусинской котловины: Георгиевская. Льнищенская. Улазы III. Сосниха. Кемерово: Кузбассвузиздат. 2012 (а). (Тр. САИПИ. Вып. Х). С. 28-56.

Миклашевич E.A. Памятники наскального искусства Оглахтинского хребта: перспективы номинирования в Список Всемирного наследия ЮНЕСКО // Археологическое наследие Сибири и Центральной Азии (проблемы интерпретации и сохранения): материалы международной конференции. Кемерово: Кузбассвузиздат, 2016. C. 268-273.

Миклашевич E.А., Панкова С.В., Мухарева А.Н. Петроглифы горы Сосниха // Памятники наскального искусства Минусинской котловины: Георгиевская. Льнищенская. Улазы III. Сосниха. Кемерово: Кузбассвузиздат, 2012 (б). (Тр. САИПИ. Вып. Х). C. 72-111.

Миклашевич E.A., Солодейников А.К. Новые возможности документирования наскальных изображений, выполненных краской (на примере Кавказской писаницы в Минусинской котловине). Научное обозрение Саяно-Алтая. 2013. № 1(5). C. $176-191$.

Радлов В. Сибирские древности. Том I, вып 2. СПб.: Типография императорской академии наук, 1891. 102 с. 
Русакова И.Д. Новый памятник наскального искусства на Енисее (писаница Абакано-Перевоз в Хакасии) // Наскальное искусство Азии. Кемерово: Кузбассвузиздат, 1997. Вып. 2. С. 101-112.

Савинов Д.Г. Изобразительные памятники раннескифского времени: искусство композиции // Изобразительные и технологические традиции в искусстве Северной и Центральной Азии. Труды САИПИ. Вып. IX. Кемерово: Кузбассвузиздат, 2012. C. 35-55.

Савинов Д.Г. Некоторые аспекты теоретического изучения петроглифов (по материалам Центральной Азии и Южной Сибири) // Археология, этнография и антропология Евразии. 2009. № 2(38). С. 92-103.

Семенов Вл.А., Килуновская М.Е., Красниенко С.В., Субботин А.В. Петроглифы Каратага и горы Кедровой (Шарыповский район Красноярского края). СПб.: ИИМК PAH, 2000. 66 c.

Cедых В.Н. О памятниках изобразительного искусства эпохи ранних кочевников из Абаканской степи // Евразия сквозь века. Сб. научных трудов, посвящённый 60-летию Д.Г. Савинова. СПб.: Филол. ф-т СПбГУ, 2001. С. 133-136.

Советова О.С. Кони - звери // Современные решения актуальных проблем евразийской археологии. Барнаул: Изд-во Алт. ун-та, 2013. С. 276-279.

Советова О.С. О новом необычном персонаже Тепсея // Научное обозрение Саяно-Алтая. 2015. № 1(9). С. 89-93.

Советова O.C. Петроглифы тагарской эпохи на Енисее (сюжеты и образы): монография. Новосибирск: Изд-во ИАиЭ СО РАН, 2005. 140 с.

Филиппова E.E. Тагарские ножи с изображением рыб из собрания ГИМ // Проблемы археологии Евразии. К 100-летию со дня рождения А.Я. Брюсова. Тр. ГИМ. Вып. 74. М., 1990. С. 89-93.

Чемякин Ю.П. Об одной гипотезе происхождения кулайской металлопластики // Вестник Кемеровского государственного университета. 2015. № 2-6(62). С. 177-181.

Членова Н.Л. Происхождение и ранняя история племён тагарской культуры. М.: Наука, 1967. 300 с.

Членова Н.Л. Тагарские лошади (О связях племён Южной Сибири и Средней Азии в скифскую эпоху) // Кавказ и Средняя Азия в древности и средневековье. М.: Наука, 1981. С. 80-94.

Шер Я.А. Петроглифы Средней и Центральной Азии. М.: Наука, 1980. 328 с.

Шер Я.А. «Господин коней» на берегах Енисея // Петербургский археологический вестник. Сб. археол. статей в честь 56-летия Д.А. Мачинского. СПб.: ФАРН, 1993. № 6. C. 17-22.

Appelgren-Kivalo H. Alt-Altaische Kunstdenkmaler (Briefe und Bildmaterialen von J.R. Aspelins Reisen in Sibirien und der Mongolei 1887-1889). Helsingfors, 1931.

Merchart G. von. Bronzezeit am Jenissei; ein Beitrag zur Urgeschichte Sibiriens. Wien: A. Schroll \& Co., 1926. 189 c. 


\section{ФИНАЛ ПОЗДНЕЙ БРОНЗЫ В ПРЕДГОРЬЯХ АДЫГЕИ} (Работа выполнена при поддержке РФФИ (проект № 19-09-00100))

\section{Эрлих В.P.}

http://10.25681/IARAS.2019.978-5-317-06274-3/230-247

Памятники финала бронзового века, послужившие субстратом феномену протомеотской группы памятников Северо-Западного Кавказа, изучены пока явно недостаточно. Подавляющее их большинство находилось исключительно в равнинной зоне, и, очевидно, являлось субстратом протомеотских памятников центрального варианта. В публикации приведены новые материалы с территории предгорного варианта протомеотской группы, памятники постдольменного горизонта: археологический комплекс Шушук, Поселение Деметра, погребение с частичной кремацией Гавердовского могильника.

Ключевые слова: предгорья Адыгеи, поздняя бронза, протомеотский период, дольменная культура

Памятники финала бронзового века, послужившие субстратом феномену протомеотской группы памятников Северо-Западного Кавказа, изучены пока явно недостаточно. Чуть больше десятилетия назад, когда автором этих строк делалась сводка памятников, предшествующих протомеотской группе, их количество ограничивалось 14-16 погребениями и несколькими поселениям (Эрлих, 2007. С. 27-31. Рис. 4-11). Подавляющее их большинство находилось исключительно в равнинной зоне, и, очевидно, являлось субстратом протомеотских памятников центрального варианта. Лишь поселение Лесное в бассейне р. Белой, материалы которого до сих пор опубликованы тезисно, можно было сопоставить с будущей территорией предгорного варианта протомеотской группы.

В предлагаемой читателю статье мы приведем новые недавно открытые Кавказской археологической экспедицией материалы, которые позволяют частично восполнить данный пробел.

Памятники постдольменного горизонта. Археологический комплекс Шушук. Продолжающиеся исследования Кавказской экспедиции выявили могильник и поселение финальной бронзы, относящиеся к так называемому постдольменному горизонту (Эрлих, 2018). Памятник находится в 1,3 км от дольменного могильника Шушук, исследованного в 2008-2010 гг. А.Д. Резепкиным, который надёжно доказывает доживание дольменной культуры, по крайней мере, до срубного времени (Резепкин, 2013, 2013 а).

Характерной особенностью постдольменных комплексов являются погребения в ящиках-рамах, для которых часто использовались плиты разобранных соседних дольменов, камни, а иногда и деревянные плахи (рис. 1, 1-4). Погребения могли сооружаться на горизонте или в небольших ямах или карстовых промоинах. Пока лишь однажды выявлен случай вторичного использования позднего дольмена (Шушук-75, п. 2) (рис. 1, 5, 6). 

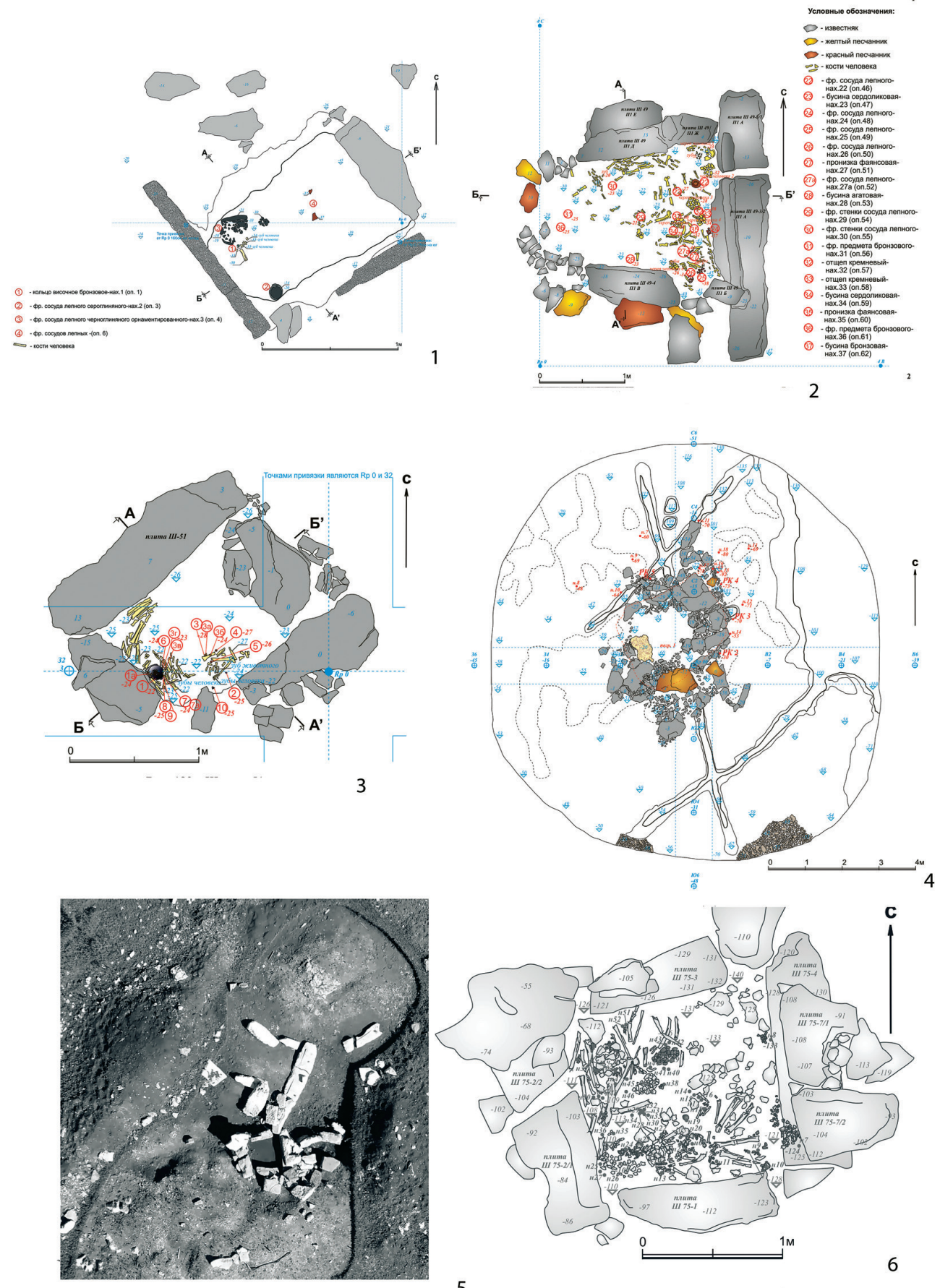

5

Рис. 1. Погребальные конструкции постдольменного горизонта.

1 - Шушук-70, п. 1; 2 - Шушук-49, п. 1; 3 - Шушук-51, п. 2.; 4 - Шушук-53;

5 - мегалитический ансамбль Шушук-75-76; 6 - Шушук-75, п. 2 

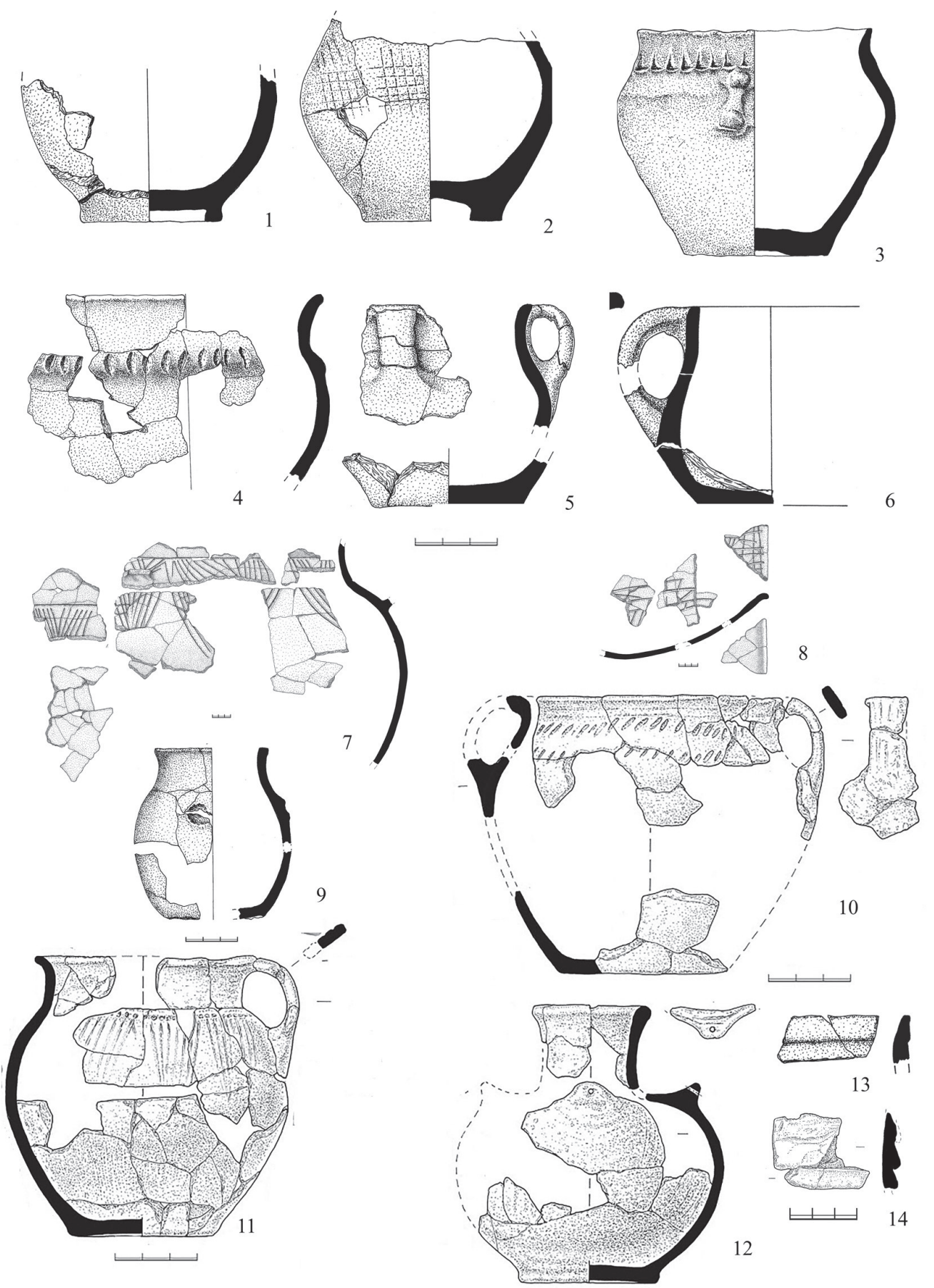

13

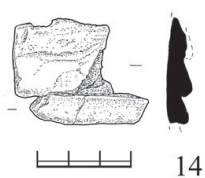

12

Рис. 2. Керамика постдольменного горизонта.

1, 4 - Шушук-70, п. 2; 2, 3 - Шушук-48 новый; 5, 6, 13 - Шушук-53;

7 - Шушук-64; 8, 9 - Шушук-51; 10-12 - Шушук-75; 14 - Шушук-76 
Инвентарь погребений представлен керамикой и украшениями.

Это височные колечки 1,5 оборота или с примыкающими концами из бронзы, серебра и золота (рис. $3,1-4,38-41$ ), костяные подвески из зубов животных, (рис. $3,13-17,56,57$ ) и подражания им, выполненные из местного гипса (рис. 3 , $22,27,52-55$ ), фаянсовые пронизи (рис. 3, 6, 10, 11, 12, 19), бусы и пронизи из бронзы (рис. $3,18,23,42$ ); сердолика или селенита (кристаллического гипса) (рис. 3, 9, 20, 25, 26, 32-37, 43-48, 60), бронзовые грибовидные подвески (рис. $3,58,59$ ) и местные им подражания из селенита (рис. $3,50,51$ ).

Можно отметить определённую преемственность публикуемых материалов с дольменным могильником Шушук, которая проявляется, прежде всего, в металле. Однако, заметим, что металла здесь гораздо меньше, чем в дольменах. Это пластинчатые височные подвески с приострёнными концами, бронзовые бочонковидные бусины, фрагмент бронзовой спирали накосника (рис. 3, 4). Все эти украшения находят близкие аналогии в дольменах 1 и 9 дольменного могильника Шушук (Резепкин, 2013 а. Рис. 1, 1-4, 6, 10; Резепкин, 20136. Табл. 21, 1-4, 6, 7, 11).

В то же время, височные привески из бронзовой ленты с заострёнными концами в памятниках Нижнего Подонья и Предкавказья выступают как определённые маркеры финала эпохи поздней бронзы (Потапов, 2010. С. 155-157). Среди территориально близких параллелей является височная подвеска с заострёнными концами из п. 7 кургана 11 Михайловского могильника в Закубанье, относящегося к финалу эпохи бронзы (Шарафутдинова, Каминский, 1988. С. 217. Рис. 2, 1).

Подвески из зубов оленя или подражающие им встречаются в погребениях всех периодов эпохи бронзы Северного Кавказа и Причерноморья, начиная с энеолита вплоть до финала бронзового века (Ильюков, 2013. С. 174. Рис. 2, 5; Резепкин, 2012. С. 259. Рис. 131, 2. С. 308. Рис. 180, 13; Вангородская, 1987. С. 40, 41; Рис. 2, 1; Ванчугов, 1990. С. 90. Рис. 38, 1). Находки подвесок из зубов оленя в дольменных памятниках нам не известны, однако в дольмене 84 Дегуакской поляны и в дольмене 1 в Красной Поляне встречены их имитации, выполненные из сердолика (Марковин, 1978. С. 271. Рис. 131, 32; 132, 5-9).

Сердоликовые и селенитовые бусы в публикуемых комплексах встречены уплощённо-кольцевидной и цилиндрической формы. Каменные бусы близкой формы встречаются и в дольменных памятниках Западного Кавказа (Марковин, 1978. Рис. 132, 2, 4, 10).

Определённый интерес представляют рубчатые или рифлёные пронизи из фаянса либо глухого стекла. Безусловно, они требуют спектрального анализа для уточнения материала, из которого были изготовлены. Немногочисленные бусы из «стекловидной пасты» известны по материалам дольменной культуры. Они, как правило, были мелкими и имели цилиндрическую либо биконическую форму и происходили из дольменов Верхней Эшеры, Красной Поляны, Дегуакской поляны и Солонников (Марковин, 1978. С. 272. Рис. 132, 11-23). 

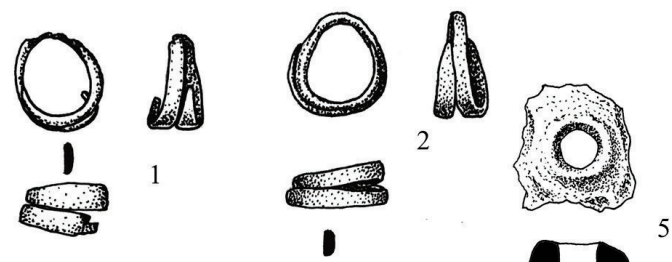

$\begin{array}{ccc}0 & 0 & 0 \\ 7 & 0 & 0\end{array}$

$\begin{array}{cccc}6 & 6 & 0 & 11\end{array}$
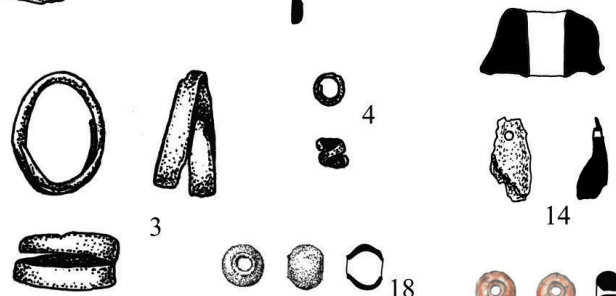

5

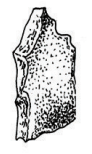

12

A 13

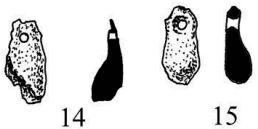

(3)

(10) $\bigcirc_{18}$ (9) (9) 20

影

17

\section{9}

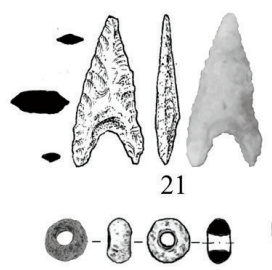

26

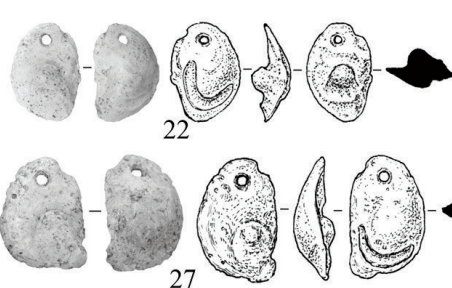

1023

8-

24

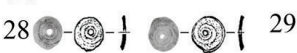

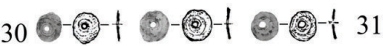
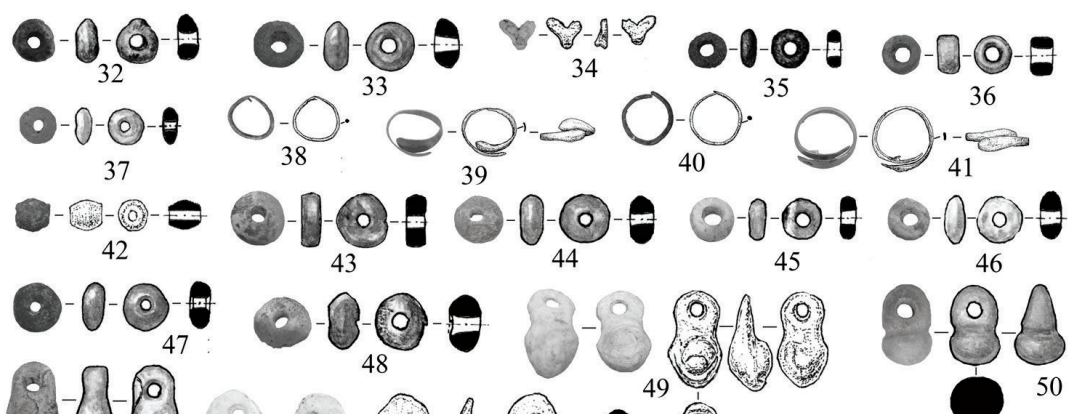

080

48

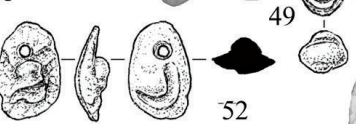

(1) 51

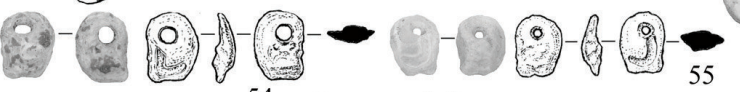

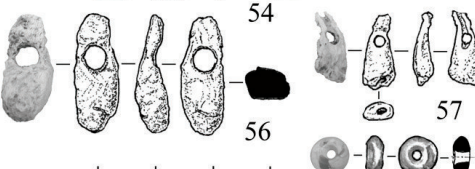

$0-3$

138

8- -9

60

59

Рис. 3. Инвентарь постдольменных погребений.

1, 2 - Шушук-48, новый, п. 1; 3, 4 - Шушук-70, п. 1; 5-17 - Шушук-51, п. 2;

18-20 - Шушук-49, п. 1; 21 - Шушук-75, ск. 2; 21-37 - Шушук-75, п. 1; 38-57 - Шушук-75, п. 2; 58-60 - Шушук-76, п. 1.

$1-4,18,23,24,34,42,58,59$ - бронза; 5 - керамика; 6, 7, 10-12, 19 - фраянс;

14-17, 28-31, 56, 57 - кость; 8, 9, 20, 60 - сердолик; 21 - кремень;

22, 27, 49, 52-55 - гипс; 25, 26, 32, 33, 35-37, 43-48, 50, 51 - селенит 
Иногда они встречаются сдвоенными, как пронизи из Солонников, что по форме их сближает с рифлёными пронизями, обнаруженными в погребальных объектах Шушук-49 и Шушук-51. В.И. Марковин справедливо указал на «определённую редкость» подобных находок в дольменном инвентаре и отнёс их к предметам «переднеазиатского и ближневосточного импорта» (Марковин, 1978. С. 274). Пронизи из комплекса Шушук-51 (рис. 3, 6, 10-12) имеют определённое сходство с четырёхчастной фаянсовой пронизью из погребения 11, кургана 5 могильника у с. Соколово Днепетровской области, относящемся к культуре Бабино/КМК (Березанская и др., 1986. С. 27. Рис. 9, 8; Вангородская, 1987. С. 41. Рис. 2, 8).

В то же время хотелось бы обратить внимание на морфологическую близость обнаруженных нами фаянсовых (?) пронизей с костяными рельефными, как правило, трёхчастными пронизями, которые, по мнению В.В. Потапова, являются одними из маркеров финала бронзового века в Причерноморье (Потапов, 2016. С. 73, 74. Рис. 2, 20-24). Мы не исключаем, что данные костяные пронизи подражали высоко ценившимся привозным фаянсовым.

Керамика представлена сосудами со значительной примесью гипса, что говорит о местном её происхождении.

Имеются сосуды на низком кольцевом поддоне, обнаруженные в погребальных объектах Шушук новый 48 и Шушук 70 (рис. 2, 1-3). Подобные сосуды появляются в предшествующее время и были встречены в дольменах № 5 и 9 могильника Шушук (Резепкин, 2013. С. 369. Табл. 2, III, 1, 2; Резепкин, 2013б. Табл. 12, 2, 3; 14, 2, 3; 16, б). А.Д. Резепкин привёл две аналогии сосудам на кольцевых поддонах срубного времени из п. 1 Филатовского кургана покровско-абашевской культуры и из п. 2, Ясиновского кургана 1 на р. Чир (Резепкин, 2013. С. 367; Синюк, 1996. С. 217. Рис. 53, 2; Шарафутдинова, Житников, 2011. С. 124. Рис. 70, 6). В то же время, сходные сосуды на полых кольцевых поддонах встречены и в других памятниках дольменной культуры, например, в дольмене Колихо и погребении дольменной культуры, совершённом в каменном ящике могильника Гнокопсе, расположенного возле поселка Агуй-Шапсуг в Туапсинском районе (Трифонов и др., 2012. С. 105. Рис. 1, 3, 4).

Мы можем отметить, что небольшие сосуды («рюмочки») на полых ножкахподдонах встречены и на Западном Кавказе в Эшерских кромлехах, содержавших материал с эпохи средней бронзы до раннего железного века (Шамба, 1974. C. 60. Табл. XVIII, 4, б). Встречаются сосуды на низком кольцевом поддоне и памятниках срубного горизонта степного Прикубанья (Гришковское, I, курган 2, погр. 10) (Шарафутдинова, 1991. С. 75. Рис. 2, 7).

Отметим, что для керамики дольменного могильника Шушук, как и для керамики публикуемых погребальных объектов, характерна примесь известняка (гипса) в тесте, орнамент в виде наколов и прочерченных линий, образующих иногда «шевроны», либо ряды треугольников. Имеется также близкое сходство в оформлении ложных ручек выступов (рис. 2, 3, 7) в виде прямоугольника- 
упора либо двух соцевидных налепов (Резепкин, 2013. С. 369. Рис. III, 1; Резепкин, 2013б. Табл. 11, 2, 3). Можно отметить особую морфологическую и орнаментальную близость части сосуда из п. 1 объекта 70, украшенного расчлененным валиком (рис. 2, 4), и сосуда из могильника Гнокопсе (Трифонов и др., 2012. Рис. 1, 3). Близкие по форме и орнаментации горшки мы находим в кобяковских памятниках Кубани и Нижнего Дона финала бронзового века (Шарафуддинова, 1980. Таб. XII, 5-7; Шарафутдинова, 1989. Рис. 2, 1).

В то же время имеются и инновации, которые, прежде всего, касаются формы сосудов. Это блюдо из ритуального комплекса объекта Шушук-51 и корчага из ритуального комплекса Шушук-64 (рис. 2, 7, 8).

Интересную керамическую серию дал мегалитический ансамбль Шушук75-76, исследованный нами в 2017 г. Отсюда происходит ряд сосудов-кувшинов с ленточными вертикальными ручками (рис. 2,11 ), узкогорлый сосуд с четырьмя ушками для подвешивания (рис. 2, 12), сосуд с парными ленточными ручками (рис. 2,10$)$. На одном из кувшинов этого комплекса встречен орнамент в виде свисающих треугольников с лентой жемчужин (рис. 2, 11). Подобный орнамент характерен для кобяковской культуры финала поздней бронзы Прикубанья и Нижнего Подонья (Анфимов, Шарафутдинова, 1982. Рис. 4, 11, 15, 16; 5, 5-7; Шарафутдинова, 1980. Рис. 20, 7, 16. Таб. XVI, 10; XXI, 10, 11).

Также инновацией являются и кубковидные кружки-черпаки, фрагменты которых встречены в тризновых комплексах объекта Шушук-53 (рис. 2, 5, 6). Отметим, их некоторую особенность, заключающуюся в том, что ручка сосуда не возвышается над туловом, как у классических черпаков протомеотского времени.

Поселение. Кроме этого, в непосредственной близости к исследованным погребальным объектам на территории Победовского карьера гипса имеется поселение. Оно было обнаружено по распространению нарушенного земляными работами культурного слоя. На поверхности были найдены фрагменты керамики, кости, кремневые отщепы. В подъёмном материале обнаружена исключительно лепная керамика, преимущественно красноглиняная с примесью гипса. Характерной её особенностью являются валики у крупных сосудов. Экспедицией была исследована сохранившаяся часть слоя, который представлял собой смыв с уничтоженной карьером площадки, и большая карстовая промоина, использовавшая жителями поселения в качестве свалки мусора.

Среди керамического материала, полученного на поселении, выделяются корчаги, горшки, кубки и черпаки с петельчатыми ручками (рис. 4, 3-7). Черпаки кубковидной формы (рис. $4,3,7$ ) находят соответствия как в памятниках финальной бронзы Прикубанья - Батуринский I, к. 9, п. 10, поселения Красногвардейское I (Шарафутдинова, 1991а. С. 188, рис. 3, 2; Анфимов, Шарафутдинова, 1982. С. 144. Рис. 5, 8, 9, 11, 12), так и среди черпаков 1 и 2 группы в протомеотских памятниках пос. Красногвардейское II, Фарс/Клады и других (Эрлих, 2007. Рис. 134, 8, 11, 19; 136, 12, 13, 15; 137, 2, 5, 10). 

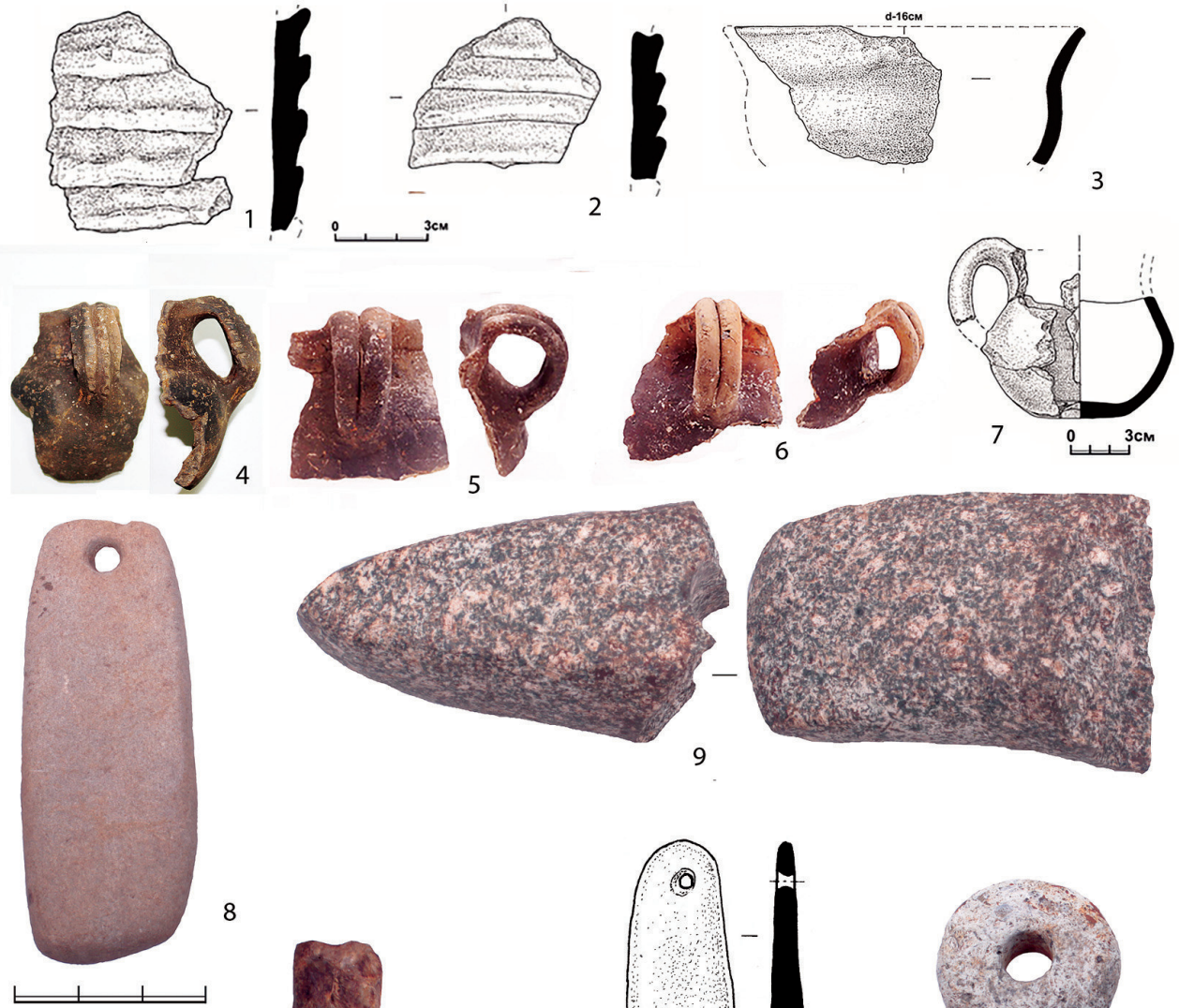

8
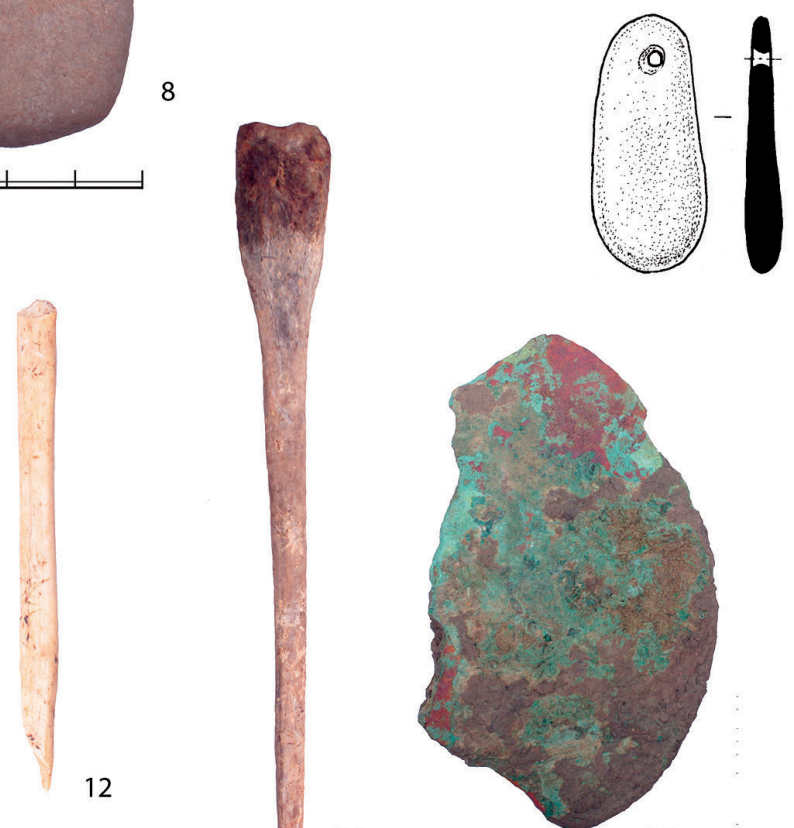

10

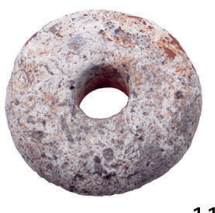

11

13
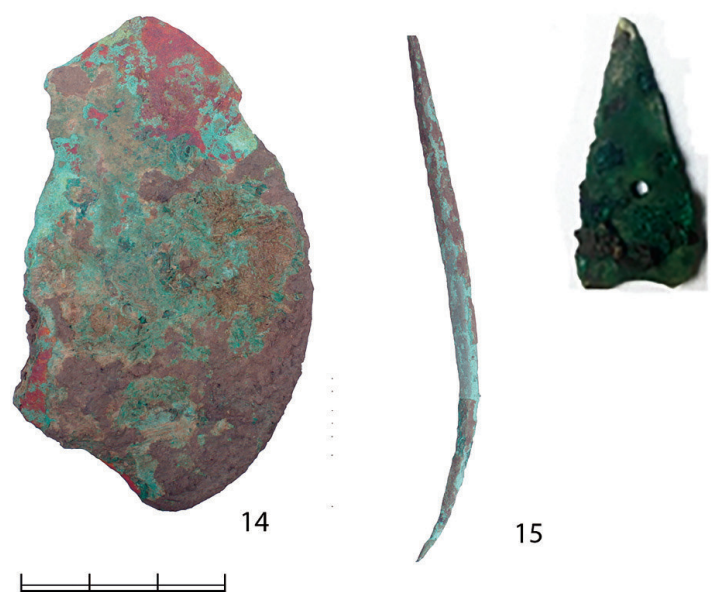

16

Рис. 4. Шушук, находки на поселении.

1-7 - керамика, 8-11 - камень, 12, 13 - кость; 14-16 - бронза 
В то же время на поселении Шушук встречены черпаки с дуствольными и желобчатыми ручками, аналогии которым нам не известны (рис. 4, 4-6). Характерной особенностью керамики поселения являются сосуды, верхняя часть которых орнаментирована рядами валиков. Эти ряды валиков формовались при помощи жгутов глины, внутренняя сторона сосуда при этом заглаживалась (рис. 4, 1, 2). Фрагменты сосудов с валиками лишь дважды встречены в погребальных объектах Шушук-53 и 76 (рис. 2, 13, 14). Сходная валиковая организация обнаружена на сосудах финала бронзового века на поселениях Гум-Баши и Ран-Сырт в Карачаево-Черкессии, а также у сосуда, обнаруженного в Абхазии на перевале Алаштраху ${ }^{1}$. Сходная орнаментация в качестве рудимента встречается и на некоторых протомеотских сосудах, однако эти валики формируются не с помощью жгутов, а глубокими бороздами (Эрлих, 2007. Рис. 134, 13-15; Шарафутдинова, 1989. С. 52, 53, 68. Рис. 7, 3, 5; Черных, Сазонов, 2013. С. 62. Рис. 13, 3, 4).

Из других находок можно отметить изделия из камня - фрагмент топора с клиновидной рубящей частью и проушным отверстием, просверленным с двух сторон (рис. 4, 9), прямоугольный в плане оселок с просверленным отверстием для подвешивания (рис. 4, 8), сверлины также имеет каменная подвеска и пряслице (рис. 4, 10, 11). Встречены костяная проколка и булавка из кости «весловидной» формы (рис. $4,12,13$ ). Бронзовые изделия пока ограничиваются массивным четырёхгранным в сечении шилом с двусторонне заострёнными концами (рис. 4, 15), находящим аналогии среди кобанских шильев типа 1 (Козенкова, 1982. С. 7; Козенкова, 1998. С. 15), лезвийной частью топора либо тесла (рис. 4, 14) и закавказского наконечника стрелы-площика, однако лишенного черешка, близкого по форме к кремневым кавказским наконечникам в виде «ласточкина хвоста» (рис. 4, 16). По костям животных, обнаруженных среди мусорных отбросов, мы можем судить о составе стада и характере мясной диеты местного населения. По данным сотрудника Кавказского биосферного заповедника Ю.Н. Спасовского, обработавшего более 2000 костных остатков, среди определимых костей на первом месте находился крупный рогатый скот (407 фрагментов от 98 особей). Второе место занимает свинья (157 фрагментов от 74 особей). Ещё меньше костей мелкого рогатого скота - 63 фрагмента от 43 особей. Очень незначительны кости лошади, очевидно только начинавшейся появляться в стаде горцев - 15 фрагментов от 7 особей. Дикие животные, представлявшие собой охотничью добычу, представлены костями оленя и косули.

По углю из нижних штыков шурфа, попавшего в «мусорную яму», получена радиокарбонная дата в лаборатории г. Мангейма - MAMS-28352 - 2980 24 BP (Cal. б 1258-1131 BC Cal. бо 1273-1122 BC). Эта дата - XIII-XII вв. до н.э.,

${ }^{1}$ Благодарю А.Б. Белинского за возможность ознакомится с отчетными материалами по исследованию поселений Ран-Сырт и Гум-Баши, а также директора Абгосмузея А.И. Джопуа за возможность ознакомиться с сосудом из Алаштраху. 
в реальности может быть несколько моложе, т.к. получена по углю массивного дерева, возможно дуба, возраст которого мог быть 100-200 лет ${ }^{1}$.

Таким образом, первые результаты исследований, проведённых на археологическом комплексе Шушук, позволили выделить в предгорьях СевероЗападного Кавказа новый горизонт памятников, который мы предварительно можем назвать постдольменным. Он возникает после прекращения существования дольменного могильника Шушук, относящегося к эпохе поздней бронзы и синхронного срубной общности. Постдольменный горизонт хронологически частично (или полностью) «закрывает» хиатус, существовавший в предгорьях Западного Кавказа между дольменной культурой эпохи средней и поздней бронзы и предгорным вариантом протомеотских памятников эпохи перехода в раннем железном веку. Памятники постдольменого горизонта, по-видимому, синхронны кобяковской культуре равнинного Закубанья.

Погребение с частичной кремацией Гавердовского могильника. Ещё одним комплексом, относящимся к этому периоду, в ареале предгорий является погребение, открытое Кавказской экспедицией музея Востока весной 2017 г. на окраине г. Майкопа в пос. Гавердовский на территории известного Гавердовского могильника. При отводе земель под застройку и прокладке улиц здесь была обнаружена серия каменных вымосток, одна из которых была исследована. По поверхности она представляла прямоугольную раму размером 4,2×2,6 м из крупных валунов, ориентированную длинной осью по линии С3-ЮВ. Юго-восточная стенка рамы была нарушена бульдозером. Внутри рамы находилась мелкая окатанная галька. После выборки мелкой гальки в северо-западной части рамы обнаружено большое угольное пятно, вытянутое с севера на юг (рис. 5, 14). Размеры пятна, имеющего неправильную форму, около $2 \times 1$ м. В районе пятна и рядом с ним обнаружены обожжённые кости двух погребённых. Ориентировка первого погребённого предположительно северная. Обожжённые кости черепа, зубы и длинные кости второго погребённого находились в центре ямы у южной окраины угольного пятна. Первоначальное положение этого костяка и ориентировка неопределимы. При погребённых обнаружены остатки восьми лепных сосудов и не менее восьми фрагментированных бронзовых височных подвесок в 1,5 оборота и три кремневых отщепа.

Три сосуда имеют орнаментацию в виде треугольников, выполненных прочерченными линиями либо штампом, имитирующим шнур (рис. 5, 1, 2, 4). Один сосуд имеет вертикальную петельчатую ручку (рис. 5, 4). Два сосуда имеют горизонтальные выступы-ручки в виде парных налепов (рис. 5, 1, 5). Один неорнаментированный горшочек имеет валик, образованный отдельно сформованным и прилепленным венчиком (рис. 5, 3).

${ }^{1}$ В то же время необходимо заметить, что по новым радиоуглеродным данным, полученным недавно, значительно понижены даты памятников кобяковской культуры до рубежа XV-XIV вв. до н.э. (Потапов, 2012. С. 297). 

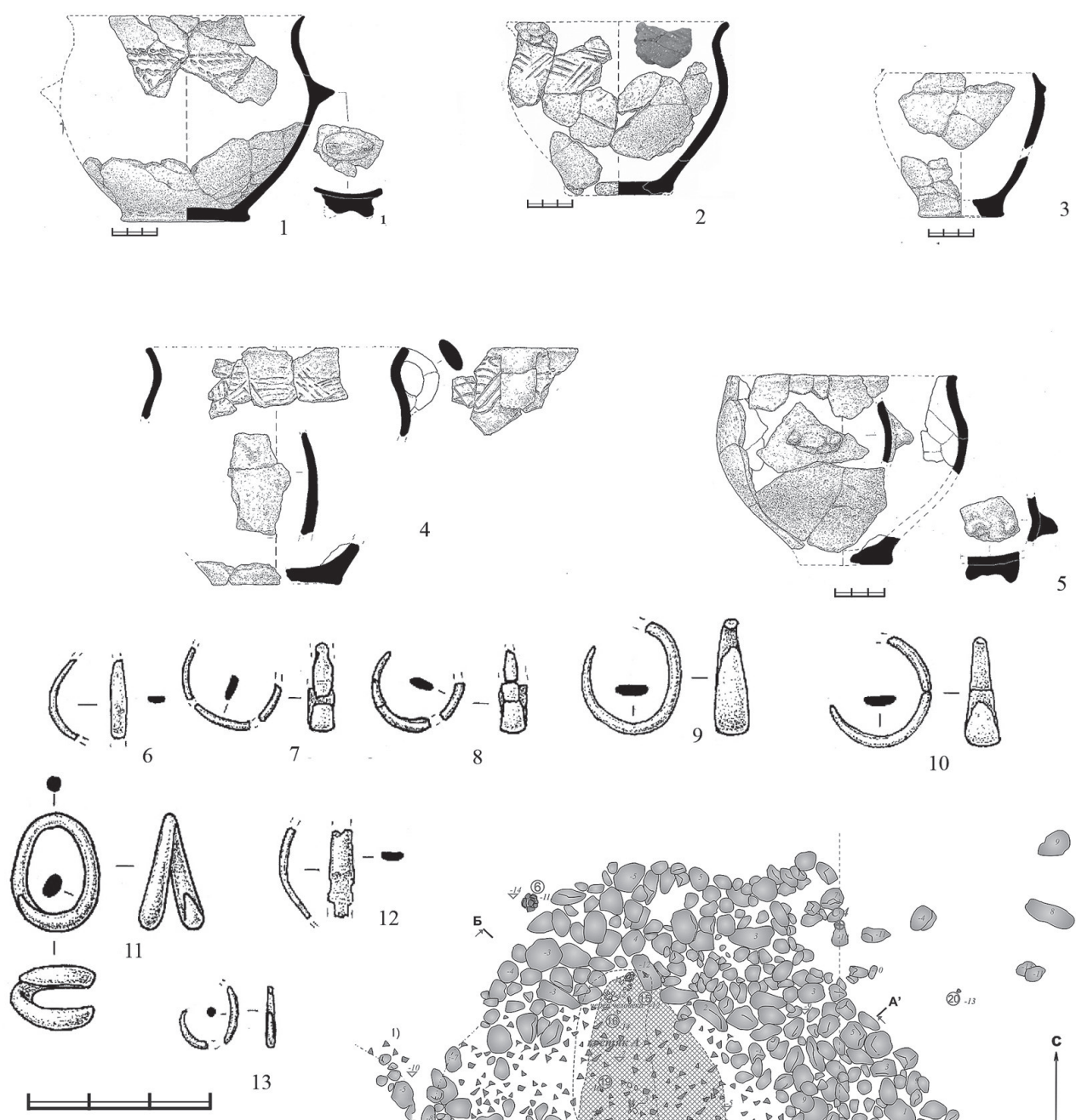

\footnotetext{
Условные обозначения:

- камни

的 - колотая галька

- кости человека

D. - фр. керамики

- угольное пятно

- граница вымостки колотой галькой

- граница распространения кальцинированных костей человека

(1) - фр. кольца височного бронзового-нах.1 (оп.1)

(2) - фр. сосуда лепного красноглиняного-нах.2 (оп.2)

(3) - фр. сосуда лепного черноглиняного-нах.3 (оп.3)

(4) - фр. сосуда лепного черноглиняного

с орнаментом-нах.4 (оп.4)

(5) - фр. сосуда лепного красноглиняного-нах.5 (оп.5)

- фр. донца сосуда лепного
коричневоглиняннго-нах 6 .

- фр. сосуда лепного коричневогл

(8) - фр. сосуда лепного черноглиняного-нах.8 (оп.8)

(9) - зуб коровы-нах.9 (оп.9)

(11) - отщеп кремневый-нах.10 (оп.10)
}

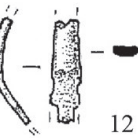

12

(11) - отщеп кремневый-нах.11 (оп.11)

(12) - отщеп кремневый-нах.12 (оп.12)

(13) - фр. донца сосуда лепного коричневоглиняного-нах.13 (оп.13)

(14) - фр. кольца височного бронзового-нах. 14 (оп.14)

(18. - фр. кольца височного бронзового-нах. 15 (оп. 15)

(16) - фр. кольца височного бронзового-нах.16 (оп.16)

(17) - фр. кольца височного бронзового-нах.17 (оп. 17 )

(18) - фр. кольца височного бронзового-нах.18 (оп. 18)

(19) - кольцо височное бронзовое-нах.19 (оп.19)

(20) - фр. донца сосуда лепного красноглиняного-нах.20 (оп.20)

(22) - фр. кольца бронзового-нах.21 (оп. 21)

10

Рис. 5. Гавердовский могильник. Погребение 1, 2017 г. 
Форма и орнаментация сосудов находит близкие параллели с керамикой постдольменного горизонта, описанной нами выше. Не противоречат этому и находки бронзовых металлических височных колец, выполненных из уплощённой либо округлой проволоки и имеющие приострённые концы (рис. 5, 6-13), аналогии которым мы также находим в постдольменных погребениях.

Весьма интересен обряд публикуемого погребения. По всей видимости, оно относилось к грунтовому могильнику, т.к. остатков курганной насыпи в зачищенном профиле бульдозерной траншеи нами не обнаружено. Само погребальное сооружение - раму из валунов, имитирующую каменный ящик, можно сопоставить с сооружениями постдольменного горизонта, где имелись подобные ящики-рамы, которые делались из периспользованных дольменных плит и крупных камней.

В то же время, обнаруженная здесь частичная кремация на месте обоих погребённых пока уникальна для Северо-Западного Кавказа эпохи поздней бронзы - раннего железа. Кремации на стороне известны для памятников перехода к железному веку кобанской и колхидской культуры, а также характерны для погребений конца бронзового века Средней Европы. Безусловно, мы можем рассматривать появление этого обряда в Северо-Западном Предкавказье в эпоху финала бронзового века как результат внешнего воздействия ${ }^{1}$.

Поселение Деметра. Ещё одним памятником эпохи финала бронзового века, недавно открытым в предгорной части Адыгеи, является поселение Деметра у ст. Ханской к западнее Майкопа. Оно было частично исследовано работами совместной археологической экспедиции Государственного музея Востока и ООО «Культурное наследие» в 2011-2012 гг. в процессе охранноспасательных работ в зоне реконструкции газопровода (Эрлих, Болелов, 2014). В ходе этих работ выяснилось, что поселение «Деметра» делится на два участка или отдельных поселения «Деметра-1» (юго-западный) и «Деметра-3» (северовосточный), разделённых ложбиной. Большую помощь в осмыслении ситуации с поселениями «Деметра-1» и «Деметра-3» оказал почвенный анализ, проведённый почвоведом О.С. Хохловой, которая высказала гипотезу о существовании в этой ложбине древнего озера. Во влажный период это озеро могло переполняться, и часть воды по протоке могла устремляться в сторону р. Белой. Хотя ландшафт поселения значительно изменён недавней антропогенной деятельностью (в настоящее время это пахотное поле), но и сейчас в части террасы, обращенной к р. Белой, можно отметить фрагменты извилистой ложбины, напоминающей русло водотока, по которой могла время от времени спускаться вода из озера. Возможно, влажный период наступил в протомеотское время,

${ }^{1}$ Дискуссионная проблема появления в разных регионах Кавказа кремационных погребений в эпоху поздней бронзы не так давно вновь подробно была рассмотрена А.Ю. Скаковым (Скаков, 2009. С. 155-159). Не имея возможности отразить здесь все имеющиеся точки зрения, мы отсылаем читателя к этой работе. 
когда протока от озера к реке возобновлялась ежегодно и произошло переселение на северный берег озера. В связи с возникновением такой протоки можно найти объяснение, почему керамика поселения «Деметра-1» (к югу от протоозера) имеет следы замытости, окатанности и переотложенности (Хохлова, Эрлих, 2013. С. 335-337).

Отметим, что слой из северного участка поселения «Деметра» («Деметра-3») был более насыщен археологическим материалом, имеющим лучшую сохранность. Здесь обнаружен и ряд хозяйственных комплексов (объектов): очаг, скопление костей животных, развал крупных керамических сосудов.

В целом следует отметить определённую гомогенность керамического материала, открытого на обоих участках поселения «Деметра». Керамика отличается преобладающим охристым цветом поверхности сосудов, наличием валика под венчиком, практически полным отсутствием прочерченного и штампованного орнамента, характерного для кобяковской культуры. В то же время, керамика южного участка «Деметра-1» отличалась окатанностью, хрупкостью и имела пачкающую поверхность. Фрагменты керамики этого участка были полностью лишены всякой орнаментации.

Наиболее насыщенный археологическими находками слой выявлен в югозападной части поселения «Деметра-3», т.е. ближе к «берегу» древнего озера.

Культурный слой, соответствующий периоду жизни поселения, здесь залегал достаточно глубоко под толщей наносов на глубине 1-1,20 м. На этом уровне фиксируется значительное количество камней, в том числе обломков зернотерок, костей животных и керамики.

Кроме того, на этом же уровне выявлены профильные фрагменты более чем 20 керамических сосудов. В основном это крупные тарные или хозяйственные сосуды.

Весьма примечательно скопление 2, обнаруженное в квадрате - 14/1 на глубине 152-166 см. Оно имело размеры 2×2 м и состояло из трёх тарных сосудов, два из которых удалось реставрировать. Один из них представлял крупную красноглиняную корчагообразную форму на сплошном поддоне с яйцевидным туловом и вертикальным воротничковым венчиком, имеющим налепной валик. Тесто с примесью дресвы, частицы проступают на поверхность. Высота сосуда 42 см, максимальный диаметр тулова - 45 см (рис. 6, 23). Отметим, что крупный корчагообразный сосуд с почти вертикальным венчиком был встречен на поселении Красногвардейское II в нижнем кобяковском слое (Шарафутдинова, 1989. С. 64, рис. 3,10$)$. Однако он не имел налепного валика, а был украшен сосцевидным налепом.

В этом же скоплении был обнаружен сосуд открытого типа (чан) желторозового цвета. Он имел также сплошной прилепленный поддон, тулово, приближающееся к усечённо-конической форме с небольшим закруглением в верхней части, а также загнутый венчик, оформленный налепным валиком. Высота сосуда - 50 см, диаметр устья - 49,5 см (рис. 6, 22). Близкие аналогии 

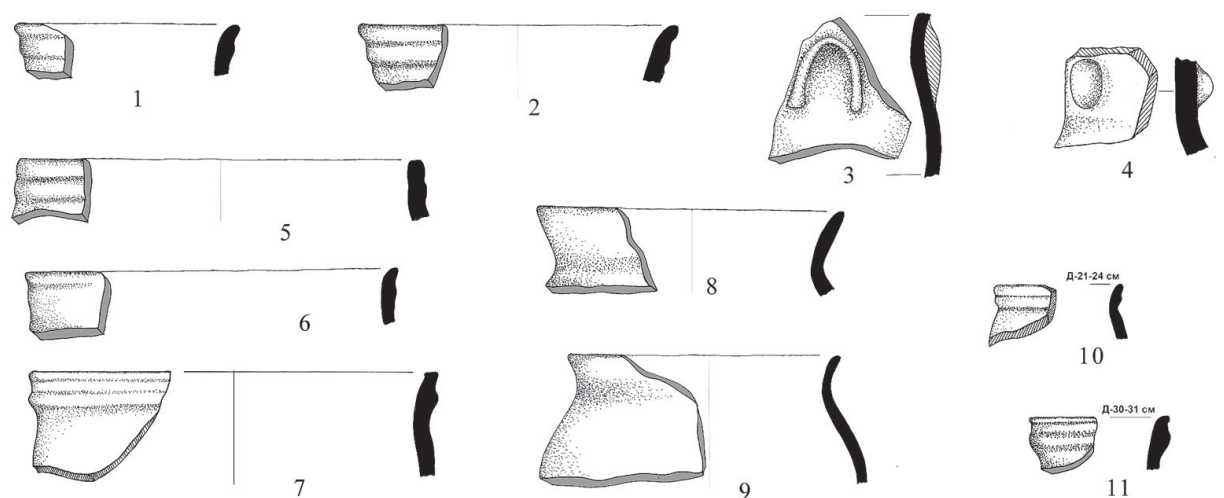

10

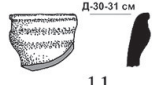

11
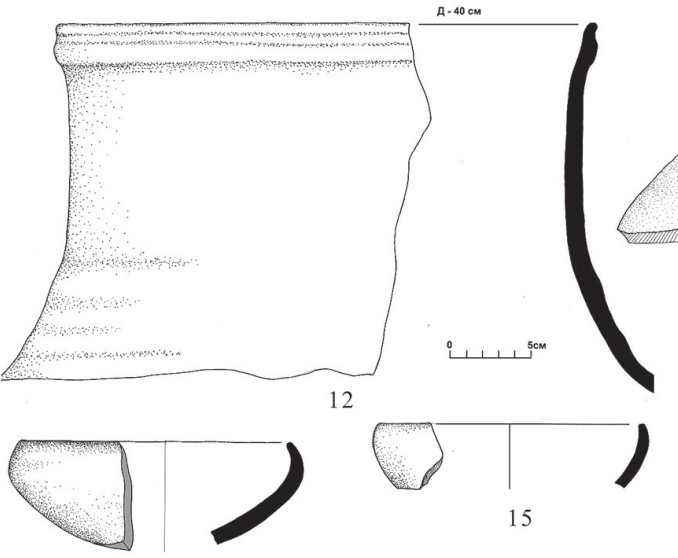

15

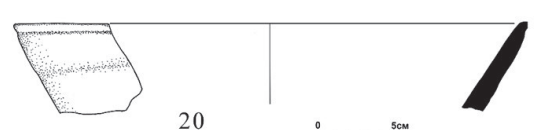

13
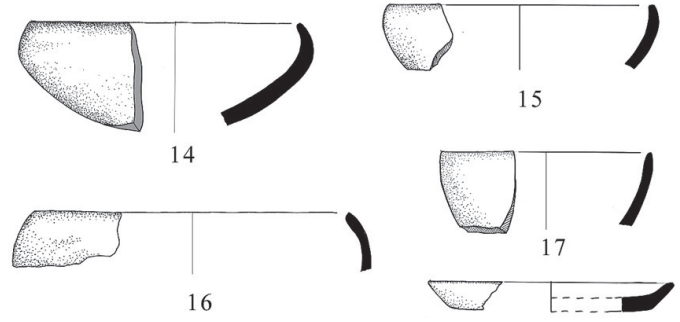

20
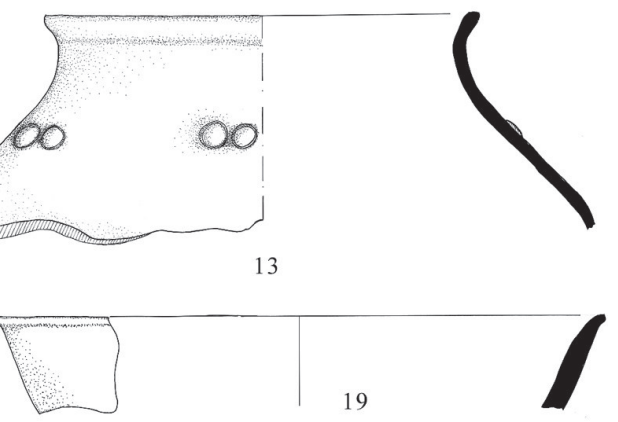

16

18
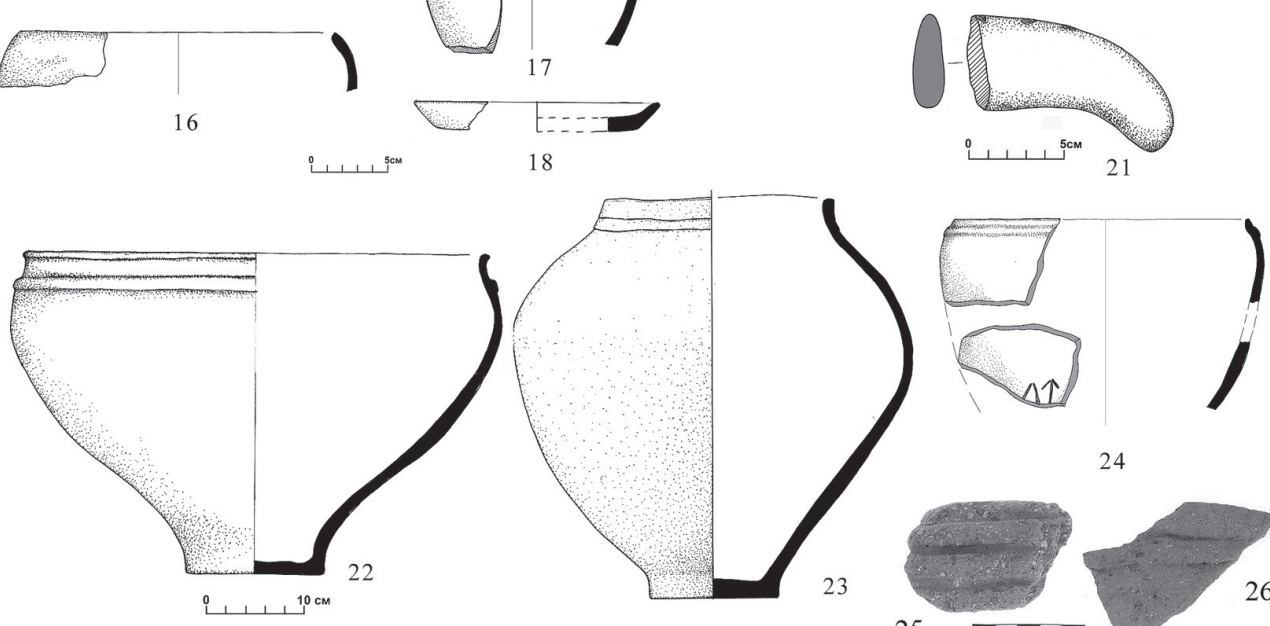

24
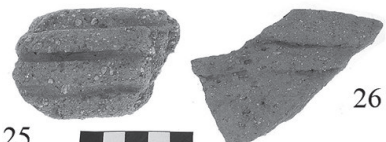

Рис. 6. Материалы поселения Деметра. 21 - камень, остальное - керамика 
последней форме пока нам неизвестны, в то же время его верхняя часть напоминает верхнюю часть сосуда из поселения Лесное в Майкопском районе Адыгеи, датируемого автором раскопок эпохой поздней бронзы (Черных, 2009. С. 418 , рис. 4,1$)$.

Ещё один сосуд удалось реконструировать лишь частично. Он представлял собой округлобокую глубокую большую миску, со слегка загнутым венчиком диаметром 30 см, подкреплённым налепным валиком. На тулове сосуда имелись процарапанные знаки (рис. 6, 24).

В целом, полученный керамический материал поселения «Деметра», представленный исключительно лепной керамикой, предварительно можно разделить на несколько основных категорий.

Открытые формы сосудов представлены двумя основными типами:

1. Округлобокие чаши или миски с загнутым внутрь краем (рис. 6, 14-17). Черепок в изломе чёрного цвета, костровой обжиг. Глина с примесями дресвы и слюды. У одного сосуда под краем проходит налепной валик.

2. Открытые сосуды со слегка отогнутым венчиком, тулово, не округлое, а близкое к усечённо-конической форме (лохани) - (рис. 6, 19, 20), иногда в утрированном виде представляют собой тарелку (рис. 6,18 ).

Отметим, что эти формы не находят полных аналогий, как в памятниках финальной бронзы (Красногвардейское I, II), так и протомеотских предгорного варианта, хотя и в тех и других имеются глубокие миски (Шарафутдинова, 1989. С. 63, рис. 2, 13; Эрлих, 2007. Рис. 145, 4).

К открытым формам относятся и два из трёх уникальных сосудов из скопления 2, описанные нами выше (рис. 6, 22, 24).

Закрытые формы сосудов (рис. 6, 1-13) представлены венчиками горшков или корчагообразных сосудов, с низкой, но выделенной шейкой и отогнутым наружу венчиком, часто подкреплённым налепным валиком.

Характерным признаком керамики поселения «Деметра» являются и сосцевидные налепы, встреченные на ряде сосудов (рис. 6, 4, 13). Такие налепы имеются как на протомеотской керамике (Кочипэ), так и на некоторых сосудах из поселения Красногвардейское II (нижний горизонт эпохи финальной бронзы) (Эрлих, 2007. Рис. 144, 11; Шарафутдинова, 1989. С. 64, рис. 3, 9, 10). Отметим также, среди керамического материала и несколько фрагментов стенок с рядами валиков, сформованных из жгутов глины, что сближает их керамикой постдольменного поселения Шушук (рис. 6, 25, 26).

В то же время следует отметить отсутствие в керамическом комплексе поселения черпаков и кувшинов с ленточной ручкой.

Изделия из камня представлены многочисленными кремневыми отщепами, а также рядом хозяйственных орудий - тёрочников. Одно каменное изделие можно соотнести с фрагментом каменного птицеголового скипетра (рис. 6, 21), характерного для протомеотской группы памятников (Эрлих, 2007. С. 354, рис. 164, 8-10). 
Таким образом, на сегодняшний день, мы можем констатировать, что исследование поселения с керамическим комплексом типа «Деметра-1, 3» знаменует собой открытие своеобычного керамический комплекса, бытовавшего в Закубанье на границе равнины и предгорий в эпоху финала поздней бронзы - протомеотское время. Для поселения «Деметра-3» была получена дата по костям животных, оказавшаяся на «гальштатском плато» и давшая очень широкий хронологический диапазон $-2650 \pm 400$ ВР. Подобные даты характерны для протомеотского периода и эпохи скифской архаики (см. Эрлих, 2007. С. 186, табл. 9), что позволяет думать, что поселение «Деметра-3» может относиться уже к началу раннего железного века.

Открытие керамического комплекса типа «Деметра» знаменует собой открытие ещё одного местного, но не «кобяковского» компонента в формировании протомеотской группы памятников (VIII-VII вв. до н.э.) в его предгорной версии.

Подводя итоги нашему обзору, уже сейчас можно сказать, что предгорный вариант протомеотской группы памятников формировался не на пустом месте. Вероятнее всего, его формирование было многокомпонентным. В горных районах одним из компонентов являлся постдольменный горизонт, в котором появляются впервые сосуды типа черпаков, он же оказал влияние и на район предгорий (Гавердовский м-к). Ещё одним компонентом очевидно являлся керамический комплекс типа Деметра, в котором, однако, отсутствовали черпаки, но уже проявился ряд черт, присутствующих в более поздних протомеотских памятниках.

Всё это имеет чрезвычайно важное значение для понимания механизма формирования памятников протомеотской группы эпохи раннего железа и меотской культуры в целом.

\section{ЛИТЕРАТУРА}

Анфимов Н.В., Шарафутдинова Э.С. Поселение Красногвардейское на Кубани новый памятник кобяковской культуры // СА. № 3. С. 139-148.

Березанская С.С., Отрощенко В.В., Чередниченко Н.Н., Шарафутдинова И.Н. Культуры эпохи бронзы на территории Украины. Киев: Наукова думка, 1986. 168 с.

Ванчугов В.П. Белозерские памятники в Северо-Западном Причерноморье. Киев: Наукова думка, 1990. 168 с.

Вангородская С.Г. О связях культуры многоваликовой керамики по материалам украшений // Межплеменные связи эпохи бронзы на территории Украины / Отв. ред. И.И. Артеменко. Киев: Наукова думка, 1987. С. 38-48.

Ильюков Л.С. Древнейшие погребения в бассейне реки Егорлык // Историко-археологические исследования в г. Азове и на Нижнем Дону в 2011 г. Вып. 27 / Отв. ред. А.А. Горбенко. Азов: Изд-во Азовского музея-заповедника, 2013. С. 171-181.

Козенкова В.И. Типология и хронологическая классфикация предметов кобанской культуры. Восточный вариант. М.: Наука, 1982. 177 с. (САИ. Вып. В2-5). 
Козенкова В.И. Материальная основа быта кобанских племен. Западный вариант. М.: ИА РАН. 200 с. (САИ. Вып. В2-5).

Кононенко А.П. Грунтовый могильник эпохи средней бронзы в устье реки Дюрсо в районе Новороссийска // Первая Абхазская международная археологическая конференция. Материалы конференции / Отв. ред. В.В. Бжания. Сухум: Алашарбага, 2006. C. 202-205.

Марковин В.И. Дольмены Западного Кавказа (некоторые итоги изучения) // СА. 1973. № 1. С. 3-23.

Марковин В.И. Дольмены Западного Кавказа. М.: Наука, 1978. 328 с.

Потапов В.В. Пластинчатые височные кольца и подвески на Нижнем Дону и в Предкавказье // РА. 2010. № 1. С. 155-162.

Потапов В.В. Кобяковские памятники в низовьях Дона: проблема появления и исчезновения // РАЕ (Российский археологический ежегодник). 2012. № 2. С. 287-308.

Потапов В.В. Маркеры памятников финала бронзового века от Северного Причерноморья до Алтая // ЗИИМК. 2016. № 13. С. 68-89.

Резепкин А.Д. Новосвободненская культура (на основе материалов могильника «Клады»). СПб.: Нестор-История, 2012. 342 с.

Резепкин А.Д. Вопросы относительной хронологии дольменов // Шестая Международная Кубанская археологическая конференция. Материалы конференции / Отв. ред. И.И. Марченко. Краснодар: Экоинвест, 2013. С. 365-369.

Резепкин А.Д. Комплекс украшений из дольмена Шушук в Адыгее // Третья Абхазская международная конференция: Проблемы древней и средневековой археологии Кавказа. Материалы / Отв. ред. А.Ю. Скаков. Сухум: РУП «Дом печати», 2013 а. C. 119-121.

Резепкин А.Д. Отчет о работах на дольменном могильнике Шушук в 2013 // Архив Национального музея Республики Адыгея. 2013 б.

Синюк А.Т. Бронзовый век бассейна Дона. Воронеж: Изд-во Воронежского педуниверситета, 1996. 350 с.

Скаков А.Ю. Некоторые проблемы истории Северо-Западного Закавказья в эпоху поздней бронзы - раннего железа // КСИА. 2009. Вып. 223. С. 143-172.

Трифонов В.А., Зайцева Г.И., Плихт Х., Бурова Н.Д., Семенцов А.А. Ришко. Первые радиоуглеродные даты альтернативных форм погребального обряда «дольменной» культуры на Северо-Западном Кавказе // Культуры степной Евразии и их взаимодействие с древними цивилизациями. СПб: ИИМК РАН, Периферия, 2012. Кн. 2. С. 100-107.

Хохлова О.С., Эрлих В.Р. Изменчивость увлажненности климата и комплексного почвенного покрова мочарного ландшафта во времени на основе изучения археологического памятника Деметра близ г. Майкопа, Адыгея // Современное состояние чернозёмов. Международная научная конференция. Материалы конференции. Ростовна-Дону: Изд-во Южного федерального университета, 2013. С. 335-337.

Черных E.H. Новые данные о керамическом комплексе Закубанья в конце эпохи бронзы // Пятая Кубанская археологическая конференция. Материалы конференции / Отв. ред. И.И. Марченко. Краснодар: Кубанский государственный университет, 2009. С. 413-419.

Черных E.Н., Сазонов А.А. Курган и поселение у хутора Грозный // Историко-археологический альманах. 2013. Вып. 12 / Отв. ред. Р.М. Мунчаев. Армавир - Краснодар М.: ИП Дедкова С.А. С. 47-89. 
Шамба Г.К. Эшерские кромлехи. Сухуми: Алашара, 1974. 70 с.

Шарафутдинова Э.С. Памятники предскифского периода на Нижнем Дону (Кобяковская культура). Л.: Наука, Ленинградское отделение, 1980. 128 с.

Шарафутдинова Э.С. Двуслойное поселение Красногвардейское II - памятник эпохи поздней бронзы начала раннего железа на Кубани // Меоты предки адыгов / Отв. ред. Н.В. Анфимов. Майкоп: Адыгполиграфобъединение, 1989. С. 46-73.

Шарафутдинова Э.С. Новые данные о памятниках эпохи поздней бронзы и начала раннего железа на Кубани // Древние культуры Прикубанья / Отв. ред. В.М. Массон. Л.: Наука, Ленинградское отделение, 1991. С. 70-91.

Шарафутдинова Э.С. 1991 а. Памятники эпохи поздней бронзы на Нижнем Дону и в Степном Прикубанье // СА. № 1. С. 184-196.

Шарафутдинова Э.С., Житников В.Г. Курганные могильники раннесрубной культуры на Верхнем Чире. СПб.: Нестор-История, 2011. 178 с.

Шарафутдинова Э.С., Каминский В.Н. Михайловский могльник конца эпохи поздней бронзы в Закубанье // СА. 1988. № 4. С. 214-221.

Эрлих В.P. Северо-Западный Кавказ в начале железного века. Протомеотская группа памятников. М.: Наука, 2007. 430 с.

Эрлих В.Р. Постдольменный горизонт на Северо-Западном Кавказе // КСИА. 2018. № 250. C. 7-24.

Эрлих В.Р., Болелов С.Б. Поселение «Деметра» и неизвестный ранее керамический комплекс эпохи перехода к железному веку // Е.И. Крупнов и развитие археологии Северного Кавказа. XXVIII Крупновские чтения / Отв. ред. Д.С. Коробов. М.: ИА РАН. С. 211-215. 

РАННИЙ ЖЕЛЕЗНЫЙ ВЕК ЕВРАЗИИ:

САРМАТСКАЯ ЭПОХА

И ВЕЛИКОЕ ПЕРЕСЕЛЕНИЕ НАРОДОВ 



\section{ВРЕМЯ ПОЯВЛЕНИЯ И ПРОИСХОЖДЕНИЕ НАБОРОВ БУС ИЗ РАННЕСАРМАТСКИХ ПОГРЕБЕНИЙ МОГИЛЬНИКА ФИЛИППОВКА II}

Аникеева О.В.

http://10.25681/IARAS.2019.978-5-317-06274-3/251-266

Применение при изучении бус минералого-техногологического анализа позволяет разделить их на определённые по технологии изготовления типы. Анализ найденных им аналогий в одновременных наборах бус Индии, Древнего Ирана, Средней Азии, Средиземноморья, Северного Причерноморья, Кавказа дает возможность предположить вероятные центры производства этих типов бус. По минералогическим характеристикам среди стеклянных бус выявлены каменные бусы из хризолита и флюорита. Анализ характера их распределения показывает, что время появления на Южном Урале бус из кургана 1 погребения 2 - не ранее второй половины IV в. до н.э., бус из кургана 1 погребений 4 и 6 и из кургана 2 погребения 6 - не раньше конца IV III в. до н.э.

Ключевые слова: Южный Урал, наборы бус, технология изготовления, происхождение, сравнительный анализ распределения, последовательность появления

Курганный могильник Филипповка 2 расположен на территории Илекского района Оренбургской области, в междуречье Урала и Илека. Он состоял из семи курганов, древнейшие из которых относятся к эпохе бронзы, а другие - к эпохе раннего железа (Яблонский, 2014. С. 88). Наиболее крупная насыпь кургана 1 была расположена в его центре и имела высоту 4 м и диаметр около 50 м. Вокруг кургана 1 находились шесть курганов малых размеров. Могильник был раскопан полностью в ходе полевых работ 2009-2012 гг. Приуральской экспедиции ИА РАН под руководством Л.Т. Яблонского ${ }^{1}$

Наборы бус были найдены в кургане 1 (погребения 1, 2, 4, 6), в кургане 2 (погребение 6). Погребение 1 кургана 1 относится к эпохе средневековья, поэтому бусы из него в данной работе не рассматриваются. Наборы насчитывают более 70 бус ${ }^{2}$ из золота (19 шт.), камня (39 шт.), стекла (5 шт.) и пасты (12 шт.), кости (сохранилась 1 шт.), серебряное ожерелье из мелких спиралевидных проволочных пронизок, низки бисера из стекла и пасты белого и голубого цветов. Среди каменных бус преобладают бусы из агата и хризолита, в единичных экземплярах присутствуют бусы из флюорита, сардера, сердолика, гагата, мела, мрамора и гематита-кровавика.

Методика исследования включала установление материала и основных типов бус методом минералого-технологического анализа, выявление их распространения в раннесарматских курганах Южного Урала и проведение аналогий с появлением и распределением выделенных типов бус в регионах с развитым

${ }^{1}$ Автор выражает глубокую благодарность С.Ю. Гуцалову, И.В. Рукавишниковой и Л.Т. Яблонскому за предоставленные для исследования неопубликованные находки.

${ }^{2}$ На иллюстрации приведены бусы, сохранившие форму. 
ремесленным производством. На основании сравнительного анализа полученного материала установлено происхождение и время появления определённых типов бус на Южном Урале.

Погребение 2 является центральным в кургане 1. Специфика его погребального обряда состояла в том, что по мере совершения в эту камеру многоактных захоронений (обнаружено 17 человеческих скелетов), яму не засыпали, и она заполнялась естественным образом за счет смывов с её отвалов. По мере осуществления новых захоронений уже захороненные костные останки сдвигались или перемещались. Кроме того, стратиграфия профилей погребения показывает наличие двух более поздних грабительских ям. (Яблонский, 2014. С. 88-89). Поэтому вначале идёт описание отдельных бус из заполнения грабительских ям (рис. 1, 1-3), затем украшений, связанных с перемещёнными скелетами (рис. 1, 7), последними идут бусы, найденные при нетронутых скелетах (рис. 1, 4-22).

Подвеска из синего прозрачного стекла (рис. 1,1 ) имеет форму кувшинчика и размеры: длина 15 мм, диаметр венчика 6 мм, диаметр тулова 8 мм, диаметр сквозного отверстия 2 мм. Отверстие просверлено сквозь венчик, сверление одностороннее, производилось трубчатым сверлом с мелким абразивом под наклоном вниз после отливки формы (входное отверстие на 0,8 мм ниже выходного).

Бусина мраморная имеет форму сжатой сферы (рис. 1, 2), поверхность каннелирована металлическим сверлом (штырь или проволока диаметром 0,8-1 мм). Размеры: длина 17 мм, высота 15 мм, диаметр отверстий 4 мм. Сверление двустороннее, производилось трубчатым сверлом.

Бусина меловая сферической формы (рис. 1,3) имеет размеры: диаметр 15 мм, высота 13 мм, диаметр отверстий 4 мм, сверление одностороннее металлической трубкой. На поверхности видны следы бороздок стёртого в ходе бытования каннелюра.

В северо-восточном секторе в придонной части могильной ямы расчищено плотное скопление переотложенных человеческих костей трёх скелетов. Под ними на дне лежало шейное ожерелье, состоящее из серебряных пронизок (рис. 1, 7), нанизанных на кожаный шнурок (сохранность плохая). При расчистке ожерелья в нем прослеживалось не менее 5 оборотов. Каждая пронизка - это скрученная из проволоки спираль с шагом от 4 до 6 оборотов. Длина каждой пронизки 4-7 мм, диаметр 3 мм.

Нетронутые скелеты сохранились вдоль северного борта погребальной камеры. Бусы присутствуют при всех скелетах. Скелеты 9 и 10 лежали рядом и были захоронены одновременно. Скелет 13 лежал непосредственно над скелетом 14 в северо-западном углу могильной ямы (Яблонский, 2012. Рис. 53, 54).

У скелетов 9 и 10 каменные бусины располагались вместе со скоплением золотых нашивок у кистей рук (рис. 1, 4-6, 8-12). Очевидно, они украшали расшивку рукавов погребальных нарядов. 

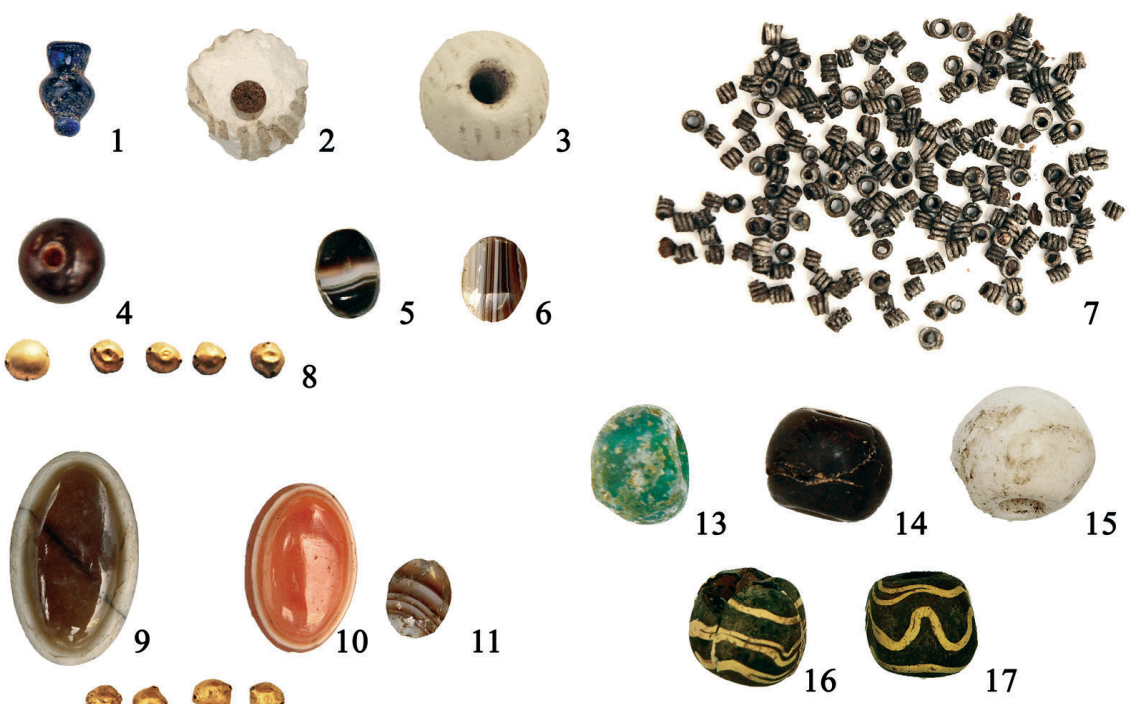

15

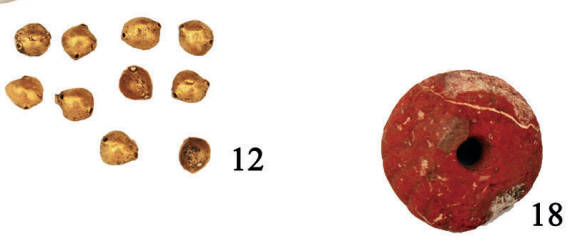

\section{1}

16

17

(6) GITIND
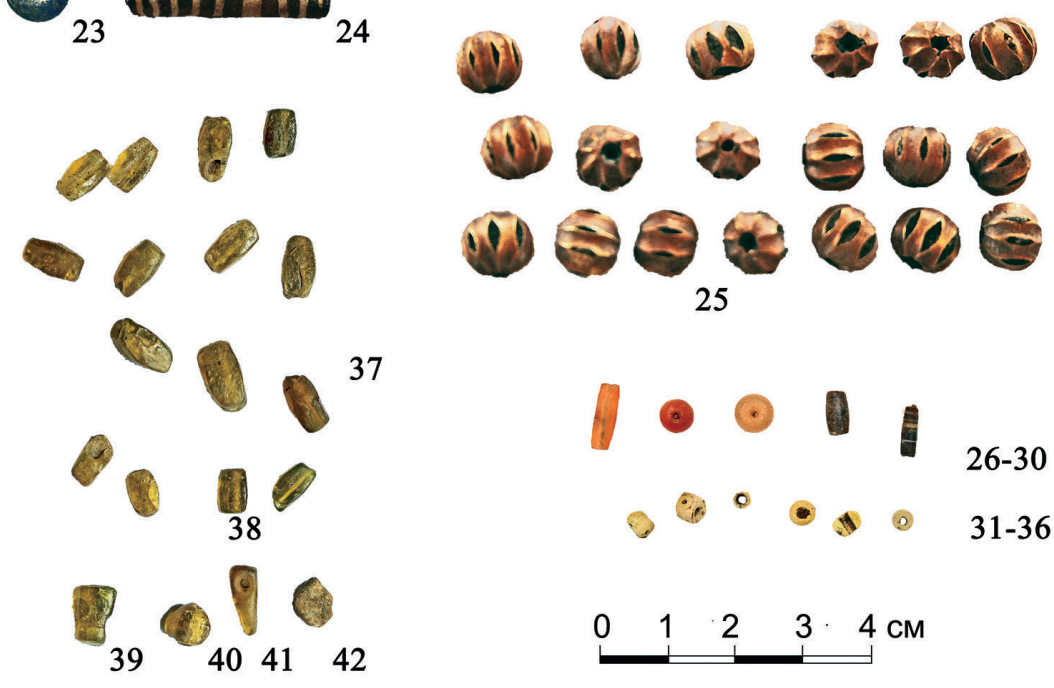

25
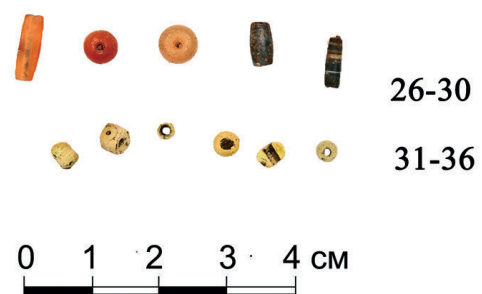

Рис. 1. Украшения из погребений могильника Филипповка 2.

Курган 1: 1, 2 - бусы из заполнения погребения 2;

7 - ожерелье из придонной части погребения 2 под перемещёнными скелетами; 4-6, 8-12 - бусы при скелетах 9 и 10; 13-22 - бусы при скелете 13;

23, 24 - бусы при скелете 14; 25 - бусы из погребения 6;

26-36 - бусы из погребения 4.

Курган 2: 37-42 - бусы из погребения 6 
Бусина сардеровая найдена у правой кисти скелета 9 в окружении пяти золотых нашивок (рис. 1,8 ). Нашивки имеют форму полусферок (четыре диаметром 5 мм, высотой 2,5 мм; одна диаметром 7 мм и высотой 3,5 мм), по краям меньших нашивок сделано по два отверстия, по краям большой - четыре отверстия для пришивания. Бусина (рис. 1, 4) имеет идеально выведенную форму сжатой сферы. Её размеры: диаметр 12 мм, высота 8 мм, диаметр входных отверстий 2,8 мм, диаметр отверстий при стыковке 1,5 мм. Сверление двустороннее, производилось металлическим штырем (стержнем). Камень просвечивает, окраска его неоднородная желтовато-коричневая.

Две линзовидные агатовые бусины-пронизи (рис. 1, 9, 10) найдены под левым и правым запястьями скелета 10. Они расчищены вместе с золотыми нашивками (рис. 1, 12) в форме полусферок (всего десять шт., диаметр 5 мм, высота 2,5 мм, по краям два отверстия для пришивания). Бусы имеют плоские овальные нижние грани, уплощённо-округлые овальные верхние грани, меньшего по сравнению с основанием размера, и скошенные вверх боковые грани, так что поперечным сечением является длинная трапеция. Бусина из коричнево-белого просвечивающего агата крупнее: нижняя грань $-32 \times 19$ мм, верхняя грань $28 \times 13$ мм. Бусина из оранжевого агата меньше: нижняя грань $-25 \times 16$ мм, верхняя грань $-21 \times 12$ мм. Высота боковых граней одинакова -6 мм. Способ сверления, выведения формы, качество шлифовки и полировки у этих бус идентичны. Перед сверлением отверстия надсверливались сверлом большего размера (1,5-1,8 мм), чтобы избежать выколки камня. Канал сверления односторонний (диаметр 0,8-1 мм), сделан алмазным сверлом, не доходя 3-4 мм до выхода, отверстие досверливалось с другого конца во избежание разрушения камня. Сверление строго коаксиально. Интенсивность и чистота окраски камня получены с использованием термической обработки.

Три более мелкие агатовые скарабеоидные бусины найдены отдельно. Одна - между кистями рук скелетов 9 и 10 (рис. 1, 11), рисунок камня представлен чередованием белых, коричневых и бесцветных поперечных микрополосок толщиной 0,1-1,8 мм. Вторая - за черепом скелета 9 (рис. 1, 6), рисунок камня близок вышеописанной бусине, но расположение полосок продольное. Третья справа под нижней челюстью скелета 9 (рис. 1, 5), камень чёрно-коричневый просвечивающий, в середине поперечная полоса, состоящая из чередования бело-коричнево-бесцветных микрополосок 4 мм.

Форма скарабея сильно стилизована: практически это правильный уплощенный эллипс с размерами продольного сечения (12-13)×(9-10) мм и высотой 2,5-4 мм. Нижняя грань плоская, верхняя гранью округлая выпуклая. Каналы некоаксиальны, сверление двустороннее: производилось металлической трубкой с одной стороны и алмазным сверлом с другой стороны. Перед сверлением отверстия надсверливались сверлом большего диаметра. Интенсивность и чистота окраски камня получены с использованием термической обработки. 
Анализ технологии изготовления этих 5 агатовых бусин позволяет говорить, что они производились в одном крупном ремесленном центре, мастерские которого используют единый способ сверления - металлической трубкой и алмазным сверлом (Леммлейн, 1950. С. 157-158; Аникеева, 2012. С. 186). Такой способ сверления характерен для мастерских, осваивающих индийскую технику сверления алмазным сверлом (Аникеева, 2012. С. 178, 181, 187). Различия в технологических нюансах (способы выведения формы и применения смешанных насадок для сверления) свидетельствуют о широко развитом производстве, а наличие во всех агатах этих бусин искусственного улучшения глубины и цвета камня показывает, что эти мастерские использовали индийские агаты (Аникеева, Бытковский, 2013. С. 286-287).

Вокруг левой голени скелета 9 бисеринки из стекла или пасты (15 шт.) лежали в два ряда. У правой стопы скелета 10 был зафиксирован один ряд бисера, по составу аналогичный вышеописанному (не сохранился). Вероятно, это ножные браслеты.

Крупные бусины вокруг кистей скелета 13 были нанизаны на кожаный ремешок (его фрагменты сохранились в каналах бус). В скоплении каменного стеклянного и костяного бисера у шеи отчётливо прослеживалось 5 линейных рядов, переплетённых между собой. Вероятно, из бисера было составлено шейное ожерелье, а из бус составлены в браслеты. Овальное скопление бисера $(14 \times 7$ мм) у левого локтя и левого предплечья имело плоскостное расположение. Можно предположить, что бисер использовался для расшивки одежды.

Браслет с правого запястья состоял из шести бус (целыми сохранилось пять):

- бусина (рис. 1, 18) в форме сжатой сферы диаметром 18 мм, высотой 12 мм, с диаметром отверстий 4 мм. Сделана из красного железняка, на 90\% состоящего из гематита-кровавика. Эта порошковидная порода кирпично-красного цвета с белыми вкрапленниками легко крошится, при растирании размазывается, состоит преимущественно из гематита, присутствуют гетит, гидрогетит, мушкетовит и другие минералы железа из кор выветривания;

- бочковидная бусина (рис. 1, 19) из чёрно-жёлтого стекла длиной 15 мм, диаметром 12 мм, диаметром отверстий 4-4,5 мм. Бусина орнаментирована: на чёрном фоне волнистые жёлтые полосы;

- рубленная бочковидная агатовая бусина (рис. 1, 20) длиной 12 мм диаметром 7 мм, диаметром отверстий 1,5 мм. Торцевые грани резаные, полированные, сверление одностороннее алмазным сверлом. Рисунок камня: чёрно-белые поперечные полосы. Камень непрозрачный;

- круглая меловая бусина (рис. 1, 21) с каннелюрами высотой 11 мм, диаметром 12 мм, диаметром торцевых граней 6 мм, диаметром отверстий 3 мм; 
- бусина из синего стекла (рис. 1, 22) диаметром 9 мм, высотой 7 мм, диаметром отверстий 5 мм. Поверхность кривогранная, поперечное сечение цветок с 7 лепестками;

- глазчатая сине-белая стеклянная бусина фрагментирована.

Браслет с левого запястья состоял из пяти бус:

- стеклянная бусина (рис. 1,13 ) в форме сжатой сферы из голубовато-зелёного прозрачного стекла диаметром 15 мм, высотой 13 мм, диаметром отверстий 4 мм. Торцевые грани выделены, диаметр 12 мм;

- шаровидная гагатовая бусина (рис. 1, 14) диаметром 16 мм, высотой 15 мм, диаметром отверстий 4 мм, торцевые грани выделены (диаметр 13 мм);

- мраморная шаровидная бусина (рис. 1, 15) диаметром 17 мм, высотой 15 мм, диаметром отверстий 4 мм, торцевые грани выделены, диаметр - 8 мм;

- бочковидная бусина (рис. 1, 16) из чёрно-жёлтого стекла длиной 15 мм, диаметром 12 мм, диаметром отверстий 4-4,5 мм. Бусина орнаментирована: на чёрном фоне волнистые жёлтые полосы;

- кубическая со сглаженными краями бусина (рис. 1, 17) из чёрно-жёлтого стекла длиной 15 мм, шириной 15 мм, диаметром отверстий 4 мм. Поверхность орнаментирована: на чёрном фоне волнистые жёлтые полосы;

У левого запястья скелета 14 найдены две бусины, использованные, вероятно, для расшивки рукава:

- одна из глухого синего стекла (рис. 1, 23) имеет форму сжатой сферы диаметром 8 мм, высотой 7 мм, диаметром отверстий 3,5 мм;

- другая (рис. 1, 24) - удлинённая в форме усечённого конуса (веретенообразная) трубочка из чёрно-жёлтого стекла цвета с орнаментом виде поперечных прямых и волнообразных колечек. Её длина - 24 мм, диаметр в средней части -7 мм, диаметр отверстий 3 мм.

Погребение 4 кургана 1 являлось впускным в насыпь кургана, погребённая лежала в подбойной нише. В районе шейных позвонков под позвоночником и ключицами скелета были расчищены мелкие каменные, стеклянные и пастовые бусы и бисер. Их расположение позволяет предположить, что они использовались для расшивки ворота одежды. Сохранилось пять каменных и пять стеклянных бус и одна бисерина:

- трубчатая бусина-пронизь (рис. 1, 26) из прозрачного жёлто-оранжевого сердолика имеет поперечное сечение - квадрат. Размеры: длина 9 мм, ширина 2,5 мм, диаметр отверстий 1,5 мм. Сверление двустороннее алмазным и трубчатым сверлом;

- сферическая бусина (рис. 1, 27) из просвечивающего оранжевого сердолика. Размеры: диаметр 5 мм, диаметр отверстий 1,5 мм, сверление одностороннее с досверливанием (1 мм) алмазным сверлом. Отверстия просверлены на круглых шлифованных площадках, после сверления тщательно выполированных;

- сферическая бусина (рис. 1,28$)$ из прозрачного желтоватого сердолика имеет обозначенные резаные торцевые грани. Размеры: диаметр 6 мм, диаметр 
торцевых граней 4 мм, диаметр отверстий 1,5 мм. Сверление двустороннее алмазным и трубчатым сверлом, каналы коаксиальны под углом;

- «рубленная» агатовая бусина (рис. 1, 29) имеет форму усечённого с краев эллипсоида, резаные приполированные торцевые грани. Размеры: длина 6 мм, диаметр средней части 3 мм, диаметр отверстий 1 мм. Сверление одностороннее алмазным сверлом. Рисунок камня: поперечные чёрно-бело-коричневые полосы;

- трубчатая агатовая бусина (рис. 1, 30) имеет поперечное сечение - круг, шлифованные и полированные торцевые грани. Размеры: длина - 8 мм, диаметр в средней части - 2 мм, диаметр отверстий - 1 мм. Сверление двустороннее алмазным сверлом. Рисунок камня - поперечные чёрно-коричневые полосы;

- две сферические бусины (рис. 1, 31,36) из прозрачного стекла с внутренней позолотой имеют размеры: диаметр 4-5 мм, диаметр отверстий 1,5 мм;

- костяная глазчатая бусина (рис. 1, 32) дисковидной формы имеет размеры: диаметр 4,5 мм, высота 4 мм, диаметр отверстий 1 мм. Глазки представлены резаным кругом с точкой в центре;

- одна дисковидная бисерина (рис. 1, 33) белого цвета имеет размеры: диаметр 3 мм, диаметр отверстия 1 мм, высота 1,5 мм.

- две бусины (рис. 1, 34, 35) из непрозрачной желтоватой пасты имеют формы сжатой сферы (диаметр 5 мм, диаметр отверстий 1,5 мм) и короткого цилиндра (диаметр 4,5 мм, высота 5 мм, диаметр отверстий 1,5 мм).

Погребение 6 кургана 1 являлось впускным в насыпь кургана, погребённая лежала в подбойной нише. В районе шейных позвонков находилось ожерелье (рис. 1, 25) из однотипных бус (19 шт.). Каждая бусина сделана из золотой фольги, натянутой на органическую основу (вероятно, дерево, пропитанное смолой), в центре которой имеется сквозное отверстие. Форма сферическая кривогранная: на поверхности выделяется восемь ребер. Размеры: диаметр 8-9 мм, диаметр отверстия 1,5-2 мм.

В кургане 2 помимо центрального, находились пять впускных погребений, расположенных по кругу вокруг ямы центрального погребения. Бусы найдены в единственном нетронутом женском погребении 6. Под черепом было расчищено 24 бусины, из них пять сохранились во фрагментах, форма определялась по контуру при расчистке:

- 2 бусины имели шаровидную форму (диаметр 6-7 мм) и сделаны из яркого зелёного стекла;

- 3 бусины $^{1}$ имели форму шестигранной призмы (идентичные целые экземпляры см. фото 2788, 2789, Яблонский, 2013. С. 208), одностороннее свер-

${ }^{1}$ Бусины сохранились во фрагментах, по фрагментам одной из них можно было установить форму, но размеры восстановить не удалось. Неустойчивость флюорита к процессам окисления, особенно присутствию влаги и щелочной среде хранения, обусловлена и строением, и структурой. 
ление широкого канала (диаметр отверстий 3 мм) трубчатым сверлом, длину 10-12 мм и были сделаны из голубовато-зеленоватого прозрачного флюорита (рентгенофазовый анализ, лаборатория ИГЕМ РАН). Визуально минерал похож на стекло. Отличия от стекла: меньшая твёрдость (по шкале Мооса 4), хрупкость, отсутствие плёнок иризации и патины, повышенная трещноватость при сохранении прозрачности и однородной окраски.

Остальные 20 бусин (рис. 1, 37-42, представлены целые 19 экз.) сделаны из материала, визуально неотличимого от прозрачного стекла. Микроскопия и качественный микрохимический анализ показали, что это хризолит - минерал с анизотропией цвета в жёлтых, жёлто-зелёных и буро-оливковых тонах, прозрачный. Основные отличия от стекла: твёрдость по шкале Моoса 6,5-7 (твёрже стекла, особенно выветрелого), наличие буроватого налета, не скрывающего прозрачности камня, отсутствие плёнок иризации, кристаллическая структура, порошок минерала реагирует с концентрированной серной кислотой, давая коллоидный буроватый осадок (аморфный кремнезём).

Для всех бус характерна одинаковая технология изготовления: сверление одностороннее и двустороннее металлической трубкой (диаметр отверстий 1,5-2 мм), поверхность практически не шлифована, приполирована, сохраняет природные неровности окатанной гальки, поэтому форма грубовата. Среди них по форме выделяются:

- 14 бусин (рис. 1, 37) имеют форму окатанных природных кристаллов (прослеживается форма четырёхгранной призмы). Размеры: длина 7-11 мм, ширина грани 3-5 мм, поперечное сечение - четырёхугольник;

-2 бусины (рис. $1,38,40$ ) в форме ромбоэдра длиной 6 мм, высотой 7 мм, поперечное сечение - ромб;

- бусина (рис. 1, 42) в форме уплощённого ромба длиной 5,5 мм, высотой 7 мм;

- подвеска (рис. 1, 39) имеет грубоватую форму четырёхгранной усечённой пирамиды с отверстием в верхней части. Размеры: высота 11 мм, основание четырёхугольник со сторонами 5 и 3,5 мм;

- подвеска в форме зуба (рис. 1, 41) с отверстием в широкой части, продольное сечение имеет треугольные очертания, поверхность тщательно полирована. Размеры: длина 11 мм, ширина в месте сверления 3 мм.

\section{Обсуждение полученных результатов.}

В погребениях могильника Филипповка 2 найдено 75 бусин, не считая бисера и серебряных пронизок ожерелья. Среди них преобладают каменные (40 шт.) - 53,4\%; соотношение металлических (19 шт.) и стеклянных (15 шт.) близкое - 25,4\% и 20\%; бусы из кости единичны - 1,45\%. Установленные аналогии с появлением и распространением выделенных типов каменных бус в Индии, Северном Причерноморье, Древнем Иране, Средней Азии, Средиземноморье, на Кавказе и Памире позволяют установить их возможное происхождение. Анализ распределения выделенных типов бус в наборах ран- 
них кочевников Южного Урала позволяет предложить очередность появления представленных бус и наборов в этом регионе.

Подвеска из синего стекла в форме кувшинчика (рис. 1, 1). Аналогичные подвески из стекла разного цвета широко распространены в погребениях Приднепровья и Побужья в течение IV в. до н.э. (Онайко, 1970. Табл. XLIII). Широкое их распространение в Ольвии и окружающих могильниках V-I вв. до н.э. позволяет предположить их производство в мастерских Северного Причерноморья (Граков, 1954. С. 149; Онайко, 1970. С. 55).

Найденная подвеска по форме идентична ранним подвескам этой формы, найденным на Южном Урале в погребениях курганной группы Победа (Аникеева, Таиров, 2015. С. 198) и могильника Новый Кумак (Аникеева, 2016. Табл. 1,25 ; Рис. $1, I V$, $V I I I)$ и датированным К.Ф. Смирновым и А.Д. Таировым концом V - ранним IV в. до н.э.

В погребениях прохоровского времени ${ }^{1}$ стеклянные подвески такой формы редки, зато получают широкое распространение флюоритовые подвески, отличающиеся упрощённо-грубоватыми контурами. Изготовление подвесок из флюорита свидетельствует о трансформации этой формы при копировании её, вероятно, азиатскими ремесленниками, так как месторождения флюорита локализованы преимущественно в Азии².

Шаровиднье бусы из мела и мрамора (рис. 1, 2, 3, 21) имеют следующие технологические особенности: их поверхности каннелированы и они сверлены металлической трубкой. Округлые бусы из мела и мрамора, распространенные в Северном Причерноморье в V-II вв. до н.э. (Алексеева, 1982. С. 29), сверлены, как правило, металлическим штырем, и каннелированная поверхность для них не характерна (Алексеева, 1982. Табл. 44). Мел и мрамор традиционно использовались для декоративных работ в Месопотамии, Вавилоне и Ассирии. Сверление белого камня медной трубкой применяется в Месопотамии с конца IV тысячелетия до н.э. (Gorelick, Gwinnett, 1978. Р. 42-43). Каннелированные бусы из мрамора, лазурита, гематита, халцедона, кварца, стекла и египетского фаянса широко распространены в наборах бус ахеменидского времени из Ура и Суз. Подобные бусы широко распространены в наборах из Филипповки 1. Их изучение позволяло мне предположить, что такие бусы производились в ремесленных центрах Месопотамии (Аникеева, 2011. С. 134, 146).

${ }^{1}$ Бережновка II курган 65 погребение 8; Матвеевский курган 3 (Мошкова, 1963. С. 17); могильники Покровка 10 курган 4 погребение 2 (Яблонский, 1996. Рис. 70, 7) и Сегизсай II курган 1 погребение 6 (раскопки А.А. Бисембаева, 2012), датированное автором раскопок концом IV-III вв. до н.э.

${ }^{2}$ Бэрх, Хондор-Умх и другие месторождения Восточно-Монгольского флюоритового пояса (Монголия); месторождения провинций Хубэй, Чжэцзян, Шаньдун и Внутренней Монголии в Китае; Кондомское, Таштагольское (Горная Шория); Такоб, Магоф (Таджикистан), месторождения в районе Чаткальского заповедника (Узбекистан), Хайдаркан (Киргизия), Таскайнарское и Бадамское месторождения (Казахстан). 
Сферические бусины из мрамора и гагата (рис. 1, 14, 15), сверлённые металлическим штырем, начинают поступать в Северное Причерноморье из средиземноморских стран и Северного Кавказа в VI-V вв. до н.э. Они не пользуются популярностью у жителей мегаполисов и уходят к кочевникам в степь (Алексеева, 1982. С. 45-46). Вероятно, оттуда они попадают на Южный Урал и появляются в погребениях IV в. до н.э. (Филипповка 1 курган 16 погребение 2, курган 17 погребение 1), широко распространяются в погребениях конца IV-II вв. до н.э. (могильники Прохоровка, Шумаево, Бердянка) вместе с рублеными гагатовыми бусами и бисером, стеклянными бусами.

Бусы из зеленовато-чёрного стекла с линейно-волнистым жёлтым орнаментом (рис. 1, 16, 17, 19, 24) появляются на Южном Урале в конце V в. до н.э.: набор из погребения 4 кургана 3 могильника Кичигино (Аникеева, 2017. С. 21. Рис. 2, 3, 7, 10). В нём они идут в ассоциации с разнообразными глазчатыми стеклянными бусами, поздние типы которых дают дату набора как рубеж V-IV вв. до н.э. Широко распространены в погребениях IV в. до н.э. (наборы из Лебедевки V, Филипповки 1, Новоорского могильника, МечетСая), их количество сокращается в погребениях конца IV - II в. до н.э. (наборы из Покровки 2 и 7, Быково, Ново-Никольского). Их обычная ассоциация - разнообразные стеклянные бусы и единичные индийские рубленные бусы из агата/сардера, по технологии идентичные бусине 20 на рис. 1. Округлые бусы из белого камня на Южном Урале широко распространены в погребениях V-IV вв. и практически исчезают на рубеже IV-III вв. до н.э. По типологии наборы из Филипповки 2 наиболее близки бусам из могильника Лебедевка V курган 9 погребение 5, датированного концом V - IV в. до н.э. (Железчиков, Клепиков, Сергацков, 2006. Рис. 27, 4-23). Отличаются они наличием крупной гагатовой бусины (Рис. 1,14$)$. Крупные гагатовые бусы появляются на Южном Урале в IV века и широко распространяются в погребениях конца IV - II в. до н.э. (Аникеева, 2011. С. 134-134). Следовательно, появление наборов бус при скелете 13 из кургана 1 погребения 2, надо отнести ко времени не ранее второй половины - последней трети IV в. до н.э.

Сферическая бусина из сардера (рис. 1, 4). Такие бусы в курганах V-IV вв. до н.э. на Южном Урале единичны (Филипповка 1 курган 3, курган 16 погребение 2, Кичигино курган 2 погребение 7, Четыре Мара группа 2 курган 20) и встречаются в ассоциации с эллипсоидными бусами из сердоликового оникса, кривогранными бусами, мелкими сферическими сердоликовыми бусами. Их количество возрастает в погребениях конца IV - II в. до н.э. (могильники Прохоровка, Шумаево, Бердянка): из них составлены ожерелья, в браслетах они встречаются вместе с бусами из гагата и янтаря (Аникеева, 2011, С. 136). Их широкое распространение на Кавказе с конца IX по V в. до н.э., минералогические характеристики камня и способ сверления позволили Г.Г. Леммлейну предположить, что они производились в ремесленном центре, предположительно находившемся к югу от древней Мцхеты (Леммлейн, 1951. С. 18). Как 
совершенно справедливо считала С.А. Трудновская, верхняя дата (V в. до н.э.), указанная Г.Г. Лемлейном для многих типов сердоликовых бус Кавказа, отражала лишь время прекращения их распространения на Кавказе, а не прекращения их производства (Трудновская, 1979. С. 108).

Скарабеоидные бусы-пронизи из полосчатого агата (рис. 1, 5, 6, 11) по технологии сверления и способу выведения формы близки более крупным бусам из красно-оранжевого сердолика, горного хрусталя, яшмы, которые в единичных экземплярах часто встречаются в южноуральских наборах конца V - IV в. до н.э. (Аникеева, Бытковский, 2013. С. 286-303, тип 16). От представленных бус они все отличаются более крупными размерами (длина 21-28 мм) и имеют характерную чётко выведенную форму: плоскую нижнюю грань, выраженную линзовидную верхнюю грань, отчётливые, скошенные вниз торцевые грани. Они широко распространены в Сузах и Уре в погребениях ахеменидского времени, где, вероятно, и производились с импортом и трансформацией формы скарабея из Египта (Аникеева, 2012. С. 184).

Данная разновидность формы более мелких размеров из агата, в которой все вышеотмеченные особенности сглажены таким образом, что торцевые грани обозначены или не выдержаны, верхняя и нижняя грани имеют легкий линзовидный изгиб или уплощаются, и форма близка к уплощенному эллипсу, среди южноуральских раннесарматских бус встречена впервые. Очевидно, они являются одной из поздних форм иранских скарабеоидных бус, при массовом производстве которых происходит трансформация и сглаживание формы, что, безусловно, уменьшает время и облегчает изготовления одной бусины.

Бусы-пронизи линзовидной формы (рис. I. 9, 10) в зарубежной литературе получили название «глаз из камня» (еye stone). Они являлись оберегами от сглаза. Их находят оправленными в золото, нижние грани таких бус часто декорированы вотивными надписями. Широко распространены в ахеменидской Персии в Персеполе (Schmidt, 1957. Р. 76-78), в Сузах (Rehm, 1992. S. 94-95, 107-108, 391) и Пасаргадах (Stronach, 1978. Р. 206-207). Начинают производиться ещё в Ассирии и Вавилоне, в ахеменидское время их производство широко развивается на территории Древнего Ирана, о чём свидетельствует многообразие технологических приемов выведения данной формы. На Южном Урале встречаются в погребениях IV в. до н.э. (Аникеева, 2012. С. 175, 184; Аникеева, Бытковский, 2013. С. 299), исчезая на рубеже IV-III вв.

Таким образом, наличие среди бус при скелетах 9 и 10 погребения 2 поздних форм скарабеоидных бус и линзовидных бус (eye-stone) позволяет датировать их в пределах второй половины - конца IV в. до н.э. и говорить, что они одновременны бусам, найденным при скелете 13.

Мелкие бусы из кургана 1 погребение 4.

Трубчатая бусина-пронизь, поперечным сечением которой является квадpam (рис. I. 26). Такие бусы появляются на Урале в VI в. до н.э. (Тара-Бутак курган 2 погребение 3, Смирнов, 1964. С. 311), широко распространены в на- 
борах IV века (Новый Кумак курган 13 погребение 1; Филипповка 1 курган 16 погребение 3; Алимбай VII, депаспортизированы) и исчезают в начале III в. (Старые Кишки курган 13 погребение 10, Мошкова, 1963. С. 52. Таб. 30, 44). Для таких бус отчётливо прослеживается эволюция технологии изготовления и использования определённых сортов сердолика в течение времени: от крупных ранних экземпляров длиной до 25 мм, сверлёных металлическим штырем и сделанных из матово-просвечивающего буровато-красного сердолика до мелких бус длиной 8-11 мм, сверлёных металлической трубкой и алмазным сверлом и сделанных из прозрачных жёлтых, оранжевых и красных индийских сердоликов в поздних экземплярах.

Отсутствие таких бус в Индии (единичные экземпляры из лазурита найдены в слоях V в. до н.э.), широкое распространение их на Переднем Востоке, разнообразие материалов, применяемых для их изготовления (сердолик, агат, лазурит, кальцит и кварц), грубоватость выведения формы, эволюция способов сверления отверстий показывают, что в ахеменидское время такие бусы производятся иранскими мастерскими (Аникеева, Бытковский, 2013. С. 286-303, тип 10б).

Трубчатые бусы-пронизи, поперечным сечением которых является круг (рис. $1,29,30$ ), по технологии изготовления относятся к рубленым бусам. Этот традиционно индийский тип бус производился в западной Индии со II тыс. до н.э. до III в. до н.э. От более узких и мелких бус такой формы, характерных для наборов Древнего Египта, их отличают способ сверления и минералогические характеристики камня (Аникеева, Бытковский, 2013. С. 286-303, тип 10a).

Мелкие сферические бусы из сердолика (рис. 1, 27, 28) характеризуются совершенной техникой обработки и сверлением отверстий алмазным сверлом. Они производились в Индии во II и I тыс. до н.э. и попадали на Южный Урал через Среднюю Азию (Аникеева, 2012. С. 186). На Южном Урале они появляются в IV в. до н.э. (Акоба, курган 1 погребение 3 скелет 1) и распространены до II в. до н.э.

Среди стеклянных бус надо отметить мелкую бесиветную бусину с внутренней позолотой (рис. 1, 36). Такие бусы появляются на Южном Урале в конце IV в. до н.э. и распространены по II век включительно (Мошкова, 1963. C. 46. Таб. 30).

Присутствие в данном наборе стеклянной бусины с внутренним золочением, а также отмеченная эволюция трубчатой формы сердоликовых бус-пронизей (от более крупных в ранних экземплярах до мелких в более поздних) позволяет датировать этот набор рубежом IV-III вв. до н.э.

Бусы из погребения 6 кургана 1.

Бусы из золотой фольги, натянутой на округлую рифлёную основу (рис. 1, 25). История этого типа бус детально разобрана Б.А. Литвинским (Литвинский, 1973. С. 162). Он считал, что они воспроизводят форму лотоса, что предпо- 
лагало их магическое значение. Форма зарождается в Египте и воплощается в фаянсе и стекле в наборах бус Нового царства. Бусы из золотой фольги на рифлёной основе широко распространяются в птолемеевском Египте, где начинают производиться, вероятно, немного ранее. В единичных экземплярах они встречаются в этрусских погребениях IV в. до н.э., где эволюция данной формы заключается в постепенном увеличении числа долек, расширении отверстия, так что поздние экземпляры имеют вид каннелированных трубочек. Известны находки таких бус в Китае, Корее, Японии, но точные датировки для них отсутствуют.

Поскольку в Египте такие бусы распространяются в последней трети IV в. до н.э., так что вероятное из появление на Южном Урале - не раньше конца IV - начала III в. до н.э.

Бусы из погребения 6 кургана 2.

Бусы флюоритовые восьмигранные редки из-за плохой сохранности (80\% находок фрагментированы) и неправильного определения (визуально трудноотличимы от светлого голубоватого или зеленоватого стекла, восьмигранную форму которых они полностью копируют). На Южном Урале аналоги определены мною в могильниках Филипповка 1 (курган 29, погребение 2, курган 3 погребение 1, курган 4 погребение 5); Лабазы (курган 2 погребение 4); Алимбай VII (депаспортизированы); Свистунка I, где датируются концом IV - началом III в. до н.э. (Бытковский, 2012. С. 39). В могильнике Мечет-Сай курган 7 погребение 8 флюоритовые бусы имеют другую форму - они крупные веретенообразной формы (усечённого биконуса).

Поскольку основные месторождения флюорита находятся в Монголии, Средней Азии, Китае (см. сноску 5), то разумно предположить, что добывался камень в этих районах.

Флюоритовые бусы не известны в одновременных наборах из Средиземноморья, Древнего Ирана, Индии, Кавказа ${ }^{1}$. В наборах на Южном Урале они встречаются в ассоциации преимущественно с хризолитовыми бусами и индийскими бусами из сердолика и агата. Отсутствие в этом наборе иранских эллипсоидных бус из сердоликового оникса (Аникеева, Таиров, 2015. С. 208; Аникеева, Бытковский, 2013. С. 296-296, 301-302) и преобладание в ней однотипных хризолитовых бус (см. ниже) позволяют с уверенностью говорить, что такие бусы появляются на Южном Урале не ранее второй половины IV в. до н.э., а возможно и позднее. Вероятно, они начинают производиться в азиатских ремесленных центрах как имитация аналогичной формы индийских

${ }^{1}$ Существует вероятность, что их единичные экземпляры, особенно если они найдены во фрагментированном состоянии, были определены как стеклянные. В Европе и Средиземноморье известны единичные находки чаш и кубков из флюорита (с предположением их восточного происхождения), но они относятся к раннеримскому времени. 
кристаллических бус из аметиста и берилла - с одной стороны, и средиземноморских стеклянных бус - с другой стороны.

Мелкие хризолитовые бусы (рис. 1, 37-42). Они появляются в южноуральских погребениях конца V-IV вв. до н.э.: могильники Лабазы курган 2 погребения 2 и 4; Филипповка 1 курган 4, погребение 4, погребение 5; курган 16, погребение 2; курган 28 погребение 1; Новый Кумак курган 17 погребение 1.

Представленный здесь набор резко отличается от этих наборов однотипной и однородной ассоциацией бус: из 23 бус - 20 экз. представлены хризолитовыми и 3 экз. флюоритовыми. Технологический анализ показал, что такие бусы производились в одном ремесленном центре. Хризолит - редкий минерал и его месторождения единичны. Древние выработки хризолита известны на о. Зебергет в Красном море (Египет), в местности Шаварын-Царам (Северная Монголия), в Гималаях (Пакистан, Афганистан), в Шишимских горах (Южный Урал). Египетское месторождение начинает разрабатываться позднее - в римское время (Ферсман, 1954. С. 146). Такие бусы отсутствуют в одновременных наборах бус в Индии, Иране и на Переднем Востоке. Их полные аналоги по технологии изготовления и ассоциации установлены в двух наборах из могильника Свистунка 1, где они убедительно датируются концом IV - III в. до н.э. (Бытковский, 2012. С. 40). Это позволяет предположить, что набор из погребения 6 кургана 2 появляется не ранее этого времени.

Преобладание хризолитовых бус и подвесок в найденном ожерелье (19 шт.), присутствие среди них бус и подвесок разной формы, сделанных из одинакового минерала и изготовленных в одном ремесленным центре является признаком малоразвитого производства, расположенного в ближних районах (Леммлейн, 1950. С. 167). Поэтому не исключена возможность, что эти бусы изготовлены из уральского хризолита местными мастерами, либо из азиатского хризолита в одном из близлежащих среднеазиатских ремесленных центров.

Анализ технологии изготовления изученных бус, найденных аналогий по каменным бусам этого времени в Индии, Древнем Иране, Средней Азии, Северном Причерноморье, на Кавказе и характера их появления и распределения в раннесарматских погребениях Южного Урала позволяют отнести бусы из погребения 2 кургана 1 ко второй половине IV в. до н.э., а бусы из погребений 4 и 6 кургана 1 и погребения 6 кургана 2 - к рубежу IV-III вв. до н.э.

\section{ЛИТЕРАТУРА}

Алексеева Е.M. Античные бусы Северного Причерноморья // Археология СССР. САИ. Вып. Г1-12. М.: Наука, 1982. 104 с.

Аникеева О.В. Происхождение и время появления на Южном Урале бус из погребения 5 кургана 3 могильника Кичигино // Этнические взаимодействия на Южном 
Урале. Материалы VII Всероссийской научной конференции. Челябинск: Рифей, 2015. C. 14-23.

Аникеева О.В., Таиров А.Д. Происхождение и распределение каплевидных подвесок и эллипсоидных бус в раннесарматских наборах конца V - IV в. до н.э. // Этнические взаимодействия на Южном Урале. Материалы VI Всероссийской научной конференции. Челябинск: Рифей, 2015. С. 202-208.

Аникеева О.В., Бытковский О.Ф. Происхождение и распределение каменных бус из погребений конца V - IV в. до н.э. из погребений Южного Зауралья // Этнические взаимодействия на Южном Урале. Материалы V Всероссийской научной конференции. Челябинск: Рифей, 2013. С. 286-303.

Аникеева O.B. Украшения ахеменидского круга из цветного камня (на примере изучения каменных бус из курганов ранних кочевников Южного Приуралья) // Влияния ахеменидской культуры в Южном Приуралье (V-III вв. до н.э.). М.: Таус, 2012. C. $168-188$.

Аникеева О.В. Минералого-технологическое изучение каменных бус из могильника Филипповка 1 // Естественно-научные методы в изучении Филипповского 1 могильника. МИАР. Вып. 14. М.: Таус, 2011. С. 131-157.

Бытковский О.Ф. Среднеазиатский «след» в погребальном обряде ранних кочевников Южного Урала (по материалам Свистунского I могильника) // Исторические, философские, политические и юридические науки, культурология и искусствоведение. Вопросы теории и практики. 2012. № 7(21). Ч. II. С. 38-44.

Граков Б.Н. Каменское городище на Днепре. МИА. М.: Наука, 1954. 296 с.

Железчиков Б.Ф., Клепиков В.М., Сергаџков И.В. Древности Лебедевки (IV-II вв. до н.э.). М.: Вост. Лит., 2006. 159 с.

Леммлейн Г.Г. Каменные бусы из Самтаврского некрополя //Материалы по истории Грузии и Кавказа. Вып. 29. Тбилиси, 1951. С. 196-214.

Леммлейн Г.Г. Опыт классификации форм каменных бус // Краткие сообщения Института истории материальной культуры. Вып. XXXII. 1950. С. 157-172.

Литвинский Б.А. Украшения из могильников западной Ферганы // Могильники Западной Ферганы. Вып. III. М.: Наука, 1973. 226 с.

Мошкова М.Г. Памятники прохоровской культуры. Археология СССР. САИ. Вып. Д1-10. М.: Наука, 1963. 53 с.

Онайко Н.A. Античный импорт в Приднепровье и Побужье в IV-II вв. до н.э. Археология СССР. САИ. Вып. Д1-27. М.: Наука, 1970. 210 с.

Смирнов К.Ф. Савроматы. Ранняя история и культура сармат. М.: Наука, 1964. $367 \mathrm{c}$.

Трудновская C.A. Ранние погребения юго-западной курганной группы могильника Туз-Гыр // Кочевники на границах Хорезма. Труды Хорезмской археолого-этнографической экспедиции. Т. ХІ. М.: Наука, 1979. С. 101-111.

Ферсман А.Е. Очерки по истории камня. Т. 2. М.: АН СССР, 1954. 744 с.

Яблонский Л.Т. Курган-святилище Филипповка 2 (предварительное сообщение) // Всадники Великой степи: традиции и новации. Астана, 2014. С. 88-93.

Яблонский Л.Т. Золото сарматских вождей. Элитный некрополь Филипповка 1. Каталог коллекции. Т. 1. М.: ИА РАН, 2013. 231 с.

Яблонский Л.Т. Отчет о раскопках кургана 1 могильника Филипповка 2 в 2012 году // Архив ИА РАН. 2012. Т. 1. 121 с. 

$152 \mathrm{c}$.

Яблонский Л.Т. Курганы Левобережного Илека. Вып. 4. М.: ИА РАН, 1996.

Beck H.C. The beads from Taxila // Antiquity. Vol. XVIII. Iss. 72. 1944. P. 48-59.

Gorelick L., Gwinnett A.J. Ancient seals and modern science // Expedition. Vol. 20. Iss. 2. 1978. P. 38-47.

Rehm E. Der Schmuck der Achameniden. Altertumskunde des Vorderen Orients. Munster: Ugarit-Verlag, 1992. 436 s.

Schmidt E.F. Persepolis II. Contents of the treasury and other discoveries. Vol. LXIX. Chicago-Illinois, 1957. 249 p.

Stronach D. Pasargadae. A report on the excavations conducted by the British institute of Persian studies from 1961 to 1963. Oxford, 1978. 287 p. 


\section{МОНЕТЫ «НЕИЗВЕСТНОГО НАРОДА» НА ПОЛУОСТРОВЕ АБРАУ}

Бабиец А.И., Богачук Е.О.

http://10.25681/IARAS.2019.978-5-317-06274-3/267-270

Монетные типы с изображением идущего Марса, получившие распространение в основном на азиатской части Боспора и в прилежащих районах Северного Кавказа, получили название монет «неизвестного народа». Ареал находок связан с азиатским Боспором, причем особое место занимает его юго-восточная периферия - в античную эпоху хора Горгиппии. Более того, их находки явно тяготеют к региону между современными Новороссийском (в древности Бата-гавань) и Анапой (Горгиппия). В последние десятилетия в результате широкого использования металлодетекторов резко возросло находок и отдельных монет, и монетных кладов, в которых были представлены либо только варварские подражания, либо комплексы с позднебоспорскими монетами, что важно для уточнения хронологии.

Ключевые слова: нумизматика, Боспорское государство, чеканка, денарий, подражание, азиатский Боспор

В сводке А.В. Орешникова (1892) монетные типы с изображением идущего Марса, получившие распространение в основном на азиатской части Боспора и в прилежащих районах Северного Кавказа, получили название монет «неизвестного народа». Пожалуй, наиболее полно монеты этой группы были охарактеризованы в работе А.Н. Зографа «Распространение находок античных монет на Кавказе», в которой они были определены как варварские подражания римским императорским денариям с изображением фигуры идущего римского божества войны Марса (Зограф, 1945. С. 29-85). Изображение бога войны с копьём наперевес появляется ещё на римских республиканских монетах, однако на лицевой стороне монет «неизвестного народа» изображение кудрявой бородатой головы, по всей видимости, римского императора Марка Аврелия. Таким образом, наиболее вероятным прототипом этой разновидности варварских подражаний, по мнению А.Н. Зографа, стали денарии Марка Аврелия (161-180 гг.).

На более грубых подражаниях пышная шевелюра превращается в точки и лучеобразно расходящиеся в стороны волнистые линии или дугообразные чёрточки. Реверс монет украшало схематическое изображение фигурки человека: идущий вправо Марс или воин с копьём. На наиболее деградированных туловище превращается в треугольник, который пересекает линия (копьё).

Отмеченная ещё А.Н. Зографом постепенная деградация и в стиле, и в металле (от серебра к практически чистой меди) позволила Л.Н. Казамановой и В.В. Кропоткину выделить три хронологические группы (Казаманова, Кропоткин, 1961. С. 131-132). Несмотря на очевидный прогресс в исследовании датировки, важная для определения исторического места этой группы монет 
абсолютная хронология остается довольно спорным вопросом (Абрамзон, Фролова, 2010. С. 320-321). Terminus post quem, по общему мнению, даёт датировка монет-прототипов - денариев Марка Аврелия, которые, по данным В.В. Кропоткина, находятся в обращении на территории Восточной Европы до начала III в. н.э. Массовость появления подражаний, имеющих прототипом римские монеты, как правило, объясняется широким распространением римских денариев на памятниках Центральной и Восточной Европы (Казаманова, Кропоткин, 1961. С. 130). Монеты самой ранней группы, как справедливо отметил Д.Б. Шелов, появляются в период массового проникновения их прототипов - в конце II или в самом начале III вв. н.э. (Шелов, 1973. С. 193). Чекан самой поздней группы также укладывается в пределы III в.

Ареал находок связан с азиатским Боспором, причём особое место занимает его юго-восточная периферия - в античную эпоху хора Горгиппии ${ }^{1}$. Более того, их находки явно тяготеют к региону между современными Новороссийском (в древности Бата-гавань) и Анапой (Горгиппия): здесь обнаружено три из четырёх засвидетельствованных кладов, состоящих исключительно из монет этого типа (рис. 1). В последние десятилетия в результате широкого использования металлодетекторов резко возросло находок и отдельных монет, и монетных кладов, в которых были представлены либо только варварские подражания (рис. 1, 1-3), либо комплексы с позднебоспорскими монетами (рис. 1, 12, 13), что важно для уточнения хронологии. Хотя большая часть находок локализуется в пределах Анапской долины, в культурных слоях и комплексах кладов античной Горгиппии варварские подражания практически отсутствуют (Кругликова, Фролова, 1980. С. 5-17; Фролова, 1980. С. 122-135; Фролова, 1997. С. 143-175).

Среди находок в этом районе в основном монеты наиболее многочисленной второй группы. Близость по стилю, весу и качеству металла свидетельствует, по мнению исследователей, о кратковременности выпуска (Казаманова, Кропоткин, 1961. С. 132). Они изготовлены из низкопробного серебра, выпуск состоит из многих серий с различными дифферентами.

Помимо очевидно узкой локализации находок «монет неизвестного народа», Л.Н. Казаманова и В.В. Кропоткин обратили внимание на их изготовление из серебра (первая и вторая группы), в то время как для чеканки синхронных монет крупных номиналов «золотых статеров» на Боспоре во второй половине III в. н.э. использовали бронзу (Казаманова, Кропоткин, 1961. С. 130). Данное обстоятельство позволяет предположить, что эта чеканка не факт слепого следования моде, а попытка политической структуры, которой принадлежала эта чеканка, подчеркнуть свою автономию или даже независимость от боспорских правителей.

${ }^{1}$ Территория расположена на северо-западных отрогах Большого Кавказского хребта, и известна в специальной литературе как полуостров Абрау. 

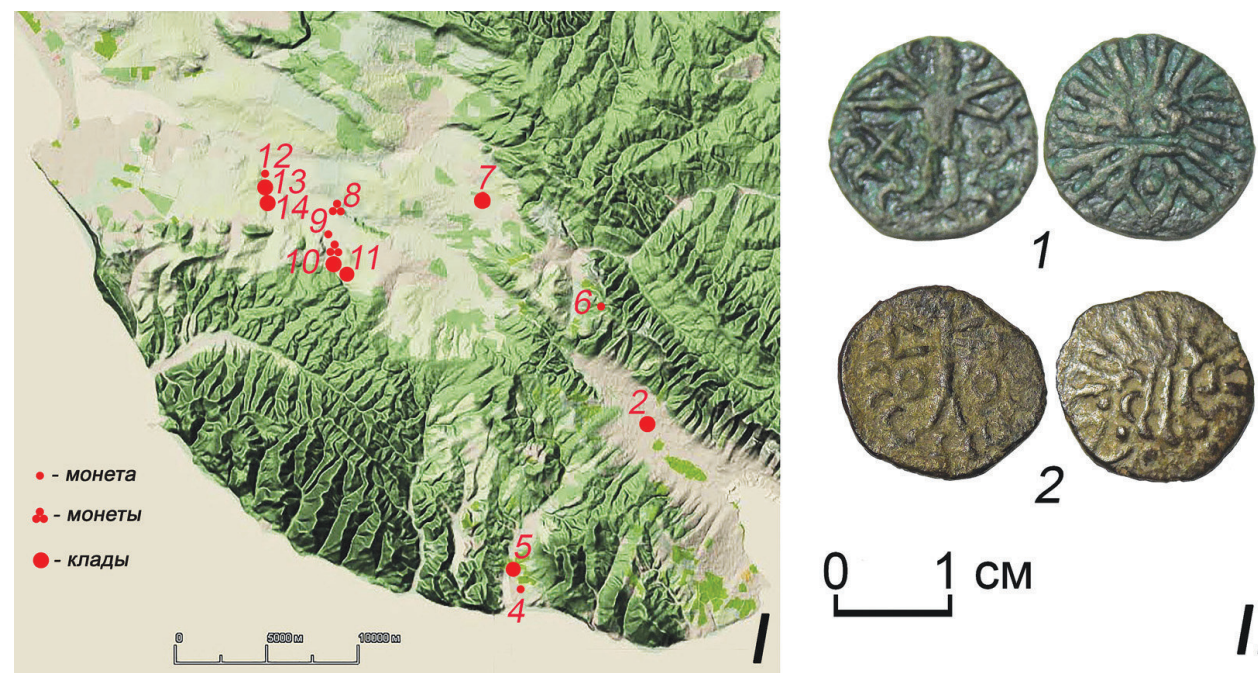

Рис. 1

I Местонахождения монет неизвестного народа на полуострове Абрау:

1 - Новороссийск: клад (1928) (Кропоткин, 1961. С. 39);

2 - Новороссийск (Цемдолина?): клад (1933) (Кропоткин, 1961. С. 39);

3 - Новороссийск: клад (1935) (Кропоткин, 1961. С. 39);

4 - Севернее пос. Южная Озерейка: монета (1995);

5 - Северная Озерейка: клад (ок. 200 экз.) (2004-2005);

6 - Атакаевская Щель: монета (2019);

7 - к сев. от ст. Натухаевская: клад (ок. 100 экз.) (2004-2005);

8 - Раевское г-ще: 4 монеты

(1962 - Онайко Н.А., 1967. С. 2002 - раскопки А.А. Малышева);

9 - р. Бедричка, пос. Раевское-3: монета (2019);

10 - р. Бедричка, Бутылка: клад (ок. 100 экз.) (1999);

11 - р. Бедричка, фрерма: клад (ок. 20 экз.) (1999);

12 - р. Шум-речка: монета (1961) (Салов, архив);

13 - р. Шум-речка: клад (1972) (Салов, 1975. С. 172-175);

14 - р. Шум-речка: клад (1977) (Абрамзон М.Г, Фролова Н.А. 2007-2008. С. 544-560);

15 - долина р. Дюрсо (могильник, погр. 330, раскопки А.В. Дмитриева, 1974);

I/ Находки в Анапской долине в последние годы:

1 - Атакаевская Щель; 2 - р. Бедричка, пос. Раевское-3

Концентрация находок указывает на то, что эта государственное (?) образование сложилось на юго-восточной периферии Боспорского царства в первой половине III в. н.э. Более того, территория, на которой обнаружено максимальное количество этих монет этого типа, могла быть какое-то время единым политическим и экономическим пространством. Распространение монет до самых отдалённых районов Северного Кавказа, возможно, указывает на то, что к созданию этого политического государства причастна политическая элита северокавказских племен, как считал Д.Б. Шелов, сармато-аланского круга (Шелов, 1973. С. 193). 


\section{ЛИТЕРАТУРА}

Абрамзон М.Г, Фролова Н.А. Корпус боспорских кладов античных монет. Т. I (1834-2005 гг.). Симферополь - Керчь // БИ. Suppl. 2. 2007. 870 с.

Абрамзон М.Г, Фролова Н.А. Денежное обращение // Античное наследие Кубани. T. 2. М., 2010. C. 290-351.

Зограф А.Н. Распространение находок античных монет на Кавказе // Труды Отдела нумизматики Гос. Эрмитажа, Т. І. Л., 1945. С. 29-85.

Казаманова Л.Н., Кропоткин В.В. «Варварские» подражания римским денариям с типом идущего Марса // ВДИ. 1961. № 1. С. 128-136.

Кропоткин В.В. Клады римских монет на территории СССР // САИ. Г4-4. М., 1961. 119 c.

Кругликова И.Г., Фролова Н.А. Монеты из раскопок Горгиппии 1967-1972 гг. // Горгиппия: Материалы Анапской археологической экспедиции. Ч. 1. Краснодар, 1980. C. 5-17.

Онайко Н.А. «Варварские» подражания римским денариям из раскопок Раевского городища // КСИА. 1967. Вып. 109. С. 52-54.

Орешников A.B. Материалы по древней нумизматике Черноморского побережья. М., 1892.39 c.

Салов А.И. Клад III-IV вв. с Шум-речки (Анапский район) // СА. 1975. № 3. C. $172-175$.

Шелов Д.Б. О датировке северокавказских подражаний римским денариям // Кавказ и Восточная Европа в древности. М.: Наука, 1973. С. 190-195.

Фролова Н.А. Монеты из раскопок Горгиппии 1973-1977 гг. // Горгиппия: Материалы Анапской археологической экспедиции. Ч. 1. Краснодар, 1980. С. 122-135.

Фролова Н.А. Монеты из раскопок Горгиппии 1979-1989 гг. // Проблемы истории, филологии, культуры. Вып. 4. Часть 1. История. М.; Магнитогорск, 1997. С. 143-175. 


\section{МУЖСКИЕ ПОГРЕБЕНИЯ САРМАТОВ НОВОЧИГОЛЬСКОГО КУРГАННОГО МОГИЛЬНИКА}

\section{Березуцкий В.Д.}

http://10.25681/IARAS.2019.978-5-317-06274-3/271-279

В статье рассматриваются мужские погребения сарматов Новочигольского курганного могильника, исследования которого проводятся с 2012 г. Среди них выделяются мужские захоронения взрослых мужчин-воинов I - середины II в. н.э., снабжённых различными предметами вооружения $(23,5 \%)$. В совокупности с данными по остальным погребениям могильника обращает на себя внимание зрелый возраст погребённых, который находится в основном в пределах 30-40 лет. В совокупности с особенностями женских и детских погребений могильника выявляется его нерядовой социальный статус.

Ключевые слова: лесостепное Подонье, сарматы, курганы, погребения, среднесарматское время, воинские погребения

С 2012 г. по настоящее время археологическая экспедиция Воронежского государственного педагогического университета и школьников археологических объединений Воронежской области «Возвращение к истокам» проводит раскопки курганов в Побитюжье, у с. Новая Чигла Таловского района Воронежской области (донское левобережье). Памятник расположен на восточной окраине с. Новая Чигла, на правом высоком берегу р. Чигла, левого притока Битюга, на его широком мысовом выступе высотой над уровнем поймы до 1520 м. К настоящему времени исследовано 18 курганов из известных 24 с погребениями эпохи бронзы (главным образом, катакомбной культуры) (Березуцкий, Килейников, 2016), сарматов I-II вв. н.э. (Березуцкий, 2016а; 2016 б; Березуцкий, 2017), эпохи Великого переселения народов (Березуцкий, Мастыкова, 2016$).$ В настоящее время это один из представительных сарматских памятников в донском левобережье после Третьяковского могильника (Ефимов, 1998).

Курганы Новочигольского могильника в основном небольшие по размерам: диаметр большинства из них не превышал 10-20 м при высоте 0,1-0,5 м. Выделяется несколько курганов более значительных размеров, по-видимому, эпохи бронзы. 12 исследованных курганов содержали, кроме погребений эпохи бронзы, 17 захоронений сарматов. Среди них выделяются женские погребения со жреческими признаками, признаками социальной значимости (бронзовыми котлами). Особое место в могильнике занимают мужские захоронения, анализу которых посвящена настоящая статья.

Курган № 1, погребение 4 (впускное) обнаружено в центральной части кургана эпохи бронзы. Погребальное сооружение представляло собой яму прямоугольной формы 1,2×1,8 м с закруглёнными углами, углублённую в материк на 0,75 м и ориентированную длинной осью по линии ЮЮВ-ССЗ (рис. 1, 1). Заполнение ямы состояло из чернозёма с примесью карбонатов, меловой крошки и глины. 


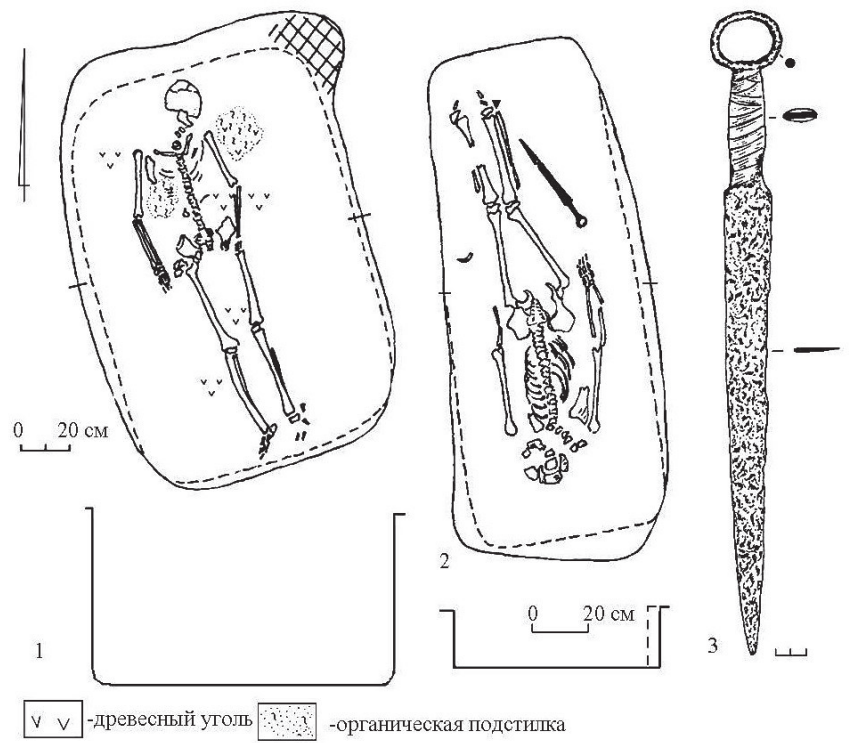

Рис. 1. Сарматские погребения Новочигольского курганного могильника. 1 - погребение 1/4: план и профиль;

2, 3 - погребение 1/7: 2 - план и профиль; 3 - железный меч

На органической подстилке чёрного цвета, сохранившейся местами, лежал скелет мужчины 40-50 лет ${ }^{1}$ вытянуто на спине, ориентированный головой на ССЗ. Руки умершего чуть согнуты в локтях, кисти находились у таза, череп наклонен левой частью к полу. На полу кроме органики встречены местами мелкие древесные угли.

Курган № 1, погребение 7 (впускное) обнаружено в центральной части кургана. Погребальное сооружение представляло собой прямоугольноудлинённую яму $0,95 \times 2,3$ м с закруглёнными углами, углублённую в материк на 0,2 м и ориентированную длинной осью по линии север - юг с незначительным отклонением на ЮЮВ и ССЗ (рис. 1, 2). Заполнение ямы состояло из чернозёма, в котором встречалась местами на различной глубине перегнившая труха деревянного перекрытия.

На материковом полу ямы лежал скелет мужчины 30-35 лет вытянуто на спине головой на юг. Череп был повернут на левый бок. Руки вытянуты вдоль скелета, ноги в коленях притянуты друг к другу (возможно, были связаны).

У кисти правой руки рукоятью на юго-восток и лезвием на северо-запад к правой голени лежал железный меч с кольцевым навершием без перекрестья (рис. 1, 3). Клинок однолезвийный, с сужающимся к острию лезвием, сечение треугольное. Рукоять плоская овальной формы, была обмотана, вероятно, тон-

${ }^{1}$ Антропологические определения Р.А. Тюрина и И.К. Решетовой. 
кой кожей в виде полос шириной 0,8 см жёлтого цвета. По краям полос видны следы прострочки. Меч находился в деревянных ножнах, от которых на лезвии и рукояти сохранился древесный тлен.

Длина меча 44 см, длина лезвия 32 см (максимальная ширина у основания рукояти - 3,2 см, к острию сужается), рукояти -8 см. Размеры чуть овального кольца $4 \times 4,5$ см.

Курган № 10, погребение 1 (основное и единственное). Курган представлял собой едва заметную полусферическую насыпь диаметром 6 м и высотой до 0,1-0,12 м. Погребение находилось в центре насыпи. Материковый выкид располагался с юга от погребения, вплотную примыкая к нему, и имел неровную овально-серповидную форму.

Погребальное сооружение представляло собой квадратную яму с закруглёнными углами $1,9 \times 1,9$ м, ориентированную углами по сторонам света и углублённую в материк на 0,7 м (1 м от зафиксированного уровня погребённой почвы) (рис. 2, 1).

На материковом полу лежал скелет мужчины 30-35 лет вытянуто на спине головой на юг. Скелет поврежден сурчиными норами, в особенности его левая половина. В погребении обнаружен гончарный кувшин и железный кинжал.

Гончарный кувшин (рис. 2, 2) одноручный, сероглиняный, со сливом, с прямым горлом, округлым туловом, плоским дном без закраины. Поверхность лощеная, местами видны чёрные подпалины, идущие от верха сосуда до дна. По горлу проведены горизонтальные параллельные пролощённые линии. Такие же две линии проведены по границе горла и тулова. Ручка кувшина подтреугольная в профиле с закруглёнными углами, ложновитая. Соединение с горлом «штифтовое». Высота ручки 9 см, высота горла со сливом 9 см, наименьший диаметр горла 8 см, дна 10,5 см. Высота сосуда 28 см, наибольший диаметр тулова 21 см.

Железный кинжал (рис. 2, 3) находился между тазом и правой рукой умершего острием на север. Общая длина изделия 24,6 см. Рукоять сохранилась не полностью, сохранившаяся же часть имела длину 3,5 см, в сечении она прямоугольной формы, ширина 1,3 см, толщина 0,3 см. Длина лезвия составляет 21,1 см, окончание закруглено, профиль линзовидный. Наибольшая ширина лезвия до 3 см, толщина 0,3 см. При переходе от рукояти к лезвию выделен упор. На кинжале сохранились остатки деревянных ножен.

Курган № 12, погребение 1 (основное и единственное). Курган представлял собой едва заметную полусферическую по форме насыпь диаметром до 8 м и высоту до 0,1 м. Погребение имело неоформленный могильный выкид, располагавшийся с севера от погребения.

Погребальное сооружение - квадратная яма 2,35×2,35 м с сильно закруглёнными углами, ориентированная этими углами по сторонам света и углублённая в материк на 0,4 м (0,6 м от уровня погребённой почвы) (рис. 2, 4). Заполнение чёрное, «жирное», без примесей. 


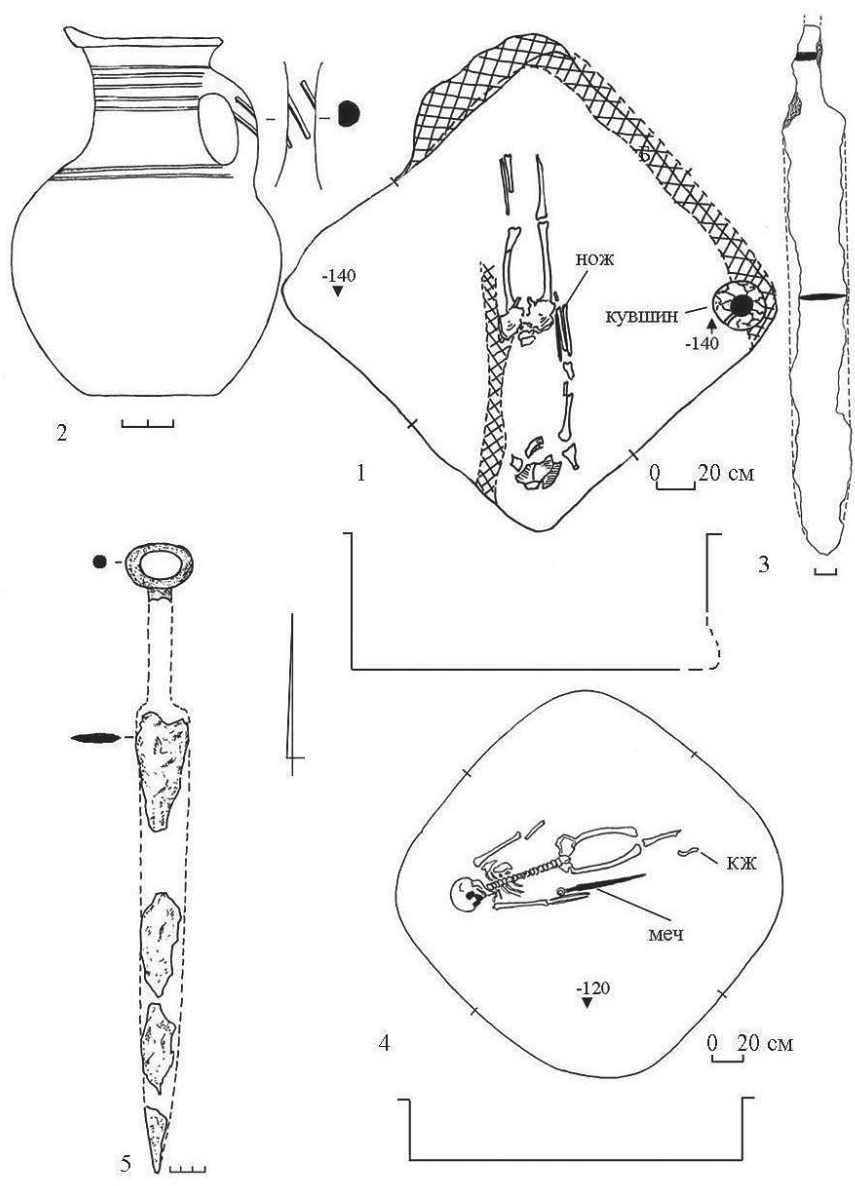

Рис. 2. Сарматские погребения Новочигольского курганного могильника.

1-3 - погребение 10/1: 1 - план и профриль; 2 - сероглиняный кувшин; 3 - кинжал.

4, 5 - погребение 12/1: 4 - план и профиль; 5 - меч. 2 - глина; 3, 5 - железо

На материковом полу ямы, почти по её оси - линии запад - восток, чуть смещаясь к северу, лежал скелет мужчины 30-40 лет вытянуто на спине, руки вытянуты вдоль скелета и в стороны. Скелет был ориентирован головой на ЗЮЗ. Левая рука, ребра, а также левая нога повреждены. Нижняя конечность левой ноги отсутствовала.

У конечности правой ноги умершего находилась кость ноги мелкого рогатого скота. В заполнении могилы найдена стенка гончарного сероглиняного сосуда. При погребённом обнаружен железный меч.

Железный меч (рис. 2, 5) с кольцевым навершием без перекрестья находился у правой руки, у лучевой кости и параллельно ей остриём к ногам, к ВСВ. Меч сохранился фрагментарно. Удалось установить его длину - 53 см. Длина рукояти 9,4 см, в профиле она имеет вид прямоугольника толщиной 
0,3-0,4 см и шириной 1,7 см. Длина треугольного по форме лезвия линзовидного в сечении составила 43,6 см. Окончание лезвия заострённое, а наибольшая его ширина $-3-3,5$ см. Кольцо навершия овальное $3,5 \times 4,7$ см, в сечении круглое диаметром до 1 см. На мече сохранились следы деревянных ножен в виде древесного тлена.

Курган № 26, погребение 2 (впускное в курган эпохи бронзы) находилось рядом с центральной частью кургана. Из погребения происходит могильный материковый выкид. Он имел в плане форму, близкую к серповидной.

Погребальное сооружение представляло собой овальную яму 1,4×2,4 м, ориентированную по линии северо-запад - юго-восток и углублённую в материк на 0,6 м (рис. 3,1 ). Заполнение состояло из того же грунта, что насыпь кургана.

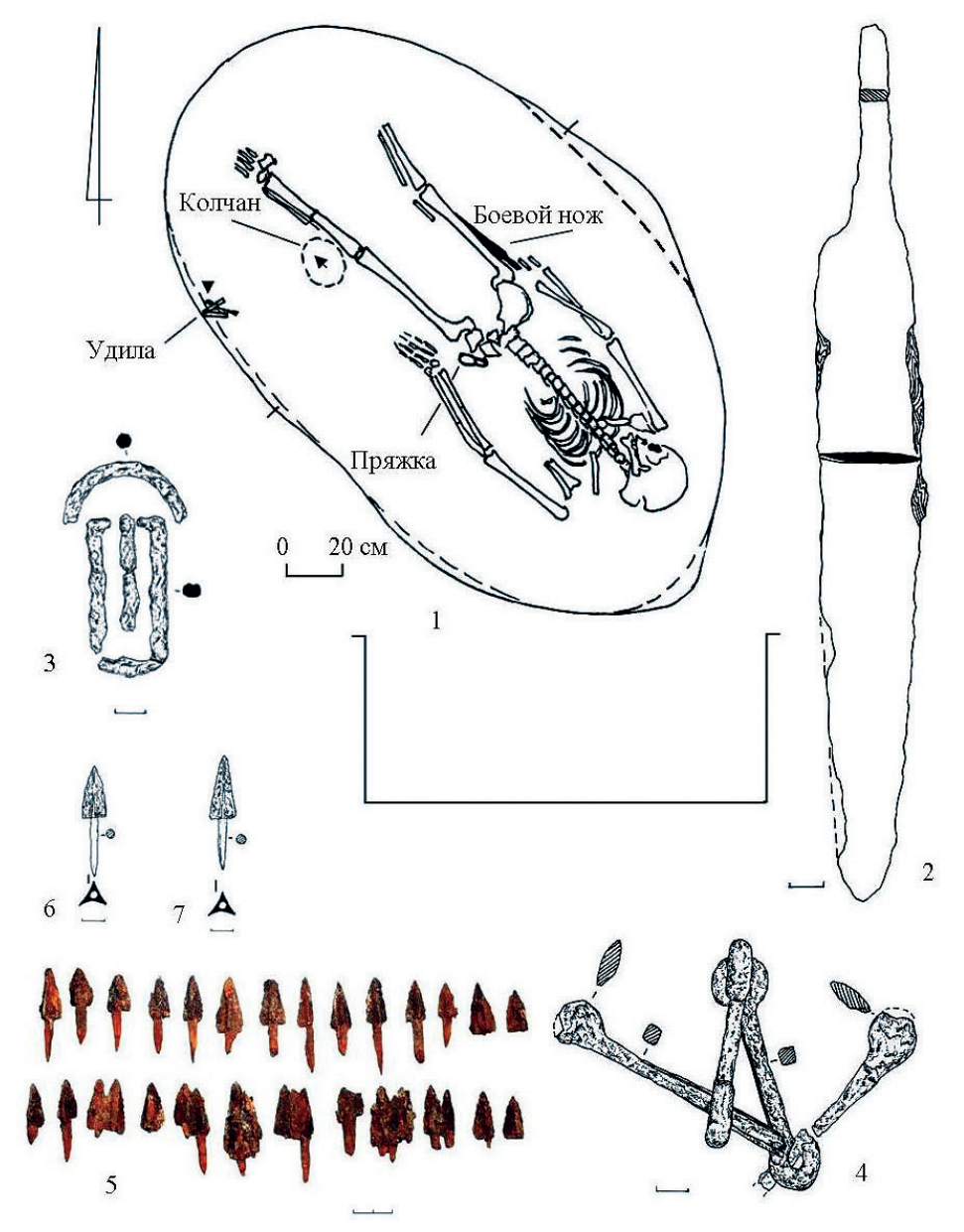

Рис. 3. Сарматские погребения Новочигольского курганного могильника.

Погребение 26/2: 1 - план и профиль; 2 - кинжал; 3 - пряжка; 4 - удила с псалиями; 5-7 - наконечники стрел. 2-7 - железо 
На материковом полу ямы лежал вытянуто на спине, головой на юговосток скелет мужчины 30-40 лет. Руки умершего вытянуты вдоль скелета, левая рука чуть согнута в локте. Череп лицевой частью повернут на северовосток. Конечность правой ноги отсутствовала. При погребённом находились железный кинжал, железная пряжка, скопление наконечников стрел, первоначально находившихся в колчане, а также остатки железных удил.

Железный кинжал (рис. 3, 2) располагался с внешней стороны правого бедра, у кисти правой руки острием на северо-запад. На кинжале сохранились остатки дерева от ножен.

Общая длина изделия 25,7 см. Длина рукояти 6,5 см, в сечении она прямоугольной формы, ширина 0,8 см, толщина 0,3 см. Окончание сохранившейся полностью рукояти закруглено. Длина лезвия составляет 19,2 см, профиль его линзовидный. Наибольшая ширина лезвия 3 см, толщина 0,3-0,4 см. При переходе от рукояти к лезвию выделен с одной стороны упор, как это делалось на ножах.

Железная пряжка (рис. 3, 3) находилась у левой тазовой кости в районе пояса. Сохранилась фрагментарно. Имела прямоугольную рамку 2,5×5,5 см, язычок в её центре, а также дужку сверху рамки. Рамка сделана из овального в сечении прута толщиной $4 \times 6$ мм.

Железные удила с остатками псалиев находились у юго-западной стенки ямы на полу (рис. 3, 4). Рядом с удилами лежали две мелкие кости мелкого рогатого скота плохой сохранности.

Удила кольчатые, сделаны из квадратного прута $0,5 \times 0,5$ см. Грызла неодинаковые по длине: одно длиной 6,8 см вместе с кольцами, другое 7,8 см. Псалии сохранились хуже, но тип их восстанавливается. Они стержневидные, прямые, изготовлены из прямоугольного прута 0,5×0,6 см. С одной стороны псалии раскованы под округлые в плане и линзовидные в профиле окончания. Длина одного относительно хорошо сохранившегося псалия 8,5 см, другого 7,3 см.

Железные наконечники стрел (рис. 3, 5-7) располагались у левого колена погребённого в куче остриями на юго-восток и, по-видимому, входили в состав колчана. Расположение колчана слева от погребённого, у левой ноги характерно для способа его ношения у скифов и сарматов.

Всего насчитывается 35 единиц наконечников. Сохранность большинства из них неудовлетворительная, многие спеклись в комки железа, другие сохранились лучше. Все наконечники однотипны - трёхлопастные, черешковые. Края лопастей срезаны под прямым углом к черешку. Черешки круглые в сечении (диаметр 0,4 см), их длина, судя по сохранившимся экземплярам, составляет от 1,5 до 2 см. Окончания заострены. Длина пера от 1,8 до 2,5 см. Ширина по максимальному срезу составляет до 1-1,2 см.

Среди наконечников выделяются два варианта по оформлению головки. Первый вариант (рис. 3, 6) характеризуется сводчатой головкой: лопасти 
по дуге сводятся к острию. Второй вариант характеризуется прямыми лопастями, сводящимися к острию (рис. 3, 7). Количество типов выявить трудно из-за плохой сохранности изделий. На всех наконечниках - остатки древесной трухи, дерева на черешках.

Безынвентарное погребение 1/4 по ориентировке погребённого может претендовать на его датировку позднесарматским временем. В погребении встречены древесные угли. Это всего второй случай в могильнике, для которого эта черта обряда не характерна. По замечанию А.С. Скрипкина, угли встречаются в большинстве случаев в позднесарматских курганах, датируемых рубежом I-II - серединой III в. н.э. (Скрипкин, 1984. С. 77). Радиоуглеродный анализ, сделанный по кости скелета, показал некалиброванную дату $2330 \pm 40$ ВР. Её вполне можно было бы принять, учитывая новые явления в погребальном обряде сарматов уже в конце среднесарматского периода (распространение северной ориентировки). Однако радиоуглеродные даты для сарматского времени не так надежны. Об этом свидетельствует дата ограбленного погребения 7/2: радиоуглеродный анализ по древесному углю показал дату $2420 \pm 40$ ВР. Между тем, погребение 2 и 3 кургана № 7, как показали данные стратиграфии, осуществлены в одно время. Погребение же 3 имело не только южную ориентировку, но и два глиняных сосуда, которые уверенно датируются I-II вв. н.э. и уж никак не серединой III в. н.э.

Остальные мужские погребения датируются среднесарматским временем. Южная ориентировка умерших - норма сарматов среднесарматской культуры. Она господствует в I - до середины II в. н.э., когда появляется северная ориентировка (Степи..., 1989. С. 179). За исключением погребённого 12/1, ориентированного в направлении ЗЮ3, умершие (погребения 1/7, 10/1, 26/2) ориентированы в южную половину круга, что является характерной чертой среднесарматской культуры. Не противоречит, а подкрепляет это мнение и погребальный инвентарь. В двух погребениях это железные мечи с кольцевым навершием без перекрестья, являющиеся показателем среднесарматского времени $(1 / 7,12,1)$. Они появляются в I в. до н.э. и бытуют до середины II в. н.э. Учитывая то обстоятельство, что в могильнике нет погребений, датирующихся I в. до н.э., захоронения с мечами этого типа следует датировать I - началом II в. н.э.

Сероглиняный кувшин со сливом и псевдовитой ручкой из погребения 10/1 имеет аналогии в ранних среднесарматских погребениях Нижнего Дона (тип М10 по А.С. Скрипкину) (Скрипкин, 1990. Рис. 49; Глебов, 2005. Рис. 59, 8-11, 60, 1, 2). По А.А. Глухову это тип XVI, который имеет кавказское происхождение. Кувшины этого типа встречаются в сарматских погребениях междуречья Дона и Волги с рубежа эр - начале I в. н.э. (Глухов, 2005. С. 70). В Центральном Предкавказье они датируются ещё более ранним временем III-I вв. до н.э. (Абрамова, 1993. С. 40. Рис. 8, б).

В погребении 26/2 есть несколько датирующих предметов. Хотя железная пряжка сохранилась неудовлетворительно, тем не менее, ей можно найти 
близкие аналогии - в частности, похожие пряжки найдены в Крыму в УстьАльме (склеп 550/34-35, I в. н.э.) (Пуздровский, 2007. Рис. 96, 8). Менее похожи пряжки не с прямоугольной, а трапециевидной рамкой из I Чертовицкого могильника (Медведев, 2008. Рис. 46, 13, 14), датирующиеся 2-3 четвертью І в. н.э. (Медведев, 2008. С. 49).

Железные удила со стережневидными псалиями относятся по А.В. Антипенко к типу III (стержневидные), варианту 6 (с лопастями с обеих сторон) (Антипенко, 2016. С. 94). Стержневидные псалии обычны для среднесарматских памятников I-II вв. н.э. Нижнего Дона, междуречья Дона и Волги (Глухов, 2005. С. 21-24).

Железные трёхлопастные наконечники стрел отмеченных двух вариантов (26/2) типичны для среднесарматского времени (Хазанов, 1971. С. 37-38; Скрипкин, 1990. С. 72-73).

Таким образом, обнаруженные в Новочигольском могильнике погребения мужчин зрелого возраста (в основном в пределах 30-40 лет) принадлежат воинам, вооружённым мечами $(1 / 7,12 / 1)$, кинжалами $(10 / 1,26 / 2)$, луком и стрелами (26/2). Отметим также, что тип погребального сооружения для умерших различен: прямоугольная яма (1/4), удлинённо-прямоугольная яма (1/7), квадратные ямы с диагональным положением умершего (10/1, 12/1), овальная яма (26/2). Причины существования различных типов погребальных сооружений, бытовавших у сарматов в одно и то же время, неясны, и этот вопрос остается дискуссионным.

Отметим в заключение о половозрастных особенностях могильника. Детских погребений в могильнике всего три: в одном случае ребёнок сопровождал погребение женщины, в двух других случаях детские погребения были осуществлены одновременно со взрослыми представителями общества в индивидуальных могилах на краю насыпи. Возраст женщин также в подавляющем большинстве случаев находится в пределах 30-40, 35-45 лет, а их погребальный инвентарь свидетельствует либо о знатности (погребённые с бронзовыми котлами, в одном случае парой сосудов), либо об исполнении ими жреческих функций. В итоге могильник представляет собой место погребения не всех представителей сарматской кочевой орды, а определённого круга социально значимых лиц, куда входили и зрелые мужчины-воины.

\section{ЛИТЕРАТУРА}

Абрамова М.П. Центральное Предкавказье в сарматское время (III в. до н.э. IV в. н.э.). М.: ИА РАН, 1993. 240 с.

Антипенко A.B. Типология псалий I-IV вв. н.э. (по материалам погребальных памятников Северного Причерноморья) // Материалы по археологии, истории, этнографии Таврии. Вып. XXI. Симферополь: Крымский федеральный университет им. В.И. Вернадского, 2016. С. 84-109. 
Березуцкий В.Д., Килейников В.В. Позднекатакомбное погребение в курганном могильнике у с. Новая Чигла в левобережье Среднего Дона // Известия Воронежского государственного педагогического университета: Воронеж: ВГПУ, 2015. № 4 (269). C. 49-54.

Березуикий В.Д. Диагональные сарматские погребения Новочигольского курганного могильника // Археология восточноевропейской лесостепи. Материалы II межд. науч. конф. Воронеж: ВГПУ, 2016а. С. 181-189.

Березуикий В.Д. Новочигольский курганный могильник // Россия как археологическое пространство. М.: ИА РАН, 2016 б. С. 100-101.

Березуикий В.Д. Бронзовые котлы из сарматского погребения Новочигольского курганного могильника // Вестник ВГУ. История. Политология. Социология. Воронеж: ВГУ, 2017. № 2. С. 21-25.

Березуцкий В.Д., Мастыкова А.В. Погребение эпохи Великого переселения народов на Левобережье Среднего Дона // КСИА. 2016. № 245-I. С. 219-243.

Глебов В.П. Сарматские погребения могильника Отрадный II // Труды научно-исследовательского бюро / Ред. Ю.В. Потапова. Ростов-на-Дону: РГУ, 2005. С. 161-198.

Глухов А.А. Сарматы междуречья Дона и Волги в I - первой половине II в. н.э. Волгоград: Волгоградское научное изд-во, 2005. 239 с.

Ефимов К.Ю. Сарматские курганы в могильнике у с. Третьяки // Археологические памятники Верхнего Подонья первой половины І тысячелетия н.э. / Отв. ред. А.П. Медведев. Вып. 12. Воронеж: ВГУ, 1998. С. 19-35.

Медведев А.П. Сарматы в верховьях Танаиса. М.: Таус, 2008. 252 с.

Пуздровский A.E. Крымская Скифия II в. до н.э. - III в. н.э. Погребальные памятники. Симферополь: Бизнес-Информ, 2007. 273 с.

Скрипкин А.С. Нижнее Поволжье в первые века нашей эры. Саратов: СГУ, 1984. $150 \mathrm{c}$.

Скрипкин А.С. Азиатская Сарматия. Саратов: СГУ, 1990. 300 с.

Степи Евразии в скифо-сарматское время. М.: Наука, 1989. 464 с. 


\title{
АРАБСКИЙ УЧЁНЫЙ АЛ-ХОРЕЗМИ (ІХ В.) О СКИФИИ И САРМАТИИ
}

\author{
Калинина Т.М.
}

http://10.25681/IARAS.2019.978-5-317-06274-3/280-287

Для исследователя средневековых письменных памятников основополагающим значением должен являться тот факт, что письменные источники избирательны и тенденциозны. Описания реальности далеко не всегда соответствуют этой самой реальности. Зачастую, если не всегда, этнонимы, использованные для воспроизведения картины мира, представляют собой конструкты, т.е. созданные современниками схемы для идентификации того или иного народа в соответствии с авторскими знаниями, традициями, зависимостью от более ранних источников, собственными представлениями. Если античные и римские географы под Скифией разумели восточноевропейские земли, то арабский учёный ал-Хорезми, вслед за Птолемеем, считал Скифией прежде всего территории далёкой Азии. Арабскому автору были известны общие реалии его времени, но представлять ал-Хорезми, как и других арабских географов средневековья, знатоком населения и путей Восточной Европы и Азии ошибочно.

Ключевые слова: Птолемей, ал-Хорезми, Скифия, Сарматия, сравнение информации

Учёные Арабского халифата приобретали знания об ойкумене, опираясь на достижения цивилизаций древней Греции, Ирана, Индии. Наиболее значительную роль в землеописании играла античная география и космография; именно они дали арабским теоретикам фундаментальное понимание о Земле. Модели географических образов ойкумены в одних случаях соответствовали реальности, в других «подгонялись» под традиционные, накопленные ранее или взятые из других культур представления, которые зачастую переплетались друг с другом, давая сложный комплекс образов пространства (Замятин, 2004. C. 15, 39 et passim).

В VIII-IX вв. при дворах властителей Арабского халифата переводились труды античных и восточных авторов. Арабские писатели широко использовали сведения об отдалённых землях иноязычных сочинений, а также свидетельства, полученные в общении с торговцами, моряками, путешественниками, которые передавались от одного автора к другому. Служители науки при описании Земли ссылались на Гиппократа, Галена, Аристотеля, Птолемея и других античных предшественников (Honigmann, 1929. S. 156 et passim; Крачковский, 1957. С. 87-88).

В «Доме мудрости» (Байт ал-Хикма), созданном халифом ал-Ма'муном (813-833), учёные из разных стран переводили научные трактаты с других языков на арабский, занимались астрономическими, математическими, географическими вычислениями. Там работал Мухаммад ибн Муса ал-Хорезми (ок. 783 - ок. 850), участвуя в измерении градуса земного меридиана, по следам 
Эратосфена и Птолемея и, как считают современные исследователи, участвуя в составлении «Проверенных мамуновских таблиц» с координатами населённых пунктов (утрачены) и составлена карта мира (утрачена).

Опираясь на «Географическое руководство» Птолемея, ал-Хорезми создал свою «Книгу картины Земли». Он использовал систему семи климатов

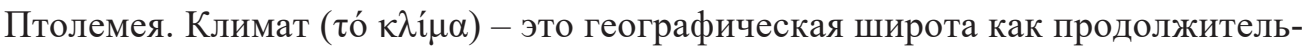
ность самого долгого светового дня, и долгота - как разница в местном времени суток. На этом принципе строились Птолемеем (и, вероятно, до него - Марином Тирским) списки широт и долгот (Honigmann, 1929; Neugebauer. 1975. P. 43-45, 333-336, 725-733; Щеглов, 2014. С. 95-97).

Внутри семи «климатов» ал-Хорезми расположил топонимы, гидронимы, ойконимы и проч. по точкам координат современных ему данных, при этом он использовал новые сведения о долготах дня и солнцестоянии (Nallino, 1944. Р. 458-532; Крачковский, 1954. С. 94-97). В рукописи «Книги картины Земли» ал-Хорезми нет карты мира, хотя отдельные изображения были в ней представлены (например, карта истока и течения Нила; Меотиды, которая в труде ал-Хорезми имеет связь посредством двух рек с Северным внешним морем, но не с Чёрным) (Калинина, 1988. С. 104).

При издании «Книги картины Земли» её исследователь и издатель $\mathrm{X}$. фон Мжик пронумеровал все встречающиеся в труде ал-Хорезми точки координат оронимов, береговых линий морей, озер, течений рек и топонимов, показав их в круглых скобках (Das Kitab, 1926). Ал-Хорезми изменил координаты Птолемея, хотя во многих случаях пользовался названиями из его книги, но переданы они были в искажённой или арабизированной форме.

Учёные составили реконструкцию изображений частей Земли по координатам ал-Хорезми, нанеся точки координат на плоскость (сначала на миллиметровку, а позднее при помощи компьютера) (Mžik, 1936. S. 165-166; Калинина, 1988. C. 105; Daunicht, 1970, Taf.; Wieber, 1974, Taf; Разийа Джафри, 1985, таблицы; Крюков, 2009. С. 67/68).

Один из разделов «Книги картины Земли» ал-Хорезми назвал «Места [на карте], где названы пределы стран», однако показаны им не границы (=«пределы»-xyдyd), а только центры с их координатами. Названия основаны на данных Птолемея, но изменены в соответствии с новыми материалами, которыми располагал ал-Хорезми.

Ал-Хорезми отметил географические координаты для центра Европейской Сарматии Птолемея (Сарматтийа - земля бурджан) и Азиатской Сарматии (Сарма̄тийа - земля ал-лан). Помимо этого, названы две Скифии (Искусийа) земля тюрков (ат-турк) и Искусийа - земля токузогузов (ат-тугузгуз) (Das Kitab, 1926. S. 32; Калинина, 1988. С. 40).

Две Сарматии Птолемея выбраны ал-Хорезми для координат Восточной Европы, однако он не повторял данных книги Птолемея. 
В «Хорографии» Помпония Мелы, автора I в. н.э., впервые встречается название Сарматия, с отсылкой на Марка Випсания Агриппу (64/63 - 12 г. до н.э.), автора несохранившихся «Хорографии» и карты мира; они известны лишь по ссылкам более поздних географов (Подосинов, 2002. С. 35-38). Сарматией считалась территория восточнее Германии, от Балтийского моря до Дуная (Подосинов, 2011. С. 123. Примеч. 249).

Клавдий Птолемей впервые ввёл понятия двух Сарматий - Европейской

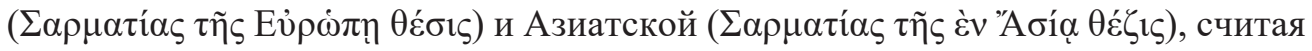
границей между ними реку Танаис. Европейская Сарматия Птолемея охватывала Восточную Европу от Балтики до Чёрного моря и от Германии до Дона (Ptol. III, 5; Древняя Русь, 2009. С. 190. Примеч. 9).

Ал-Хорезми воспринял это представление (Das Kitab, 1926. S. 105), показав, однако, только координаты центров этих земель. В его книге Сарма̄тийа - зем-

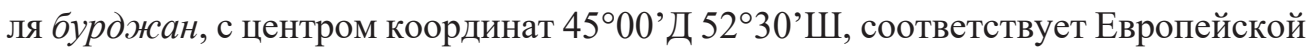
Сарматии Птолемея (Ptol. III, 5). По поводу Сарма̄тийи - земли бурджан, по ал-Хорезми, имеются разногласия среди учёных.

По мнению украинского востоковеда В.Г. Крюкова, «в таблицах координат географических пунктов шестого климата и в перечне населения стран Восточной Европы упомянуты донецко-приазовские аланы - бурджан, хазары - ал-хазар, среднедонские аланы - ал-лан и меотийские языги (ал-йатиз)» (Крюков, 2009 а. С. 443). Территорию Европы с запада на восток - от Вислы, через систему горных гряд Центральной Европы (Бескиды, Татры, Западные Карпаты и т.д.) до Керченского пролива, западного побережья Азовского моря и речной системы Северский Донец - Нижний Дон; с севера на юг - от юговосточной части Балтийского моря до придунайских провинций Римской империи (Нижней Мёзии и Дакии), и до южного побережья Чёрного моря - как полагает В.Г. Крюков, и во времена Птолемея, и в эпоху ал-Хорезми занимали дунайские и донецко-приазовские болгары, которых ал-Хорезми назвал бурджанами (Крюков, 2009 а. С. 441-454; Крюков, 2009. С. 216-385). Описание, начиная с эпохи Геродота, этноисторической и геополитической ситуации в Северном Причерноморье и Приазовье, территории которых В.Г. Крюков считает землями якобы всегда существовавшей именно и только Украины (Крюков, 2009. С. 385, 537), ставит под серьезное сомнение научные разыскания этого учёного.

Центр страны бурджан В.Г. Крюков предлагает искать в местности, находящейся к югу от античного города Истрия на берегу не существующего ныне южного устья дельты Дуная, что в данном случае справедливо может связываться с придунайской Болгарией (Крюков, 2009. С. 83).

Однако территория Европейской Сарматии Птолемея и координатные данные ал-Хорезми для «Сарматии - центра страны бурджан» несопоставимы, поскольку, во-первых, данные Птолемея и ал-Хорезми не одинаковы, а во- 
вторых, в книге ал-Хорезми нигде не обозначены границы Сарматии - земли бурджан.

Кроме этих данных, в книге ал-Хорезми, в перечне населённых пунктов шестого климата, упомянут ещё город Бурджан, с совсем иными координатами, чем «центр страны бурджан», и именно эти координаты могут показывать территорию Придунайской Болгарии (Крюков, 2009. Там же).

Обращение же В.Г. Крюкова к археологам, работающим на территории Подонечья и Приазовья, «подогнать» свои изыскания под сомнительные выкладки, как и призыв называть болгарское население этих областей бурджанами, заставляет предостеречь археологов, к которым обращается исследователь (см., например, Крюков, 1981. С. 7-8), от ненадёжных и местами просто ошибочных выводов автора.

Координаты для центра Европейской Сарматии Птолемея в книге алХорезми не стоит воспринимать как руководство для определения местоположения народа бурджан, тем более что сам этноним далеко не однозначен, хотя в большинстве научных трудов он соотносится с Дунайской Болгарией (Калинина, 1988. С. 92-93; Калинина, 2013. С. 192-216; здесь же критика сомнительных изысканий на темы этимологии названия и сведений арабских авторов о бурджанах в книге: Хамидуллин, 2013).

Сарматийа, а она земля алан, названная ал-Хорезми, с координатами 7800’Д 59³0’ Ш (Das Kitab, 1926. S. 105), соотносится с Азиатской Сарматией Птолемея (Ptol. V. 9). По его данным, Азиатская Сарматия располагалась между Доном и Волгой, Кавказом и северными неизвестными землями (Древняя Русь, 2009. С. 190. Примеч. 9). Народы, названные Птолемеем в Азиатской Сарматии (Ptol. V. 16-25), не всегда поддаются отождествлению, однако аланы в этом перечне не названы. Ранее считалось, что аланы поименованы Птолемеем среди народов Европейской Сарматии, между венедами и роксоланами, по побережью Меотиса (Ptol. III, 19). Однако позднее, с привлечением иных рукописей, учёные

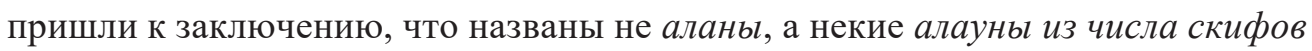
(Древняя Русь, 2009. С. 186. Примеч. 5). Этноним аланы же, как известно, был известен письменным источникам в самых разных землях, от Каспия и Арала, областей Дона, Причерноморья, Кавказа до Западной Европы и Африки. По координатным данным ал-Хорезми, центр Сарматии - земли алан находился восточнее Волги (птолемеевой Ра) и южнее Рипейских гор, в области, вполне соотносимой с Азиатской Сарматией Птолемея.

Помимо такого упоминания алан, ал-Хорезми называл также в шестом климате «Ворота хазар и алан»: гора Баб ал-Хазар ва-л-Лан (863-864) - реальное, современное ему название, под которым разумелся Дарьяльский горный проход (Das Kitab, 1926. S. 58; Калинина, 1988. C. 42). Кроме того, показаны координаты для горы Алан (джабал ал-Лан) (939-940); она находится далеко

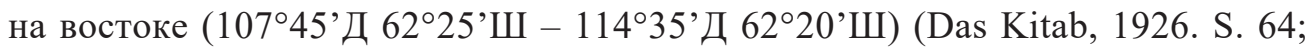


Калинина, 1988. С. 45, 85). Этот ороним, вероятнее всего, соответствует дан-

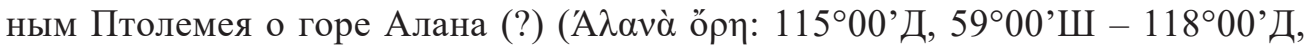
59³0’Ш) (Ptol. VI, 14).

Разграничение Сарматий в книге ал-Хорезми получилось иное, чем у Птолемея: в пределы Европейской Сарматии он поместил народ бурджан, не ясный ни по происхождению, ни по местоположению; на территории Азиатской Сарматии он показал алан, однако искать конкретное местоположение этого народа на основании координатных данных ал-Хорезми не стоит.

Скифией в античности и древнем Риме называлась обширная территория от Северного Ледовитого океана (как части охватывающего всю сушу Океана) с севера до реки Танаис, Меотиды и Боспора Киммерийского на востоке и Понта Эвксинского - на юге; с севера же проходили Рифейские (или Рипейские) горы, тянувшиеся в широтном направлении. Однако позднее такие географы как Помпоний Мела, Плиний и другие включили в понятие Скифии и Кавказ, и земли Северной и Северо-Восточной Азии (Подосинов, 2002. С. 29).

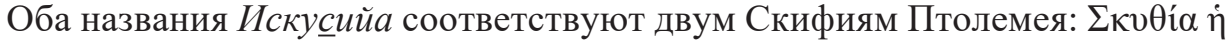

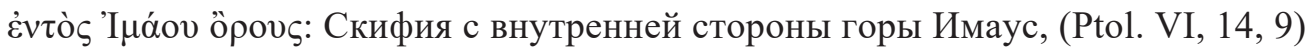

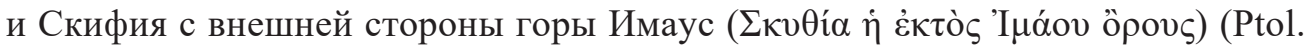
VI, 15, 1). Имаус, по данным Птолемея, это - меридионально протянувшийся с севера на юг горный хребет. Однако в книге ал-Хорезми нет такого названия, хотя даны координаты для двух соединяющихся под углом безымянных гор, обозначенных издателем под номерами (821-822) и (823-824) (Das Kitab, 1926. S. 56-57; Калинина, 1988. С. 22, 41). Первая часть соответствует фрагменту горы Имаус Птолемея, вдоль которой проходила, по его данным, торговая дорога (Ptol. VI, 12, 1). Продолжение этой горы соединяется с предыдущей и уходит резко на север, соответствуя основной части горы Имаус, которая проходила вдоль линии меридиана (Ptol. VI, 14, 1 и 8). Таким образом, горы (821-822) и (823-824) в книге ал-Хорезми, действительно, соответствуют Имаусу Птолемея, несмотря на отсутствие имени (Daunicht, 1968. S. 230-231; Калинина, 1988. С. 41). Есть предположение, что эти материалы следует соотносить в реальности с горами южного Памира, Гиндукуша, западных Гималаев, средней части Алтынтага, западной части западных Трансгималаев, западной часть Тибета (Daunicht, 1968, S. 231, 262-263, Мухаммад ибн Муса ал-Хорезми, 1983. С. 406, примеч. 586 (на узб. яз.).

Итак, античный термин «Скифия» наполнен вполне реальными этнонимами для времени ал-Хорезми: территория тюрков к IX в. граничила с владениями Арабского халифата до Исфиджаба на востоке; через территории тюрков и тогузгузов проходил торговый путь в Китай (Бартольд, 2002. С. 584; Кляшторный, Султанов, 2004. С. 99-101, 112).

Таким образом, если античные и римские географы под Скифией разумели восточноевропейские земли, то арабский учёный ал-Хорезми вслед за Птолемеем считал Скифией прежде всего территории далёкой Азии. 
Однако указанные общие выкладки ал-Хорезми были предназначены ТОЛЬКО ДЛЯ КАРТЫ. Рассматривать координатные данные его книги как реальные материалы не следует, поскольку учёный указал лишь самые общие представления своего времени о расположении указанных им народов, координаты же были представлены только для теоретических выкладок, сильно отличавшихся от материалов Птолемея. Основной задачей ал-Хорезми было не приведение в соответствие этнополитической ситуации времён Птолемея с эпохой ал-Хорезми, это было подчинённой и далеко не основной задачей. Ал-Хорезми выбирал пункты из труда Птолемея прежде всего по принципу выделения долготы дня и положению солнца в полдень, что являлось характерным именно для астрономической географии (Honigmann, 1929. S. 134-138 etc.; Mžik, 1915. S. 157 et passim; Крачковский, 1957. С. 94-97; Shcheglov, 2018. P. 18. Note 18), но не по значимости тех или иных пунктов в разнообразных маршрутах. Такие знания исключать нельзя; конечно, арабскому автору были известны общие реалии его времени, но представлять ал-Хорезми, как и других арабских географов средневековья, знатоком населения и путей Восточной Европы и Азии ошибочно.

Для исследователя средневековых письменных памятников основополагающим значением должен являться тот факт, что письменные источники избирательны и тенденциозны. ОПИСАНИЯ реальности далеко не всегда соответствуют этой самой реальности. Зачастую, если не всегда, этнонимы, использованные для воспроизведения картины мира, представляют собой конструкты, т.е. созданные современниками схемы для идентификации того или иного народа в соответствии с авторскими знаниями, традициями, зависимостью от более ранних источников, собственными представлениями. Многозначность этнонимов ат-турк, ат-тугузгуз, бурджан, ал-лан является конкретным примером этого постулата (Крадин, 2009. С. 16-17).

\section{ЛИТЕРАТУРА}

Бартольд В.В. Тюрки // Бартольд В.В. Работы по истории и филологии тюркских народов. (Перепеч. с изд. 1968 г.: Сочинения. Т. V.) М.: Вост. лит., 2002. С. 576-595.

Древняя Русь в свете зарубежных источников. Хрестоматия. Т. І. Античные источники / Сост. А.В. Подосинов. М.: Русский фонд содействия образования и науке, 2009. $346 \mathrm{c.}$

Замятин Д.Н. Метагеография: пространство образов и образы пространства. М.: Аграф, 2004. 508 с.

Калинина T.М. Сведения ранних учёных Арабского халифата. Тексты, перевод, комментарий. М.: Наука, 1988. 108 с.

Калинина T.M. Этноним «бурджан» в сочинениях арабских средневековых географов (варианты соотношения устной и письменной традиции) // ДГ. 2011 год. Устная традиция в письменном тексте. М.: Русский фонд содействия образования и науке, 2013. C. $192-216$. 
Кляшторный С.Г., Султанов Т.И. Государства и народы Евразийских степей. СПб.: Петербургское востоковедение, 2004. 362 с.

Крадин Н.Н. Археологические культуры и этнические общности // Теория и практика археологических исследований. Барнаул: Азбука, 2009. Вып. 5. С. 9-19.

Крачковский И.Ю. Арабская географическая литература // Избр. соч. М.; Л.: Издво Академии наук, 1957. T. IV. 965 с.

Крюков В.Г.(а) Арабская астрономическая география 1-ой половины IX в. об Азовском море, ландшафте и населении Приазовья // Степи Европы в эпоху средневековья. Труды по археологии. Т. 7. Хазарское время. Донецк: Дон НУ, 2009 С. 441-458.

Крюков В.Г. «Ал-Ху варізмі про “Сарматію - землю бурджанів” та сусідні з нею “крайни”». Луганьск: Вид-во ДЗ ЛНУ імені Тараса Шевченка, 2009. 539 с.

Крюков В.Г. Этноним «бурджан» у арабских авторов IX в. // Вопросы истории, идеологии, философии, культуры народов Востока. Тезисы конференции аспирантов и молодых научных сотрудников ИВ АН СССР. М.: Наука, 1981. Т. 1. Источниковедение и историография. С. 7-8.

Мухаммад ибн Муса ал-Хорезми. Избранные произведения. Математика, астрономия, география. Ташкент: Фан, 1983 (на узб. яз.).

Подосинов A.B. Восточная Европа в римской картографической традиции. Тексты, перевод, комментарий. М.: Индрик, 2002. 487 с.

Подосинов А.В., Скржинская М.В. Римские географические источники: Помпоний Мела и Плиний Старший. Тексты, перевод, комментарий. М.: Индрик, 2011. 502 с.

[Разийа Джафри C.] Географическая карта мира ал-Хорезми по книге «Сурат ал-арз» / Введение и интерпретация карты С. Разийи Джафри. Вводное исследование Ю.С. Мальцева. Предисловие и редакция К.С. Айни. Душанбе; Сринагар: Дониш, 1985.

Хамидуллин С.И. Бурджаны в истории Евразии. Уфа: Гилем, Башк. Энц., 2013. $224 \mathrm{c}$.

Щеглов Д.А. Предыстория географии Птолемея // Аристей. Вестник классической филологии и античной истории. М.: Русский фонд содействия образованию и науке, 2014. Вып. 10. С. 82-131.

Щеглов Д.А. Карта Птолемея и античные периплы // $\mathrm{HО} \Lambda$ Н. Философское антиковедение и античная традиция. Т. 10. Вып. 2. Новосибирск: Аквилон, 2016. C. 671-698.

Daunicht H. Der Osten nach der Erdkarte al-Huwarizmi’s. Bonn: Reinische FriedrichWilgelm Universität, 1968-1970. Bd. I-II. 496 p.

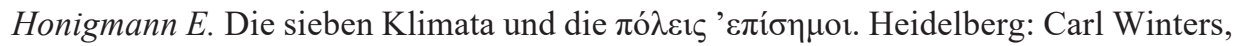
1929. $130 \mathrm{~S}$.

Das Kitab Surat al-ard des Abu Ğa'far Muhammad Ibn Musa al-Huwarizmi / H.v. Mžik. Leipzig: Otto Harrassowitz, 1926. 161 S. + 5 Taf.

Mžik H. Ptolemaeus und die Karten der arabischen Geographen // Mitteilungen der Kaiserlich-Königlichen geographischen Geschichte. Wien: R. Lehner (Wilh. Müller), 1915. Bd. 58. S. 152-175.

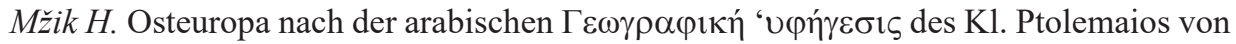
Muhammad ibn Musa al-Huwarizmi // Wiener Zeitschrift für die Kunde des Morgenländes: Verlag des Verbandes der wissenschaftlichen Gesellschaften Österreichs, 1936. Bd. 43, H. 3-4. S. 161-193. 
Nallino C.A. Al-Khuwarizmi e il suo rifacimento della Geografia di Tolomeo // Raccolta di Scritti. Editi e inediti. Roma: Pubblicazioni dell'Istituto per l'Oriente. AstrologiaAstronomia, 1944. Vol. 5. P. 458-532.

Neugebauer $O$. A History of Ancient Mathematical Astronomy. Studies in the History of Mathematics and Physical Sciences, Pt. 1-3. New York; Heidelberg; Berlin: SpringerVerlag, 1975. $1457 \mathrm{p}$.

Shcheglov D. The length of coastlines in Ptolemy's Geography and in ancient periploi // History and Geo-and Space Sciences. Vol. 9. 2018. P. 9-24. Publisher: Copernicus Publications. www.hist-geo-space-sci.net/9/9/2018.

Wieber R. Nordwesteuropa nach der arabischen Bearbeitung der Ptolemäischen Geographie von Muhammad B. Musa al-Hwarizmi. Walldorf-Hessen: Verlag für Orientkunde Dr. H. Vorndran, 1974. $141 \mathrm{~S}$. 


\section{ВОЗНИКНОВЕНИЕ РАННЕАЛАНСКОЙ КУЛЬТУРЫ КАВКАЗА В СВЕТЕ ТЕОРЕТИКО-МЕТОДИЧЕСКИХ ПРОБЛЕМ}

\section{Ковалевская В.Б.}

http://10.25681/IARAS.2019.978-5-317-06274-3/288-296

Рассмотрен механизм порождения культуры при миграции на примере создания раннеаланской культуры на Кавказе, основываясь на последних разработках В.Ю. Малашева, явившихся прорывом как в методическом плане, так и на содержательном уровне. Субстратной для ранних алан культуры больше подходит предложенное мною ранее название - кобанско-сарматская, но это ещё требует обсуждения, тем более, что между рассмотренными предгорными группами памятников имеются существенные локальные и хронологические отличия. Суперстратом для ранних алан, как в самое последнее время надёжно показал В.Ю. Малашев, является среднесарматская культура. Представляет большую важность оценить удельный вес субстрата и суперстрата во вновь созданной культуре северокавказских алан.

Ключевые слова: раннеаланская культура, раннесарматская культура, субстрат, суперстрат, курган, катакомба

В теоретико-методических проблемах, связанных с изучением археологической культуры, были периоды приливов и отливов в интересах к ней. На протяжении развития археологии в СССР и России в ХХ столетии, такие периоды повышенного интереса были в конце 1920-х годов (Б.С. Жуков; Б.А. Куфтин), в 1950-е годы (5 специализированных статей). Расцвет пришёлся на 19601970 гг. (около 20 статей). Фактически, за это время высказались почти все исследователи, проявившие интерес к разработке теоретических вопросов.

В истории нашей науки был недолгий, но очень продуктивный момент, когда большая группа серьезных и высокого класса специалистов в области археологии, этнографии, древней истории Европы и Востока вплотную занимались именно теми вопросами, которые нами поставлены во главу угла. А именно: «В области изыскания закономерностей зарождения, превращения и распространения культурных форм... В центр внимания было поставлено изучение и разработка вопросов генетики культуры с точки зрения их статики и динамики: выявление культурных центров - очагов культуры, выяснение путей и факторов процесса распространения культурных элементов и культурных комплексов (динамика культуры) и изучение происхождения культурных элементов, возникающих в одних случаях путем конвергентности, в других путем диффузии» (Бондарев, 2014. С. 154). Это были 1926-1929 годы, когда Н.Я. Марр в структуре ГАИМК под своим руководством создал наряду с археологическим, этнологическим и художественно-историческим отделением «своего рода теоретико-методологический центр» (Бондарев, там же) - секцию генетики культуры. Эта секция объединила самые славные имена в археологии и истории культуры. Сюда входили маститые академики С.А. Жебелев, В.В. Бартольд, 
С.Ф. Ольденбург, чл.-корр. Д.В. Айналов, Б.В. Фармаковский, а кроме того А.А. Спицын, А.А. Миллер, С.И. Руденко, П.П. Ефименко, И.А. Орбели и молодые тогда, но сыгравшие позднее важную роль в развитии науки, М.И. Артамонов, А.А. Иессен, Т.С. Пассек, Б.А. Латынин, глава московской палеоэтнологической школы Б.С. Жуков и многие другие. К сожалению, мы можем судить о научных достижениях этой группы исследователей только по тем материалам, которые отложились в архивах и были изучены А.В. Бондаревым, по статье Б.С. Жукова, конкретным результатам более поздних полевых работ А.А. Миллера и связанных с ним кавказоведов, или всей богатой научной деятельности М.И. Артамонова, Б.Б. Пиотровского, С.И. Руденко, Т.С. Пассек и т.д. Работы только начались и были силой прекращены, многие учёные были уволены, репрессированы или погибли в тот страшный год «великого перелома», когда ГАИМК была перестроена на марксистский лад. Только теперь, через 88 лет, мы можем оценить тот непоправимый вред, который нанесён теоретической археологии в деле изучения Археологической Культуры.

В дальнейшем интерес к этим исследованиям сократился до минимума. Несмотря на разнообразие аспектов, рассмотренных в специальных статьях, тот аспект, который стал темой настоящего сообщения, хотя ему и уделялось большое внимание в конкретных исследованиях, не нашёл места в имеющейся теоретической литературе.

Выбор сарматской проблематики для перехода от конкретных разработок к теоретическому осмыслению объясняется тем, что сарматоведение развивалось как плодотворное направление с концентрацией научных сил с планированием полевых работ и периодическим обобщением результатов крупнейшими специалистами - сначала М.И. Ростовцевым, П.Д. Рау, Б.Н. Граковым, принятыми затем с уточнениями и корректировками когортой исследователей прошлого и нашего столетия.

Интерес к скифо-сарматской археологии до революции вызвал большие полевые исследования в евразийских степях. Впервые сарматские памятники были обобщены М.И. Ростовцевым в 1918 г., но не отделены от скифских, а появление их объяснялось рядом волн кочевников с Востока, докатившихся до Урала и Днепра. После революции начались планомерные полевые работы силами краеведческих организаций на Волге, а с 1925 г. начаты полевые работы экспедиции ГИМа (Б.Н. Граков). Далее в 1920-1930-е годы выходят обобщающие работы П.Д. Рау, Б.Н. Гракова, наметившие периодизацию сарматских культур и их ареал. В 1947 г. Б.Н. Граков создал ту периодизацию, которая с некоторыми корректировками существует и поныне.

Определённая некорректность заключалась в том, что вся последовательность несет название «сарматская культура», а члены деления тоже называются культурами. Как об этом писала М.Г. Мошкова: «Кажущаяся терминологическая путаница, приводящая к существованию культуры в культуре, во-первых, отражает чрезвычайную сложность и многогранность процессов, происходив- 
ших в течение многовековой истории сарматов, а во-вторых, свидетельствует о неразработанности археологической понятийной терминологии» (Мошкова, 1974. С. 5). Как выход из этой ситуации она предлагала для всей последовательности сарматских культур - принять в качестве общего определения «сарматская этническая общность» (Мошкова, там же). Правильнее было бы говорить о последовательности савромато-сарматских культур как о КИО, имея в виду культурно-историческую общность. Правда, понятие КИО в качестве культурно-исторической области с пространственной точки зрения также можно относить к рассматриваемой последовательности культур. В конкретных работах большое внимание уделено происхождению культур и выделению двух моделей происхождения (автохтонной и миграционной), которые я и рассмотрю на содержательном уровне на ряде примеров. Не могу не согласиться с точкой зрения Б.Ф. Железчикова, что труды П.Д. Рау, Б.Н. Гракова, К.Ф. Смирнова и М.Г. Мошковой «подготовили прекрасную практическую и теоретическую базу для современных и будущих обобщающих исследований» (Статистическая обработка, 1997. С. 41). Но значит ли это, что сегодня можно оставить в стороне вопросы специфики формирования различных сарматских культур в разное время и на разных пространствах при разных соотношениях роли субстрата и суперстратов? Тем более, что это соотношение и отличает ту или иную культуру в последовательности савромато-сармато-аланских культур I тыс. до н.э. - начала I тыс.

Происхождение савромат рассмотрено К.Ф. Смирновым в двух монографиях и ряде обобщающих статей. Он рассматривает проблему последовательно и доказательно, показывая, где, когда и как вызревала савроматская культура в недрах андроновской и срубной культур. Причем начало этому процессу положило смешение этих культур в эпоху поздней бронзы на территории Приуралья, когда в памятниках андроновской культуры появляется позднесрубная керамика, а в ряде памятников срубной культуры появляются андроновские черты. Моделируя процесс порождения савроматской культуры для уточнения этапов её сложения, К.Ф. Смирнов выделяет несколько десятков комплексов переходного типа VIII-VII вв. до н.э., в которых наблюдается сочетание артефактов, сохраняющих традиции предшествующего времени в керамике, орнаментах, костяном инвентаре и в погребальном обряде, а именно северную ориентацию, погребения на боку, подогнутые ноги - с новыми признаками, характерными для савроматской культуры. Новые признаки характеризуют изменения в погребальном обряде: вытянутое положение, западная ориентировка, положение кисти руки на таз и появление типичного савроматского инвентаря. Далее материал савроматской культуры стал предметом изучения в первом выпуске фундаментальной серии «Статистическая обработка погребальных памятников Азиатской Сарматии», объединившем усилия всего научного сообщества сарматоведов в изучении и математической обработке последовательности всех сарматских культур, все интерпретации и обобщения становится возможным 
выразить в количественных показателях и четко скоррелировать их со временем и пространством. В сложившемся виде, по мнению исследователей, савроматская культура появилась в Южном Приуралье во второй половине VI в. до н.э. и только в середине V в. до н.э. освоила весь регион (Статистическая обработка, 1994. С. 151). Интересно, что время формирования культуры, включая и переходные памятники VII-VI вв. до н.э., выносятся из времени существования савроматской культуры, что, как методический приём, будет использоваться всеми сарматоведами при изучении последующих культур. К завершающему этапу существования савроматской культуры в ней складываются те признаки, которые будут характеризовать следующую за ней на этой же территории раннесарматскую культуру. Для понимания механизма сложения культуры важно, что мы получаем представление о длительности процесса. М.Г. Мошкова показывает, что если начался процесс сложения раннесарматской (прохоровской) культуры в Приуралье в самом начале IV в. до н.э., хотя отдельные её признаки были уже в V в. до н.э., то окончательное оформление на всей территории происходит к концу IV в. до н.э. (Статистическая обработка, 1997. С. 41). Это касается изменений в местном субстрате. Но в происхождении раннесарматской культуры большая роль принадлежит миграциям как лесостепного зауральского населения, так и кочевого степного населения Казахстана и Приуралья. Б.Ф. Железчиков подчеркивает, что по мысли К.Ф. Смирнова более активная роль в процессе происхождения прохоровцев принадлежала именно кочевым степным племенам, которые, захватывая новую территорию, ассимилировали местное население (Статистическая обработка, 1997. С. 42). Причём, иным, судя по работам А.Х. Пшеничнюка, видит Б.Ф. Железчиков роль зауральского местного оседлого населения. Они, по-видимому, были ассимилированы продвинувшимися на их территорию савроматами и вовлечены последними в их дальнейшее возвратное продвижение на Запад. Хотя, как справедливо подчеркивает Б.Ф. Железчиков, эти построения не могут опираться только на археологические данные и требуют привлечения палеоантропологических материалов. Первоначально среднесарматская культура была датирована II в. до н.э. - II в. н.э. Позднее, после длительной дискуссии, её нижняя дата оказалась омоложена в определённой мере в угоду тому методическому положению, по которому время формирования новой культуры принято в сарматоведении относить к завершающему этапу предшествующей культуры, поскольку это подчеркивает факт генетической связи культур в рассматриваемом ареале. Некая предвзятость, или скажем устойчивая методическая традиция, всегда существует в научной практике адептов сложившейся научной школы, а сарматская школа, восходящая к Борису Николаевичу Гракову и Константину Фёдоровичу Смирнову, безусловно существовала и продолжает существовать, используя сложившуюся ранее традицию и насыщая её новыми знаниями.

Но подробно я остановлюсь на механизме порождения культуры при миграции на примере создания раннеаланской культуры на Кавказе, основываясь 
на последних разработках В.Ю. Малашева, явившихся прорывом как в методическом плане, так и на содержательном уровне (Малашев, 2007; Габуев, Малашев, 2009; Дзуцев, Малашев, 2015; Малашев, 2016). Как мы отмечали в периодизации сарматских культур, четвёртым этапом является позднесарматская, она же аланская культура II-IV вв. Но следует подчеркнуть, что появление ряда восточных черт, часто в устойчивых сочетаниях (зеркала с центральной петелькой, тамги и бирюзово-золотой звериный стиль), в восточно-европейских степях приходится на I в. н.э., именно тогда, когда у античных авторов мы узнаем об аланах на этой территории (Скрипкин, 2010. С. 27). На Северном Кавказе в это же время (по археологическим данным в середине II в. н.э.) появляются памятники новой раннеаланской культуры, представленные огромными курганными могильниками с т-образными катакомбами, расположенными вокруг «протогородов» - обширных так называемых земляных городищ. По условиям времени и места мы имеем полное основание считать именно их аланами. Каким рисуется механизм сложения этой культуры? В качестве местного субстрата выступает, по мнению В.Ю. Малашева, группа предгорных памятников, которые он называет памятниками Хумара - Подкумок - Нижний Джулат - Чегем - Заманкул - Манаскерт II в. до н.э. - II/III вв. н.э. Автор раскопок и публикаций М.П. Абрамова предлагает их называть предаланскими или раннеаланскими, что не кажется удачным. Относительно оставившего их населения она отмечает смешанный состав «включающий как автохтонные племена, так и осевших здесь ираноязычных кочевников» (Абрамова, 1989. С. 280). Мне кажется, что для этой субстратной для ранних алан культуры больше подходит предложенное мною ранее название - кобанско-сарматская, но это ещё требует обсуждения, тем более, что между рассмотренными предгорными группами памятников имеются существенные локальные и хронологические отличия.

Эта тема генетической связи указанной культуры с раннеаланской ещё недостаточно разработана в археологии, но уже ранее указывалось (Мошкова, Малашев, 1999), что т-образные катакомбы у ранних алан имеют именно это происхождение, по мнению В.Ю. Малашева, керамическая традиция ранних алан II-IV вв. также имеет местное происхождение - а это уже достаточно заметный вклад местного субстрата в возникшую культуру, если добавить к этому использование для жизни в ряде случаев, например, в Бруте, того же поселения.

Суперстратом для ранних алан, как в самое последнее время надёжно показал В.Ю. Малашев, является среднесарматская культура. С нею пришёл курганный обряд, свойственный всем сарматским племенам, центральное положение катакомбы в кургане. Создание тайников с богатым конским снаряжением объединяет раннеаланские погребения исключительно с традицией среднесарматской культуры. С нею генетически связан и уникальный золотой звериный стиль ранних северокавказских алан, отличный по технике изготовления и морфологически от сарматского бирюзово-золотого звериного 
стиля, но близкий по репертуару образов, указывающих на восточное происхождение, и восходящий к сарматскому звериному золото-бирюзовому стилю. Об этих предметах искусства М.Б. Щукин справедливо заметил: «Было бы соблазнительно связать распространение вещей бирюзово-золотого стиля с распространением аланов.» (Щукин, 2005. С. 65). Оценить в целом вклад кочевых племён среднесарматской культуры в раннеаланскую оседлую культуру следует очень высоко, поскольку они связаны с духовным миром, а именно с искусством и погребальным обрядом (идея кургана). Очевидно именно эти кочевники и принесли в население складывающейся культуры язык и этноним, которые сохранились до наших дней. Производственные навыки, оседлость, так же как и погребальное сооружение в виде т-образной катакомбы, следовательно навыки хозяйственной и частично духовной жизни - пришли из местного субстрата.

Для нас представляет большую важность оценить удельный вес субстрата и суперстрата во вновь созданной культуре северокавказских алан. Разработок в теории археологической культуры на эту тему нет, в этнографии они существуют. Обобщая эти данные, академик В.П. Алексеев писал: «При более высоком уровне культуры мигрантов, они в первую очередь формируют этническое лицо народа, возникшего в процессе смешения» (Алексеев, 1993. С. 10). То, что именно носители среднесарматской культуры передали свой этноним, язык и тот духовный мир, который выражался в искусстве золотого бесланского Звериного стиля и некоторых элементах погребального обряда, показывает решающую роль мигрантов в сложении культуры ранних алан Северного Кавказа. Пассионарность пришельцев скорее всего и определяет дальнейшее быстрое освоение окружающей территории культурой ранних алан (Дзуцев, Малашев, 2015. Рис. 34) В первой половине III в. происходит продвижение ранних алан к Средней Кубани, в середине III в. - освоение Нижнего Дона и Терско-Сулакского междуречья, в первой половине IV в. продвижение в Южный Дагестан и начало освоения Пятигорья, т.е. движение на запад, югозапад и восток, юго-восток. В последнем случае мы видим конкретное выражение этого процесса на примере раскопок Д.С. Коробовым и В.Ю. Малашевым в 2012 г. Левоподкумского 1 могильника в окрестностях Кисловодска (Коробов, Малашев, Фассбиндер, 2014. С. 120-135). Уникальность этих раскопок заключается в том, что в зоне тех небольших «земляных городищ», которые открыты на левобережье Подкумка к западу от Кисловодска на южных отрогах Боргустанского хребта, рядом с поселениями открыты чересполосно расположенные, как подкурганные катакомбные погребения, аналогичные раннеаланским катакомбным подкурганным погребениям Центрального Предкавказья, так и грунтовые катакомбные погребения типа Хумара-Подкумок-Клин-Яр III.

На основании дешифровки аэрофотосъемки, проведения магнитометрического обследования и последующих археологических раскопок выяснено, что данные укреплённые земляные городища - новый памятник для Кисловодской 
котловины начала I тыс. - окружены такими могильными памятниками примерно в равном отношении: 37 подкурганных катакомб и примерно 35 грунтовых катакомбных погребений, характеризующих местную традицию (Коробов, Малашев, Фассбиндер, 2014. С. 123). Раскопки выявили достаточно стандартные подкурганные катакомбы, в которых сходства с центральнокавказскими больше, чем отличий, хотя катакомбы могут быть, как т-образной формы, так и находящиеся на той же центральной оси, что и входная яма. Погребения местной культуры планиграфически связаны с подкурганными, находясь между их ровиками, представляя из себя двухкамерную грунтовую катакомбу, характерную для местных субстратных памятников. Поскольку все погребения ограблены в древности, хотя по инвентарю позволяют дробно датировать время их сооружения, у нас недостаточно данных для того, чтобы судить о степени близости материальной культуры могильника. Антропологические исследования показали, что в разных типах погребальных сооружений захоронены погребённые разных антропологических типов: европеоидные с высоким относительно узким лицом, высокими орбитами и высоким носом для мигрантов и европеоидные с низким и широким лицом, носом и орбитами у погребённых в грунтовой катакомбе. Особенно интересные данные, свидетельствующие о характере адаптации пришлого населения к окружающей среде и новым условиям жизни, представлены материалами патологии позвоночника у мужчины из кургана 1. У него выявлены артроз в шейном и грудном отделе, центральные узлы Шморля в грудном и поясничном отделах, прижизненный отрывной перелом 1 грудного позвонка, компрессионный перелом тела 12 грудного позвонка, спондилолиз 5 поясничного позвонка. Эти множественные травмы и заболевания позвоночника, по мнению антропологов, свидетельствуют «о тяжёлой работе, связанной с нагрузкой верхних конечностей, осевыми нагрузками (поднятие и перенос тяжестей) и активным образом жизни, который вёл мужчина, невзирая на полученные травмы» (Березина и др., 2014. С. 176). Один из прижизненных переломов носит название «перелом землекопа», что говорит, очевидно, об активной деятельности в непривычной ранее для данного индивидуума работе. Поскольку выбор для раскопок максимально близко расположенных к поселению погребений свидетельствовал о том, что речь идет о первых насельниках поселения, такая активная и тяжелая физическая нагрузка могла быть связана с созданием обороны в виде рвов городища. Эти данные рисуют нам трудности жизни первых мигрантов, осваивающих новые территории и новые условия жизни, что остается уникальным археологическим примером, требующим продолжения работ на этом памятнике. К сожалению, археологических материалов, позволяющих представить себе механизм сложения раннеаланской культуры, в нашем распоряжении нет. Археологи констатируют, что наиболее ранние погребения раннеаланской культуры середины II в. н.э. в Бруте представлены уже полностью сложившейся культурой (погребальный культ, керамическое производство и другие местные производства). 
Дальнейшее развитие раннеаланской культуры прослеживается на основании изучения более поздних материалов, включая аланскую культуру V-XIII вв. В целом именно материалы, свидетельствующие о происхождении раннеаланской культуры, вскрывают механизмы создания культуры, анализ удельного веса культурного субстрата и суперстрата в создании новой культуры и позволяют далее выделить динамику развития. При этом во всех новых построениях мы должны опираться на опыт наших предшественников, о чем мы говорили в начале сообщения. Действительно, как писал Л.М. Леонов: «Без изучения прошлого нельзя наметить столбовой дороги и в наше завтра: человеческий опыт питается памятью о содеянных ошибках» (Леонов, 1957. С. 284). То есть, говорить об ошибках и недоговоренностях, пожалуй, в большей мере, чем о достижениях. Важны не так ответы на поставленные вопросы, как сами поставленные вопросы. А ими и сегодня остаются вопросы механизма создания культур по археологическим данным, что важно изучить на различном археологическом материале, используя комплексный подход.

\section{ЛИТЕРАТУРА}

Абрамова М.П. Центральный Кавказ в сарматскую эпоху // Степи европейской части СССР в скифо-сарматское время. М., 1989.

Алексеев В.П. Очерки экологии человека. М., 1993.

Березина Н.Я., Фризен С.Ю., Коробов Д.С. Антропологические материалы из курганного могильника Левоподкумский 1 (Кисловодская котловина) // Вестник Антропологии - Новая серия. 2014. № 1(27).

Бондарев А.В. Вклад петербургских учёных в становление отечественных культурогенетических исследований // Арии степей Евразии: эпоха брозы и раннего железа в степях Евразии и на сопредельных территориях. Сборник памяти Елены Ефимовны Кузьминой / Отв. ред. ак. В.И. Молодин, проф. А.В. Епимахов. Барнаул: Изд-во Алтайского государственного университета, 2014. С. 152-162.

Габуев Т.А., Малашев В.Ю. Памятники ранних алан Центральных районов Северного Кавказа. М.: Таус, 2009.

Дзуцев Ф.С., Малашев В.Ю. Бесланский археологический комплекс раннеаланской эпохи. Некоторые итоги исследований 1988-2014 гг. Алано-Кавказская библиотека. Владикавказ, 2015.

Коробов Д.С., Малашев В.Ю., Фассбиндер И. Предварительные результаты раскопок на курганном могильнике Левоподкумский 1 близ Кисловодска // КСИА. Вып. 232. М., 2014. С. 120-135.

Леонов Л. Русский лес. М., 1957.

Малашев В.Ю. Памятники среднесарматской культуры северокавказских степей и их традиции в курганных могильниках северо-восточного Кавказа второй половины II - середины V в. М.: ИА РАН, 2016. 202 с.

Малашев В.Ю., Гаджиев М.С., Ильюков Л.С. Страна маскутов в Западном Прикаспии. Курганные могильники прикаспийского Дагестана III-V вв. н.э. Махачкала: Мараевъ, 2015. 
Мошкова М.Г. Происхождение раннесарматской (прохоровской) культуры. М., 1974.

Мошкова М.Г., Малашев В.Ю. Хронология и типология сарматских катакомбных погребальных сооружений // Научные школы волгоградского государственного университета Археология Волго-Уральского региона в эпоху раннего железного века и средневековья. Волгоград, 1999.

Скрипкин А.С. Сарматы и Восток. Избранные труды. Волгоград, 2010.

Смирнов К.Ф. Савроматы. М.: Наука, 1964.

Статистическая обработка погребальных памятников Азиатской Сарматии. Савроматская эпоха. Вып. І. М., 1994.

Статистическая обработка погребальных памятников Азиатской Сарматии. Раннесарматская культура. Вып. II. М., 1997.

Статистическая обработка погребальных памятников Азиатской Сарматии. Среднесарматская культура. Вып. III. М., 2002.

Статистическая обработка погребальных памятников Азиатской Сарматии. Позднесарматская культура. Вып. IV. М., 2009.

Щукин М.Б. Готский путь. Готы, Рим и черняховская культура. СПб., 2005. 


\section{ЭЛЕМЕНТЫ КОНСКОЙ СБРУИ ИЗ НЕКРОПОЛЯ «ИВАНОВСКИЕ І КУРГАНЫ» НА ЮЖНОМ УРАЛЕ}

\section{Сиротин С.B.}

http://10.25681/IARAS.2019.978-5-317-06274-3/297-304

В статье анализируются элементы конской узды, найденные в курганах некрополя «Ивановские I курганы». Некрополь расположен в юго-восточной (Зауральской) Башкирии. Многие элементы имеют аналогии в скифских комплексах. Констатируется влияние скифских традиций на формирование конской узды у кочевников Южного Урала.

Ключевые слова: элементы конской узды, Южный Урал, ранние кочевники

Во многих памятниках ранних кочевников Южного Урала VI-IV вв. до н.э. исследователями отмечается заметное присутствие коня в погребальных ритуалах (Смирнов, 1964; Очир-Горяева, 2012; Мышкин, 2012). Это присутствие, помимо целых захоронений коня, в большей степени представлено в южноуральских комплексах находками частей конских скелетов и элементов конского снаряжения, как правило, в южной части кургана (Очир-Горяева, 2012; Мышкин 2012; Сиротин, 2015 б).

Серия предметов, входящих в состав раннепрохоровских уздечных наборов, была получена в ходе исследования курганного некрополя «Ивановские I курганы», расположенного в юго-восточной Башкирии.

Всего курганный некрополь «Ивановские I курганы» насчитывал 11 курганных насыпей. Впервые работы на данном могильнике были проведены А.Х. Пшеничнюком в 1974 г. Он исследовал 4 кургана южной группы, в которых были выявлены погребения срубно-алакульской культуры (курган № 1 и № 4) и савроматской культуры (курганы № 1-3) (Пшеничнюк, 1983. С. 35-37). В 2013-2016 гг. работы на могильнике были продолжены (Сиротин, 2015 a. С. 18-19; 2017. С. 132-139). Были исследованы курганы № 5-11, в которых выявлены два срубно-алакульских комплекса (курган № 6, 7), 21 комплекс раннепрохоровского времени (курганы № 5-11), 2 комплекса эпохи средневековья (курган № 7).

В шести курганах могильника (курганы № 5, 7-11) были найдены элементы уздечных наборов, символизирующие присутствие коня в погребальном ритуале. Следует отметить, что предметы конского снаряжения в данном некрополе были выявлены только в насыпях курганов. Ни в одном из погребений принадлежностей уздечных наборов не найдено. В подавляющем большинстве, предметы обнаружены в южных полах курганных насыпей. Исключение составляет лишь курган № 9, где элементы конского снаряжения найдены в северо-восточном секторе кургана.

В жертвенных комплексах были найдены как уздечные наборы, так и отдельные элементы узды. Среди найденных предметов имеются железные дву- 
составные удила, железные стержневидные двудырчатые псалии, фрагмент С-видного двудырчатого псалия, железные налобники (наносники), фрагмент железного дуговидного предмета (нахрапник), бронзовые двусоставные ассиметричные удила и бронзовые уздечные бляхи.

Удила. Удила и их фрагменты найдены во всех шести насыпях некрополя, где отмечены находки элементов конского снаряжения. Все удила относятся к двучастным с загнутыми в петли окончаниями. Часть из них имеет звенья различной длины. Большинство удил и их фрагментов железные, кованые, округлые или подквадратные в сечении. Подобные удила широко представлены в уздечных наборах кочевников Южного Урала V-III вв. до н.э.

Исследователи отмечают, что такая форма железных удил появляется во второй половине - конце VI в. до н.э. (Смирнов, 1961. С. 82; Мошкова, 1963. С. 36). Их появление, вероятнее всего, связано с общими изменениями в конструкции конского снаряжения степной Скифии. На рубеже VI-V вв. до н.э. литые бронзовые удила активно заменяются железными коваными. $\mathrm{C} \mathrm{V}$ в. до н.э. они широко используются на обширной территории степной и лесостепной Евразии и наибольшее распространение получают в V-IV вв. до н.э. (Савченко, 2009. С. 228, 230). Привлекают внимание бронзовые асимметричные удила, найденные в кургане № 7. Эти удила повторяют форму железных удил с завитыми в петли окончаниями и изготовлены тем же способом, что и кованые железные.

Псалии. Подавляющее большинство псалиев, найденных в курганах (как целых, так и фрагментированных), являются двудырчатыми псалиями с восьмёркообразным утолщением по центру и концами, оформленными шишечками или утолщениями (курганы № 5, 7-10) (Сиротин, 2015 б; 2017). Они относятся по типологии К.Ф. Смирнова к IV типу. Такие псалии широко представлены на Южном Урале (см. обзор: Васильев, 2004; Сиротин, 2015 б. С. 252) в комплексах второй половины IV в. до н.э. (Смирнов, 1961. С. 86; Васильев, 2004. C. 157).

Вызывает интерес псалий с оформлением восьмёркообразных утолщений в виде больших ромбов из насыпи кургана № 10 (рис. 1: 1). Данный псалий имеет аналогии в комплексах Шиповских курганов (курган 9) из Южного Приуралья, а также широко представлен в скифских комплексах Северного Причерноморья и Среднего Дона (См. обзор: Савельев, 2007. С. 332-333, 335. Рис. 1: 1).

Помимо этого, среди найденных псалиев обращает на себя внимание фрагмент железного псалия С-видной схемы из кургана № 7 (рис. 1: 2) (III тип по типологии К.Ф. Смирнова) (Смирнов, 1961. С. 85). Похожие по форме железные псалии также отмечены в ряде южноуральских комплексов (См. обзор: Васильев, 2004. С. 155; Сиротин, 2015 б. С. 252). Псалии такого типа найдены в скифских комплексах Среднего Дона (Савченко, 2009. С. 236-237). В Скифии они получают распространение в IV в. до н.э. Этим же временем, вероятнее всего, их следует датировать для Южного Приуралья. 

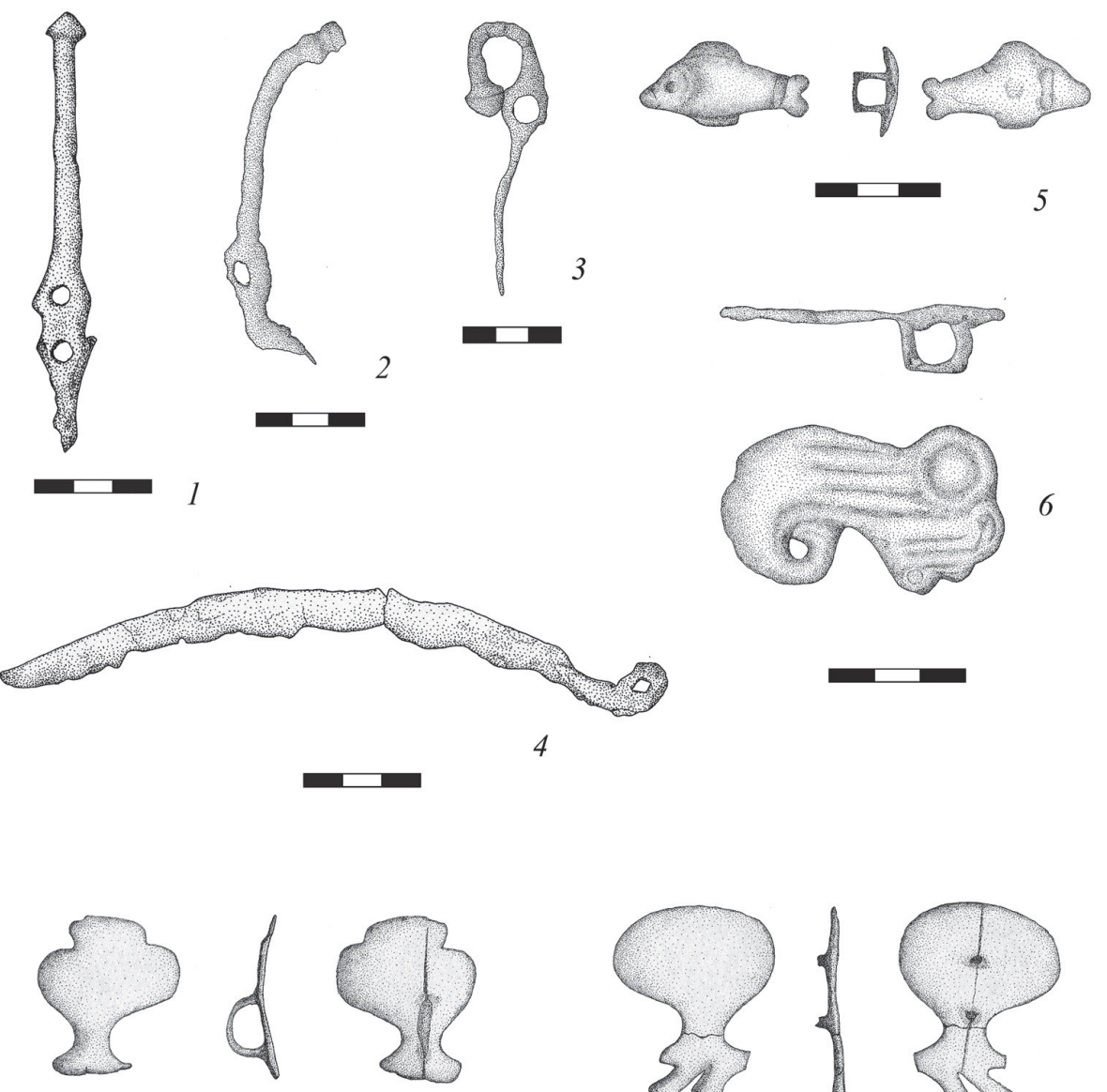

7
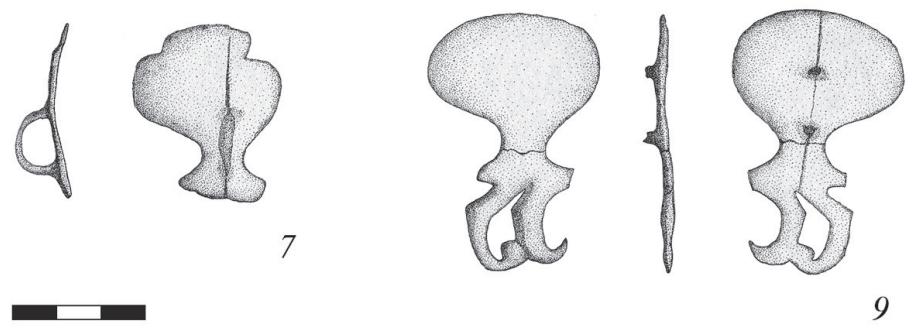

9
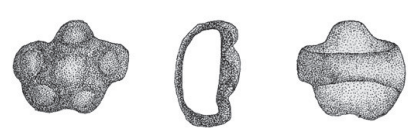

8
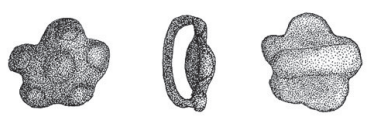

10

Рис. 1. Уздечные принадлежности из курганов некрополя «Ивановские I курганы»:

1, 2 - псалии; 3 - налобник; 4 - дуговидный предмет (нахрапник);

5-10 - уздечные бляхи; 1-4 - железо, 5-10 - бронза 
Налобники. Железные налобники (наносники) с загнутыми в петлю навершиями и шишечкой на окончании найдены в кургане № 5 (рис. 1: 3) и кургане № 10. Такие налобники имеют ряд аналогий в южноуральских комплексах (Васильев, 2004; Сиротин, 2015 б). Более многочисленны находки таких налобников (наносников?) на Среднем Дону. Е.И. Савченко относит их к III типу налобников, которые появились на Среднем Дону в конце V в. до н.э. и более широкое распространение получили во второй половине IV в. до н.э. на обширных территориях Среднего Подонья и Северного Причерноморья (Савченко, 2009. C. 258-260). Считается, что прототипы таких налобников имеются в украшениях скифской узды V-IV вв. до н.э. (Симоненко, 2009. С. 188). В.Н. Васильев определённо относит их ко второй половине или концу IV в. до н.э. (Васильев, 2004. С. 157).

Дуговидный предмет (нахрапник). Железный дуговидный предмет с загнутыми в петли окончаниями (курган № 10) (рис. 1: 4), относящийся к элементам узды повышенной строгости (Вальчак, 2009. С. 126), встречается в раннепрохоровских комплексах Южного Урала IV в. до н.э. (Васильев, 2004; Сиротин, Трейстер, 2014). Подобный по форме (вероятно, и по назначению) предмет, изготовленный из бронзы, был найден в кургане № 4 (жертвенный комплекс № 1) могильника Филипповка I (Сокровища..., 2008. С. 104. № 54). Похожие предметы найдены в кургане у пос. Шолоховский (IV в. до н.э.) (Смирнов, 1984. Рис. 62: 6. С. 136, 139) и в кургане 10 могильника Горки I на Среднем Дону, материалы которого датируются концом третьей четверти IV в. до н.э. (Гуляев, Савченко 2004. С. 43. Рис. 5: 18; Савченко 2009. С. 243-244).

С.Б. Вальчак приводит ещё один комплекс с подобным предметом с территории Румынии (могильник Зимниче) с датировкой IV в. до н.э. и несколько экземпляров из материалов лесостепных городищ скифского времени (Вальчак, 2009. С. 127).

Уздечные бляхи. Среди предметов конского снаряжения в кургане № 7 и № 10 были найдены бронзовые уздечные бляхи.

Бляха с выпуклым щитком, оформленным в виде рельефного изображения рыбки и петлёй на оборотной стороне, была найдена в составе уздечного набора № 1 кургана № 7 (фрагментированные железные удила, фрагменты трёх (?) железных двудырчатых псалиев, бронзовая бляха). На изображении хорошо выделены хвостовой, спинной и брюшной плавники, глаз и жабры (рис. 1: 5).

Примечательной находкой является бронзовая литая уздечная бляха с плоским щитком с рельефным изображением головы хищной птицы (грифона?) с хорошо выраженным глазом и характерно загнутым клювом. На оборотной стороне щитка фиксировалась петля (рис. 1: б). Бляха была найдена в составе уздечного набора № 2 кургана № 7 (фрагмент железных удил (?), двух (?) железных двудырчатых псалиев, две бронзовые бляшки). Вторая бронзовая бляшка из этого же набора была с округлым полусферическим щитком и петлёй на оборотной стороне. 
Помимо этого, в кургане № 7 был найден отдельный комплекс из трёх бронзовых бляшек: бронзовая литая бляшка с плоским полированным щитком неправильной овальной формы и петлёй на оборотной стороне; бронзовая литая бляшка с плоским зооморфным щитком и петлёй на оборотной стороне (рис. 1: 7); бронзовая литая пятилепестковая бляшка из шести полусфер с одной полусферой в центре и массивной петлёй на оборотной стороне (рис. 1: 8).

Кроме того, в кургане найдены единичные бляшки вне наборов или скоплений.

Сломанная бронзовая уздечная бляшка с зооморфным плоским щитком и остатками утраченной в древности петли. Часть деталей изображения, так же как и петля на обороте, были утрачены в древности (рис. 1: 9).

Отдельно были найдены литая бронзовая уздечная бляшка с плоским щитком неправильной овальной формы и петлёй на оборотной стороне и литая бронзовая пятилепестковая бляшка из шести полусфер с одной полусферой в центре и массивной петлёй на оборотной стороне (рис. 1: 10).

В кургане № 10 была найдена одна бронзовая бляшка с плоским щитком округлой формы и петлёй на оборотной стороне.

Особый интерес среди найденных украшений узды вызывают бляхи с зооморфными изображениями: бляха с изображением рыбы, головы грифона и лапы хищного животного.

Изображения рыб на Южном Урале представлены немногочисленными находками бронзовых уздечных блях и оковок деревянных сосудов (см. обзор Фёдоров, 2015; Полидович, Малюк, 2016), а также единственной находкой бронзового двудырчатого псалия, выполненного в виде фигурного изображения рыбы (Сиротин, 2015 б, С. 248. Рис. 1: 3). Найденная в кургане № 7 бляха относится к категории рельефных изображений и имеет наиболее близкие аналогии с бляхой из кургана № 23 могильника Уркач I (раскопки С.Ю. Гуцалова) (Королькова, 2006, С. 170, Табл. 1: 7).

Точные аналогии бляхи с изображением головы хищной птицы (грифона?) среди южноуральских комплексов мне неизвестны. Вместе с тем, подобные бляхи есть в уздечных наборах скифских курганов Северного Причерноморья. Изображение обособленной головы хищной птицы характерно для скифского искусства в широком хронологическом диапазоне, начиная с самых ранних этапов (Канторович, 2015. С. 953). Бляхи с похожими изображениями М.А. ОчирГоряева выделяет в составе уздечных наборов с типичными для скифского звериного стиля образами и мотивами из таких комплексов как Ковалевка-2, к. 6, п. 1; Нимфей, к. 24; Стеблев, к. 7 (Очир-Горяева, 2012. С. 66-67. Илл. 21: $2,12,16)$. Подобные изображения А.Р. Канторович объединяет в особый тип (тип 4 Ковалёвско-басовский) в скифском искусстве конца VI - IV в. до н.э. (Канторович, 2015. С. 957, 1584). Определённые параллели (прежде всего, круто закрученный (волютовидный) клюв) усматриваются и в изображениях на бляхах Ольвийско-завадского (близкого к Ковалёвско-басовскому типу) типа (тип 3), 
оказавшего влияние на соседние скифскому миру территории (Нижняя Волга и Румыния) (Канторович, 2015. С. 956, 1583). Некоторая схожесть отмечается и в изображениях поднепровско-среднедонского Волковецко-елизаветовского стиля (тип 22) (Канторович, 2015. С. 956, 1602). Вероятнее всего, рассматриваемая бляха является местным подражанием блях скифского мира.

Примечательной находкой являются бляхи, изображающие конечности хищников. Так же как и рассмотренная выше бляха с изображением головы хищной птицы, подобные украшения узды характерны для скифских уздечных наборов (Очир-Горяева, 2012. С. 67. Илл. 21: 11).

По наблюдениям А.Р. Канторовича, большинство изображений данного типа характерно для оформления элементов узды и широко представлено в пределах скифской археологической культуры в основном Лесостепного Поднепровья и Подонья, степного Северного Причерноморья, реже, на Северном Кавказе (Канторович, 2012. С. 4). На Южном Урале бляха, имеющая сходный мотив оформления, однако, относящаяся к другой группе изображений, известна лишь в кургане 28 Филипповского I могильника (Канторович, 2012. С. 11, Рис. 3: б). По разработанной А.Р. Канторовичем классификации рассматриваемые бляхи относятся к 1-му отделу II группы изображений (отображение одной ноги). Наиболее близкие аналогии по характеру оформления имеют бляхи типа «Нимфейско-Завадская могила» (тип 7), представленные в комплексах Восточного Крыма (Нимфейский некрополь), Нижнего Поднепровья (I Завадская могила) и Среднего Поднепровья (Берестняги, Перещепенский могильник) второй четверти V в. до н.э. - второй половины V в. до н.э. (Канторович, 2012. С. 20, 21. Рис. 8). Найденные в кургане № 7 нащёчные бляхи также следует рассматривать, на мой взгляд, как местную реплику украшений скифской узды.

Обращают на себя внимание бронзовые литые пятилепестковые бляшки из шести полусфер с одной полусферой в центре и массивной петлёй на оборотной стороне. По стилю исполнения они очень близки к литым крестовидным бляшкам из пяти полусфер (первый вариант III типа по Е.И. Савченко), найденным в комплексах IV в. до н.э. могильников Частые курганы, у с. Русская Тростянка и у с. Колбино на Среднем Дону (Савченко, 2009. С. 279, 320, Рис. 16: 3-10).

Мысль о скифских истоках раннепрохоровского уздечного набора неоднократно высказывалась в литературе (Смирнов, 1961. С. 77, 81; Савельев, 2007. С. 336; Сиротин, 2015 б. С. 253). Если обратиться к элементам, составляющим комплекс конского снаряжения южноуральских номадов конца V - IV в. до н.э., обращает на себя внимание наличие широких аналогий в уздечных наборах Скифии. Наличие большого количества параллелей в скифском мире для южноуральского конского снаряжения констатирует В.Н. Васильев при выделении раннепрохоровского комплекса инвентаря (Васильев, 2004. С. 155-157). Н.С. Савельев, анализируя материалы Шиповских курганов, приходит к выво- 
ду об инородности и миграционном характере всей раннепрохоровской узды (Савельев, 2007. С. 336).

Найденные в курганах некрополя элементы конского снаряжения ярко характеризуют раннепрохоровские уздечные наборы южноуральских кочевников.

Широкие аналогии в скифских комплексах целого ряда предметов, найденных как в курганах могильника «Ивановские I курганы», так и в других раннекочевнических южноуральских комплексах, свидетельствуют о значительном воздействии западных традиций на формирование раннепрохоровского комплекса конского снаряжения.

\section{ЛИТЕРА ТУРА}

Вальчак С.Б. Об одной из функциональных деталей скифской уздечки Восточной Европы // Археология Среднего Дона в скифскую эпоху / Ред. В.И. Гуляев. М.: ИА РАН, 2009. C. 126-140.

Васильев В.Н. К хронологии раннепрохоровского комплекса // Уфимский археологический вестник. Вып. 5. Уфа: Гилем, 2004. С. 153-172.

Гуляев В.И., Савченко Е.И. Новый памятник скифского времени на Среднем Дону // Археология Среднего Дона в скифскую эпоху / Ред. В.И. Гуляев. М.: ИА РАН, 2004. C. 35-52.

Канторович А.Р. Скифский звериный стиль Восточной Европы: классификация, типология, хронология, эволюция. Дисс. ... докт. ист. наук. М., 2015. 1724 с.

Канторович А.Р. Изображения обособленных конечностей хищников в искусстве скифского звериного стиля Восточной Европы: типология, хронология, анализ истоков и эволюция // Stratum plus. 2012. № 3. С. 3-54.

Королькова Е.Ф. Звериный стиль Евразии. Искусство племен Нижнего Поволжья и южного Приуралья в Скифскую эпоху (VII-IV вв. до н.э.). СПб.: Петербургское востоковедение, 2006. 272 с.

Мошкова М.Г. Памятники прохоровской культуры (САИ, А1-10) / Б.А. Рыбаков (общ. ред.). М.: Изд-во Академии наук СССР, 1963. 55 с.

Мышкин В.Н. Конь и сбруя в курганах кочевников // Южного Урала Уфимский археологический вестник. Вып. 12. Уфа: Гилем, 2012. С. 81-96.

Очир-Горяева М.А. Древние всадники степей Евразии. М.: ТАУС, 2012. 469 с.

Полидович Ю.Б., Малюк Н.И. Образ рыбы в искусстве скифо-сарматского времени // Константин Фёдорович Смирнов и современные проблемы сарматской археологии. Материалы IX Международной научной конференции «Проблемы сарматской археологии и истории», посвящённой 100-летию со дня рождения Константина Фёдоровича Смирнова: сборник статей / Ред. Л.Т. Яблонский, Л.А. Краева. Оренбург: Изд-во ОГПУ, 2016. С. 209-215.

Пшеничнюк А.Х. Культура ранних кочевников Южного Урала. М.: Наука, 1983. 199 c.

Савельев Н.C. Конская узда IV-III вв. до н.э. из Шиповских курганов в лесостепи Южного Приуралья // Формирование и взаимодействие уральских народов в изменяющейся этнокультурной среде Евразии: проблемы изучения и историография. Чтения 
памяти К.В. Сальникова (1900-1966). Материалы Международной конференции (2022 апреля 2007 г., г. Уфа) / Отв. ред. В.С. Горбунов, В.А. Иванов, Г.Т. Обыденнова, И.А. Шутелева, Н.Б. Щербаков. Уфа: Китап, 2007. С. 330-339.

Савченко Е.И. Снаряжение коня скифского времени на Среднем Дону как археологический источник // Археология Среднего Дона в скифскую эпоху / Ред. В.И. Гуляев. М.: ИА РАН, 2009. С. 221-325.

Симоненко А.В. Сарматские всадники Северного Причерноморья. СПб.: Факультет филологии и искусств СПбГУ, 2009. 328 с.

Сиротин C.B. Охранные исследования на могильнике «Ивановские I курганы» в 2013-2014 годах // Известия Археологического общества Республики Башкортостан. 2015 а. Вып. 1(2). С. 18-19.

Сиротин C.B. Предметы конской сбруи из насыпей курганов ранних кочевников Южного Урала (по материалам раскопок 2008-2013 годов) // Этнические взаимодействия на Южном Урале. Материалы VI Всероссийской научной конференции / Отв. ред. А.Д. Таиров. Челябинск: Челябинский государственный краеведческий музей, 2015 б. С. 247-255.

Сиротин C.B. Хронология и планиграфия курганного некрополя «Ивановские I курганы» в Зауральской Башкирии // Этнические взаимодействия на Южном Урале. Материалы VII Всероссийской научной конференции / Отв. ред. А.Д. Таиров. Челябинск: Челябинский государственный краеведческий музей, 2017. С. 132-139.

Сиротин С.В., Трейстер М.Ю. Погребение с ближневосточными (?) и центральноазиатскими импортами из кургана Яковлевка II // Сарматы и внешний мир: Материалы VIII Всероссийской (с международным участием) научной конференции «Проблемы сарматской археологии и истории», Уфа ИИЯЛ УНЦ РАН, 12-15 мая 2014 г. / Отв. ред. Л.Т. Яблонский, Н.С. Савельев (Уфимский археологический вестник. Вып. 14). Уфа: ИИЯЛ УНЦ РАН, Центр «Наследие», 2014. С. 207-217.

Смирнов К.Ф. Вооружение савроматов (МИА, № 101). М.: Наука, 1961. 161 с.

Смирнов К.Ф. Савроматы. М.: Наука, 1964. 376 с.

Смирнов К.Ф. Сарматы и утверждение их политического господства в Скифии. М.: Наука, 1984. 183 с.

Сокровища сарматских вождей (Материалы раскопок Филипповских курганов) / Яблонский Л.Т. (ред.). Оренбург: Димур, 2008. 142 с.

Федоров В.К. Уздечные наборы с бляхами в виде рыб из погребений ранних кочевников Южного Урала // Этнические взаимодействия на Южном Урале. Материалы VI Всероссийской научной конференции / Отв. ред. А.Д. Таиров. Челябинск: Челябинский государственный краеведческий музей, 2015. С. 256-260. 


\section{ФРАГМЕНТ ОДЕЖДЫ \\ ИЗ КУРГАНА № 4 ПАМЯТНИКА БУГРЫ \\ (предгорно-степная зона Алтая, скифо-сарматское время)}

(Работа выполнена при финансовой поддержке РНФ (проект № 16-18-10033 «Формирование и эволюция систем жизнеобеспечения у кочевых социумов Алтая и сопредельных территорий в поздней древности и средневековье: комплексная реконструкция»))

\section{Тишкин А.A.}

http://10.25681/IARAS.2019.978-5-317-06274-3/305-316

В ходе археологических исследований курганов скифо-сарматского времени в степной зоне юга Обь-Иртышского междуречья очень редко обнаруживаются погребения, которые не пострадали от грабительских раскопок. Особенно это касается объектов с земляными насыпями больших размеров. Кроме всего, природно-климатические условия не способствуют сохранению изделий из органических материалов. Поэтому любые сведения об одежде древнего населения указанного региона чрезвычайно важны для реконструкции системы жизнеобеспечения социумов, которые оставили хорошо заметные курганы, относимые современными исследователями к каменской археологической культуре. С 2006 года в предгорно-степной зоне Алтая в течение нескольких лет осуществлялась программа по изучению памятника скифо-сарматского времени «Бугры» совместными усилиями специалистов Алтайского государственного университета (г. Барнаул) и Государственного Эрмитажа (г. Санкт-Петербург). Полученные результаты частично опубликованы. В данной статье будет подробно представлена находка, демонстрирующая возможности для частичной реконструкции верхней плечевой одежды. Обнаруженный фрагмент зафиксирован в подземном ходе, который вёл в центральную могилу, рядом с мумифицированными останками погребённого человека, вытащенными грабителями из погребальной камеры. Найденные бляхи-нашивки указывают на их использование в качестве украшений одежды.

Ключевые слова: Алтай, скифо-сарматское время, Бугры, курган, мумифицированные останки человека, фрагмент одежды, бляхи-нашивки

В 2006 г. сотрудники Алтайского государственного университета (г. Барнаул) и Государственного Эрмитажа (г. Санкт-Петербург) приступили к реализации программы исследований курганной группы Бугры, которая располагается в Рубцовском районе Алтайского края возле одноимённого села (рис. 1,1$)$. Было выполнено детальное обследование памятника, осуществлена тахеометрическая съёмка всего археологического комплекса, а также собиралась известная информация о нём (Тишкин, 2006. С. 491; Тишкин, Чугунов, 2008).

В 2007 г. перед началом раскопок двух внешне отличавшихся курганов (№ 1 и 4) проводились геофизические исследования, которые расширили сведения 


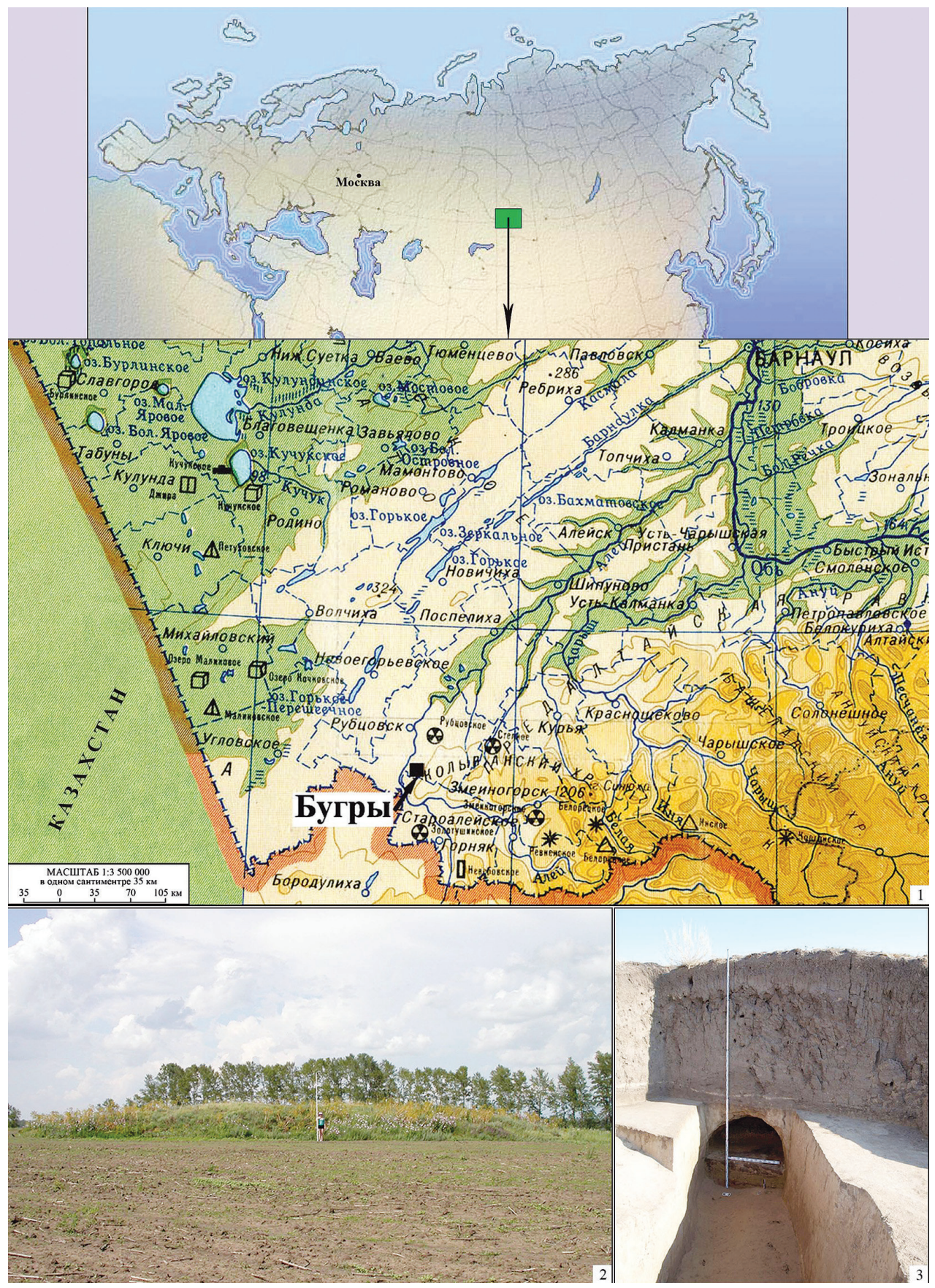

Рис. 1. Бугры. Курган № 4.

1 - место расположения памятника на картах-схемах;

2 - вид сохранившейся земляной насыпи до раскопок;

3 - подземный ход, ведущий от края насыпи в центральную могилу-1

(фоотоснимки выполнены А.А. Тишкиным) 
о структуре насыпей и использовании прикурганной территории. Сложная картина, зафиксированная на магнитограммах, отражала внутреннее устройство надмогильных сооружений, следы многократных проникновений и разрушений, а также особенности современных воздействий (Тишкин, 2007. С. 383-385; Тишкин и др., 2007; Чемякина и др., 2007; Тишкин, Чугунов, 2008. С. 87).

Раскопки кургана № 4, реализованные под руководством автора статьи, в определённой мере подтвердили полученные геофизические данные. Земляная насыпь длительное время опахивалась со всех сторон и частично повреждена бульдозерами (рис. 1, 2). Курган находился в 225 м к северу северо-востоку от центрального и самого высокого объекта (№ 3) в рассматриваемой группе, немного в стороне от основной цепочки древних сооружений, выстроенных на гребне водораздела примерно по линии Ю-С. На его поверхности выявлены 14 грабительских ям и западин разной конфигурации, а также многочисленные норы. Географические координаты центра полностью исследованного объекта № 4 были получены с помощью GPS-приёмника: $\mathrm{N}-51^{\circ} 18.476^{\prime} ; \mathrm{E}-081^{\circ} 25.276^{\prime}$. Диаметр земляной насыпи, сохранившейся к началу археологических работ, составлял около 60 м, а высота - почти 3 м (Тишкин, 2012. С. 503).

После внимательного изучения данных, зафиксированных в ходе обследований, тахеометрической съемки и геофизических исследований, раскопки были начаты в юго-восточной части кургана № 4. На первом же вскрытом участке обнаружился подземный ход (рис. 1, 3), который, как выяснилось позже, шёл от края насыпи между двумя ограбленными могилами, получившими обозначения № 3 и 4, к центральному захоронению (Тишкин, 2007. С. 383-384; Тишкин, Чугунов, 2008. С. 87). Все работы по снятию насыпи кургана и изучению отдельных объектов осуществлялись вручную на современном методическом уровне. При этом реализовывалась программа отбора проб и образцов для проведения естественнонаучных анализов.

Наиболее необычным стало обнаружение в «дромосе» верхней части мумифицированного человеческого тела (рис. 2, 1, 3). Рядом с ней зафиксированы разные археологические материалы, среди которых выделялся крупный фрагмент сохранившейся одежды (рис. 2, 1, 2) (Тишкин, 2009 а. Рис. 1 и 2; Тишкин, 2012. Рис. 2-4; Тишкин и др., 2014. Рис. 7). Основная задача данной статьи - ввести в научный оборот имеющиеся к настоящему времени сведения об этой редкой находке на территории южного Обь-Иртышья для последующей комплексной реконструкции костюма элиты степных кочевников скифосарматского периода.

Следует отметить, что подземный ход представлял собой устроенный в материке длинный и довольно высокий аркообразный коридор (высотой около 1,7 м, местами немного больше или меньше), имевший на момент раскопок участки с пустотой (рис. 1, 3). По всей видимости, он был сделан в древности. Именно через него грабители проникли в центральную могилу (№ 1), откуда 


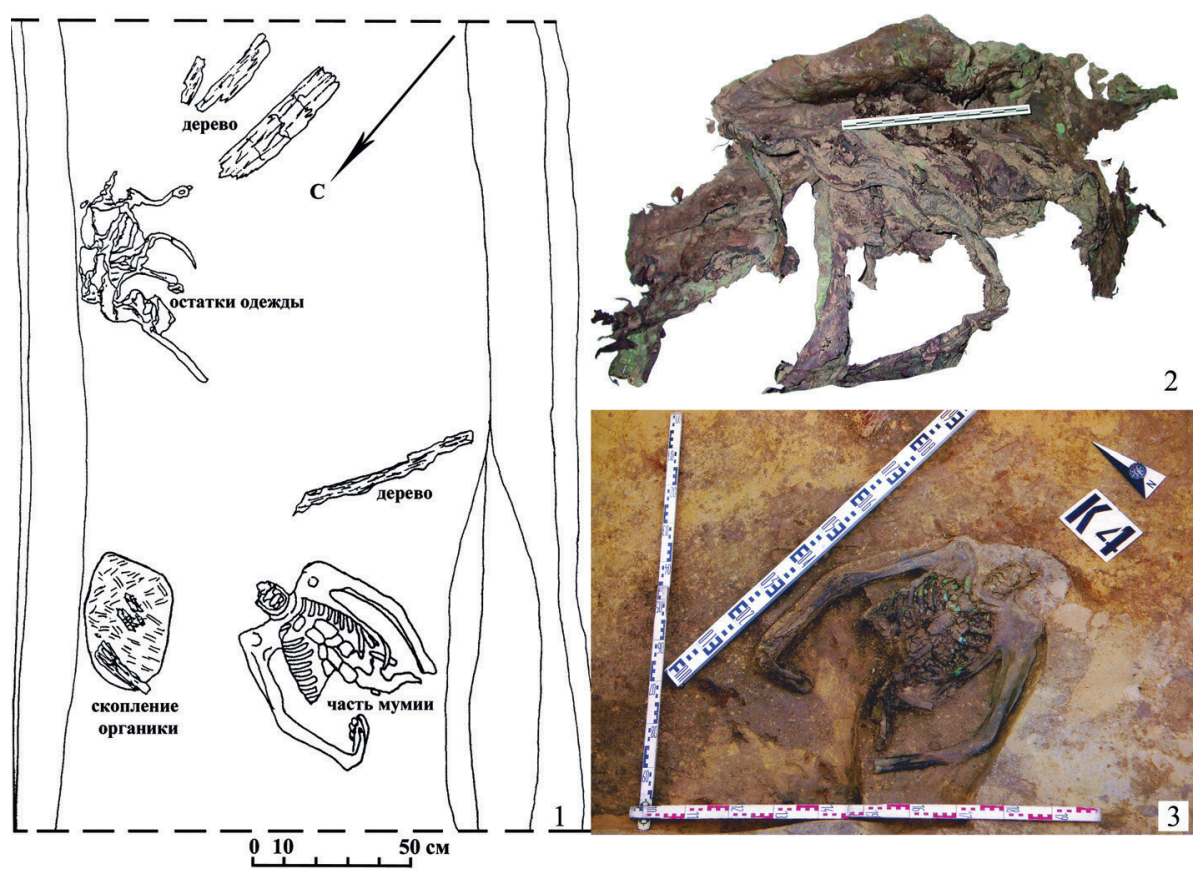

Рис. 2. Курган № 4. Находки в «дромосе». 1 - часть плана (рисунок сделан А.Л. Кунгуровым); 2 - извлечённый фрагмент одежды; 3 - мумифицированные останки погребённого человека (фотоснимки выполнены А.А. Тишкиным)

извлекли погребённого там мужчину ${ }^{1}$ вместе с его вещами. На дне подземного хода находилось существенное число различных предметов. Был обнаружен комплекс украшений, связанный с одеждой, и масса фрагментов от других изделий. Многочисленными находками стали бляхи-нашивки, в том числе хорошо сохранившиеся деревянные фигурки с зооморфными изображениями и остатками нитей для пришивания (Тишкин, 2009 б. Рис. 1; Тишкин, 2012. Рис. 3, 140-141, 144-149; 4, 1, 12-14). Среди прочих археологических свидетельств можно отметить части железных ножей, обломок кинжала и, возможно, часть чекана, инкрустированного толстой золотой фольгой, фрагменты китайского лака и прочее. Своим количеством выделялись металлические нашивки, аналогии которым известны в материалах раскопок одной из гробниц периода

${ }^{1}$ В ходе первичного осмотра отдельных человеческих костей было сделано предположение о том, что в могиле, возможно, была погребена женщина (?) в возрасте не менее 40 лет (Тишкин, 2009 а. С. 245). Однако палеогененетические исследования, осуществлённые в Научном парке СПбГУ, позволили уточнить пол умершего. Оказалось, что мумифицированная часть тела принадлежат мужчине (материалы пока не опубликованы, устное сообщение научного сотрудника Отдела археологии Восточной Европы и Сибири Государственного Эрмитажа К.В. Чугунова). 
Западная Хань в г. Сиане (Китай) (Тишкин, 2012. Рис. 3, 107-139; 4, 8-11). Уже эти материалы в совокупности с обозначенными параметрами демонстрировали то, что курган № 4 памятника Бугры являлся погребальным комплексом представителя «элиты» кочевого социума, проживавшего в предгорно-степной зоне Алтая. Данный факт подтверждает и обнаруженный фрагмент верхней плечевой одежды, который первоначально представлял собой крупный комок органических материалов, покрытых в основном материковым грунтом (рис. 2,1 ). Зафиксированная находка была взята монолитом (рис. 2, 2), упакована и отправлена в Государственный Эрмитаж вместе с мумифицированной частью умершего человека. Там в реставрационной лаборатории доставленный фрагмент очищался от земли и других внешних загрязнений․․ В результате кроме основного куска с наибольшими размерами $56,5 \times 28$ см (рис. $3,1-2 ; 4,1-2$; 5,$1 ; 6,1-4$ ) выявились две полосы, явно с ним связанные (рис. $3,3-4 ; 4,3-4$; $6,5-6)$. Однако дальнейшие реставрационные работы не были проведены изза определённых трудностей. Дело в том, что обнаруженная часть одежды представляет собой совокупность отличающихся материалов (кожа разной толщины, шерсть, мех, остатки металлических изделий и др.), требующих специальных подходов при детальном изучении и последующей консервации. Для такой работы необходима отдельная продуманная программа. На данном этапе важнее всего зафиксировать то, что удалось выявить после удаления загрязнений и частичного распрямления. Для этого автором статьи проводилась детальная фотосъёмка находок ${ }^{2}$, что нашло отражение в иллюстрациях, представленных в данной публикации (рис. $3 ; 5,1 ; 6,1-6$ ). Имевшийся фрагмент и две детали от неё в таком же виде были зафиксированы графически (рис. 4) ${ }^{3}$. После зарисовки предпринимались попытки представить место обнаруженной части на предполагаемой одежде (рис. 6, 7-8). Но эти версии лишь первый шаг к возможной реконструкции, и они требуют основательных подтверждений. Поэтому не исключены другие варианты.

Осмотр крупного фрагмента показал, что общий покрой (вероятнее всего, это была верхняя плечевая одежда в виде утеплённой куртки или кафтана (халата-«шубы»)) состоит из двух основных частей: лицевой и изнаночной (внутренней) (рис. 3, 1-2; 4, 1-2). Вид лицевой поверхности свидетельствует о том, что для верхнего покроя использовалась основа из толстой кожи с различного рода вставками. На большей части её видны чёткие следы от прикреплённых украшений в виде блях-нашивок с «ушками» (рис. 3,$1 ; 5,1 a$ ). Местами хорошо фиксируются окислы от них и оставшиеся металлические

${ }^{1}$ Автор благодарен сотруднице Отдела научной реставрации и консервации Государственного Эрмитажа Елене Алексеевне Чеховой за осуществленную работу.

${ }^{2}$ Автор благодарен научному сотруднику Государственного Эрмитажа Константину Владимировичу Чугунову за организацию фотосъёмки и всей работы по фиксации и изучению находки.

${ }^{3}$ Работа выполнена художницей А.О. Машезерской. 


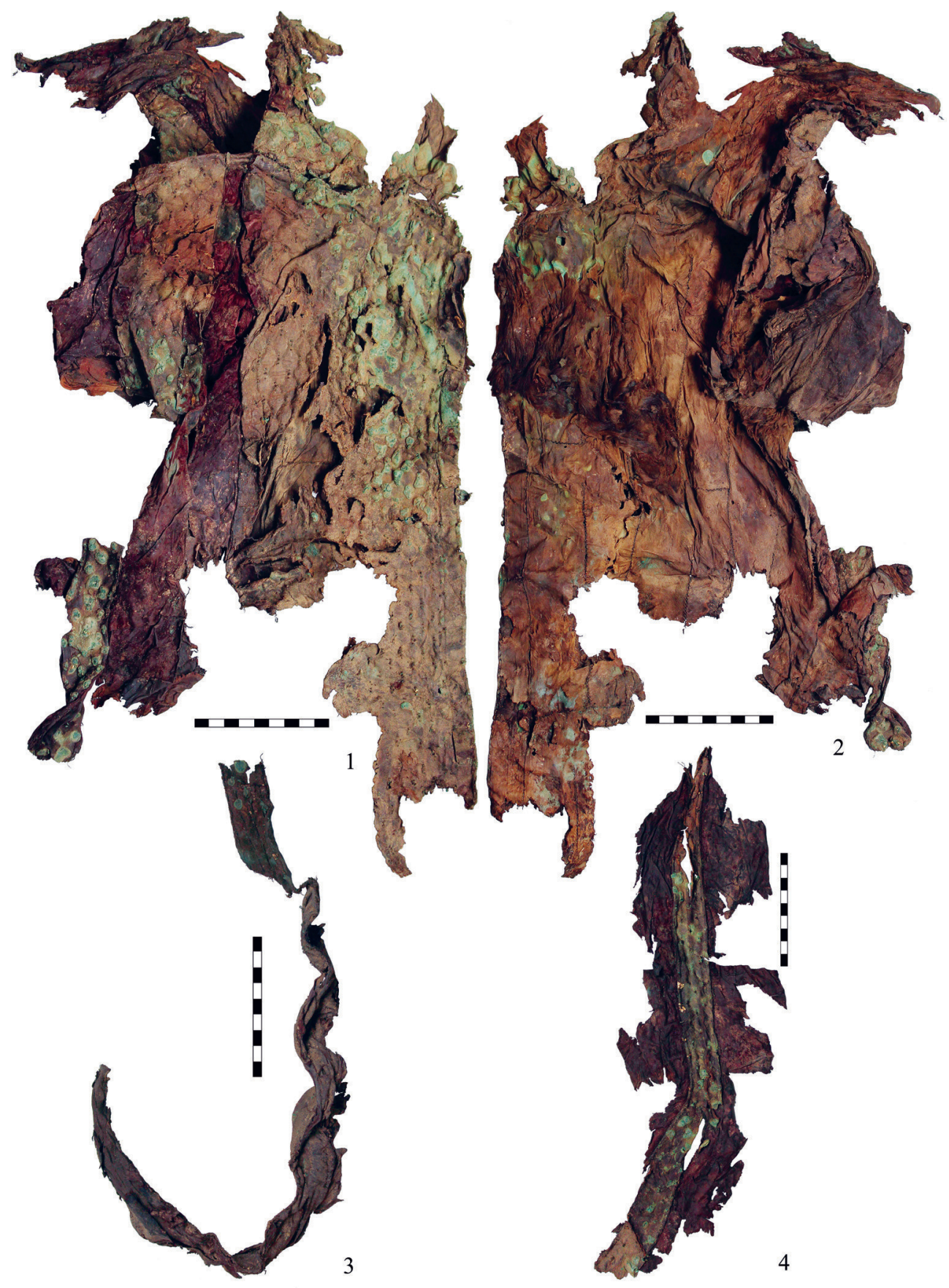

Рис. 3. Фрагмент верхней плечевой одежды после очистки от грунта. 1 - лицевая поверхность; 2 - изнаночная сторона (подкладка); 3, 4 - отделившиеся детали

(фотоснимки выполнены А.А. Тишкиным) 


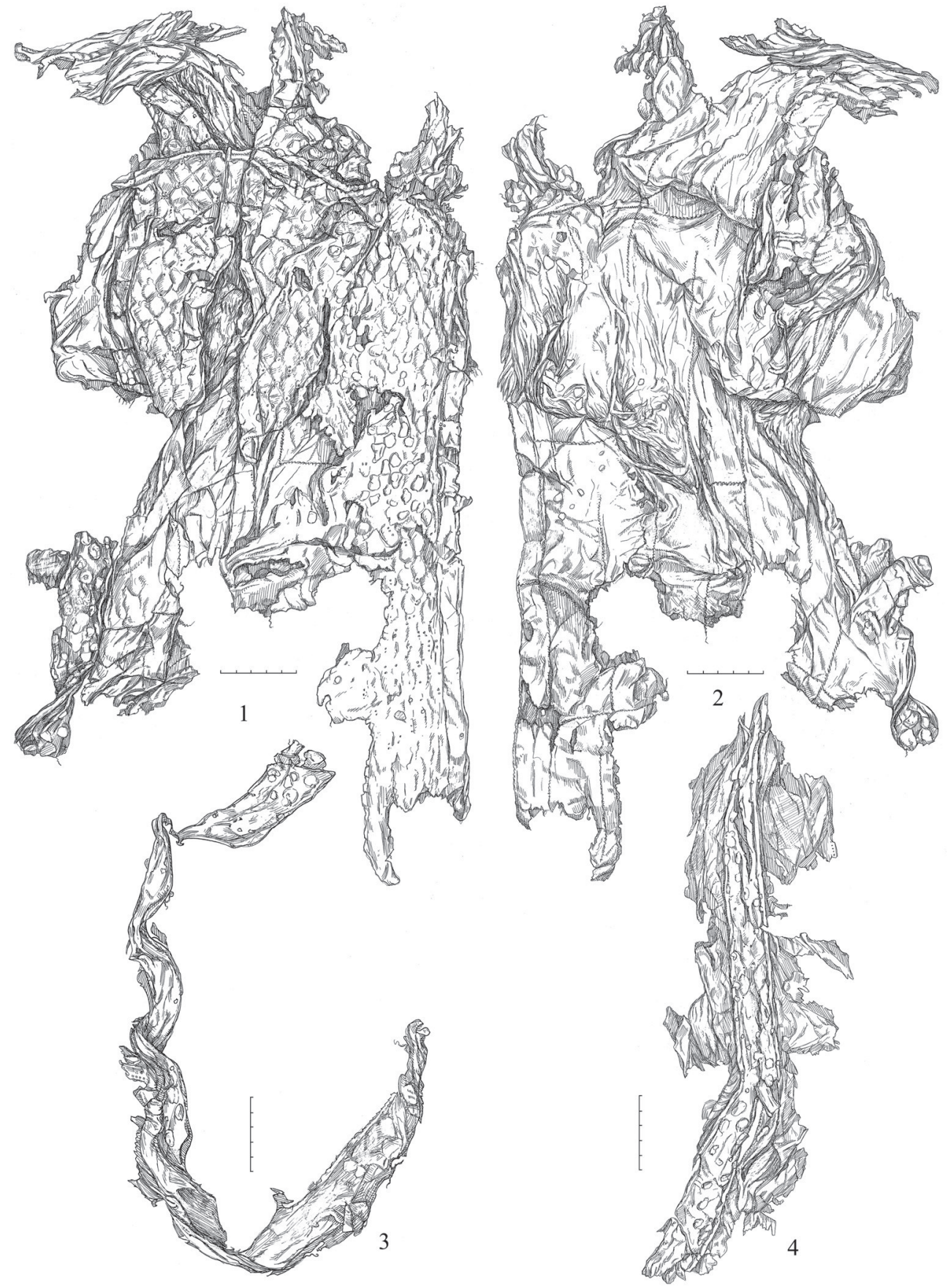

Рис. 4. Графическая фриксация фрагмента одежды

и отделившихся деталей

(рисунки подготовлены А.О. Машезерской) 

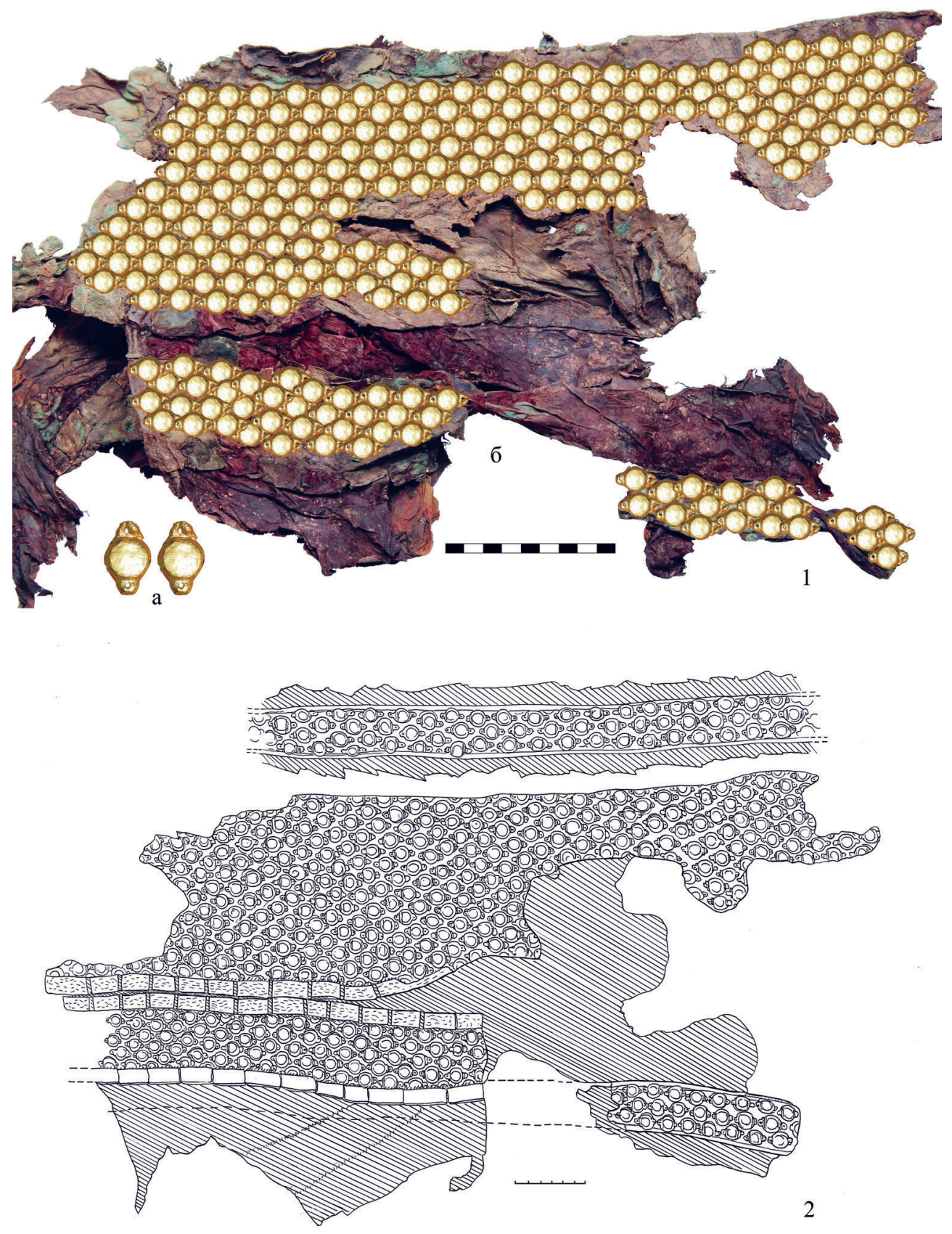

Рис. 5. Реконструкция части одежды

с использованием найденных блях-нашивок:

1 а-б - на сфотографированном фрагменте

(выполнена А.А. Тишкиным и М.Ю. Кузевановой);

2 - на графической схеме (выполнена А.О. Машезерской) 

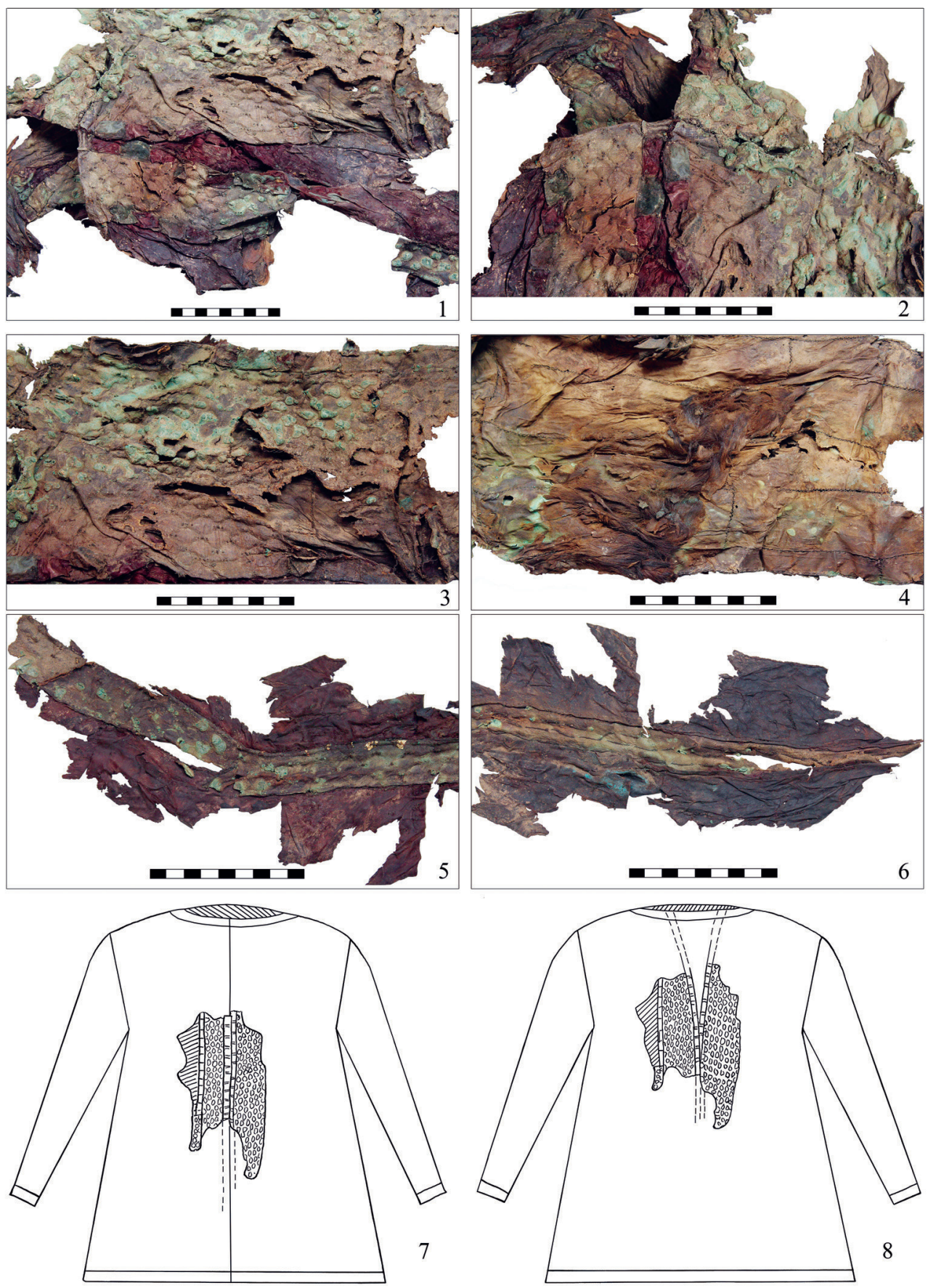

Рис. 6. Детали обнаруженного фрагменты одежды

(1-6, фоотоснимки выполнены А.А. Тишкиным)

и возможные места расположения в предварительной реконструкции

(7-8, графрические схемы подготовлены А.О. Машезерской) 
детали (рис. 6, 1-3). Характерные изделия, покрытые золотой фольгой и использовавшиеся для украшения поверхности одежды, были обнаружены при исследовании подземного хода (рис. 5, 1a) (Тишкин, 2012. Рис. 4, 79-80, 98; Тишкин и др., 2014. Рис. 7), правда, большинство из них оказалось в обломках. Такое чёткое соответствие позволило наглядно восстановить фрагменты лицевого покрытия (рис. $5,16,2$ ), свидетельствующего о «богатом» и ярком костюме. Особое внимание привлекают вставки-полосы (рис. 3, 3-4; 4, 3-4; 6, 5-6), которые, по всей видимости, не только скрепляли детали одежды и предохраняли изделие от деформации, но и выполняли эстетическую функцию. На них тоже имеются отпечатки указанных блях-нашивок (рис. 5, 1; 6, 5-6). Отдельное декорирование представляют собой полосы из чередующихся прямоугольных кусочков кожи с мехом, имеющих разный цвет. Одни бордовой окраски, другие сине-зелёной. Такое визуальное заключение позволяет сделать относительно хорошо сохранившийся фрагмент (рис. 3,$1 ; 6,1-2$ ), а также наличие характерных следов в других местах найденной части одежды (рис. 3, 1; $6,3)$. Видимая цветовая гамма, вероятнее всего, демонстрирует искусственную покраску. Определения перечисленных материалов и красителей ещё не производились. Для этого планируется отдельная работа. Следует указать, что автору статьи не удалось до конца разобраться во всех деталях конструирования и украшения лицевой стороны. Дело в том, что весь имеющийся фрагмент до конца не расправлен, а сам сохранившийся материал оказался довольно уязвимым (хрупким) при работе с ним. Поэтому потребуется дополнительное и неоднократное обследование важной находки совместно со специалистами разных научных направлений. Важным моментом данного процесса может стать полное выпрямление имеющегося фрагмента и детальный осмотр обратных поверхностей, оказавшихся внутри рассматриваемой части изделия.

Изнаночная сторона представляет собой подкладку из сшитых кусков довольно тонкой и тщательно выделанной кожи (рис. 3, 2; 4, 2). В некоторых местах на ней сохранились скопления шерсти и волоса (рис. 3, 2; 6, 4). Хорошо видны линии соединения и укрепления полос прошитыми нитями. Весь этот зафиксированный материал также нуждается в детальной идентификации.

В ходе раскопок кургана № 4 подтвердилось расположение нескольких могил под курганной насыпью. Погребальный обряд и конструктивные особенности зафиксированных внутримогильных сооружений демонстрировали особенности памятников, которые исследователи относят к каменской культуре (Могильников, 1997; Шульга, 2003; Фролов, 2008; Шульга, Уманский, Могильников, 2009; и др.). Имеющиеся радиоуглеродные даты, полученные по древесине из могил-3 и 4 кургана № 4 в лаборатории Института истории материальной культуры РАН и откалиброванные с помощью специальной программы, определяют время сооружения указанных объектов позже III в. до н.э., а основной предметный комплекс укладывается в рамки IV-II вв. до н.э. (Тишкин, 2012. С. 509). 
Ближайшим комплексом находок, связанных с костюмом носителей так называемой каменской культуры является памятник Локоть-4а (Шульга, 2003 ). Но, несмотря на то, что там под одним из курганов обнаружено неограбленное погребение, остатки органической основы одежды не сохранились. При этом тщательная фиксация и детальное изучение золотых украшений позволили П.И. Шульге (2003. С. 67-70, рис. 37) выполнить вероятную реконструкцию куртки, опираясь на известные исследования К.А. Акишева (1978) и С.И. Руденко (1953).

Относительно хорошо сохранившаяся одежда обнаружена в пазырыкских курганах Алтая благодаря мерзлоте, образовавшейся в могиле (Грязнов, 1950; Руденко, 1953, 1960; Полосьмак, 2001; и др.). Верхняя плечевая одежда впервые была найдена В.В. Радловым в 1865 г. ходе раскопок Большого Катандинского кургана (Фирсов, Демиденко, Лантратова, 2008). Эти и другие сведения, несомненно, нужно учитывать в ходе дальнейшей работы. Необходимо отметить, что представленный фрагмент одежды из кургана № 4 памятника Бугры добавляет сведения о костюме древних ираноязычных народов, которые обобщил С.А. Яценко (2006). Все находки, полученные при раскопках указанного объекта, переданы автором статьи на хранение в Государственный Эрмитаж (г. Санкт-Петербург). Планируется дальнейшее проведение реставрации и детальное изучение органических материалов естественнонаучными методами.

\section{ЛИТЕРАТУРА}

Акишев К.А. Курган Иссык. Искусство саков Казахстана. М.: Искусство, 1978. $132 \mathrm{c}$.

Грязнов М.П. Первый Пазырыкский курган. Л.: Изд-во Гос. Эрмитажа, 1950. $92 \mathrm{c}$.

Могильников В.A. Население Верхнего Приобья в середине - второй половине I тысячелетия до н.э. М.: Пущинский научный центр, 1997. 196 с.

Полосьмак Н.В. Всадники Укока. Новосибирск: ИНФОЛИО-пресс, 2001. 336 с.

Руденко С.И. Культура населения Горного Алтая в скифское время. М.; Л.: Издво АН СССР, 1953. 402 с.

Руденко С.И. Культура населения Центрального Алтая в скифское время. М.; Л.: Изд-во АН СССР, 1960. 360 с. + CXXVI табл.

Тишкин A.A. Археологические обследования на Алтае и в Монголии // Проблемы археологии, этнографии, антропологии Сибири и сопредельных территорий. Вып. ХІІ, Ч. 1. Новосибирск: Изд-во Ин-та археологии и этнографии СО РАН, 2006. C. 489-492.

Тишкин A.A. Обзор исследований в Западной Монголии и на Алтае // Проблемы археологии, этнографии, антропологии Сибири и сопредельных территорий. Вып. ХІІІ. Новосибирск: Изд-во Ин-та археологии и этнографии СО РАН, 2007. С. 382-387.

Тишкин A.A. Находка мумифицированной части умершей женщины на памятнике Бугры в северо-западных предгорьях Алтая // Роль естественно-научных методов в археологических исследованиях. Барнаул: Изд-во Алт. ун-та, 2009 а. С. 243-246. 
Тишкин А.А. Программа ксилотомических исследований археологических находок из древних и средневековых памятников Алтая // Роль естественно-научных методов в археологических исследованиях. Барнаул: Изд-во Алт. ун-та, 2009 б. С. 330-332.

Тишкин А.А. Значение археологических исследований крупных курганов скифосарматского времени на памятнике Бугры в предгорьях Алтая // Peregrinationes archaeologicae in Asia et Europa, Joanni Chochorowski dedicatae. Krakow: Instytut Archeologii Uniwersytetu Jagiellonskiego, 2012. С. 501-510 (на рус. яз.)

Тишкин А.А., Зайков В.В., Хворов П.В., Зайкова Е.В. Результаты анализа части золотых находок из кургана № 4 памятника Бугры (северо-западные предгорья Алтая) // Теория и практика археологических исследований. 2014. № 1(9). С. 115-126.

Тишкин A.A., Чугунов K.B. Начало исследований курганов памятника Бугры в предгорьях Алтая // Труды II (XVIII) Всероссийского археологического съезда в Суздале. Т. II. М.: ИА РАН, 2008. С. 86-88.

Тишкин А.А., Чугунов К.В., Чемякина М.А., Дядьков П.Г., Манштейн А.К., Позднякова О.А., Миненко М.И., Адайкин А.А. Геофизические исследования на памятнике Бугры в предгорьях Алтая // Алтае-Саянская горная страна и история освоения её кочевниками. Барнаул: Изд-во Алт. ун-та, 2007. С. 215-220.

Фирсов К.Б., Демиденко Ю.В., Лантратова О.Б. Уникальные одежды из Большого Катандинского кургана на Алтае: проблемы сохранения археологических памятников из собрания ГИМ // Труды II (XVIII) Всероссийского археологического съезда в Суздале. Т. ІІ. М.: ИА РАН, 2008. С. 90-95.

Фролов Я.В. Погребальный обряд населения Барнаульского Приобья в VI в. до н.э. - II в. н.э. (по данным грунтовых могильников). Барнаул: Азбука, 2008. 479 с.

Чемякина М.А., Дядьков П.Г., Манштейн А.К., Позднякова О.А. Предварительные итоги геофизических исследований курганного могильника Бугры // Проблемы археологии, этнографии, антропологии Сибири и сопредельных территорий. Вып. XIII. Новосибирск: Изд-во Ин-та археологии и этнографии СО РАН, 2007. С. 392-397.

Шульга П.И. Могильник скифского времени Локоть-4а. Барнаул: Изд-во Алт. ун-та, 2003. 204 с.

Шульга П.И., Уманский А.П., Могильников В.А. Новотроицкий некрополь. Барнаул: Изд-во Алт. ун-та, 2009. 329 с.

Яиенко С.А. Костюм древней Евразии (ираноязычные народы). М.: Вост. лит., 2006. $664 \mathrm{c}$. 


\section{ПАРФЯНСКАЯ РЕЗНАЯ КОСТЬ ИЗ ПОГРЕБЕНИЙ КОЧЕВНИКОВ АЗИАТСКОЙ САРМАТИИ}

\section{Трейстер М.Ю.}

http://10.25681/IARAS.2019.978-5-317-06274-3/317-327

Рассматриваются резные костяные изделия из погребений кочевников азиатской Сарматии первых веков н.э., которые атрибутируются как парфянские. Они включают рукояти ножей, накладки ножен кинжала и гребни.

Среди них выделяется рукоять ножа из датирующегося первой половиной II в. н.э. погребения могильника Красногоровка-ІІІ в окрестностях Азова, на которой изображён, вероятно, парфянский царь Вологез I (51-78 гг. н.э.). Остальные рукояти ножей, накладки ножен кинжала и гребни являются работой II в. н.э. Их объединяет плоскостная манера декора, выполненного прорезанными линиями с использованием дополнительной раскраски, изображение женских персонажей со сложными причёсками с буклями или животных, помещённых в примыкающие друг к другу арки, орнаментальные фризы в виде «бегущей волны», розетт и венков с перевязями.

Есть все основания предполагать изготовление гребня и рукояти ножа, найденных в кургане № 1 могильника «Горелый-І», в одной мастерской. Находки из этого кургана заслуживают внимание ещё и потому, что и ювелирные украшения, найденные здесь же, также относятся к парфянской работе. Локализация мастерской затруднена ввиду отсутствия близких аналогий и сравнительно ограниченного круга парфянских художественных изделий из кости рассматриваемого времени.

Ключевые слова: Азиатская Сарматия, Нижнее Поволжье, Южное Приуралье Парфия, Вологез I, Беграм, резная кость, рукояти ножей, гребень

15 лет назад, когда я публиковал нож с костяной рукоятью с портретом парфянского царя, предположительно Вологеза I (51-78 гг. н.э.), из погребения № 1 кургана № 18/1989 первой половины II в. н.э. могильника Красногоровка-III в окрестностях Азова, вероятно трофей или царский подарок (рис. 1) (Treister, 2001. Р. 37-51), казалось, что это единственная находка парфянской резной кости в погребениях кочевников азиатской Сарматии. В ходе проекта, посвящённого исследованию погребальных комплексов, включающих импортные предметы, были выявлены и другие изделия из резной кости, которые могут быть атрибутированы как парфянские.

В курганах Нижнего Поволжья и Южного Приуралья II-III вв. н.э. была найдена серия ножей с костяными рукоятями и накладки ножен кинжала, украшенные гравированными изображениями.

В погребении № 1 мальчика 6-7 лет кургана № 24/1980 у с. Кардаилово, датирующемся I-II вв. н.э., костяные пластины, гладкие и с гравированными изображениями, украшали ножны железного кинжала (Моргунова, 1996. C. 18, 41. Рис. 20, б). Одна из них изображает обнажённого мальчика, стоящего с поднятой и закинутой за голову рукой (рис. 2,1 ), и находит параллели как в изображении на гипсовом слепке медальона серебряного сосуда алек- 

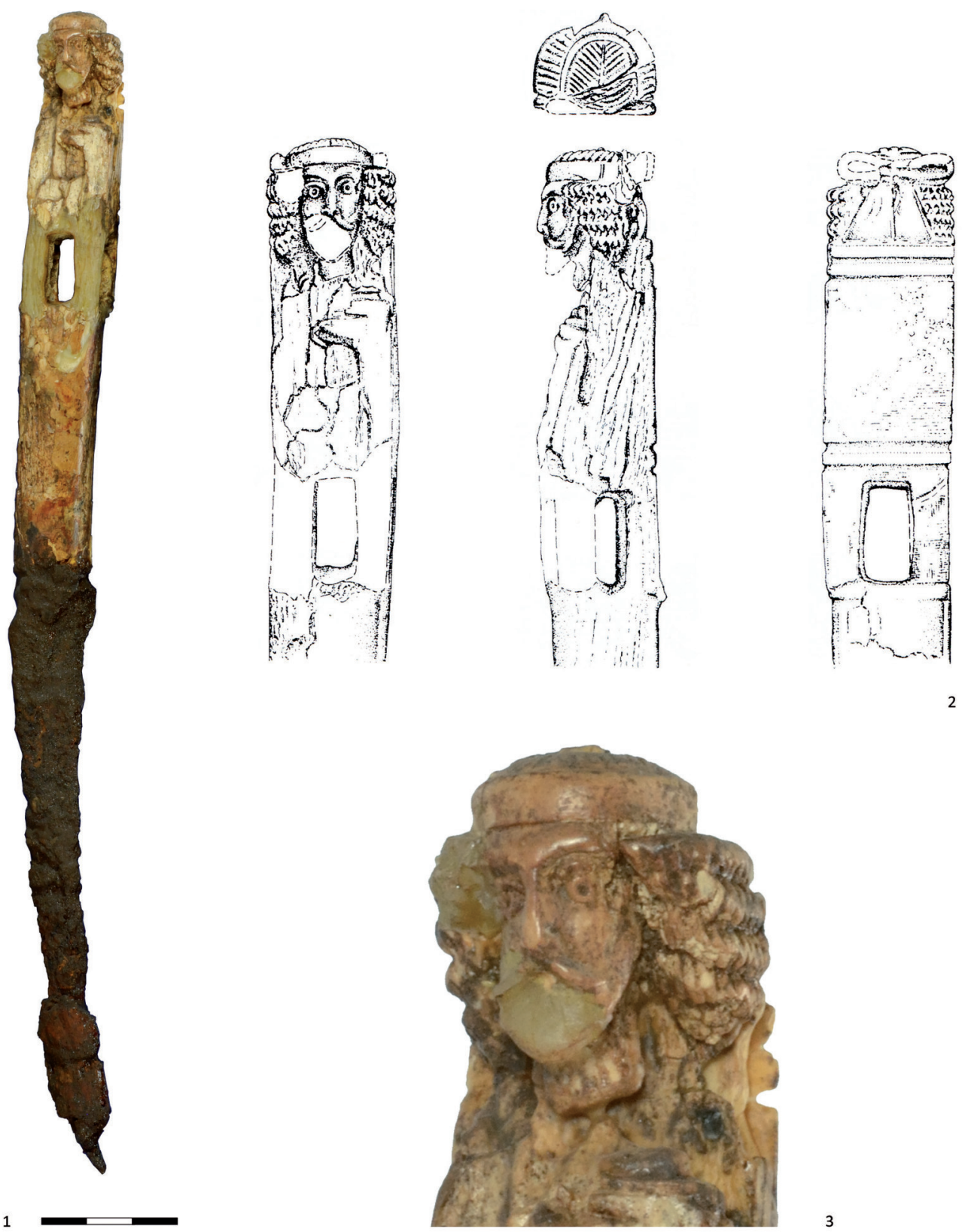

Рис. 1. Красногоровка-ІІІ. Курган 18/1989.

Погребение 1. Нож с фигурной костяной рукоятью.

Азов, Историко-археологический и палеонтологический музей-заповедник, инв. № 24549/1. Фото М.Ю. Трейстера, рисунки В.К. Гугуева 

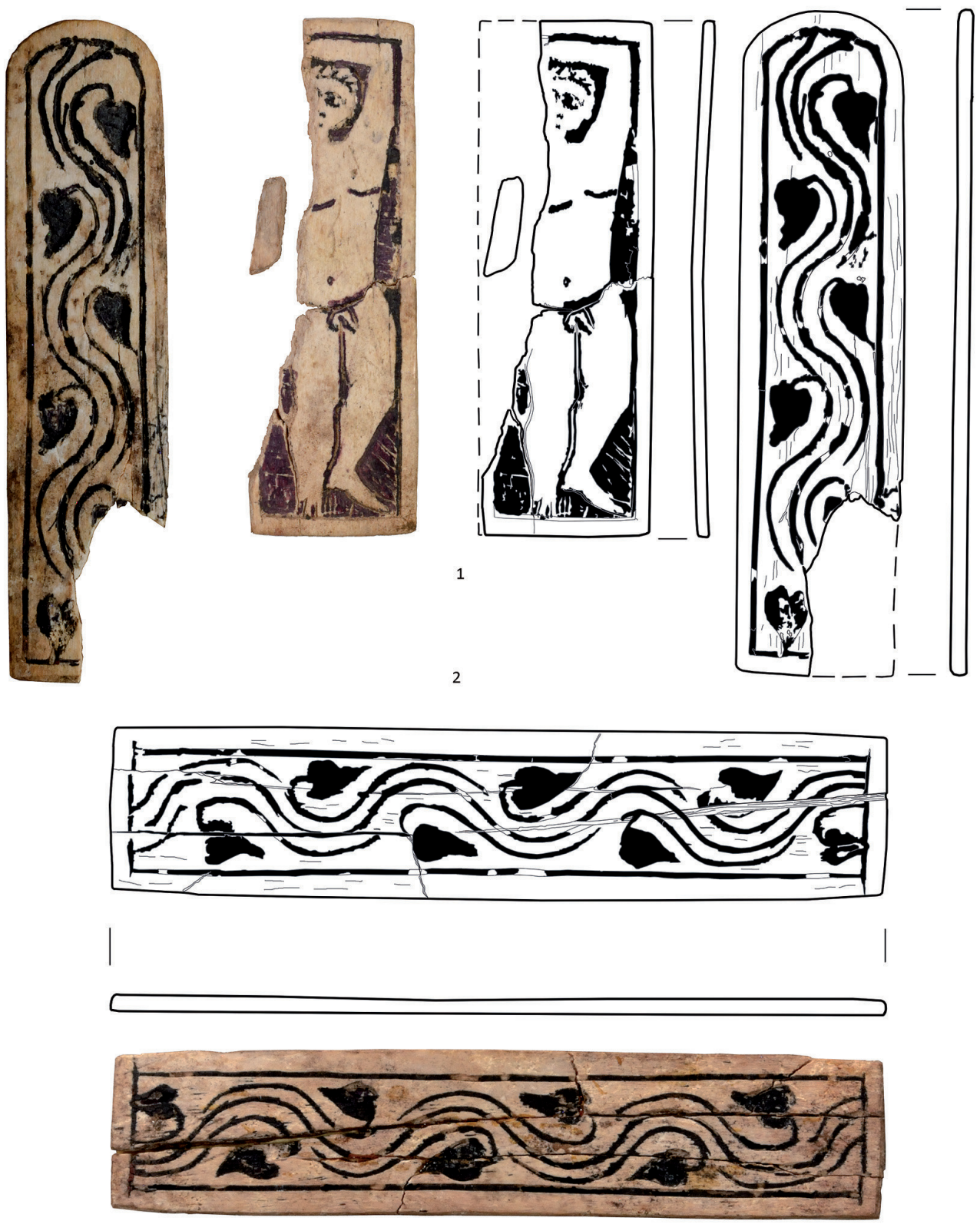

3

Рис. 2. Кардаилово-І. Курган 24/1980.

Погребение 3. Накладки ножен кинжала.

Оренбург, Губернаторский историко-краеведческий музей, инв. № 17342/64-68.

Фото М.Ю. Трейстера, рисунки Н.Е. Беспалой 
сандрийской работы (?) августовского времени из сокровищницы в Беграме (Kurz, 1954. P. 137-146. No. 146. Fig. 317; Menninger, 1996. S. 124-125, 173, M24), так и в искусстве Гандхары, например, на шиферном разделителе сцен из Северо-Западного Пакистана (Alexander der Grosse, 2009. S. 407. Nr. 343). Пластины с декором в виде гирлянды из листьев плюща (рис. 2, 2-3) представляют чрезвычайно популярный мотив, получивший широкое распространение в эпоху эллинизма и в первые века н.э. Особенности изображений на пластинах из Кардаилово - тройные параллельные извивавшиеся линии побегов и крупные листья позволяют сопоставить этот декор с памятниками II в. н.э.: украшением основания алебастрового наиска из храма VII в Хатре (Sumer, Assur, Babylon, 1978. S. 206. Nr. 176) и с оформлением вертикальной полосы одежды на статуе кушанского правителя из Сурх Котала (Ghirshman, 1962. S. 279. Abb. 361; Colledge, 1977. P. 87. Fig. 14a).

Пристальное внимание привлекают две находки из ограбленного женского погребения в кургане № 1/2003 могильника «Горелый-І» у с. Большой Карамыш Саратовской области, который надежно датируется импортными материалами не позднее II в. н.э. Они заслуживают внимание ещё и потому, что и ювелирные украшения, найденные здесь же, также относятся к парфянской работе.

Рукоять ножа (рис. 3) украшена в технике гравировки с затиркой краски в резные линии - её декор образуют розетта и расположенные над ней и под ней венки с перевязями, мотив, встречающийся и на резных костяных пластинах из Беграма (Kurz, 1954. No. 221a. Fig. 111).

Уникальна найденная здесь же верхняя пластина плоского костяного гребня вытянутой формы с закруглёнными верхними углами. Пластина украшена резными изображениями с обеих сторон, обрамлёнными со всех сторон фризом в форме «бегущей волны». Внутри образовавшегося поля представлены погрудные изображения в арках женских персонажей со сложными причёсками с буклями. Изначально фризы на каждой стороне гребня состояли из трёх арок, из которых сохранились полностью две, а с одной стороны гребня - небольшая часть - третьей (рис. 4-5).

В комплексах азиатской Сарматии известны находки костяных гребней, но они не имеют резных изображений, за исключением фрагмента гребня из погребения II в. н.э. в кургане могильника у с. Лебяжье, известного по очень невнятному рисунку (Сергацков, 2000. С. 18, 192. Рис. 14, б). Из находок гребней рассматриваемого времени в Передней и Центральной Азии и Индостане ближайшие по форме, украшенные гравированными изображениями, происходят из Сиркапа (Таксила) (Mehendale, 2001. P. 495-496, 499, 512. Fig. 13; 2012. P. 75-76. Fig. 17; Potts, 2011, 339-340. Figs. 10-11) и Беграма (Hackin, 1939. Р. 7. Fig. 237; Potts, 2011. P. 339-340. Fig. 12). Не исключено, что они, как и некоторые гребни других форм, в частности, находки из Тилля-тепе (Sarianidi, 1985. S. 200. Abb. 142; S. 243, Nr. 3.56; Mehendale 2001, 495, 499, 511, fig. 11; Santoro 

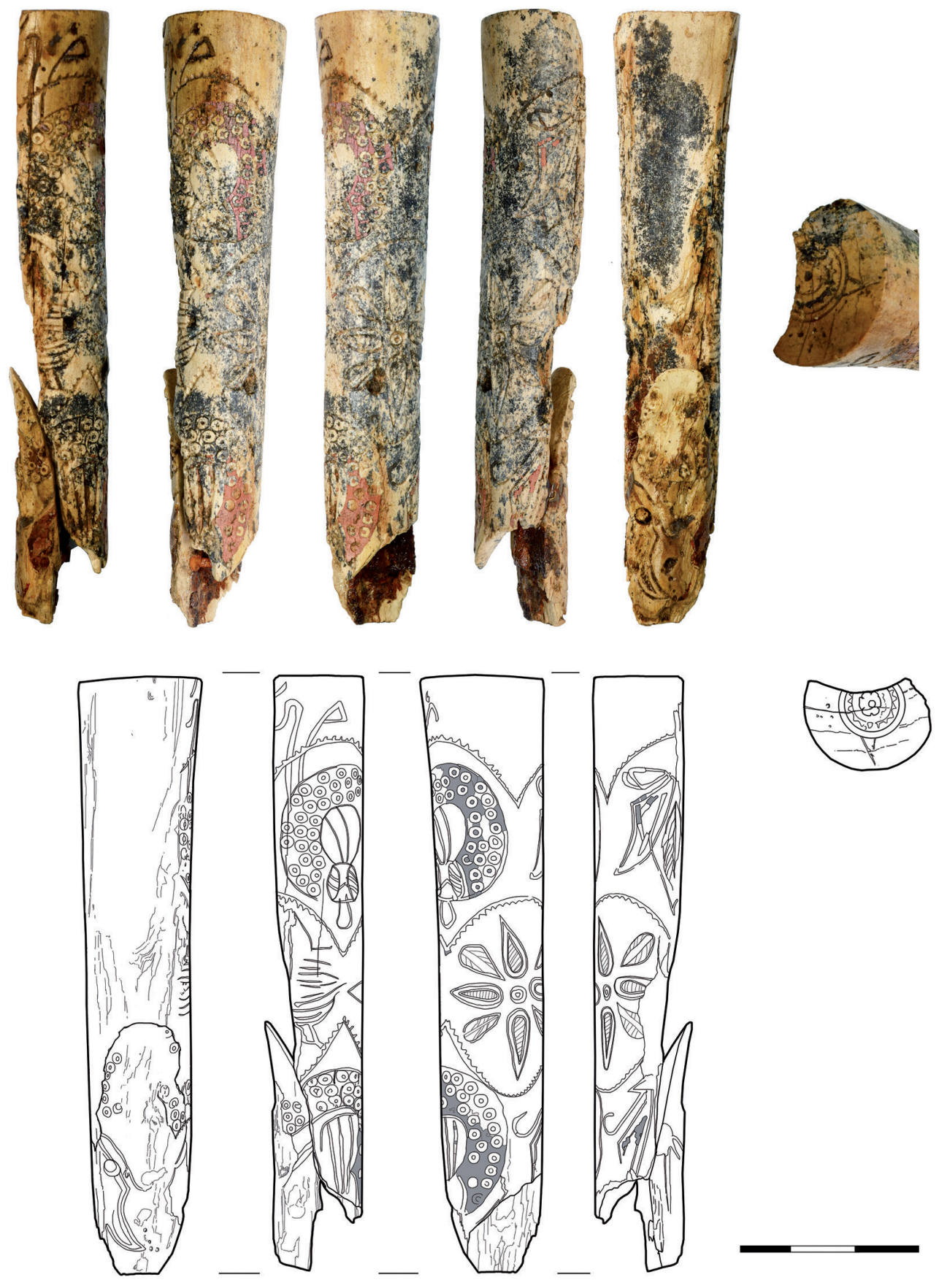

Рис. 3. Горелый-І. Курган 1/2003.

Погребение 1. Рукоять ножа костяная.

Энгельс, Краеведческий музей, инв. № 15351.

Фото М.Ю. Трейстера, рисунки Н.Е. Беспалой 


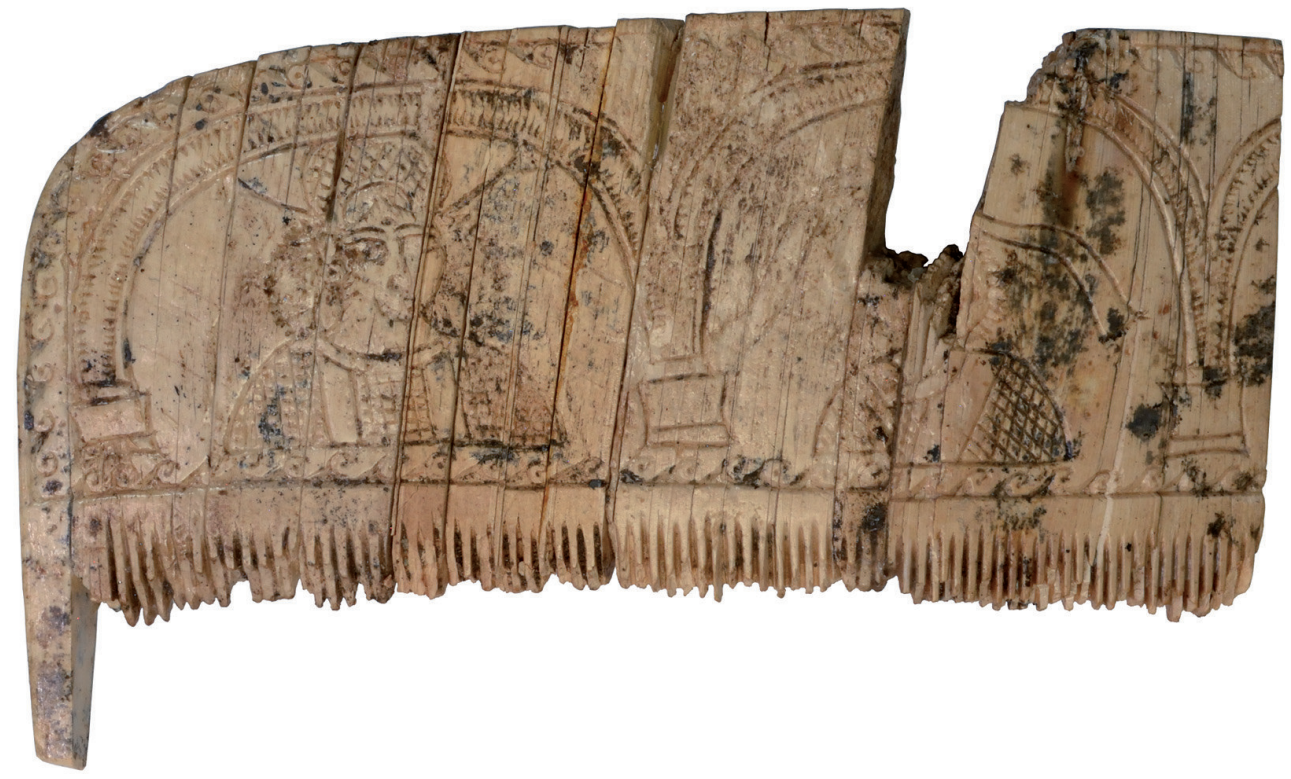

1

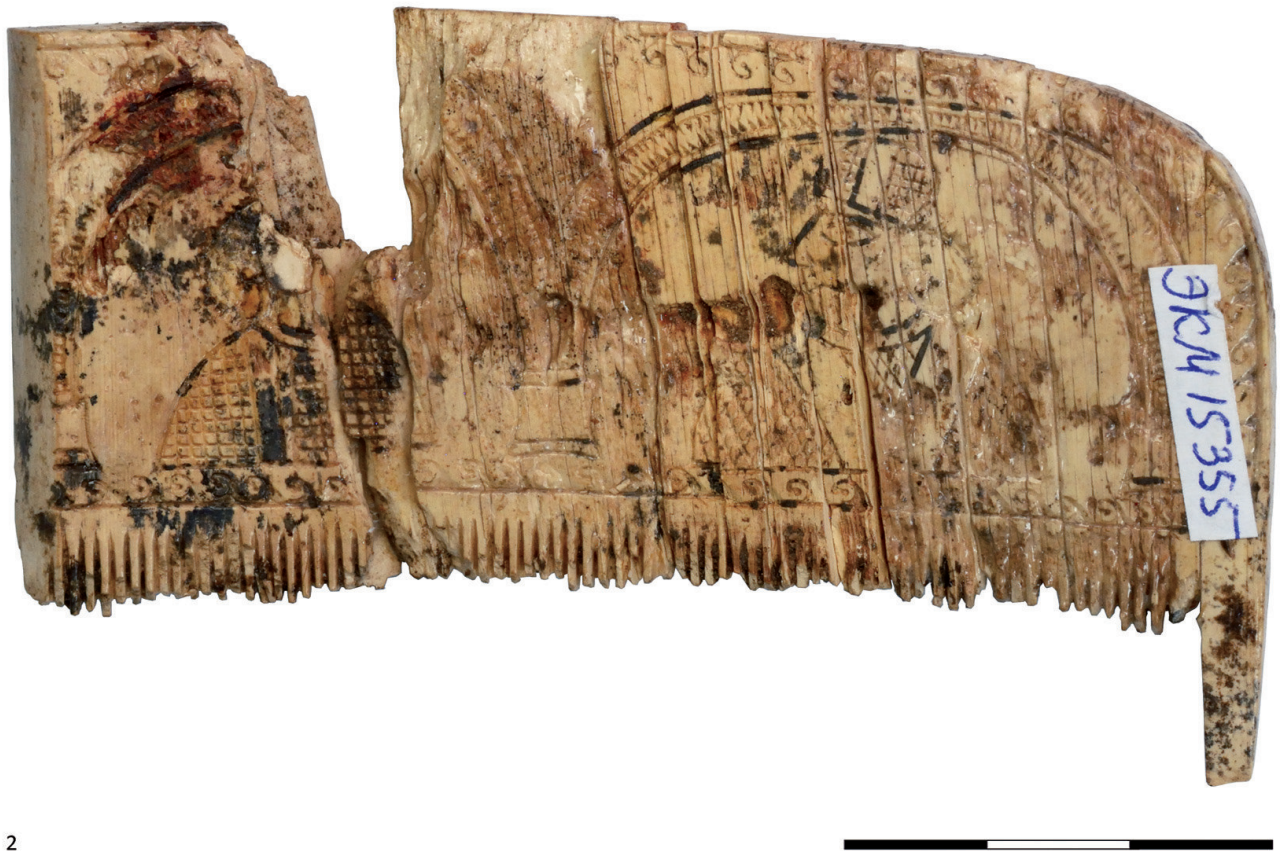

Рис. 4. Горелый-І. Курган 1/2003.

Погребение 1. Гребень костяной.

Энгельс, Краеведческий музей, инв. № 15355.

Фото М.Ю. Трейстера 

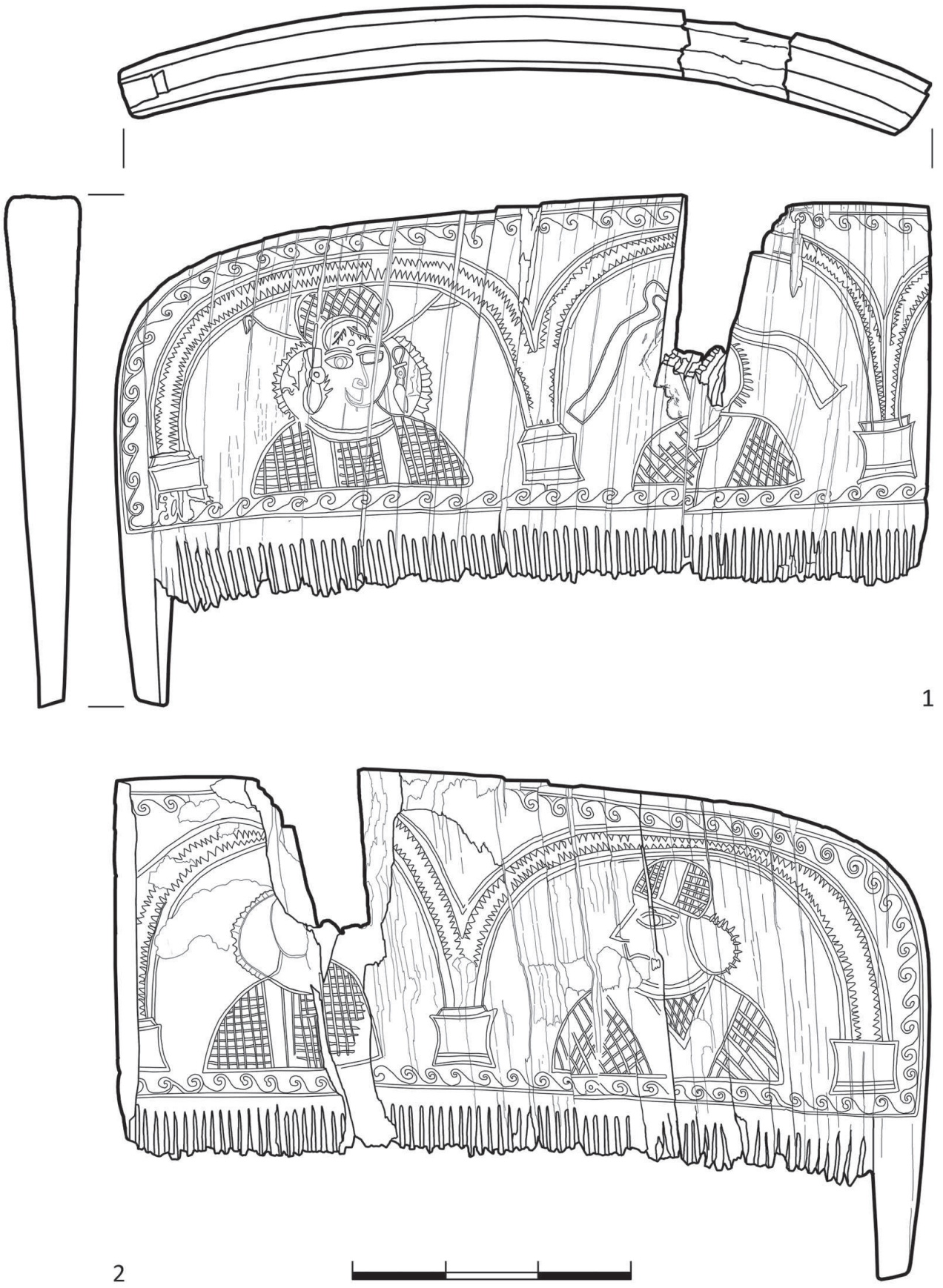

Рис. 5. Горелый-І. Курган 1/2003.

Погребение 1. Гребень костяной.

Энгельс, Краеведческий музей, инв. № 15355.

Рисунки Н.Е. Беспалой 
2009, 104, 105, fig. 3; Potts 2011, 341, figs. 15-16; Mehendale 2012, 75, fig. 17) и Дальверзин-тепе (Pougatchenkova, 1978. P. 87-91. Figs. 65-67; Mehendale, 2001. P. 486, 493-495, 499, 508-509. Figs. 8-9; 2012. P. 74-75. Fig. 16; Santoro, 2009. P. 104, 105. Fig. 4; Potts, 2011. P. 340-341. Figs. 13-14), могли быть изделиями индийских мастеров (Potts, 2011. P. 335-344), что, впрочем, не означает, что их изготовляли в Индии - такая мастерская могла находиться и в Беграме. Тем не менее, ни сюжеты, ни иконография изображений на указанных выше гребнях не находят параллелей на гребне из кургана Горелый. Женские фигуры, изображённые на упомянутых выше гребнях, всегда представлены с обнажённым торсом, а не задрапированным, как на гребне из кургана могильника Горелый-I, или выглядят иначе, как на нанесённом чёрной тушью изображении на гребне из Кампыртепа (Никоноров, 2000. С. 131-138).

Высокая причёска в сочетании с буклями представлена на парфянском глазурованном ритоне в форме женской головы в Нью-Йорке, который датируют приблизительно III в. н.э. (The Metropolitan Museum of Art Bulletin 59. 2, 2001, 13 (J. Aruz)). Однако чаще такие трёхчастные причёски с буклями носили мужчины. Они представлены на царских (?) изображениях костяных пластин из Ольвии (ОАК за 1906 г., 1909. С. 41. Рис. 41; Pharmakovsky, 1907. Sp. 147-148. Abb. 16; 1909. P. 134-135. Fig. 61; Ghirshman, 1962. S. 268, 271, Abb. 352 (слева); Mathiesen, 1992. P. 187. No. 151 с библиографией; Weihrauch und Seide, 1996. S. 228 (Abb.), 397. Nr. 73 (в центре) (Е. Zejmal)) и Меле Хайрам в Юго-Западной Туркмении (Kaim, 2010. P. 325-329. P1. 3; Olbrycht, 2013. S. 86. Abb. 10; Olbrycht, 2015. P. 359. Fig. 17), на глазурованной керамике из Дура Европос (Toll, 1943. Р. 9-10. Fig. 3, H-I. Pl. XX, 1934. 608; Olbrycht, 2013. S. 86. Abb. 11), на терракотовых плакетках из Мерва (Пилипко, 2010. С. 103-115. Рис. 1-4, 9), а также на монетах Осроя I и Вологеза V (Sellwood, 1980. Types 80, 86).

Разделение высокой тиары(?) на ромбы или прямоугольники, возможно, говорит о том, что это не головной убор, а сетка для волос (ср. Sumer, Assur, Babylon, 1978. S. 195. Nr. 164). Укажем также на то, что подобным образом оформлены причёски обнажённых юношей на резных костяных пластинах из Меле Хайрам, датированных II в. н.э. (Kaim, 2010, 323-324. Pl. 2), и у фигурок на навершиях булавок первой половины II в. н.э. из Бактрии, Хорезма (Трудновская, 1981. С. 117. Рис. 57; Guillaume, Rougeulle, 1987. P. 81. No. F3. Pl. XXIV, 11; Rtveladze, 2011. P. 161-163. Figs. 5-6; Ilyasov, 2016. P. 18-19. Fig. 5-6) и из Селевкии на Тигре (из слоя, относящегося к 115-227 гг. н.э.) (Van Ingen, 1939. P. 342-343. Pl. XXIV, 616-618). Аналогичным образом оформлены и прически обнажённых мальчиков-флейтистов и танцовщиц на пластинах из Ольвии (ОАК за 1906 г., 1909. С. 40-43. Рис. 36, 38, 40, 42-48; Pharmakovsky, 1907. Sp. 147-152. Abb. 18, 20-28; 1909. P. 135, figs. 63-65; Ghirshman, 1962. S. 268. Abb. 348). Расчерченная на ромбы тиара представлена на скульптурном портрете парфянского царя из Хатры II в. н.э. (Ghirshman, 1962. S. 91. 
Abb. 102). Подобным же образом расчерченный на ромбы головной убор изображён на голове «царя» на фреске дворца в Кухе-Ходжа в Сейстане I в. н.э. (Ghirshaman, 1962. S. 42. Abb. 56).

Близким образом, в обрамлении из арок в парфянской терракоте изображались богини - на форме для оттиска вотивов, приобретённой в Алеппо и датированной II-III вв. н.э. (Ghirshman, 1962. S. 107. Abb. 123; Mathiesen, 1992. P. 219. No. 227. Fig. 85; Weihrauch und Seide, 1996. S. 229 (Abb.), 398. Nr. 75), на терракотах из Дура Европос (Downey, 2003. P. 53-55. Nos. 7-8. Figs. 6-7), Селевкии на Тигре (Menegazzi, 2005. P. 89. Figs. 15-16) и Арташата (Arménie, 1996. Р. 242-243. Nos. 250, 252). Аналогичным образом обрамлены фигуры танцовщиц и мальчиков-флейтистов на пластинах из Ольвии (ОАК за 1906 г., 1909. С. 40-43. Рис. 36, 43-48; Pharmakovsky, 1907. Sp. 149-152. Аbb. 22-28; 1909. Р. 135, figs. 63, 65; Ghirshman, 1962. S. 268. Abb. 348).

Рукояти ножей, детали декора ножен кинжала и гребень являются работой II в. н.э. Их объединяет плоскостная манера декора, выполненного прорезанными линиями с использованием дополнительной раскраски, использование мотивов соединённых между собой арок (двойных и тройных), фризы «бегущей волны».

Есть все основания предполагать изготовление гребня и рукояти ножа, найденных в кургане № 1 могильника Горелый-І в одной мастерской. Об этом, в частности, свидетельствует использование характерных дугообразных линий с выступами для обозначения буклей персонажей на гребне и в обрамлении элементов декора на рукояти ножа. Локализация мастерской в пределах Парфянской державы представляет, однако, на сегодняшний день трудно разрешимую задачу ввиду отсутствия близких аналогий и в связи с довольно ограниченным кругом парфянских художественных изделий из кости рассматриваемого времени.

Публикация выполнена в рамках проекта, финансируемого DFG и РГНФ «Формы и пути культурных контактов кочевников Азиатской Сарматии. Импорты в сарматских памятниках II в. до н.э. - III в. н.э.» (FL-334/15-1). Партнер проекта с российской стороны - Б.А. Раев. Моя искренняя благодарность М.Е. Филимоновой (Азов), Е.Н. Плаховой (Энгельс) и О.А. Халяпиной (Оренбург) за возможность работы с находками в музеях.

\section{ЛИТЕРАТУРА}

Моргунова Н.Л. Курганы у сел Краснохолм и Кардаилово в Илекском районе // Археологические памятники Оренбуржья / Н.Л. Моргунова (ред.). Оренбург: Димур, 1996. С. 8-43.

Никоноров В.П. Уникальный гребень из Кампыртепа // Материалы Тохаристанской экспедиции 1. Археологические исследования Кампыртепа / Э.В. Ртвеладзе, Дж. Ильясов (ред.). Ташкент: SAN'AT, 2000. С. 131-138. 
Пилипко В.Н. Об одной группе «мужских» терракот из Мерва // ПИФК. 2010. № 1. C. 103-115.

Сергацков И.В. Сарматские курганы на Иловле. Волгоград: Изд-во ВолГУ, 2000. 394 c.

Трудновская C.A. Предметы вооружения и быта. Украшения // Городище Топраккала (Раскопки 1965-1975 гг.) (Труды ХАЭЭ. Т. 12). М.: Наука, 1981. С. 101-123.

Alexander der Grosse und die Öffnung der Welt / S. Hansen, A. Wieczorek, M. Tellenbach (Hrsg.). Regensburg: Schnell, Steiner, 2009. 447 S.

Arménie. Trésors de l'Arménie ancienne des origines au IVe siècle / J. Santrot (ed.). Paris: Somogy, 1996. 288 p.

Downey S.B. Terracotta Figurines and Plaques from Dura-Europos. Ann Arbor: Univ. of Michigan Press, 2003. 220 p.

Ghirshman R. Iran. Parther und Sasaniden. München: C.H. Beck, 1962. 408 S.

Guillaume O., Rougeulle A. Fouilles d'Ai Khanoum. T. VII. Les petit objets (MDAFA 31). Paris: de Boccard, 1987. 90 p.

Hackin J. Recherches archéologiques à Begram. Chantier No. 2 (1937). (MDAFA 10). Paris: Éd. d’Art et d’Histoire, 1939. 137 p.

Ilyasov J. Works of Applied Art from Kushan Bactria // San'at. 2016. No. 3. P. 16-19.

Kaim B. Bone Reliefs from Fire Temple at Mele Hairam, South-West Turkmenistan // Iranica Antiqua. 2010. Vol. XLV. P. 321-335.

Kurz O. Begram et L’Occident Gréco-Romain // Hackin J., Kurz O., Hamelin P. Nouvelles recherches archéologiques à Begram (ancienne Kâpicî) (1939-1940) (MDAFA 11). Paris: Impr. nationale, 1954. P. 93-146.

Mathiesen H.E. Sculpture in the Parthian Empire. A Study in Chronology. Aarchus: Aarhus Univ. Press, 1992. 231 p.

Mehendale $S$. The Begram Ivory and Bone Carvings: Some Observations on Provenance and Chronology // Topoi. 2001. Vol. 11. P. 485-514.

Mehendale S. The Begram Carvings: Itenerancy and the Problem of the «Indian»Art // Afghanistan: Forging Civilizations along the Silk Road/ J. Aruz, E. Valtz Fino (eds.). New York: The Metropolitan Museum of Art, 2012. P. 64-77.

Menegazzi R. Le figure femminili ammantate nella coroplastica di Seleucia al Tigri // Parthica. 2005. Vol. 7. P. 81-92.

Menninger M. Untersuchungen zu den Gläsern und Gipsabgüssen aus dem Fund von Begram/Afghanistan. Würzburg: ERGON-Verlag, 1996. 259 S.

Olbrycht M. Die Geschichte der Seidenstraße in antiker Zeit // Die Krim. Goldene Insel im Schwarzen Meer. Griechen - Skythen - Goten / LVR - Landesmuseum Bonn (Hrsg.). Bonn: Landesmuseum, 2013. S. 67-87.

Olbrycht M. Arsacid Iran and the Nomads of Central Asia - Ways of Cultural Transfer // Complexity of Interaction along the Eurasian Steppe Zone in the First Millenium CE / J. Bemmann, M. Schmauder (eds.). Bonn: Rheinische Friedrich-Wilhelms-Universität, 2015. P. 333-390.

Pharmakovsky B. Archäologische Funde im Jahre 1906. Südrußland // AA. 1907. S. 126-153.

Pharmakowsky B. Olbia 1901-1908. Fouilles et trouvailles // ИАК. 1909. Вып. 33. P. 103-137. 
Potts D.T. Indianesque Ivories in Southeastern Arabia // Un impaziente desiderio di scorrere il mondo. Studi in onore di Antonio Invernizzi per il suo settantesimo compleanno (Monografie di Mesopotamia, XIV) / C. Lippolis, S. de Martino (eds.). Firenze: La Lettere, 2011. P. 335-344.

Pougatchenkova G. Les trésors de Dalverzine-Tépé. Leningrad: Aurore. 1978. 98 p. Rtveladze E.V. Parthians in the Oxus Valley // Anabasis. 2011. Vol. 2. P. 149-178.

Santoro A. Influssi di cultura Indiana // Parthica. 2009. Vol. 11. P. 103-112.

Sarianidi V.I. Baktrisches Gold. Leningrad: Aurora, 1985. 262 S.

Sellwood D. An Introduction to the Coinage of Parthia. $2^{\text {nd }}$ ed. London: Spink \& Son, 1980. 322 p.

Sumer, Assur, Babylon. 7000 Jahre Kunst und Kultur an Euphrat und Tigris / E. Strommenger (Hrsg.). Mainz: Philipp von Zabern, 1978. 165 S.

Toll N. The Green-Glazed Pottery (Excavations at Dura-Europos. Final Report IV. Part 1. Fasc. 1). New Haven: Yale Univ. Press, 1943. 95 p.

Treister M. A Portrait of a Parthian King on an Ivory Dagger Handle from Sarmatian Burial in the Lower Don Basin // SRAA. 2001. Vol. 7. P. 37-51.

Van Ingen $W$. Figurines from Seleucia on the Tigris. Ann Arbor: Univ. of Michigan Press, 1939. 374 p.

Weihrauch und Seide: alte Kulturen an der Seidenstrasse / W. Seipel (Hrsg.). Wien: Skira, 1996. 452 S. 


\title{
ПОГРЕБЕНИЕ СРЕДНЕСАРМАТСКОГО ВРЕМЕНИ В ОКРЕСТНОСТЯХ ТАНАИСА С КИТАЙСКОЙ ЛАКОВОЙ ЧАШЕЙ «ЭР БЭЙ»
}

\author{
Прюх М., Трейстер М.Ю.
}

http://10.25681/IARAS.2019.978-5-317-06274-3/328-337

В 1987 г. экспедицией Ростовского университета в кургане № 46 могильника «Царский», в окрестностях Танаиса, было открыто погребение женщины с ребёнком последней трети I - первой половины II в. н.э. Среди находок в заполнении могильной ямы Л.С. Ильюков отметил «лоскутки красной и чёрной краски с поверхности истлевшего ларца». Эти фрагменты были атрибутированы одним из авторов во время работы в фондах Музея-Заповедника Танаис в 2015 г. как остатки лака китайского изделия.

Декор фрагментов (в частности мотив «двойного феникса») позволяет определить их как части чаши с боковыми выступами-ручками erbei 耳杯 ханьского времени. Такие чаши производили как в государственных, так и в частных мануфактурах, чаще в виде наборов. Качество росписи сохранившихся фрагментов свидетельствует о том, что чаша из могильника «Царский» была изготовлена в одной из государственных мастерских Шу и Гуанхань в совр. провинции Сычуань. Такие чаши изготавливались начиная со среднего периода династии Западной Хань, т.е. ок. 150 г. до н.э., и продолжали оставаться в репертуаре лакового производства и в период династии Восточной Хань, примерно до 80 г. н.э.

Ключевые слова: Нижний Дон, могильник «Царский», Танаис, среднесарматский период, китайские лаковые изделия, чаши эр бей, мотив «двойного феникса», династия Хань, Евразия

В 1987 г. экспедиция лаборатории Ростовского государственного университета исследовала могильник «Царский», расположенный с напольной стороны Танаиса на водоразделе балок: Каменной и Донской Чулек, впадающих в р. Мёртвый Донец. Здесь было выявлено 13 курганов с погребениями, датированными I-II вв. н.э. (Ильюков, 1994. С. 198-214). В погребении кургана № 46 были обнаружены разрушенные скелеты женщины и ребенка. Инвентарь включал (Ильюков, 1994. С. 202-203. Рис. 3): железный нож (рис. 1, 7), бисер из гешира и стекла (рис. 1, 1-3), фрагменты алебастрового сосуда (рис. 1, 6) и диска бронзового зеркала с валиком по краю (рис. 1, 4), железную иглу (рис. 1, 5), гончарные: кувшин с биконическим туловом (утрачен?; Ильюков, 1994. С. 203. Рис. 3, 9) и высоким горлом и сероглиняный - с цилиндрическим горлом, округлым туловом и вертикальной петлеобразной ручкой (рис. 2). Кувшин из погребения (рис. 2) и найденные в насыпи фрагменты двух светлоглиняных амфор типа В (Ильюков, 1994. С. 202. Рис. 2, 19; 3, 4) позволяют датировать погребение в рамках последней трети I - первой половины II в. н.э.

Среди находок в заполнении могильной ямы Л.С. Ильюков (1994. С. 202. Рис. 3, 6) отметил «лоскутки красной и чёрной краски с поверхности истлевшего ларца». Эти фрагменты, хранящиеся и частично экспонирующиеся в Музее 


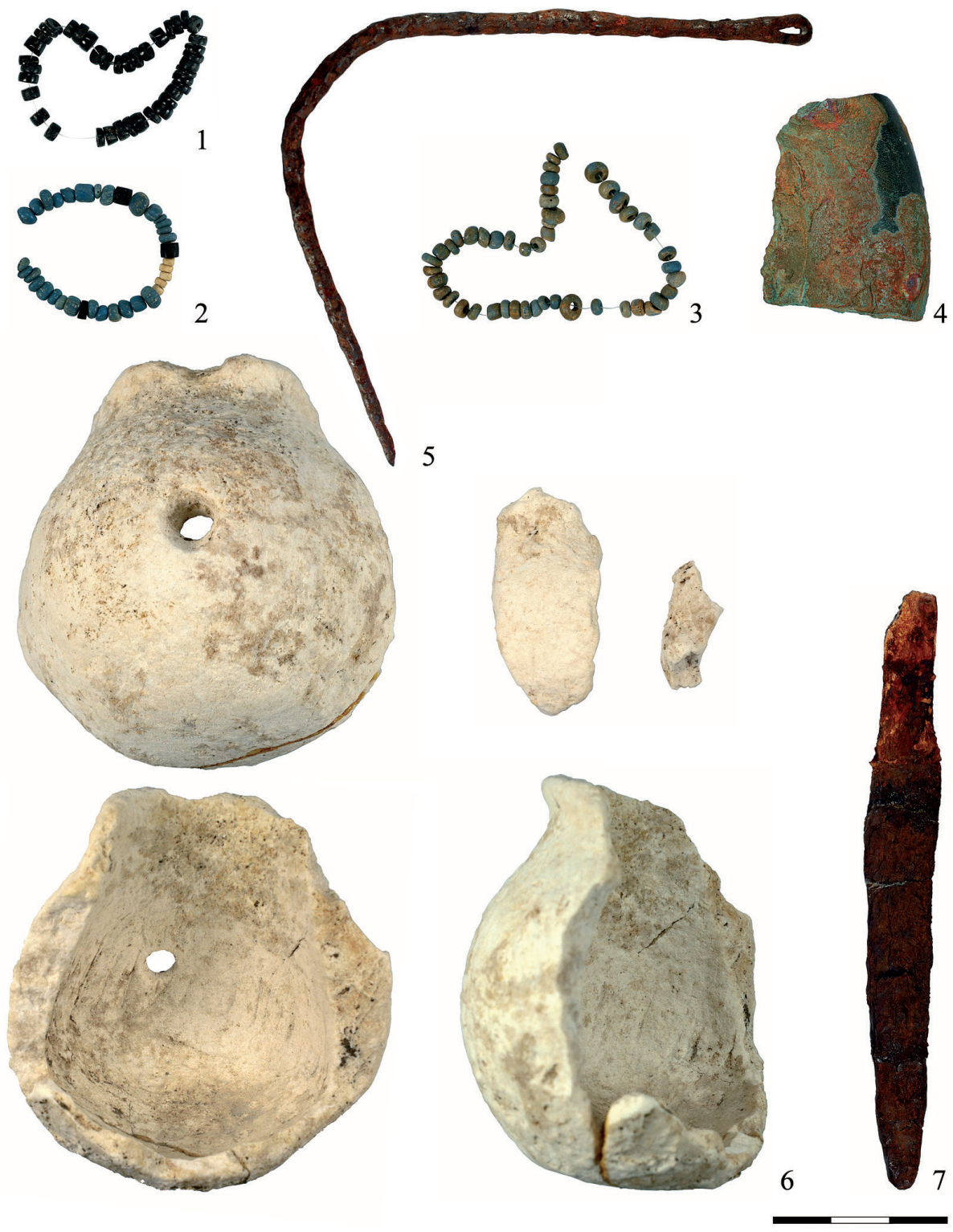

Рис. 1. Могильник «Царский».

Курган № 46/1987. Погребение № 1. Находки.

Археологический музей-заповедник Танаис.

1-3 - бисер, 4 - фрагмент зеркала бронзового; 5 - игла железная;

6 - фрагменты сосуда алебастрового; 7 - нож железный

Фото М.Ю. Трейстера 


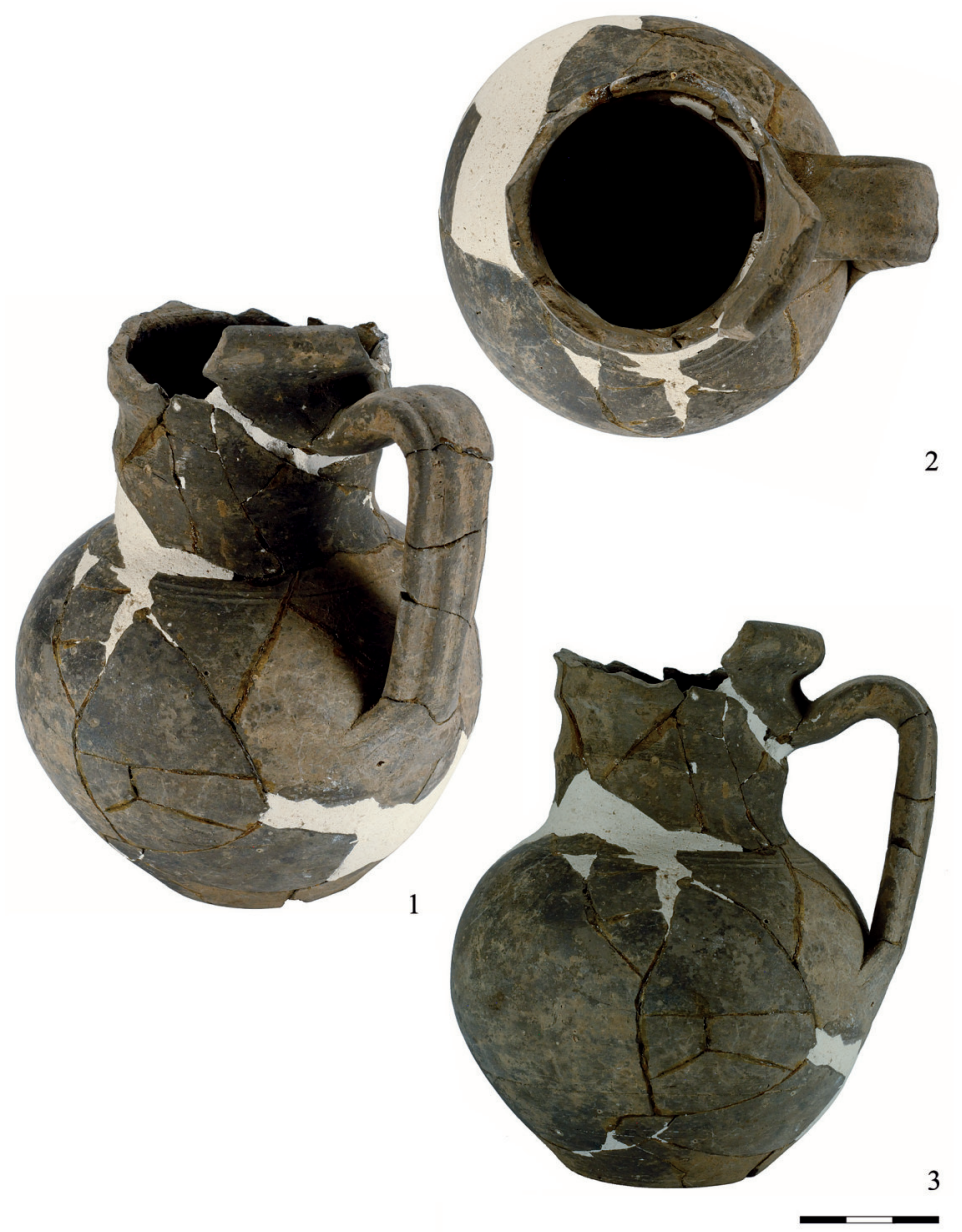

Рис. 2. Могильник «Царский».

Курган № 46/1987. Погребение № 1. Кувшин сероглиняный. Археологический музей-заповедник Танаис, инв. № 398/71.

Фото М.Ю. Трейстера

Танаиса, были атрибутированы одним из авторов этой работы во время работы в фондах Музея в июне 2015 г. как остатки лака китайского изделия.

Всего было найдено около 40 фрагментов изделия из лака размером от $0,2 \times 1,2$ см до $5,2 \times 5,5$ см. Сохранились только части тонкой чёрной лаковой поверхности, а деревянное ядро материала истлело, что не позволяло распознать форму предмета. При этом тонкий нанесённый красным лаком по чёрному декор частично сохранился очень хорошо: это узкие полоски, концентрические окружности, диагональные изгибающиеся линии и части мотива феникса (рис. 3-4).

Учитывая декор фрагментов (в частности мотив «двойного феникса») (рис. 4), можно определить их как части чаши с боковыми выступами-ручками 
erbei ханьского времени. Такие чаши производили как в государственных, так и в частных мануфактурах и по отдельности, но чаще в виде наборов. Два наиболее крупных центра находились в Шу 蜀 и в Гуанхань 广汉 в современной провинции Сычуань 四川(Wang, 1982. P. 80-99; Barbieri Low, 2001. P. 41-92; Liu, 2012. Р. 15-17). На государственных мануфактурах работали высокоспециализированные ремесленники. Маркировка на лаковых изделиях свидетельствует о хорошо продуманном рабочем процессе модульного характера, который позволял производить большое количество предметов без утраты качества. Стандартизированы были также и декоративные мотивы, вероятно, собранные в книгах шаблонов и, соответственно, они могли использоваться в течение многих лет (Wang, 1982. P. 85-91; Hong, 2006а. P. 152-158; Hong, 2006 b. 页. 160-207; Hu, Pan, 2014. 页. 51-109).

Мотив «двойных фениксов» с изображением противостоящих пар птиц появляется ещё в ранний период династии Западной Хань. Повторяющиеся изображения противостоящих пар фениксов вписывались в узкие орнаментальные пояса. Позднее этот мотив начинает использоваться также на тарелках pan и шкатулках he, впрочем, до среднего периода династии Западной Хань, довольно редко (Louis, 2006/07. Р. 48-53; Bai, 2014. 页. 45-51; Yu, 2014. 页. 114-118; Zhang, 2014. 页. 5-8; Prüch 2017. 页. 614-616). Примеры подобных изделий происходят из всех районов Китая времени Хань. С конца царствования императора Хань У-ди (156-87 гг. до н.э.) мотив двойных фениксов становится стандартным мотивом для декора чаш с боковыми выступами-ушками и остается им вплоть до периода Восточной Хань. Данный мотив пользовался популярностью и в государственных, и в локальных мастерских и за исключением отдельных сосудов с надписями, украшал наборы, состоящие из серий одинаковых сосудов (до 8 штук).

В настоящее время известно более 50 чаш с горизонтальными выступамиушками, украшенных мотивами «двойного феникса» и происходящих из гробниц основной территории царства Хань и его окраинных областей, из комендатуры Леланг (совр. Пхеньян) (Jung, 2013. P. 158-159), а также из Евразии (Погодин, 1998. С. 26-38; Brosseder, 2015. Р. 288-291; Sutiagina, Novikova, 2016. P. 83-91). Целая серия таких чаш происходит из Монголии, где они были найдены в гробницах сюнну в Ноин-Уле (Waugh, 2006. Р. 32-36; Pirazzoli-t'Serstevens, 2009. P. 31-41; An, Xi, 2009. 页. 69-88; Chistyakova, 2011. P. 83-89; Elikhina et al., 2014. Р. 93-107; Полосьмак, Богданов, 2015. С. 68-72; 2016. С. 65-81) и из Афганистана - из сокровищницы Беграма (Élisseeff, 1954. Р. 151-155; Pirazzoli-t'Serstevens, 2001. P. 473-484; Louis, 2006/07. P. 48-53; Zhang, 2011. P. 1-24; Mehendale, 2009. Р. 131-143). Фризы с мотивом феникса выполнены различным образом, что свидетельствует об изготовлении сосудов в разных мастерских. На чашах с горизонтальными выступами-ушками, изготовленных для использования при императорском дворе, которые, как правило, подписывались двумя иероглифами chengyu «для императорского использования», 


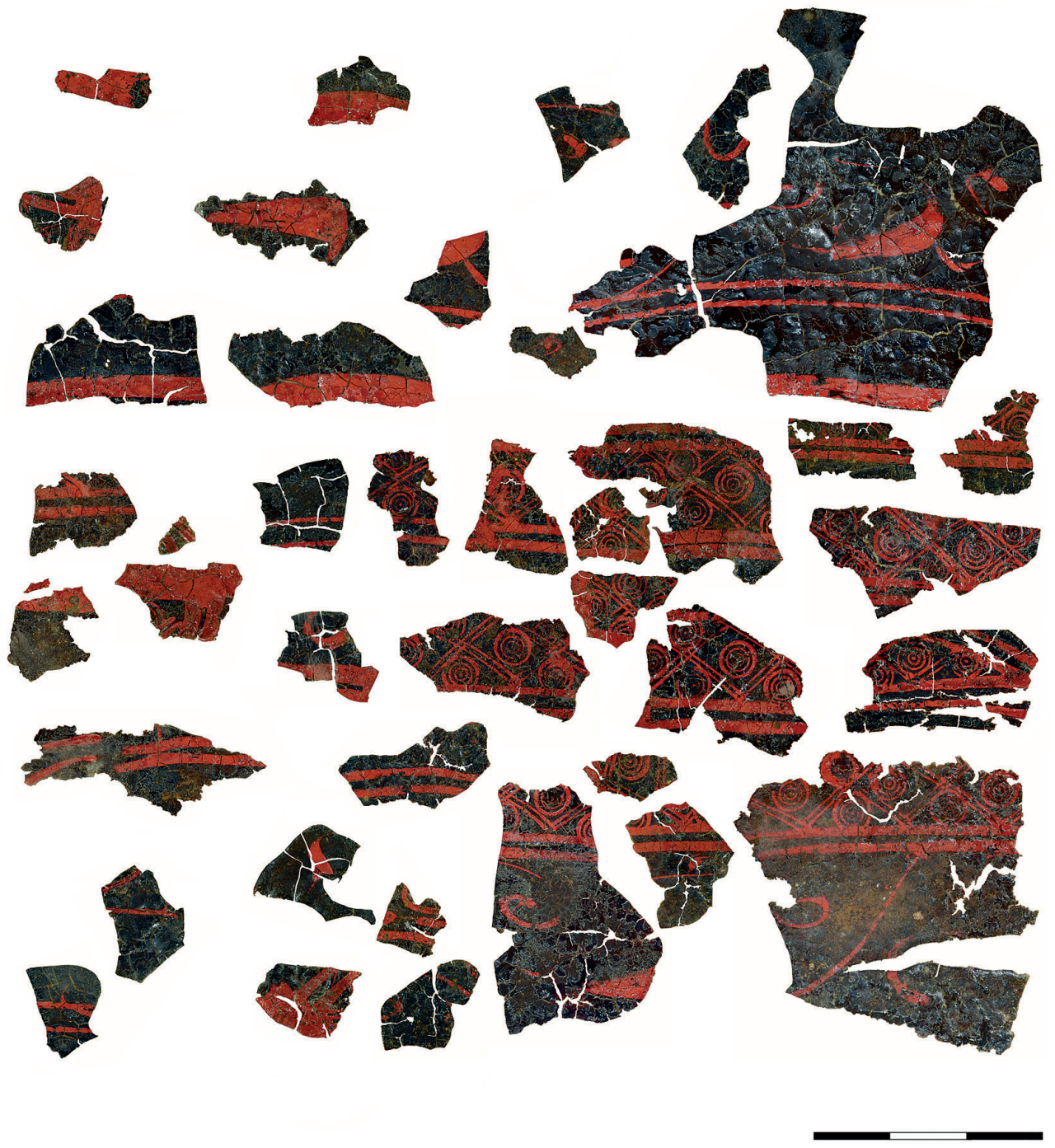

Рис. 3. Могильник «Царский».

Курган № 46/1987. Погребение № 1. Фрагменты лаковой чаши эрбей. Археологический музей-заповедник Танаис, инв. № НВФ 102. № 138. Фото М.Ю. Трейстера 


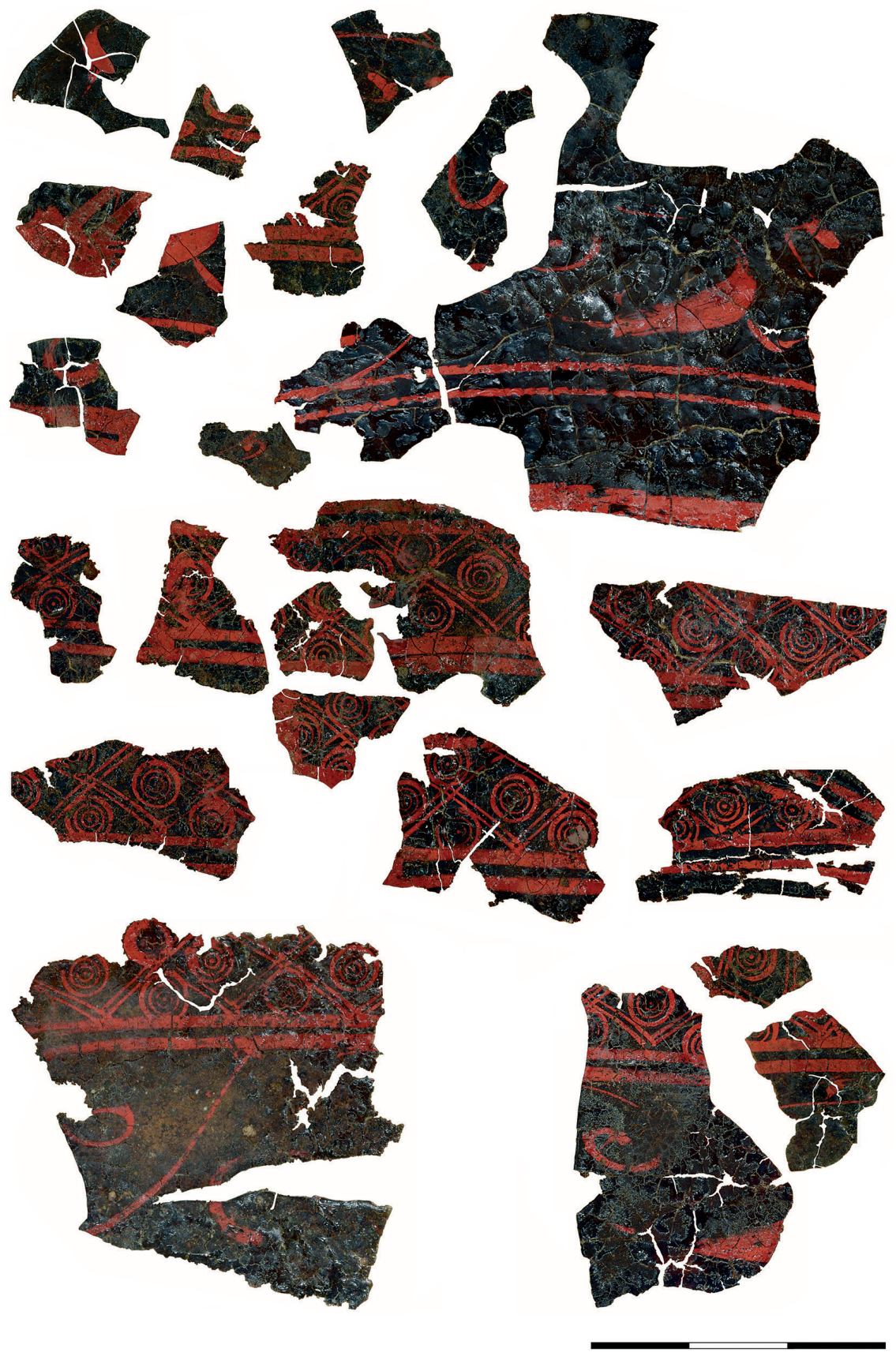

Рис. 4. Могильник «Царский».

Курган № 46/1987. Погребение № 1. Фрагменты лаковой чаши эрбей. Археологический музей-заповедник Танаис, инв. № НВФ 102. № 138.

Фото М.Ю. Трейстера 
мотивы феникса рисуются более толстым мазком, почти рельефным и заполняют всю полосу фриза на стенке сосуда. На других чашах они менее статичны и расписаны тонкими штрихами кисточки. Эти различия получают развитие вплоть до эпохи Восточной Хань во всё новых комбинациях.

Чаши с ручками-выступами с рельефными мотивами пар фениксов приписываются, в большинстве случаев на основе надписей, обеим государственным мануфактурам в Шу и Гуанхань. Наиболее ранняя из них датируется 44 г. до н.э. Фрагменты чаши из курганного могильника «Царский» относятся к этой категории чаш с выступами-ушками. Качество росписи сохранившихся фрагментов свидетельствует о том, что чаша была изготовлена в одной из государственных мастерских Шу и Гуанхань в совр. провинции Сычуань. Такие чаши изготавливались, начиная со среднего периода династии Западной Хань, т.е. ок. 150 г. до н.э., и продолжали оставаться в репертуаре лакового производства и в период династии Восточной Хань, примерно до 80 г. н.э.

Помимо находки в могильнике «Царский» фрагменты китайских лаковых изделий были найдены ещё в трёх погребальных комплексах Нижнего Подонья и междуречья Дона и Волги (рис. 5). Не исключено, что они также принадлежали чашам с выступами-ушками.

Составленная У. Бросседер карта распространения китайских лаковых изделий в Евразии наглядно показывает их широкое распространение на территории к востоку от Иртыша: в Западной Сибири, однако в массовых масштабах ещё восточнее - в степях Монголии, Бурятии и на Алтае. Напротив, их находки в погребениях кочевников в Поволжско-Уральском регионе и далее на запад - чрезвычайно редки (Brosseder, 2015. P. 250. Fig. 21). Новый импульс к вопросу об их распространении на запад придали находки китайских лаковых шкатулок в погребениях Усть-Альминского могильника в Юго-Западном Крыму, датирующихся в рамках второй четверти - второй половины I в. н.э. (Prüch, 2013. S. 142-151; Brosseder, 2015. Р. 291. Nos. 227-231).

Судя по картам У. Бросседер, на запад от Урала попадали преимущественно шкатулки (Brosseder, 2015. Р. 258. Fig. 27). Четыре находки в могильниках Нижнего Подонья и междуречья Дона и Волги кардинально меняют эту картину, так как они представляют фрагменты чаш. Коррективу следует внести и в карту распространения изделий государственных и частных мастерских, судя по которой на запад попадали лишь изделия частных мастерских (Brosseder, 2015. Р. 258. Fig. 28). Между тем, чаша из могильника «Царский» происходит, вероятно, из одной из государственных мастерских, чего нельзя, однако, с уверенностью сказать о других находках из Нижнего Подонья и междуречья Дона и Волги.

Находки чаш с выступами-ушками показывают распространение китайских лаков по территории Азиатской Сарматии и позволяют точнее представить себе путь, по которым они, а также лаковые шкатулки могли попадать в Крым и Северо-Западное Причерноморье. Наиболее ранним комплексом Азиатской 


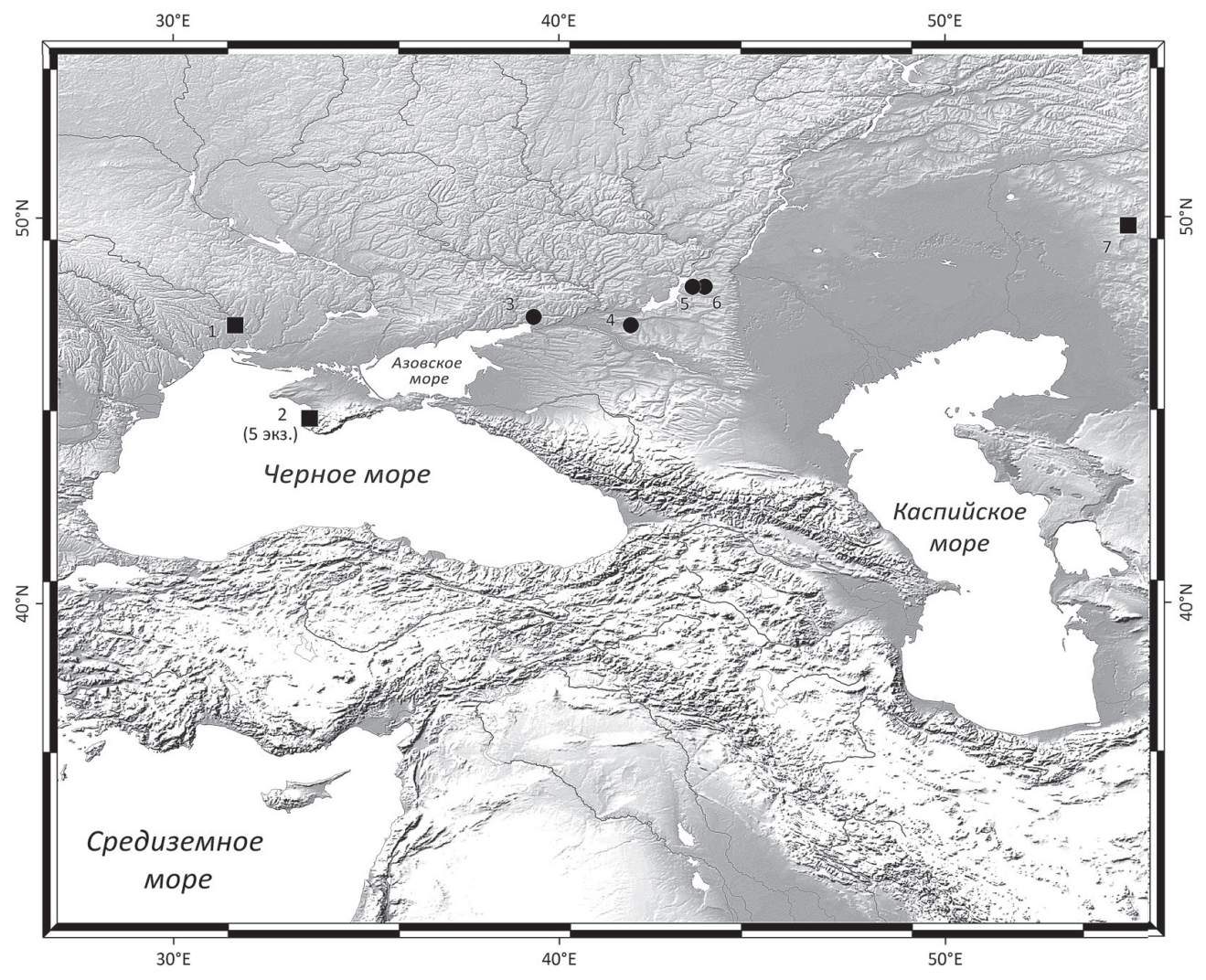

Рис. 5. Карта.

Распространение китайских лаковых изделий времени династии Хань в Восточной Европе и Южном Приуралье (М.Ю. Трейстер, 2018).

1 - Соколова Могила; 2 - Усть-Альма; 3 - «Царский»;

4 - Криволиманский-I; 5 - Октябрьский-V; 6 - Жутово, 7 - Лебедевка

Сарматии, в котором были найдены фрагменты лакового изделия, является погребение № 1 кургана № 3/1998 могильника Октябрьский-V, которое на основании керамики и нашивных бляшек датируется концом I в. до н.э. - началом I в. н.э. (Мордвинцева, Мыськов, 2005. С. 316-317. Рис. 1-2).

Таким образом, хронология комплексов Азиатской Сарматии, в которых были найдены лаковые чаши с выступами-ручками, не противоречит датировке погребений с находками китайских лаковых изделий в Усть-Альминского могильнике и в Соколовой могиле (Ковпаненко, 1986. С. 106, 108. Рис. 112; Brosseder, 2015. Р. 291. No. 226), где они появляются не позднее второй четверти - середины I в. н.э. Вопрос, каким образом (через цепочку межплеменных обменов или как следствие формирования северного ответвления Шёлкового, так наз. Мехового пути) чаши с ручками-выступами попали в погребения кочевников, не может пока быть решён однозначно. 
Публикация выполнена в рамках проекта, финансируемого DFG и РГНФ «Формы и пути культурных контактов кочевников Азиатской Сарматии. Импорты в сарматских памятниках II в. до н.э. - III в. н.э.» (FL-334/15-1). Партнер проекта с российской стороны - Б.А. Раев. Наша искренняя благодарность - С.А. Науменко и Н.С. Щербаковой (Танаис, Археологический музей-заповедник) за возможность изучения находок могильника «Царский» в мае-июне 2015 г.

\section{ЛИТЕРАТУРА}

Ковпаненко Г.Т. Соколова могила. Сарматское погребение I в. н.э. на Южном Буге. Киев: Наукова думка, 1986. 151 с.

Мордвинщева В.И., Мыськов Е.П. Погребение с остатками китайской лаковой шкатулки из могильника Октябрьский-V // Нижневолжский археологический вестник. 2005. Вып. 7. С. 314-318.

Погодин Л.И. Лаковые изделия из памятников Западной Сибири раннего железного века // Взаимодействие саргатских племен с внешним миром / Н.П. Довгалюк (ред.). Омск: Омский гос. ун-т, 1998. С. 26-38.

Полосьмак Н.В., Богданов Е.С. Курганы Суцзуктэ (Ноин-Ула, Монголия). Ч. 1. Новосибирск: Инфолио, 2015. $136 \mathrm{c.}$

Полосьмак Н.В., Богданов Е.С. Ноин-улинская коллекция. Новосибирск: Инфолио, 2016. $176 \mathrm{c}$.

An Wei 安维, Xi Zhifang 奚芷芳. Menggu Xiongnu guizu mudi chubu yanjiu 蒙古匈 奴贵族墓地初步研究 // Kaogu xuebao. 2009. No. 1. 2009. 页. 69-88.

Bai Yunxiang 白云翔. Handai «Shu jun Xigong zao» de kaoguxue lunshu 汉代“蜀君西工造”的考古学论述 // Sichuan wenwu. 2014. No. 6. 页.39-51.

Barbieri-Low A.J. The Organization of Imperial Workshops during the Han Dynasty. Diss. Princeton University, 2001. 497 p.

Brosseder U. A Study on the Complexity and Dynamics of Interaction and Exchange in Late Iron Age Eurasia // Complexity of Interaction along the Eurasian Steppe Zone in the first Millennium CE / J. Bemmann, M. Schmauder (eds.). Bonn: Rheinische FriedrichWilhelms-Universität, 2015. P. 199-332.

Chistyakova A.N. Lacquer cups of the Western Han Noin Ula Mongolia: an analysis of inscriptions // Archaeology, Ethnology and Anthropology of Eurasia. 2011. Vol. 39. No. 4. P. 83-89.

Elikhina J., Novikova O., Khavrin S. Chinese Lacquered Cups of the Han Dynasty from the Collection of Noyon-Uul, the State Hermitage Museum: Complex Research Using the Methods of Art History and Natural Science // Asian Archaeology. 2014. Vol. 2. P. 93-107.

Élisseeff $V$. Les Lacques chinois de Begram // Nouvelles Recherches archéologiques à Begram (anciènne Kâpicî). Recontre de trois civilisations. Inde,-Grèce,-Chine (MDAFA 11) / J. Hackin (ed.). Paris: Impr. nationale, 1954. P. 151-155.

Hong Shi. Production and Management of the Lacquer Industry during the Warring States, Qin and Han Periods // Chinese Archaeology. 2006 (a). No. 1. P. 152-158. 
Hong Shi 洪石. Zhanguo Qin Han qiqi yanjiu 战国秦汉漆器研究. Beijing: Wenwu chubanshe 文物出版社, 2006. 273 页.

Hu Yukang 虎玉康, Pan Tianbo 潘天波. Zhongguo xibu Qin Han qiqi yishu 中国西 部秦汉漆器艺术. Beijing: Renmin meishu chubanshe 人民美术出版社, 2014. 266 页.

Jung, In-seung. The Material Culture of Lelang Commandery // The Han Commanderies in Early Korean History / M. Byington (ed.). Harvard: Harvard University, 2013. P. 137-164.

Liu Yan. Primary study of the Han dynasty official workshops based on the inscribed lacquer dining vessels for imperial use 由 “乘舆" 铭漆器看汉代的官府制作" // Zhuangshi. 2012. No. 8. P. 15-17.

Louis F. Han Lacquerware and the Wine cups of Noin Ula // Silk Road. 2006/07. Vol. 4. No. 2. P. 48-53.

Mehendale S. Begram: At the Heart of the Silk Roads // Afghanistan. Hidden Treasures from the National Museum, Kabul / F. Hiebert, P. Cambon (eds.). Washington: National Geographic, 2009. P. 131-143.

Pirazzoli-t'Serstevens $M$. Les laques chinois de Begram. Un réexamen de leur identification et de leur datation // Topoi. 2001. Vol. 11. P. 473-484.

Pirazzoli-t'Serstevens M. Chinese Lacquerware from Noyon uul: Some Problems of Manufacturing and Distribution // Silk Road. 2009. Vol. 7. P. 31-41.

Prüch M. Die Lackkästchen aus der Grabung von Ust'-Al'ma // Die Krim. Goldene Insel im Schwarzen Meer. Griechen - Skythen - Goten / LVR - Landesmuseum Bonn (Hrsg.). Bonn: Landesmuseum, 2013. S. 142-151.

Prüch M. Mawangdui Hanmu qiqi de guili - youguan Handai qiqi wenyang de jidian kanfa 马王堆汉墓漆器的瑰丽 - 有关汉代漆器纹样爹几点看法: // Jinian Mawangdui Hanmu fajue sishi chou nian. Guoji xueshu yanlunhui lunwenji 纪念马王堆汉墓发掘四十 周年 / Hunansheng bowuguan 湖南省博物馆 (ed.). Changsha 2017. 页. 614-616.

Qian Yanhui 钱彦惠. Mingwen suo jian Xi Han zhuhou wang qiqude shengchan jigou-jian lun Xi Han gonguan de shezi yu guanli 铭文所见西汉诸侯王器物的生产机构 兼论西汉工官的设置与管理 // Kaogu suotan. 2016. No. 3. 页. 40-46.

Sutiagina N.A., Novikova O.G. Chinese Lacquer Cup from the «Golden Man» Tomb at Bugry, Northern Altai // Archaeology, Ethnology and Anthropology of Eurasia. 2016. Vol. 44. No. 4. P. 83-91.

Yu Xiantang 于献堂. 战国秦汉漆器装饰的构成方式和布局意识 Zhanguo Qin Han qiqi zhuangshi de goucheng fangshi he buju yishi // Yishu tansuo. 2014. Vol. 28. No. 5. 页. 104-118.

Wang Zhongshu. Han Civilization. Yale: Yale University, 1982. 261 p.

Waugh D.C. The Challenges of Preserving Evidence of Chinese Lacquerware in Xiongnu Graves // Silk Road. 2006. Vol. 4. No. 1. P. 32-36.

Zhang Jing 张晶. Zhujian qianghua de dongshi - shilun Chu Qin, Han qiqi qin niao zhuti zhuangshi de chuancheng yu fazhan 逐渐强化的动势 - 试论楚、秦、汉漆器禽 鸟主题装饰的传承与发展 // Zhongguo shengqi. 2014. Vol. 33. No. 3. 页. 1-8.

Zhang Liangren. Chinese Lacquerware from Begram: Date and Provenance // International Journal of Asian Studies. 2011. Vol. 8. No. 1. P. 1-24. 



\section{КОМПЛЕКСНЫЙ ПОДХОД В ИССЛЕДОВАНИЯХ ПАМЯТНИКОВ ЭПОХИ РАННЕГО ЖЕЛЕЗА}





\title{
МЕТАЛЛООБРАБОТКА \\ ЭПОХИ РАННЕГО ЖЕЛЕЗА \\ ПО МАТЕРИАЛАМ ИССЛЕДОВАНИЙ \\ МЕТАЛЛУРГИЧЕСКОГО КОМПЛЕКСА \\ ГОРЫ КУРМАНТАУ В ГАФУРИЙСКОМ РАЙОНЕ РЕСПУБЛИКИ БАШКОРТОСТАН
}

\begin{abstract}
Воробъёва С.Л.
http://10.25681/IARAS.2019.978-5-317-06274-3/341-351

В статье описаны результаты исследований 2012-2014 гг. металлургического комплекса горы Курмантау эпохи раннего железа на территории Гафурийского района Республики Башкортостан. В эпоху поздней бронзы - раннего железа на данной территории одним из видов деятельности у носителей культуры курмантау и караабызской культуры были металлообработка и бронзо-литейное производство. Об этом свидетельствуют находки шлаков, сплесков металла, литейной чаши, литейных форм и других изделий. Результаты работ автора статьи показывают преемственность в хозяйстве между носителями двух культур на территории Гафурийского района.

Ключевые слова: кара-абызская культура, культура курмантау, эпоха раннего железа, гафурийский тип, комплексные исследования, металлургия, металлобработка
\end{abstract}

В фондах Национального музея Республики Башкортостан (г. Уфа) хранится археологическая коллекция, происходящая с территории горы Курмантау, собранная по легенде в начале 2000-х годов. Коллекция депаспартизирована, имеется только напечатанная на компьютере надпись «гора Курмантау, подъёмный материал 2000-х гг.» (Национальный музей Республики Башкортостан. Фонд «Археология». ОФ 29692). Среди 455 бронзовых и железных предметов имеются обломки бронзовых котлов, гривен, заготовки бронзовых украшений (бляшки, подвески, обоймы и т.д.), бронзовые сплески металлов и железные ножи. Эта коллекция свидетельствует о существовании на территории горы Курмантау мощного металлургического комплекса по производству и обработке цветного металла в эпоху раннего железа.

Для установления наличия подобного очага металлообработки или металлургии на территории горы Курмантау и её окрестностей в 2012-2014 гг. в Гафурийском районе Республики Башкортостан проводились археологические работы под руководством автора статьи.

Участок в окрестностях горы Курмантау приурочен к возвышенному правому берегу р. Белая, ограниченному с запада правым берегом реки, с востока - горой Михайловская (топографическое название), получившей у местного населения названия «Курман-Тау» / «Табынская»/ «Жертвенная гора», с севера - левым берегом р. Бурлы, с юга - южными склонами горы Михайловская (рис. 1). Гора Михайловская - самая высокая возвышенность в округе в системе отрогов уральских гор высотой около 200 м (высотная отметка 261.6). На участке преобладает степная растительность, песчаные почвы. 


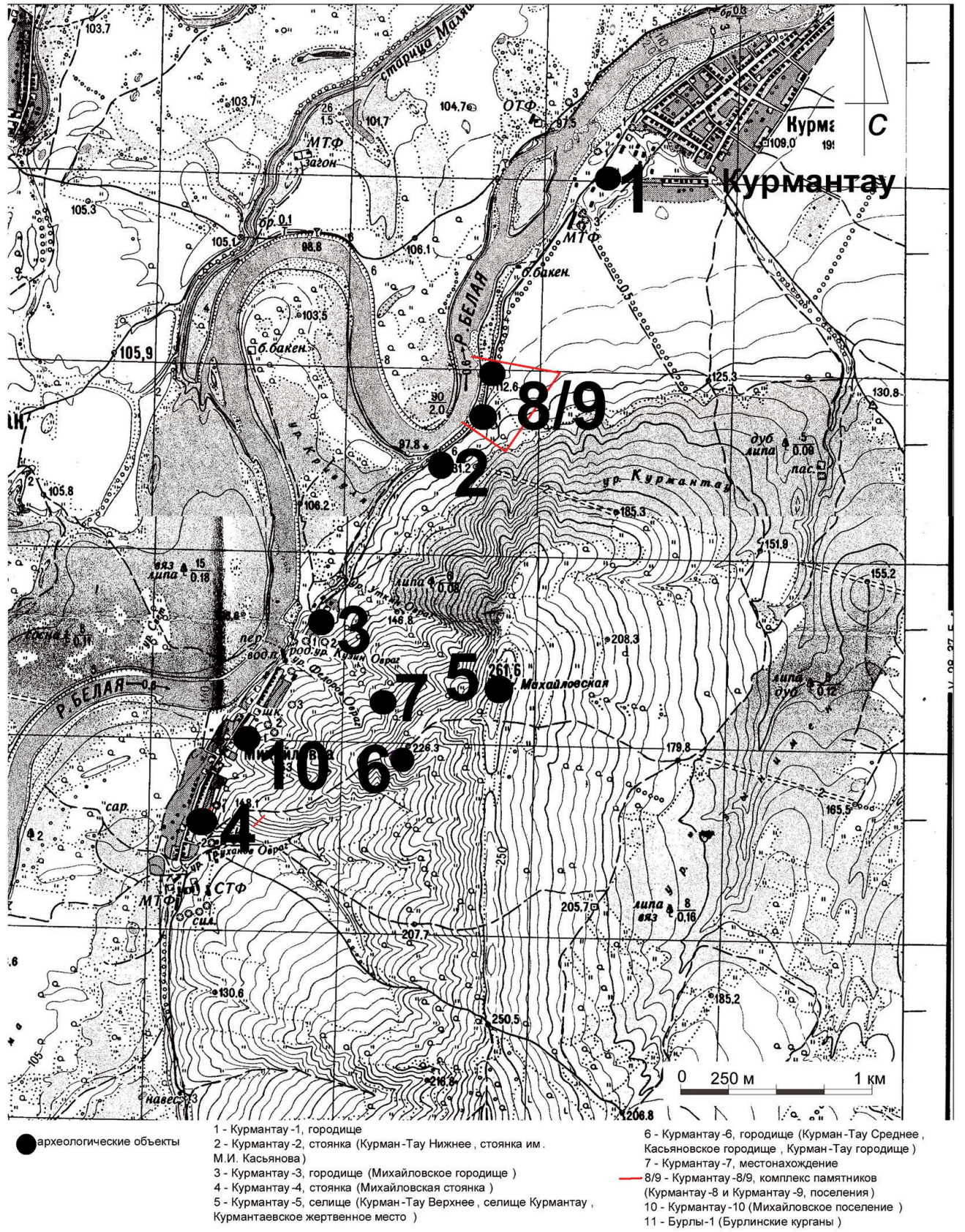

Рис. 1. Памятники археологического микрорайона горы Курмантау, Гафурийский район Республики Башкортостан.

Карта 1:25000. Лист V-28-37-Г-а 
В разные годы здесь было найдено и изучено семь поселенческих объектов переходного периода от эпохи бронзы к раннему железу и эпохи раннего железа «Курмантау Нижнее» (стоянка им. М.И. Касьянова), «Курмантау Среднее» (Касьяновское городище), «Курмантау Верхнее» (Курмантаевское селище), Курмантаевское и Михайловское городища, Михайловская стоянка, Михайловское поселение.

Первооткрывателем археологических памятников, расположенных на горе Михайловская (Курмантау) и в её окрестностях, является уроженец дер. Михайловка краевед М.И. Касьянов, который в 1928-1929 гг. открыл три поселенческих объекта: «Курмантау Нижнее» (Курмантау-2 или стоянка им. М.И. Касьянова), «Курмантау Среднее» (Курмантау-6 или Касьяновское городище) и «Курмантау Верхнее» (Курмантау-5 или Курмантаевское селище). На найденных памятниках он собрал значительный подъёмный материал, который сейчас хранится в Национальном музее РБ, отчёта по его работам нет (Национальный музей Республики Башкортостан. Фонд «Археология». ОФ 296-300). По керамике, полученной в ходе изучения материалов стоянки им. М.И. Касьянова, К.В. Сальниковым была выделена культура курмантау переходный период от эпохи бронзы к раннему железу в лесостепной зоне Южного Урала (Сальников, 1967. С. 76).

В 1953-1955 гг. была организована башкирская археологическая экспедиция АН СССР под руководством А.В. Збруевой и Г.В. Юсупова, в ходе которой найдены новые объекты (Курмантаевское и Михайловское городища). На всех известных памятниках в это время были организованы археологические раскопки (Юсупов, 1953; 1954; 1955, 1956). Г.В. Юсупов впервые в своих исследованиях пишет о том, что на территории селища Курмантау «найдено много вещей, связанных непосредственно с металлургией: литейные формы, железный и бронзовый шлаки, слиток бронзы, обломок сопла плавильной печи, бронзовая проволока и др.» (Юсупов, 1959. С. 63). По отчетам Г.В. Юсупова проходит 8 литейных форм из глины и камня, две из них были для отливки кельта, одна - для отливки гривны (Юсупов, 1957. С. 15-17).

В 1954 г. студент заочного отделения исторического факультета Уральского Государственного Университета (научный руководитель К.В. Сальников), краевед А.П. Шокуров в ходе археологической разведки в Гафурийском районе РБ нашёл ещё одну стоянку в деревне Михайловка (Михайловская стоянка) (Шокуров, 1954).

Последующее изучение памятников этого компактного микрорайона связано с археологическими раскопками В.А. Иванова и А.Х. Пшеничнюка в 19751980 гг. (Иванов, 1975; Пшеничнюк, 1979), И.Б. Васильева, В.А. Иванова и М.Ф. Обыденнова в 1975-1977 гг. (Васильев, Иванов, 1976; Васильев и др., 1985), И.Б. Васильева и М.Ф. Обыденнова в 1976 г. (Васильев, Обыденнов, 1977). Исследования И.Б. Васильева, В.А. Иванова и М.Ф. Обыденнова на стоянке им. М.И. Касьянова показали, что носители культуры курмантау зани- 
мались бронзолитейным производством, о чём свидетельствуют раскопанные производственные площадки, где были найдены шлак, глиняный тигель и двусторонняя тальковая форма для отливки иглы (Васильев и др., 1985. С. 39).

В 2012-2013 гг. на рассматриваемой территории обнаружено ещё два новых археологических объекта: местонахождения эпохи раннего железа Курмантау-7, комплекс памятников Курмантау-8/9, также было дополнительно изучено селище Курмантау-5 (Воробьёва, Савельев, 2015).

Селище Курмантау-5 расположено на вершине горы Курмантау (рис. 1). На территории селища были собраны предметы, имеющие отношение к металлообработке: 2 ошлакованных слитка меди и 3 сплеска металла (рис. 5). Четыре образца сплесков и слитков меди были отданы на спектральный анализ старшему научному сотруднику Уральского отделения Российской академии наук С.А. Григорьеву (г. Челябинск). Они (образцы № 2233-2235) представлены небольшими бесформенными и тяжёлыми кусками с ошлакованной поверхностью. На некоторых из них на поверхности выступали небольшие включения медной зелени. При изготовлении аншлифов и отборе проб на химический анализ выяснилось, что образцы являются ошлакованными слитками меди, которые получены, вероятно, при литье металла.

Таблийа 1

Спектральный анализ сплесков металла с селища Курмантау-5 (селище Курмантау), выполненный в химической лаборатории

Челябинской геолого-съёмочной экспедиции (\%) (С.А. Григорьев)

\begin{tabular}{|c|l|l|l|l|l|l|l|l|l|l|l|l|l|l|l|l|l|}
\hline $\begin{array}{c}\text { № } \\
\text { обр. }\end{array}$ & Назв. & $\mathrm{Ni}$ & $\mathrm{Co}$ & $\mathrm{Cr}$ & $\mathrm{Mn}$ & $\mathrm{V}$ & $\mathrm{Ti}$ & $\mathrm{Cu}$ & $\mathrm{Zn}$ & $\mathrm{Pb}$ & $\mathrm{Ag}$ & $\mathrm{As}$ & $\mathrm{Bi}$ & $\mathrm{Mo}$ & $\mathrm{Ba}$ & $\mathrm{Sn}$ & $\mathrm{Sb}$ \\
\hline 2233 & шлак & 0,02 & 0,003 & 0,01 & 0,05 & 0 & 0,05 & $>>1$ & 0,02 & 0,5 & $>>0,003$ & 0,1 & 0,015 & nd & 0,015 & $>0,3$ & 0,07 \\
\hline 2234 & медь & 0,015 & 0,007 & 0,003 & 0,3 & 0,003 & 0,1 & $>>1$ & 0,02 & 0,15 & $>0,003$ & 0,05 & 0,005 & nd & 0,03 & $>0,3$ & 0,015 \\
\hline 2235 & медь & 0,007 & 0,003 & 0,007 & 0,07 & 0 & 0,05 & $>>1$ & 0,007 & 0,1 & $>0,003$ & 0,1 & 0 & $\mathrm{nd}$ & 0,015 & 0,03 & 0,003 \\
\hline 2236 & медь & 0,03 & 0,003 & 0,007 & 0,05 & 0 & 0,05 & $>>1$ & 0,01 & 0,07 & $>0,003$ & 0,07 & 0,015 & nd & 0,01 & $>0,3$ & 0,02 \\
\hline
\end{tabular}

Два образца (№ 2235, 2236) представлены чистой медью, с отсутствием заметных посторонних включений. С.А. Григорьевым был сделан вывод о том, что на селище Курмантау-5 практиковалась металлообработка меди. Селище датируется IV-III вв. до н.э., преобладает керамика кара-абызской культуры.

В 2013 г. на Курмантаевском городище был заложен шурф размером 1×2 м, где, кроме множества фрагментов керамики (около 300), 7 скоплений сосудов и костей, найдены три пряслица, шлак, 2 бронзовых трёхлопастных наконечника стрелы (см.: Воробьёва, 2017). Городище датируется IV-III вв. до н.э., преобладает керамика гафурийского типа.

В 2013-2014 гг. был исследован комплекс памятников Курмантау-8/9, где раскопано 186 кв. м. Он расположен на высокой (11 м) коренной террасе правого берега р. Белая, рядом с н.п. Курмантау. С запада площадка ограни- 
чена правым берегом реки Белая, с юго-востока - подножьем горы Курмантау. Общая площадь памятника 90000 кв. м (рис. 1).

В ходе осмотра террас вдоль правого берега р. Белая, в 2012 г. к югозападу от с. Курмантау были выявлены два поселения эпохи раннего железа Курмантау-8 и Курмантау-9, расположенных в 250 м друг от друга (Воробьёва, 2012). В следующем году рядом с выявленными поселениями было обнаружено около 160 грабительских ям. В заполнении ям найдены предметы эпохи бронзы и раннего железа, в том числе обломок серпа, 2 сплеска металла, обломок ножа, заклёпка бронзового котла (рис. 2). Шурфовка площадки показала, что памятники Курманта-8 и Курмантау-9 представляют собой единый комплекс металлургическую площадку эпохи раннего железа.

По итогам исследований 2014 г. на данном объекте было выделено три археологических слоя.

Слой абашевской культуры эпохи бронзы. Зафиксирован на участке памятника вдоль берега р. Белая. Он связан со временем освоения площадки. В квадрате $2 \times 2$ м на глубине 15 см от поверхности зафиксирован развал лепного сосуда с орнаментом абашевской культуры эпохи бронзы, зернотёрка из песчаника.

Слой культуры курмантау эпохи поздней бронзы - раннего железа. Зафиксирован на всей площадке памятника, на глубине от 25 до 40 см от поверхности. Найдены мелкие кальцинированные кости животных, сплески
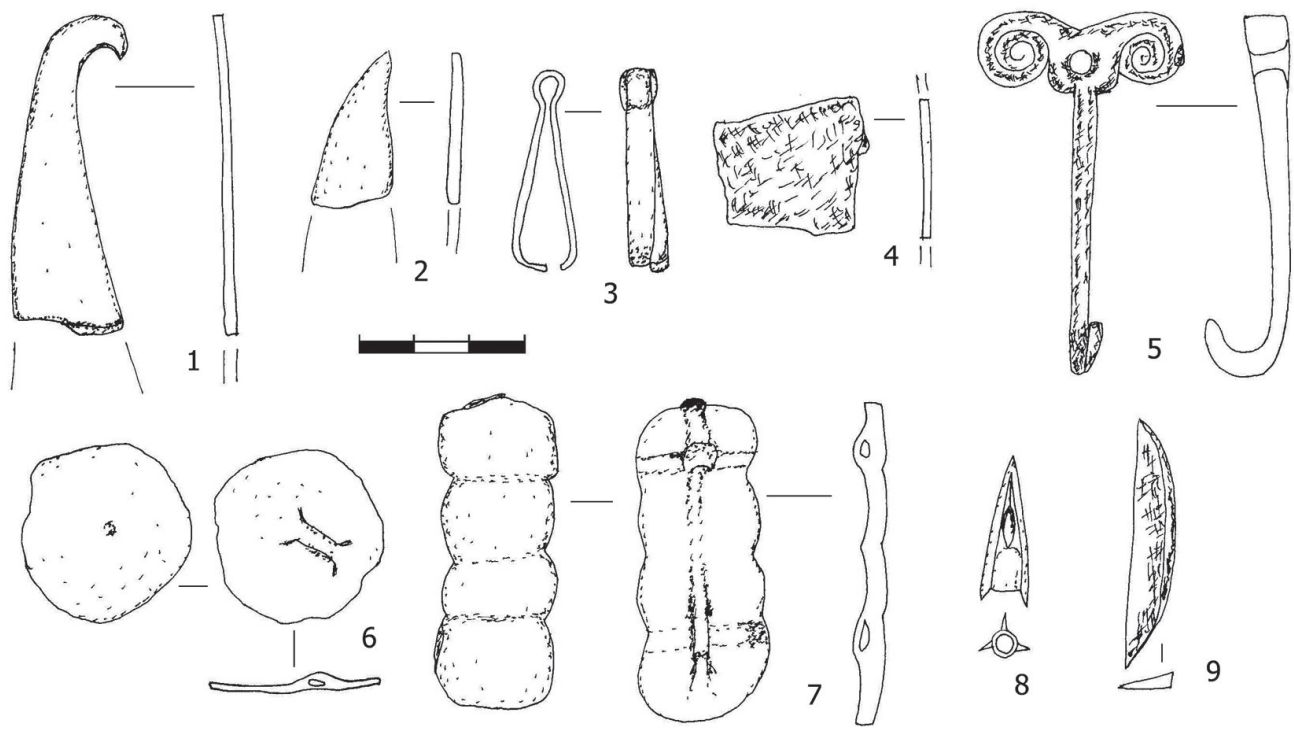

Рис. 2. Комплекс памятников Курмантау-8/9. Археологические находки 2013 г.:

1 - фрагмент серпа; 2 - фррагмент предмета неизвестного назначения;

3 - пинцет; 4 - пластина; 5 - крючок; 6 - круглая бляшка с ушком на обороте;

7 - накладка на пояс с двумя петлями на обороте; 8 - наконечник стрелы; 9 - нож; 1-3, 6-8 - бронза, 4-5, 9 - железо 
металла и шлаки, стенки лепных сосудов, литники, кремневые отщепы и кресала, венчик литейной чаши из каолиновой глины со следами нагара внутри (рис. 3, 2). С этим слоем связан объект (яма), обнаруженный в южной части раскопа. Датируется не позже V в. до н.э.

Слой кара-абызской культуры эпохи раннего железа. На глубине от поверхности до 25 см найдены мелкие кальцинированные кости животных, сплески металла и шлаки, сердечник из глины для литейной формы кельта (рис. 3, 1), бусина - подвеска гиревидной формы (рис. 3, 5), бисер, молоток для измельчения металлической поверхности из кварцито-песчаника с зеленоватыми пятнами от ударов по бронзе на сработанной поверхности, камень для заточки металлических инструментов (оселок) из яшмы, побывавший в огне и со следами царапин от металлических инструментов, орудие для растирания руды из речной гальки, сточенной с одной стороны (определение каменного инвентаря дано к.и.н., с.н.с. отдела археологии ордена «Знак Почёта» Института истории, языка и литературы УФИЦ РАН В.Г. Котова), фрагменты стенок лепных сосудов (рис. 3, 3-4). Датируется IV-III вв. до н.э.

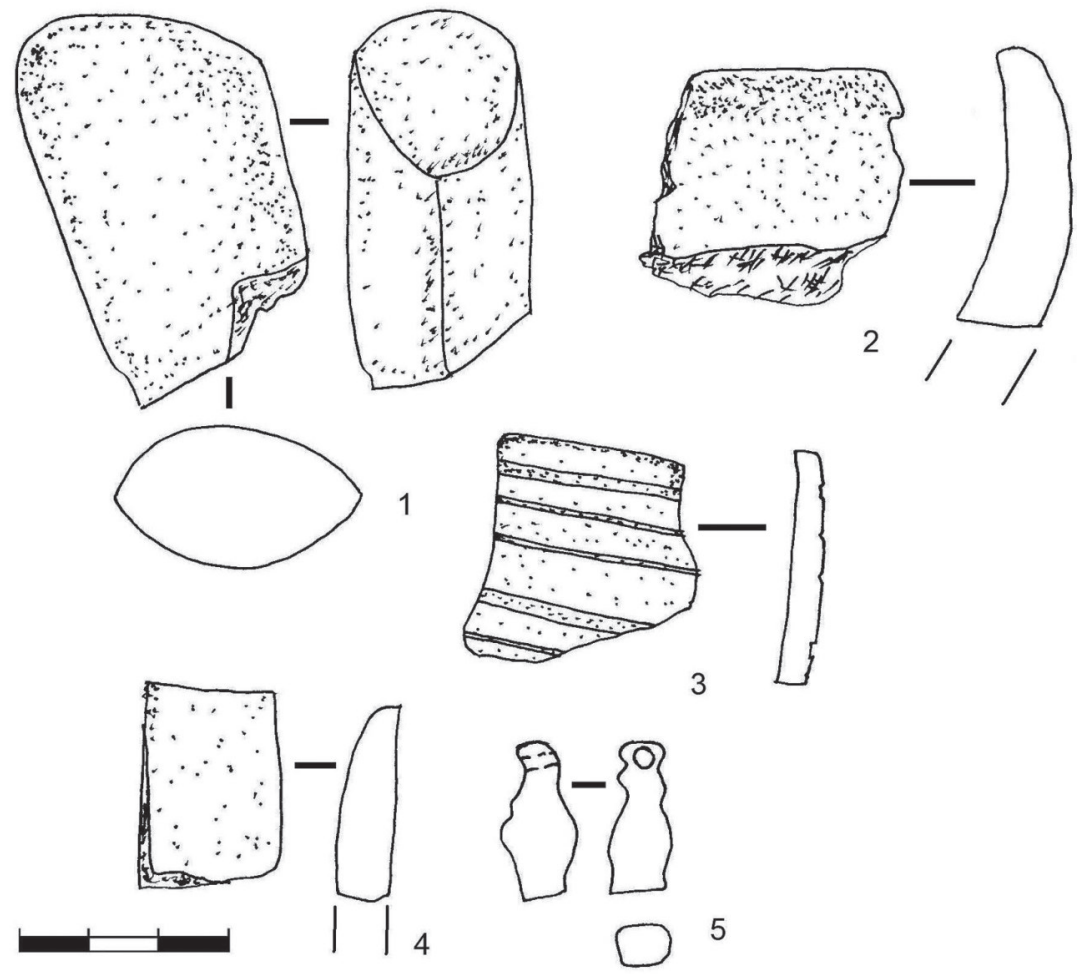

Рис. 3. Комплекс памятников Курмантау-8/9. Археологические находки 2014 г.:

1 - сердечник для литейной фрормы кельта; 2 - венчик литейной чаши; 3-4 - венчики сосудов; 5 - гиревидная подвеска; 1-4 - керамика; 5 - стекло 
К этому же слою относится жертвенный комплекс, раскопанный на площадке: под слоем дерна был найден воткнутый в землю железный наконечник копья - кавалерийская пика. Рядом лежал железный поясной крючок с орнаментированным щитком (кошачий хищник в сидячей позе) и железный нож (рис. 4).

Стратиграфические данные свидетельствуют о том, что между слоем культуры курмантау и кара-абызской культуры имеется стерильный тонкий слой нанесённого мелкого галечника, который мог образоваться в результате схода с вершины горы (полевые данные В.Е. Приходько - доктор биол. наук, ведущий научный сотрудник группы генезиса и эволюции почв Института физикохимических и биологических проблем почвоведения РАН).

Данные спектрального анализа бронзовых сплесков и шлаков (рис. 5), полученные С.А. Григорьевым (г. Челябинск), свидетельствуют о том, что население практиковало металлообработку.

Таблицุа 2

Предварительное описание сплесков металла и шлаков с комплекса памятников Курмантау-8/9 (металлургическая площадка), выполненное С.А. Григорьевым

\begin{tabular}{|c|l|l|}
\hline № образца & Местонахождение & \multicolumn{1}{c|}{ Описание } \\
\hline 2530 & кв. Т/2 № 34 & $\begin{array}{l}\text { Небольшой лёгкий и пористый кусочек шлака } \\
(1,6 \times 1,5 \times 1,2 \text { см })\end{array}$ \\
\hline 2531 & кв. У/499 № 93 & $\begin{array}{l}\text { Маленький лёгкий и пористый округлый слиток шлака } \\
(1,2 \text { см })\end{array}$ \\
\hline 2532 & кв. 01/499/2 № 50 & Небольшой слиток шлака $(1,5 \times 0,9 \times 0,5$ см $)$ \\
\hline 2533 & кв. 9/499/5 № 92 & Слиток меди $(3 \times 0,5-1$ см $)$ \\
\hline 2534 & кв. УІ/499/4 & Слиток меди $(2,8 \times 2 \times 0,4$ см $)$. \\
\hline 2535 & ПМ & Слиток меди $(3 \times 2,5 \times 0,7$ см $)$ \\
\hline 2536 & ПМ & Слиток меди $(3 \times 2,8 \times 0,8$ см $)$ \\
\hline 2537 & ПМ & Слиток меди $(6 \times 2 \times 0,5$ см $)$ \\
\hline 2538 & ПМ & Слиток меди $(4,5 \times 1,5 \times 0,7$ см $)$ \\
\hline
\end{tabular}

Анализ остеологического материала научным сотрудником отдела археологии ГБУ РИКМЗ «Древняя Уфа» А.А. Романовым показал, что характер, степень раздробленности и количество дроблёного остеологического материала, наличие большого количества мелких кальцинированных костей (1307) позволяют предположить, что на памятнике производилась целенаправленная заготовка костяного угля.

Результаты спорово-пыльцевого анализа отложений разреза, проведённые кандидатом биологических наук, научным сотрудником Института геологии 


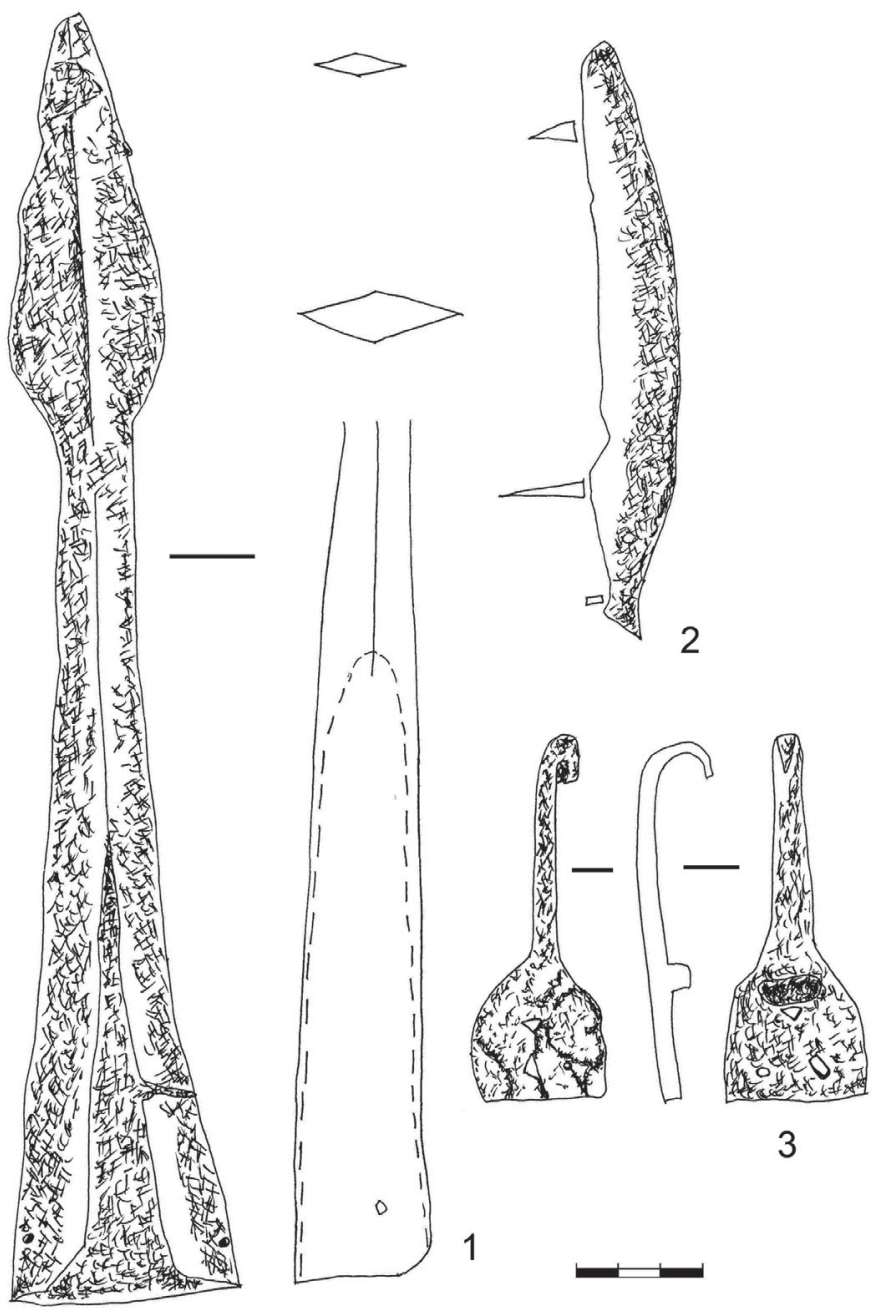

Рис. 4. Комплекс памятников Курмантау-8/9.

Археологические находки 2014 г. Жертвенный комплекс:

1 - наконечник копья; 2 - нож; 3 - поясной крючок; железо

УНЦ РАН Р.Г. Курмановым, показали, что полученные спектры характеризуют опушку мелколиственно-широколиственного леса, но отмечено, что в период формирования отложений из верхних слоев (слой кара-абызской культуры) увеличивались площади открытых луговых пространств.

Таким образом, на исследуемой площадке Курмантау-8/9 и на других памятниках горы Курмантау и её окрестностей (Курмантаевское городище, селище курмантау, стоянка им. М.И. Касьянова) вначале носители культуры курмантау, а затем и носители кара-абызской культуры занимались металлообработкой и бронзо-литейным производством. 


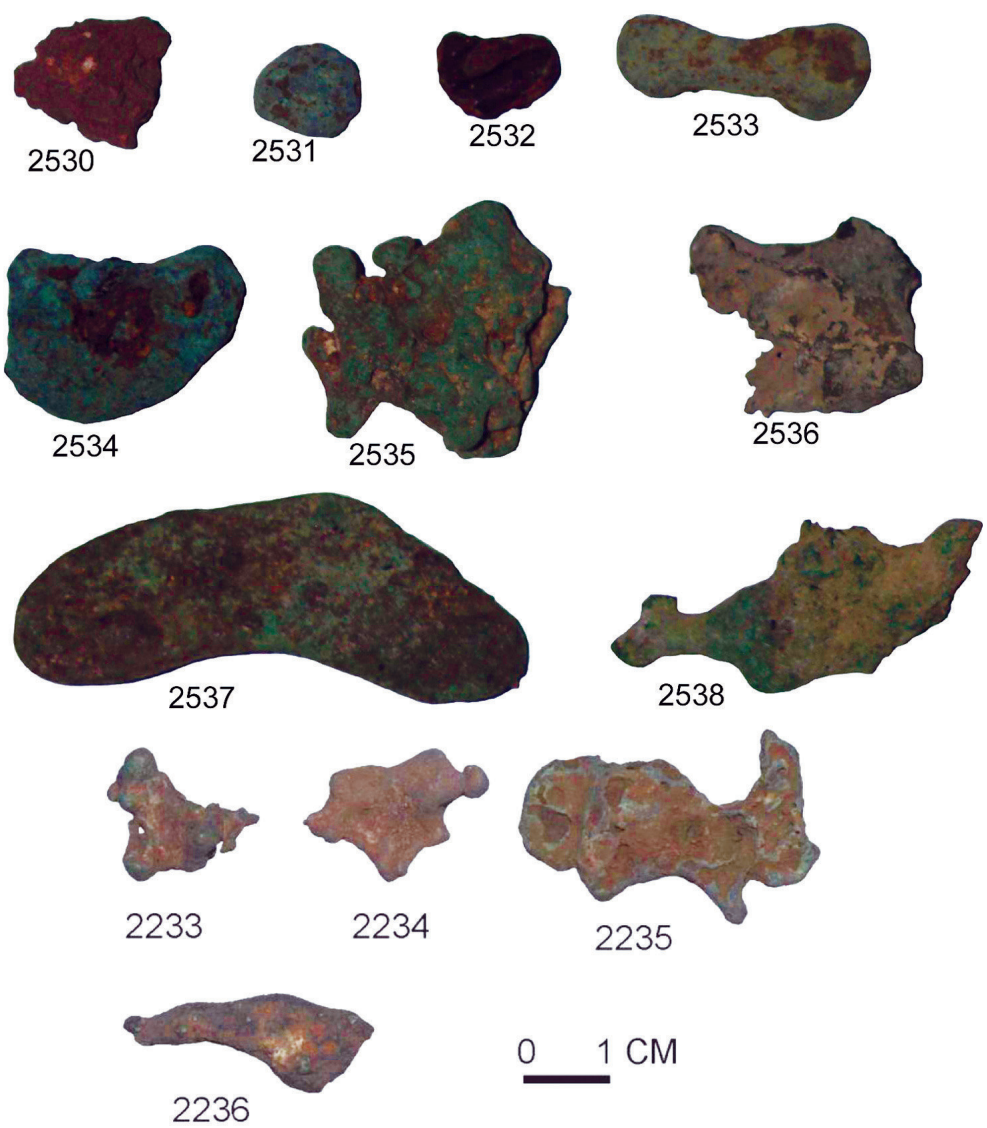

Рис. 5. Шлаки и сплески металлов с горы Курмантау (фото С.А. Григорьева): 1530-2530 - комплекс памятников Курмантау-8/9 (2014 г.); 2233-2236 - селище Курмантау-5 (2013 г.)

Металлургическое производство у носителей кара-абызской культуры впервые подробно рассмотрено в работе А.Х. Пшеничнюка, где им описаны «немногочисленные» остатки металлургического производства на караабызских поселениях - обломок каменной льячки со II Охлебининского городища, обломок сопла литейной печи, куски шлаков с остатками меди и железа, обломки литейных форм, обнаруженные на поселениях Гафурийского района (Пшеничнюк, 1973. С. 215). С.В. Кузьминых, проанализировав бронзовые изделия из Шиповского, Биктимировского и Охлебининского могильников караабызской культуры, пришёл к выводу, что большую часть составляют изделия из «чистой» меди, совершенно отсутствуют оловянистые бронзы, в связи с чем они отличаются от аналогичных ананьинских коллекций (Кузьминых, 1983. С. 51). Анализ каменных изделий с Шиповского городища, проведённых В.Г. Котовым, показал наличие на памятнике металлургического производства, с которым связаны тёрочные плиты и наковальни, а также песты и молоты для 
измельчения руды (Котов, 2009. С. 143). С.В. Савельев, в свою очередь, отмечает наличие на Шиповском городище собственной металлургии и металлообработки (Савельев, 2009. С. 140).

О наличии отливки металла носителями кара-абызской культуры в эпоху раннего железа свидетельствуют сердечник из глины для литейной формы кельта и венчик литейной чаши, а также многочисленные «недолитые» (бракованные) изделия из бронзы, которые происходят из коллекции с горы Курмантау. Двусторонняя тальковая форма для литья и обломки глиняных литейных форм из раскопок разных лет стоянки им. М.И. Касьянова, обломки литников говорят о том, что вероятнее всего ещё носителями культуры курмантау в VIII-V вв. до н.э. бронзовые изделия отливались методом литья по восковой модели. Визуальный осмотр всех изделий кара-абызской культуры IV вв. до н.э. - IV в. н.э., отлитых из бронзы (более 10000 предметов), также показывает, что они отливались методом литья по восковой модели (Воробьёва, 2012). В каменных формах отливали восковую модель, которую затем обмазывали глиной, воск вытапливали, глиняную форму сушили и обжигали на костре, а потом в неё наливали бронзу. Такое производство не требует установки специальных печей, так как медь можно плавить в литейных глиняных чашах, обломок такой чаши происходит из раскопа 2014 г. Раскопки металлургической площадки Курмантау-8/9 подтверждают мнение А.Х. Пшеничнюка, что выплавкой металла и металлообработкой занимались вне поселений - на отдельных площадках (Пшеничнюк, 1973. С. 215).

Исследования 2012-2014 гг. показали, что на территории горы Курмантау и её округи для населения, оставившего памятники культуры курмантау (стоянка им. М.И. Касьянова и Курмантау-8/9) эпохи поздней бронзы - раннего железа и кара-абызской культуры эпохи раннего железа (селище Курмантау, Курмантау-7, Курмантау-8/9), одним из главных занятий было бронзо-литейное производство, что может свидетельствовать о преемственности и возможной непрерывности носителей культуры курмантау и кара-абызского населения на данной территории.

\section{ЛИТЕРАТУРА}

Васильев И.Б., Иванов В.А. Работы в Башкирской АССР // Археологические открытия 1975 года. М.: Наука, 1976. С. 161.

Васильев И.Б., Иванов В.А., Обыденнов М.Ф. Итоги исследований стоянки им. М.И. Касьянова в Гафурийском районе БАССР // Бронзовый век Южного Приуралья: Межвузовский сборник научных трудов. Уфа: Башкирский пединститут, 1985. С. 21-40.

Воробьёва С.Л. Типология элементов убранства костюма кара-абызской культуры эпохи раннего железа (IV в. до н.э. - IV в. н.э.). Автореф. дисс. ... к.и.н. по спец. «Археология». Ижевск, 2012. 24 с.

Воробъёва С.Л. Научный отчёт о проведении разведочных археологических исследований в Гафурийском районе Республики Башкортостан по Открытому листу 
№ 367 от 01.06.2012 г. / Национальный музей Республики Башкортостан. Уфа, 2013. В 2 т. Т. 1, 108 с.; T. 2, 120 с.

Воробьёва С.Л. Научный отчёт о проведении разведочных археологических исследований в Гафурийском районе Республики Башкортостан по Открытому листу № 995 от 01.08.2013 г. / Национальный музей Республики Башкортостан. Уфа, 2014. 237 с.

Воробьёва С.Л., Савельев Н.С. Разведочные работы в Гафурийском районе Башкортостана в 2012-2013 гг. // Археологические открытия 2010-2013 годов. М.: Институт археологии Российской академии наук, 2015. С. 468-471.

Воробьёва С.Л. Результаты археологических исследований 2013 года на Курматовском городище эпохи раннего железа // Вестник Сургутского государственного педагогического университета. № 4(49) 2017. С. 101-113.

Иванов В.А. Научный отчёт 1975 г. Уфа, 1975 // Архив ИА РАН. 1976. Р-1. № 6745.

Котов В.Г. Каменные изделия с Шиповского городища кара-абызской культуры // Уфимский археологический вестник. 2009. Вып. 9. С. 141-143.

Пшеничнюк A.X. Кара-абызская культура (население центральной Башкирии на рубеже нашей эры) // Археология и этнография Башкирии. Т. V. / Под ред. Н.В. Бикбулатова, Р.Г. Кузеева, Н.А. Мажитова. Уфа: БФАН СССР, 1973. С. 162-243.

Пшеничнюк A.X. Научный отчет о раскопках поселений в Гафурийском районе и разведках по трассе строительства железной дороги Ново-Мурапталово - Оренбург. Уфа, 1979 // Научный архив Уфимского научного центра РАН. Ф. 3. Оп. 2а. Д. 36.

Савельев Н.С. Новые исследования Шиповского городища в лесостепи Южного Приуралья // Уфимский археологический вестник. 2009. Вып. 9. С. 127-140.

Сальников К.В. Очерки древней истории Южного Урала. М.: Наука, 1967. 408 с.

Шокуров А.П. Отчёт об археологической разведке летом 1954 г. в Гафурийском районе БАССР. Уфа, 1954 // Научный архив Уфимского научного центра РАН. Ф. 3. Оп. 2. Д. 295, 296.

Юсупов Г.В. Отчёт об археологических разведках, проведённых 2-9 сентября 1953 г. в Гафурийском р-не БАССР. Уфа, 1953 // Архив ИА РАН. Ф. 1. Р. 1. № 1107.

Юсупов Г.В. Отчёт об исследовании археологического памятника Курман-Тау в Гафурийском р-не БАССР за 1954 г. Уфа, 1954 // Научный архив Уфимского научного центра РАН. Ф. 3. Оп. 2. Д. 297.

Юсупов Г.В. Отчёт Гафурийского отряда башкирской археологической экспедиции АН СССР. Уфа, 1955 // Архив ИА РАН. Ф. 1. Р. 1. № 1246.

Юсупов Г.В. Древнейшие поселения Гафурийского района. Научный отчёт об археологической экспедиции в Гафурийский район. Уфа, 1956 // Научный архив Уфимского научного центра РАН. Ф. 3. Оп. 2. Д. 355.

Юсупов Г.В. Древнейшие поселения Гафурийского р-на. Научный отчёт за 19551957 гг. по теме № 11 «Древнейшая история Башкирии». Уфа, 1957 // Научный архив Уфимского научного центра РАН. Ф. 3. Оп. 2. Д. 318, 320.

Юсупов Г.В. Древнейшие поселения Гафурийского района // Башкирский археологический сборник. Уфа, 1959. С. 58-87. 


\section{КРАНИОФЕНЕТИЧЕСКАЯ ХАРАКТЕРИСТИКА РАННИХ КОЧЕВНИКОВ ЮЖНОГО УРАЛА ВТОРОЙ ПОЛОВИНЫ VI - ІІ в. ДО Н.Э. \\ (предварительное сообщение)}

Гильмитдинова А.X.

http://10.25681/IARAS.2019.978-5-317-06274-3/352-359

Статья посвящена исследованию дискретно-варьирующих признаков (анатомических аномалий) черепа в группах ранних кочевников Южного Урала второй половины VI-II вв. до н.э. Распределение частот дискретно-варьирующих признаков с большей степенью достоверности выявляет генетические связи популяций, нежели анализ измерительных признаков, что позволяет приблизиться к решению проблемы происхождения населения прохоровского времени. Всего изучено 89 черепов из фондов НИИ и Музея антропологии МГУ. Использован авторский набор признаков. Выявлены повышенные частоты надглазничных отверстий, умноженных подглазничных отверстий, отверстий на барабанном кольце, вставочных косточек в сагиттальном и лямбдовидном швах и др. Популяционные особенности номадов Южного Урала оценены на фоне краниофенетического разнообразия Восточной Европы в целом. В работе впервые проводится сравнительный анализ частот дискретно-варьирующих признаков в выборках черепов савроматского и раннесарматского времени. Достоверных различий между ними не обнаружено.

Ключевые слова: палеоантропология, краниофенетика, ранний железный век, Южный Урал, ранние кочевники, дискретно-варьирующие признаки черепа

Проблема происхождения раннесарматской (прохоровской) культуры Южного Урала является одной из актуальных тем в отечественной историографии. Из относительно недавних работ, посвящённых истории изучения и периодизации прохоровской культуры, можно выделить статьи В.Н. Мышкина, А.Д. Таирова и П.А. Коробкова, где данные вопросы освещены наиболее подробно (Мышкин, 2010. С. 265-267; Таиров, 2012. С. 8385; Коробков, 2012. С. 160-167). В этой связи рассмотрим лишь основные точки зрения на появление памятников прохоровского типа и их связи с предшествующим - савроматским - периодом.

Систематическое изучение памятников прохоровской культуры началось в первой половине ХХ века - с доследования в 1916 г. С.И. Руденко разграбленных крестьянами курганов у с. Прохоровка.

Контур проблемы формирования прохоровской культуры одним из первых обозначил ещё М.И. Ростовцев, отмечавший, что памятники прохоровского типа имеют широкое распространение во всём Южном Приуралье. Он датировал их IV-III и II-I вв. до н.э. Кроме того, он связал приуральские памятники с древними сарматами и подчеркнул пришлый, «иранский» характер их культуры (Ростовцев, 1918). 
Вопрос о происхождении прохоровской культуры впервые был поставлен К.Ф. Смирновым, который отмечал, что в IV в. до н.э. на территории Южного Приуралья происходят существенные изменения в материальной культуре ранних кочевников. Он подчеркивал, что главные черты погребального обряда «сарматов» Южного Приуралья свидетельствуют об их генетической связи с «савроматами» ${ }^{1}$. При этом, по словам исследователя, многие новые признаки нельзя объяснить непосредственно связями с предшествующим периодом, и вполне вероятно, что сложение прохоровской культуры происходило на основе не только местных, «савроматских», но и пришлых компонентов (Смирнов, 1975).

Изменения в погребальном обряде и инвентаре захоронений IV в. до н.э. подробно изучались М.Г. Мошковой, которая, как и К.Ф. Смирнов, пришла к выводу о том, что формирование памятников прохоровского типа не ограничивается лишь генетической связью с «савроматской» культурой (Мошкова, 1974. C. 10).

Как отмечал Б.Ф. Железчиков, зарождение прохоровской культуры началось ещё во второй половине $\mathrm{V}$ в. до н.э. и было вызвано с притоком нового населения на территорию Южного Урала. Согласно его точке зрения, на протяжении второй половины VI - III в. до н.э. здесь была распространена единая культура кочевников, претерпевшая в своем развитии некоторые эволюционные изменения (Железчиков, 1986. С. 62-63).

В связи с проблемой формирования прохоровской культуры стоит также отметить точки зрения А.Д. Таирова и А.Г. Гаврилюка, писавших об установлении во второй половине VI - начале V в. до н.э. в Южном Зауралье тесных контактов с племенами скифо-савроматского круга, и Л.Т. Яблонского, который считал, что в сложении раннесарматской культуры Южного Приуралья приняли участие группы автохтонного, приуральского населения, а также мигранты из Средней Азии и Казахстана (Таиров, Гаврилюк, 1988. С. 151; Яблонский, 2002. С. 26).

Проблема происхождения ранних кочевников Южного Урала решалась не только археологами, но и палеоантропологами. Значительный вклад в изучение краниологической изменчивости степного населения раннего железного века внесли Г.Ф. Дебец, М.С. Акимова, Б.В. Фирштейн, С.Г. Ефимова, Л.Т. Яблонский, М.А. Балабанова и др. В свете рассматриваемой проблемы необходимо отметить несколько относительно недавних работ. Так, например, М.А. Балабанова пришла к заключению о морфологической идентичности населения савроматской и раннесарматской эпох Южного Приуралья

${ }^{1}$ Автор статьи разделяет позицию Л.Т. Яблонского и его сторонников, призывающих отказаться от употребления исторических этнонимов в ходе археологических исследований ранних кочевников Евразии (Яблонский, 2001. С. 59-60; Таиров, 2012. С. 84). Использование здесь и далее этнонимов «савроматы» и «сарматы» вызвано лишь необходимостью цитирования существующей историографической традиции. 
(Балабанова, 2000. С. 119). О преемственности между населением савроматского и раннесарматкого времени писала также С.Г. Ефимова, которой обнаружены такие изменения, как увеличение высоты лица, уменьшение его ширины и уменьшение наклона лба в раннесарматских сериях IV-III вв. до н.э. Это объясняется ею возможными процессами метисации антропологических компонентов, существовавших ещё в савроматское время (Ефимова, 2006. С. 136; 2005. С. 270).

До недавнего времени краниологическое разнообразие населения раннего железного века Южного Урала изучалось лишь по данным измерительных признаков. Важные популяционно-генетические их системы, такие как одонтологические и краниологические фены, оставались и остаются слабо изученными. Однако именно они позволяют говорить не только о сходстве, но и о родстве ископаемых популяций, и более надежно намечать древние этногенетические связи. Исследования в области палеофенетики сарматского населения долгое время не проводились. Первый анализ дискретно-варьирующих признаков на сарматском краниологическом материале с территории Южного Урала был проведён А.А. Мовсесян. Она изучала сарматские черепа в сравнительном аспекте, однако основным объектом данного краниофенетического исследования были черепа поздних скифов Северного Причерноморья. В сборной сарматской краниологической выборке, использованной А.А. Мовсесян, присутствовали и черепа, относящиеся к савроматскому времени с территории Южного Приуралья (Мовсесян, 2010). Отметим также, что частоты дискретноварьирующих признаков анализируются наряду с измерительными признаками в диссертационном исследовании М.А. Балабановой, посвящённом позднесарматскому населению Нижнего Поволжья (Балабанова, 2013).

Таким образом, целенаправленное исследование автором частот дискретноварьирующих признаков в краниологических сериях савроматского и раннесарматского периодов Южного Урала проводится впервые.

\section{Материал}

Были изучены дискретно-варьирующие признаки на 89-ти черепах савроматского и раннесарматского времени, хранящихся в фондах Научноисследовательского института и Музея антропологии МГУ ${ }^{1}$. В работе использовались следующие коллекции: КО 3/1-21, 23; КО 231/1-3; КО 233 /4, 6-7; КО 241/1-9, 11-16, 18-22, а также инв. № 3541, 8362-8365, 9510, 10283$10285,10287,10560,10562-10563,10565-10567,10569-10570,10688$, 11108-11109, 11111-11112, 11645, 11647-11650, 11652-11657, 11661-11662, 11669-11671.

${ }^{1}$ Автор статьи выражает благодарность Директору НИИМА МГУ, академику РАН А.П. Бужиловой за предоставленную возможность изучить серии черепов ранних кочевников Южного Урала, а также ст.н.с. НИИМА МГУ, канд. биол. наук Д.В. Пежемскому за помощь в освоении методики определения дискретно-варьирующих признаков. 
Выборка савроматского времени (VI-IV вв. до н.э.) включила в себя 47 черепов из могильников: Аландский III, Новый Кумак, Пятимары I, Тара-Бутак, Увак, Барышниково, Мечет-Сай, Бис-Оба, Любимовский.

Раннесарматская серия (IV-II вв. до н.э.) представлена 42 черепами из могильников: Близнецы, Буруктал, Любимово, Мечет-Сай, Увак, Пятимары I, Агаповка, Бишунгаровский.

\section{Методы}

В данном исследовании применяется авторская программа из 27 дискретноварьирующих признаков черепа, сформированная на основе методических работ Ю.Г. Рычкова, А.А. Мовсесян и Н.Н. Мамоновой, а также ряда зарубежных авторов (Мовсесян, Мамонова, Рычков, 1975; Мовсесян, 2005; Berry \& Berry, 1967). В работе в основном используется латинская терминология, предложенная Г. Чеснисом и С. Павилонисом (Česnys G., Pavilonis, 1982).

Наряду с признаками, широко представленными в отечественной краниофенетической литературе, автор впервые изучил на материалах раннего железного века Южного Урала частоты таких фенов, как: заднескуловой шов (Козинцев, 1984. С. 55-61; 1988. С. 64), третий решётчатый канал (Томашевич, 1990. С. 106-113), двойной оптический канал (Choudhry, Choudhry, Anand, 1988. P. 113-116), Везалиево отверстие (Shapiro, Robinson, 1967. Р. 781), разомкнутое овальное отверстие и следы каменисто-чешуйчатого шва (Hauser, De Stefano, 1989. Р. 152, 207).

Статистическая обработка материала включала в себя применение парного t-критерия Стьюдента по формуле Э. Вебер (Каминский, 1959; Weber, 1961).

\section{Результаты}

Изучение дискретно-варьирующих признаков черепа ранних кочевников Южного Урала позволило не только установить конкретные значения частот 27 краниологических фенов (табл. 1), но и зафиксировать определённое краниофенетическое своеобразие изученных групп населения. Фонд сравнительных материалов, доступных по литературным данным, крайне невелик. Относительно синхронные группы древнего населения, изученного по данной программе признаков, происходят из удалённых от Южного Урала регионов. По этой причине мы оценили полученные частоты на фоне размаха изменчивости дискретно-варьирующих признаков в пределах древних и современных групп Восточной Европы (Мовсесян, 2005).

По результатам данного сравнительного анализа выявилась группа признаков, частоты которых хорошо укладываются в восточно-европейский размах изменчивости, - их не менее половины. При этом треть всех изученных признаков имеет очень высокие частоты, не характерные для известного разнообразия популяций Восточной Европы (стоит оговориться, что по изучаемой системе признаков данных в целом не много и древнее население исследовано пока крайне недостаточно). 
К признакам, имеющим повышенные для Восточно-Европейской равнины частоты, в данном случае следует отнести надглазничные отверстия (foramen supraorbitale), умноженные подглазничные отверстия (foramen infraorbitale accessorium), отверстия на барабанном кольце (foramen tympanicum), вставочные косточки в сагиттальном и лямбдовидном швах (ossa sutura sagittalis, ossa sutura lambdoideae) и зародышевые швы (sutura mendosa). Только для «савроматской» выборки характерны повышенные частоты лобных отверстий (foramen frontale) и предмыщелковых бугорков (tuberculum precondylare), впрочем, различия в парах частот для этих двух признаков у «савромат» и ранних «сармат» не достигают уровня статистической значимости.

Следующим этапом работы было сравнение частот дискретно-варьирующих признаков в двух хронологических группах кочевников. Анализ проведён при помощи попарного сопоставления и достоверных статистических различий между «савроматской» и раннесарматской выборками обнаружено не было. Этот результат не противоречит рассмотренным выше археологическим и палеоантропологическим гипотезам о происхождении ранних кочевников, оставивших памятники прохоровской культуры. Краниофенетическая система признаков также свидетельствует о сближении населения савроматского и раннесарматского времени и, возможно, указывает на генетическую связь кочевого населения рассматриваемых двух периодов.

Для окончательного ответа на вопрос о происхождении населения Южного Урала прохоровского времени необходимо располагать представительной выборкой черепов не только с данной территории, но и материалами из сопредельных регионов. М.Г. Мошкова справедливо замечает, что для решения проблемы формирования классического комплекса прохоровской культуры «важны территории, соприкасающиеся с самыми восточными районами распространения прохоровской культуры», что «надо обратить пристальное внимание на особенности погребального обряда кочевников Центрального, Северного и Юго-Восточного Казахстана и на возможности связей этого населения с «савромато-сарматскими» племенами» (Мошкова, 1974. С. 7, 39). По этой причине результаты исследования, проведённого автором, являются предварительными. В будущем планируется продолжение работы с материалами большей численности и по более широкому списку дискретно-варьирующих признаков.

\section{Вывод}

На текущем этапе изучения частот дискретно-варьирующих признаков в группах савроматского и раннесарматского времени можно сделать предварительный вывод о том, что кочевое население Южного Урала этих двух периодов не имеет между собой достоверных различий по данным краниофенетики. 
Таблиияа 1

Частоты дискретно-варьирующих признаков черепа в группах ранних кочевников савроматского и раннесарматского периодов

\begin{tabular}{|c|l|c|c|c|}
\hline № & \multicolumn{1}{|c|}{ Признак } & $\begin{array}{c}\text { Савроматский } \\
\text { период }(\mathrm{n}=47)\end{array}$ & $\begin{array}{c}\text { Раннесарматский } \\
\text { период }(\mathrm{n}=42)\end{array}$ & t-критерий \\
\hline 1 & Sutura frontalis (metopica) & 0,021 & 0,095 & 1,52 \\
\hline 2 & Spina trochlearis & 0,067 & 0,131 & 0,98 \\
\hline 3 & Foramen supraorbitale & 0,489 & 0,609 & 1,13 \\
\hline 4 & Foramen frontale & 0,217 & 0,119 & 1,28 \\
\hline 5 & Foramen ethmoidale tertius & 0,333 & 0,467 & 0,78 \\
\hline 6 & (по Tomaшевич) & 0,265 & 0,242 & 0,22 \\
\hline 7 & Sutura zygomatica & 0,0 & 0,0 & - \\
\hline 8 & Sutura zygomatica posterior & 0,25 & 0,117 & 0,98 \\
\hline 9 & FCШ по Koзинцевy) & 0,125 & 0,105 & 0,20 \\
\hline 10 & Foramen venosum & 0,695 & 0,571 & 0,86 \\
\hline 11 & Foramen tympanicum & 0,166 & 0,264 & 1,00 \\
\hline 12 & Tuberculum precondylare & 0,115 & 0,047 & 0,82 \\
\hline 13 & Condylus tertius & 0,0 & 0,0 & - \\
\hline 14 & Canalis hypoglossalis septus & 0,238 & 0,167 & 0,55 \\
\hline 15 & Os bregmae & 0,047 & 0,026 & 0,52 \\
\hline 16 & Ossa sut. sagittalis (S1-S4) & 0,148 & 0,083 & 0,72 \\
\hline 17 & Foramen parietale (все морфы) & 0,642 & 0,552 & 0,83 \\
\hline 18 & Foramen parietale (cквозн.) & 0,463 & 0,421 & 0,38 \\
\hline 19 & Os lambdae & 0,057 & 0,178 & 1,52 \\
\hline 20 & Os interparietale & 0,0 & 0,035 & - \\
\hline 21 & Os triquetrum / Os quadratum & 0,025 & 0,0 & - \\
\hline 22 & Ossa sut. lambdoideae (L1-L3) & 0,75 & 0,826 & 0,64 \\
\hline 23 & Os Incae (totum/partiale) & 0,025 & 0,0 & - \\
\hline 24 & Sutura mendosa & 0,448 & 0,285 & 1,16 \\
\hline 25 & Os pterii (totum/partiale) & 0,176 & 0,0 & - \\
\hline 26 & Sutura petrosquamosa & 0,543 & 0,689 & 1,19 \\
\hline 27 & Canalis opticus bipartitum & 0,0 & 0,167 & - \\
\hline & & & \\
\hline
\end{tabular}

Балабанова М.А. Антропология древнего населения Южного Приуралья и Нижнего Поволжья. М.: Наука, 2000. 133 с.

Балабанова М.A. Позднесарматское население Нижнего Поволжья и сопредельных территорий в антропологическом контексте раннего железа и раннего средневековья. Автореф. дисс. ... докт. ист. наук. М., 2013. 65 с.

Ефимова С.Г. Ранние кочевники степей Южного Приуралья по данным краниологии // Вопросы антропологии. Вып. 92. М.: Изд-во МГУ, 2005. С. 260-270. 
Eфимова С.Г. «Савроматы» и ранние сарматы по антропологическим материалам из Лебедевского курганного комплекса // Древности Лебедевки (VI-II вв. до н.э.). М.: Вост. лит., 2006. С. 133-149.

Железчиков Б.Ф. Савроматы и ранние сарматы (некоторые итоги исследования) // Древняя и средневековая история Нижнего Поволжья. Саратов: Изд-во СГУ, 1986. С. 54-66.

Каминский Л.С. Обработка клинических и лабораторных данных. Л.: Медгиз, 1959. 194 с.

Козинцев А.Г. Заднескуловая щель как расоразграничительный признак // Вопросы антропологии. Вып. 74. М.: Изд-во МГУ, 1984. С. 55-61.

Козиниев А.Г. Этническая краниоскопия. Расовая изменчивость швов черепа современного человека. Л.: Наука, 1988. 165 с.

Коробков П.А. Проблемы изучения периодизации раннесарматских памятников Нижнего Поволжья // Вестник Волгоградского гос. ун-та. Сер. 4. История. 2012. № 1(21). C. $160-167$.

Мовсесян А.А. Фенетический анализ в палеоантропологии. М.: Университетская книга, 2005. $272 \mathrm{c.}$

Мовсесян А.А. Поздние скифы и сарматы в свете данных палеофенетики // Вестник Московского университета, серия XXIII. 2010. № 4. С. 43-48.

Мовсесян А.А., Мамонова Н.Н., Рычков Ю.Г. Программа и методика исследования аномалий черепа // Вопросы антропологии. Вып. 51. М.: Изд-во МГУ, 1975. С. 58-77.

Мошкова М.Г. Происхождение раннесарматской (прохоровской) культуры. М.: Наука, 1974. 52 с.

Мышкин B.H. Периодизация культуры кочевников Южного Урала в I тыс. до н.э. и прохоровская культура в отечественной историографии // Известия Самарского научного центра РАН. Т. 12. № 6. Самара, 2010. С. 265-267.

Ростовиев М.И. Курганные находки Оренбургской области эпохи раннего и позднего эллинизма (Материалы по археологии России, № 37). Пг., 1918. 103 с.

Смирнов К.Ф. Сарматы на Илеке. М.: Наука, 1975. 176 с.

Таиров А.Д. Происхождение раннесарматской культуры Южного Урала в отечественной историографии // Вестник ЮУрГУ. 2012. № 18. С. 83-85.

Таиров А.Д., Гаврилюк А.Г. К вопросу о формировании раннесарматской (прохоровской) культуры // Проблемы археологии Урало-Казахстанских степей. Челябинск: ЧелГУ, 1988. С. 141-159.

Томашевич Т.В. Закономерности распределения частоты третьего решётчатого канала черепа человека // Вопросы антропологии. Вып. 84. М.: Изд-во МГУ, 1990. C. 106-113.

Яблонский Л.Т. Антропологические данные к этногенезу народов Поволжья (по материалам Поволжской экспедиции) // Нижневолжский археологический вестник. Вып. 5. Волгоград: Изд-во ВолГУ, 2002. С. 24-74.

Яблонский Л.Т. Скифы, сарматы и другие в контексте достижений отечественной археологии XX века // Российская археология. 2001. № 1. С. 56-65.

Berry A.C., Berry R.J. Epigenetic variation in the human cranium // Journal of Anatomy, 1967. Vol. 101, № 2. P. 361-379.

Česnys G., Pavilonis S. On the terminology of non-metric cranial traits (Discreta) // Homo, 1982, Bd. 33, H. 2-3. S. 125-130. 
Choudry R, Choudry S, Anand C. Duplication of optic canalis in human skulls // Journal of Anatomy, 1988; 159. P. 113-116.

Hauser G., De Stefano G.F. Epigenetic variants of the human skull. Stuttgart: Schweizerbart, 1989. 301 p.

Shapiro R., Robinson F. The foramina of the middle fossa: a phylogenetic, anatomic and pathologic study. Am J Roentgenol Radium Ther Nucl Med 101:1967. P. 779-794.

Weber E. Grundriss der biologischen Statistik für Naturwissenschaftler, Landwirte und Mediziner. Bd. 4, überarb. u. erw. Aufl. Jena: Gustav Fisher Verlag, 1961. 565 S.

Weber E. Grundriss der biologischen Statistik für Naturwissenschaftler, Landwirte und Mediziner. Bd. 4, überarb. u. erw. Aufl. Jena: Gustav Fisher Verlag, 1961. 565 S. 


\section{ДАННЫЕ ОБ ИЗОТОПНОМ СОСТАВЕ КОСТНОЙ ТКАНИ В ИЗУЧЕНИИ СТРУКТУРЫ ОБЩЕСТВ КОЧЕВНИКОВ РАННЕГО ЖЕЛЕЗНОГО ВЕКА}

(Работа выполнена при поддержке РФФИ (проект № 18-09-00159 «Хозяйство и быт населения Среднего дона в скифское время: по данным естественных наук и археологии»))

\section{Добровольская М.В., Чагаров О.С., Хартанович В.И. http://10.25681/IARAS.2019.978-5-317-06274-3/360-365}

Представлены результаты исследований изотопного состава коллагена костной ткани людей в двух крайне отдалённых частях степного коридора (запад и восток) с тем, чтобы оценить гомогенность или гетерогенность параметров, маркирующих состав усреднённого рациона питания и природно-климатическое своеобразие среды, окружавшей при жизни людей, погребённых в могильниках Терновое-Колбино (Средний Дон) и Аймырлыг (Тува). Так или иначе приведённые данные указывают на существование традиций, способствующих широкому расселению людей, проживанию ими своих жизней в разных условиях и по несколько разным «правилам», чтобы потом уже навсегда быть объединёнными погребальными насыпями.

Ключевые слова: степные номады, генетические истоки, скифы, саки, коллаген, изотопный состав, биоархеологические материалы

Вопрос происхождения общности степных номадов был и остаётся одним из центральных в археологии раннего железного века. Палеоантропологические данные свидетельствуют о том, что в основе скифского массива находились различные по генезису группы. В.П Алексеев в своей обзорной работе, посвящённой антропологическим исследованиям степного евразийского населения в скифское время, приходит к выводу: «Вопреки мнению тех исследователей, которые видят генетические истоки скифо-сибирских, или скифо-сакских, культур в единой этнической среде и сравнительно ограниченной территории, палеоантропологические данные дают возможность поддержать другую гипотезу: скифо-сакская или скифо-сибирская культурная общность не образует генетического единства и сложилась на базе нескольких разных по происхождению антропологически своеобразных компонентов, которые и этнически могли существенно отличается друг от друга» (С. 233). А.Г. Козинцев, вынося обобщённое суждение о происхождении причерноморских скифов, пишет: «Скифы Северного Причерноморья были весьма неоднородны в антропологическом отношении. Наиболее отчётливы различия между степными и лесостепными группами. По всей видимости эти группы имели разное происхождение» (Козинцев, 2007. С. 154, 155). Палеогенетические исследования, проведённые большой группой исследователей под руководством И. Бургера (Институт эволюционной биологии Университета Иоаханна Гутенберга, Майнц, Германия), показывают, что «демографическое моделирование предполагает независимое происхождение для восточных и западных групп с постоянным потоком генов между ними» (Unterländer, et al., 2017. P. 1). 
Итак, различные независимые методические и методологические исследования, касающиеся собственно населения, входившего в эту обширную культурно-историческую общность, свидетельствуют о особых формах взаимодействия, которое позволяло сохранять генетическую дискретность внутри культурного объединения. Поэтому, на наш взгляд, исследования маркеров образа жизни могут добавить сведения для понимания этих традиций взаимодействия.

В данном случае нам бы хотелось обратиться к результатам исследований изотопного состава коллагена костной ткани людей в двух крайне отдалённых частях степного коридора (запад и восток) с тем, чтобы оценить гомогенность или гетерогенность параметров, маркирующих состав усреднённого рациона питания и природно-климатическое своеобразие среды, окружавшей при жизни людей, погребённых в могильниках Терновое-Колбино (Средний Дон) и Аймырлыг (Тува).

Привлечение данных об изотопном составе биоархеологических материалов стало столь широким, что представляется излишним излагать в этом кратком сообщении основы метода, которые уже публиковались (Ambrose, 1993. Р. 71-79). Процедура пробоподготовки коллагена костной ткани выполнена в лаборатории Группы физической антропологии ИА РАН по апробированной методике (Добровольская, Решетова, 2014. С. 40). Изотопный анализ осуществлялся в Центре коллективного пользования «Масс-спектрометрические исследования» ЦКП (изотопного анализа) Института проблем экологии и эволюции им А.Н. Северцова РАН под руководством А.В. Тиунова. Анализ изотопного состава углерода и азота проведён на масс-спектрометре Thermo-Finnigan Delta V Plus IRMS с элементным анализатором (Thermo Flash 1112).

Могильник Терновое-Колбино относится к среднедонской культуре скифского времени и датируется концом V - IV в. (Гуляев, 2001). Памятник изучался в период с 1993-2003 гг. Донской археологической экспедицией РАН под руководством В.И. Гуляева. В серию из 29 образцов костной ткани, полученных от скелетных останков, погребённых в могильнике Колбино-Терновое, были включены взрослые обоих полов и дети. В качестве сопоставительных материалов проанализированы три образца костной ткани лошади из погребений.

Диапазон изменчивости дельта углерода оказался велик и составил величину в $7 \%$ (от $-20,5 \%$ до -13,8\%o) (рис. 1). Значения дельта углерода находятся как в зоне экосистем, основанных на растениях С3 типа фотосинтеза, то есть флоре умеренного пояса с относительно длительными сроками активной сезонной вегетации, так и в зоне экосистем, которые базируются на растениях C4 типа фотосинтеза, живущих в засушливых районах. В самом общем виде можно отметить, что среди домашних растений просо является видом, для которого типичен С4 тип фотосинтеза.

Величины дельта азота во всей выборке варьируют от 10,75\% до 12,65\%о (промилле), уверенно занимая место в зоне «преимущественно белковая пища». 


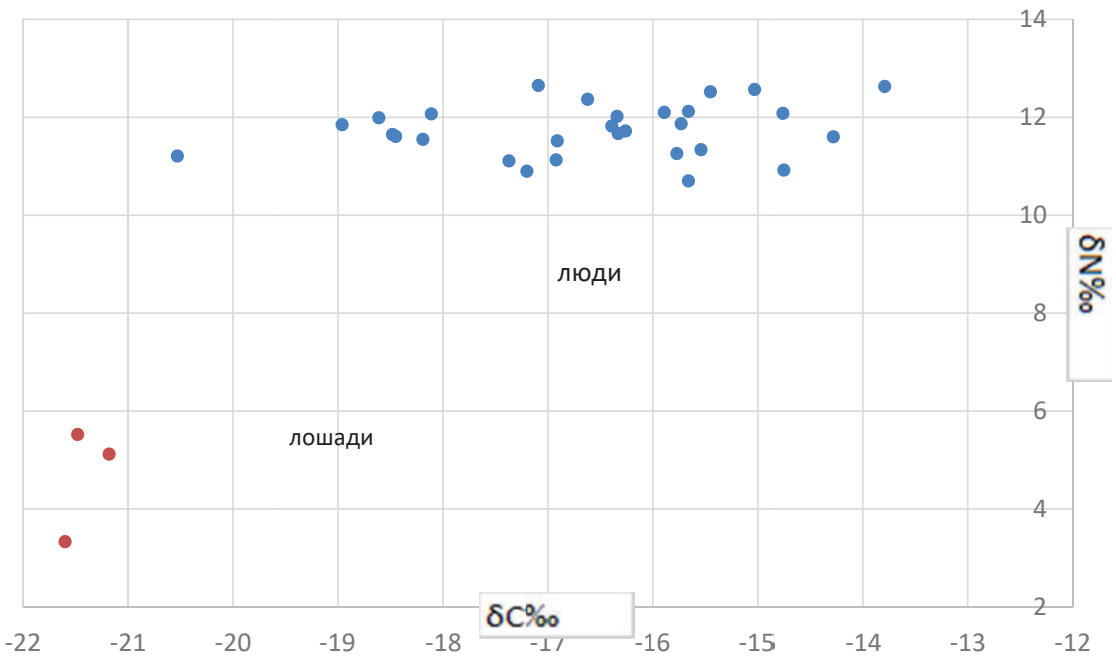

Рис. 1. Индивидуальные значения дельта углерода $\left(\delta^{13} \mathrm{C} \%\right)$ и азота $\left(\delta^{15} \mathrm{~N} \%\right)$ для людей и животных из могильника Колбино-Терновое на Среднем Дону

Таким образом, мы получили ожидаемый результат, который подтверждает преимущественно белковую пищу номадов раннего железного века и не несёт в себе принципиально новой информации.

Если мы обратимся к анализу индивидуального разнообразия величин дельта углерода, то увидим, что в поле общей изменчивости выражены лакуны. На рисунке хорошо видно, что меньшая группа индивидов характеризуется значениями дельта углерода от $-20,55 \%$ до $-18,11 \%$, а большая - значениями от -17.37 до -14,28. Между ними существует «зазор» в 0,7\%, который не является статистически достоверным, однако эта величина больше, чем остальные расстояния между индивидами с ближайшими значениями дельта углерода (за исключением одного случая - индивида из кургана № 12, из могильника Терновое). Люди, которые характеризуются столь различными величинами дельта углерода, отличались некими обстоятельствами. Возможны два наиболее вероятных фактора, определяющие эти обстоятельства:

1. Климатический. Растения, животные, люди, живущие в засушливых климатических условиях, характеризуются более высокими значениями дельта углерода и дельта азота.

2. Пищевой. Значительная доля растений С4 типа фотосинтеза в рационе животных и людей приводит к значительному повышению дельта углерода. Среди домашних растений C4 типа фотосинтеза, как правило, упоминается просо.

Вероятно, сказались оба фактора. Для пар значений дельта азота и углерода был посчитан коэффициент корреляции, который указывает на наличие 
слабой достоверной связи $(+0,203)$. Более значимым представляется пищевой фактор - фактор присутствия растений С4 типа фотосинтеза.

Можно предположить, что люди, которые были похоронены в курганном могильнике Терновое-Колбино, при жизни придерживались условно двух вариантов питания. Попытка сопоставить значения дельта углерода с планиграфией курганов результата не дала. Сравнение индивидуальных данных в коллективных погребениях выявило следующую картину: под насыпью одного кургана погребались люди, состав рационов которых значимо различался по участию в нем растений С4 типа фотосинтеза. Различие дельта углерода составляет значимую величину около 2 промилле. Это пока единичные наблюдения материалах из курганов № 7, 8, 29.

Также нами проводились аналогичные исследования изотопного состава коллагена костной ткани с палеоантропологическими материалами из могильника Аймырлыг. Это погребальное поле имеет долгую историю исследований (Мандельштам, 1983. С. 23). Мы исследовали материалы скифского времени ( $\mathrm{V}$ в. до н.э.), которые поступили в хранение Отдела антропологии Музея антропологии и этнографии им. Петра Великого (Кунсткамера) РАН после раскопок полевых сезонов 1972-1976 годов (Dobrovolskaya et al., 2012). В частности, в нашем анализе использовались скелетные материалы из двух коллективных погребений в срубах (№ 14 и 43). Коэффициент корреляции, посчитанный для всей выборки (22 человека), составляет $+0,605$. Таким образом, для данной группы связь повышения величины дельта азота и углерода вполне прочная, поэтому можно предполагать, что различия изотопных показателей определяются, в значительной мере, климатическим фактором. Для районов с чередованием котловин и высокогорий это не удивительно. В целом, изменчивость дельта углерода в выборке составляет больше 4 промилле, а изменчивость дельта азота - 2 промилле.

Оценим индивидуальную изменчивость изотопных соотношений в пределах коллективного погребения. И здесь мы также наблюдаем расхождение значений дельта углерода в образцах из скелетов из одного погребального сооружения. Для индивидов из захоронения в срубе № 43 различия величин дельта углерода составляют около 4 промилле, для людей из сруба № 14 - ниже, около 2 промилле.

Сопоставим изотопные соотношения в образцах из среднедонского и тувинского могильников. На рисунке 2 изображены индивидуальные значения параметров изотопного состава азота и углерода для индивидов из этих двух погребальных памятников. Отчётливо видно, что области их значений мало пересекаются. Образцы со Среднего Дона занимают левую нижнюю часть графика, а образцы из Тувы - правую верхнюю. Люди из погребений памятника Аймыргыг характеризуются устойчиво более высокими значениями азота и углерода. Вероятно, здесь мы как раз имеем дело с различиями, обусловленными климатическими расхождениями, так как климат Тувы - резко 


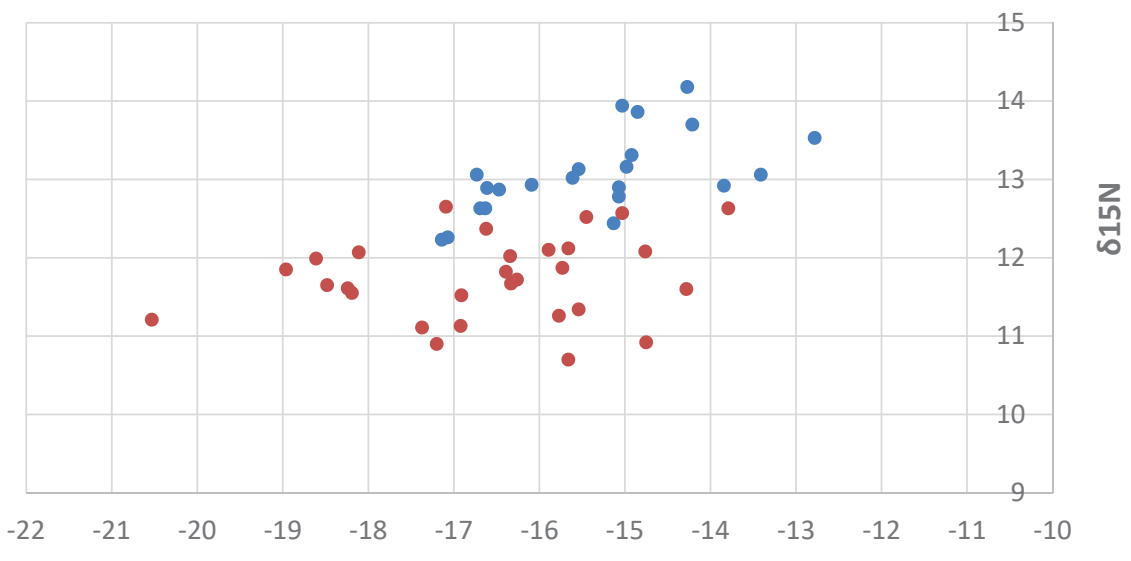

$\delta 13 C$

Рис. 2. Сопоставление индивидуальных дельта углерода $\left(\delta^{13} \mathrm{C} \%\right)$ и азота $\left(\delta^{15} \mathrm{~N} \%\right)$ в образцах костной ткани индивидов из среднедонского могильника Колбино-Терновое (красные значки) и тувинского Аймырлыг (синие значки)

континентальный, количество осадков в котловинах низкое, а среднедонской регион характеризуется умеренным или умеренно-континентальным климатом с более высокой влажностью.

Итак, после подробного описания полученных данных, вернёмся к вопросу, сформулированному в начале статьи: могут ли маркеры образа жизни добавить новую информацию в понимание сложной структурности обществ степных номадов Евразии? Полученные нами данные свидетельствуют о гетерогенности маркеров образа жизни погребённых в одном могильнике и даже в одном погребении. Мы не знаем, какие причины обусловили то, что люди, которые, предположительно, жили в разных районах и придерживались несколько разных традиций питания, должны были объединиться после смерти. Вероятно, палеогенетические исследования с целью выяснения родственных связей между погребёнными в коллективных захоронениях, могли бы прояснить этот вопрос, а, может быть, лишь усложнить его. Так или иначе приведённые данные указывают на существование традиций, способствующих широкому расселению людей, проживанию ими своих жизней в разных условиях и по несколько разным «правилам», чтобы потом уже навсегда быть объединёнными погребальными насыпями.

\section{ЛИТЕРАТУРА}

Алексеев В.П. Историческая антропология и этногенез. М.: Наука, 1989. 446 с.

Гуляев В.И. Общие проблемы археологии Среднего Дона скифского времени // Археология Среднего Дона в скифскую эпоху. Труды Потуданской археологической экспедиции. М.: ИА РАН, 2001. С. 18-52. 
Добровольская М.В., Решетова И.К. Питание носителей традиций салтово-маяцкой культуры в Доно-Донецком междуречье по данным изотопного анализа // PA. 2014. № 2. С. 39-47.

Козинцев А.Г. Скифы Северного Причерноморья: межгрупповые различия, внешние связи, происхождение // Археология, этнография и антропология Евразии. 2007. 4(32). C. $143-157$.

Мандельштам А.М. Исследование на могильном поле Аймырлыг (Некоторые итоги и перспективы) // Древние культуры евразийских степей / Отв. ред. В.М. Массон. Л.: Наука, 1983. С. 25-33.

Ambrose S.H. Isotopic analysis of paleodiets: methodological and interpretive considerations // Sandford M.K. (Ed.) Investigations of Ancient Human Tissue: Chemical Analyses in Anthropology. 1993. Gordon and Breach, PA. P. 59-130.

Dobrovolskaya M.V., Buzhilova A.P., Mednikova M.B., Tiunov A.V., Selezneva V.I., Moiseev V.G., Khartanovich V.I. Palaeodietary investigation of carbon (13/12C) and nitrogen $(15 / 14)$ stable isotopes in human bone collagen from Early Iron age burials at Aimyrlyg, Tuva // Abstracts of $18^{\text {th }}$ Annual Meeting of European Association of Archaeologists, $2^{\text {th }}$ of August $-1^{\text {st }}$ of September 2012, Helsinki, Finland, 2012. P. 162.

Unterländer M., Palstra F., Lazaridis I., Pilipenko A., Hofmanová Z., Groß M., Sell Ch., Blöcher J., Kirsanow K., Rohland N., Rieger B., Kaiser E., Schier W., Pozdniakov D., Khokhlov A., Georges M., Wilde S., Powell A., Heyer E., Currat M., Reich D., Samashev Z., Parzinger H., Molodin V., Burger J. Ancestry and demography and descendants of Iron Age nomads of the Eurasian Steppe // Nature Communications. 2017. \#8. https://doi.org/10.1038/ ncomms 14615 . 


\section{АРХЕОБОТАНИЧЕСКИЕ КОЛЛЕКЦИИ ПЛЕМЁН ДНЕПРО-ДВИНСКОЙ КУЛЬТУРЫ}

\section{Лошенков М.И.}

http://10.25681/IARAS.2019.978-5-317-06274-3/366-376

Предварительные результаты исследований палеоботанического комплекса населения днепро-двинской культуры на примере рассмотренных памятников фиксируют набор выращиваемых культур жителями восьми городищ. Установлено, что местные земледельцы культивировали просо, пшеницу мягкую, ячмень, боб и горох.

Ключевые слова: днепро-двинская общность, археоботаника, палеоботанические спектры, городище, поселение

В эпоху раннего железа население днепро-двинской общности проживало на территории современных Беларуси и России. В Беларуси оно населяло Витебщину и северо-восточную Могилёвщину, в России - юг Псковской области, большую часть Смоленщины и юго-западный край Тверской области. Общины больших патриархальных семей укрепляли свои посёлки. Городища сооружали на высоких послеледниковых останцах в поймах рек и на береговых выступах озёр. Посёлки днепро-двинцев функционировали (не повсеместно) приблизительно с VII в. до н.э. по III-IV вв. н.э. В ареале рассматриваемой культуры сотни городищ. Например, на территории Беларуси, по данным В.И. Шадыро, их 205 (Шадыра, 1999. С. 174-175, 217, мал. 52). Некоторые из них исследователи начали раскапывать уже в 1920-е годы. К началу XXI века раскопками изучено около ста памятников.

В процессе раскопок археологи не раз фиксировали находки ботанических материалов, сохранившиеся в слое поселений днепро-двинской культуры. Заметим, что ботанические находки у данного населения специально в публикациях никем не рассматривались (Кирьянова, 2005. С. 227-228, табл. 1). Нами они учтены на 11 памятниках (рис. 1). Археоботанические коллекции разные по содержанию. Мы разделили их условно на три группы. Первая - обугленные зёрна злаковых и бобовых культур, конечный продукт земледельцев. Вторая группа состоит из опосредованного материала - включений зёрен злаковых, бобовых и семян сорняков в глиняных посуде и пряслицах. Третья - остатки продуктов собирательства: лесные орехи, жёлуди, грибы, ягоды (табл. 1).

Материалы (объекты) и методы исследований. Коллекции первой группы встречены исследователями на шести памятниках: Буяново, Заговалино, Загорцы, Новое Село, Подгай и Чесноры (рис. 1). Обугленное зерно впервые обнаружено в 1933 году на городище Чесноры (Усвятский р-н Псковской обл.) при обследовании его А.Н. Лявданским и А.Д. Коваленей. В статье А.Н. Лявданский сообщил об этом факте одним предложением: «Так напр. знойдзены рэшткі абвугленых зёрнаў пшаніцы на раннім гарадзішчы каля в. Чэсноры...» (Ляўданскі, Палікарповіч, 1936. С. 215). О сожжённой 


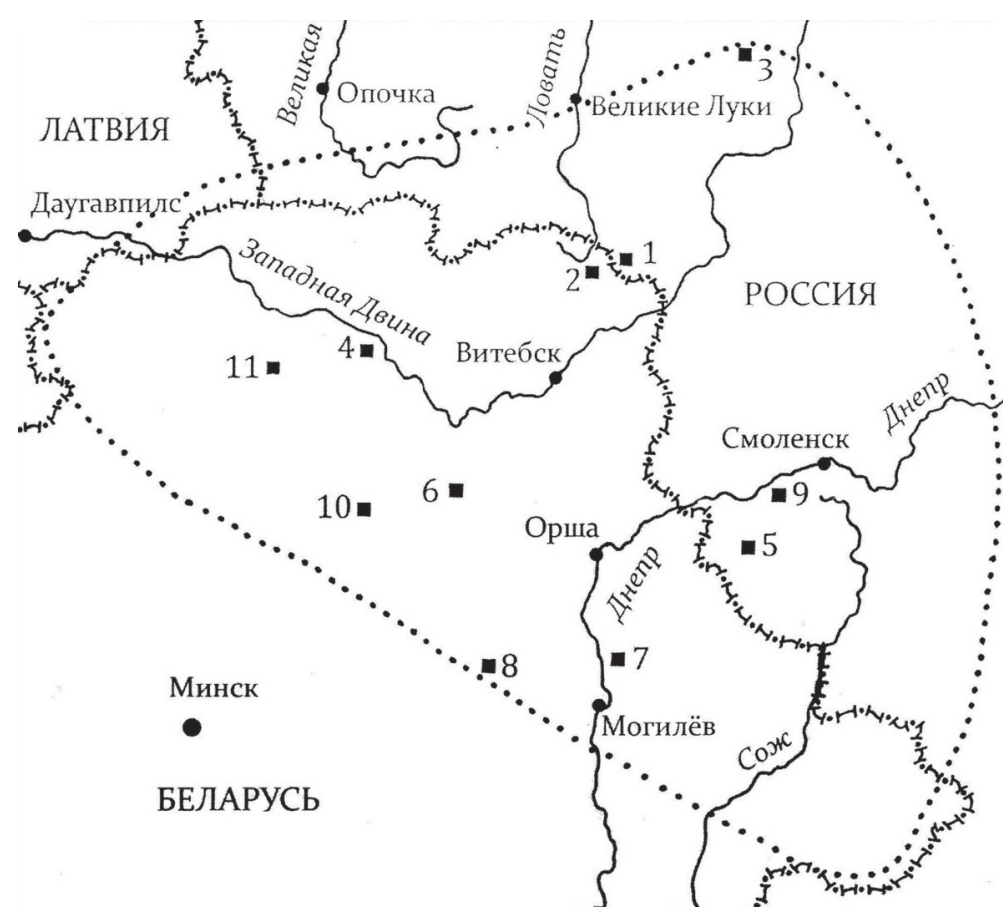

Рис. 1. Карта днепродвинских городищ с ботаническими находками. 1 - Чесноры; 2 - Загорцы; 3 - Подгай; 4 - Заговалино; 5 - Буяново; 6 - Новое Село; 7 - Кривель; 8 - Эсьмоны; 9 - Демидовка; 10 - Кострица; 11 - Поддубники

пшенице на этом поселении по 1970 год упоминали только два исследователя - К.М. Поликарпович и А.Г. Митрофанов (Палікарповіч, 1947. С. 66; Поликарпович, 1949. С. 498; Митрофанов, 1970. С. 218). После них о пшенице на городище Чесноры никто не вспоминал. Этот памятник в 1952 году обследовала Я.В. Станкевич, которая дала ему полную характеристику и датировала концом I тыс. до н.э. (1960. С. 20, 178, 180, табл. VIII: 6, X, XI).

Вторым памятником в этой группе является городище Загорцы. Оно расположено около деревни Степановичи (Городокский р-н Витебской обл. Бел.). Его в 1934 году раскапывали А.Н. Лявданский и А.Д. Коваленя. Они нашли «...pэшткі згарэўшага наземнага драўлянага жылля з прымітыўнымі агнішчамі на земляной падлозе і рэшткі абвугленых зёрнаў пшаніцы» (Ляўданскі, Палікарповіч, 1936. С. 222). Специалисты во Всесоюзном институте растениеводства (г. Ленинград) установили, что пшеница эта мягкая (Якубцинер, 1956. С. 139). На этом поселении данная культура относится к I-III вв. н.э. Именно об этом зерне упоминали исследователи Беларуси, когда писали о зарождении земледелия на севере республики (Коробушкина, 1979. С. 70, 82, табл. 5; Подгурский, 2005. С. 180; Лошенков, 2014. С. 98-99). 
Таблица 1

Ботанические материалы с памятников днепро-двинской культуры Беларуси и России

\begin{tabular}{|c|c|c|c|c|c|c|c|c|c|}
\hline $\begin{array}{c}\text { № } \\
\Pi / \Pi\end{array}$ & Памятники & $\begin{array}{c}\text { Жёлуди, } \\
\text { орехи }\end{array}$ & Просо & $\begin{array}{l}\text { Пше- } \\
\text { ница }\end{array}$ & $\begin{array}{c}\text { Яч- } \\
\text { мень }\end{array}$ & Бобы & $\begin{array}{l}\text { Гo- } \\
\text { pox }\end{array}$ & $\begin{array}{l}\text { Сор- } \\
\text { няки }\end{array}$ & Всего \\
\hline \multicolumn{10}{|c|}{ Обугленные макроостатки - 2957+ } \\
\hline 1 & Буяново (1987 г.) & $\Gamma / \mathrm{M}^{*}$ & $2205+$ & $288+$ & $392+$ & & & 26 & 2911 \\
\hline 2 & $\begin{array}{l}\text { Демидовка } \\
(1957-1967 \text { гг.) }\end{array}$ & $+ж$ & & & & & & & + \\
\hline 3 & $\begin{array}{l}\text { Заговалино } \\
(1966 \text { г.) }\end{array}$ & & & & & 2 & & & 2 \\
\hline 4 & Загорцы (1934 г.) & & & + & & & & & + \\
\hline 5 & Кострица (1966 г.) & 20 & & & & & & & 2 \\
\hline 6 & $\begin{array}{l}\text { Новое Село } \\
(2003 \text { г.) }\end{array}$ & & & & 35 & & 2 & 5 & 42 \\
\hline 7 & Подгай (1950 г.) & & & + & 2 & & & & $2+$ \\
\hline 8 & $\begin{array}{l}\text { Поддубники } \\
\text { (1956 г.) }\end{array}$ & +0 & & & & & & & + \\
\hline 9 & Чесноры (1933 г.) & & & + & & & & & + \\
\hline \multicolumn{10}{|c|}{ Включения зерна - 102} \\
\hline 10 & $\begin{array}{l}\text { Кривель (1997, } \\
1998 \text { гг.) }\end{array}$ & & 67 & 11 & 4 & 4 & & 1 & 87 \\
\hline & Новое Село & & 6 & 1 & 6 & & & & 13 \\
\hline 11 & Эсьмоны (1992 г.) & & & 1 & 1 & & & & 2 \\
\hline & В с его & $2+$ & $2278+$ & $301+$ & $440+$ & 6 & 2 & 32 & $3061+$ \\
\hline
\end{tabular}

Следующее поселение - городище в урочище Подгай, что около деревни Новобридино (Торопецкий р-н Тверской обл. Рос.). Его открыла в 1949 и раскапывала в 1950, 1951 годах Я.В. Станкевич (1960. С. 23-25, 44-66, 155-176). Время памятника по артефактам - I-IV вв. н.э. (Станкевич, 1960. С. 67, 176). Интересующие нас находки обнаружены в жилище № 14 (1950 г.). Постройка сгорела. В центре неё на полу был очаг. Ниже, под очагом, находилась прямоугольная яма небольших размеров, вся заполненная зерном (Станкевич, 1960. 
С. $52,170,172$, рис. $31: 14,35)$. В.А. Петров установил, что это - культура мягкой пшеницы (Петров, 1960. С. 323-324). В Институте ботаники АН СССР подтвердили правильность заключения В.А. Петрова и отметили ещё два зерна ячменя голозёрного (Петров, 1960. С. 324). Эта коллекция относится, вероятно, к I в. н.э.

Днепро-двинское городище Заговалино находится на левом берегу Западной Двины, в её среднем течении. Памятник локализован возле одноимённой деревни (Ушачский р-н Витебской обл. Бел.). В 1966 году К.П. Шут исследовал на нём 200 м² в юго-восточной четверти посёлка (Шут, 1969. С. 32-42). В нижнем горизонте первопоселенцев он нашёл около западной стенки квадрата 3/3 два семени обугленных конских бобов. Определение их выполнила Н.А. Кирьянова (Шут, 1969. С. 36). Учитывая, что стратиграфически бобы найдены in situ, мы относим их к III в. н.э. Об этом факте археологи Беларуси молчали почему-то более 50 лет (?). Теперь с учётом сказанного отметим, что городище Заговалино - самое северное поселение раннего железного века в Беларуси с остатками культуры бобов. Оно находится в лесной зоне на уровне $55^{\circ} 13^{\prime}$ с.ш.

Укреплённое поселение Буяново локализовано возле одноимённого населённого пункта (Краснинский р-н Смоленской обл. Рос.). Впервые обследовано В.Р. Тарасенко в 1928 году. Он установил его местонахождение, разработал шурф и снял план (Тарасенко, 1930. С. 135-136, мал. 22). В послевоенное время посёлок неоднократно обследовал Е.А. Шмидт. В 1986 году он отметил его повреждение: в 1970-е годы в северо-восточной части бульдозером прорыта поперечная траншея длиной 22 м (Шмидт, 1986. Д. 11265). В 1987 году исследователь провёл небольшие спасательные раскопки. Об этом он доложил на конференции «Дняпроўскі край», которая состоялась в г. Могилёве. В ходе спасательных работ зачищена восточная стена траншеи и исследован слой до материка. На северном краю площадки, в нижней толще слоя имелась углистая прослойка с большим количеством сожжённого зерна (Шмидт, 1987. Д. 12187). Е.А. Шмидт взял коллекцию обугленных макроостатков, которые он передал на определение Н.А. Кирьяновой (небольшую часть) в Институт археологии РАН и в Минск - в Институт экспериментальной ботаники НАН Беларуси. В лаборатории естественнонаучных методов, в Москве, Н.А. Кирьянова установила, что зерно принадлежит пшенице, ячменю и просу (Шмидт, 1992. С. 57; 1993. С. 39; Кирьянова, 2005. С. 237). Украинский исследователь С.А. Горбаненко высказал сожаление о том, что нет статистических данных по видам культур с городища Буяново (Горбаненко, 2015. С. 237).

В 2016 году автор совместно с Т.В. Якубовской определил состав минской части коллекции с данного памятника (табл. 2). По составу весь материал мы условно разделили на три части: остатки посевных злаковых культур (2885 ед.) (рис. 2: 1-5, 10-16), сорных растений (26 ед.) и других видов (66 ед.) (рис. 2: 6-9, 3). 
Таблицุа 2

Археоботанические находки городища Буяново*

\begin{tabular}{|c|c|c|c|}
\hline № п/п & Названия растений & Количество (ед.) & Примечания \\
\hline \multicolumn{4}{|c|}{ Культурные злаки - 99,1\% } \\
\hline 1 & Panicum miliaceum L. (просо) & $>2205$ & \\
\hline 2 & Hordeum vulgare L. (ячмень) & 392 & $+75 \phi p$. \\
\hline 3 & Triticum vulgare Vill. (пшеница) & 288 & \\
\hline & Triticum + Hordeum (пшеница + ячмень) & & $>425 \phi p$ \\
\hline & Всего & 2885 & $>500 \phi p$. \\
\hline \multicolumn{4}{|c|}{ Сорнье растения - 0,9\% } \\
\hline 4 & Secale cereal L. (рожь) & 18 & \\
\hline 5 & Silene venosa Asch. (хлопушка обыкновенная) & 3 & \\
\hline 6 & $\begin{array}{l}\text { Cirsium lanceolatum (L.) Scop. } \\
\text { (бодяк ланцетолистный) }\end{array}$ & 1 & \\
\hline 7 & Chenopodium album L. (марь белая, лебеда) & 1 & \\
\hline 8 & Chenopodium hybridum L. (марь гибридная) & 1 & \\
\hline 9 & Caryophylaceae gen. (гвоздичные) & 1 & \\
\hline 10 & Chenopodiaceae gen. (маревые) & 1 & \\
\hline 11 & Poaceae gen. (злаковые) & & $26 \phi p$. \\
\hline & Неопределимые & & 2 ед. \\
\hline & Всего & 26 & \\
\hline \multicolumn{4}{|c|}{ Другие растения } \\
\hline 12 & Rubus idaeus L. (малина) & 1 & косточка \\
\hline 13 & Fungi (грибы) & 55 & склероциев \\
\hline 14 & Picea abies L. (ель европейская) & 8 фр. хвои & иголки \\
\hline \multirow[t]{2}{*}{15} & Picea obovate Ledeb. (ель сибирская) & 2 фр. хвои & иголки \\
\hline & Всего & 66 & \\
\hline \multicolumn{4}{|c|}{\begin{tabular}{rl|c} 
И т о го & 2977 & \\
* Определение выполнили кандидаты геолого-минералогических наук Т.В. Яку- \\
бовская и исторических наук М.И. Лошенков.
\end{tabular}} \\
\hline
\end{tabular}

Ботанические материалы с городища Буяново, обработанные в Минске и Москве, как видим, идентичны по составу выращиваемых культур жителями посёлка. Палеоэтноботанический спектр памятника составляют три культуры: просо, пшеница и ячмень. На данном городище анализ угля с зерном на $\mathrm{C}^{14}$ показал время пожара 299 г. до н.э. \pm 40 лет (Шмидт, 1993. С. 39).

Последний памятник с находками первой группы - городище возле деревни Новое Село (Сенненский р-н Витебской обл. Бел.). В 2002-2007 годах его изучал П.Н. Подгурский. В материалах 2003 года он выявил ботанические коллекции первой и второй групп (Падгурскі, 2011. С. 136). Время посёлка по артефактам - I-III вв. н.э. Материалов первой группы немного - 42 едини- 


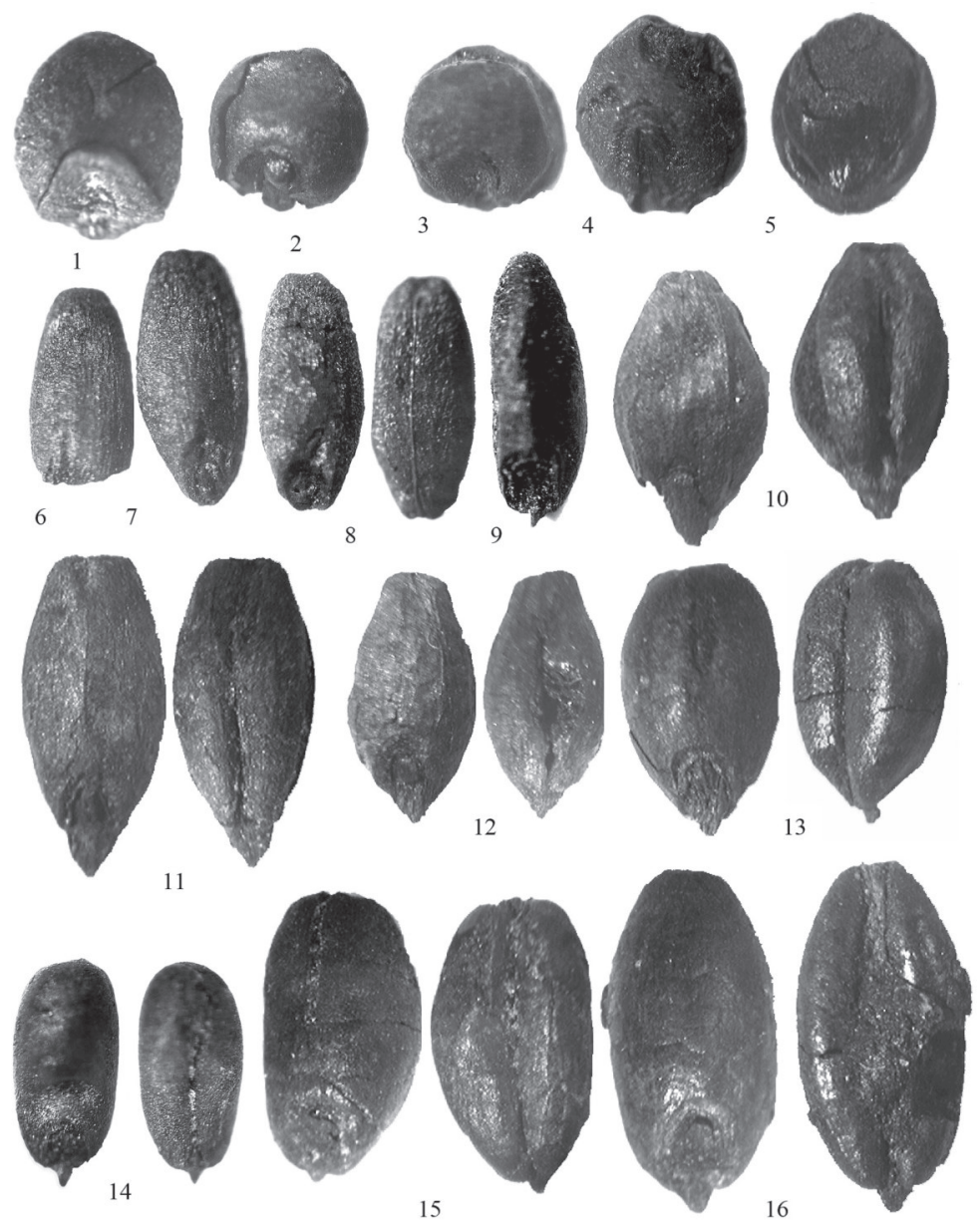

Рис. 2. Зерно злаковых с городища Буяново. 1-5 - просо; 6-9 - рожь; 10-12 - ячмень;

13-16 - пшеница (№ 1-7, 9 - односторонние; № 8, 10-16 - двухсторонние; № 1-9 - увел. в 15 раз; № 10-16 - увел. в 20 раз)

цы (табл. 1). По заключению Д.И. Третьякова, это горох (Pisum sativum L.) и ячмень (Hordeum vulgare L.). Они обнаружены в 9 квадратах нижнего горизонта слоя. Среди культурных видов было пять семян сорняков: лебеда (Chenopodium album L.) - 1, горошек дикорастущий (Vicia sp.) - 2, лопух (Arctium sp.) - 1 и рдест гребенчатый (Potomogeton pectinatum L.) - 1.

У днепро-двинских племён материалы второй группы (включения) известны на трёх поселениях: Кривель, Новое Село и Эсьмоны.

Городище Кривель, как и Буяново, находится на левом берегу Днепра, в его верхнем течении. Оно расположено в урочище Городок, около деревни Кривель (Шкловский р-н Могилёвской обл. Бел.). В 1996-1998 годах раскопки на нём провёл П.Н. Подгурский (2000. С. 242-243; 2002. С. 166-178). 


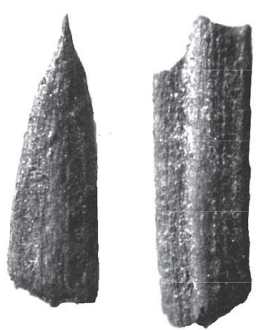

1

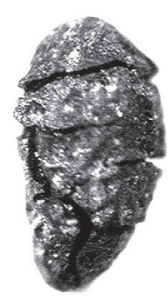

4

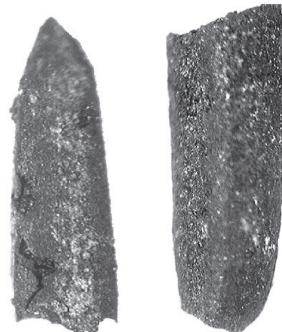

2

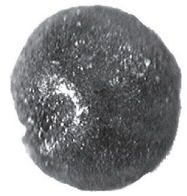

6

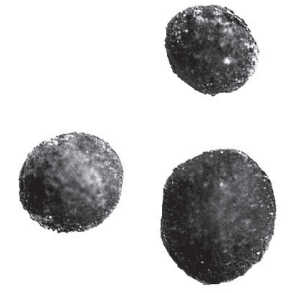

3

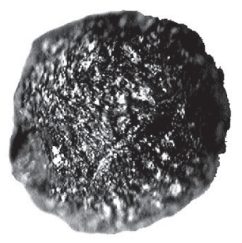

7
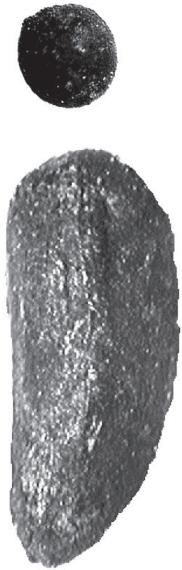

8

Рис. 3. Обугленные остатки ботанических находок с Буяновского городища.

1 - хвоя ели сибирской (Picea obovata Ledeb.); 2 - хвоя ели европейской (Picea abies (L.) Karst.);

3 - склероции грибов (Fungi);

4 - косточка малины (Rubus idaeus L.);

5 - хлопушка обыкновенная (Silena venosa Asch.);

6 - марь белая, лебеда (Chenopodium album L.);

7 - марь гибридная (Chenopodium hybridum L.);

8 - бодяк ланцетолистный (Cirsium lanceolatum L.)

(№ 1-3, 8 - увел. в 15 раз; № 4-7 - увел. в 20 раз)

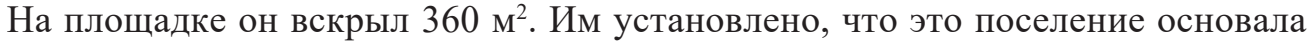
община днепро-двинцев приблизительно на рубеже эр. Функционировало оно до IV в. н.э. (Подгурский, 2000. С. 243; 2002. С. 172). В обломках лепной посуды с раскопов 1997 и 1998 годов, численностью 5634 ед., автор раскопок выбрал 77 (1,3\%) фрагментов, которые содержат 87 (1,5\%) включений злаковых и бобовых культур (Лошенков, 2013. С. 76, табл.). В лаборатории флоры и систематики растений Института экспериментальной ботаники НАН Беларуси Д.И. Третьяков определил, что выбранные документальные образцы содержат включения выращиваемых культур. В ассортименте их есть просо (Panicum miliaceum L.) - 67 ед., пшеница (Triticum aestivum L.) - 11 ед., ячмень (Hordeum vulgare L.) - 4 ед., бобы (Vicia faba L.) - 4 единицы. Из сорняков имеется семя дикорастущего горошка (Vicia sp.) (Лошенков, 2013. С. 75-86, табл).

Из 11 рассматриваемых памятников только на одном - Новое Село имеются две группы ботанических находок. О первой из них речь шла выше. В коллекции керамики (2003 г.) с этого поселения П.Н. Подгурский обнаружил восемь предметов с растительными добавками в глиняных изделиях. Он 
передал на идентификацию включений в Институт экспериментальной ботаники НАН Беларуси три обломка стенок от лепных сосудов и пять пряслиц. Заключения по ним выполнил Д.И. Третьяков. В пряслицах на поверхностях и в поперечных разломах он зафиксировал 10 зерновок. В трёх стенках посуды зерновки есть на внутренней поверхности (2) и в толще, в продольном расслоении (1). Из трёх включений одно - зерно пшеницы и два - ячменя. В числе пяти пряслиц в трёх - просо (6 ед.) и в трёх - ячмень (4 ед.). Общее количество включений (13) выглядит так: просо (Panicum miliaceum L.) - 6 ед., пшеница (Triticum aestivum L.) - 1 ед., ячмень (Hordeum vulgare L.) - 6 единиц (табл. 1). Только один образец-документ из восьми (пряслице) содержал шесть зерновок, а все остальные - по одному.

Эсьмоны - укреплённое поселение на мысу левого, высокого берега речушки Ослик (правый приток реки Друть), на правобережье Днепра. Оно находится южнее одноимённой деревни (Белыничский р-н Могилёвской обл. Бел.). В 1992 году раскопки на этом городище провёл М.И. Лошенков (1994. С. 90,

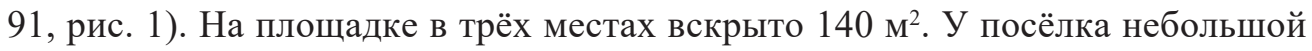
(до 0,3 м) слой, слабонасыщенный артефактами. Памятник датирован автором раскопок первой третью I тыс. н.э.

В раскопах выявлено 715 фрагментов лепной посуды днепро-двинской культуры (Лошенков, 1994. С. 94-97, рис. 3-5). При визуальном осмотре на двух обломках сосудов обнаружены включения зёрен растений. В Институте экспериментальной ботаники НАН Беларуси Д.И. Третьяков установил, что на внешней поверхности одной стенки есть зерновка от выгоревшего ячменя (Hordeum vulgare L.). Вторая зерновка находилась во внутренней толще стенки. Она выявилась в продольном расслоении. Отпечатки этого включения нечёткие. Высока вероятность того, что здесь было зерно пшеницы (Triticum aestivum L.) (Лашанкоў, Траццякоў, 2005. С. 56, табл. 1).

Базу коллекции второй группы составили 102 включения зёрен и семян растений, которые являлись органическими примесями в формовочной массе глиняных изделий.

Материалы третьей группы выявлены на четырёх поселениях (табл. 1). Скорлупа лесных орехов обнаружена в слое городищ Поддубники (Миорский p-н, Бел.) и Кострица (Лепельский р-н, Бел.). Остатки желудей - Демидовка (Смоленский р-н, Рос.), а грибов и ягоды малины - Буяново.

Результаты и их обсужжение. Картографирование 11 рассматриваемых городищ населения днепро-двинских племён показывает, что они локализуются в центральной части ареала культуры (рис. 1). По времени они в большинстве своём относятся к I-III вв. н.э., а наиболее ранние появились уже во второй половине I тыс. до н.э. В публикации 2015 года мы касались находок лишь трёх поселений (Лошенков, 2015. С. 247-248).

Среди изученных памятников только на четырёх исследователи обнаружили остатки продуктов собирательства. Лесные орехи - на городищах Кострица 
и Поддубники (табл. 1: 5, 8). Жёлуди выявлены на одном памятнике Демидовка. Грибы и ягоды малины зафиксированы на городище Буяново (табл. 2: 12, 13). Дары лесов, как видим, заготавливались на зимнее время населением днепродвинцев.

Продукция местных земледельцев отмечена на бо́льшем количестве укреплённых поселений - 9. Обугленное зерно встречено на шести памятниках, а его включения в качестве органической примеси в глиняной посуде - на трёх (табл. 1). Археоботанические коллекции первой и второй групп в количественном отношении неравнозначные. Первые составляют 96,7\%, а вторые $-3,3 \%$ от общего количества 3027 + ед. находок посевных культур. Палеоботанические спектры рассмотренных поселений выражены пятью культурами. Земледельцы городищ высевали яровые просо, пшеницу, ячмень, боб, горох.

Просо. Эта культура выявлена на трёх поселениях (Буяново, Кривель и Новое Село), которые находятся в Поднепровье. Наиболее значимая коллекция происходит с Буяновского городища на Смоленщине (табл. 1, 2). На этом памятнике нами учтена только россыпь зёрен (рис. 2: 1-5). В ходе раскопок встречались ещё и спёкшиеся комы (?). Включения проса в лепной посуде отмечены пока на двух памятниках Беларуси - Кривель и Новое Село.

Пшеница, в отличие от проса, есть на семи городищах. В трёх коллекциях, двух довоенных (Чесноры, Загорцы) и одной послевоенной (Подгай), определения выполнены специалистами без учёта количества материалов. Данное обстоятельство лишает возможности соотнести мягкую пшеницу этих городищ с таковой на других памятниках. Сведения же по этой культуре на остальных поселениях контрастируют - от не полностью учтённых зёрен (есть обломки) на городище Буяново до минимального количества включений их во фрагментах лепной посуды (табл. 1, 2). Здесь важно подчеркнуть, что мягкая пшеница уже в начале нашей эры выращивалась на северном городище днепро-двинцевПодгай на уровне $56^{\circ} 10^{\prime}$ с.ш. В то же время два южных памятника - Кривель и Эсьмоны - находятся чуть выше $54^{\circ}$ с.ш.

Ячмень обнаружен на шести памятниках. Его зерно есть в коллекциях первой и второй групп (табл. 1,2). Два полярных посёлка с этой культурой: северное - Подгай и южное - Эсьмоны (5405' с.ш.). Сведения о зерне на Буяновском городище неполные, поскольку часть коллекции сохранилась в не диагностируемых обломках (табл. 2, прим.). По имеющимся находкам можно предположить, что среди злаковых культур у днепро-двинских племён преобладали две - пшеница и ячмень.

Бобовые культуры. В меньшей мере, нежели злаковые, у днепро-двинцев представлены находки бобовых культур. Они зафиксированы на трёх городищах. Горох обнаружен двумя единицами семян на поселении Новое Село. На других памятниках он не известен. Боб же выращивали жители городищ Заговалино и Кривель. Если на первом он представлен двумя находками семян, то на втором - четырьмя включениями в глиняной посуде. Обугленные зёрна 
найдены в 1966 году, а включения - в керамике 1997 и 1998 годов. На левом берегу Днепра боб выращивали на уровне $54^{\circ} 10^{\prime}$ с.ш., а на левом берегу Западной Двины, соответственно, 55²1'.

Заключение. Палеоботанические спектры рассмотренных памятников фиксируют набор выращиваемых культур жителями восьми городищ. Местные земледельцы, как мы установили, культивировали просо, пшеницу мягкую, ячмень, боб и горох. Таков предварительный результат палеоботанического комплекса населения днепро-двинской культуры.

\section{ЛИТЕРАТУРА}

Горбаненко С.А. Палеоэтноботанические материалы Знаменского городища и зерновое хозяйство дъяковской культуры // АДІУ. 2015. Вип. 2. С. 232-239.

Кирьянова Н.А. О находках зёрен культурных растений І тысячелетия до н.э. І тысячелетия н.э. на территории лесной зоны Восточной Европы // Тр. ГИМ. 2005. Вып. 145. С. 226-230.

Коробушкина T.Н. Земледелие на территории Белоруссии в X-XIII вв. / Ин-т истории АН БССР; Ред. Э.М. Загорульский; Рец. Ю.А. Краснов и др. Минск: Наука и техника, 1979. $120 \mathrm{c.}$

Лашанкоў M.І., Траџиякоў Д.І. Палеаэтнабатанічныя даследаванні матэрыялаў 3 помнікаў ранняга жалезнага веку паўднёва-ўсходняй Беларусі // ГАЗ. 2005. № 20. C. 56-61.

Лошенков М.И. Эсьмоны - городище-убежище первой половины I тысячелетия нашей эры в бассейне реки Друть // Археалогія і старажытная гісторыя Магілёушчыны і сумежных тэрыторый: матэр. канф. / Магіл. абл. краязн. музей; Рэд. А.А. Седзін. Магілёў, 1994. С. 90-103.

Лошенков М.И. Археоботанические материалы городища Кривель // Ботаника (исследования): сб. науч. тр. Вып. 42. Минск, 2013. С. 75-86.

Лошенков М.И. Археоботанические коллекции с памятников раннего железного века Беларуси // Феномен Більського городища, 2014: зб. матеріалів наук. конф. Київ Полтава, 2014. С. 97-100.

Лошенков М.И. Археоэтноботанические коллекции с памятников раннего железного века Беларуси // АДІУ. 2015. Вип. 2(15). С. 240-249.

Ляўданскі А.Н., Палікарповіч К.М. Археалагічныя доследы ў БССР у 1933-1934 гг. // Запіскі Беларускай Акадэміі навук. Кн. 5. Менск, 1936. С. 210-223.

Митрофанов А.Г. Памятники днепродвинской культуры // Очерки по археологии Белоруссии: в 2 ч. Ч. 1: Каменный, бронзовый и железный века / Ин-т истории АН БССР; Ред. В.Ф. Исаенко. Минск: Наука и техника, 1970. С. 213-224.

Падгурскі П.М. Новае Сяло, археалагічны помнік // Археалогія Беларусі: энцыклапедыя ў 2 т. Т. 2. Л - Я / Рэд. Т.У. Бялова. Мінск, 2011. С. 136.

Палікарповіч К.M. Вынікі археалагічных даследаванняў на Беларусі пасля кастрычніцкай соцыялістычнай рэволюцыі // Весці АН БССР. Сер. Гістарычная. 1947. Вып. 1. С. 53-74.

Петров B.A. Зерновые остатки из сборов на городище в ур. Подгай (по материалам Западнодвинского отряда славянской экспедиции ИИМК в 1950 г.) // МИА. 1960. № 76. С. 323-324. 
Подгурский П.Н. Необходимость расширения источников финансового обеспечения местного самоуправления ${ }^{1 / /}$ Беларусь и Европа: взаимодействие культур (история, уроки, опыт, современность): Матер. Междунар. науч.-практ. конф. / М-во образования РБ; Витеб. гос. ун-т им. П.М. Машерова; Ред. В.А. Космач. Витебск, 2000. C. 242-243.

Подгурский П.Н. Комплекс индивидуальных находок Кривельского городища // Проблемы археологии и древней истории Верхнего Поднепровья и соседних территорий: докл. Междунар. науч. конф. / Могилёв. гос. ун-т им. А.А. Кулешова. Могилёв, 2002. С. 166-178.

Подгурский П.Н. Земледельческие орудия труда железного века и раннего средневековья Витебского Подвинья // Романовские чтения: сб. тр. Междунар. науч. конф. / Могилёв. гос. ун-т им. А.А. Кулешова; Ред. О.В. Дьяченко. Могилёв, 2005. С. $178-182$.

Поликарпович К.М. Археология в БССР за 30 лет // Наука в БССР за 30 лет: сб., посв. тридцатилетию БССР / АН БССР. Минск, 1949. С. 483-502.

Станкевич Я.В. К истории населения Верхнего Подвинья в I и начале II тысячелетия н.э. // МИА. 1960. № 76. С. 7-323.

Тарасенка В.P. Археолёгічныя досьледы гарадзішч на Смаленшчыне ў 19261928 гг. // Запіскі аддзелу гуманітарных навук. Кн. 1. Працы археолёгічнай камісіі. Менск, 1930. Т. 2. С. 121-142.

Шадыра В.І. Днепра-дзвінская культура // Археалогія Беларусі: у 4 т. Т. 2. Жалезны век і ранняе сярэднявечча. Мінск: Беларус. навука, 1999. С. 174-231.

Шмидm E.A. Отчёт о разведках археологических памятников на территории Смоленской области в 1986 году // Архив ИА РАН. 1986. Р-1. № 11265.

Шмидm E.A. Отчёт о разведках археологических памятников на территории Смоленской области в 1987 году // Архив ИА РАН. 1987. Р-1. № 12187.

Шмидт Е.А. Племена верховьев Днепра до образования Древнерусского государства. I. Днепро-двинские племена (VIII в. до н.э. - III в. н.э.). М.: Прометей, 1992. $208 \mathrm{c}$.

Шмидт E.A. Городище у дер. Буяново в бассейне р. Мерея // Дняпроўскі край: павед. абл. краязн. канф. / Магіл. абл. краязн. музей; Рэд. С.І. Бяспанскі. Магілёў, 1993. С. 36-41.

Шут К.П. Городище Заговалино Ушачского района // Вопросы истории: (тез. докл. ХІІ конф. молод. уч-х БССР) / Отд. общ-х наук АН БССР; Ред. Н.Е. Завалеев. Минск, 1969. С. 31-42.

Якубиинер М.М. К истории культуры пшеницы в СССР // МИЗ. 1956. Т. 2. C. 16-169.

\footnotetext{
${ }^{1}$ Название тезисов не соответствует их содержанию(?).
} 


\title{
ПОГРЕБЕНИЯ СКИФСКОЙ ЭЛИТЫ В МОГИЛЬНИКЕ НОВОЗАВЕДЕННОЕ II ПО ДАННЫМ АНТРОПОЛОГИИ
}

\begin{abstract}
Медникова М.Б.
http://10.25681/IARAS.2019.978-5-317-06274-3/377-387

Дана характеристика значимых захоронений, которые выделялись богатством погребального инвентаря и размерами погребальной конструкции, погребённых в курганах 2 и 7. По мнению В.Г. Петренко, курган № 2 относится к разряду усыпальниц высшей скифской аристократии. Погребённые в двух «элитарных» курганах Новозаведенного разделяли судьбу этой группы: пик смертности в этой группе приходится на необычно ранний возраст 20-24 года. Следует особо отметить высокий уровень физической активности (комплекс всадника).

Ключевые слова: раннескифская культура, Северный Кавказ, курган, палеоантропология, возрастная группа, диета
\end{abstract}

Могильник Новозаведенное II был открыт в 1985 году В.Г. Петренко на высокой надпойменной террасе р. Кумы в Георгиевском районе Ставропольского края. С 1986 года Краснознаменская экспедиция Института археологии РАН производила раскопки раннескифских курганов, датируемых последней четвертью VII в. до н.э. - первой четвертью VI в. до н.э. Курганные насыпи высотой от 1 до 8 м (средняя высота 2,5-3 м) расположены цепочкой. Под насыпями всех без исключения курганов скифской эпохи находились сложные погребальные конструкции, построенные с использованием дерева и камыша над обширной могильной ямой, перекрытой рядами бревенчатого наката. Погребённым принадлежал многочисленный заупокойный инвентарь, в том числе золотые изделия. Покойника обязательно сопровождали взнузданные лошади. Памятник несомненно относится к числу могильников раннего периода скифской истории, времени завершения переднеазиатских походов.

В 1991 г. первые скелетные останки погребённых в Новозаведеннских курганах поступили в хранение группы физической антропологии ИА РАН. Коллекция пополнялась в результате последующих раскопок, вплоть до 1998 г., после чего суммарные итоги антропологического исследования этих материалов были введены в научный оборот (Медникова, 1999, 2000, 2002). Метод биоархеологических реконструкций позволяет получить сведения о продолжительности жизни, состоянии здоровья, питании различных групп древнего населения. Пользуясь данными физической антропологии, палеопатологии, можно получить разнообразную информацию, в том числе, о стрессах, перенесённых в детстве, или даже о профессиональной принадлежности погребённых.

Особого внимания заслуживает более пристальная характеристика значимых захоронений, которые выделялись богатством погребального инвентаря и размерами погребальной конструкции. Ниже впервые приводятся подробные описания останков погребённых в курганах 2 и 7. Ранее расположение этих 
погребальных комплексов и возраст умерших позволили высказать предположение, что здесь упокоились останки семейной пары (Медникова, 2002. С. 129). При этом, по мнению В.Г. Петренко, курган № 2 относится к разряду усыпальниц высшей скифской аристократии (Петренко, 1989. С. 217).

Данная публикация представляет сведения о морфологических особенностях этих людей, параметрах их физического развития и, косвенно, о состоянии здоровья на протяжении жизни.

К у р г а н 2. Раскопки 1986 г. Пол: Мужской. Возраст: 25-35 лет (adultus maturus 1).

Сохранность: Череп, нижняя челюсть, плечевые, лучевые, локтевые, бедренные, больше- и малоберцовые, тазовые, крестцовые, мечевидный отросток грудины, лопатки, кости стопы, 18 позвонков шейного, грудного, поясничного отделов.

Остеоскопическая программа:

Череп

Зубы сильно стёрты, задняя половина сагиттального шва практически облитерирована, так же как и прилегающие к точке lambda участки лямбдовидного шва.

На верхней челюсти невозможно было обследовать поверхность первого правого резца, первого и второго левого резцов. Зафиксирована прижизненная утрата третьего моляра справа, эмалевая гипоплазия на левом клыке.

На нижней челюсти возможно было обследовать только передние правые резцы, второй левый резец, второй левый моляр. На всех резцах встречены горизонтально ориентированные нарушения зубной эмали - множественная эмалевая гипоплазия. Сильная стёртость мешает определить возраст неблагоприятных эпизодов (скорее всего после 3 лет). На втором левом моляре - кариес.

Патологических изменений в области глазниц (cribra orbitalia), лобной, теменных, затылочной, височных костей не обнаружено.

\section{Посткраниальный скелет}

При обследовании плечевых костей обнаружена начальная стадия поражения суставных поверхностей верхнего эпифиза. Подобное изменение прослеживается для суставных поверхностей верхнего эпифиза локтевой кости. На правой локтевой кости в верхней части olecranon на границе сочленовной поверхности с наружной стороны обнаружено костное разрастание округлой формы 5 мм шириной (энтесопатия, т.е. последствия микротравмы ?). С этой же стороны, но уже на сочленовной поверхности 2 насечки, по-видимому, сделанные острым предметом, почти горизонтально ориентированные, параллельно идущие, 4 мм длиной.

Энтесопатии обнаружены также в верхней передней части большеберцовых костей. Они представляют собой гребешковидные разрастания в области tuberositas tibiae. К бугристости большеберцовой кости прикреплялся широкий и толстый тяж связки надколенника (lig. patellae). Этот тяж наряду с су- 
хожильными волокнами, прикрепляющимися к верхней части надколенника, относится к сухожилию четырёхглавой мышцы бедра (m. quadriceps femoris). К бугристости большеберцовой кости также прикреплялась портняжная мышца, сгибавшая бедро и голень и поворачивавшая бедро кнаружи (имеет начало на передней подвздошной ости подвздошной кости).

На правой тазовой кости обнаружена энтесопатия в середине верхней части крыла подвздошной кости. Она представляет собой ориентированное вовнутрь костное разрастание неправильной округлой формы, приблизительно 12 мм протяжённостью. Вторая энтесопатия, по-видимому, сходной этиологии, располагается в полости большого таза на верхней границе сочленовной поверхности крестцово-подвздошного сочленения. Упомянутые морфологические образования связаны с местами прикрепления подвздошно-поясничной связки (lig. iliolumbale). Она натянута между поперечными отростками двух нижних поясничных позвонков, гребнем подвздошной кости и её бугристостью, своей прочностью обеспечивая практически полное отсутствие движения в крестцово-подвздошном суставе.

В области малого таза как правой, так и левой тазовых костей чётко выражен гребень в месте перехода седалищной кости в лобковую (можно рассматривать как морфологический вариант дугообразной линии подвздошных костей).

В верхней части мечевидного отростка грудины справа наблюдается окостенение рёберного хряща.

Обследовано 6 позвонков шейного, 8 позвонков грудного и 4 позвонка поясничного отделов. На четвёртом (5-м?) шейном позвонке - признаки остеофитоза и остеохондроза. На двух поясничных позвонках наблюдается сильная деформация тел с внутренней поверхности (но узлов Шморля, связанных с элеваторными нагрузками, нет).

При обследовании фрагментов стопы (пяточные и таранные, плюсневые кости, фаланги) патологий не выявлено.

Таблица 1

Поражение суставов у индивида из кургана 2 (балловая оценка, 0-4)

\begin{tabular}{|l|c|c|}
\hline \multicolumn{1}{|c|}{ Суставы } & Правый & Левый \\
\hline Плечевой & 0,5 & 0,5 \\
\hline Локтевой & 0,33 & 0,33 \\
\hline Лучезапястный & 0 & 0 \\
\hline Грудиноключичный & 0 & 0 \\
\hline Тазобедренный & 1 & 1 \\
\hline Коленный & 0 & 0 \\
\hline Голеностопный & 0 & 0 \\
\hline Тазокрестцовый & 0,5 & 0,5 \\
\hline
\end{tabular}


Таблицุа 2

Характеристика развития рельефа длинных костей у индивида из кургана 2 (баллы 1-3)

\begin{tabular}{|l|c|c|}
\hline \multicolumn{1}{|c|}{ Признак } & Правая сторона & Левая сторона \\
\hline 1hum. tuberculum minus & $3 !$ & $3 !$ \\
\hline 2.hum sulcus intertubercularis & 3 & 3 \\
\hline 3hum tuberositas deltoidea & $2-3$ & $2-3$ \\
\hline 4hum margo lateralis & 2 & 2 \\
\hline 1rad tuberositas radii & 2 & 2 \\
\hline 2rad margo interosseus & 3 & 3 \\
\hline 3rad crista et tuberculi distalis & 3 & 3 \\
\hline 1ul tuberositas ulnae & 3 & 2 \\
\hline 2ul margo interossea & 3 & 3 \\
\hline 3ul tuberositas ulnae & 3 & 3 \\
\hline 4ul crista musculi supinatoris & 3 & 2 \\
\hline 5ul crista distalis lateralis & 3 & 3 \\
\hline 1fem trochanter major & 3 & 3 \\
\hline 2fem trochanter minor & 3 & 2 \\
\hline 3fem tuberositas glutea & 2 & $2-3$ \\
\hline 4fem linea aspera & $2-3$ & 2 \\
\hline 5fem epicondylus lateralis & 2 & 3 \\
\hline 1tib tuberositas tibia & 3 & $2-3$ \\
\hline 2tib margo anterior & $2-3$ & 2 \\
\hline 3tib margo interossea & 2 & 3 \\
\hline 4tib linea m. Solei & 3 & 2 \\
\hline 5tib sulci et tuberculi distalis & 2 & 3 \\
\hline
\end{tabular}

Таблица 3

\section{Измерения костей посткраниального скелета индивида (номера признаков по Мартину, 1928)}

\begin{tabular}{|l|c|c|}
\hline \multicolumn{1}{|c|}{ Признак } & Правая сторона & Левая сторона \\
\hline Плечевая кость & & \\
\hline 1. Наибольшая длина & 326 & 321 \\
\hline 2. Полная длина & 321 & 319 \\
\hline 3. Ширина верхнего эпифиза & 55 & 59 \\
\hline 4. Ширина нижнего эпифиза & 66 & 66 \\
\hline 5. Наибольший диаметр середины & 26 & 25 \\
\hline 6. Наименьший диаметр середины & 21,5 & 19 \\
\hline 7. Наименьшая окружность диафиза & 70 & 67 \\
\hline 7а. Окружность середины диафиза & 76 & 72 \\
\hline 9. Наибольшая ширина головки & 46 & 43 \\
\hline 10. Вертикальный диаметр головки & 51 & 58 \\
\hline
\end{tabular}




\begin{tabular}{|c|c|c|}
\hline Признак & Правая сторона & Левая сторона \\
\hline 8. Окружность головки & 146 & - \\
\hline 7:1 Указатель прочности & 21,5 & 20,9 \\
\hline 6:5 Указатель поперечного сечения диафиза & 82,7 & 76,0 \\
\hline \multicolumn{3}{|l|}{ Лучевая кость } \\
\hline 1. Наибольшая длина & 258 & 256 \\
\hline 2. Физиологическая длина & 242 & 239 \\
\hline 4. Поперечный диаметр диафиза & 17 & 18 \\
\hline 5. Сагиттальный диаметр диафиза & 13 & 12 \\
\hline 3. Наименьшая окружность диафиза & 45 & 45 \\
\hline 3:2 Указатель прочности & 18,6 & 18,8 \\
\hline 5:4 Указатель поперечного сечения диафиза & 76,5 & 66,7 \\
\hline \multicolumn{3}{|l|}{ Локтевая кость } \\
\hline 1. Наибольшая длина & 281 & 280 \\
\hline 2. Физиологическая длина & 246 & 243 \\
\hline 3. Наименьшая окружность & 41 & 41 \\
\hline 11. Передне-задний диаметр диафиза & 15 & 15 \\
\hline 12. Поперечный диаметр & 18 & 20 \\
\hline 13. Верхний поперечный диаметр диафиза & 25 & 26,5 \\
\hline 14. Верхний сагиттальный диаметр диафиза & 25 & 28 \\
\hline 3:2 Указатель прочности & 16,7 & 16,9 \\
\hline 11:12 Указатель поперечного сечения диафиза & 83,3 & 75,0 \\
\hline 13:14 Указатель платолении & 100,0 & 94,6 \\
\hline \multicolumn{3}{|l|}{ Бедренная кость } \\
\hline 1. Наибольшая длина & 454 & 458 \\
\hline 2. Длина в естественном положении & 452 & 456 \\
\hline 21. Ширина нижнего эпифиза & 86 & 88 \\
\hline 6. Сагиттальный диаметр середины & 31,5 & 31,5 \\
\hline 7а. Поперечный диаметр середины & 27 & 27,5 \\
\hline 9. Верхний поперечный диаметр & 35 & 35 \\
\hline 10. Верхний сагиттальный диаметр & 27 & 28 \\
\hline 8. Окружность середины & 90 & 90 \\
\hline 18. Высота головки & 49 & 49 \\
\hline 19. Ширина головки & 49 & 49 \\
\hline 20. Окружность головки & 154 & 152 \\
\hline 8:2 Указатель массивности & 19,9 & 19,7 \\
\hline 6:7а Указатель пиластрии & 116,7 & 114,5 \\
\hline 10:9 указатель платимерии & 77,1 & 80,0 \\
\hline (18+19):2. Указатель массивности головки & 21,7 & 21,5 \\
\hline \multicolumn{3}{|l|}{ Большеберцовая кость } \\
\hline 1. Полная длина & 389 & 387 \\
\hline 1а. Наибольшая длина & 396 & 392 \\
\hline 5. Наибольшая ширина верхнего эпифиза & 81 & 89 \\
\hline
\end{tabular}




\begin{tabular}{|l|c|c|}
\hline \multicolumn{1}{|c|}{ Признак } & Правая сторона & Левая сторона \\
\hline 6. Наибольшая ширина нижнего эпифиза & 56 & 55 \\
\hline 8. Сагиттальный диаметр середины & 32,5 & 31,5 \\
\hline 9. Поперечный диаметр середины & 25 & 25 \\
\hline $\begin{array}{l}\text { 8а. Сагиттальный диаметр на уровне } \\
\text { питательного отверстия }\end{array}$ & 37 & 35 \\
\hline $\begin{array}{l}\text { 9а. Поперечный диаметр на уровне } \\
\text { питательного отверстия }\end{array}$ & 28 & 27 \\
\hline 10. Окружность середины диафиза & & 86 \\
\hline 10в. Наименьшая окружность диафиза & 90 & 80 \\
\hline 9а:8а Указатель платикнемии & 78 & 77,1 \\
\hline 10b:1 Указатель прочности & 75,7 & 20,7 \\
\hline Малоберцовая кость & 20,1 & 380 \\
\hline 1. Наибольшая длина & & 79,8 \\
\hline R1:Н1 Луче-плечевой указатель & 380 & 66,1 \\
\hline R1:Т1 Луче-бедренный указатель & 79,1 & 70,4 \\
\hline H1:F2 Плече-бедренный указатель & 66,3 & 84,9 \\
\hline Т1:F2 Берцово-бедренный указатель & 72,1 & 68,4 \\
\hline (Н1+R1):(F2+Т1) Интермембральный указатель & 86,1 & 97,8 \\
\hline Таз & 69,4 & 90 \\
\hline 1. Высота & 214 & 218 \\
\hline 2. Наибольшая ширина & 281 & 107 \\
\hline 1:F2 Тазо-бедренный указатель & 77,3 & \\
\hline 15. Высота седалищной кости & 79 & \\
\hline 17. Длина лобковой кости & 116 & \\
\hline Крестец & 112 & \\
\hline 2. Длина & 157 & \\
\hline 5. Ширина & 104 & \\
\hline Лопатка & & \\
\hline 1. Морфологическая ширина & & \\
\hline 2. Морфологическая длина & & \\
\hline
\end{tabular}

Особенности строения скелета, погребённого в кургане 2: короткие плечевые кости, с достаточно широкими эпифизами, массивными диафизами, размеры головки плечевой кости - средние, форма - овальная. Резко удлинены кости предплечья, размеры периметров и диаметров диафизов локтевых костей свидетельствуют о достаточной массивности (особенно высок указатель платолении). Бедренная кость характеризуется средней длиной, средними параметрами диафиза, даже некоторым снижением массивности, однако указатель пиластрии очень высок, а указатель платимерии, напротив, невысок. Головки бедренной кости средних размеров, круглые. Большеберцовые кости чрезвычайно удлинённые, ширина эпифизов средняя, поперечные диаметры диафиза - тоже, но диафизы очень сильно развиты в сагиттальной плоскости, периметры диафизов увеличены. Уплощённость большеберцовых костей про- 
является также в очень высоких значениях индекса платикнемии. В целом, наблюдается относительное удлинение сегментов предплечья и голени, относительное укорочение рук и удлинение ног.

К у р г а н 7 (основное погребение). Раскопки 1998 г.

Пол: женский. Возраст: 20-29 лет.

Сохранность: череп с разрушенным лицевым скелетом, правая и левая плечевые кости, разрушенные парные лучевые и локтевые, левая лопатка (разрушена), парные бедренные, правая большеберцовая, кости кисти, стопы, 15 позвонков различных отделов, ребра, рукоятка грудины, коленные чашечки, разрушенный крестец, фрагмент левой тазовой кости с выраженной преушковидной бороздой.

Череп овоидной формы. Степень развития надпереносья - 2 балл, надбровных дуг - 1 балл.

Таблицุа 4

Краниометрическая характеристика погребённой в кургане 7

\begin{tabular}{|l|c|}
\hline \multicolumn{1}{|c|}{ Признак, № по Мартину } & Мм \\
\hline 1. Продольный диаметр & 175 \\
\hline 8. Поперечный диаметр & 140 \\
\hline 20. Высота порион-брегма & 115 \\
\hline 9. Наименьшая ширина лба & 98 \\
\hline 10. Наибольшая ширина лба & $120 ?$ \\
\hline 11. Ушная ширина & 117 \\
\hline 12. Ширина затылка & $110 ?$ \\
\hline 65. Мыщелковая ширина & 107 \\
\hline 66. Бигониальная ширина & 96 \\
\hline 68. Длина нижней челюсти от углов & 80 \\
\hline 68(1). Длина нижней челюсти от мыщелков & 107 \\
\hline 70. Высота ветви & 58 \\
\hline 71а. Наименьшая ширина ветви & 99 \\
\hline Черепной указатель & 80,0 \\
\hline
\end{tabular}

Таблица 5

Измерения костей посткраниального скелета индивида из кургана 7 (номера признаков по Мартину, 1928)

\begin{tabular}{|l|c|c|}
\hline \multicolumn{1}{|c|}{ Признак } & Правая сторона & Левая сторона \\
\hline Плечевая кость & & \\
\hline 1. Наибольшая длина & 294 & - \\
\hline 2. Полная длина & 290 & - \\
\hline 3. Ширина верхнего эпифиза & 44 & 43 \\
\hline 4. Ширина нижнего эпифиза & 53 & - \\
\hline 5. Наибольший диаметр середины & 22 & 21 \\
\hline
\end{tabular}




\begin{tabular}{|c|c|c|}
\hline Признак & Правая сторона & Левая сторона \\
\hline 6. Наименьший диаметр середины & 15 & $18 ?$ \\
\hline 7. Наименьшая окружность диафиза & 58 & - \\
\hline 7а. Окружность середины диафиза & 60 & 60 \\
\hline 9. Наибольшая ширина головки & 35 & 35 \\
\hline 10. Вертикальный диаметр головки & 37 & 37 \\
\hline 8. Окружность головки & 115 & 110 \\
\hline 7:1 Указатель прочности & 19,73 & - \\
\hline 6:5 Указатель поперечного сечения диафиза & 68,16 & 85,71 \\
\hline \multicolumn{3}{|l|}{ Лучевая кость } \\
\hline 1. Наибольшая длина & 218 & 222 \\
\hline 2. Физиологическая длина & 208 & 211 \\
\hline 4. Поперечный диаметр диафиза & 15 & 15 \\
\hline 5. Сагиттальный диаметр диафиза & 11 & 10 \\
\hline 3. Наименьшая окружность диафиза & 40 & 40 \\
\hline 3:2 Указатель прочности & 19,23 & 18,96 \\
\hline 5:4 Указатель поперечного сечения диафиза & 73,33 & 66,67 \\
\hline \multicolumn{3}{|l|}{ Локтевая кость } \\
\hline 1. Наибольшая длина & - & 246 \\
\hline 2. Физиологическая длина & - & 215 \\
\hline 3. Наименьшая окружность & 35 & 35 \\
\hline 11. Передне-задний диаметр диафиза & 12 & 13 \\
\hline 12. Поперечный диаметр & 12,5 & 12 \\
\hline 13. Верхний поперечный диаметр диафиза & - & 21 \\
\hline 14. Верхний сагиттальный диаметр диафиза & - & 22 \\
\hline 3:2 Указатель прочности & - & 16,28 \\
\hline 11:12 Указатель поперечного сечения диафиза & 96,0 & 108,33 \\
\hline 13:14 Указатель платолении & - & 95,45 \\
\hline \multicolumn{3}{|l|}{ Бедренная кость } \\
\hline 1. Наибольшая длина & 405 & - \\
\hline 2. Длина в естественном положении & 400 & - \\
\hline 21. Ширина нижнего эпифиза & 70 & 70 \\
\hline 6. Сагиттальный диаметр середины & 25 & - \\
\hline 7а. Поперечный диаметр середины & 23 & - \\
\hline 9. Верхний поперечный диаметр & 30 & 30 \\
\hline 10. Верхний сагиттальный диаметр & 22,5 & 25 \\
\hline 8. Окружность середины & 74 & - \\
\hline 18. Высота головки & 38 & - \\
\hline 19. Ширина головки & 39 & - \\
\hline 20. Окружность головки & 121 & - \\
\hline 8:2 Указатель массивности & 18,5 & - \\
\hline 6:7а Указатель пиластрии & 108,70 & - \\
\hline 10:9 Указатель платимерии & 75,0 & 83,33 \\
\hline$(18+19): 2$ Указатель массивности головки & 19,25 & - \\
\hline
\end{tabular}




\begin{tabular}{|l|c|c|}
\hline \multicolumn{1}{|c|}{ Признак } & Правая сторона & Левая сторона \\
\hline Большеберцовая кость & & \\
\hline 1. Полная длина & 338 & - \\
\hline 1а. Наибольшая длина & 340 & - \\
\hline 5. Наибольшая ширина верхнего эпифиза & 65 & - \\
\hline 6. Наибольшая ширина нижнего эпифиза & 49 & - \\
\hline 8. Сагиттальный диаметр середины & 24 & - \\
\hline 9. Поперечный диаметр середины & 19 & - \\
\hline $\begin{array}{l}\text { 8а. Сагиттальный диаметр на уровне } \\
\text { питательного отверстия }\end{array}$ & 29 & - \\
\hline $\begin{array}{l}\text { 9а. Поперечный диаметр на уровне } \\
\text { питательного отверстия }\end{array}$ & 21,5 & - \\
\hline 10. Окружность середины диафиза & & - \\
\hline 10в. Наименьшая окружность диафиза & 69 & - \\
\hline 9а:8а Указатель платикнемии & 65 & - \\
\hline 10b:1 Указатель прочности & 74,14 & - \\
\hline R1:Н1 Луче-плечевой указатель & 19,23 & - \\
\hline R1:Т1 Луче-бедренный указатель & 74,15 & - \\
\hline Н1:F2 Плече-бедренный указатель & 64,50 & - \\
\hline T1:F2 Берцово-бедренный указатель & 73,50 & - \\
\hline (Н1+R1):(F2+Т1) & 64,50 & - \\
\hline интермембральный указатель & 69,38 & \\
\hline Лопатка & & - \\
\hline 1. Морфологическая ширина & & \\
\hline
\end{tabular}

Таблицุа 6

Характеристика развития рельефа длинных костей у индивида из кургана 7 (баллы 1-3)

\begin{tabular}{|l|c|c|}
\hline \multicolumn{1}{|c|}{ Признак } & Правая сторона & Левая сторона \\
\hline 1hum. tuberculum minus & 3 & 3 \\
\hline 2.hum sulcus intertubercularis & 3 & 3 \\
\hline 3hum tuberositas deltoidea & 3 & 3 \\
\hline 4hum margo lateralis & $2-3$ & $2 ?$ \\
\hline 1rad tuberositas radii & 3 & 3 \\
\hline 2rad margo interosseus & 3 & 3 \\
\hline 3rad crista et tuberculi distalis & $3 !$ & $3 !$ \\
\hline 1ul tuberositas ulnae & 2 & 3 \\
\hline 2ul margo interossea & 3 & 3 \\
\hline 3ul tuberositas ulnae & 3 & $3 !$ \\
\hline 4ul crista musculi supinatoris & $3 !$ & $3 !$ \\
\hline 5ul crista distalis lateralis & $3 !$ & \\
\hline
\end{tabular}




\begin{tabular}{|l|c|l|}
\hline 1fem trochanter major & 3 & \\
\hline 2fem trochanter minor & 3 & \\
\hline 3fem tuberositas glutea & 3 & \\
\hline 4fem linea aspera & $2-3$ & \\
\hline 5fem epicondylus lateralis & 3 & \\
\hline 1tib tuberositas tibia & 2 & \\
\hline 2tib margo anterior & 1 & \\
\hline 3tib margo interossea & 1 & \\
\hline 4tib linea m.solei & 3 & \\
\hline 5tib sulci et tuberculi distalis & & \\
\hline
\end{tabular}

Скелет характеризуется грацильным строением, продольные и толстотные размеры костей конечностей малы. Однако развитие рельефа в местах начала и прикрепления некоторых мышц свидетельствует об интенсивных физических нагрузках. Судя по развитию элементов рельефа плечевой кости и лопатки у женщины были сильно развиты мышцы спины, плечевого пояса и свободной верхней конечности, обеспечивавшие пронацию и приведение плеча. Хорошо тренированными были широчайшая мышца спины, подлопаточная мышца, большая круглая и клювовидно-плечевая мышцы, дельтовидная мышца. Усиленное развитие элементов рельефа костей предплечья отражает повышенные нагрузки на мышцы-разгибатели кисти и квадратный пронатор, поворачивавший кнутри предплечье и кисть. Рельеф бедренных и большеберцовых костей развит слабее, но всё же достаточно сильно. Об усиленных физических нагрузках может свидетельствовать и так называемый узел Шморля на поверхности одного из поясничных позвонков, представляющий собой морфологическое следствие межпозвоночной грыжи. Патологических изменений не выявлено. Морфологические особенности тазовой кости свидетельствуют о перенесённой беременности.

В целом, можно констатировать, что погребённые в двух «элитарных» курганах Новозаведенного разделяли судьбу этой группы. Мужчина из кургана 2, впрочем, скончался в более «зрелом» возрасте, ведь пик смертности мужского населения в этой группе приходится на необычно ранний возраст 20-24 года. Женщина из кургана 2 ушла из жизни раньше, подобно 66,7\% своих соплеменниц (Медникова, 2002. С. 129). Следует особо отметить высокий уровень физической активности, свойственной при жизни этим людям. У мужчины из кургана 2 поэтому отмечено наибольшее число поражений суставов, в частности, изменения тазовых костей могут быть интерпретированы как последствия интенсивной и постоянной верховой езды. Особенности развития костного рельефа у молодой женщины из кургана 7 также говорят о том, что она была всадницей и при этом испытывала постоянную симметричную нагрузку на пояс верхних конечностей, а также элеваторные нагрузки, что, в конечном итоге, способствовало развитию постоянных болей в спине. Если принимать 
во внимание относительное удлинение костей голени, характерное для членов этой группы, длина тела скифского «вождя», определённая по длине бедренной кости (формула Троттер - Глезер), была не столь высока, порядка 168 см. Реконструированная длина тела молодой женщины свидетельствует о ещё большей грацильности - 152 см. Таким образом, несмотря на очевидную «равноправность» в распределении физических нагрузок, мы можем констатировать заметный половой диморфизм в размерах тела у представителей элитарного населения раннескифской эпохи. Показатели физического развития, прежде всего, размеры тела служат важной интегративной характеристикой качества жизни людей. В норме разница средней величины роста мужчин и женщин составляет 10-12 см, в данном случае наблюдаемое расхождение несколько больше. Вместе с тем, именно для погребённых в курганах 2 и 7 ранее, благодаря завышенным концентрациям цинка, была определена диета, в большей степени насыщенная мясными и молочными продуктами (Медникова, 2000. C. 55). Это значит, что взрослые представители скифской элиты, во многом, вели сходный образ жизни.

\section{ЛИТЕРАТУРА}

Медникова М.Б. Реконструкция жизненных условий ранних скифов по антропологическим материалам // Вторые антропологические чтения памяти академика В.П. Алексеева, III конгресс этнографов и антропологов России. М.: Старый Сад, 1999. C. $145-146$.

Медникова М.Б. Жизнь ранних скифов: реконструкция по антропологическим материалам могильника Новозаведенное II // Скифы и сарматы в VII-VIII вв. до н.э. / Под ред. В.И. Гуляева, В.С. Ольховского. М.: Институт археологии РАН; Старый Сад, 2000. С. 51-58.

Медникова М.Б. Антропология ранних скифов: могильник Новозаведенное II // OPUS: междисциплинарные исследования в археологии / Ред. А.П. Бужилова. Вып. 1-2. М.: ИА РАН, 2002. С. 128-140.

Петренко В.Г. Скифы на Северном Кавказе // Археология СССР. Степи европейской части СССР в скифо-сарматское время. М.: Наука, 1989. С. 216-223. 


\title{
ИЗОТОПЫ СТРОНЦИЯ \\ В КРЕМАЦИЯХ МОГИЛЬНИКОВ СРЕДНЕЙ ОКИ \\ СЕРЕДИНЫ ПЕРВОГО - НАЧАЛА ВТОРОГО ТЫС. Н.Э.: ОПЫТ ИЗУЧЕНИЯ ТЕРРИТОРИАЛЬНОЙ ДИФФЕРЕНЦИАЦИИ НАСЕЛЕНИЯ
}

\author{
Сыроватко А.С., Добровольская М.В.
}

http://10.25681/IARAS.2019.978-5-317-06274-3/388-393

Исследование посвящено выявлению ландшафтной и территориальной приуроченности поселений на Средней Оке с V по XII в. новой эры. Мы попробовали подойти к этой проблеме с использованием данных о соотношении изотопов стронция в кремированных останках людей из погребений этого региона.

Ключевые слова: кремация, Средняя Ока, население, грунтовый могильник, погребальный обряд, изотопы стронция

В центральной России с началом эпохи Великого переселения народов происходят события, которые внешне выражены в сломе традиционных культур Железного века. Особенно значимые изменения происходили, вероятно, около V в., что в русскоязычной литературе известно как «война V в.», хотя никто не знает, кто в это время воевал и с кем: термин «война V в.» обозначает просто коллапс большинства археологических культур Центральной России. Около VII в. население Московской, Рязанской и некоторых других областей сильно сокращается, и до середины Х в. наступают т.н. «тёмные века».

Совсем недавно было обнаружено несколько могильников с кремациями, которые относятся к эпохе Великого переселения народов и Тёмных веков. Их погребальный обряд с помещением остатков сожжений на древнюю поверхность или в небольшую ямку ранее совершенно не был известен для данного региона. Этих памятников пока известно мало, но это единственные свидетельства существования населения в Центральной России в Тёмные века. Вот почему наш коллектив уделяет этим памятникам особое значение, а могильник Щурово близ Коломны является самым крупным и наиболее исследованным из них.

В Щурово на одном месте сосредоточено два могильника. Первый возникает около V или VI века и представляет собой курганы с конструкциями внутри. Первоначальный замысел их создателей предполагал, вероятно, особые конструкции, которые в русской археологии получили название «Домиков мёртвых», внутри которых находились кальцинированные кости и остатки погребального костра (Сыроватко, 2010. С. 302). Похожие конструкции известны на Русском Севере в железном веке и в Средневековье, но для Центральной России они крайне редкие. Естественно, что наш интерес к ним чрезвычайно велик.

Второй могильник - грунтовый - возникает здесь после перерыва и погребальный обряд его иной: кости высыпаются на древнюю поверхность или 
помещаются в небольшую ямку. Урны редки, но обычны сосуды, поставленные рядом с погребениями. В некоторых случаях повреждённые огнём вещи - бусы и капли металла - преднамеренно отделялись от костей и захоранивались отдельно.

Грунтовый могильник в Щурово обладает рядом важных особенностей. Во-первых, его площадь очень велика (могильник вытянут вдоль берега на 300400 м). Во-вторых, палинологические данные указывают на то, что в V-VI вв. здесь прослеживается значительная антропогенная активность, а во второйтретьей четверти I тыс. н.э. (во время функционирования грунтового могильника) леса восстанавливаются. Это же наблюдение подтверждают результаты фитолитных исследований: площадь памятника возросла, следов антропогенного воздействия на ландшафт почти нет (Сыроватко, Спиридонова, Трошина, 2012. С. 130). С данными палинологии согласуются неудачные попытки обнаружить поселение, которое соответствовало могильнику. Его не удалось найти в радиусе 3 км на правом берегу и пока не удалось обнаружить его на левом берегу. Поселение же середины первого тысячелетия хорошо известно: оно располагалось у подножья холма с могильником.

Отметим ещё один сюжет, сообщённый палинологией: пальца ели обнаружена только в слое кремаций и только в обожжённом виде, в то время как в фоновом спектре пыльцы ели нет. В настоящее время ареал ели только достигает левого берега р. Оки, а в более тёплое время второй половины первого тысячелетия граница её ареала была ещё севернее. Возможно, ветки ели приносили для розжига погребального костра издалека. Из анализа угля известно, что кремация осуществлялась на дровах из дуба.

Обряд грунтовых погребений вариативен. Кости уложены и в небольшие ямки, и рассыпаны по древней поверхности. Особенно разнообразна керамика: сосуды и урны имеют разные формы. Однако ещё более пёстрый состав теста: не менее 5 вариантов, с разными примесями, на серию в 11 экземпляров.

На основании полученных данных можно сформулировать гипотезу: грунтовый могильник Щурово являлся погребальным центром для нескольких поселений, удалённых друг от друга. Как только появилась возможность проверить это предположение с помощью определения соотношений изотопов стронция в кремированных останках, мы решили ею воспользоваться.

В качестве сопоставительных материалов мы использовали два средневековых могильника. Первый из них - Кременье. Курганный могильник с кремациями второй-третьей четверти XII в. Это, вероятно, самые поздние кремации Центральной России. Мы исследовали также один из курганов. Центральное погребение, вероятно, мужское, разграблено и разрушено грабителями, скорее всего, в советское время. Однако грабители не заметили ещё и женское погребение, и теперь мы располагаем сравнительным антропологическим материалом, полученным из синхронных погребений - ингумаций и кремаций. 
Второй могильник для сопоставлений - Лужки $\mathrm{E}$ - расположен возле г. Серпухов. Эти кремации мы датируем временем не ранее середины X в. (Сыроватко, 2014. С. 67) Под слоем кремаций обнаружилась и одна ингумация мужчина с травмой ноги, которая доставляла ему много неудобств. Находок в погребении не было, и мы не знаем, как его датировать: либо это член коллектива, который не был в силу каких-то причин кремирован, либо это погребение могильника Лужки Д, Эпохи переселения народов.

Общая протяженность территории вдоль русла Оки, внутри которой мы проводим сопоставления следующая: Кременье выше Щурово примерно на 52 км, Соколова Пустынь - на 72, Лужки Е - на 106 (все расстояния указаны по руслу р. Оки).

Итак, серия из 33 образцов кремированных костей с трёх могильников, включая пять фоновых, представляющих современную экосистему. Большинство погребений являются кремациями, но на двух из них есть единичные образцы из ингумаций. Проанализировано 14 образцов кремаций из Щурово: три фоновых (трава полевая, растительность водная, улитка водная), 3 образца из «Домиков мёртвых» и 8 из грунтового могильника. Из могильника Кременье проанализировано 9 образцов из погребений - кремаций и 2 из ингумаций парного погребения мужчины и женщины из одного кургана. Фоновый образец 1 , дикий злак на самом могильнике, но на соседнем могильнике Соколова Пустынь в качестве фона отобрана наземная улитка. Ещё 6 образцов взято из могильника Лужки. Определение соотношений изотопов стронция ${ }^{87 / 86} \mathrm{Sr}$ было выполнено в ИГЕМ (г. Санкт-Петербург) Е.С. Богомоловым.

Обратимся к результатам исследований Щурово. Диапазон фоновых образцов отражен на слайде. Диапазон изменчивости показателей естественного фона Щурово таков, что практически все значения, полученные для костных образцов, укладываются в него (рис. 1, 2). Однако отметим, что часть погребений тяготеет к значениям долинной растительности, а часть - к расположенной на террасах Оки.

Планиграфически близкие погребения 44 и 46 с высокими значениями соотношения, - самые северные. Однако такое сходство далеко не всегда встречается в близко расположенных друг к другу погребениях. Так, погребения 11 и 20 расположены на некотором расстоянии друг от друга, но, тем не менее, значения соотношения изотопов стронция в образцах из них - практически идентичны.

Важно отметить, что в одном кургане (№ 4) - «домике мёртвых» - оказались индивиды с различающимися величинами соотношения стронция. Такая ситуация уже была отмечена для данного типа памятников (Добровольская и др, 2014. С. 231). Индивидуальная изменчивость показателей по образцам из грунтового и курганного могильников - сопоставимы, и не отличаются друг от друга. Таким образом, во всей выборке могильника Щурово только два погребения выбиваются за пределы локальных фоновых значений. 


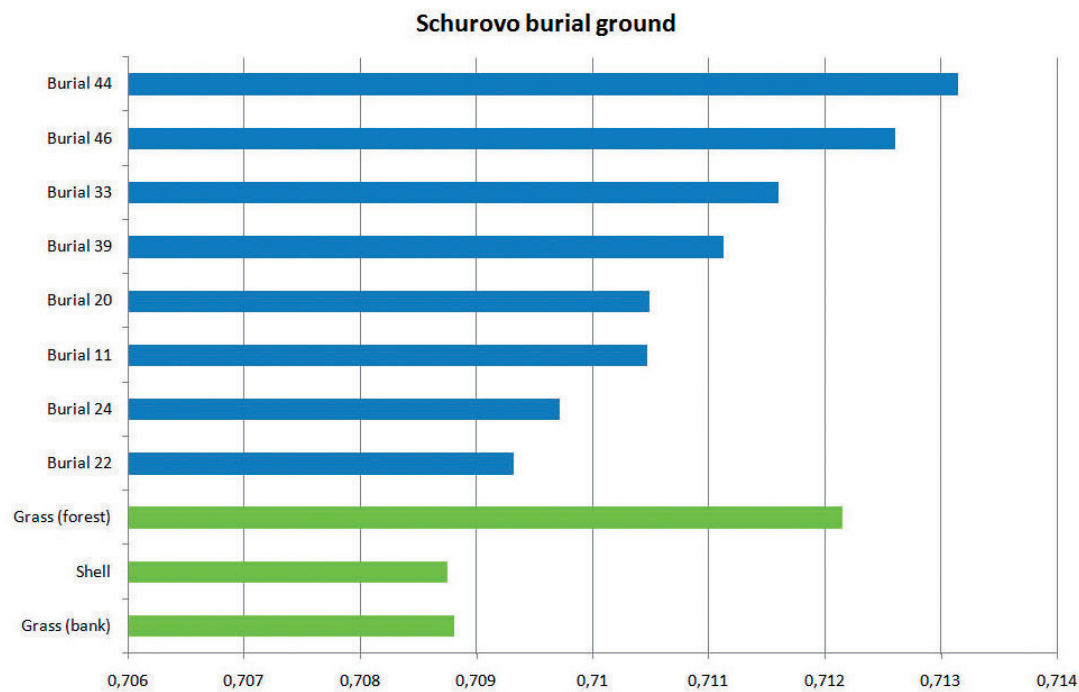

Рис.1. Значения соотношения изотопов стронция ${ }^{87 / 86} \mathrm{Sr}$ для кремаций из грунтовых погребений могильника Щурово (голубой цвет)

в сравнении с фоновыми значениями (зелёный цвет)

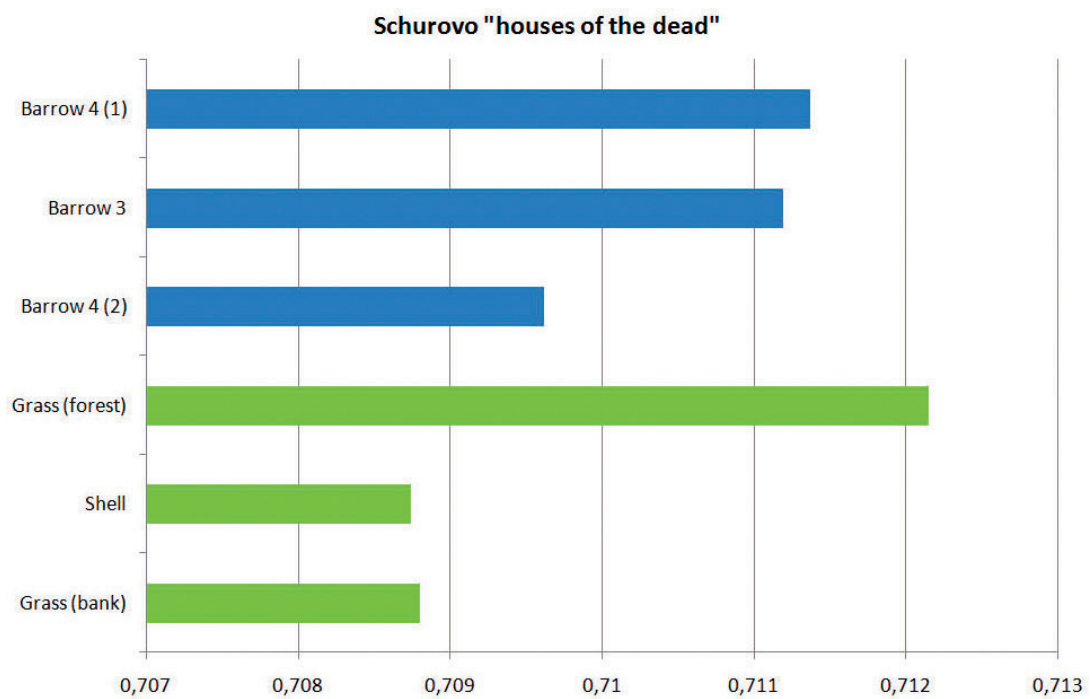

Рис. 2. Значения соотношения изотопов стронция ${ }^{87 / 86} \mathrm{Sr}$ для кремаций из курганных (домиков мёртвых) погребений могильника Щурово (голубой цвет) в сравнении с фоновыми значениями (зелёный цвет)

В Кременье материал такой же гомогенный и абсолютные значения соотношения изотопов в образцах в целом такие же, как в Щурово. Можно отметить, что ингумации имеют в среднем значения выше, чем в кремациях, но наша выборка слишком мала для полноценной статистики (рис. 3). Очевидно, что 


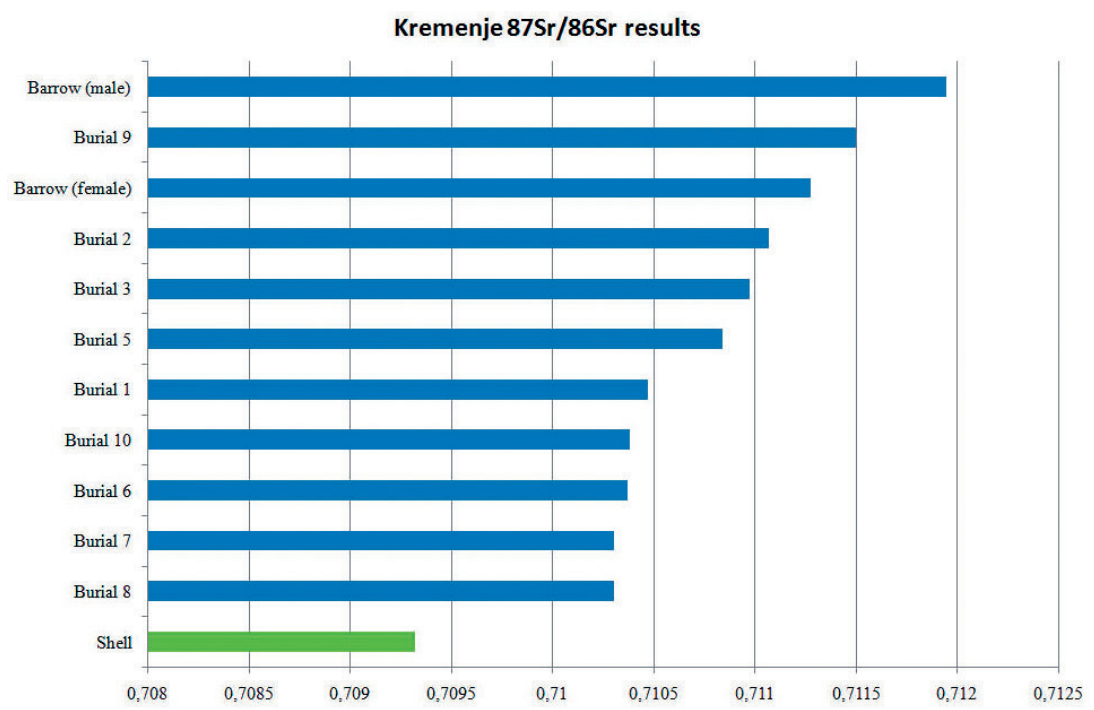

Рис. 3. Значения соотношения изотопов стронция ${ }^{87 / 86} \mathrm{Sr}$ для кремаций из грунтовых и курганных погребений могильника Кременье (голубой цвет) в сравнении с фоновыми значениями (зелёный цвет)

нам не хватает природных образцов для понимания ландшафтной изменчивости фоновых значений.

Лужки Е пока также не обеспечены надёжными природными образцами, но и на этом памятнике мы видим те же средние значения соотношения изотопов стронция в кремациях и ингумациях, что в Щурово и Кременье. Точно так же, как и в Кременье, значения в ингумации выше, чем в кремациях (рис. 4). Мы не исключаем, что эти результаты могут отражать изменения в содержании стронция, происходящие в результате самого процесса сжигания тел.

Подведём итог. Все образцы кремаций и ингумаций на протяжении более 100 км продемонстрировали сходные значения стронциевого соотношения. Из этого следует, что различать места жительства людей, располагавшихся по среднему течению Оки на базе данных изотопного анализа, сложно, так как все эти места находятся примерно в сходных геологических условиях.

Различия в соотношении изотопов стронция в образцах травы, взятых в различных геоморфологических обстоятельствах, свидетельствуют о том, что основные различия проявляются в координатах пойма - терраса или водораздельный район.

Вероятно, люди, погребённые в могильниках на Средней Оке, в различной степени были связаны с собственно долиной реки и террасами или иными, более высоко расположенными элементами рельефа. Наша гипотеза нуждается в проверке на базе более подробного сбора фоновых образцов и увеличения общей численности проанализированных индивидов. Среди образцов из Щурово только два наиболее северных погребения характеризуются соотношением 


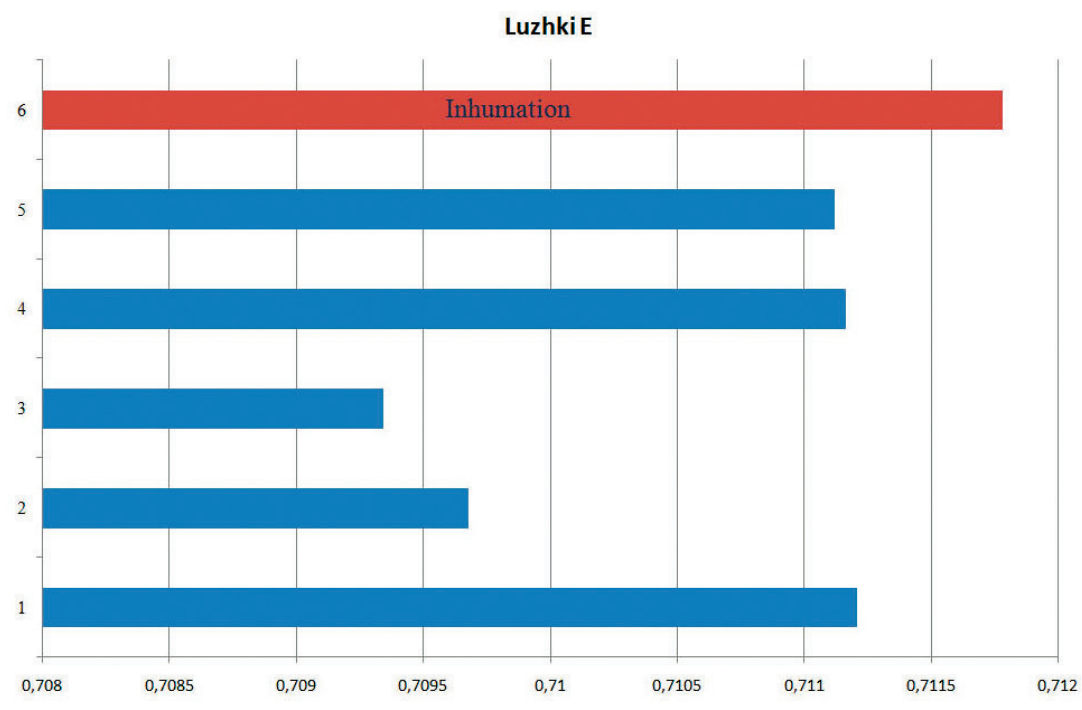

Рис. 4. Значения соотношения изотопов стронция ${ }^{87 / 86} \mathrm{Sr}$ для кремаций и ингумации из грунтовых погребений могильника Лужки $\mathrm{E}$

${ }^{87 / 86} \mathrm{Sr}$, которое выходит за рамки локальной изменчивости. То, что значения ингумаций выше в среднем, чем кремаций, требует дополнительных исследований, возможно - экспериментальных кремаций.

Таким образом, проведённое исследование не позволяет ответить на вопрос о более точной территориальной приуроченности индивидов, но открывает совершенно иную область исследований. Она связана с вопросами приуроченности мест поселения и землепользования к различным ландшафтным ситуациям долины и высоких участков коренного берега реки Оки.

\section{ЛИТЕРАТУРА}

Сыроватко А.С. Реконструкция погребальных сооружений Щуровского могильника // КСИА. 2010. Вып. 224. С. 297-304.

Сыроватко А.С., Спиридонова Е.А., Трошина А.А. Хронология Щуровского могильника по естественно-научным данным // Лесная и лесостепная зоны Восточной Европы в эпохи римских влияний и Великого переселения народов. Вып. 3 / Отв. ред. А.М. Воронцов, И.О. Гавритухин. Тула: Гос. музей-заповедник «Куликово поле», 2012. C. 119-132.

Добровольская М.В., Клещенко Е.А., Богомолов Е.С., Захаров С.Д. Опыт применения изотопных исследований в изучении погребальных кремаций // КСИА. 2014. Вып. 236. С. 322-331.

Сыроватко А.С. Могильники с кремациями на Средней Оке // РА. 2014. Вып. 3. C. $63-76$. 


\section{СПИСОК СОКРАЩЕНИЙ}

АлтГУ - Алтайский государственный университет

АСГЭ - Археологический сборник Государственного Эрмитажа

АЭАЕ - Археология, этнография и антропология Евразии. Новосибирск

БГПИ - Барнаульский государственный педагогический институт

ВГУ - Воронежский государственный университет

ВГПУ - Воронежский государственный педагогический университет

ВДИ - Вестник древней истории

ВГПУ - Воронежский государственный педагогический университет

ВУАК - Воронежская учёная архивная комиссия

ГАГУ - Горно-Алтайский государственный университет

ГИМ - Государственный исторический музей. Москва

ДАЭ - Донская археологическая экспедиция

ЗВОРАО - Записки Восточного отделения (Императорского) Русского археологического общества. СПб., Пг.

ЗИИМК - Записки Института истории материальной культуры. СПб.

ЗТКА - Западный Тюркский каганат. Атлас. Астана, 2013

ИА НАНУ - Институт археологии Национальной академии наук Украины

ИА РАН - Институт археологии Российской Академии наук. М.

ИА им. А.Х. Маргулана - Институт археологии им. А.Х. Маргулана

ИАЭт СО РАН - Институт археологии и этнографии Сибирского отделения Российской академии наук. Новосибирск

ИАК - Известия Археологической комиссии. Санкт-Петербург

ИАН - Известия Академии наук. Алма-Ата

ИА НАН РК / ИА МОН РК - Институт археологии имени А.Х. Маргулана Национальной академии наук/ Министерства образования и науки Республики Казахстан. АлмаАта / Алматы

ИИАЭ АН Каз ССР - Институт истории, археологии и этнографии имени Ч.Ч. Валиханова Академии наук Казахской ССР. Алма-Ата

ИИМК РАН - Институт истории материальной культуры РАН. СПб.

КарГУ - Карагандинский государственный университет имени академика Е.А. Букетова КемГУ - Кемеровский государственный университет

КИО - культурно-историческая общность (область)

КСИА - Краткие сообщения Института археологии Российской академии наук. М.

МАИКЦА - Международная ассоциация по изучению культур Центральной Азии

МАР - Материалы по археологии России. СПб

МАЭ - Музей антропологии и этнографии РАН

МИА - Материалы и исследования по археологии СССР. М.; Л. 
МИЗ - Материалы по истории земледелия СССР. М.; Л.

МКМ - Минусинский краеведческий музей им. Н.М. Мартьянова

МГУ - Московский государственный университет им. М.В. Ломоносова

НГУ - Новосибирский государственный университет

ОАК - Отчет археологической комиссии

ПИФК - Проблемы истории, филологии, культуры

PAE - Российский археологический ежегодник

PА - Российская археология. М.

РАН - Российская академия наук

РГУ - Ростовский государственный университет

РЖВ - Ранний железный век

СА - Советская археология. М.

САИ - Свод археологических источников. М.

САИ - Сарыаркинский археологический институт при Карагандинском государственном университете имени Е.А. Букетова

САИПИ - Сибирская ассоциация исследователей первобытного искусства

СГУ - Саратовский государственный университет

СПбГБУК МИСР - Санкт-Петербургский государственный музей-институт семьи Рерихов

СПбГУ - Санкт-Петербургский государственный университет

СУАР - Синьцзян-Уйгурский автономный район

ТГЭ - Труды Государственного Эрмитажа. Ленинград. Санкт-Петербург

ТПАЭ - Труды Потуданской археологической экспедиции ИА РАН

Тр. ГИМ - Труды государственного исторического музея. М.

Труды ХАЭЭ - Труды Хорезмской археолого-этнографической экспедиции

ХАЭЭ - Хорезмская археолого-этнографическая экспедиция

ЮУрГУ - Южно-Уральский государственный университет

АДІУ - Археологія і давня історія України. Київ

ГАЗ - Гістарычна-археалагічны зборнік. Мінск

AA - Archäologischer Anzeiger

AE - Archäologie in Eurasien

ACSS - Ancient Civilizations from Scythia to Siberia. Leiden; Boston

MDAFA - Mémoires de la Délégation archéologique française en Afghanistan

SRAA - Silk Road Art and Archaeology 



\section{CONTENT S}

Gulyaev V.I., Kantorovich A.R., Korobov D.S., Malashev V.Yu., Skoryy S.A. International scientific conference «New achievements in the research

of the Early Iron Age of Eurasia: problems, discoveries, methods»

(Moscow, November 13-14, 2017).....

\section{To the $100^{\text {th }}$ anniversary of the birth of K.F. Smirnov}

Batchenko V.S., Malyshev A.A., Gorlanov S.S. Personal Fund of K.F. Smirnov in the archive of IA RAS

Lukyashko S.I. The last field seasons of K.F. Smirnov and the problem of interpretation of monuments between the Don and Seversky Donets rivers

Chugunov K.V. Classification of arrows by K.F. Smirnov and quiver sets of the early Scythian time of the Eastern zone as a chronological indicator

\section{Early Iron Age of Eurasia in the Scythian Era}

Gulyaev V.I. On the North-Eastern borders of Scythia: the Middle Don in the $\mathrm{V}-\mathrm{IV}$ centuries $\mathrm{BC}$.

Ivanov A.V. Elite complex of the beginning of the IV century BC

on the Western borders of the Maeotian culture.....

Ivanov S.S. On the problem of differentiation of local variants of the Saka culture of Cistyanshan

Kadieva A.A., Maslov V.E., Birkina N.A., Demidenko S.V. Burial of the end of VII-V centuries BC from the cemetery Zayukovo-3

Kantorovich A.R., Maslov V.E. Bronze bucket from the burial ground kurgan group Novozavedennoe-III in the Stavropol region

Kisel V.A. «Complex curl» motif in the Scythian animal style and joined belts of ancient nomads

Kuznetsova T.M. «Whales» of Scythian chronology and dating system of monuments

Likhacheva O.S. Accidental finds of weapons' components of the Early Iron Age from the forest-steppen zone of Altai.

Marsadolov L.S. Sacral orientation of the «chains» of nomadic burial mounds of Sayan-Altai region of the $1^{\text {st }}$ thousand $\mathrm{BC}$ as an ethnocultural characteristic

Molodin V.I., Parzinger G. Burial complexes with permafrost in the North-West region of Mongolia (the Pazyryk culture).....

Novozhenov V.A. Communication model of early nomads of Central Asia

Polin S.V., Daragan M.N. Excavations of the Alexandropol Kurgan kurgan in the period of 2004-2009. 
Popova E.A. Ornamented non-rolled incense burners

from the settlement «Chaika» in the North-West of Crimea

Razuvaev Y.D. Bronze artifacts of the Scythian time from the upper settlement at Verkhneye Kazachye village

Sovetova O.S., Moore N.N. Two «Worlds» of the Tagar art:

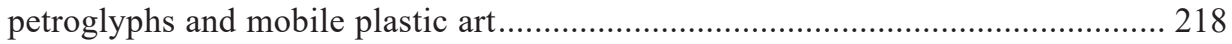

Ehrlich V.R. Final of the Late Bronze Age in the foothills of Adygea ........................ 230

The Early Iron Age of Eurasia:

the Sarmatian Era and the Great Nations Migration

Anikeeva O.V. Time of appearance and origin of sets of beads

from early Sarmatian burials of Filippovka II kurgan group.

Babiets A.I., Bogachuk E.O. Coins of the «unknown people» on the Abrau Peninsula.....

Berezutsky V.D. Men burials of the Sarmatians

of the Novochigolsky kurgan group

Kalinina T.M. The Arab scholar al-Khorezmi (IX century)

about Scythia and Sarmatia

Kovalevskaya V.B. The emergence of the early Albanian culture

of the Caucasus in the context of theoretical and methodological problems 288

Sirotin S.V. Elements of horse harness from the necropolis

«Ivanovo I barrows» in the southern Urals.

Tishkin A.A. A fragment of clothing from the mound number 4 of the Bumps kurgan group (foothill-steppe zone of Altai, Scythian-Sarmatian period)

Treister M.Yu. Parthian carved bone artifacts from the tombs of the nomads of Asiatic Sarmatia

Pruch M., Treister M.Yu. Burial of the middle Sarmatian period in the vicinity of Tanais with the Chinese lacquer bowl of the «Ar Bay» type.

\section{Complex approaches to research of monuments of the Early Iron Age}

Vorobyeva S.L. Metalworking of the Early Iron age based on the research of the metallurgical complex of Kurmantau mountain in the Gafuriysky region of the Republic of Bashkortostan

Gilmitdinova A.H. Craniophenetic characteristics of the early nomads of the southern Urals of the second half of the VI-II centuries BC (preliminary report) 
Dobrovolskaya M.V., Chagarov O.S., Hartanovich V.I. Data

on the isotopic composition of bone body tissue in the study

of the structure of nomadic societies of the Early Iron Age

Losenkov M.I. Archaeobotanical collection of tribes

of the Dnieper-Dvina culture

Mednikova M.B. Burials of the Scythian elite

in the kurgan group Novozavedennoe II (anthropological data)

Syrovatko A.S., Dobrovolskaya M.V. Strontium Isotopes in cremations

of burial grounds of the Middle Oka river of the middle

of the $1^{\text {st }}$ - beginning of the $2^{\text {nd }}$ millennium $\mathrm{AD}$ :

the experience of studying of the territorial differentiation of the population.

List of abbreviations 394

SCYTHIA et SARMATIA: Collected papers / Edited by A. A. Malyshev. - Moscow: MAKS Press, 2019, 400 p.

ISBN 978-5-317-06274-3

http://10.25681/IARAS.2019.978-5-317-06274-3

On November 13-14, 2017, the Institute of Archaeology of the Russian Academy of Sciences jointly with the State Historical Museum successfully realized the International scientific conference "New aspects of the studies of the Early Iron age of Eurasia: problems, discoveries, methods". The conference was dedicated to the seventieth anniversary of the Institute of Archaeology Department of Scythian-Sarmatian archaeology, created by the efforts of Boris Nikolaevich Grakov in 1947. This fact, as well as the centenary of the birth of Konstantin Fedorovich Smirnov, the prominent Soviet archaeologist, a specialist in the field of Sauromato-Sarmatian and Meotian archaeology, were widely discussed at the conference. The collection of articles contains materials that were somehow highlighted in oral and poster reports presented at the conference, with the intention of the editorial board articles do not always overlap with topics that are as relevant abstracts were specially published in the conference proceedings (cf. http://scythia-sarmatia.ru/publish/;https://drive.google.com/file/d/ 1rj7KhpCV5TAKw4Z9EvCSsWmMCQ0xXx3M/view).

In this context, this publication is of special importance as a kind of monitoring of the contemporary situation of researches in the sphere of archaeology of the Early Iron age of Eurasia.

Keywords: Early iron age, Scythians, Sauromatians, Sarmatians, archaeological culture, Eurasia, complex methods. 
Научное издание

\section{SCYTHIA ET SARMATIA}

Сборник статей

Под редакцией А. А. Малышева

Издательство «МАКС Пресс»

Главный редактор: $E$. М. Бугачева

Верстка: В. Е. Иванов

Корректор: А. С. Клемешова

Обложка: B. A. Катина

Отпечатано с готового оригинал-макета

Подписано в печать 02.12.2019 г.

Формат 70х100 1/16. Усл. печ. л. 32,5.

Тираж 300 экз. (1-й 3-д 1-100). Изд. № 285.

Издательство ООО «МАКС Пресс»

Лицензия ИД N00510 от 01.12.99 г.

119992, ГСП-2, Москва, Ленинские горы,

МГУ им. М. В. Ломоносова, 2-й учебный корпус, 527 к.

Тел. 8(495) 939-3890/91. Тел./Факс 8(495) 939-3891

Отпечатано в полном соответствии с качеством предоставленных материалов в ООО «Фотоэксперт»

115201, г. Москва, ул. Котляковская, д.3, стр. 13. 